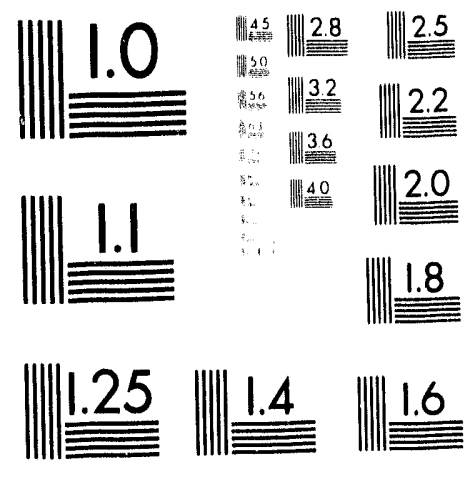



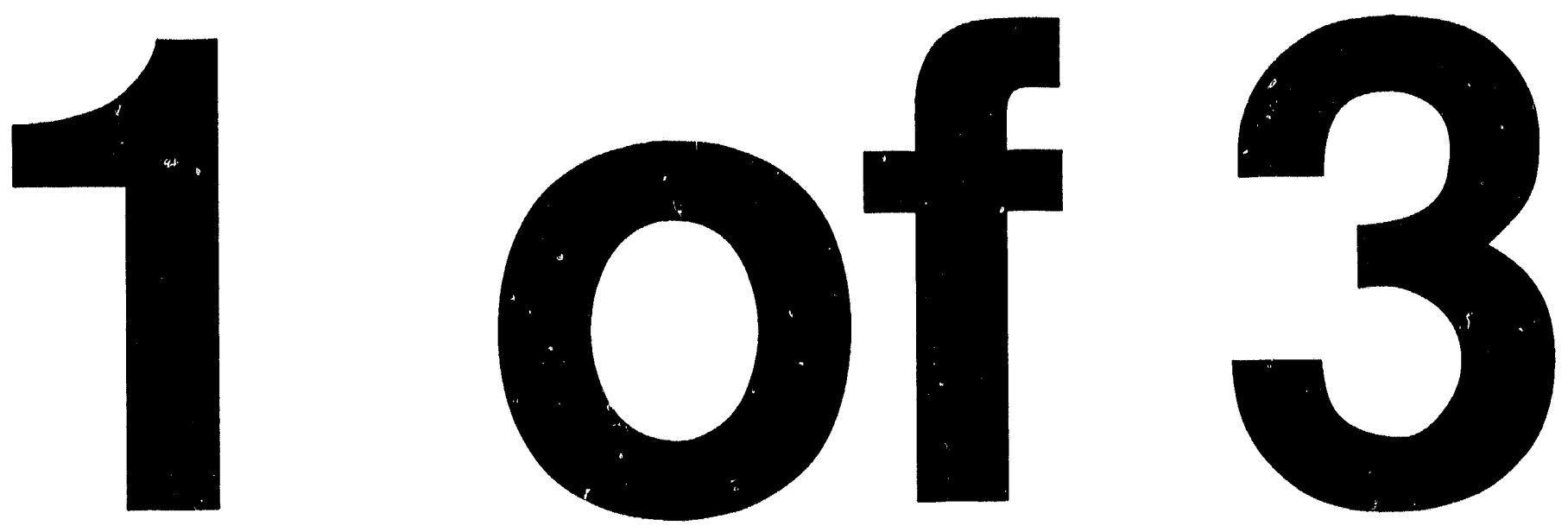


\title{
Groundwater Impact Assessment Report for the 216-Z-20 Crib, 200 West Area
}

\author{
V. G. Johnson \\ Date Published \\ October 1993
}

\section{DISCLAIMER}

This report was prepared as an account of work sponsored by an agency of the United States This report was prepared as an account of work sponsored by agency thereof, nor any of their employees, makes any warranty, express or implied, or assumes any legal liability or responsibility for the accuracy, completeness, or usefulness of any information, apparatus, product, or process disclosed, or represents that its use would not infringe privately owned rights. Referprocess disclosed, or represents that its use would not infringe privale by trade name, trademark, manufacturer or otherwise does not necessarily constitute or imply its endorsement, recommanufacturer, or otherwise dos United States Government or any agency thereof. The views and opinions of authors expressed herein do not necessarily state or reflect those of the United States Government or any agency thereof.

Prepared for the U.S. Department of Energy Office of Environmental Restoration and

Waste Management

\section{(2)} Westinghouse Hanford Company Richiand, Washington 99352

Hanford Operations and Engineering Contractor for the

U.S. Department of Energy under Contract DE-AC06-87RL10930 


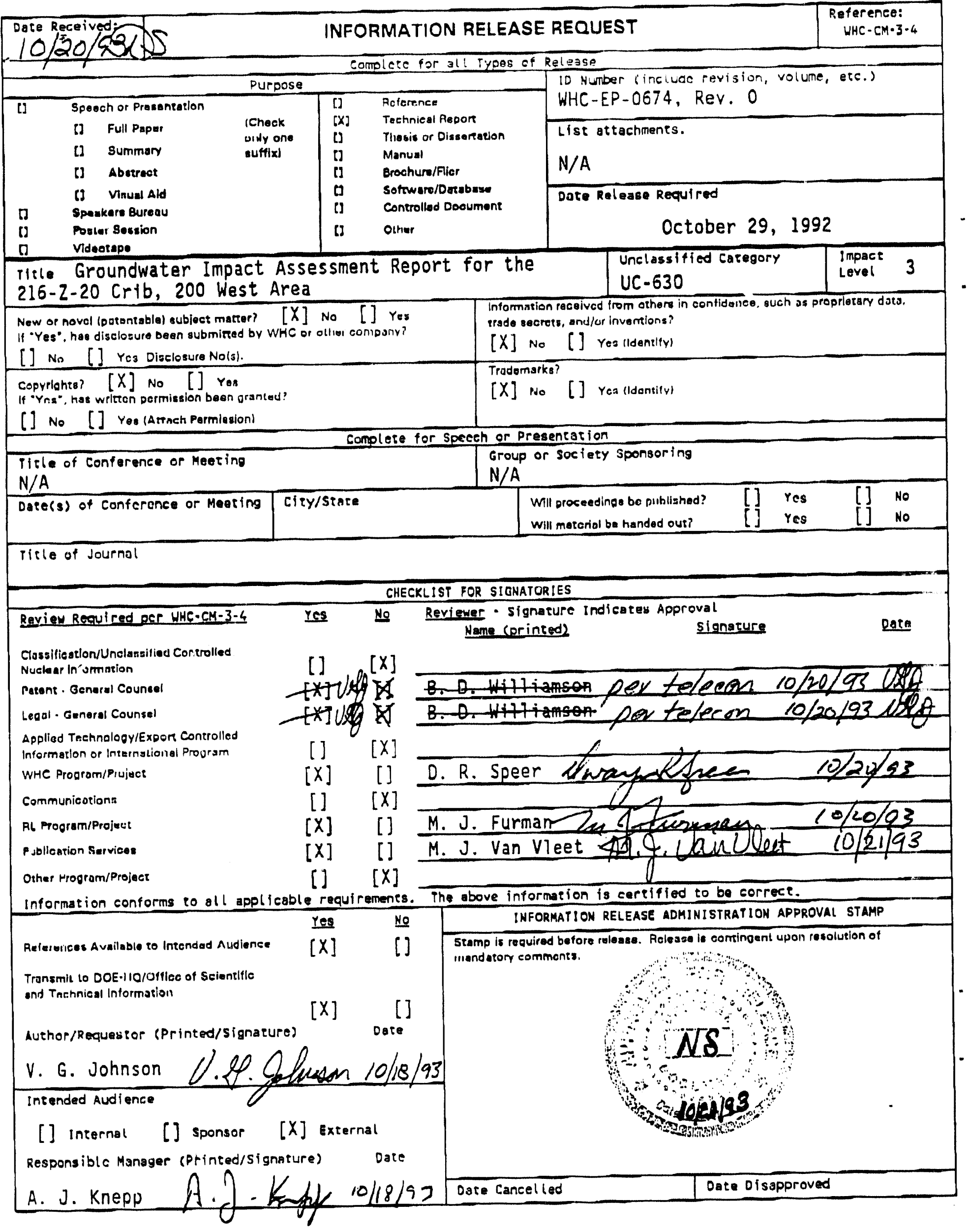


Document Title: Groundwater Impact Assessment Report for the 216-2-20 Crib, 200 West Area

Prepared by:

Reviewed by:

Approved by:

Approved by:
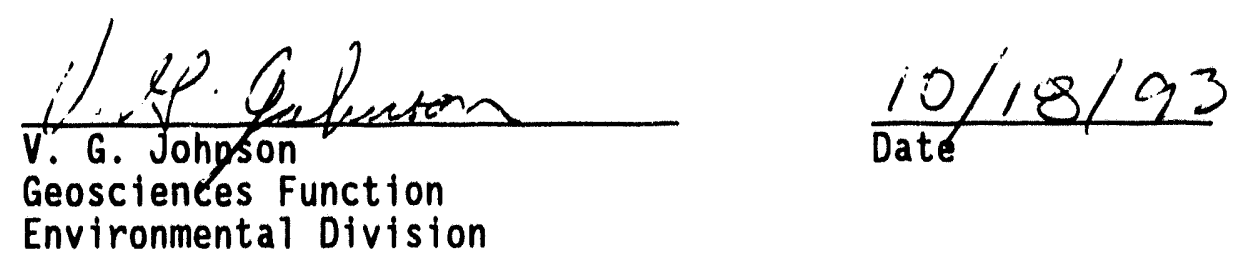

\section{Environmental Division}

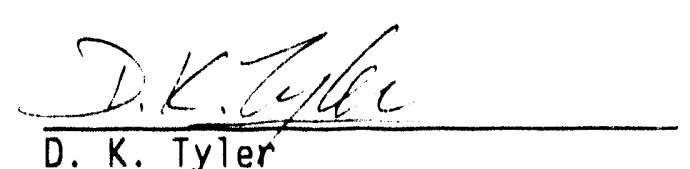

D. K. Tyler

Geosciences Function

Environmental Division

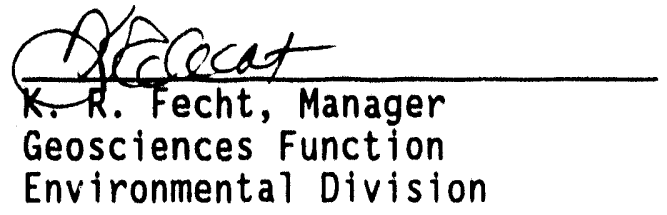

$\frac{10 / 21 / 93}{\text { Date }}$

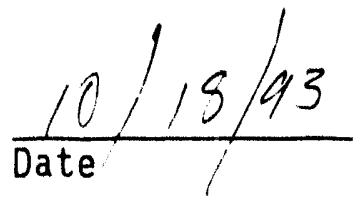

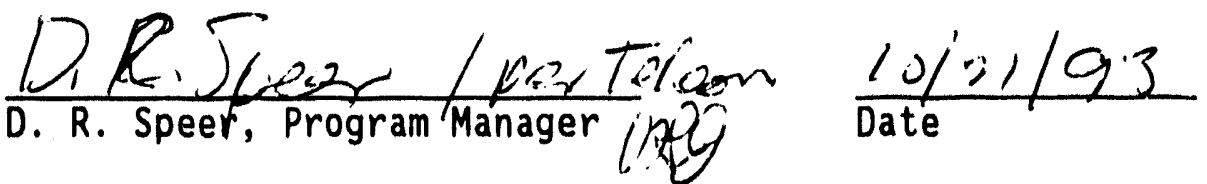


WHC-EP-0674

This page intentionally left blank. 


\section{EXECUTIVE SUMMARY}

As required by the Hanford Federal Facility Agreement and Consent Order ([Tri-Party Agreement] Milestone M-17-00A), this report assesses the impact of wastewater discharges to the 216-Z-20 Crib on groundwater quality. The assessment reported herein extends the initial analysis conducted from 1989 through 1990 for the Liquid Effluent Study Final Project Report. ${ }^{2}$ Three primary issues are addressed in response to regulator concerns with the initial analysis:

- The magnitude and status of the soil column transuranic inventory

- Potential interactions of wastewater with carbon tetrachloride from adjacent facilities

- Preferential pathways created by unsealed monitoring wells.

Facility Description. The $216-2-20 \mathrm{Crib}$ is located in the 200 West Area of the Hanford Site and is situated among major chemical processing and waste management facilities. The 216-Z-20 Crib was constructed and commissioned for use in September 1981 to dispose of wastewater previously discharged to a contaminated ditch and pond system, thus allowing these facilities to be decommissioned. The crib is approximately $457 \mathrm{~m}(1,500 \mathrm{ft})$ 1ong and approximately $3 \mathrm{~m}(10 \mathrm{ft})$ wide in cross section at the bottom. Gravel was

${ }^{1}$ Ecology, EPA, and DOE, 1990, Hanford Federal Facility Agreement and Consent Order, Washington State Department of Ecology, U.S. Environmental Protection Agency, and U.S. Department of Energy, Oiympia, Washington.

${ }^{2}$ WHC, 1990, Liquid Effluent Study Final Project Report, WHC-EP-0367, Westinghouse Hanford Company, Richland, Washington. 
used to backfill the crib excavation to a depth of approximately $0.8 \mathrm{~m}$ $(2.6 \mathrm{ft})$. Perforated pipes, connected to the building effluent headers, were embedded in the gravel backfill to distribute effluents throughout the crib. Effluents entering the $216-\mathrm{Z}-20 \mathrm{Crib}$ originate in various Plutonium Finishing Plant buildings. Production operations at the Plutonium Finishing Plant Complex consisted of plutonium reclamation and plutonium conversion. The recoverable material was treated to produce soluble and/or leachable forms of plutonium for recovery as plutonium nitrate. Plutonium nitrate was converted to plutonium oxide and then to metallic plutonium. Most of the effluent generated from these operations was either equipment cooling water or heating and ventilation steam condensate, neither of which came into contact with process materials or process chemicals under normal operating conditions. However, past accidental releases from equipment failures resulted in transuranics and fission product waste releases to the crib. Facility upgrades have eliminated such discharges, and will ultimately reduce the wastewater flow rate from an average of $757 \mathrm{~L} / \mathrm{min}(200 \mathrm{gal} / \mathrm{min})$ to about $38 \mathrm{~L} / \mathrm{min}(10 \mathrm{gal} / \mathrm{min})$. Additionally the waste stream will be treated before release.

Findings, Principal findings associated with the primary issues noted above are summarized below.

Analysis of groundwater data, effluent records, previous soil core analytical results, spectral gamma logs from wells at the 216-2-20 crib, and migration depth calculations all indicate that this crib is not a transuranic site (i.e., transuranic radionuclide content of soil beneath the crib is far less than $100 \mathrm{nCi} / \mathrm{g})$. There is no evidence of breakthrough of transuranics to 


\section{WHC-EP-0674}

efther perched water or groundwater. Most of the radionuclide inventory (ca. $1 \mathrm{Cl}$ of plutonium-239 and $2 \mathrm{Cl}$ of americium-241) should remain in the top few meters of the soil column.

It is likely that four previously unsealed groundwater monitoring wells at the 216-2-20 Crib historically served as preferential pathways for migration of contaminants directly to groundwater. This condition was mitigated using an innovative approach that not only corrected the problem but also resulted in four new perched water and/or deep soll gas monitoring wells. Application of this same approach to convert several other unsealed wells at adjacent past-practice disposal facilities containing carbon tetrachloride and radioactive wastes could be applicable.

Perched water and soil gas sampling and analysis results to date suggest wastewater discharged to the 216-2-20 Crib absorbs only small amounts of carbon tetrachloride from adjacent past-practice disposal facilities. Much " higher soll gas concentrations occur immediately north of the 216-2-20 Crib near several miscellaneous wastewater discharge sites. These sources may also contribute to the elevated concentrations of carbon tetrachloride in groundwater near the $216-2-20 \mathrm{crib}$.

Conclusions. Based on the analysis described in this report, it was concluded that continued discharge of wastewater until 1995 at currently projected rates will have very little additional impact on groundwater quality beneath the $216-\mathrm{Z}-20 \mathrm{Crib}$. The relatively small volume of treated effluent expected in the late fall of 1993,23 to $45 \mathrm{~L} / \mathrm{min}$ (6 to $12 \mathrm{gal} / \mathrm{min}$ ), will have 


\section{WHC-EP-0674}

a minimal impact on the soll column inventory of transuranics beneath the 216-Z-20 Crib and the fate and transport of carbon tetrachloride from adjacent facilities. 


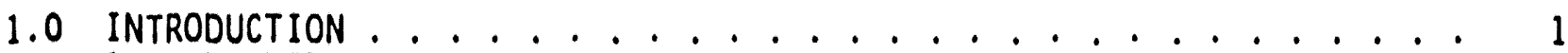

1.1 BACKGROUND ...................... 1

1.2 METHODOLOGY . . .................... . 1

1.3 SITE-SPECIFIC ISSUES ................... 2

2.0 FACILITIES DESCRIPTION . . . . . . . . . . . . . . . 5

2.1 LOCATION . . . . . . . . . . . . . . . 5

2.1.1 Plutunium Finishing Plant Complex . . . . . . . . . 5

2.1.2 216-Z-20 Crlb and Related Waste Streams . . . . . . . . 9

2.2 EFFLUENT SOURCE DESCRIPTION ................ 10

2.3 ADJACENT WASTE FACILITIES . . . . . . . . . . . . . . . . 15

2.3.1 216-U-10 Pond .................... 18

2.3.2 216-Z-1D Ditch................. 18

2.3.3 216-Z-11-2 Ditch................. 20

2.3.4 216-Z-19 Ditch.................. 20

$2.3 .5216-2$ Cribs ..................... 20

2.3.6 Waste Inventories ................... 27

2.3.7 Miscellaneous Waste Streams ............. 27

3.0 EFFLUENT CHARACTERISTICS . . . . . . . . . . . . . . . . 29

3.1 DISCHARGE VOLUMES AND FLOW REGIME . . . . . . . . . . . . . . . . . . . 29

3.2 EFFLUENT CONSTITUENTS, QUANTITIES AND

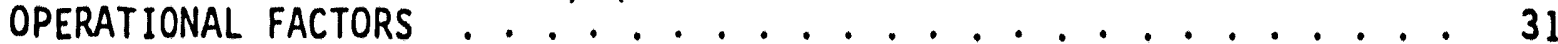

4.0 CONCEPTUAL MODEL OF HYDROLOGIC RESPONSE AND

CONTAMINANT MIGRATION ....................... 41

4.1 HYDROGEOLOGIC FRAMEWORK ................... . . 41

4.1.1 Regional and Hanford Site Geology . . . . . . . . . . . 41

4.1.2 200 West Area Hydrogeology............... 44

4.1.3 Crib Site Stratigraphy ................ 48

4.2 HYDROLOGIC RESPONSES TO EFFLUENT DISPOSAL . . . . . . . . . . . . . 55

4.3 GROUNDWATER QUALITY .................... 61

4.3.1 Area Groundwater Quality............. . 61

4.3.2 Local Influences on Groundwater Quality ......... 65

4.3.3 Depth Distribution of Carbon Tetrachloride . . . . . 75

4.4 SOIL COLUMN CHEMICAL FACTORS ............... . 79

4.4.1 Calcium Carbonate ................ . 81

4.4.2 Soil Organic Matter ................. . . 85

4.4.3 Crib Sediment Chemical Characteristics......... 85

4.5 SUMMARY AND CONCEPTUAL MODEL ................. 86

4.5.1 CONSTITUENTS OF INTEREST . . . . . . . . . . . . . . 86

4.5.2 CONCEPTUAL MODEL . . . . . . . . . . . . . . 86

5.0 IMPACT ASSESSMENT . . . . . . . . . . . . . . . . 89

5.1 Hydrologic Impacts . . . . . . . . . . . . . . . . . . 89

5.2 Contaminant Impacts on Groundwater ............. 89

5.2.1 Analytical Methods . . . . . . . . . . . . . . . . 90

5.2.2 Mode1 Calibration Check and Related Assumptions . . . 92

5.2.3 Analog Site Calibration Check (216-Z-12 Crib) ..... 96

5.2.4 Previous Results (Liquid Effluent Study) ........ 99

5.2.5 Analytical Results for Revised Conceptual Model . . . 104 


\section{CONTENTS (cont.)}

5.2.6 Implications of Soll Gas and Perched Water Sampling Results.................. 111

5.2.7 Comparison of Groundwater Data with Guidelines:... 111 5.3 MONITORING WELL ADEQUACY .................. 115 5.3.1 Remediation and Conversion of Existing Groundwater Monitoring Wells ............. 115

5.3.2 Future Needs and Data Reporting . . . . . . . . . . . . 117

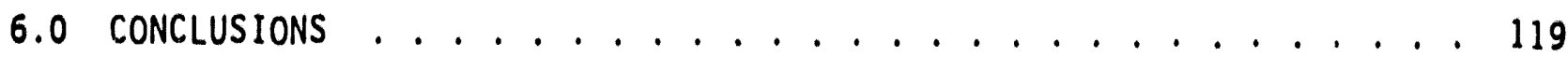

7.0 REFERENCES . . . . . . . . . . . . . . . . . . . 121 APPENDIXES:

A. PLUTONIUM FINISHING PLANT WASTEWATER CONTRIBUTORS . . . . A-1

B. GROUNDWATER DATA ....... B-i

c. SOIL COLUMN RADIONUCLIDE AND CHEMICAL DATÁ $\ldots \ldots$

D. WELL REMEDIATION AT THE $216-2-20$ CRIB $\ldots \ldots \ldots$. . . . . 


\section{LIST OF FIGURES}

1 Location Map for the Hanford Site and the 200 Areas . . . . . . . 6

2 Map Showing Location of the 216-2-20 Crib in Relation to Adjacent Facilities in the 200 West Area ........... 7

3 Layout of 216-2-20 Crib and Plutonium Finishing Plant Wastewater Line connections ............... 8

4 Plot Plan and Design Detail for Original 216-2-20 Crib ...... 11

5 Cutaway Diagram of the 216-2-20 Crib (Original Design) . . . . . . 12

6 Cross Section. Showing Design Modification of the 216-z-20 crib (1987) ............... 13

7 Vertical Drainage Borehole Locations in the 216-z-20 Crib ..... 14

8 Schematic of Plutonium Finishing Plant Effluent Sources, Routing, and Sampling Points (Pre-1993) ........... 17

9 The 216-U Pond System (Pre-1981 Configuration) . . . . . . . . 19

10 Location of Current Wastewater Discharge Sites in Relation to Past-Practice Carbon Tetrachloride Disposal Facilities . . . . . 26

11 Discharge and Event History at the 216-2-20 Crib .........30

12 Correlation of Riser Water Levels and Discharge for the $216-2-20$ crib .................. 32

13 Concentration History Plot for Plutonium-239 in Effluent Discharged to the 216-2-20 Crib ............

14 Generalized Geologic Map of the Pasco Basin and the Hanford Site ......................

15 Stratigraphic Nomenclature for the Hanford Site . . . . . . . . . 43

16 Hanford Site Stratigraphy Showing the Relationship Between Units ................... 45

17 Location of Wastewater Disposal Sites on the Hanford Site. . . . . 46

18 Water Table Map for the 200 West Area, December $1991 \ldots 49$

19 Longitudinal Stratigraphic Cross Section Through the 216-z-20 crib................ 51/52

20 Lithology and Stratigraphic Units Beneath the 216-Z-20 Crib . . . . 53 
21 Stratigraphic Relationships Between 216-Z-20 Crib Site and Adjacent 200 West Area ................

22 Correlation of Discharge History and Water Table Fluctuations in the Vicinity of the 216-Z-20 crib ............ 56

23 Discharge History at the 284 Powerplant Pond . . . . . . . . . 57

24 Specific Conductivity of Groundwater in the 200 West Area . . . . . 59/60

25 Areal Distribution of Nonradioactive Contaminants in the 200 West Area Groundwater. . . . . . . . . . . . . . . 62

26 Area? Distribution of Radioactive Contaminant Indicators in 200 West Area Groundwater ............... 63

27 Areal Distribution of Chlorinated Hydrocarbons in 200 West Area Groundwater. . . . . . . . . . . . . . . . 64

28 Carbon Tetrachloride Sources Near the 216-Z-20 Crib . . . . . . . 66

29 Relative Change in Water Table Elevations in the 200 West Area (December 1988 to December 1991) . . . . . . . . 67

30 Hydraulic Conductivity in the 200 West Area . . . . . . . . . 69/70

31 Water Table Elevations in the Immediate Vicinity of the 216-Z-20 Crib................... 71

32 Contour Map of Carbon Tetrachloride Concentrations in 200 Areas Groundwater (Average for 1989 through 1991) . . . . . . . 72

33 Carbon Tetrachioride Concentration Versus Time in Groundwater from Well 2-W18-17 (216-Z-20 Crib) ........ 74

34 Vertical Distribution of Carbon Tetrachloride and Chloroform in Groundwater Near the 216-2-20 Crib . . . . . . . 77/78

35 Soil Gas and Groundwater Concentration Contours in Relation to Active Wastewater Disposal Sites and Carbon Tetrachloride Sources ..................... 80

36 Lithology and Calcium Carbonate Depth Profiles Near the

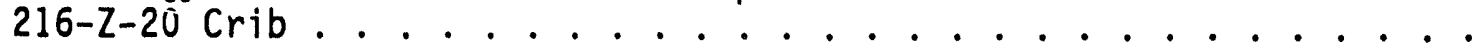

37 Sorption of Plutonium By Soil as a Function of $\mathrm{pH}$ and

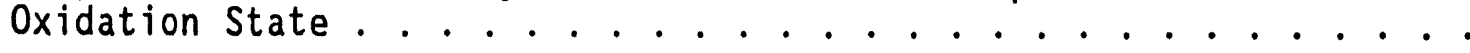

38 Schematic Illustration of Contaminant and Wastewater Transport Beneath and Adjacent to the 216-Z-20 Crib .......... 


\section{LIST OF FIGURES (cont.)}

39 Hydraulic Conductivities Varsus Moisture Content for

Various Hanford Site Soil Types ......... . . . . . . . . 91

40 Observed Vertical Distribution of Plutonium-239 in the

Vadose Zone Beneath the 216-Z-12 Crib .............. 94

41 Plot Plan of the 216-Z-12 Crib Showing Soil Sampling Locations . . 95

42 Observed and Predicted Plutonium Migration Depths Beneath

the 216-z-12 crib.................. . 98

43 (a) Two-dimensional Simulation of Liquid Phase Carbon Tetrachloride in the Soil Column and Unconfined Aquifer Beneath the 216-2-9 Trench, Near-Field Cross Section . . . . 107/108

43 (b) Two-dimensional Simulation of Liquid Phase Carbon Tetrachloride in the Soil Column and Unconfined Aquifer Beneath the 216-Z-9 Trench, Extended North-South Cross Section . 109/110 
WHC-EP-0674

This page intentionally left blank. 


\section{LIST OF TABLES}

1 Major Process Chemicals Used in the Plutonium Finishing Plant and Related $\mathrm{Z}$ Plant Processes .............. 16

2 Transuranic and Carbon Tetrachloride Inventories for Major Adjacent Past-Practice Disposal Factlities . . . . . . . . . 28

3 Effluent Stream Description, Plutonium Finishing Plant Wastewater ..................... 29

4 Key Contaminants Previously Identified in Plutonium Finishing Plant Waste Stream Discharges to the 216-2-20 Crib . . . . . . 34

5 Loading Rates to the $216-z-20$ Crib (Nonoperating Mode) . . . . . 35

6 Inventory of Contaminants Discharged to the 216-2-20 Crib . . . . 3 37

7 Summary of Radiological and Chemical Constituent Concentrations in Effluent Discharged to the 216-Z-20 Crib (1986 through 1993) . . . . 38

8 Plutonium Finishing Plant Wastewater Radioanalytical Results for August 27, 1992................. . . 40

9 Statistical Summary of Observed Plutonium Migration Depths (in Meters) Beneath the 216-Z-12 Crib ............... 97

10 Contaminant Migration Rate Estimates for the Soil Column Beneath the 216-z-20 crib and the 216-z-12 Crib ........... 100

11 Summary of Carbon Tetrachloride Concentrations in Soll Gas from Monitoring Wells at the 216-2-20 Crib (1993) . . . . . . . 112

12 List of Constituents of Interest and Associated Regulatory Guidelines 
WHC-EP-0674

This page intentionally left blank. 


\section{LIST OF TERMS}

\begin{tabular}{|c|c|}
\hline 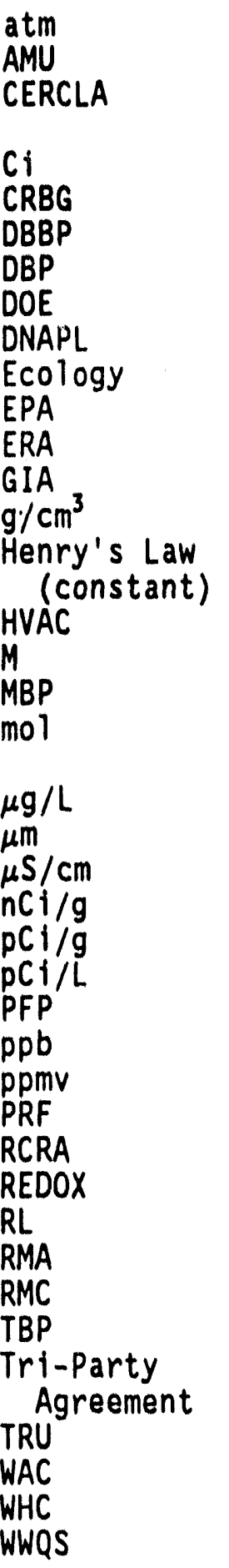 & $\begin{array}{l}\text { atmosphere } \\
\text { aqueous makeup } \\
\text { Comprehensive Environmental Response, Compensation, and } \\
\text { Liability Act of } 1980 \\
\text { curie } \\
\text { Columbla River Basalt Group } \\
\text { dibutyl butyl phosphorate } \\
\text { dibutyl phosphate } \\
\text { U.S. Department of Energy } \\
\text { dense, nonaqueous phase } 1 \text { iquid } \\
\text { Washington State Department of Ecology } \\
\text { U.S. Environmental Protection Agency } \\
\text { expedited response action } \\
\text { groundwater impact assessment } \\
\text { grams per cubic centimeter } \\
\text { water/air partition coefficient for a volatile organic } \\
\text { compound } \\
\text { heating, ventilation, and air conditioning } \\
\text { moles per liter of a substance } \\
\text { monobutyl phosphate } \\
\text { abbreviation for the chemical term mole (the quantity of a } \\
\text { substance that is equal to its formula mass in grams) } \\
\text { micrograms per liter } \\
\text { micrometers } \\
\text { microsiemens per centimeter } \\
\text { nanocuries per gram } \\
\text { picocuries per gram } \\
\text { picocuries per iter } \\
\text { Plutonium Finishing Plant } \\
\text { parts per billion } \\
\text { parts per million by volume } \\
\text { Plutonium Reclamation Facility } \\
\text { Resource Conservation and Recovery Act of 1976 } \\
\text { reduction-oxidation process/facility } \\
\text { DoE, Richland Operations Office } \\
\text { remote mechanical "A" (line) } \\
\text { remote mechanical "C" (line) } \\
\text { tributyl phosphate } \\
\text { Hanford Federal Facility Agreement and Consent order } \\
\text { transuranic } \\
\text { Washington Administrative Code } \\
\text { Westinghouse Hanford Company } \\
\text { Washington Water Quality Standard }\end{array}$ \\
\hline
\end{tabular}




\section{LIST OF RADIOISOTOPES/CHEMICAL FORMULAS}

$\begin{array}{ll}{ }^{241} \mathrm{Am} & \text { Americium-241 } \\ { }^{\mathrm{CCl}_{4}} & \text { Carbon tetrachloride } \\ { }^{144} \mathrm{Ce} & \text { Cerium-144 } \\ { }^{60} \mathrm{Co} & \text { Cobalt-60 } \\ { }^{134} \mathrm{Cs} & \text { Cesium-134 } \\ { }^{137} \mathrm{Cs} & \text { Cesium-137 } \\ { }^{154} \mathrm{Eu} & \text { Europium-154 } \\ { }^{155} \mathrm{Eu} & \text { Europium-155 } \\ { }^{\mathrm{HAsO}_{4}}{ }^{-2} & \text { Arsenate (anton) } \\ { }^{\mathrm{HNO}} \mathrm{O}_{3} & \text { Nitric acid } \\ { }^{40} \mathrm{~K} & \text { Potassium-40 } \\ { }^{22} \mathrm{Na} & \text { Sodium-22 }\end{array}$

$\begin{array}{ll}{ }^{238} \mathrm{Pu} & \text { Plutonium-238 } \\ { }^{239} \mathrm{Pu} & \text { Plutoni Im-239 } \\ { }^{24{ }^{4} \mathrm{Pu}} & \text { Plutonium-241 } \\ { }^{226} \mathrm{Ra} & \text { Radium-226 } \\ { }^{106} \mathrm{Ru} & \text { Ruthenium-106 } \\ { }^{125} \mathrm{Sb} & \text { Antimony-125 } \\ { }^{85} \mathrm{Sr} & \text { Strontium-85 } \\ { }^{90} \mathrm{Sr} & \text { Strontium-90 } \\ { }^{234} \mathrm{U} & \text { Uranium-234 } \\ { }^{235} \mathrm{U} & \text { Uranium-235 } \\ { }^{238} \mathrm{U} & \text { Uranium-238 }\end{array}$


WHC-EP-0674

GROUNDWATER IMPACT ASSESSMENT FOR THE 216-Z-20 CRIB

\subsection{INTRODUCTION}

Groundwater impact assessments (GIA) for several liquid effluent receiving sites are required by Hanford Federal Facility Agreement and Consent order (Ecology et al. 1990) (Tri-Party Agreement) milestones M-17-00A and M-17-00B. This report assesses the impacts to groundwater from the disposal of effluent to the $216-2-20 \mathrm{crib}$ in the 200 West Area.

\subsection{BACKGROUND}

In response to public comments on the original Tri-Party Agreement, and at the request of the signatories on the Tri-Party Agreement, the U.S. Department of Energy (DOE), Richland Operations Office (RL) conducted a study to assess the impact of liquid effluents discharged to the ground at the Hanford Site (Westinghouse Hanford Company [WHC] 1990a; 1990b). The U.S. Environmental Protection Agency (EPA) and the Washington State Department of Ecology (Ecology) expressed concerns regarding uncertainties in the evaluations made by RL. Foremost among these concerns were the lack of site-specific data, the need to consider interactions with adjacent liquid discharge facilities, and the need for more rigorous models of contaminant transport. As a result of these concerns, the RL, Ecology, and EPA (the three parties) created a series of Tri-Party Agreement milestones (M-17-00A, $M-17-00 B, M-17-13$, and $M-17-13 A$ ) that pertain to GIAs.

Tri-Party Agreement milestones $M-17-00 A$ and $M-17-00 B$ require impact assessments for Phase I and II waste streams. Phase I and II waste streams are defined in Stordeur and Flyckt (1988). The 216-2-20 Crib recelved a higher priority Phase I waste stream classification. Tri-Party Agreement milestone $M-17-13$ required the development of a methodology for assessing the impact of liquid effluent discharge on groundwater, which resulted in the document, A Methodology for Assessing Impacts to Groundwater from Disposal of Liquid Effivent to the Soil at the Hanford Site (Tyler 1991). A schedule for performing the assessments at 13 receiving sites was completed 30 days after regulatory approval of the methodology document, as required by Tri-Party Agreement milestone M-17-13A. The 216-2-20 Crib was among the first group of receiving sites identified for GIAs.

\subsection{METHODOLOGY}

Preparation of the GIA for the $216-2-20 \mathrm{Crib}$ followed the aforementioned methodology document (Tyler 1991). Included in that document is the categorization of each of the 13 receiving sites into 1 of 3 ievels based on the amount of effort needed to perform the assessment. A GIA for a level 1 receiving site relies on avallable information. A level 2 receiving site may require nonintrusive field work to verify the extent of existing contamination. A level 3 site may require intrusive fleld work. If it is 
discovered that existing information is inadequate through the course of performing a level 1 impact assessment, the assessment may be raised to a level 2 or 3 assessment.

The methodology document outlines several of the following tasks to be conducted as part of the GIA for level 1 receiving sites.

- Prepare and present plan describing how the groundwater assessment will be conducted

- Characterize the liquid effluent stream

- Evaluate the site-specific hydrogeology

- Develop a receiving site conceptual model relevant to moisture and contaminant movement

- Assess the hydrologic impact of the liquid effluent stream

- Assess the contaminant impact of the liquid effluent stream

- Evaluate the adequacy of the existing monitoring well network

- Prepare a written report of the results.

The tasks required for level 2 and 3 receiving sites are similar to those outlined above, but also include field work-related activities. The 216-z-20 Crib was categorized as a level 2 receiving site, primarily on the basis of past effluent discharges and the potential for preferential pathways.

Several key assumptions inherent to all GIAs are explained in the methodology document and warrant summarizing here. For this impact assessment, the following assumptions are relevant.

- The expected level of impact from use of the receiving site determines how well the chemistry, geology, and hydrology need : , be understood.

- Modeling sophistication is tallored to avallable information and the expected level of impact of the receiving site.

- Historical data are fully useable.

\subsection{SITE-SPECIFIC ISSUES}

In addition to the general methodology guidance discussed above, sitespecific issues identified during the pubilic review process are addressed in this impact assessment. The primary issues can be summarized as follows:

(1) The possibility that the 216-2-20 Crib should have been designated as a transuranic (TRU)-contaminated soil site (i.e., when the sum of 
the average soil concentrations of the isotopes of plutonium and americium exceed 100 nanociries per gram $(\mathrm{nCi} / \mathrm{g})$, discharge of wastewater to such sites is disallowed)

(2) The potential interaction of wastewater from the crib with adjacent liquid waste disposal facilities containing residual carbon tetrachloride $\left(\mathrm{CCl}_{4}\right)$ and related wastes from past-practice waste disposal operations

(3) The possible existence of preferential pathways for contaminant transport directly to groundwater (e.g., via the four unsealed groundwater monitoring wells at the 216-2-20 (rib).

The TRU issue ( 1 above) was addressed in 1991 using previous site characterization data and high resolution spectral gamma logs for the four groundwater monitoring wells at the 216-2-20 Crib and it was determined that the 216-2-20 crib was not a TRU waste site. This data and associated conclusions are provided in Appendix $C$. The other two issues ( 2 and 3 above) are addressed in the matn body of the report. (Chapters 2.0 through 5.0). 
WHC-EP-0674

This page intentionally left blank. 
WHC-EP-0674

\subsection{FACILITIES DESCRIPTION}

\subsection{LOCATION}

The location of the 216-2-20 Crib in relation to past-practice disposal facilities and their associated waste inventories, as well as previous effluent characteristics, are important source term factors for this GIA. Accordingly, the following review focuses on both past and current operations that have the potential for interaction with discharges from the 216-2-20 Crib.

The 216-2-20 Crib is located in the 200 West Area of the Hanford Site (Figures 1 and 2 ) and is situated among major chemical processing and waste management facilities. Effluents entering the $216-2-20 \mathrm{Cr}$ ib come from various bullidings located inside the fenced Plutonium Finishing Plant (PFP), a protected access area, and from one nearby bullding. This group of bulldings is referred to as the PFP Complex and $Z$ Plant. The buitidings include: $234-5 Z$ (PFP); 236-Z (Plutonium Reclamation Facility [PRF]); 291-Z, 2736-ZB, 232-Z, and 242-Z (all inside the fence); and 231-Z (outside the fence) (Figure 3 ).

The 234-52 Bullding is a concrete and sheetmetal structure that was constructed originally in 1949 and has subsequently been expanded. The major areas of the 234-5Z Bullding are divided into "frontside" and "backside, "with the latter containing the process areas and associated laboratories, or otherwise potentially contaminated spaces. Offices and other administrative areas are located throughout the building, both frontside and backside, for the convenience of the personnel working in these areas. Mechanical and other equipment rooms, safety showers, floor drains, eyewashes, and drinking fountains exist both frontside and backside.

Other bulldings within the PFP protected access area are considered to be backside areas, with the exception of $2736-2 B$. The frontside of the 2736-2B Building consists of administrative areas.

The major operations bufldings are 234-5Z, 236-Z, 291-Z, and 2736-ZB. The 234-52 Building houses the active remote mechanical "C" (RMC) Iine; the inactive remote mechanical "A" (RMA) Iine; the Analytical and Development Laboratories; and various workshops, storerooms, offices, and locker rooms. The 236- $z$ Bullding houses the PRF. Equipment is housed in the 291-z Building to handle the ventilation exhaust from the 234-5z,236-z, 232-z, and 242- 2 Bufldings. Special nuclear material storage is conducted in the 2736-2B Bullding. Bulldings in 1ayaway status are the 232- $Z$ Incinerator Bullding and the 242-z Waste Treatment Facility. The 231-z Building, containing offices, workshops, and inactive operations cells, is located outside the exclusion fence for the PFP Complex protected access area.

\subsubsection{Plutonium Finishing Plant Complex}

Production operations at the PFP Complex consisted of plutonium reclamation and plutonium conversion. The PRF reclaimed plutonium from recoverable solutions and solids. The recoverable material was treated in 
WHC-EP-0674

Figure 1. Location Mao for the Hanford Site and the 200 Areas.

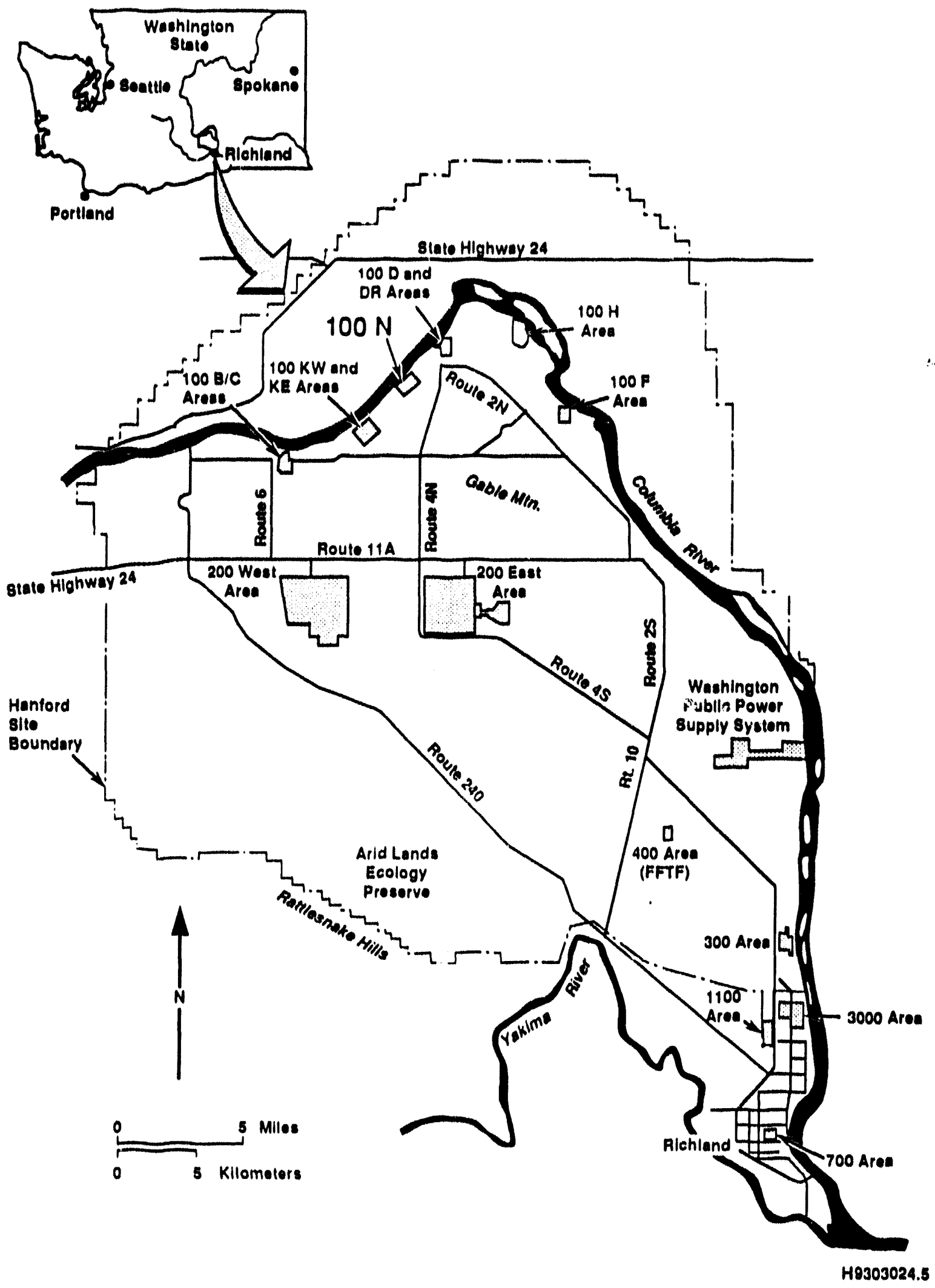


Figure 2. Map Showing Location of the 216-2-20 Crib in Relation to Adjacent Facilities in the 200 West Area.

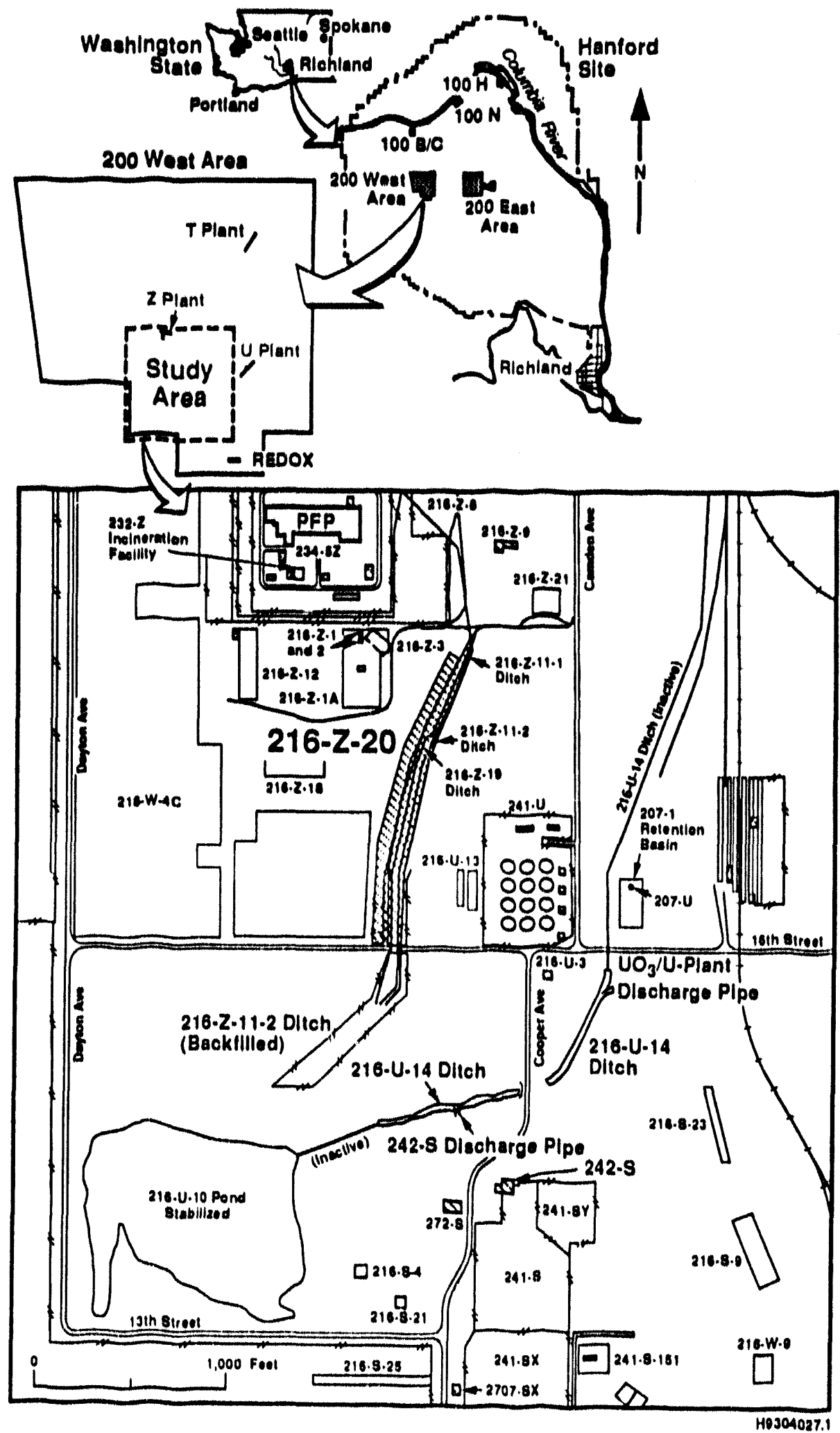


Figure 3. Layout of 216-Z-20 Crib and Plutonium Finishing Plant Wastewater Line Connections (not to scale).

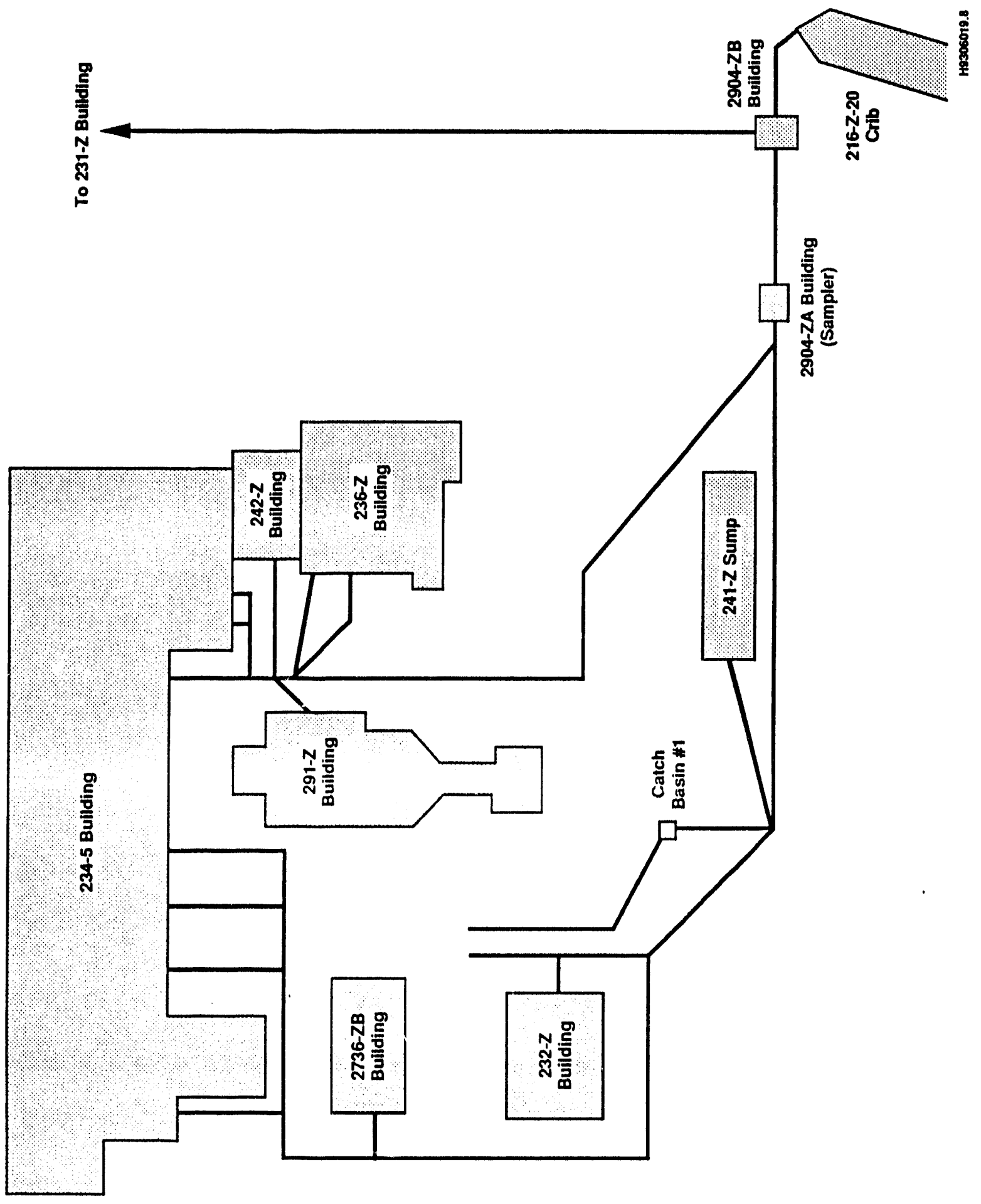


various ways to produce soluble andior leachable forms of plutonium for recovery as plutonium nitrate. Plutonium nitrate was received as feed and converted to plutonium oxide and then metal in the RMC line.

Under normal operating conditions, none of the solutions from these operations contacted the $216-2-20 \mathrm{crib}$ effluents. The vast majority of the effluent going to the $216-\mathrm{Z}-20 \mathrm{Crib}$ is either equipment cooling water or heating and ventilation steam condensate, neither of which comes into contact with process materials or chemicals under normal operating conditions. The only exception to this was the possibility of an overflow from the drains in the two aqueous makeup (AMU) chemical preparation areas, al though there was a sump in each of these areas sized to hold the contents of the largest chemical tank. A recently completed project rerouted these drains to a catch tank, where any solution can be held and sampled to determine its eventual disposition and the room floor drains in the AMU were plugged.

Previously no alternative to the discharge of safety-related effluents (e.g., cooling water) to the 216-Z-20 Crib existed. Such effluents could not be eliminated without serious consequences to personnel saftey. For example, a major portion of such effluent consists of air compressor cooling water; if this water is turned off, ventilation control instruments and associated ventilation equipment throughout the plant would cease to operate. In turn this would cause a loss of the carefully adjusted, staged negative pressure that ensures confinement of the radioactive materials within the process areas. Thus, it is essential that the ventilation system operates continuously. The air compressor and related cooling water will be permanently isolated from the discharge lines to the 216-Z-20 Crib by January 1994 when the recently constructed closed-100p cooling system is activated. This will contribute to a major reduction in wastewater flow to the crib (i.e., a reduction to approximately 23 to $45 \mathrm{~L} / \mathrm{min}$ [6 to $12 \mathrm{gal} / \mathrm{min}$ ] by January 1994).

Effluents discharged from the PFP Complex to the 216-Z-20 Crib before 1985 are assumed to include small concentrations of most chemicals in use at the plant. In 1986, Ecology imposed limits on discharges of hazardous waste. Subsequently, routine discharges of process and maintenance chemicals that exceeded those limits (Washington Administrative Code [WAC] 173-303) ceased.

\subsubsection{6-Z-20 Crib and Related Waste Streams}

The 216-2-20 Crib was constructed and commissioned for use in September 1981 to dispose of wastewater previously discharged to 216-U-10 Pond via the 216-Z-19 Ditch. Construction of the 216-Z-20 Crib allowed the radioactively contaminated 216-Z-19 Ditch and 216-U-10 Pond to be decommissioned.

Two liquid waste facilities were actually built. The 216-2-20 Crib was designed and constructed to dispose of potentially radioactive liquid effluents from the $231-Z, 232-Z, 236-Z, 242-Z, 291-Z, 234-5 Z$, and 2736-ZB Buildings. A seepage basin, 207-Z (1ater renamed 216-Z-21), was designed and constructed to dispose of noncontaminated water from the storm sewer north of the 234-5Z Building. 
The 216-z-20 Crib is approximately $457 \mathrm{~m}(1,500 \mathrm{ft})$ long and approximately $3 \mathrm{~m}(10 \mathrm{ft})$ wide in cross section at the bottom. A diagram of the original crib is provided in Figure 4. Gravel was used to backfill the crib excavation to a depth of approximately $0.8 \mathrm{~m}(2.6 \mathrm{ft})$. Perforated pipes, connected to the building effluent headers, were embedded in the gravel backfill to evenly distribute effluents throughout the crib (shown in cutaway view in Figure 5). A vapor barrier was placed above the gravel backfill and local soil was placed over the vapor barrier to make it a level surface with the surrounding grade. Modifications to the original design to improve drainage (as discussed in the following paragraph) are shown in Figures 6 and 7 .

In early 1984, liquid-level measurements in the 216-2-20 Crib were initiated. Liquid levels were discovered to be rising at a time when discharges to the crib were believed to be relatively constant. This trend suggested that the crib's infiltration capacity was being exceeded. As a result of an investigation into this problem, crib coring and core analysis were performed. The liquid-level problems were thought to be caused by compaction of cribbed soll caused by the use of heavy construction equipment, siltation of the crib, and an assumption of a much lower rate of discharge to the crib for design sizing calculations than the rate that was actually experienced. Formation of chemical precipitates was also considered as a contribution to the loss in inflitration capacity. In late 1987, 30 additional vertical drainage boreholes were installed to accommodate the difference between the original design's assumed infiltration rate and the actual infiltration rate. Additionally, nonradiologically contaminated cooling water streams were segregated from the 216-2-20 Crib and routed to the 216-Z-21 (formerly 207-Z) seepage basin beginning in 1988, further reducing wastewater flows to the $216-2-20 \mathrm{crib}$.

As noted previously, Tri-Party Agreement milestone M-17-00 is a major milestone, with completion scheduled for June 1995, for liquid effluent treatment facilities or upgrades for 19 streams being discharged to cribs on the Hanford Site. The PFP Complex effluent discharged to the 216-Z-20 Crib is 1 of the 19 streams. The PFP Wastewater Treatment, Project B-680, is complete and is scheduled for first use in fall 1993 or early 1994. Project B-680 will eliminate the discharges to the 216-2-20 Crib of those solutions with constituents not meeting water quality standards (WAC 173-200; WHC-CM-7-5). Best available technology for segregation and recycle of cooling water streams will be implemented with treatment of the remaining discharge streams. Another project, with construction completed in 1990, was Project $\mathrm{C}-035$ (AMU Installment Upgrade and Sp 111 Containment). Although there is a sump in each of the AMU areas, which is sized to hold the contents of the largest chemical tank, Project $\mathrm{C}-035$ was constructed to preclude the possibility of an overflow from the drains in the two AMU chemical preparation areas. This project has rerouted these drains to a catch tank, where any solution can be held and sampled to determine its eventual disposition.

\subsection{EFFLUENT SOURCE DESCRIPTION}

The PFP Complex effluent streams discharged to the 216-2-20 Crib are produced by drinking fountains, cooling water, steam condensate, air conditioning condensate, chemical laboratory sinks, nonradiological laboratory 
Figure 4. Plot Plan and Design Detałl for Original 216-2-20 Crib.

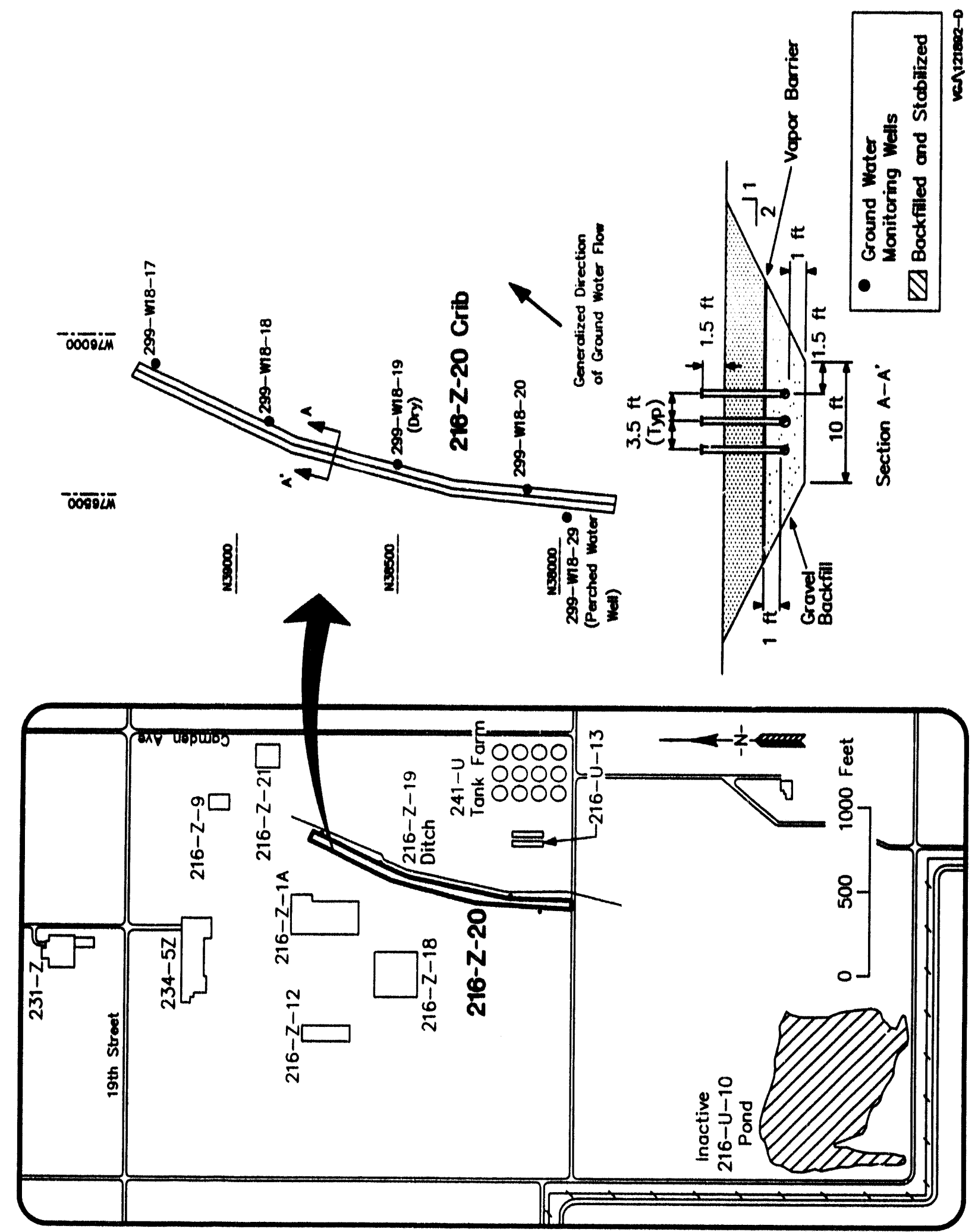


Figure 5. Cutaway Diagram of the 216-2-20 Crib (Original Design).

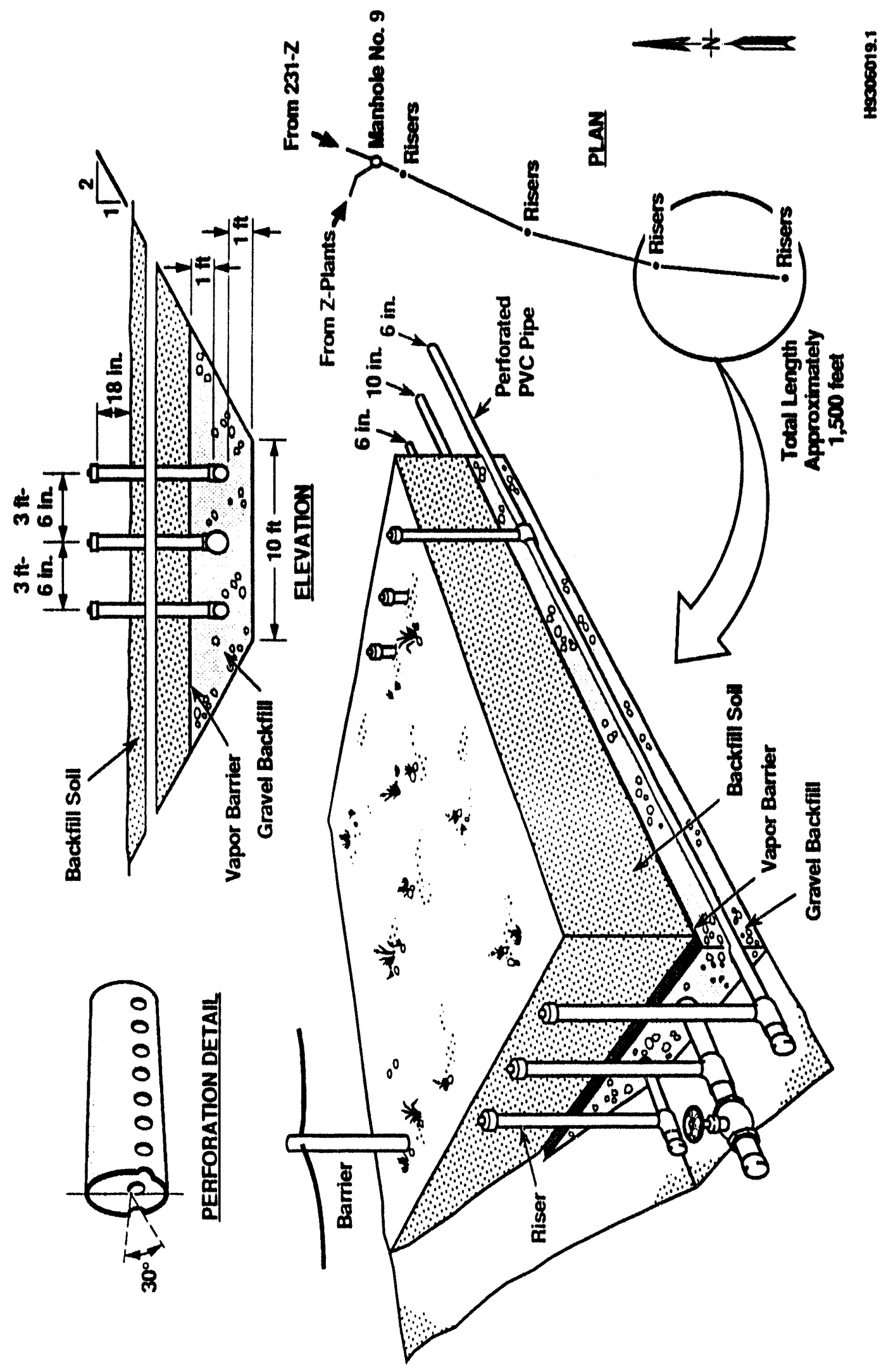


Figure 6. Cross Section Showing Design ilodification of the 216-2-20 Crib (1987).

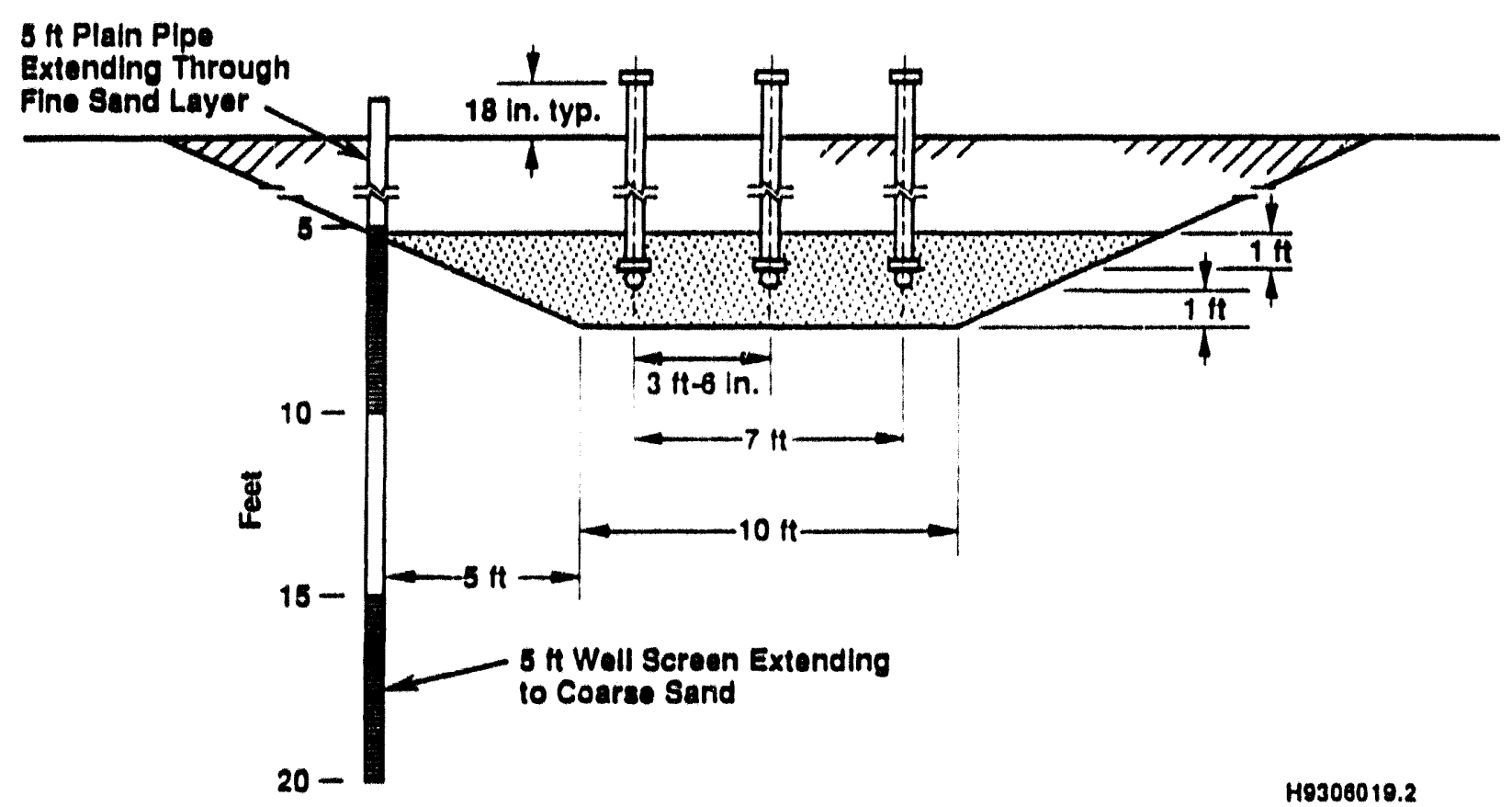


Figure 7. Vertical Drainage Borehole Locations in the 216-2-20 Crib.

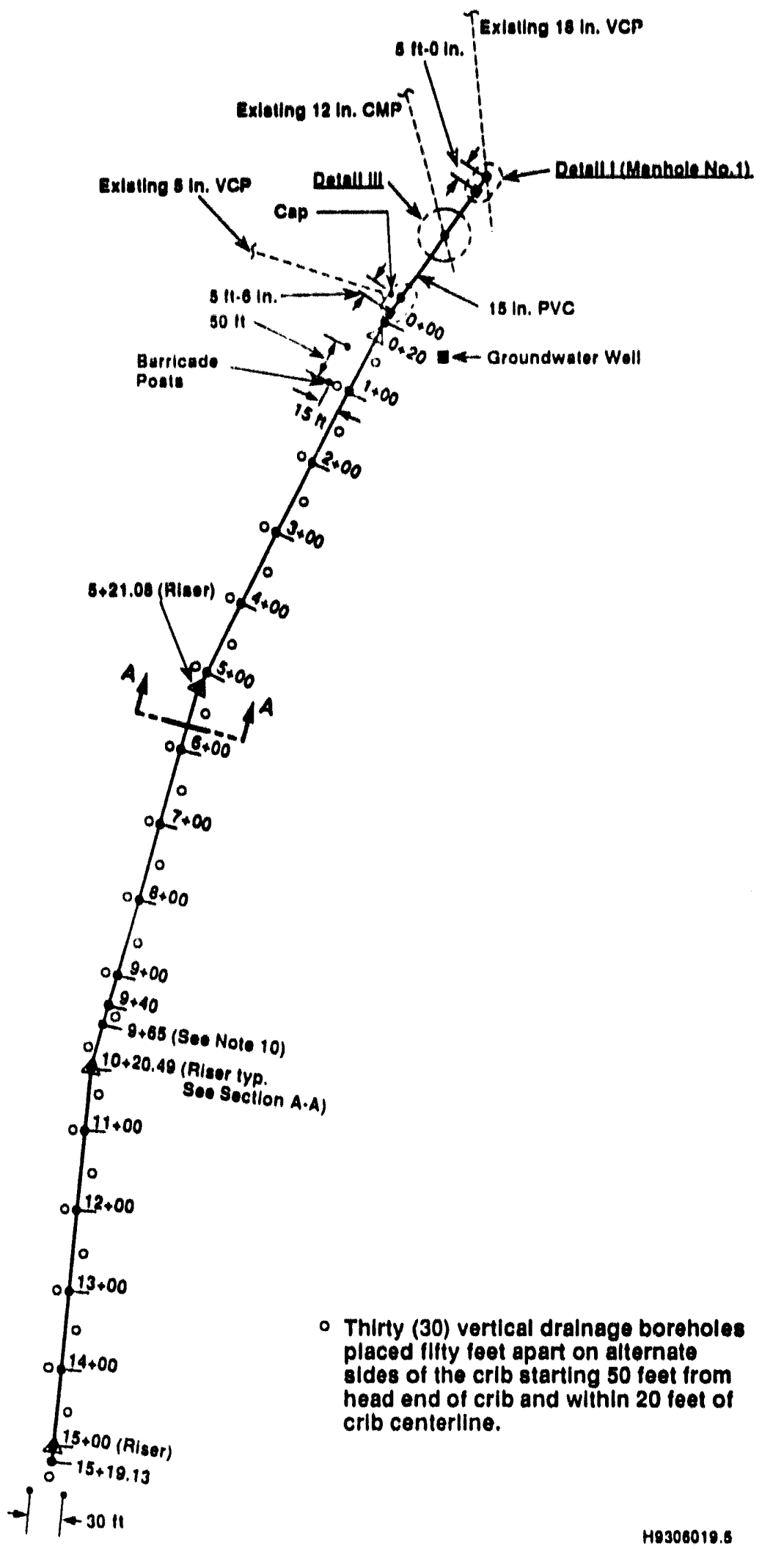


sinks in radiation zones, wound flushing stations, eyewash stations, safety showers, floor drains, roof drains, and storm sewers south of the 234-52 Building. This stream flow, its constituents, and their concentrations will vary depending on plant operations and seasonal changes.

Although current processes at the PFP Complex involve recovery of radioactive material, the chemicals and water used for the processing are not released to the 216-2-20 Crib. This material goes to another facility, and eventually to storage tanks. There is no process solution contact with $\mathrm{crib}$ effluents under normal operating conditions. The vast majority of the effluent that does go to the 216-2-20 Crib is either equipment cooling water or heating and ventilation steam condensate, neither of which comes into contact with process materlals or chemicals under normal operating conditions. The routine contributor streams do not contribute to the chemicals of concern in this report. Typically these streams are sanitary water streams with the same constituents as those of the supplied river water with treatment chemicals added. The only exception to this was the possibility of an overflow from the drains in the two AMU chemical preparation areas, although there is a sump in each of these areas sized to hold the contents of the largest chemical tank. Additionally, these drains were recently rerouted to a catch tank, where any solution can be held and sampled to determine its eventual disposition.

Major chemicals historically or currently used or stored in the PFP Complex bulldings are presented in Table 1 . These chemicals are not necessarlly discarded or eliminated in a manner that contributes to the effluent waste stream. Table 1 is furnished only to provide an indication of the avallable chemicals that potentially could have contributed to the waste stream through spills or other accidents.

Effluent monitoring capability consists of an online alpha monitor for effluent radionuclide activity level, a flow-proportional grab sampler, a $\mathrm{pH}$ probe, and a flow probe. The alpha monitor and the grab sampler are in the 2904-ZA Building (Figure 8). The $\mathrm{pH}$ and flow probes are near Manhole 9 in the 2904-2B Building (see Appendix A).

The grab sampler draws an al iquot approximately every 7 minutes from the effluent stream and deposits this into a receiving vessel (a 19-L- [5-gal-] capacity plastic carboy). An al lquot ranging from 1 to $4 L(0.3$ to $1 \mathrm{gal})$ is removed from the carboy during each shift and sent to the 222-S Laboratory for analysis. The laboratory adds preservatives, stores the sample, and prepares a monthly composite for analysis. The grab sampler provides some redundancy to any samples taken at Manhole 9 .

The $\mathrm{pH}$ and flow probes both send signals to a date- and time-stamped paper strip chart, which records these parameters for each month. A pH alarm signal is sent to at least one continuously manned location.

\subsection{ADJACENT WASTE FACILITIES}

This section summarizes descriptions of waste management facilities and estimates of their radiological and chemical inventory in the immediate vicinity of the 216-2-20 Crib. This information will be used to assess the 
Table 1. Major Process Chemicals Used in the Plutonium Finishing Plant and Related 2 Plant Processes.

\begin{tabular}{|c|c|}
\hline Chemical name & MSOS Number \\
\hline Aluminum nitrate & 1018 \\
\hline Antifoam concentrate & 10329 \\
\hline Carbon tetrachloride & 1102 \\
\hline Hydrofluoric acid & 1251 \\
\hline Hydrogen peroxide & $1257 / 1742$ \\
\hline Hydroxylamine nitrate & 1264 \\
\hline lodine & 1266 \\
\hline Mistron (talc-powder) & 14033 \\
\hline Nitric acid & 1384 \\
\hline Oxaltc acid & 81 \\
\hline Potassium hydroxide & 114 \\
\hline Potassfum permanganate & $1445 / 2055$ \\
\hline Sodium carbonate & 223 \\
\hline Sodium hydroxide & 226 \\
\hline Sodium nitrite & 1495 \\
\hline Tributyl phosphate & 235 \\
\hline
\end{tabular}

MSOS - Material Safety Data Sheet.

"Mistron is a trademark of Cyprus

Industrial Minerals Company. 
Figure 8. Schematic of Plutonium Finishing Plant Effluent Sources, Routing, and Sampling Points (Pre-1993).

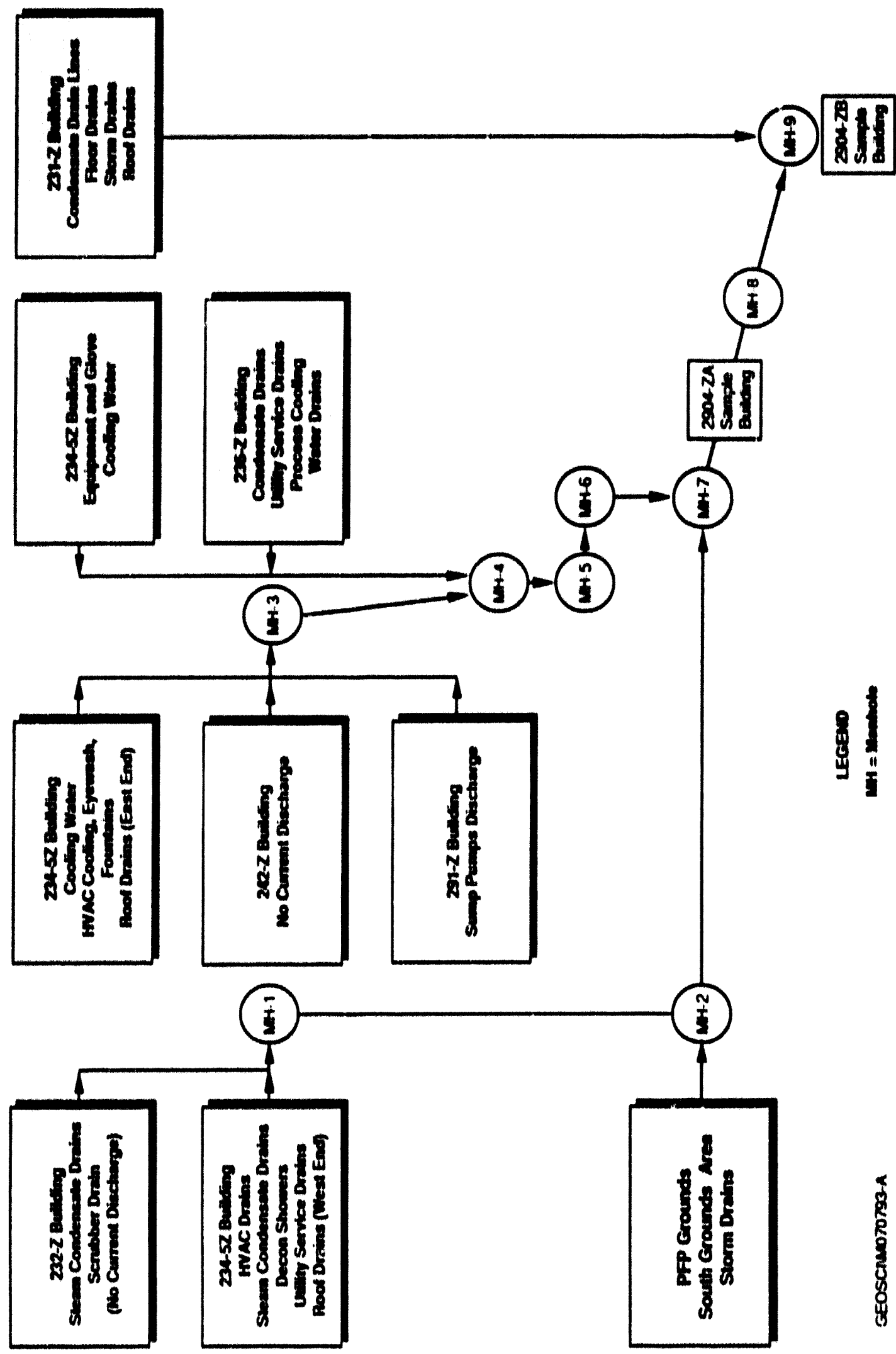


possible impact of recent 216-2-20 Crib operations on adjacent facillties as well as potentlal effects of adjacent past-practice waste disposal sites on groundwater quality near the 216-2-20 Crib.

\subsubsection{6- -10 Pond}

The decommisstoned 216-U-10 Pond is located $37 \mathrm{~m}$ (120 ft) southwest of the active section of the pond's 216-U-14 Ditch. The pond was constructed in 1944 to receive low-level liquid effluent. At its maximum extent, the pond covered approximately $12 \mathrm{ha}\left(30\right.$ acres) and received more than $1.63 \times 10^{\mathrm{pl}} \mathrm{L}$ $\left(4.3 \times 10^{18} \mathrm{gal}\right)$ of contaminated liquid. The 216-U-10 Pond was deactivated in 1985. After deactivation, the pond was stabllized with a minimum of $1.2 \mathrm{~m}$ $(4 \mathrm{ft})$ of clean soll. The pond system consisted of two primary open-ditch conveyances that served the $2 \mathrm{Pl}$ ant, $U \mathrm{Plant}$, and $\mathrm{m} / \mathrm{sce} / \mathrm{l}$ aneous facilities: the 216-2 Ditches and the 216-U-14 Ditch (Figure 9). (Also see Figure 2 for locations in relation to the $216-2-20$ (rib.)

The estimated radiological inventory for the 216-U-10 Pond includes $8.2 \mathrm{~kg}\left(18 \mathrm{ib}\right.$ ) plutonium, $1,500 \mathrm{~kg}(3,300 \mathrm{ib})$ uranium, 15.3 curles $(\mathrm{C} 1)^{137} \mathrm{Cs}$, and $22.6 \mathrm{Cl} \mathrm{Sr}$. Radionuclides detected in U pond sediment samples before

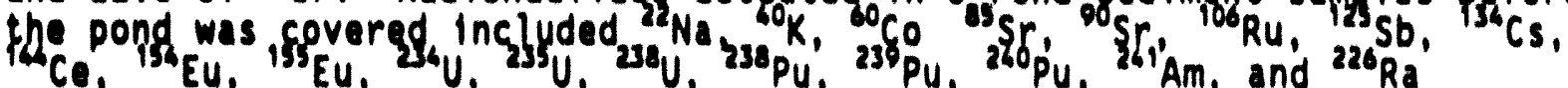
(RHO-HS-SA-19 [Last ot al. 1981]).

The lateral extent and persistence of perched water from the large volume of wastewater discharged to this site are unknown. It is possible that lateral migration may have extended to the southern end of the 216-2-20 Crib.

The groundwater mound resulting from the large volume of water discharged to the 216-U-10 Pond system had a major impact on the direction of groundwater flow and transport in the vicinity of the 216-2-20 Crib. Today the influence of the residual groundwater mound is modifled by the continual inputs of wastewater from the 216-U-14 Ditch, as well as from the 216-2-20 Crib and the 284-WB Powerplant Ponds.

\subsubsection{6-2-10 Ditch}

The 216-2-10 Ditch is located about $152.5 \mathrm{~m}(500 \mathrm{ft})$ northwest of the 216-U-14 Ditch. The 216-2-10 Ditch operated from December 1944 unt 11 March 1959 as a liquid disposal site for 2 Plant operations. Z Plant operations included the PFP, the Recuplex Plutonium Recovery Plant, the PRF, and the Waste Treatment and Americium Recovery Facility. The 216-2-10 Ditch received approximately $1,000,000 \mathrm{~L}(264,173 \mathrm{gal})$ of process cooling water, steam condensate, and vacuum pump sealant waters from the 321-2, 234-52, and 291-2 Bulldings. Wastewater from this factlity drained into the 216-U-10 Pond. The 216-2-10 Ditch was deactivated and replaced by the 216-2-11 Ditch in 1959. An estimated $140 \mathrm{Cl}$ of $23,240 \mathrm{Pu}$ and unknown amounts of $\mathrm{CCl}_{4}$ and tributyl phosphate (TBP) were released to the ditch. 
Figure 9. The 216-U Pond System (Pre-1981 Configuration).

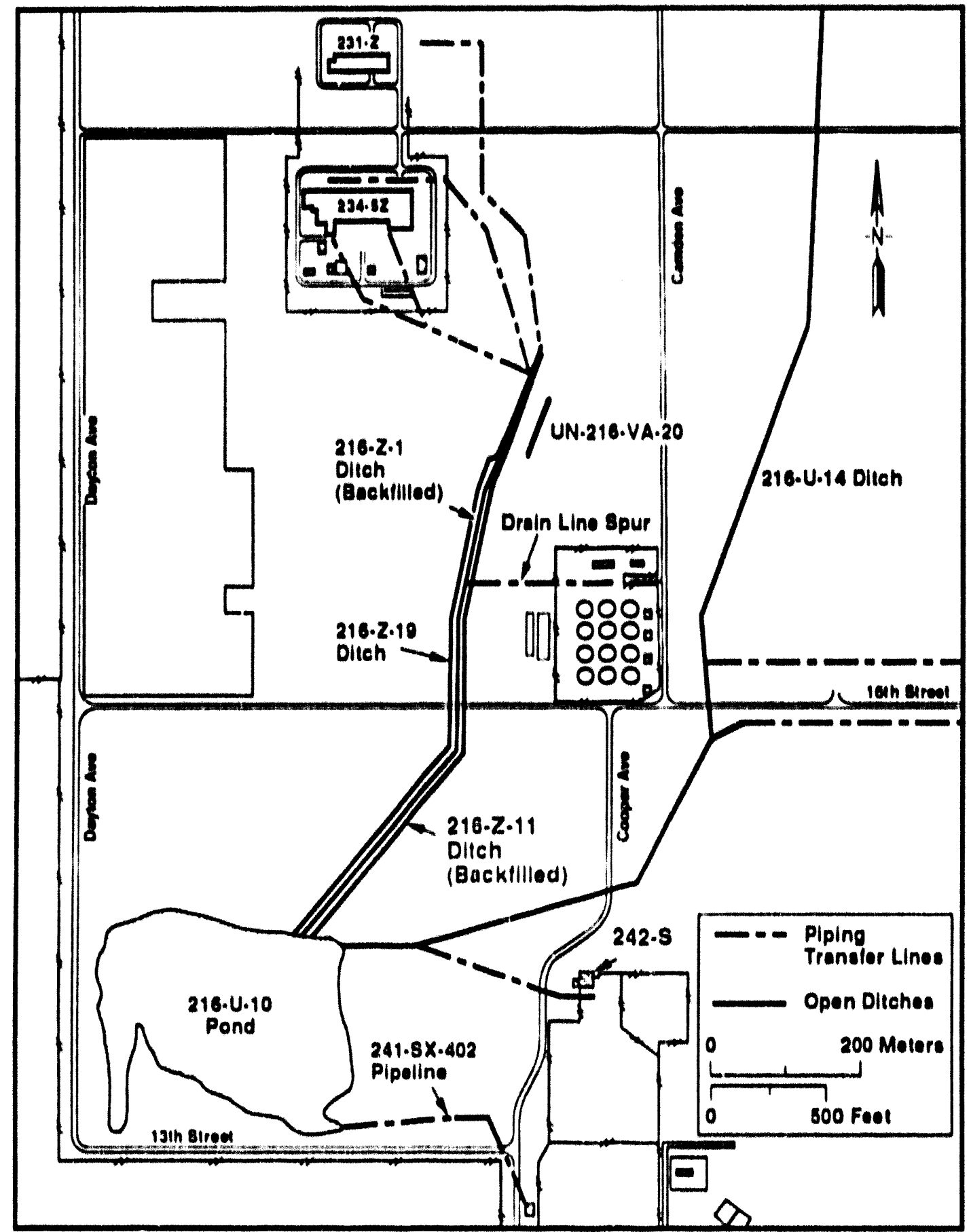

H0308033.1 
WHC-EP-0674

\section{$2.3 .3216-2-11-2$ D1tch}

The 216-2-11-2 Ditch is located about $152.5 \mathrm{~m}(500 \mathrm{ft})$ northwest of the 216-U-14 Ditch boundary. The 216-2-11 Ditch began operations in 1959 and served as a replacement ditch for the 216-2-10 Ditch. It paralleled the earlier ditch from a point immediately east of the 241-2 Building to the 216-U-10 Pond. The 216-Z-11 Ditch recelved 11quid waste from PFP operations unt11 it was deactivated and replaced by the 216-2-19 Ditch in 1971. The site was stabilized (1.e., backfilled and graded) when it was retired. Additional f111 was added during the deactivation of the 216-2-19 Ditch in 1981. The ditch was $798 \mathrm{~m}(2,618 \mathrm{ft})$ long, $0.6 \mathrm{~m}(2 \mathrm{ft})$ deep, and $1.2 \mathrm{~m}(4 \mathrm{ft})$ wide at the bottom with side slopes of $2: 5: 1$ and $0.05 \%$ grade.

The chemical inventory for the ditch is reported as part of the 216-U-10 Pond inventory (WHC 1991). The total volume of liquid processed is not reported.

\subsubsection{6-2-19 Ditch}

The 216-2-19 Ditch is about $305 \mathrm{~m}(1,000 \mathrm{ft})$ northwest of the 216-U-14 Ditch at its closest approach. The 216-2-19 01tch operated from May 1971 unt 11 September 1981 and replaced the 216-2-11-2 Ditch as a liquid waste disposal site for the varlous PFP facllities. The ditch received process cooling waste and steam condensate from the 234-52 Building, vacuum pump seal water from the 291-2 Building, and cooling water from the 231-2 Bullding. The total volume of liquid processed is not reported.

An extensive soll/sediment sampling effort was conducted in ca. 1980 that revealed high concentrations of $230^{\circ} \mathrm{a}$ and ${ }^{26} \mathrm{Am}$ in the top $5-\mathrm{cm}(2-1 \mathrm{n}$. sections of cores taken from the center of the ditch at various locations (Last et al. 1981). The TRU releases to the ditch resulted from accidental splllage of aqueous product. Maximum soll concentrations found in the ditch were nearly 100,000 picocuries per gram ( $\mathrm{pCl} / \mathrm{g})$ of $239,240 \mathrm{Pu}$ and $29,000 \mathrm{pCl} / \mathrm{g}$ of "Am. Oniy trace amounts of fission products were found. The TRU contaminants appeared to be within the upper $30 \mathrm{~cm}(12 \mathrm{in}$.$) of the soll column$ beneath and or adjacent to the ditch. Thus it is unlikely that lateral migration of water from the $216-2-20 \mathrm{Crib}$, located immediately adjacent to the 216-2-19 Ditch, could come in contact with this previous shallow contaminant loading of the adjacent soll column. Total inventory of plutonfum within the ditch was estimated at several kilograms (Last et al. 1981).

\subsubsection{6-2 Cribs (Potential Carbon Tetrachloride Sources)}

Although $\mathrm{CCl}_{4}$ has never been discharged to the $216-2-20 \mathrm{Crib}$, it is one of the most significant groundwater contaminants in the 200 West Area (Johnson 1993b). Therefore, evaluation of past and continuing sources, espectally near the 216-2-20 Crib, is of particular concern to this GIA. The following summary was excerpted from Rohay and Johnson (1991).

2.3.5.1 Process Description. Historically, $\mathrm{CCl}_{4}$ was used, in mixtures with other organics, to recover plutonium from aqueous streams containing plutonium 
nitrate. Solvent extraction processes using pulse columns were used in the PRF and its pllot facllity, the Recuplex, to recover the plutonium.

The extraction process involved an aqueous feed containing impurities and plutonium entering the bottom of the column, whlle the dense organic stream entered the top. As the aqueous stream moved upward and the organic stream moved downward in the column, the organic phase extracted the plutonium from the aqueous stream. The plutonium then left the bottom of the column with the dense organic stream, and most of the impurities left the top of the column with the aqueous waste. The plutonium-rich organic phase then entered another extraction column, where the organic stream was stripped of its plutonium by another aqueous stream. Although the solvent was recycled routinely, it was perlodically purged and discharged as waste to the soll column until 1973. (Release history is discussed in greater detall later in this section.)

The organic stream in the process consisted of a mixture of $\mathrm{CCl}_{4}$ and TBP. The TBP forms several complexes with the plutonium in the organic phase, thus extracting the plutonium from the aqueous phase. The $\mathrm{CCl}_{4}$ was added as a dlluent (meaning that the TBP was diluted with $\mathrm{CCl}_{4}$ ) for several reasons:

(1) To increase the density of the organic stream. (TBP alone has a density nearly equal to that of the aqueous stream; the extraction processes require that the aqueous and organic streams have significantly different densities.)

(2) To dissolve the TBP while remaining immiscible with the aquinus stream.

(3) To serve as a fire suppressant in combination with the TBP, thereby reducing the potential for fire in the process.

(4) To reduce the viscosity of the TBP, thus improving mass transfer.

$\mathrm{CCl}_{4}$ was also used, in lesser amounts, in the americium recovery process as a diluent for dibutyl butyl phosphorate (DBBP) and in lubrication oil for machining of metal parts.

The aqueous waste stream, characterized as a high-salt aqueous waste, was primarlly a concentrated nitrate solution that had a $\mathrm{pH}$ of 1 (Kasper 1982). The aqueous phase was saturated with organic liquids consisting of $\mathrm{CCl}_{4}, \mathrm{TBP}_{\text {, }}$ and DBBP; the organic content of the aqueous phase was <1\%. Large quantities of aqueous wastes were also discharged to the soll column through the same cribs that received the organic liquids described above. Some of this waste may have been released occasionally (accidentally) to the $Z$ Ditches located immediately adjacent to the 216-2-20 crib.

The chemical processes used to recover plutonium resulted in the production of actinide-bearing aqueous and organic waste ljquids. The primary radionuclide components of these liquids were ${ }^{230,240} \mathrm{Pu}$ and $24 \mathrm{Am}$.

2.3.5.2 Recuplex Operations. The Recuplex Facility, located in the 234-5Z Building (see Figure 2), operated from 1955 through 1962. Initially it was a semiworks (pilot) plant and was later used as a semiproduction operation. Serving as a multipurpose solvent extraction plant for plutonium 
purification and fabrication production lines, the Recuplex Facility's main purpose was to recover plutonium from various $Z$ Plant streams.

Two solvents were used for the entire period of plant operation. An 85:15 ratio (by volume) of $\mathrm{CCl}_{4}$ to TBP was used in the extraction and stripping columns for the bulk of the separations. A 50:50 ratio of $\mathrm{CCl}_{4}$ to DBBP was used for batch rework of process liquids that did not meet waste discharge specifications because of high plutonium concentrations.

Other ratios of $\mathrm{CCl}_{4}$ to TBP were tested during the semiworks ( $\mathrm{pilot}$ ) period of operation and were used during plant operation, but 85:15 gives the most conservative estimate and is used for all Recuplex waste volume calculations in this report.

With exposure to ionizing radiation and nitric acid, the TBP with in the soivent would gradually degrade to dibutyl phosphate (DBP). DBP has a much greater affinity for plutonium than TBP and would not work in the process because of its poor stripping properties. The degraded solvent was periodically discharged batchwise, and was replaced with fresh solvent. Each batch of TBP-based solvent was $200 \mathrm{~L}$ (53 gal). All solvent discharges were received by the 216-Z-9 Trench.

Degradation products of $\mathrm{CCl}_{4}$ include chloroform and methylene chloride. Breakdown products of TBP include DBP, monobutyl phosphate (MBP), and butyl alcohol.

On occasion, aqueous 1 iquid from the primary extraction column would exceed the maximum allowable plutonium concentration. To reclaim plutonium, a batch of aqueous liquid was mixed with DBBP solution. The organic phase would extract most of the plutonium, leaving aqueous phases that met the waste discharge concentration specification. The aqueous phase was discharged, and the DBBP solution was stripped, providing for the recycle of plutonium to the Recuplex feed. The DBBP solution was then discharged to the 216-2-9 Trench. Each batch of DBBP-based solvent was $100 \mathrm{~L}(26 \mathrm{gal})$.

The DBBP solution was not retained because of the danger of mixing it with the TBP-based solvent. It was kept completely separate from the TBP-based solvent because the properties of both would be destroyed if mixed.

Tetrachloroethylene (also called perchloroethylene) and tetrabromoethane were used at different times in combination with $\mathrm{CCl}_{4}$ as a diluent for TBP or for cleaning agents (Smith 1973).

2.3.5.3 PRF Operations. Recuplex operation was discontinued after a criticality incident in April 1962 and it was replaced in 1964 by the PRF, which operated until 1979 and again from 1984 through 1987 . The facility is scheduled to resume operation sometime in 1994 to complete one operation campaign for the purpose of stabilizing reactive materials remaining in the PFP Complex. PRF is housed in the 236-z Building (see Figure 3 ).

PRF had essentially the same mission as the Recuplex and used similar but superior solvent extraction column technology with $\mathrm{CCl}_{4} /$ TBP as the extractant. An $80: 20$ ratio (by volume) was used. 
Solvent degradation continued to be a problem and degraded solvent was again disposed of to the soil column, this time through the 216-Z-1A Tile Field (1964 through 1969) and the 216-Z-18 Crib (1969 through 1973). No solvent was sent to cribs after May 1973 (Rohay and Johnson 1991). From 1973 to the present, these wastes were routed to the tank farms.

An americium recovery facility, the Waste Treatment and Americium Recovery Facility in the 242-Z Building (see Figure 3 ), was added on to the PRF and also began operation in 1964. The process used a 70:30 volumetric mixture of $\mathrm{CCl}_{4}$ and DBBP. Between 1964 and 1970, americium was recovered by a batch operation. Between 1970 and 1976, this process operated as a continuous countercurrent solvent extraction process. The $\mathrm{CCl}_{4} /$ DBBP mixture was discharged to the 216-Z-1A Tile Field from 1964 through 1969 and to the 216-Z-18 Crib from 1969 through 1973, both of which are located immediately west of the 216-Z-20 Crib (see Figure 4). This ancillary waste treatment facility was operated concurrently with the PRF and was not considered a separate operation.

2.3.5.4 Lubrication 0il. Another source of $\mathrm{CCl}_{4}$ discharged to the soil involved a cutting oil used in 2 Plant. "Fabrication oil" (a 75:25 volumetric mixture of $\mathrm{CCl}_{4}$ and lard oil) was used as a lubricant on 2 Plant plutonium cutting and milling tools. In 1967, the composition of stored fabrication oil was estimated to be 50:50 volumetric mixture of $\mathrm{CCl}_{4}$ and 1 ard $0 i 1$ because of evaporation of $\mathrm{CCl}_{4}$ (Appendix $\mathrm{B}$ of Sloat 1967). The $\mathrm{CCl}_{4}$ was al so used to clean the cutting oil from the millings and work surfaces. The $\mathrm{CCl}_{4} / 0 \mathrm{il}$ mixture was disposed to the same cribs used for solvent disposal until 1973 when waste was rerouted to the tank farms.

2.3.5.5 Liquid Waste Disposal Facilities. Recuplex- and PRF-generated wastes were chemically and radiologically contaminated, but they were disposed of based on their radiological content. The organic solvent-bearing wastes were classified as intermediate-level wastes and, from 1955 until 1973, were disposed of to the several cribs that supported $Z$ Plant operations.

Two types of cribs exist at $Z$ Plant and both types received $\mathrm{CCl}_{4}$. The first type of crib is an underground chamber that received liquid wastes into a box-like, open-bottomed, underground structure usually made of wooden timbers. The second type of crib is a drain field or tile field. Not unlike a common septic tank drain field, these cribs lack the large open-bottomed chamber and, instead, introduce liquid wastes to soil through many meters of perforated underground pipe. Both types typically rest on a gravel bed to aid in rapid dispersion of liquid to soil. Particulate matter contained in the waste liquid would be filtered by the first few centimeters or decimeters of soil and, thus be effectively contained in the soils immediately beneath the crib. The two types of waste units were sometimes combined to provide a chambered crib overflowing into a drain field.

Certain cribs were designated as specific-retention cribs, meaning that the pore space in the soil column below the crib was intended to hold the wastewater against the force of gravity because of the attractive forces between sediment grains and the liquid (i.e., surface tension). In practice, the total volume of liquid that could be discharged to a disposal site of known dimensions without leakage to the groundwater was determined and specified before discharge to ensure that contaminants did not reach the 
groundwater. After the specified quantity of liquid waste had been discharged, i.e., the specific-retention capacity had been reached, the specific-retention crib was no longer used to receive waste. Specificretention cribs have not been used since 1973 (Rohay and Johnson 1991).

2 Plant disposed of 1 iquid $\mathrm{CCl}_{4}$-bearing solvents and associated aqueous wastes primarily to three waste sites from 1955 until 1973, when solvent discharge to soil was discontinued: (1) the 216-2-9 Trench (a chambered crib), (2) the 216-Z-1A Tile Field (specific-retention drain field), and (3) the 216-z-18 Crib (specific-retention drain field). A small volume of $\mathrm{CCl}_{4}$ may have been discharged to other sites (e.g., 216-z-1 and 216-z-2 Cribs, 216-z-12 (rib, 216-z-19 Ditch).

2.3.5.5.1 216-Z-9 Trench. The 216-Z-9 Trench operated from 1955 through 1962 to receive all solvent and aqueous wastes discharged to soil by the Recuplex Facility. No other cribs were used for this purpose. Furthermore, the 216-z-9 Trench only received wastes from the Recuplex Facility.

The 216-2-9 Trench is an enclosed earthen trench, located about $215 \mathrm{~m}$ (705 ft) east of the 234-5Z Building and about $150 \mathrm{~m}(492 \mathrm{ft}$ ) south of 19th Street. The base of the trench is an $18.3-$ by $9.1-\mathrm{m}(60-$ by $30 \cdots \mathrm{ft}$ ) excavation, and is $6.1 \mathrm{~m}(20 \mathrm{ft})$ deep. The surface is a $36.5-$ by $27.4-$ by $0.23-\mathrm{m}-$ (120- by $90-$ by $0.75-\mathrm{ft}-$ ) thick concrete trench cover at ground level. Waste was transferred by gravity through one of two $3.8-\mathrm{cm}(1.5-\mathrm{in}$.$) stainless$ steel lines that entered the trench about $5 \mathrm{~m}(16 \mathrm{ft})$ above its bottom. The concrete pad is supported by six, 7-m- $(23-\mathrm{ft}-)$ tall concrete columns (Ludowise 1978; Owens 1981; WHC 1991a).

Because of the high salt content and acidic nature of the Recuplex wastes, considerable gassing and soil plugging were expected when the wastes contacted the soil. As a result, the enclosed trench volume and active floor area were designed to handle the slow percolation rates of the wastes. However, the 216-z-9 Trench was not designed as a specific-retention facility (Brown et al. 1990).

2.3.5.5.2 216-Z-1A Tile Field. The 216-Z-1A Tile Field was constructed in 1949 and was used between 1949 and 1959 to receive overflow liquid waste from three adjacent cribs $(216-z-1,216-z-2$, and $216-z-3)$. The waste stream consisted of basic ( $\mathrm{pH} 8$ to 10 ) process waste and analytical and development laboratory waste from $Z$ Plant via the 241-Z Settling Tank. Disposal to these facilities ceased in 1959. However, in 1964, the 216-Z-1A Tile Field was reactivated to receive aqueous and organic waste from the PRF in the 236-Z Building and the 242-Z Waste Treatment and Americium Recovery Building. This waste stream was routed directly to the tile field.

Between 1964 and 1969, the tile field was divided into three operational sections ( $Z-1 A A, Z-1 A B, Z-1 A C)$ to preclude waste buildup at the northern end of the field. This tile field was designed and operated as a specificretention facility. No other facility received PRF wastes from 1964 through 1969 except on two brief occasions while modifications were being made to the tile field effluent piping and PRF wastes were discharged to the 216-Z-1 and 216-Z-2 Cribs. 
The 216-Z-1A Tile Field is a drain field located about $150 \mathrm{~m}$ (492 ft) south of the 234-5Z Bullding and about $300 \mathrm{~m}(984 \mathrm{ft}$ ) west of Camden Avenue (Figure 10). The tile field has surface dimensions of approximately 60 by $110 \mathrm{~m}$ (197 by $361 \mathrm{ft}$ ). The side walls of the $5.8-\mathrm{m}-(19 \mathrm{ft}-$ ) deep excavation were sloped inward, resulting in a floor dimension for the facllity of approximately 35 by $84 \mathrm{~m}$ ( 115 by $276 \mathrm{ft}$ ). The floor of the excavation was covered by a $1.2-\mathrm{m}-(4-\mathrm{ft}-)$ thick cobble layer with a minimum north-to-south surface slope of $1 \%$. A herringbone pattern of $20-\mathrm{cm}-(8-\mathrm{in} .-)$ diameter pipe, composed of a 79-m- (259-ft-) long, north-southcentral distributor pipe and seven pairs of $21-\mathrm{m}-(69-\mathrm{ft}-)$ long laterals, was placed on this cobble layer. The 30- by 79-m (98- by 259-ft) rectangular area covered by the piping system was then overlain with $15 \mathrm{~cm}(6 \mathrm{in}$.$) of cobbles and 1.5 \mathrm{~m}(5 \mathrm{ft})$ of sand and gravel. A sheet of $0.05-\mathrm{cm}-(0.02-i \mathrm{n} .-)$ thick polyethylene covered by $30 \mathrm{~cm}$ (12 in.) of sand and gravel was also added to the factlity. Effluent piping in the 216-2-1A Tile Field is vitrified clay pipe. The central distributor pipe is a continuous line, without perforations; the laterals are divided into $0.3-\mathrm{m}-(1-\mathrm{ft}-)$ long segments. A $5-\mathrm{cm}-(2-i \mathrm{n} .-)$ diameter stainless steel pipe was added inside the central distributor clay pipe as the field was modified into three operational sections (Price et al. 1979; Owens 1981). The tile field has not been backfilled; the surface remains about $2.5 \mathrm{~m}(8.2 \mathrm{ft})$ below grade.

The 216-Z-1 and 216-Z-2 Cribs received PRF aqueous and organic wastes for a few weeks in 1966 and again in 1967 while modifications were being made to the 216-Z-1A Tile Field. The cribs are located immediately north of the 216-Z-1A Tile Field. They are wooden box structures arranged in a north-south line. Each crib is 3.7 by 3.7 by $4.3 \mathrm{~m}$ ( 12 by 12 by $14 \mathrm{ft}$ ) high, constructed of 15- by $15-\mathrm{cm}$ ( 6 - by 6-in.) timbers, and has a open bottom. Each box stands in a $4.3-\mathrm{m}(14-\mathrm{ft})$ square by $6.4-\mathrm{m}-(21-\mathrm{ft}-)$ deep, backfilled excavation. By design, the 216-z-2 Crib overflowed into the 216-z-1 Crib, which in turn overflowed into the tile field (WHC 1991a).

2.3.5.5.3 216-Z-18 Crib. The 216-Z-18 Crib operated from 1969 through 1973, receiving PRF aqueous and organic wastes as a replacement for the 216-Z-1A Tile Field. The 216-z-18 Crib is a drain field-type crib located southwest of the $216-Z-1 A$ Crib and about $300 \mathrm{~m}$ ( $984 \mathrm{ft}$ ) south of the 234-5Z Building. It consists of five parallel, north-south-oriented Excavations, each 63 by $3 \mathrm{~m}(207$ by $10 \mathrm{ft}$ ), ranging from 4.5 to $5.5 \mathrm{~m}$ (15 to $18 \mathrm{ft})$ deep. A $91-\mathrm{m}-(298-\mathrm{ft}-)$ 1ong, $7.6-\mathrm{cm}-(3-i n .-)$ diameter steel pipe runs east and west, bisecting the length of each excavation. Two $30-m-$ (98-ft-) long, 7.6-cm- (3-in.-) diameter, perforated, fiberglass-reinforced, epoxy pipes exit each side of the steel pipe in each excavation (two lines north and two lines south). These distribution lines are $0.3 \mathrm{~m}(1 \mathrm{ft})$ above the crib bottom in a $0.6-\mathrm{m}-(2-\mathrm{ft}-)$ thick bed of 3.8 to $7.6 \mathrm{~cm}(1.5$ to 3 in.) of gravel. The gravel is covered by a membrane barrier overlain by approximately $15 \mathrm{~cm}$ ( 6 in.) of sand. The excavations are backfilled to grade. The westernmost of the five trenches was never used (WHC 1991a). This crib was designed and operated as a specific-retention facility.

2.3.5.5.4 216-2-12 crib. Located near the northwest corner of the 216-z-18 Crib, the 216-z-12 Crib received analytical and development laboratory waste from the 234-5Z Building from 1959 through 1973. The contribution from the Development and Analytical Laboratories constituted approximately $8 \%$ of the total monthly input to the crib. Although little 
Figure 10. Location of Current Wastewater Discharge Sites in Relation to Past-Practice Carbon Tetrachloride Disposal Facilities.

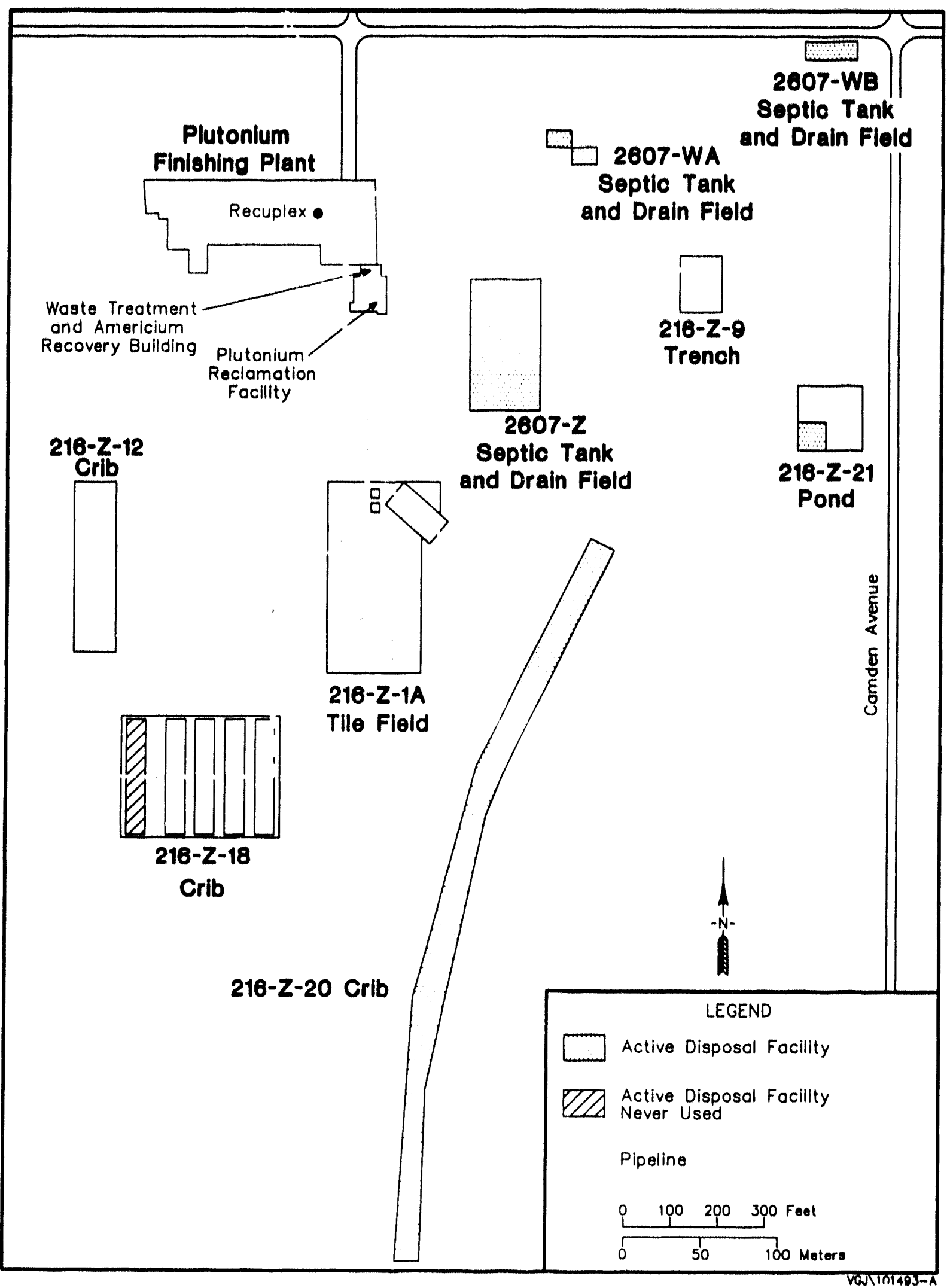


information is avallable on the nature of this waste, it is assumed to be representative of the nature of experimental and analytical work done during that time period. Most of the development work would have been related to studies of separation processes in support of $Z$ Plant operations and probably involved nitrate solutions and organic phases containing $\mathrm{CCl}_{4}$; Bulk organics were collected and disposed of in batches to the $\mathrm{CCl}_{4}$ disposal sites (216-2-9, 216-z-1A, or 216-2-18 Cribs). Thus only a small volume of organics would have been discarded to the 216-Z-12 Crib (Kasper 1981).

As previously noted, the 216-z-19 Ditch was used to convey process cooling water and steam condensate from the 234-5Z Bullding to the 216-U-10 Pond from 1971 through 1981. Apparently $\mathrm{CCl}_{4}$ was al so occasionally or accidentally released to this ditch (Rohay and Johnson 1991).

\subsubsection{Waste Inventories}

The following estimates of the volumes and quantities of various liquids and contaminants discharged to the three principal $\mathrm{CCl}_{4}$ disposal facilities are based on existing documentation, eye witness descriptions, and process knowledge (Rohay and Johnson 1991). A total of 363,000 to $580,000 \mathrm{~L}$ $(95,832$ to $153,120 \mathrm{gal})$ of $\mathrm{CCl}_{4}$ is estimated to have been discharged to the soll column between 1955 and 1973 (Table 2).

It is significant to note that less than $1 \%$ of the above inventory is accounted for as a dissolved phase in the widespread groundwater $\mathrm{CCl}_{4}$ plume beneath the 200 West Area. Thus, a very small fraction of the total discharged to the soll column can cause widespread groundwater contamination. A major soil remediation project has been underway since 1991 to mitigate the potentially continuing contamination of local groundwater from this source.

\subsubsection{Miscellaneous Waste Streams}

Other noncontaminated water sources that may have an indirect impact on local area groundwater include the septic systems and sanitary drain fields located north of the $216-z-20 \mathrm{Crib}$ (see Figure 10). The significance of water sources in this area is that absorption of $\mathrm{CCl}_{4}$ vapor, emanating from residual liquid-phase $\mathrm{CCl}_{4}$ in the soil column beneath the cribs previousiy described, may serve as an indirect source of groundwater contamination. Thus, even though $\mathrm{CCl}_{4}$ and related organics may not have been discharged to the 216-2-20 Crib, the wastewater may absorb the volatile organics from adjacent facilities and result in a secondary groundwater contamination pathway. The existence of other sources of water near the 216-Z-20 Crib (see Figure 10) may be even larger potential contributors to this hypothetical pathway because of their proximity to higher soil vapor $\mathrm{CCl}_{4}$ concentrations. 
Table 2. Transuranic and Carbon Tetrachloride Inventories for Major Adjacent Past-Practice Disposal Facilities.

\begin{tabular}{|l|c|c|c|}
\hline \multicolumn{1}{|c|}{ Contaminant } & $216-Z-9$ & $216-Z-1 A^{\circ}$ & $216-Z-18$ \\
\hline Carbon tetrachloride (L) & $\begin{array}{c}83,000 \text { to } \\
300,000\end{array}$ & $170,000^{\mathrm{b}}$ & 110,000 \\
\hline Plutonium (kg) & $106^{\mathrm{c}}$ & 57 & 23 \\
\hline Americium (kg) & 2.5 & 1 & -0.4 \\
\hline Total liquid (L) & $4.09 \mathrm{E}+06$ & $5.2 \mathrm{E}+06$ & $3.86 \mathrm{E}+06$ \\
\hline Period of use & $\begin{array}{c}1955 \\
\text { through } \\
1962\end{array}$ & $\begin{array}{c}1964 \\
\text { through } \\
1969\end{array}$ & $\begin{array}{c}1969 \\
\text { through } \\
1973\end{array}$ \\
\hline
\end{tabular}

"From 1949 through 1959, the 216-Z-1A Tile Fleld received approximately $1 E+06 L$ of slightly basic, aqueous waste via overflow from associated $216-2-1,-2$, and -3 Cribs before disposal of PRF waste (Price et al. 1979). From 1964 through 1969, Plutonium Reclamation Facility wastes were discharged directly to the 216-z-1A Crib.

Includes fabrication oll.

${ }^{\circ} 58 \mathrm{~kg}$ were later removed (Ludowise 1978). 


\subsection{EFFLUENT CHARACTERISTICS}

The primary focus of this section is on physical and chemical characteristics of wastewater discharged to the 216-2-20 Crib from 1981 to the present. Past operating conditions are of interest for assessing the status of contaminants stored on the soll column beneath the crlb and the likel thood of additional downward migration in response to additional or future wastewater disposal (addressed in Section 5.0).

\subsection{DISCHARGE VOLUMES AND FLOW REgIME}

Average flow rates, total volume, and related effluent characteristics are summarized in Table 3 . The variation in flow rates of the waste stream discharged to the 216-2-20 Crib and liquid effluent-related events history are summarized in figure 11. The maximum flow rates shown in figure 11 during the 1984 to 1986 period occurred during major PRF campaigns.

Table 3. Effluent Stream Description, Plutonium Finishing Plant Wastewater.

\begin{tabular}{|c|c|}
\hline $\begin{array}{l}\text { Total volume of effluent discharged to } \\
\text { subject recelving site }\end{array}$ & $4.05 E+09 \mathrm{~L}$ from $9 / 81$ to $9 / 93$ \\
\hline $\begin{array}{l}\text { Average effluent discharge rate, by } \\
\text { operat ing mode (Jensen 1990, } \\
\text { WHC-EP-0342, Addendum 8) }\end{array}$ & $\begin{array}{ll}\text { PRF: } & 15.9 \mathrm{~L} / \mathrm{sec}^{\circ} \\
\text { RMC: } & 10.2 \mathrm{~L} / \mathrm{sec}^{\circ} \\
\text { Other: } & 9 \mathrm{~L} / \mathrm{sec} \\
\text { (before } & 1990 \text { ) }\end{array}$ \\
\hline $\begin{array}{l}\text { Current average effluent discharge rate } \\
(9 / 93)\end{array}$ & $3 \mathrm{~L} / \mathrm{sec}$ \\
\hline $\begin{array}{l}\text { Effluent designation (Jensen } 1990 \text {, } \\
\text { WHC-EP-0342, Addendum } 8 \text { ) }\end{array}$ & Nondangerous, radioactive \\
\hline Effluent status & $\begin{array}{l}\text { Active; mode is not PRF nor RMC, } \\
\text { 1.e. "other" discharging to } \\
216-2-20 \text { Crib }\end{array}$ \\
\hline
\end{tabular}

PRF - Plutonium Reclamation Facility.

RMC - remote mechanical "C" (line).

Unpublished data, source is plant operating personnel. 
WHC-EP-0674

Figure 11. Discharge and Event History at the 216-2-20 Crib.

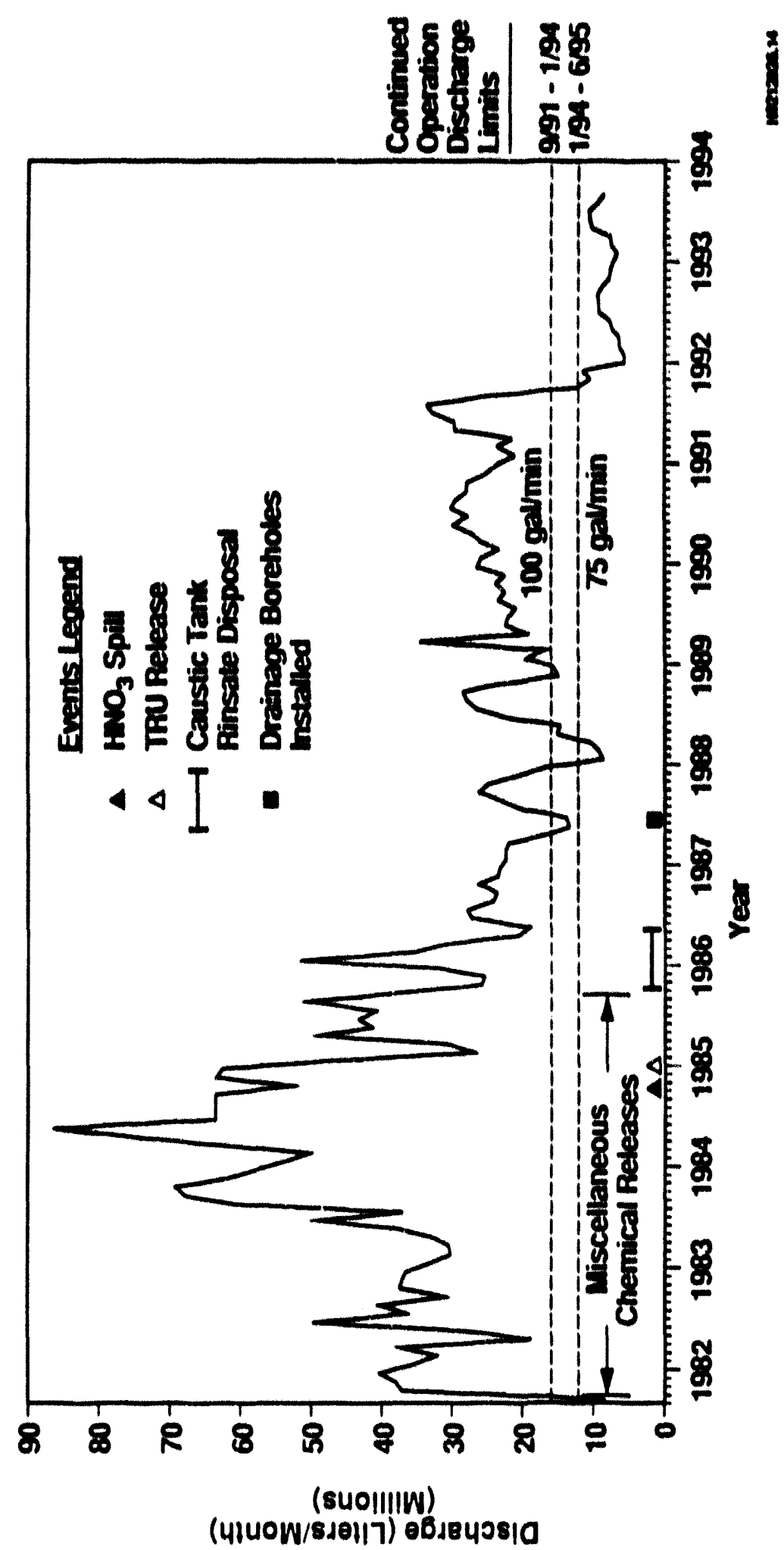


The decline in wastewater discharges to the 215-2-20 crib after January 1986 were in part due to reduced inflitration capacity of the crib. The loss in infiltration capacity that occurred abruptly in January 1986 (Figure 12) as evidenced by the sharp increase in water levels in the crib risers, appeared to be related to a rapid change in operating conditions. For example, correlation with chemical releases (caustlc tank rinsate disposal) during this same perlod suggested that formation of chemical precipitates decreased the porosity of the underlying soll. Consequently, flow rates were reduced significantly after 1986. The reduced inflitration capacity required rerouting of some of the wastewater (storm drains; heating, ventilation, and alr conditioning (HVAC] water; etc.) to a new crib $(216-2-21)$.

\subsection{EFFLUENT CONSTITUENTS, QUANTITIES AND OPERATIONAL FACTORS}

As indicated in Figure 11, both chemical and radioactive wastes were released to the $216-2-20 \mathrm{Crib}$ as a result of spllis and operational releases. Before 1986 process chemical transfer tank rinsates were discharged to the storm sewer that was connected to the drain system routed to the crlb. No record of these releases is avallable, however, it can be assumed that small quantitles of all the major process makeup chemicals listed in Table I were included in tank rinsates. Accidental releases of nitric acid al so occurred, the largest of which involved $3,447 \mathrm{~kg}(7,600 \mathrm{lb})$ in 1984 .

The most significant contaminant loading to the 216-2-20 Crib involved accidental releases of TRUs (plutonium and americium). A total of $1 \mathrm{Cl}$ of 241 Am and $2 \mathrm{Cl}$ of ${ }^{250} \mathrm{Pu}$ was released to the crib, which resulted from contamination of process vessel cooling water in 1985 (Figure 13). Secondary coolant loops have been installed to prevent any recurrence of this type of accidental release.

A summary of key constituents previously identified in the PFP and related waste streams discharged to the 216-2-20 Crib are shown in Table 4. This listing provides an indication of the types and maximum concentrations of known chemical and radioactive constituents discharged to the crib in the past during the operating modes indicated. These include (1) during operation of the PRF, (2) during operation of the RMC line, and (3) operations where neither the PRF nor RMC line were active, referred to as "other." Loading rate estimates for various constituents are shown in Table 5 and estimated total quantities are listed in Table 6.

Effluent chemical and radiological data for the time period of 1986 through 1993 are summarized in Tables 7 and 8 , respectively. 
Figure 12. Correlation of Riser Water Levels and Discharge for the 216-2-20 Crib.

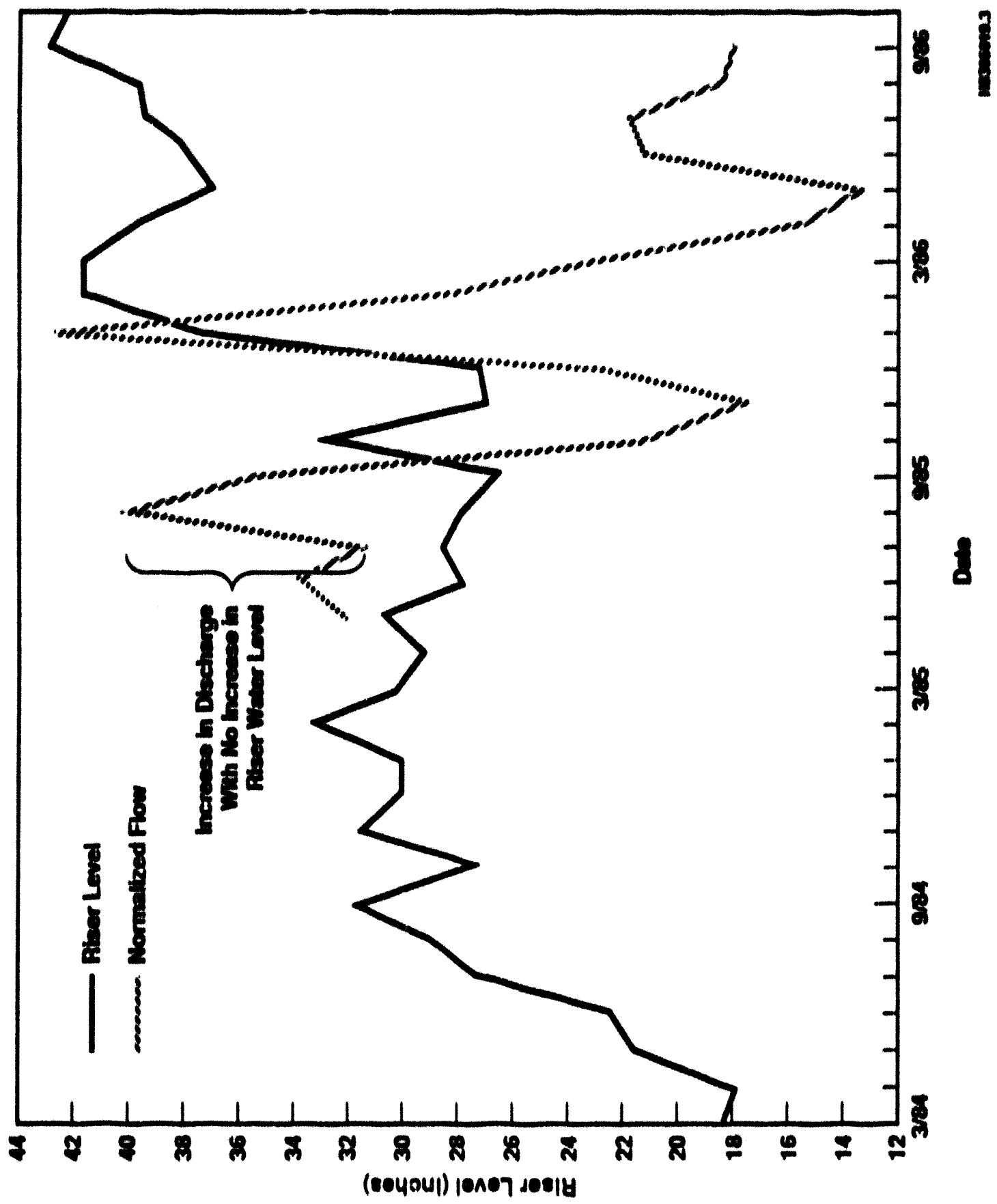


Flgure 13. Concentration History Plot for Plutontum-239

in Effluent Discharged to the 216-2-20 Crib.

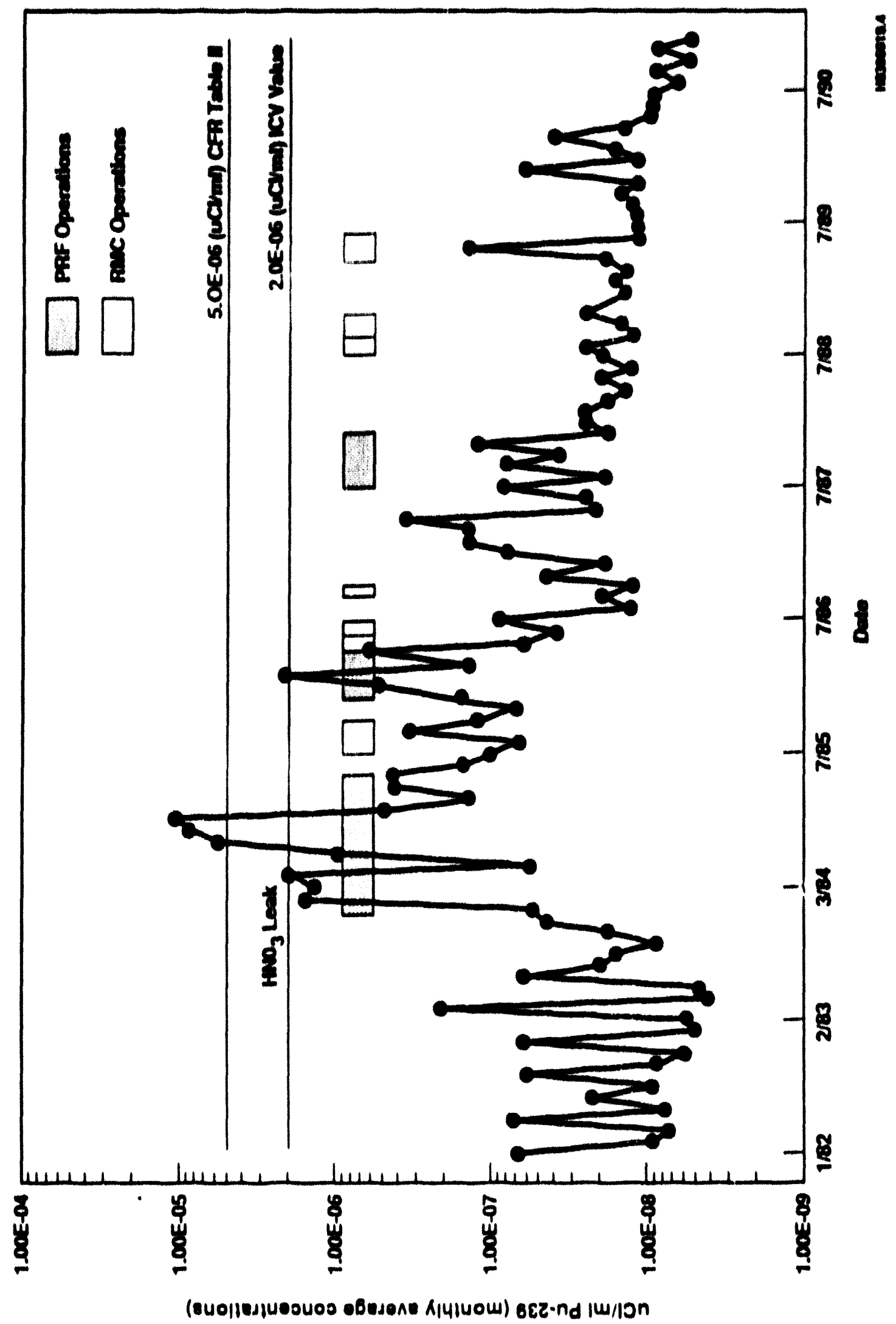


Table 4. Key Contaminants Previously Identified in Plutonium Finishing Plant Waste Stream Discharges to the 216-2-20 Crib.

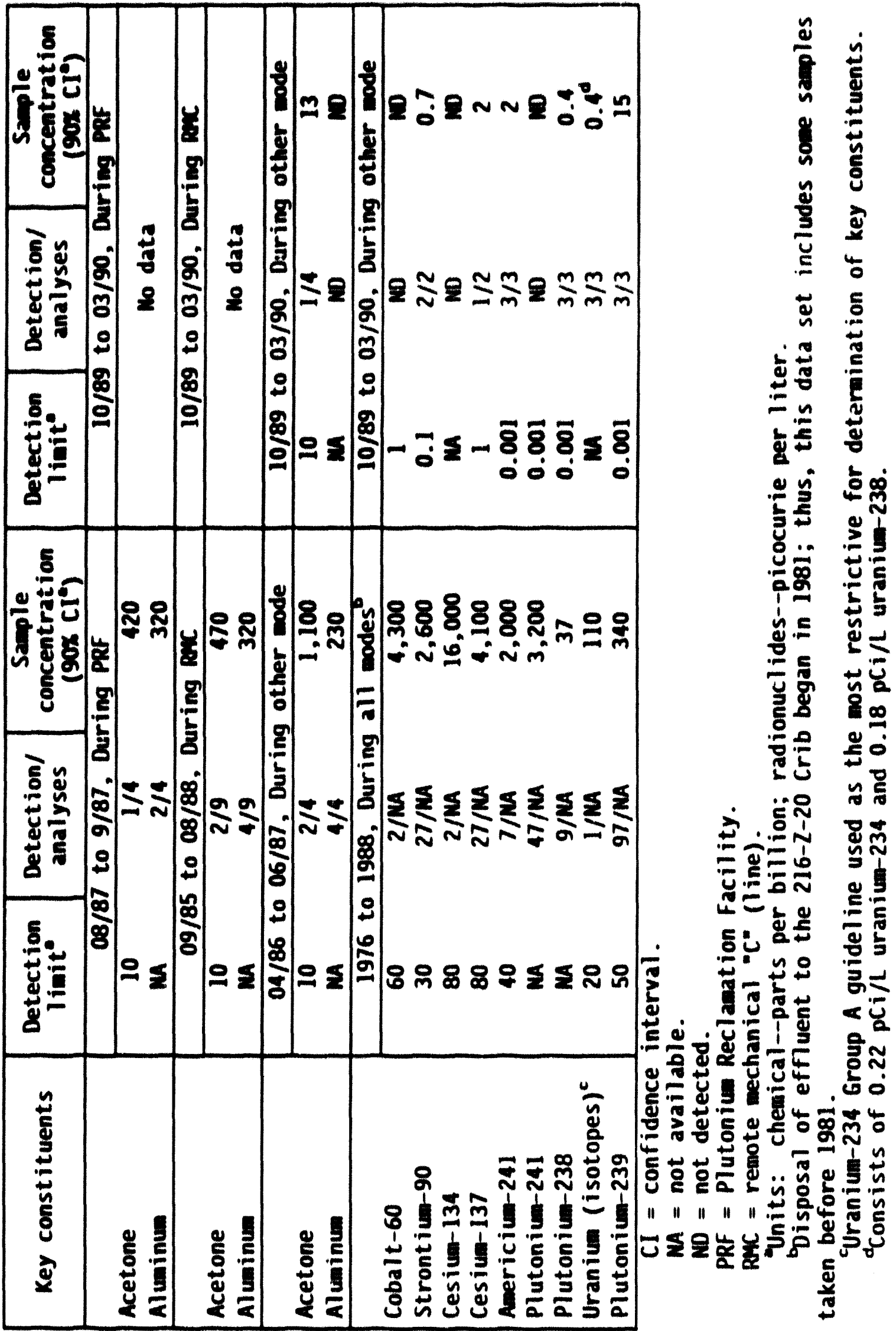


Table 5. Loading Rates to the $2: 5-2-206$, ib (Nonoperating Mode). (2 sheets)

\begin{tabular}{|c|c|c|}
\hline \multicolumn{3}{|c|}{ Flow rate $=2.33 \mathrm{E}+07 \mathrm{~L} /$ month } \\
\hline Const ttuent & $\mathrm{kg} / \mathrm{L}^{\circ}$ & $\mathrm{kg} / \mathrm{month}^{\mathrm{b}}$ \\
\hline Bartum & $2.82 \quad E-08$ & $6.57 E-01$ \\
\hline Boron & $1.50 E-08$ & $3.49 E-01$ \\
\hline Calclum & $1.80 E-05$ & $4.19 E+02$ \\
\hline Chloride & $2.53 E-06$ & $5.89 E+01$ \\
\hline Copper & $1.30 E-08$ & $3.03 E-01$ \\
\hline Fluoride & $1.35 E-07$ & $3.14 E+00$ \\
\hline Iron & $7.27 E-08$ & $1.69 E+00$ \\
\hline Magnes Ium & $4.28 E-06$ & $9.97 E+01$ \\
\hline Mercury & $2.75 E-10$ & $6.40 E-03$ \\
\hline Potassium & $7.16 E-07$ & $1.67 E+01$ \\
\hline sllicon & $2.00 E-06$ & $4.66 E+01$ \\
\hline Sodtum & $2.00 E-06$ & $4.66 E+01$ \\
\hline Strontium & $9.07 E-08$ & $2.11 E+00$ \\
\hline Sulfate & $1.31 E-05$ & $3.05 E+02$ \\
\hline Urantum & $3.84 E-10$ & $8.94 E-03$ \\
\hline $2 \ln c$ & $1.45 E-08$ & $3.38 E-01$ \\
\hline Acetone & $1.12 E-08$ & $2.61 E-01$ \\
\hline Caffeine & $9.00 E-09$ & $2.10 \mathrm{E}-01$ \\
\hline Decane & $8.00 E-09$ & $1.86 E-01$ \\
\hline Tetrachloromethane & $5.00 E-09$ & $1.10 \mathrm{E}-01$ \\
\hline Trichloromethane & $2.05 E-08$ & $4.77 E-01$ \\
\hline Unknown & $6.50 E-08$ & $1.51 E+00$ \\
\hline Unknown al iphatic $H C$ & $1.00 E-08$ & $2.33 E-01$ \\
\hline Unknown hydrocarbon & $5.00 E-09$ & $1.16 E-01$ \\
\hline Alpha activity" & $8.35 E-12$ & $1.94 E-04$ \\
\hline Total dissolved solids & $6.85 E-05$ & $1.59 E+03$ \\
\hline Total organic carbon & $1.00 \mathrm{E}-06$ & $2.33 \mathrm{E}+01$ \\
\hline
\end{tabular}


Table 5. Loading Rates to the 216-Z-20 Crib (Nonoperating Mode). (2 sheets)

\begin{tabular}{|l|c|c|}
\hline \multicolumn{2}{|c|}{ Flow rate $=2.33 \mathrm{E}+07 \mathrm{~L} /$ month } \\
\hline \multicolumn{1}{|c|}{ Constituent } & $\mathrm{kg} / \mathrm{L}^{\mathrm{a}}$ & $\mathrm{kg} /$ month $^{\mathrm{b}}$ \\
\hline Total carbon & $1.36 \mathrm{E}-05$ & $3.17 \mathrm{E}+02$ \\
\hline $\begin{array}{l}\text { Total organic halogen (as } \\
\text { chloride) }\end{array}$ & $1.49 \mathrm{E}-07$ & $3.47 \mathrm{E}+00$ \\
\hline Americium-241 & $1.29 \mathrm{E}-12$ & $3.00 \mathrm{E}-05$ \\
\hline Cesium-137 $^{\mathrm{a}}$ & $7.73 \mathrm{E}-13$ & $1.80 \mathrm{E}-05$ \\
\hline Plutonium-238 & $3.22 \mathrm{E}-13$ & $7.50 \mathrm{E}-06$ \\
\hline Plutonium-239,240 & $8.66 \mathrm{E}-12$ & $2.02 \mathrm{E}-04$ \\
\hline Radium tota1 & $2.15 \mathrm{E}-13$ & $5.01 \mathrm{E}-06$ \\
\hline Strontium-90 & $3.35 \mathrm{E}-13$ & $7.80 \mathrm{E}-06$ \\
\hline Uranium-234 & $1.57 \mathrm{E}-13$ & $3.66 \mathrm{E}-06$ \\
\hline Uranium-238 & $1.48 \mathrm{E}-13$ & $3.45 \mathrm{E}-06$ \\
\hline
\end{tabular}

Notes:

Data collected from October 1989 through March 1990.

Flow rate is the average of rates from the Plutonium

Finishing Plant Wastewater Stream-Specific Report

(Jensen 1990, Addendum 8).

Constituent concentrations are average values from the statistics in the Plutonium Finishing Plant Wastewater

Stream-Specific Report (Jensen 1990, Addendum 8).

Concentration units of flagged $\left({ }^{a}\right)$ constituents are reported as curies per liter.

Loading units of flagged $\left({ }^{b}\right)$ constituents are reported

as curies per month.

$H C=$ Hydrocarbon. 
Table 6. Inventory of Contaminants Discharged to the $216-2-20 \mathrm{Crib}$.

\begin{tabular}{|c|c|c|c|c|c|}
\hline \multicolumn{6}{|c|}{$\begin{array}{l}\text { These values are decayed through: December } 31,1988^{*} \\
\text { Site Name: } 216-2-20 \text { Crib }\end{array}$} \\
\hline Chemical & Curies & Chemical & Curies & Chemical & Curies \\
\hline $\mathrm{H}-3$ & -- & $R u-103$ & -- & Th-232 & -- \\
\hline$C-14$ & -- & $R u-106$ & 0.00021 & $U-233$ & -- \\
\hline $\mathrm{Na}-22$ & -- & $S n-113$ & -- & $U-234$ & -- \\
\hline$M n-54$ & -- & $S b-125$ & -- & $U-235$ & -- \\
\hline Co-58 & -- & $I-129$ & -- & $U-238$ & -- \\
\hline $\mathrm{Fe}-59$ & -- & Cs -134 & -- & $N p-237$ & -- \\
\hline $\mathrm{C}_{0}-60$ & -- & Cs-137 & 0.06720 & $P u-238$ & 0.00889 \\
\hline $\mathrm{Ni}-63$ & -- & $\mathrm{Ce}-141$ & -- & $P u-239$ & 0.69000 \\
\hline $\mathrm{Kr}-85$ & -- & Ce-144 & - & $P u-240$ & -- \\
\hline $5 r-90$ & 0.05930 & Pr-144 & -- & $\mathrm{Pu}-241$ & 2.57000 \\
\hline$Y-91$ & -- & $\mathrm{Pm}-147$ & -- & $\mathrm{Pu}-242$ & -- \\
\hline $\mathrm{Nb}-95$ & -- & $E u-152$ & -- & $A m-241$ & 0.99600 \\
\hline $2 r-95$ & -- & $E u-154$ & -- & $A m-243$ & -- \\
\hline Tc-99 & -- & $E u-155$ & -- & $\mathrm{Cm}-245$ & -- \\
\hline & & $\begin{array}{l}\text { ported } a \\
\text { ported } b\end{array}$ & $\begin{array}{l}2.2200 \\
0.3770\end{array}$ & & \\
\hline
\end{tabular}

*As reported in the Waste Information Data System, Westinghouse Hanford Company, Richland, Washington. 
Table 7. Summary of Radiological and Chemical Constituent Concentrations in Effluent Discharged to the 216-2-20 Crib (1986 through 1993). (2 sheets)

\begin{tabular}{|c|c|c|c|c|c|c|c|}
\hline \multirow[t]{2}{*}{ Constituent } & \multicolumn{7}{|c|}{$\begin{array}{c}\text { Plutonfum Finishing Plant wastewater (units in ppb } \\
\text { unless otherwise noted) }\end{array}$} \\
\hline & 1986 & 1987 & 1988 & 1989 & 1990 & 1992 & 1993 \\
\hline Aluminum & 210 & 170 & -- & $<150$ & $<150$ & 290 & 145 \\
\hline Bartum & 25 & 32 & -- & 28 & 28 & -- & 31 \\
\hline Boron & - & -- & -- & 11 & 16 & -- & -- \\
\hline Calcium & 18,000 & 16,000 & - & 18,000 & 18,000 & 20,000 & 23,133 \\
\hline Chloride & 2,700 & 4,900 & -- & 2,700 & 2,500 & 2,100 & 2,300 \\
\hline Copper & 23 & 20 & - & 18 & 14 & -- & 13 \\
\hline Fluoride & $<500$ & $<500$ & -- & 140 & 130 & -- & $<500$ \\
\hline Iron & $<50.0$ & $<50.0$ & -- & 84 & 89 & -- & 79 \\
\hline Lead & 5.5 & $<5.0$ & -- & $<5.0$ & $<5.0$ & -- & 6.2 \\
\hline Magnesium & 4,100 & 4,000 & -- & 4,000 & 4,400 & -- & 5,357 \\
\hline Manganese & 11 & $<5.0$ & -- & $<5.0$ & $<5.0$ & -- & 4.5 \\
\hline Mercury & 0.10 & $<0.10$ & -- & $<0.10$ & 0.45 & $=$ & $<0.10$ \\
\hline Nitrate & 970 & $<500$ & - & $<500$ & $<500$ & 700 & 190 \\
\hline Potassium & 1,700 & 750 & -- & 710 & 720 & - & 877 \\
\hline Silicon & -- & -- & -- & 2,100 & 2,000 & -- & -- \\
\hline Sodium & 2,400 & 2,300 & -- & 2,000 & 2,000 & - & 2,360 \\
\hline Strontium & $<300$ & $<300$ & -- & 89 & 91 & -- & -- \\
\hline Sulfate & 13,000 & 15,000 & -- & 12,000 & 13,000 & 13,000 & 16,000 \\
\hline Uranium & 0.58 & 0.15 & -- & 0.36 & 0.39 & -- & - \\
\hline Zinc & 32 & 20 & -- & 17 & 14 & - & 21 \\
\hline Acetone & 340 & - & -- & 15 & $<10$ & - & ND \\
\hline Ammonia & 70 & $<50$ & -- & $<50$ & $<50$ & -- & -- \\
\hline Caffeine & -- & -- & -- & - & 9 & -- & -- \\
\hline Decane & - & -- & -- & -- & 8 & -- & ND \\
\hline Carbon tetrachloride & -- & -- & -- & -- & 5 & -- & ND \\
\hline Chloroform & 31 & 45 & -- & 28 & 18 & 31 & 27 \\
\hline Methylene chloride & -- & -- & - & -- & -- & -- & 2 \\
\hline Arsenic & -- & -- & -- & -- & -- & -- & $<2.5$ \\
\hline
\end{tabular}


Table 7. Summary of Radiological and Chemical Constituent Concentrations in Effluent Discharged to the 216-2-20 Crib (1986 through 1993). (2 sheets)

\begin{tabular}{|c|c|c|c|c|c|c|c|}
\hline \multirow{2}{*}{ Constituent } & \multicolumn{7}{|c|}{$\begin{array}{c}\text { Plutonium Finishing Plant wastewater (units in ppb } \\
\text { unless otherwise noted) }\end{array}$} \\
\hline & 1986 & 1987 & 1988 & 1989 & 1990 & 1992 & 1993 \\
\hline Alkalinity & -- & $\overline{--}$ & $\overline{--}$ & 52,000 & 54,000 & 57,000 & 50,200 \\
\hline Gross alpha (pCi/l.) & 22 & 6.4 & -- & 3.0 & 11 & $1_{1.2}^{3.8 \pm}$ & 6.03 \\
\hline Gross beta $(p C i / L)$ & 6.8 & 0.98 & -- & $<0.57$ & $<1.2$ & $1.7 \pm$ & 1.04 \\
\hline $\begin{array}{l}\text { Specific conductivity } \\
(\mu s)\end{array}$ & 100 & 130 & -- & 150 & 150 & 130 & 151 \\
\hline Ignitability $\left({ }^{\circ} \mathrm{C}\right)$ & -- & - & -- & 210 & 210 & -- & -- \\
\hline $\mathrm{pH}$ & 7.2 & 5.54 & -- & 8 & 6.89 & 7.50 & 7.5 \\
\hline Total dissolved solids & -- & -- & -- & 62,000 & 71,000 & 90,000 & 70,500 \\
\hline Temperature $\left({ }^{\circ} \mathrm{F}\right)$ & 26.8 & 26.1 & -- & 19.0 & 16.7 & -- & -- \\
\hline Total organic carbon & 1,900 & 1,500 & -- & $<1,000$ & 1,100 & -- & -- \\
\hline Total carbon & - & -- & - & 14,000 & 13,000 & - & - \\
\hline $\begin{array}{l}\text { Total organic halogen } \\
\text { (as chloride) }\end{array}$ & 200 & 250 & -- & 200 & 100 & -- & -- \\
\hline$A m-241(p C i / L)$ & -- & -- & -- & 0.37 & 1.8 & -- & 0.6 \\
\hline$C s-137(p C i / L)$ & -- & -- & -- & -- & 1.0 & -- & ND \\
\hline $\mathrm{Pu}-238(\mathrm{pCi} / \mathrm{L})$ & -- & -- & -- & 0.25 & 0.36 & $\begin{array}{c}2.0 \pm \\
0.16\end{array}$ & 0.2 \\
\hline $\mathrm{Pu}-239 / 240(\mathrm{pCi} / \mathrm{L})$ & -- & -- & -- & 2.5 & 12 & $0.93^{5.9 \pm}$ & 3.7 \\
\hline $\mathrm{Pu}-241 \quad(\mathrm{pCi} / \mathrm{L})$ & -- & -- & -- & -- & -- & $\frac{2.2}{15} \pm$ & 0.7 \\
\hline Radium total (pCi/L) & -- & -- & -- & -- & 0.35 & -- & ND \\
\hline$S r-90(p C i / L)$ & -- & $\overline{--}$ & -- & 0.21 & 0.47 & $\begin{array}{c}4.9 \pm \\
0.65\end{array}$ & 0.32 \\
\hline$U-234(p C i / L)$ & -- & -- & -- & 0.0098 & 0.19 & -- & -- \\
\hline$U-238(p C i / L)$ & -- & - & -- & 0.13 & 0.16 & -- & -- \\
\hline
\end{tabular}

ND $=$ Not detected.

ppb = Parts per billion.

Notes: (1) When multiple values were available the average was reported.

(2) 1992 and 1993 sampling data consisted of the Appendix IX (40 CFR 264) list for semi-volatile organics, volatile organics, organophosphate pesticides, and chiorinated herbicides; only detected constitutents were reported. 
Table 8. Plutonium Finishing Plant Wastewater Radioanalytical Results fo." August 27, 1992.

\begin{tabular}{|c|c|c|c|}
\hline \multirow{2}{*}{ Nuclide $(p C i / L)$} & \multicolumn{3}{|c|}{ Radiochemistry (samples collected 8-27-92) } \\
\hline & $92081685-004$ & $92081685-005$ & $92081685-008$ \\
\hline $5 r-90$ & $<0.70$ & $<1.0$ & $<1.0$ \\
\hline Sr-90 & $6.5 \pm 0.45$ & $1.9 \pm 0.87$ & $6.2 \pm 0.62$ \\
\hline $\mathrm{Be}-7$ & $<80$ & $<90$ & $<70$ \\
\hline$k-40$ & $<90$ & $<90$ & $<90$ \\
\hline$M n-54$ & $<5.0$ & $<7.0$ & $<6.0$ \\
\hline Co-58 & $<7.0$ & $<8.0$ & $<9.0$ \\
\hline $\mathrm{Fe}-59$ & $<20$ & $<20$ & $<21$ \\
\hline Co-60 & $<6.0$ & $<8.0$ & $<6.0$ \\
\hline $2 n-65$ & $<10$ & $<20$ & $<10$ \\
\hline $2 r-95$ & $<10$ & $<9.0$ & $<8.0$ \\
\hline$R u-103$ & $<10$ & $<10$ & $<10$ \\
\hline$R u-106$ & $<50$ & $<70$ & $<60$ \\
\hline$I-131$ & $<100$ & $<100$ & $<100$ \\
\hline$C s-134$ & $<6.0$ & $<7.0$ & $<6.0$ \\
\hline Cs -137 & $<7.0$ & $<9.0$ & $<7.0$ \\
\hline$B a-140$ & $<50$ & $<50$ & $<30$ \\
\hline $\mathrm{Ce}-141$ & $<20$ & $<30$ & $<20$ \\
\hline $\mathrm{Ce}-144$ & $<50$ & $<70$ & $<50$ \\
\hline$E u-152$ & $<20$ & $<20$ & $<20$ \\
\hline$E u-154$ & $<20$ & $<20$ & $<20$ \\
\hline$E u-155$ & $<20$ & $<40$ & $<20$ \\
\hline $\mathrm{Ra}-226$ & $<100$ & $<200$ & $<100$ \\
\hline Th-228 & $<10$ & $<20$ & $<10$ \\
\hline Th-234 & $<200$ & $<200$ & $<100$ \\
\hline $\mathrm{Pu}-238$ & $2.0 \pm 0.16$ & $<0.10$ & $<0.30$ \\
\hline $\mathrm{Pu}-239$ & $2.6 \pm 0.5$ & $9.1 \pm 0.35$ & $<0.30$ \\
\hline$P u-241$ & $<20$ & $<20$ & $3.4 \pm 22$ \\
\hline$P u-238$ & $<0.10$ & $3.8 \pm 0.098$ & $2.2 \pm 0.26$ \\
\hline $\mathrm{Pu}-239$ & $<0.10$ & $<0.20$ & $2.5 \pm 0.17$ \\
\hline $\mathrm{Pu}-241$ & $2.1 \pm 14$ & $2.2 \pm 15$ & $<30$ \\
\hline
\end{tabular}




\title{
4.0 CONCEPTUAL MODEL OF HYDROLOGIC RESPONSE AND CONTAMINANT MIGRATION
}

\begin{abstract}
A conceptual model of wastewater-contaminant behavior and hydrologic impacts requires consideration of the subregional stratigraphic and geohydrologic setting as well as the setting in the immediate vicinity of the disposal site. Accordingly, the following sections briefly describe the regional setting followed by a description of the 200 West Area and disposal site geohydrology. This information, together with the physical and chemical effluent data and related operational factors previously discussed, are then synthesized into an overall conceptual model of contaminant migration associated with wastewater discharges from the 216-2-20 $\mathrm{Crib}$. The conceptual model so derived serves as the "working hypothesis" for the impact assessment and evaluation presented in Section 5.0.
\end{abstract}

\subsection{HYOROGEOLOGIC FRAMEWORK}

\subsubsection{Regional and Hanford Site Geology}

The Hanford Site is located in the Pasco Basin, a broad alluvial basin within the Columbia Plateau (Figure 14). The geology and hydrology of the Pasco Basin and Hanford Site have been discussed in numerous reports (i.e., Delaney et al. 1991; DOE 1987; DOE 1988; Gephart et al. 1979; Lindsey 1991; Myers et al. 1979; Myers and Price 1981; and Reidel and Hooper 1989). The reader is referred to these reports for detailed descriptions.

The geohydrology of the 200 West Area has been the subject of much study and many reports over the past several decades (i.e., Gephart et al. 1979; Graham et al. 1981; Myers et a1. 1979; Myers and Price 1981; Routson and Johnson 1990; and Tallman et a1. 1979). The most recent work on the 200 West Area geology is by Lindsey et al. (1991).

The 200 Areas lie on the north limb of the Cold Creek syncline. The uppermost flow of the Columbia River Basalt Group (CRBG) is the Elephant Mountain Member (Figure 15). The suprabasalt stratigraphy consists of the Ringold Formation, the Plio-Pleistocene unit, the early "Palouse" soil, and the Hanford formation.

The hydrogeology of the Hanford Site is characterized by a multiaquifer system that consists of four hydrogeologic units that correspond to the upper three formations of the CRBG (Grande Ronde Basalt, Wanapum Basalt, and Saddle Mountains Basalt) and the suprabasalt sediments (see Figure 15). The basalt aquifers consist of the CRBG and relatively minor amounts of intercalated fluvial and volcaniclastic sediments of the Ellensburg Formation. The uppermost aquifer system, the unconfined aquifer, consists of fluvial, lacustrine, and glaciofluvial sediments. This aquifer is contained largely within the Ringold Formation and the Hanford formation. 
Figure 14. Generalized Geologic Map of the Pasco Basin and the Hanford Site.
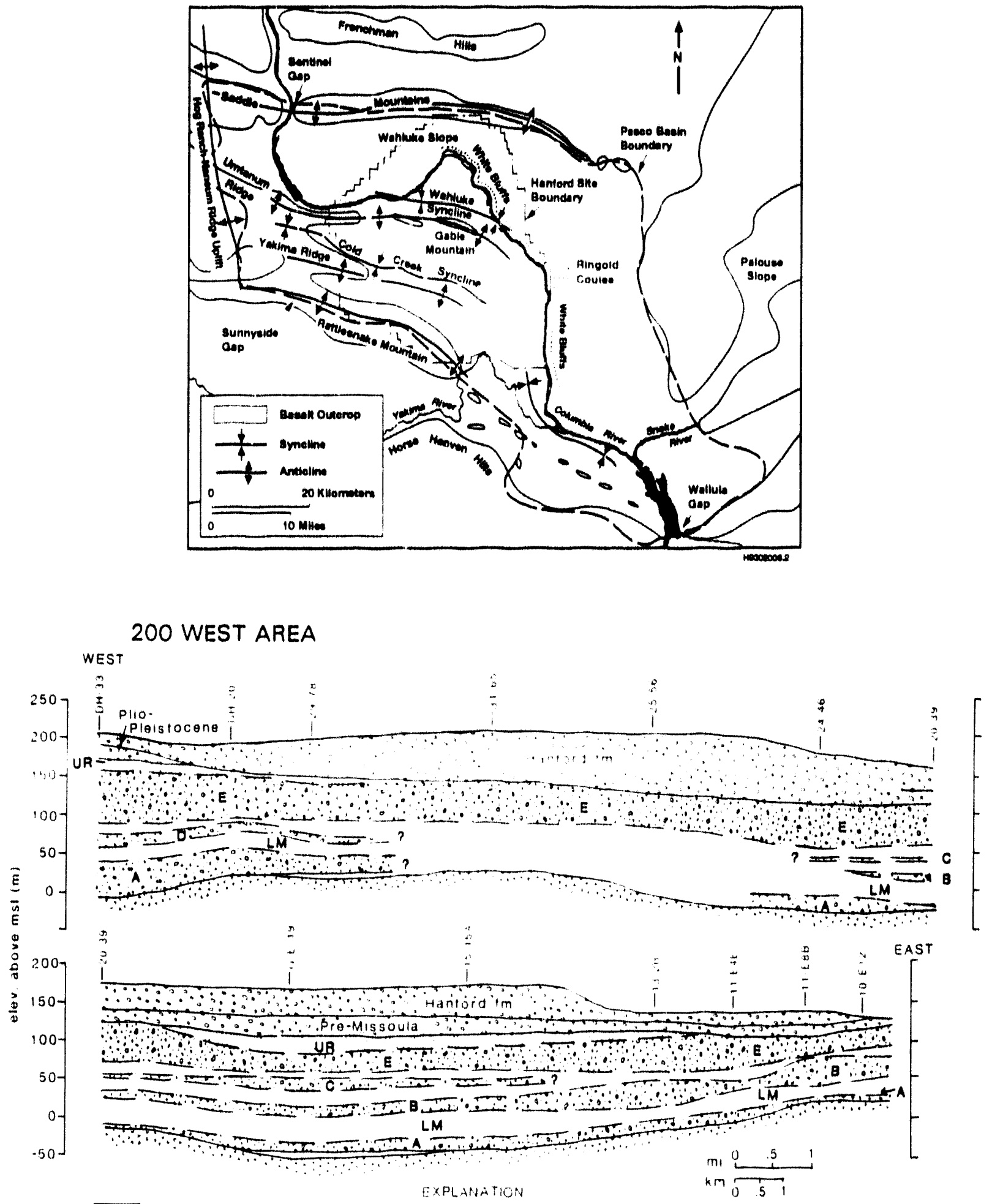

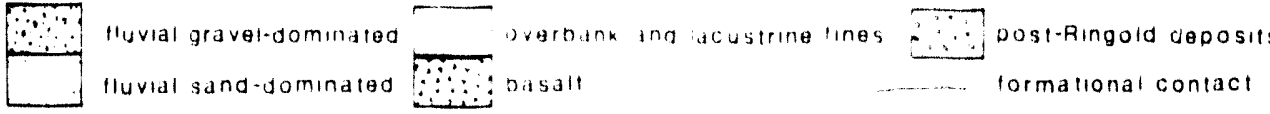


Figure 15. Stratigraphic Nomenclature for the Hanford Site.

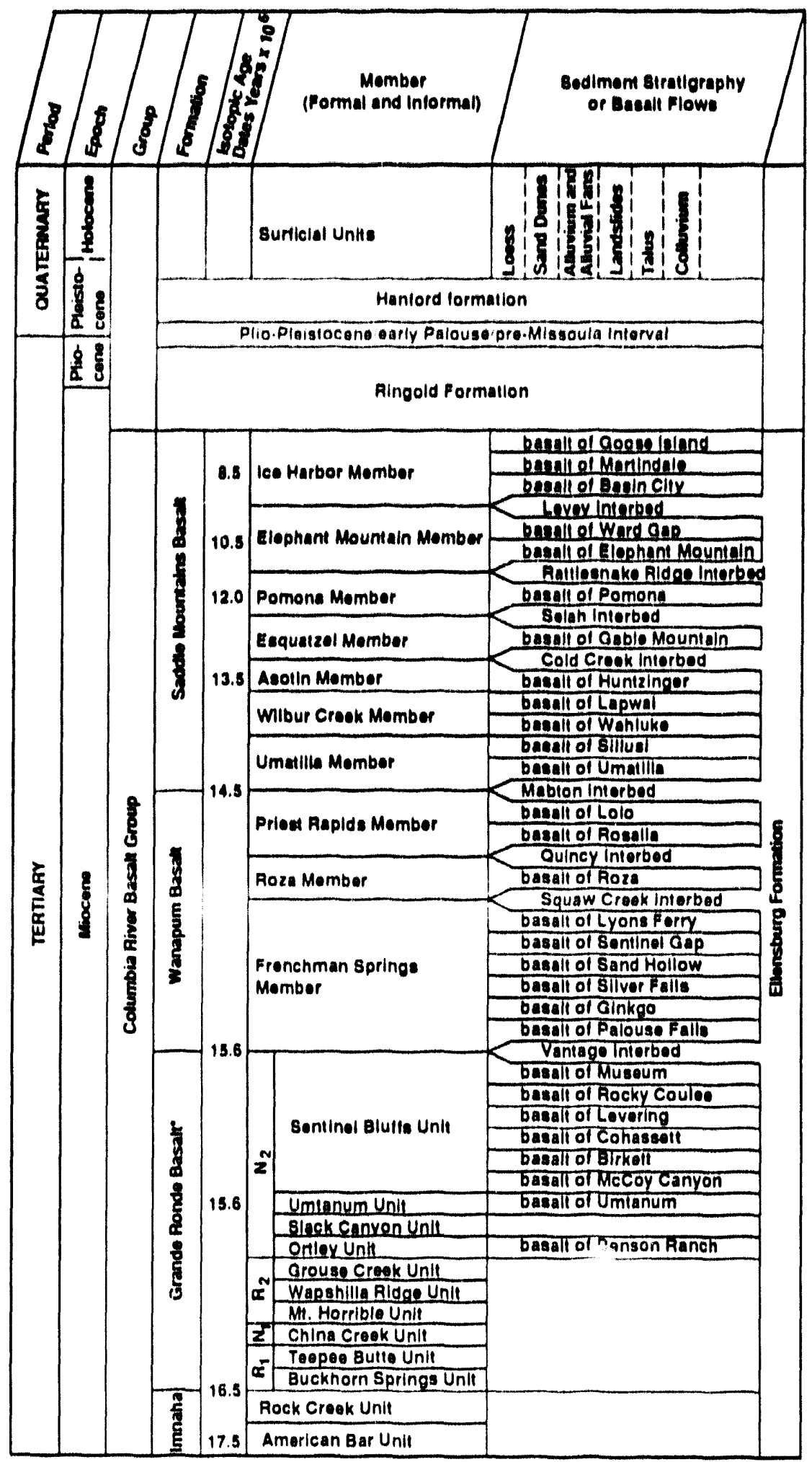

-The Grande Ronde Basalt consists of at least 120 major basalt flows. Only a low llowe have been named. $N_{2}, R_{2}, N_{1}$ and $R_{1}$ are magnelostratigraphic unlts. 
The base of the uppermost aquifer system is definou as the top of the uppermost basalt flow. However, fine-grained overbank and lacustrine deposits in the Ringold Formation locally form confining layers for Ringold fluvial gravels underlying unit $E$ (Figure 16). The uppermost aquifer system is bounded laterally by anticlinal basait ridges and is approximately $152.4 \mathrm{~m}$ $(500 \mathrm{ft})$ thick near the center of the Pasco Basin.

Sources of natural recharge to the uppermost aquifer system are rainfall and runoff from the higher bordering elevations, water infiltrating from small ephemeral streams, and river water along influent reaches of the Yakima and Columbia Rivers. The movement of prectpitation through the unsaturated (vadose) zone has been studied at several locations on the Hanford site (Gee 1987; Rockhold et al. 1988; Routson and Johnson 1990). Conclusions from these studies vary. Gee (1987) and Routson and Johnson (1990) concluded that little if any downward percolation of precipitation occurs at und sturbed sites on the 200 Area Plateau where the sediments are layered and vary in texture, and that moisture penetrating the soil is removed by evapotranspiration. These earlier conclusions have been confirmed more recently by Murphy (1992) who used meteoric chloride mass balance methods that suggest a long-term average net inflitration of $<1 \mathrm{~mm} / \mathrm{yr} \quad(<0.04 \mathrm{in} / \mathrm{yr})$ at an undisturbed site west of the 200 West Area.

\subsubsection{Hest Area Hydrogeology}

The main near-surface hydrostratigraphic units in the 200 West Area and 216-2-20 Crib are (1) the Rattlesnake Ridge interbed, (2) the Elephant Mountain Member, (3) the Ringold Formation, (4) the Plio-Pleistocene unit and early "Palouse" soll, and (5) the Hanford formation (see Figures 15 and 16).

The uppermost regionally extensive aquifer beneath the 200 West Area consists of the Rattlesnake Ridge interbed, the overlying flow bottom of the Elephant Mountain Member, and the underlying flow top of the Pomona Mountain Member. The Rattlesnake Ridge interbed consists of a clayey basalt conglomerate, an epiblastic fluvial-floodplain unit, an airfall tuff, and a tuffite derived from fluvial reworking of the tuff and detrital sediments (Graham et al. 1984; Reidel and Fecht 1981). The interbed is 15.2 to $25 \mathrm{~m}$ (50 to $82 \mathrm{ft}$ ) thick beneath the 200 West Area, and generally thickens toward the west (Reidel and Fecht 1981). Recharge to the Rattlesnake Ridge interbed aquifer occurs in the higher elevations surrounding the Pasco Bas in to the west, north, and northeast. The flow of groundwater generally is toward the northeast beneath the 200 West Area (Figure 17) and west to west-northwest beneath the 200 East Area. Graham et al. (1981; 1984) reported transmissivity values of 2.4 to $355.1 \mathrm{~m}^{2} /$ day $\left(26\right.$ to $\left.3,821 \mathrm{ft}^{2} / \mathrm{day}\right)$ over the entire thickness of the aquifer.

Beneath the 200 West Area the Rattlesnake Ridge interbed aquifer is separated from the overlying uppermost aquifer system by the Elephant Mountain Member. The Elephant Mountain Member is up to $35 \mathrm{~m}(115 \mathrm{ft})$ thick, and divided into two flow units separated by an interflow zone approximately $0.9 \mathrm{~m}$ $(3 \mathrm{ft})$ thick that consists of interconnected vesicles and rubble zones (Reidel and Fecht 1981). 
WHC-EP-0674

Figure 16. Hanford Site Stratigrapny snowing the Relationship Between Units.

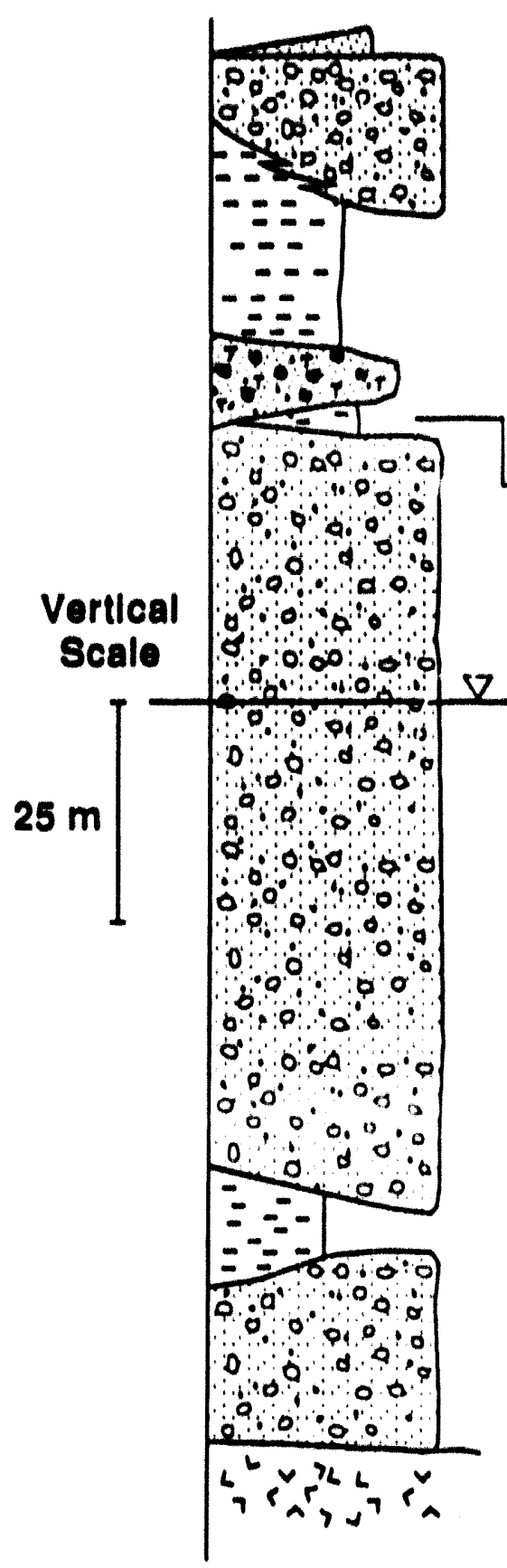

- Eollan sands, restricted to SE, $0.4 \mathrm{~m}$ thick

- Hanford im, upper coarse unlt, thlckens to NW, 6-12 $\mathrm{m}$ thlck

- Hanford im, fine unlt, thlckens to SW, 20.32 $\mathrm{m}$ thick

- Early Palouse/Pllo-Plelstocene, thins and dips $10 \mathrm{~S}, 3.3-10.6 \mathrm{~m}$ thick

- Ringold Fm, upper unit, restricted to $\mathrm{N}, 0.4 \mathrm{~m}$ thlck

June 1992 water table, elevation 137-140 $\mathrm{m}$ above msl, dips to E

- Ringold Fm, unit E, dips to S, - $82 \mathrm{~m}$ thick

- Ringold Fm, lower mud unit, dips $\mathrm{S}, 3.12 \mathrm{~m}$ thlck

- Ringold Fm, unlt A, dips S, $17-23 \mathrm{~m}$ thick

- Elephant Mountain Member, dips $S$, top of basalt $46-58 \mathrm{~m}$ above msl

H9307034.2 
Figure 17. Location of Wastewater Disposal sites on the Hanford Site.

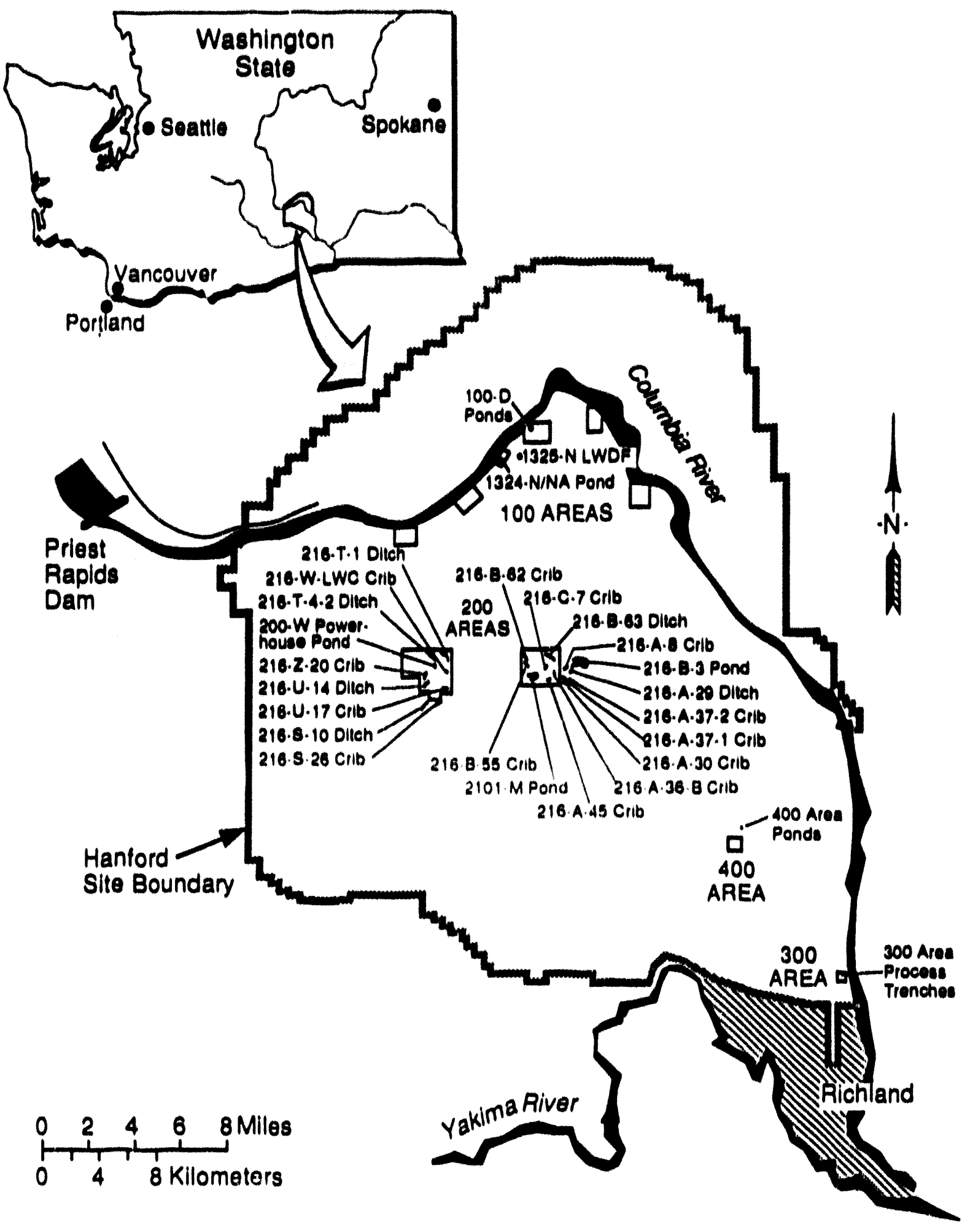

890070280 
The uppermost aquifer system in the 200 West Area occurs primarlly within the sediments of the Ringold Formation and the Hanford formation. The upper aquifer is contalned within the Ringold formation and displays unconfined to locally confined or semiconfined conditions. The depth to groundwater in the upper aquifer underlying the former 216-U-10 Pond System (U Pond) in 200 West Area (see Flgure 17) is approximately $57.9 \mathrm{~m}$ (190 ft). The saturated thickness of the unconfined aquifer is approximately 67.2 to $112.2 \mathrm{~m}$ (220 to $368 \mathrm{ft}$ ) in the 200 West Area.

The lower part of the upper aquifer system consists of Ringold unit $A$, and generally is confined by fine-grained sediments of the lower mud sequence (see figure 16). The thickness of this confined zone ranges from greater than $15.2 \mathrm{~m}(50 \mathrm{ft})$ in the southern portion of the 200 West Area near the 216-U-17 $\mathrm{Cr} / \mathrm{b}$, to less than $6.1 \mathrm{~m}(20 \mathrm{ft})$ beneath the northern portion of 200 West Area (Last ot al. 1989). The lower mud sequence is absent in the northern portion of 200 West Area, and a single, undifferentlated gravel sequence consisting of unit $A$ and the overlying deposits of unit $E$ is found. In this area it is not possible to hydraulically differentiate units $A$ from $E$. The confining zone overlying unit $A$ is up to $21.3 \mathrm{~m}(70 \mathrm{ft})$ thick below the western section of 200 West Ares before pinching out in the eastern section of the 200 West Area. A mean hydraullc conductivity of $1.6 \times 10^{.5} \mathrm{~m} /$ day $\left(5.19 \times 10^{-5} \mathrm{ft} /\right.$ day) has been obtained from permeameter testing of core samples from the top of the unlt (Last et al. 1989). The upper part of the uppermost aquifer system in the 200 West Area is contained mostly within the fluvial gravel of unit $E$. Unit $E$ is more than $76.2 \mathrm{~m}(250 \mathrm{ft})$ thick in this area. Hydraulic conductivities of this unit range from 0.2 to $61 \mathrm{~m} / \mathrm{day}$ (0.6 to $200 \mathrm{ft} /$ day) (Last et al. 1989).

The vadose zone beneath the 200 West Area extends for approximately $54.9 \mathrm{~m}(180 \mathrm{ft})$ beneath the former U Pond. Sediments in the vadose zone consist of the (1) fluvial gravel of Ringold unit $E$, (2) upper unit of the Ringold Formation, (3) Plio-Plelstocene unit, (4) early "Palouse" soll, and (5) Hanford formation (see Figure 16).

As much as $42.7 \mathrm{~m}$ (140 ft) of Ringold strata belonging to unit E occur above the water table in the 200 West Area. Pre-Hanford strata that overlle Ringold unit $E$ in the vadose zone are only found in the 200 West Area. These strata include: (1) fluvial sand and mud of the upper unit of the Ringold Formation, (2) pedogenic carbonates and alluvium of the P1io-Pleistocene unit, and (3) loess comprising the early "Palouse" soll. The upper unit of the Ringold Formation reaches a maximum thickness of $10.7 \mathrm{~m}(35 \mathrm{ft}$ ) and is most commonly encountered in the central, northern, and western parts of the 200 West Area. Pedogenic carbonate horizons of the P1 lo-pleistocene unit are up to $10.7 \mathrm{~m}$ (35 ft) thick and overl te the Ringold formation throughout most of the 200 West Area. The top of the Plio-pleistocene unit dips approximately 1.5 degrees to the southwest beneath the 200 West Area. The cementation and laterally extensive nature of this unit beneath the 200 West Area may create an interval with relatively low permeablilty. Thus a potential exists for lateral movement of vadose zone recharge water above the Pl lo-Plelstocene unit. Unconsolidated loess or sandy silt up to $4.6 \mathrm{~m}$ (15 ft) thick and designated the early "Palouse" soll overlies the pllo-pleistocene unit beneath the southern portion of 200 West Area. This deposit is uniformly finegrained, micaceous, and moderately calclum carbonate rich. 
The Hanford formation is the uppermost unit in the unsaturated zone except for discontinuous recent collan sands present in the northwestern section of the 200 West Area. Hanford formation sediments range from finegrained sllty sands in the southern parts of 200 West Area to granule to boulder gravels in the northern part of 200 West Area. The Hanford formation is less than $6.1 \mathrm{~m}(20 \mathrm{ft})$ thick where the Pl10-Pleistocene unit is near the surface (Last et 11 . 1989) to more than $42.7 \mathrm{~m}$ (140 ft) thick. On the average, fleid molsture content of unsaturated Hanford formation sediments beneath the 200 West Area ranges from $2 \%$ to slightly greater than $6 \%$ (Last ot al. 1989).

Artifictal recharge to the unconfined aquifer is estimated to be ten times greater than natural recharge (Graham et al. 1981). The major source of artificlal recharge in the 200 West Area has been $U$ Pond (see Figure 17). A comparison of the hindcast water table map of the Hanford Site for 1944 and the present 200 Areas water table maps indicates that the natural water table elevation in the 200 West Area was approximately $19.8 \mathrm{~m}$ (65 ft) lower in 1944. The estimated hindcast map indicates that the direction of regional flow was toward the east, and the natural hydraulic gradient was on the order of $0.3 \mathrm{~m} / 305 \mathrm{~m}(1 \mathrm{ft} / 1,000 \mathrm{ft})$ in the 200 West Area. The $U$ Pond, located in the 200 West Area, and Gable Mountain Pond, located north of the 200 East Area, were decommisstoned in 1984 and 1987, respectively.

Groundwater elevations for December 1991 for the unconfined aquifer in the 200 Areas are shown in Figure 18. Groundwater flow beneath the 200 West Area is generally toward the north and the east, away from the mound created by past discharges to $U$ Pond. The horizontal hydraulic gradient is expected to decrease and shift to the east as the mound dissipates. The horizontal hydraulic gradient in the 200 West Area is relatively high, ranging from $1.2 \mathrm{~m} / 305 \mathrm{~m}(4 \mathrm{ft} / 1,000 \mathrm{ft})$ to $0.45 \mathrm{~m} / 305 \mathrm{~m}(1.5 \mathrm{ft} / 1,000 \mathrm{ft}$ ) (Graham et al. 1981). The steep gradient is due to the presence of the water table exclusively in the Ringold Formation. Downward vertical hydraulic gradients are expected to be present within the unconfined aquifer in parts of the 200 West Area as a result of the $U$ Pond groundwater mound (Graham et 1. 1981). This has been confirmed by recent groundwater monitoring activity. However, locally perched water horizons have been identified in the vadose zone.

\subsubsection{Crib site Stratigraphy}

Stratigraphy based on the four 216-2-20 Crib groundwater monitoring wells and selected adjacent wells is shown in Figure 19, and in greater detaif in Figure 20. The relationship between the stratigraphy at the 216-2-20 Crib and the southern part of the 200 West Area is shown in Figure 21. These figures show that the stratigraphy at the 216-2-20 Crib is typical of that in the 200 West Area. This is of particular significance for vadose zone modeling because physical parameters are avallable for only a limited number of locations in the 200 West Area (1.e., an underlying assumption for vadose zone transport modeling is that soll physical propertles for the same stratigraphic unit are uniform within the 200 West Area). 
Figure 18. Water Table Map for the 200 West Area, December 1991.
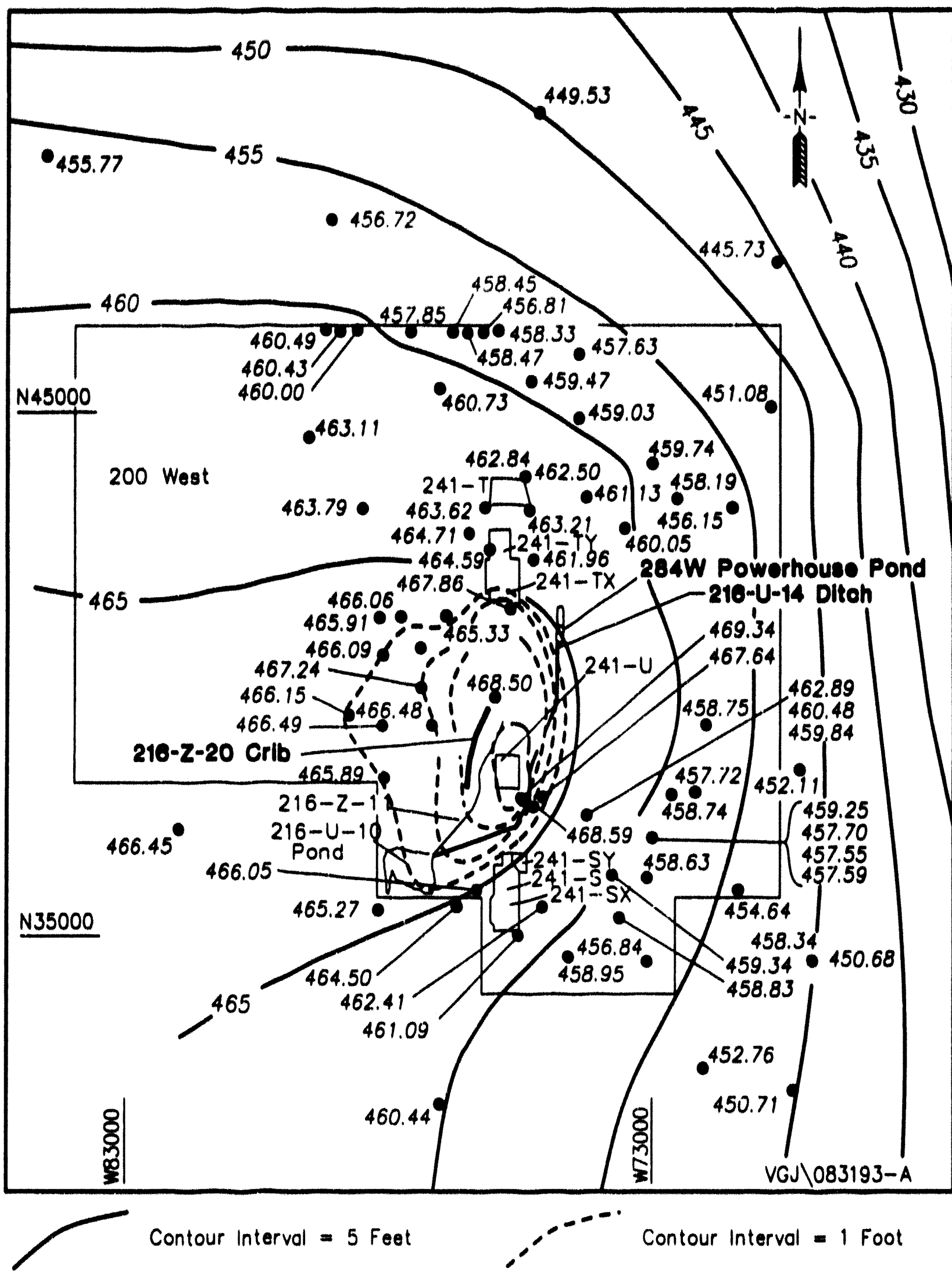
WHC-EP-0674

This page intentionally left blank. 
Stratigraphy Beneath the 216-Z-9 and 216-Z-20

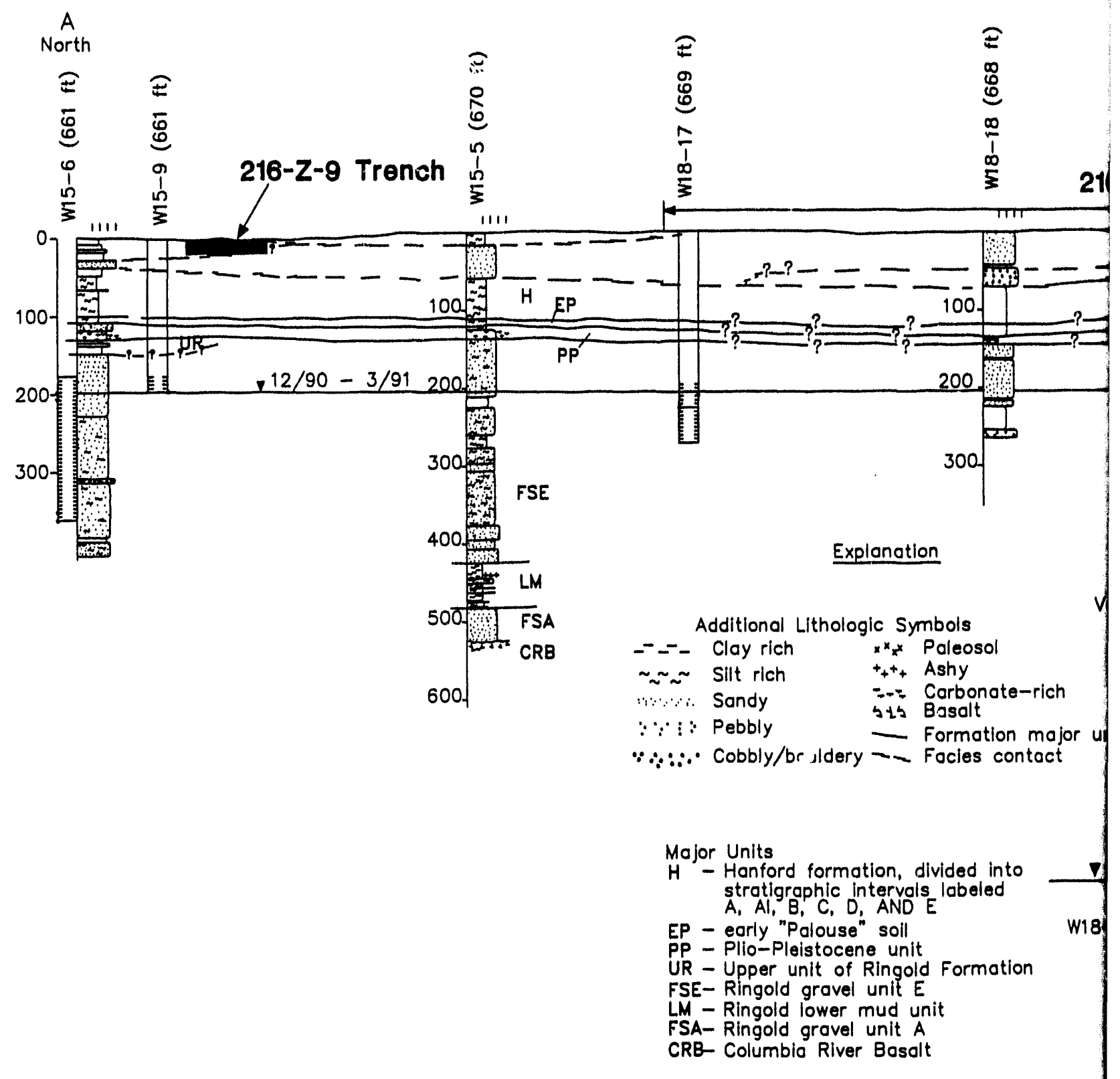


Figure 19. Longitudinal Stratigraphic Cross Section Through the 216-2-20 Crib.

\section{z-20 Cribs}
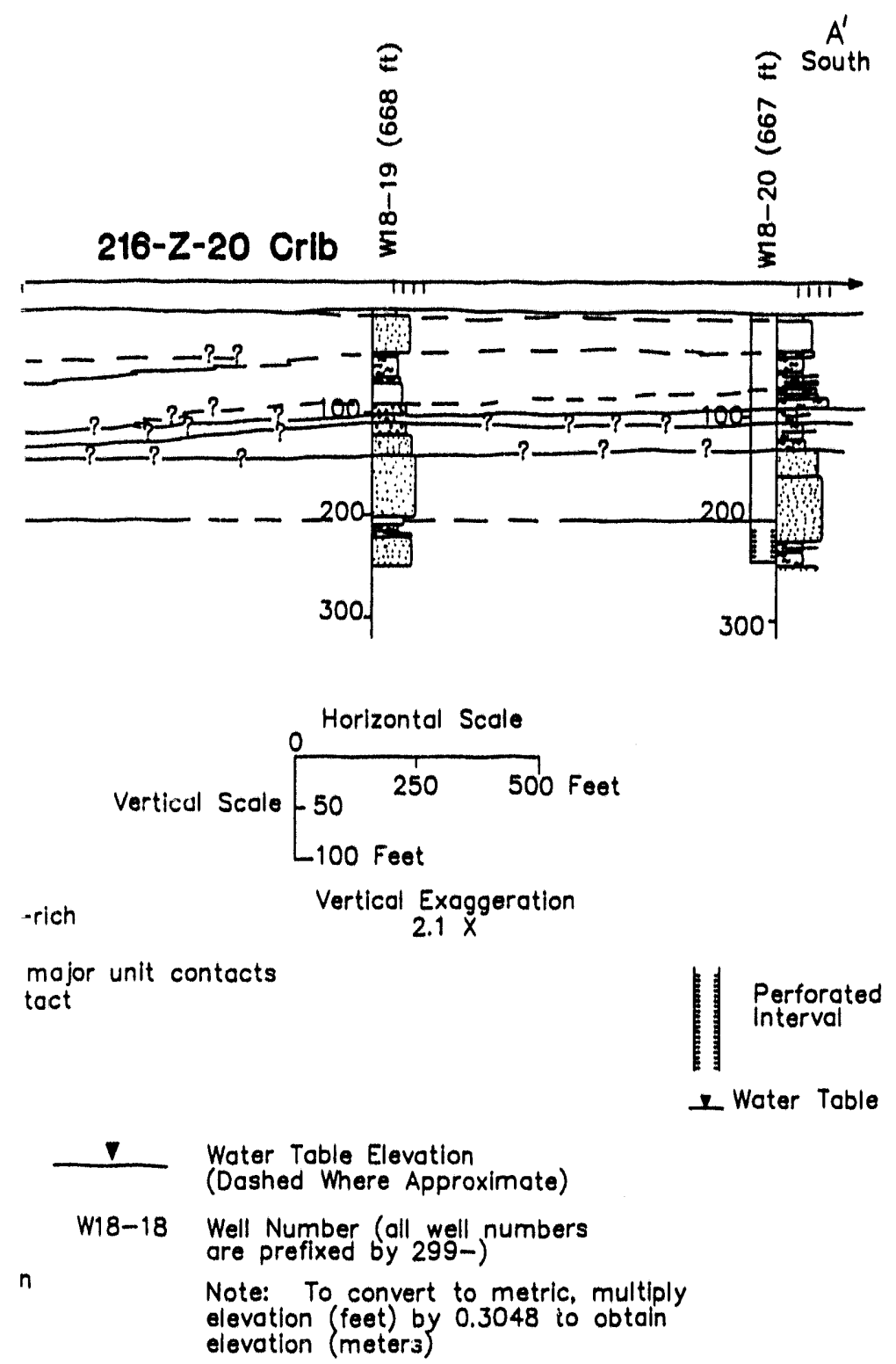
Figure 20. Lithology and Stratigraphic Units Beneath the 216-z-20 Crib.

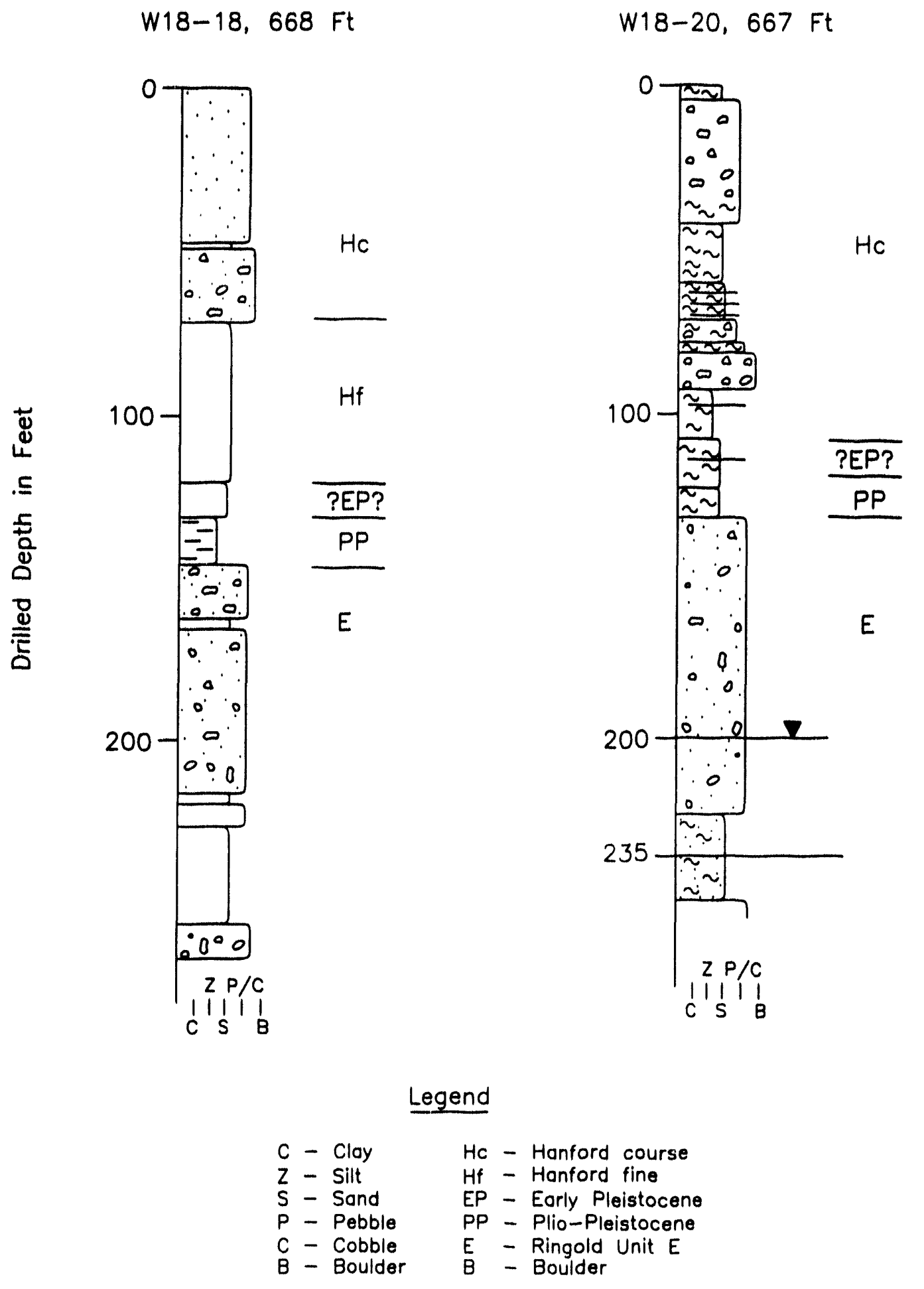


Figure 21. Stratigraphic Relationships Between 216-2-20 Crib Site and Adjacent

200 West Area.
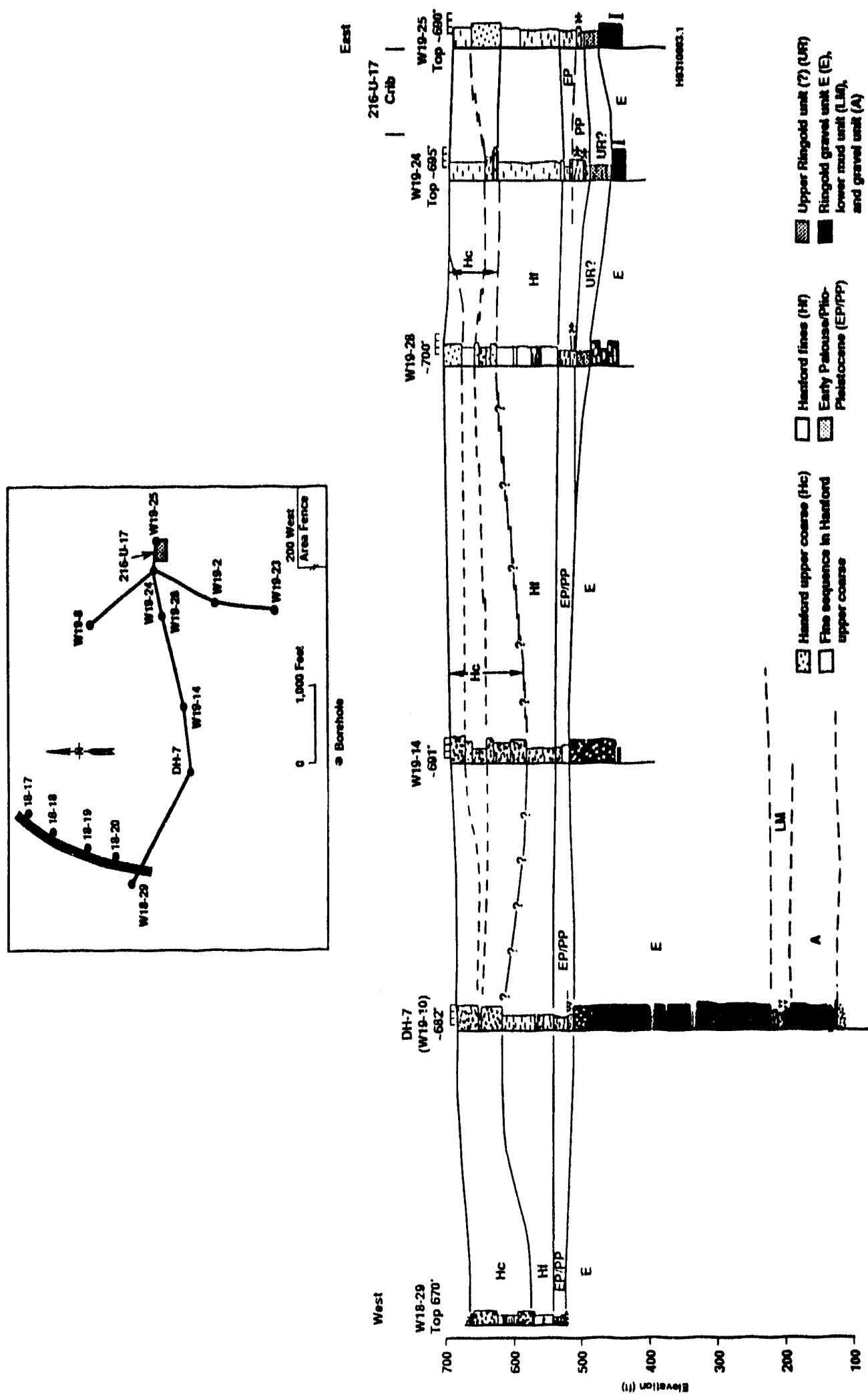


\subsection{HYDROLOGIC RESPONSES TO EFFLUENT DISPOSAL}

The 216-2-20 Crib predecessors (PFP Complex ditches), combined with the 216-U-14 Ditch wastewater conveyance system, the 284-WB Powerplant Ponds, and the $U$ Pond system, accounted for most of the wastewater discharged in the 200 West Area during the operating history of the 216-2-20 Crib. Past discharges from these sources also account for the major impact on the hydrologic regime in the southcentral 200 West Area.

Figure 22 shows the historical flows discharged to the $U$ Pond system between 1966 and 1992. Figure 22a illustrates the corresponding response of water table elevations in the vicinity of the $216-2-20 \mathrm{crib}$. As illustrated in Figure 22, an increase in average discharge from 5,678 to approximately $11,356 \mathrm{~L}(1,500$ to approximately $3,000 \mathrm{gal} / \mathrm{min})$ resulted in an increase in water table elevation of $3 \mathrm{~m}(10 \mathrm{ft}$ ) near the 216-Z-20 Crib (we11 2-W15-5). Discharge rates during the operating life of the 216-2-20 Crib are shown for comparison beneath the total discharge rate (see Figure 22b). By analogy, recent discharge rates at the $216-2-20 \mathrm{Crib}$ (568 to $246 \mathrm{~L} / \mathrm{min}$ [150 to $65 \mathrm{gal} / \mathrm{min}])$ should account for less than a $0.3-\mathrm{m}(1-\mathrm{ft})$ increase in water table elevation in the immediate vicinity of the crib (e.g., at well 2-W15-5, Figure 22a).

Recent discharge history (Figure 23) at the 284-WB Powerplant Ponds is also of potential significance to water level responses in the vicinity of the 216-2-20 Crib. The high discharge rates in the mid-1980's and abrupt decline after 1988, contribute to the changes in water table elevational contours and groundwater movement in the southcentral 200 West Area.

From 1982 to the present, the 216-z-20 Crib at times contributed a significant portion of the total wastewater discharge to the southwestern 200 West Area. The localized influence of this discharge can be seen in the distribution of specific conductivity (Figure 24). The areal distribution pattern shows the dilution effect of wastewater from the crib on the local groundwater (e.g., cooling water has an average specific conductivity of about 140 microsiemens per centimeter $[\mu \mathrm{S} / \mathrm{cm}]$ as compared to average groundwater of about $360 \mu \mathrm{S} / \mathrm{cm})$. The declining discharge rates, and corresponding decrease in the water table elevations, result in shallower gradients in water table elevations. In this regard, it is noteworthy that discharges to the cribs will be reduced to only 23 to $45 \mathrm{~L} / \mathrm{min}$ ( 6 to $12 \mathrm{gal} / \mathrm{min}$ ) by January 1994 .

In view of the above considerations and declining PFP wastewater discharge rates, impact of the $216-2-20 \mathrm{Crib}$ on the groundwater flow regime, even immediately beneath the crib, will become undetectable. Drainage of the residual water stored in the soil column will continue for a while after input is terminated but will not have a perceptible impact on groundwater flow directions.

Development of an overall model of groundwater response to wastewater disposal and proposed pump and treat scenarios is underway as part of the 200 West Aggregate Area studies (DOE-RL 1992) and related expedited response actions (ERA) (DOE-RL 1991). 
Figure 22. Correlation of Discharge History and Water Table Fluctuations in the Vicinity of the 216-z-20 crib.
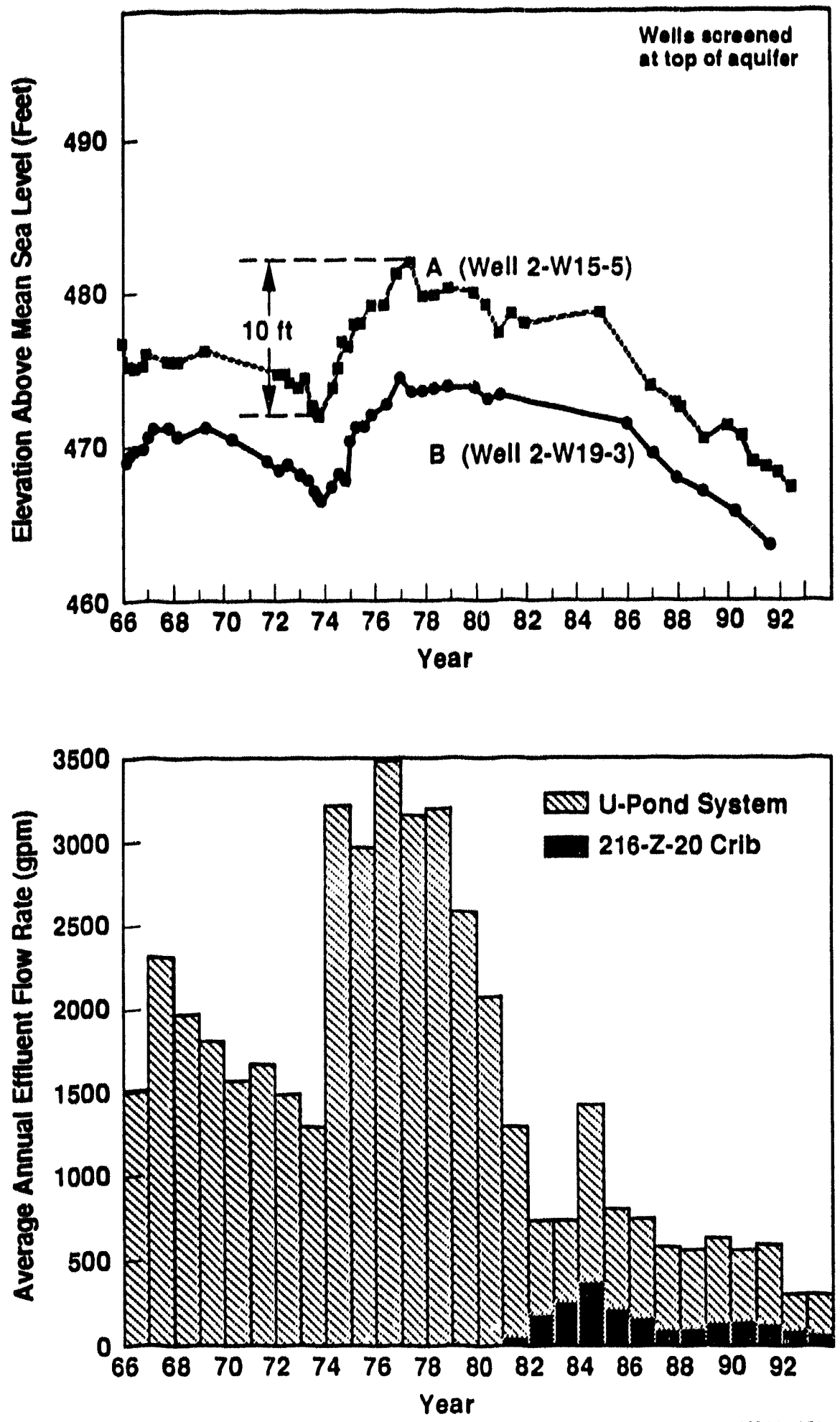

H9302035.10 
WHC-EP-0674

Figure 23. Discharge History at the 284 Powerplant Pond.

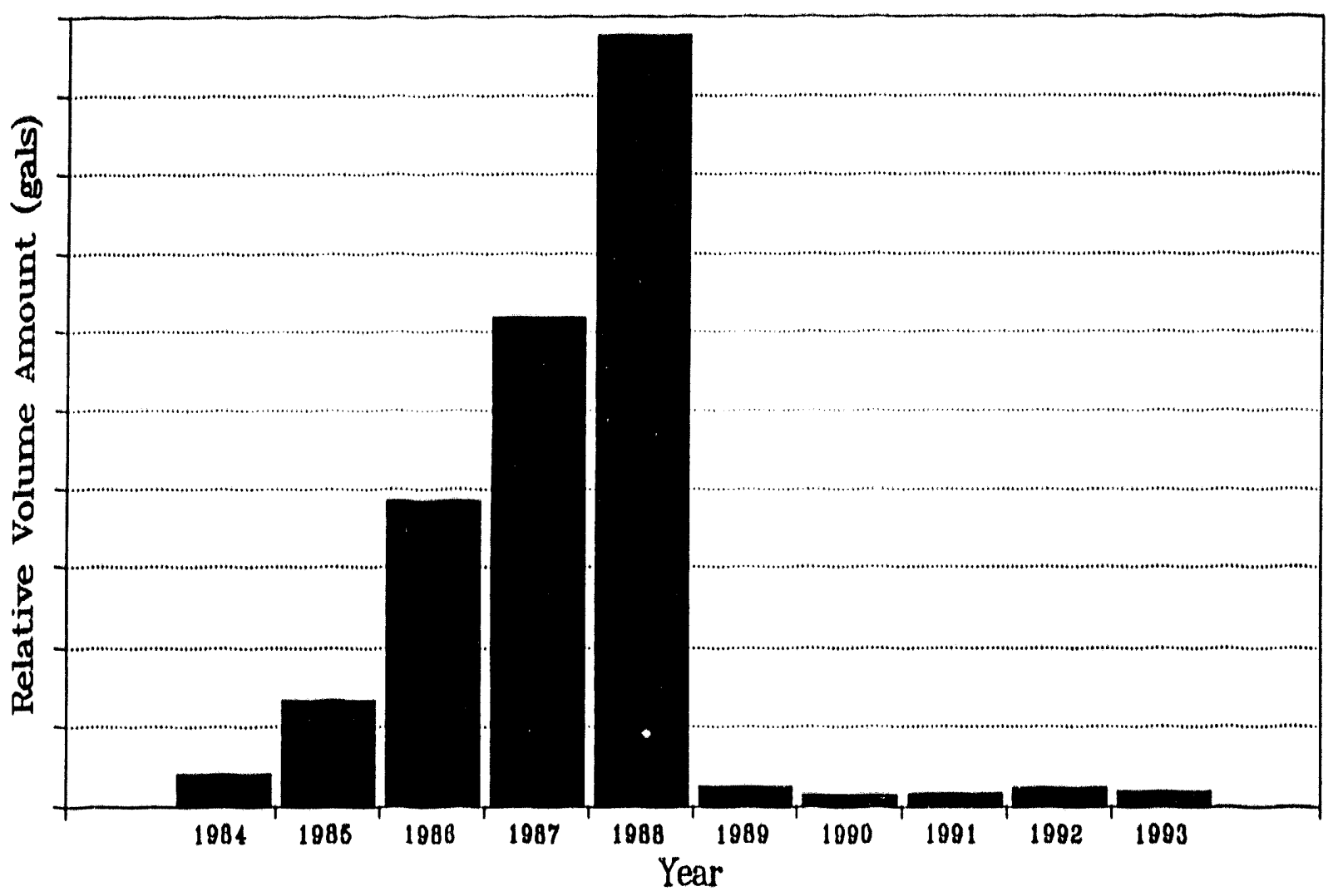


WHC-EP-0674

This page intentionally left blank. 
I Igure 24. Specific Conductivity of Groundwater in the 200 West Area (1988-1991 Data).

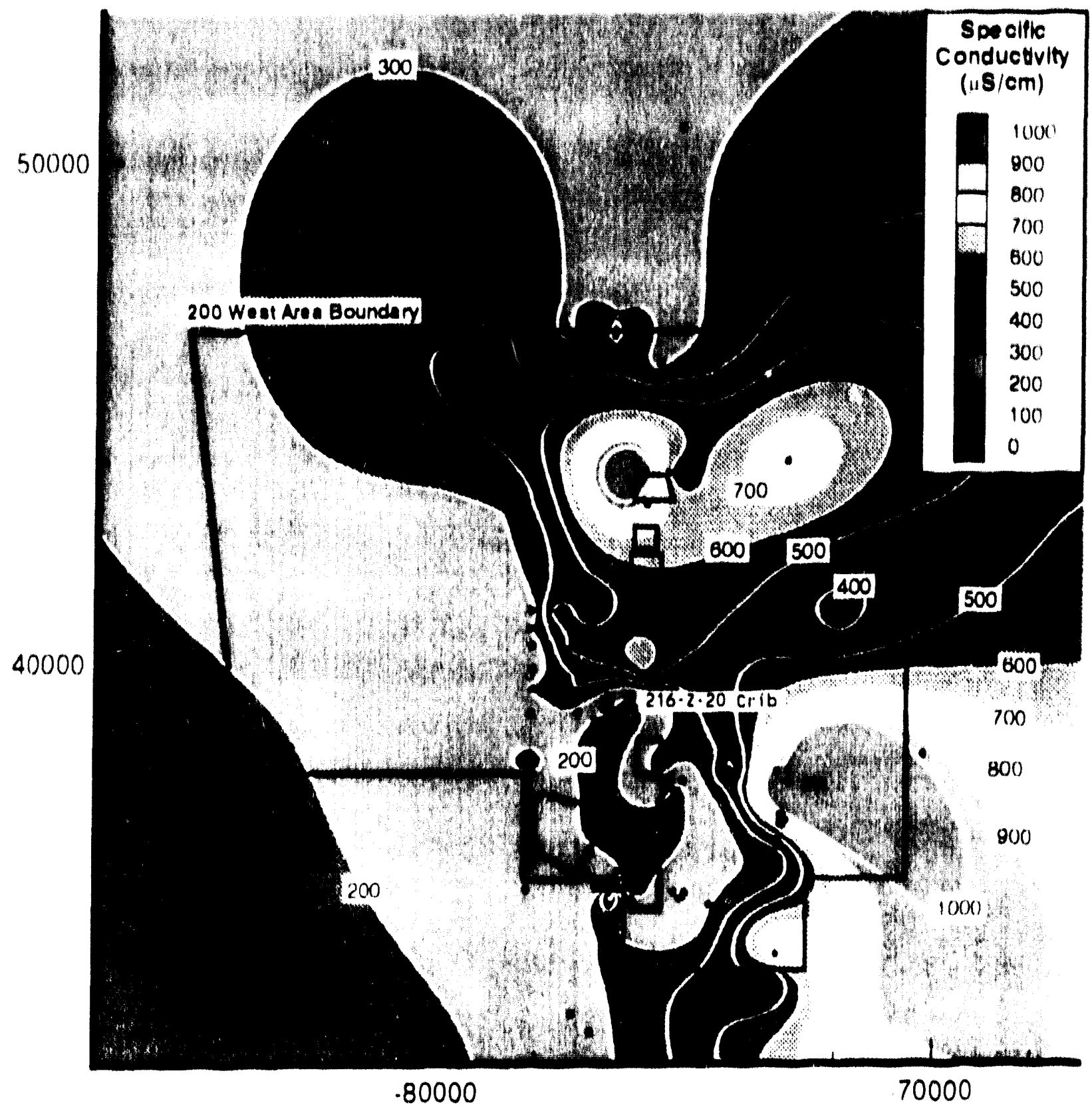

Areas in hlue show the distrihution of low conductivity cox)ling water from 11 Pond and currently active cribs in the 7 . Plant area ("(" shaped dark blue zone). Areas in red and yellow are zones of significant chemical contamination and coincide with several contaminant plumes (e.g., see nitrate, fluoride. arsenic, chromium) The localized zone of red and yellow in the center of the figure is due to past practice disposal of large volumes of high salt waste (first and second cycle supernatant) near the TX, TY and T Tank Farms (outlined in hlack). The large tongue of high conductivity shown in red in the lower right corner is attributed 10 past-practice disposal of $110_{3}$. Plant process condensate 
WHC-EP-0674

\subsection{GROUNOWATER QUALITY}

\subsubsection{Area Groundwater quality}

The major groundwater contaminant plumes in the unconfined aquifer beneath the 200 West Area originated from the PFP Complex and assoclated pastpractice liquid waste disposal sites. The second largest source of recent groundwater contamination arises from the Uranium/Uranium Trloxide $\left(U / \mathrm{UO}_{3}\right)$ Plant operations. Past disposal activities assoclated with REDOX nuclear fuel reprocessing activitles inc ized discharge of process condensates containing large amounts of tritium and $12 \% 1$, which account for the widespread plumes of these highly moblle radionuclides in the southeast area. T Plant and assoclated past-practice disposal of liquid radioactive wastes are largely responsible for the contaminant plumes in the northern area of the 200 West Area. These four major source areas account for the major contaminant plumes in the 200 West Area. Composite plume maps (Flgures 25, 26, and 27) of major nonradioactive contaminants and radionuclide indicators (gross alpha, gross beta, and trittum) show the distribution patterns of contaminants in relation to the 216-2-20 Crib and the major source areas described above. Spectfic contaminant occurrences and factors influencing their movement in the immediate vicinity of the 216-2-20 Crib are discussed in more detall as follows.

As suggested by the composite contaminant plume maps, the only indication of signiflcant groundwater contamination beneath the 216-2-20 Crib involves the chlorinated hydrocarbons assoclated with past-practice discharges from PFP Complex operations. This is consistent with the findings reported for the Liquid Effluent Study (WHC 1990b) for which the complete Appendix IX ( 40 CFR 264) list of analytes as well as site-specific constituents were analyzed in wells 2-W18-17 and 2-W18-20 locatad at the north and south and of the 216-2-20 Crib. The only slaniflcant exceedances found were for the chlorinated hydrocarbons $\left(\mathrm{CCl}_{6}\right.$, chloroform, and trichloroethylene). Naturally occurring constituents were two to three times lower than natural groundwater background for the Hanford Site, because of dilution of the ambient groundwater with coolant water discharged to the 216-2-20 Crib. One exception is the occurrence of arsentc at concentrations slightly above the average natural background for the Hanford site (about 6 parts per billiton (ppb]). For example, a groundwater plume of arsenic occurs immediately south of the 216-2-20 Crib (see Figure 25). In addition, perches...ter at the south end of the 216-2-20 Crib (weil 2-W18-29) is three to four times higher than the average natural background. The origin of the slightly elevated arsenic is unknown. Arsentc in local groundwater may be assoclated with past-practice chemical waste releases or may be leached from the soll column.

Based on the above findings, the focus of the following local groundwater quality discussion is on chlorinated hydrocarbons and factors influencing their distribution in the vicinity of the 216-2-20 Crib. 
Figure 25. Areal Distribution of Nonradioactive Contaminants in the 200 West Area Groundwater.

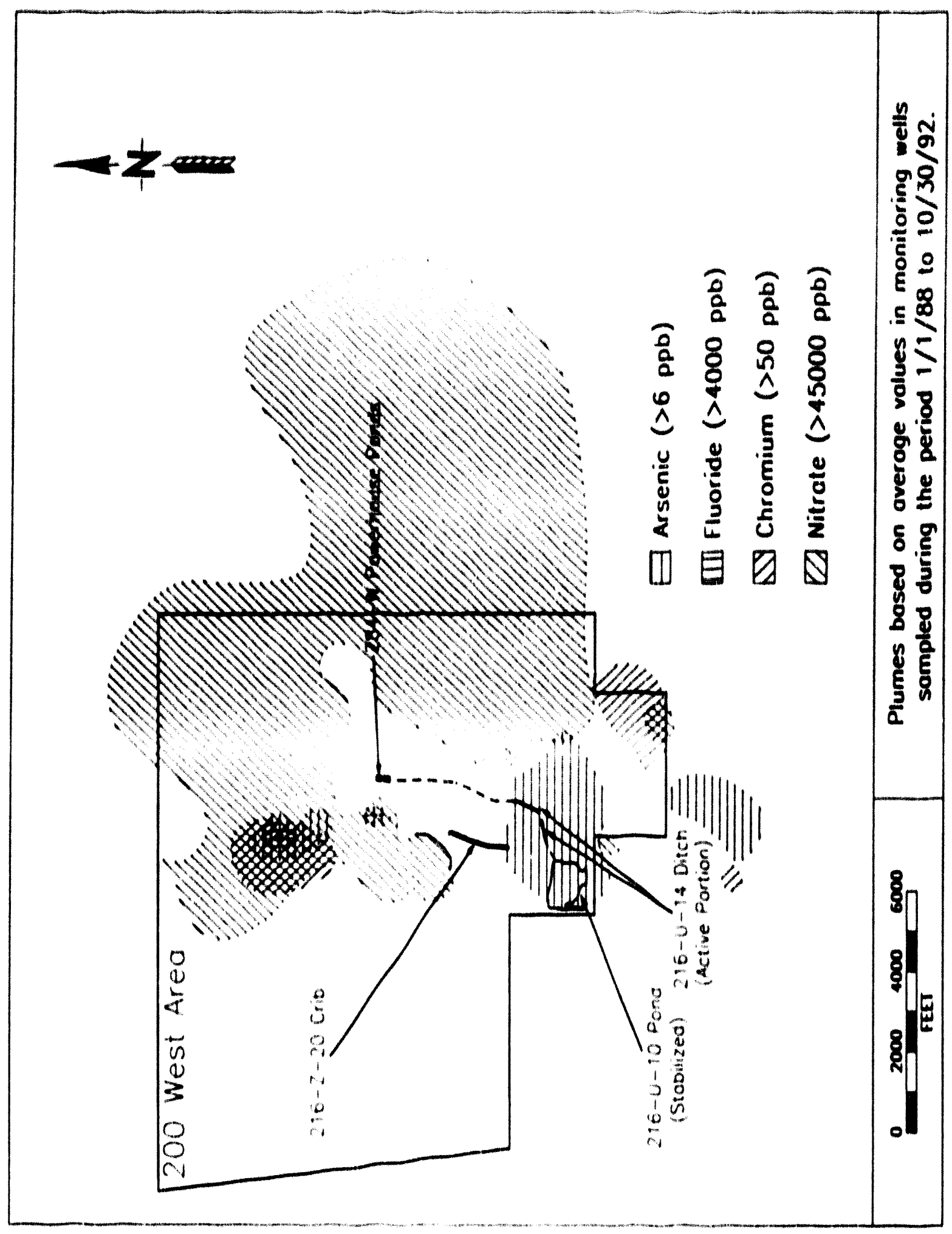


Figura 26. Areal Distribution of Radloact ive Contaminant Indicators in 200 West Area Groundwater.

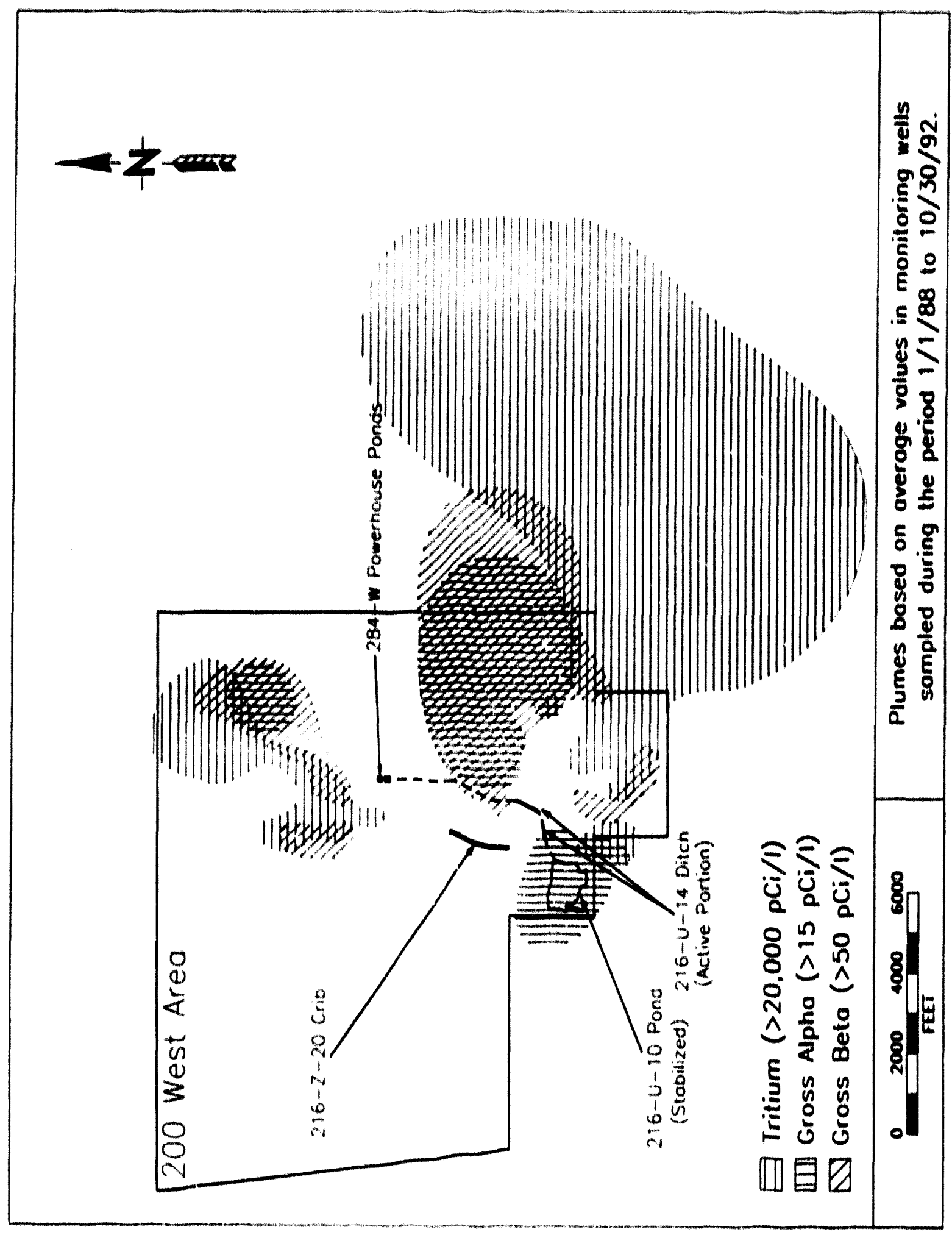


Figure 27. Areal Distribution of Chlorinated Hydrocarbons in 200 West Area Groundwater.

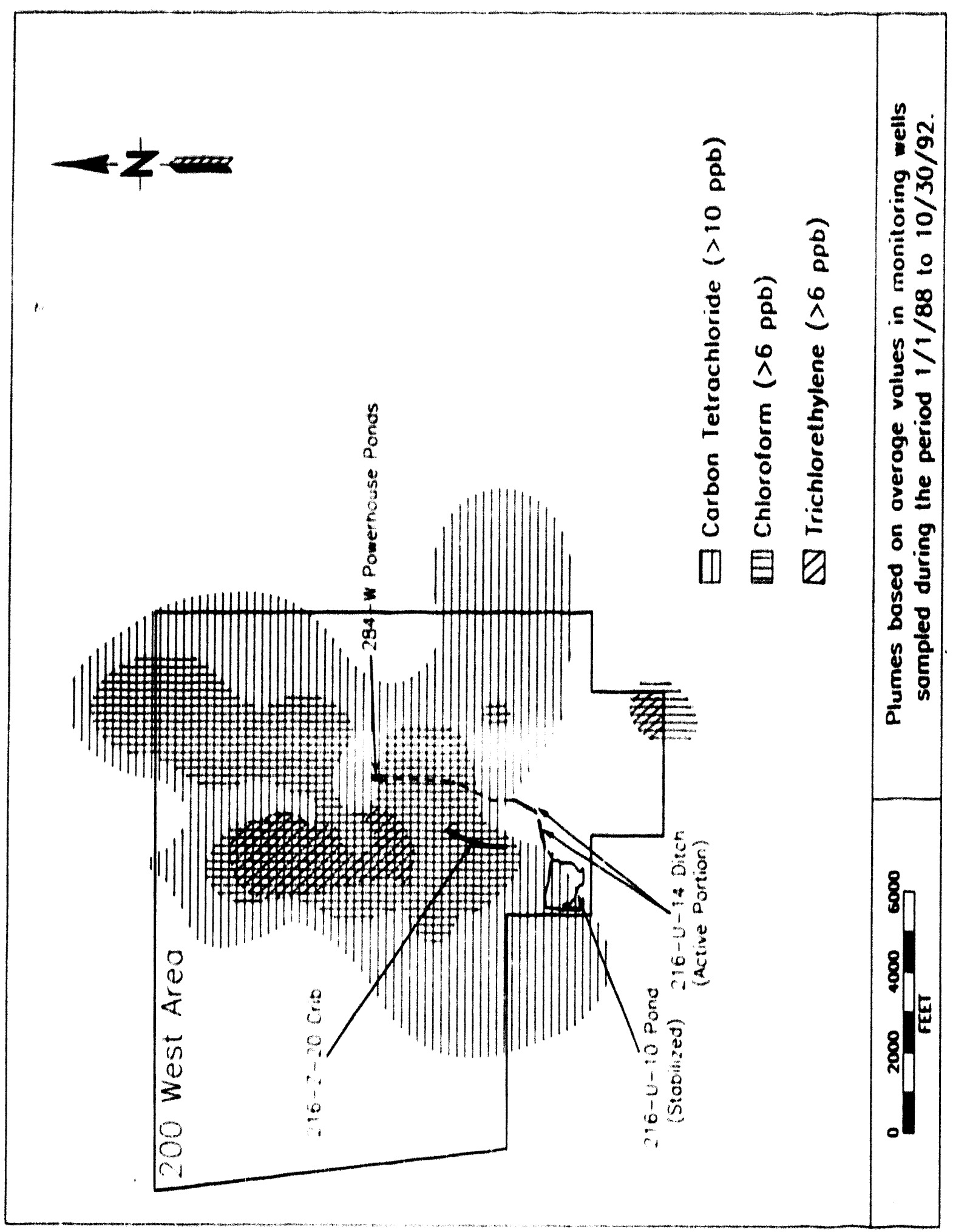




\subsubsection{Local Influences on Groundwater quality}

Locations of active and inactive liquid waste disposal facilities associated with current and past Z Plant operations are shown in Figure 28. As previously indicated (see Section 2.0), these facilities account for most of the chlorinated hydrocarbon contamination in 200 West Area groundwater as well as some of the highly localized metal and TRU occurrences (e.g, well 2-W15-8 at the 216-Z-9 (rib).

The PFP Complex liquid waste disposal sites are approximately centered within the residual 200 West Area groundwater mound because of:

- Residual influence of past wastewater disposal to the $U$ Pond system

- Smaller inputs from currently active sites.

The area shown in Figure 28 is also within a zone of rapidly declining water levels as illustrated in Figure 29. The core area with the greatest change in water elevations also corresponds to the area with the greatest hydraulic conductivities (Figure 30 ). The significance for future interpretation of plume movement, is that this area may be subiect to greater changes in water level and flow direction than other locations in the 200 West Area.

Recent water table elevations in the immediate vicinity of the 216-2-20 Crib are shown in Figure 31 . These data suggest there is 1ittle if any gradient along or adjacent to the crib. This area is also near the center of the groundwater mound previously described; thus, groundwater flow directions could be in any or all directions (based only on water table elevations) from this general location. In addition, a net groundwater movement in the southwest-northeast direction near the north end of the 216-Z-20 crib could occur because of the zone of high hydraulic conductivity in this area (see Figure 30 ). If this occurs, the distribution of $\mathrm{CCl}_{4}$-contaminated groundwater from the principal source area (216-2-9 Crib) could be spread to the west and southwest, which is consistent with the general 200 West Area groundwater $\mathrm{CCl}_{4}$ plume (Figure 32).

There are two potential secondary pathways for groundwater contamination (i.e., not directly discharged to active cribs):

- High vapor phase/soil gas concentrations of $\mathrm{CCl}_{4}$ from adjacent PFP Complex cribs may be absorbed by the infiltrating water from the 216-Z-20 Crib and other active wastewater disposal sites

- A more dense $\mathrm{CCl}_{4}$ vapor (or a dense, nonaqueous phase liquid [DNAPL]) could migrate down the outside of unsealed wells.

Soil gas sampling during 1992 and 1993 in the vicinity of the PFP Complex cribs revealed concentrations of up to a few hundred parts per million by volume (ppmv) between the 216-Z-18 and 216-z-1A Cribs. Much higher concentrations (to $\sim 10,000 \mathrm{ppmv}$ ) havt been measured in vadose zone boreholes near the 216-2-9 Trench (the disposal facility that received the greatest amount of chlorinated hydrocarbon waste; see Table 2, Section 2.0). Thus, 
Figure 28. Carbon Tetrachloride Sources Near the 216-z-20 crib.

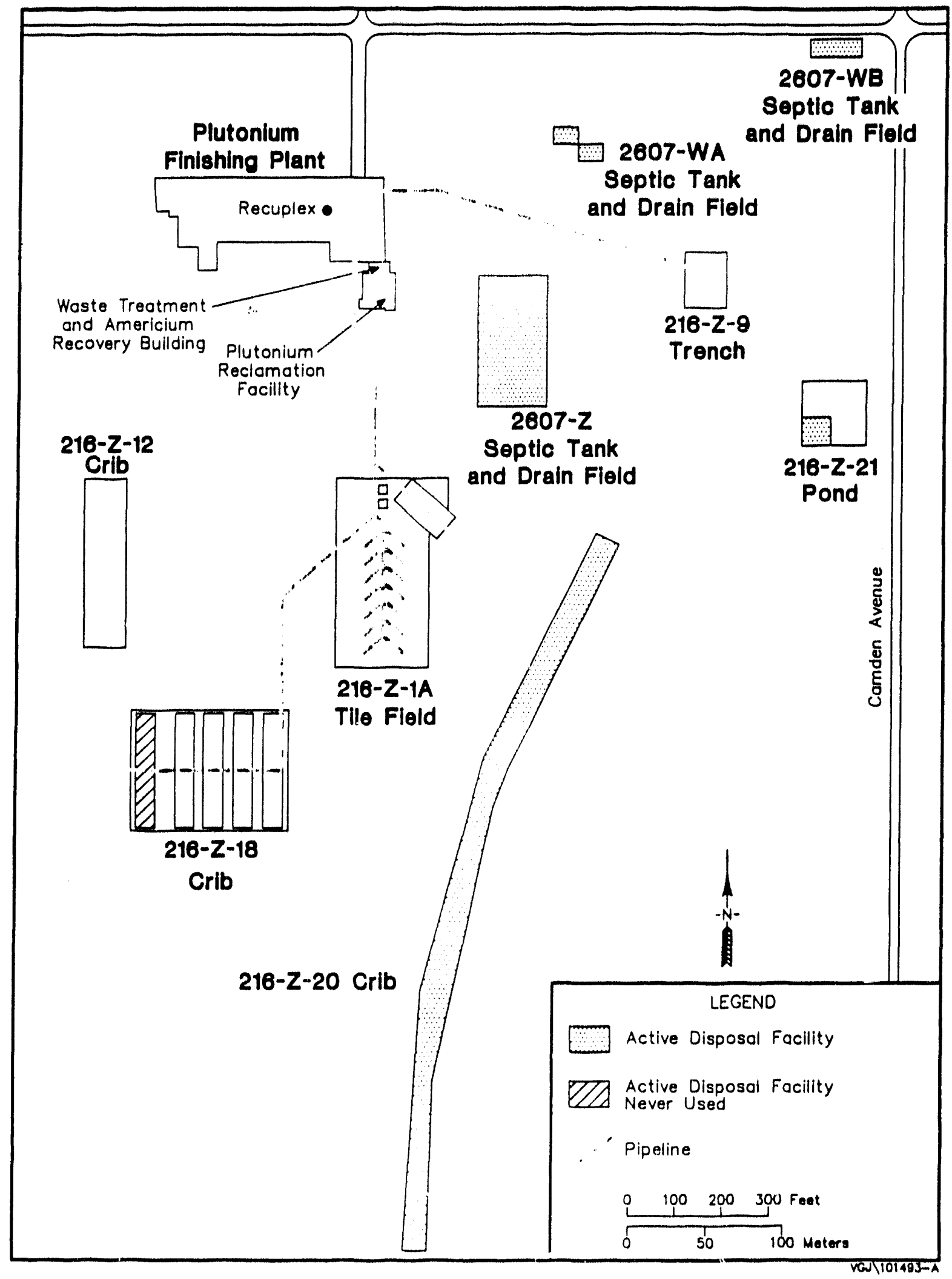


Figure 29. Relative Change in Water Table Elevations in the 200 West Area (December 1988 to December 1991).
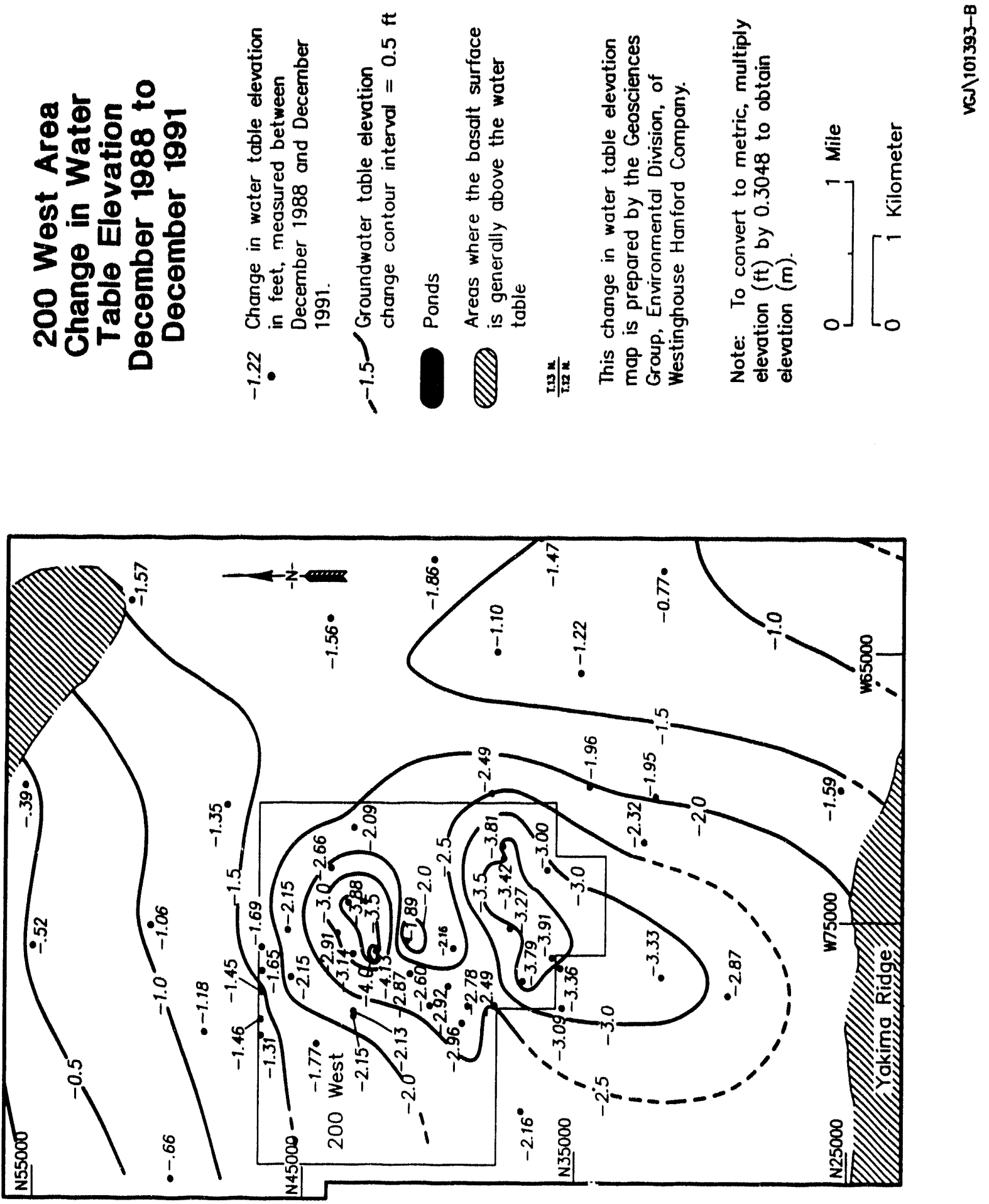
WHC-EP-0674

This page intentionally left blank. 
Figure 30. Hydraulic Conductivity in the 200 West Area.

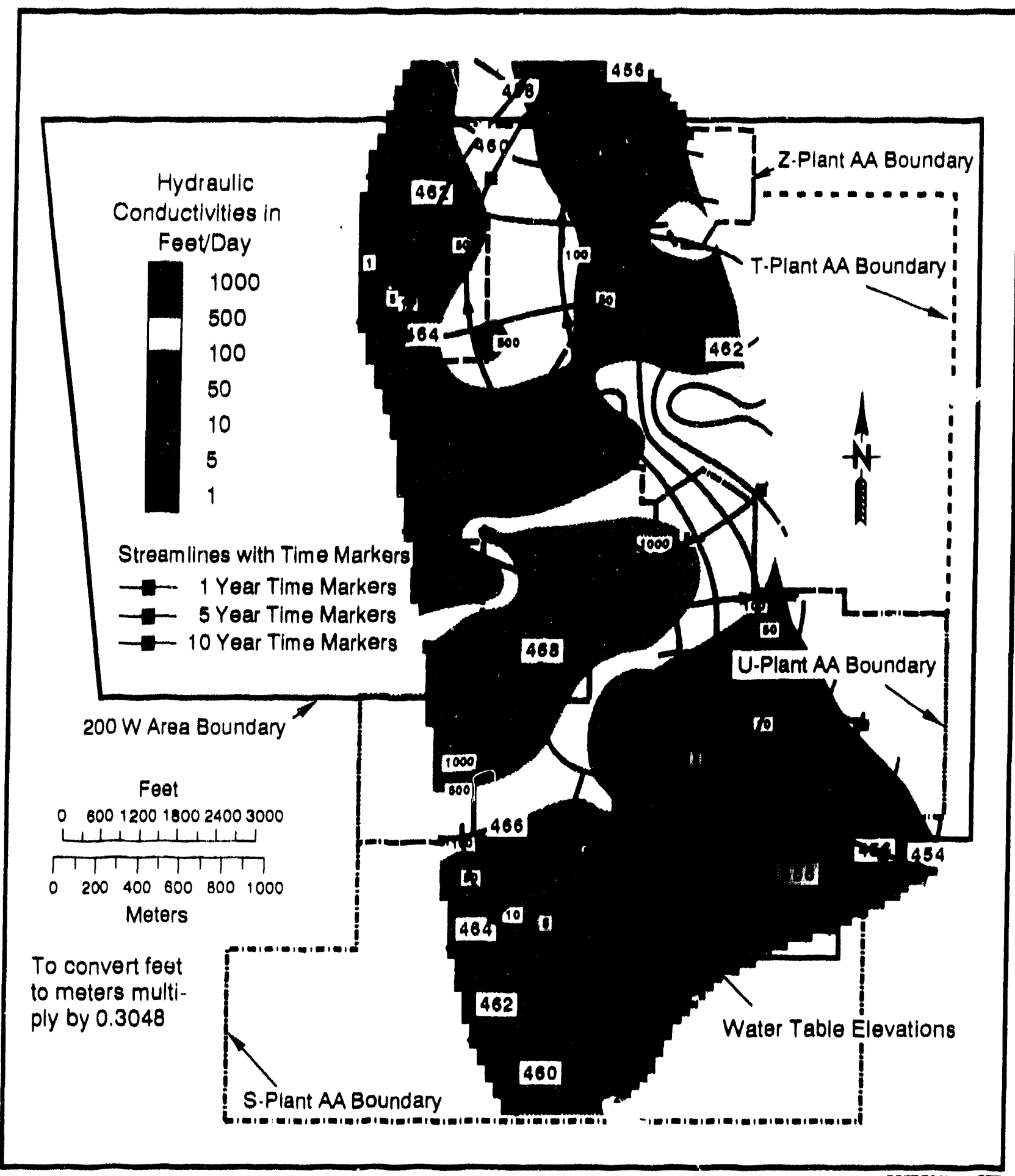


Figure 31. Water Table Elevations in the Immediate Vicinity of the 216-Z-20 Crib.

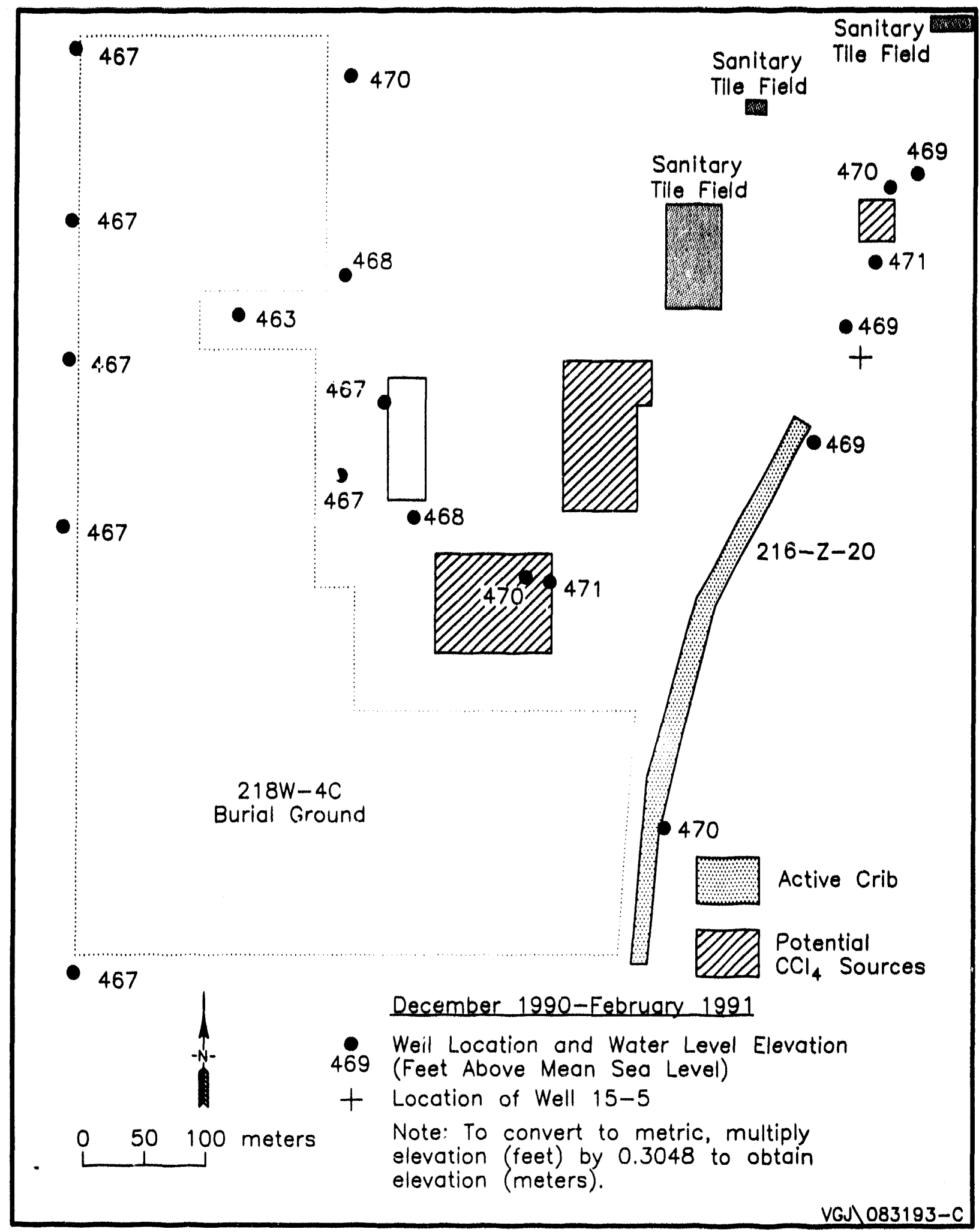


Figure 32. Contour Map of Carbon Tetrachloride Concentrations in 200 Areas Groundwater (Average for 1989 through 1991).

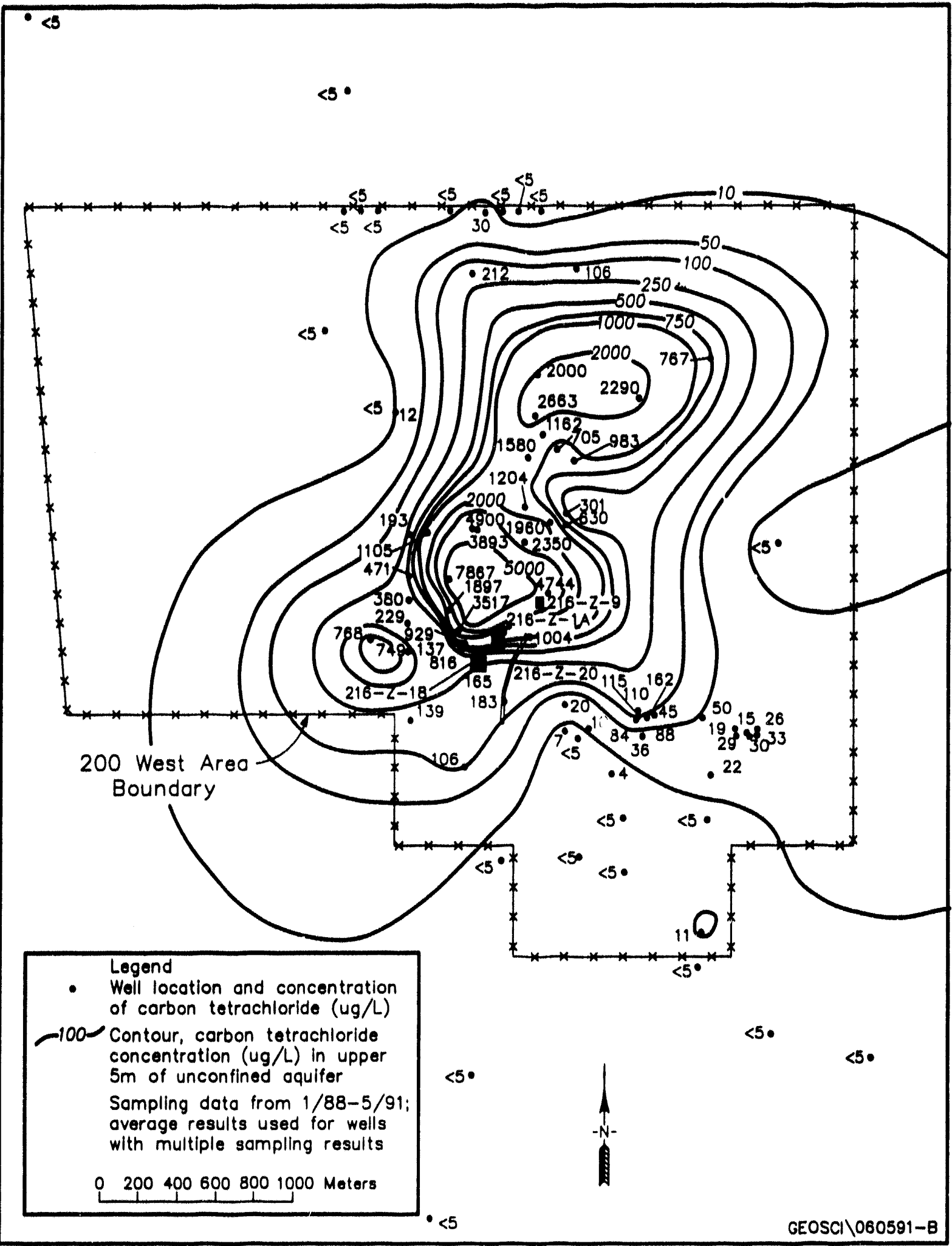


WHC-EP-0674

ample evidence now exists for the presence of high soll gas concentrations of $\mathrm{CCl}_{4}$ concentrations in the vicinity of active wastewater uisposal sites in the PFP Complex area.

An aqueous phase, in equilibrium with a vapor phase concentration of 100 ppmv of $\mathrm{CCl}_{4}$, would reach a theoretical concentration of 600 micrograms per 1iter $(\mu \mathrm{g} / \mathrm{L})$ (Rohay and Johnson 1991). Thus, if vapor phase transport from the 216-Z-1A and 216-2-18 Cribs or 216-z-9 Trench occurs and results in soll gas $\mathrm{CCl}_{4}$ concentratioris of the above magnitude, perched water from the 216- $z-20 \mathrm{Crib}$ should yield concentrations of several hundred $\mu \mathrm{g} / \mathrm{L}$ (assuming Henry's Law applies in a porous medium of varying moisture content). That is, water beneath the active 216-2-20 crib that accumulates as a perched water zone above the fine sediments should have adequate time to absorb the chlorinated hydrocarbons from the soll gas or vapor phase before the water migrates to the water table. Data from only a few wells were avallable to partially test this possibility. For example, a Resource Conservation and Recovery Act of 1976 (RCRA) well was completed in the perched water zone near the southern end of the 216-2-20 Crib as part of the Low-Level Waste Burial Ground (\#4) monitoring network. This well (2-W18-29) was sampled for the operational surveillance, RCRA, and $\mathrm{CCl}_{4}$ ERA programs during 1992 and 1993 (AppendiX B). An average concentration of $27 \mathrm{ppb}$ was obtained for $\mathrm{CCl}_{4}$ during seven separate groundwater sampling events. Soll gas $\mathrm{CCl}_{4}$ concentrations of 10 ppmv or less could accolint for equilibrium aqueous phase concentrations in this range (recent soli gas measurements from the nearby 2-W18-20 well were in this range; see Section 5.2.6). However, groundwater concentrations of nearly $200 \mu \mathrm{g} / \mathrm{L}$ have been measured in samples from well 2-W18-20 (Appendix B). Perched water grab samples collected in September 1993 from converted wells 2-W18-19 and 2-W18-20 (Appendix D) had $\mathrm{CCl}_{4}$ concentrations of $<5 \mathrm{ppb}$ and soll gas $\mathrm{CCl}_{4}$ concentrations of about $10 \mathrm{ppmv}$. It should al so be noted that low concentrations of chlorinated hydrocarbons $(e . g .,<35 \mu \mathrm{g} / \mathrm{L}$ chloroform and $<5 \mu \mathrm{g} / \mathrm{L} \mathrm{CCl}_{4}$ ) occur in the effluent stream discharged to the crib (WHC 1990b), which is consistent with the perched water data.

The above observations suggest that:

- $\mathrm{CCl}_{4}$ in groundwater at the $216-2-20 \mathrm{Crib}$ is not due to recent waste inputs from the PFP Complex

- Perched water $\mathrm{CCl}_{4}$ concentrations in wells immediately adjacent to the crib (2-W18-19 and 2-W18-20) appear to be lower than predicted concentrations based on observed soll gas concentrations and Henry's Law

- Groundwater concentrations directly beneath the crib appear to be significantly higher than perched water $\mathrm{CCl}_{4}$ concentrations.

If perched water $\mathrm{CCl}_{4}$ concentrations are much lower than in groundwater directly beneath the $216-2-20 \mathrm{crib}$, a vapor phase/perched water pathway, at least at this location, seems unlikely. This observation and the elevated and nearly constant $\mathrm{CC}_{4}$ concentrations in groundwater immediately beneath the crib (Figure 33), suggest there is some other pathway. An alternative source must account for a continuous supply of dissolved $\mathrm{CCl}_{4}$ in the wastewater/ groundwater directly beneath the crib. Some possibilities are explored in the following section. 
Figure 33. Carbon Tetrachloride Concentration Versus Time in Groundwater from We11 2-W18-17 (216-2-20 Crib).

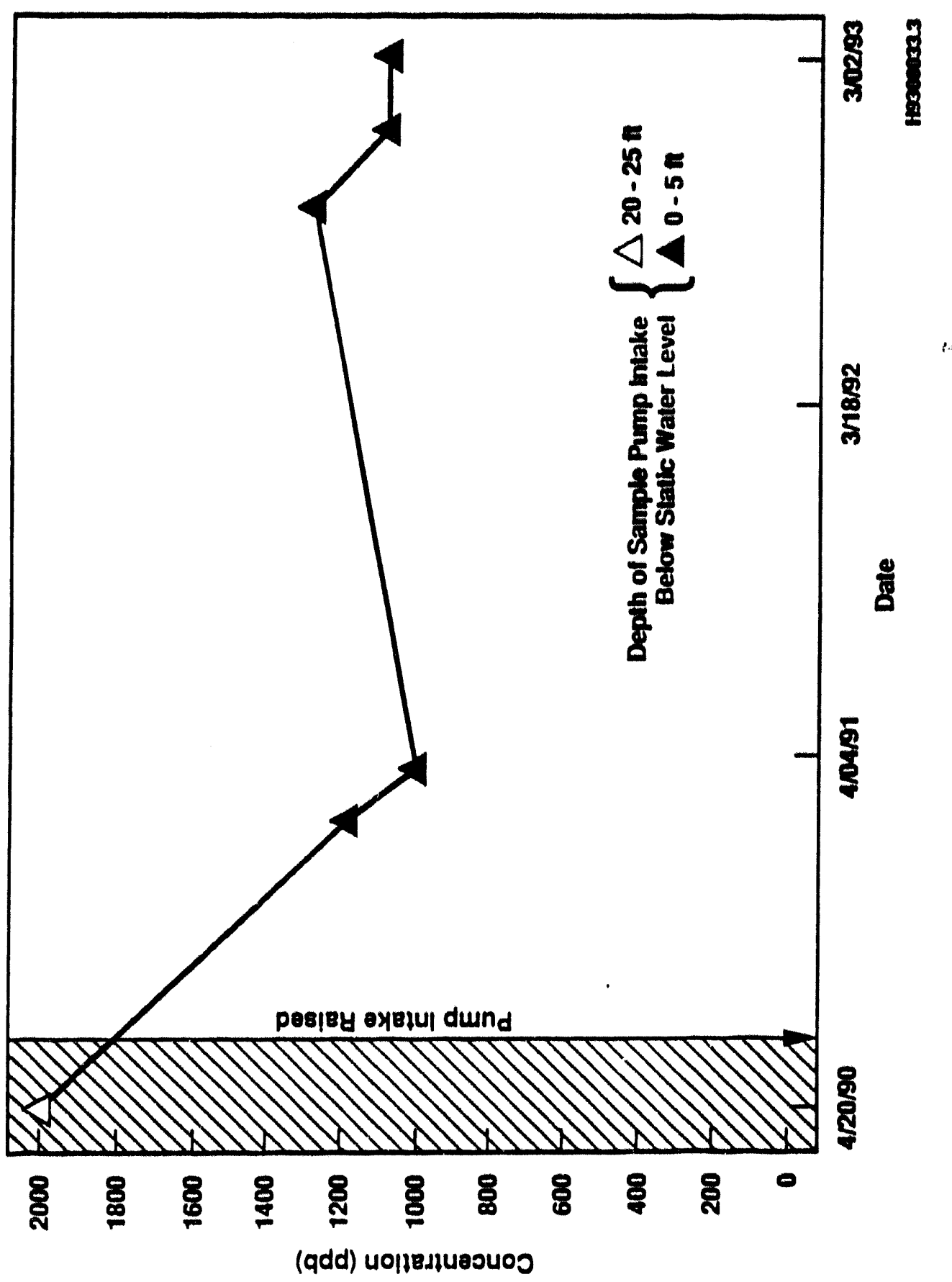


WHC-EP-0674

\subsubsection{Depth Distribution of Carbon Tetrachloride}

As noted in Section 2.0, this contaminant was discharged to the PFP Complex cribs as a separate ilquid phase as well as dissolved in the wastewater (Rohay and Johnson 1991). The relatively high density of liquid phase $\mathrm{CCl}_{4}$ (1.6 grams per cubic centimeter $\left.\left[\mathrm{g} / \mathrm{cm}^{3}\right]\right)$ leads to the speculation that a free phase (DNAPL) could migrate to the water table and subsequently settle deeper in the saturated zone. Preferential pathways, such as older inadequately sealed wells with gaps or vold spaces around the outside of the casings, or wells with extensive screens or perforated intervals, could provide a more direct pathway for downward transport of the DNAPL (Johnson 1993b; Last and Rohay 1993). Several older wells installed in the $1950^{\prime} \mathrm{s}$ and 1960's with deeper perforated intervals were located adjacent to the PFP Complex cribs. One such well, 2-W15-6, is located near the

216-2-9 Crib and is perforated to a depth of approximately $52 \mathrm{~m}$ (170 ft) below the water table. Another well with similar characteristics, 2-W15-5, lies between the 216-2-9 and the 216-2-20 Cribs. If downward transport occurred in these locations, dissolved $\mathrm{CCl}_{4}$ should be present at greater depths in the aquifer than just near the surface or top of the water table.

Near-surface (top of the water table) and deeper groundwater samples were collected in 1991 for a collaborative effort between the ERA project and the operational groundwater survelllance program. Balled samples were taken at the surface and bottom of well 2-W15-6, and pumped samples (after purging) were taken from approximately $3 \mathrm{~m}(10 \mathrm{ft})$ below the surface and near the bottom of the well after installation of a packer in an attempt to 1solate the lower section of perforated interval. Some additional depth-related information was acquired from the two monitoring wells at the 216-2-20 crib. These data are arranged in relation to stratigraphic position and location with respect to the 216-2-9 and 216-z-20 Cribs in Figure 34 . Very high $\mathrm{CCl}_{4}$ concentrations were encountered at the bottom of this well (2-W15-6), and near the water table elevation. Both the balled and pumped sample sets showed this pattern. However, a somewhat lower concentration was obtained with the deeppumped sample than with the deep-bailed sample (the latter was taken before installation of the packer and pump). The contamination may be localized in the immediate vicinity of the borehole rather than widespread in the deeper part of the aquifer. Near-surface and deeper samples at the other monitoring wells shown in Figure 34 al so suggest deeper contamination than just at the very top of the aquifer. More detailed vertical-depth profiles are needed in this area to determine if $\mathrm{CCl}_{4}$ is present in the deeper part of the aquifer as a separate liquid phase that could continue to slowly dissolve over time. If so, this may account for the observation that the zone of highest groundwater concentrations of $\mathrm{CCl}_{4}$ remain near the PFP Complex cribs even though the cribs have been inactive for the last 20 to 30 years (see Figure 32 ). Recent modeling of downward migration of $\mathrm{CCl}_{4}$ beneath the 216-2-9 Crib (Piepho et al. 1993), suggests a slow, long-term drainage of liquid phase $\mathrm{CCl}_{4}$ could account for the persistent presence of high concentrations dissolved in groundwater at this location, even long after termination of input to the crib.

Regardless of the actual transport mechanism for movement of $\mathrm{CCl}_{4}$ to groundwater in the vicinity of the 216-2-9 Crib (the largest single source of $\left.\mathrm{CCl}_{4}\right)$, it is difficult to correlate this source with the occurrence of significant concentrations beneath the 216-2-20 Crib. For example, the major 
WHC-EP-0674

This page intentionally left blank. 


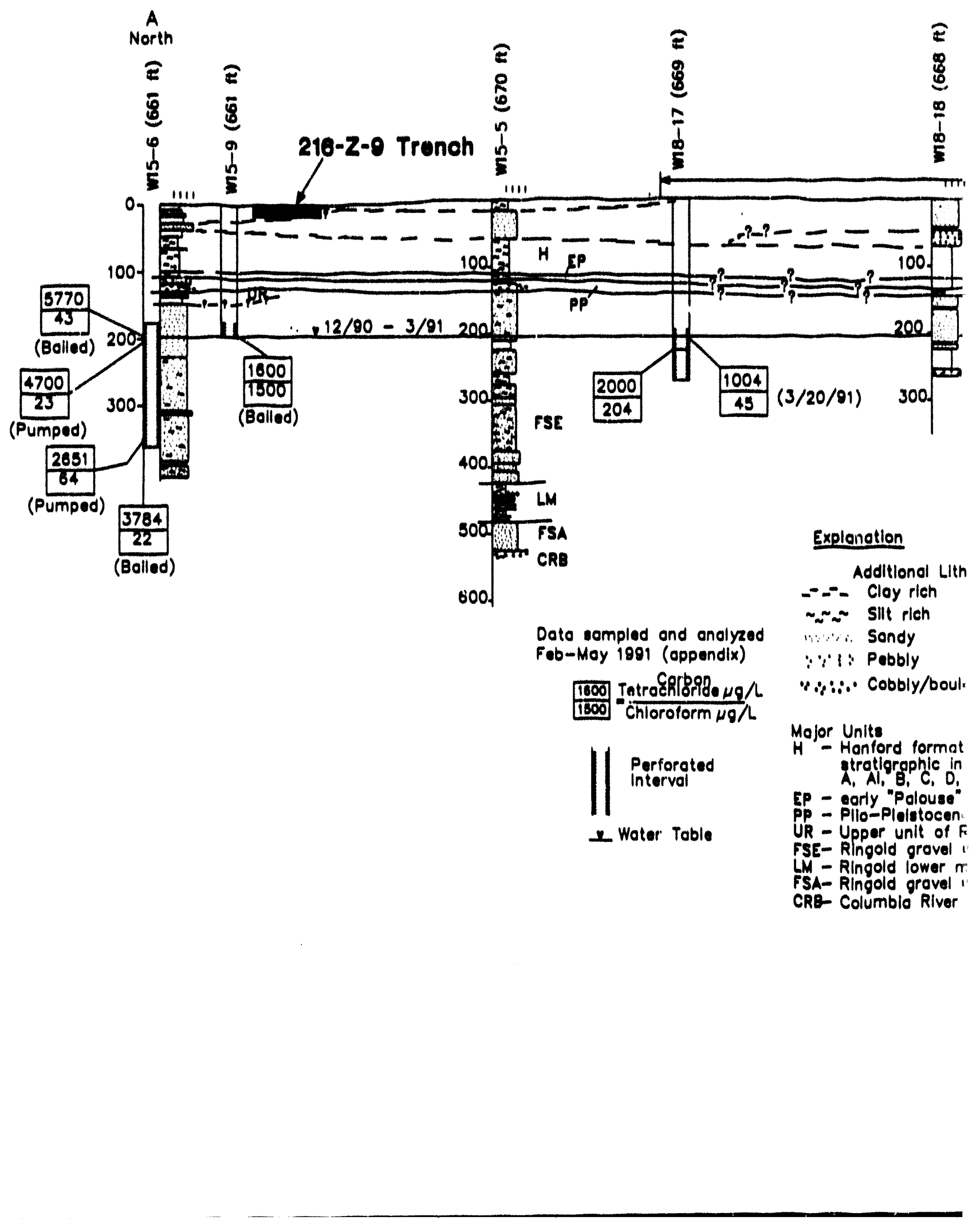


Figure 34. Vertical Distribution of Carbon Tetrachloride and Chloroform In Groundwater Near the 216-2-20 crib.

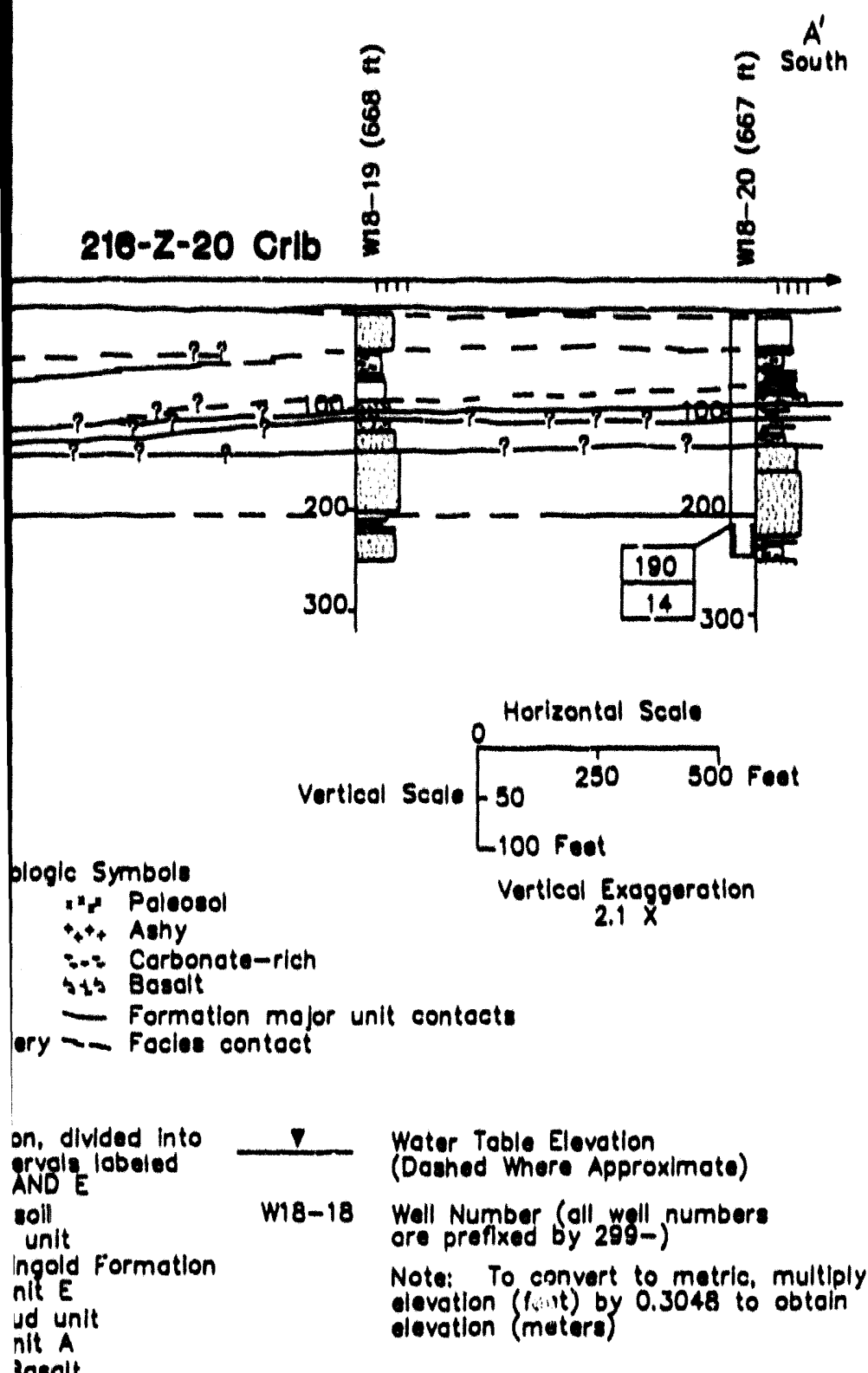

verionas-c 
sources of water in this area have been the 216-2-20 and adjacent 216-2-21 Cribs. These two sources should have at least created a slight but decreasing gradient to the north. This inference is also supported by the distribution pattern for specific conductivity, suggesting wastewater (essentlally cooling water) moves northward as well as to the west and east from the 216-2-20 and 216-2-21 Cribs. That is, the recent hydrologic conditions suggest southerly transport direction from the 216-2-9 Crib is not likely. Also, potential nearby sources of a slow-draining liquid CCl. phase from the 216-2-18 and 216-2-1A Cribs would be displaced to the west because of lateral groundwater movement away from the 216-2-20 Crib induced by PFP Complex wastewater as it spreads along the surface of the aquifer.

The potential interaction of $\mathrm{CCl}_{4}$ vapor phase with various water sources in the general area north of the 216-2-20 Crib appears to be a likely possibility based on the coincidence of the shallow soll gas CCl "halo," groundwater concentration contours, and source areas as fllustrated in Figure 35. The limited southerly extension of the halo, however, is not consistent with the elevated groundwater levels beneath the 216-2-20 Crib. Additionally, the transport of a gas phase through saturated or partially saturated soll directly adjacent to and beneath the 216-2-20 Crib (1.e., near the monitoring wells) would be unlikely. Thus, even though vapor phase and DNAPL sources exist beneath adjacent past-practice CCl disposal factlities, wastewater entering the aquifer directly beneath the 216-2-20 Crib (1.e, near the monitoring wells) may be isolated from these sources. If so, additional pathways or source areas must account: for the relatively high $\mathrm{CCl}_{4}$ concentrations in the monitoring wells at the 216-2-20 Crib.

Although $\mathrm{CCl}_{\text {, }}$ and related wastes were not intentionally discharged to the 2 Ditches, apparently, as previously discussed, occaslonal process upsets or splils resulted in such releases. All of the 2 Ditches ran close to and parallel to the 216-Z-20 Crib (see Figures 2 and 9). The monitoring wells for the 216-2-20 Crib are located between the edge of the crib and the 216-2-19 Ditch. Thus, while perhaps only a minor source, the proximity of the 2 Ditches make them likely DNAPL sources for the occurrence of elevated $\mathrm{CCl}_{4}$ in groundwater samples from the 216-2-20 crib monitoring wells. The potential source could be either long-term drainage of DNAPL from beneath the ditches or restdual DNAPL that may have entered the annular space of the unsealed wells. (All four of the groundwater monitoring wells installed in 1982 at the 216-2-20 (rib were unsealed.)

\subsection{SOIL COLUMN CHEMICAL FACTORS}

Soll column chemical factors such as percentage of calcium carbonate and soll organic matter content can influence the transport and behavior of contaminant, in wastewater migrating through the soll column. Accordingly, this section provides a brief summary of soll chemical conditions in the vicinity of the 216-2-20 Crib and nearby cribs. Data for this summary are from the recent work for the $\mathrm{CCl}_{4}$ ERA (Last and Rohay 1993) and other previous characterization reports. 


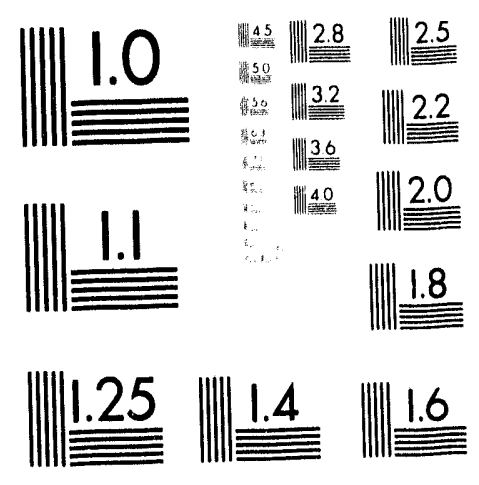



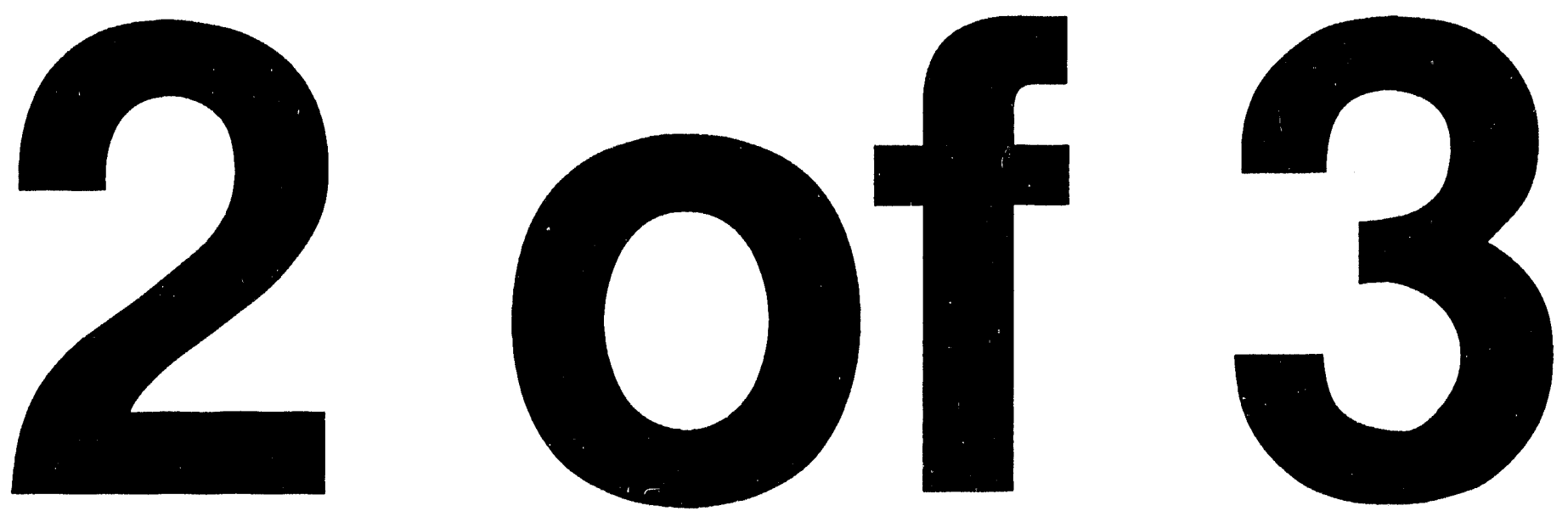

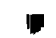


Figure 35. So 11 Gas and Groundwater Concentration Contours in Relation to Active Wastewater Disposal Sites and Carbon Tetrachioride Sources.

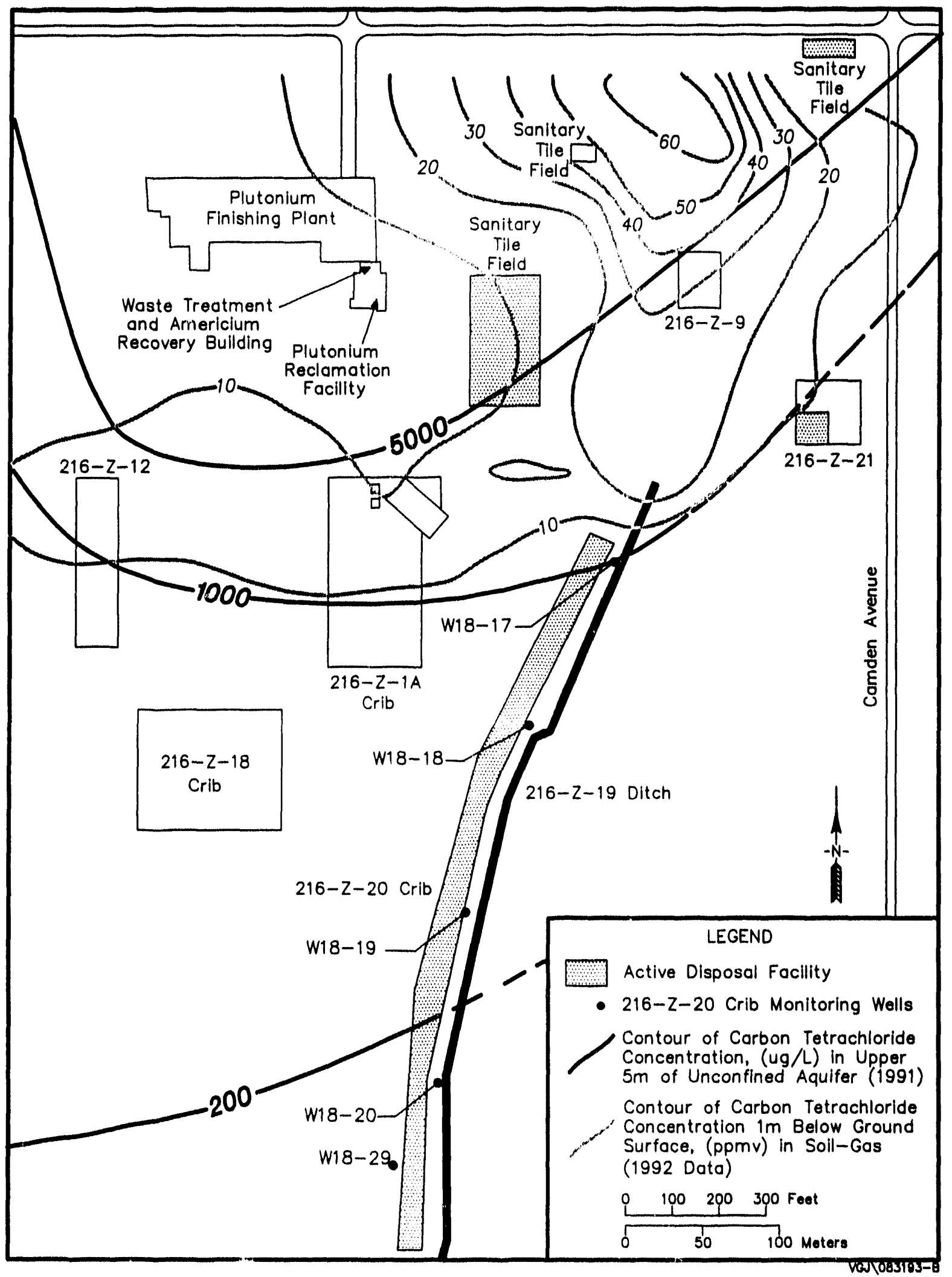




\subsubsection{Calcium Carbonate}

The relative abundance, depth distribution, and chemical reactions

involving calcareous sediments beneath or in the vicinity of the 216-Z-20 Crib are discussed in relation to contaminant mobility in the follow sections. For this purpose, both site-specific data and literature results relating to soil and sediment chemical controls on pore fluid chemical conditions are used.

4.4.1.1 Depth Distribution. Depth profiles for calcium carbonate content in relation to lithology and grain size from test borings conducted near the 216-2-20 Crib for the $\mathrm{CCl}_{4}$ ERA are shown in Figure 36. These plots show that calcium carbonate content is approximately 1 to $2 \%$ in the upper portion of the stratigraphic column (Hanford formation), reaches a maximum of 5 to $10 \%$ in the "early" Palouse/P1io-Pleistocene units, and declines to less than $1 \%$ in the Ringold Formation. The significance of this distribution for the 216-2-20 Crib is that most of the calcium carbonate occurs well above the water table where possible chemical reactions with downward migrating wastewater would first occur. (The relatively high calcium carbonate content is typical of soil profile development in arid environments.)

Maintenance of a slightly alkaline $\mathrm{pH}(-8)$ is the primary soil/chemical control on wastewater as it moves through the soil column. The significance of a slightly alkaline $\mathrm{pH}$ for sorption of many heavy metals, especially TRUs, and the buffering effect of a soil carbonate/aqueous system is discussed in the following section.

4.4.1.2 Reaction with Acids and pH Buffering. The acid neutralizing capacity of calcareous soils is another important soil chemical factor, especially for the 216-2-20 Crib because acid releases to this crib occurred during earlier PFP Complex operations (before 1986; see Section 3.0).

The neutralizing chemical reaction can be summarized as follows:

$$
2 \mathrm{H}^{+}+\mathrm{CaCO}_{3}=\mathrm{H}_{2} \mathrm{O}+\mathrm{Ca}^{2+}+\mathrm{CO}_{2} \text {. }
$$

The above reaction shows that two moles of acid are consumed for every mole of calcium carbonate. Assuming uniform infiltration of wastewater and an area of the dimensions of the crib $\left(1,412 \mathrm{~m}^{2}\right)$, and a calcium carbonate content of $1 \%$, the moles of calcium carbonate in a $1-m$ layer of soil or sediment immediately beneath the crib can be estimated as follows:

$$
\text { moles } \mathrm{CaCO}_{3}=\frac{A * Z * D * C}{M W}=\frac{(1,412) *(1) *(2,000) *(0.01)}{100.08}=282 \mathrm{kmol}
$$

where:

$$
\begin{aligned}
A & =\text { area of crib, } \mathrm{m}^{2} \\
Z & =\text { soil depth increment, } \mathrm{m} \\
D & =\text { bulk density of soil, } \mathrm{kg} / \mathrm{m}^{3} \\
C & =\mathrm{CaCO}_{3} \text { weight fraction }(\mathrm{e} . \mathrm{g} ., 1 \%=0.01) \\
M W & =\text { molecular weight of } \mathrm{CaCO}_{3}, \mathrm{~g} / \mathrm{mol} \text { or } \mathrm{kg} / \mathrm{kmol} .
\end{aligned}
$$


Figure 36. Lithology and Calcium Carbonate Depth Profiles Near the 216-2-20 Crib (modified from Last and Rohay 1993).
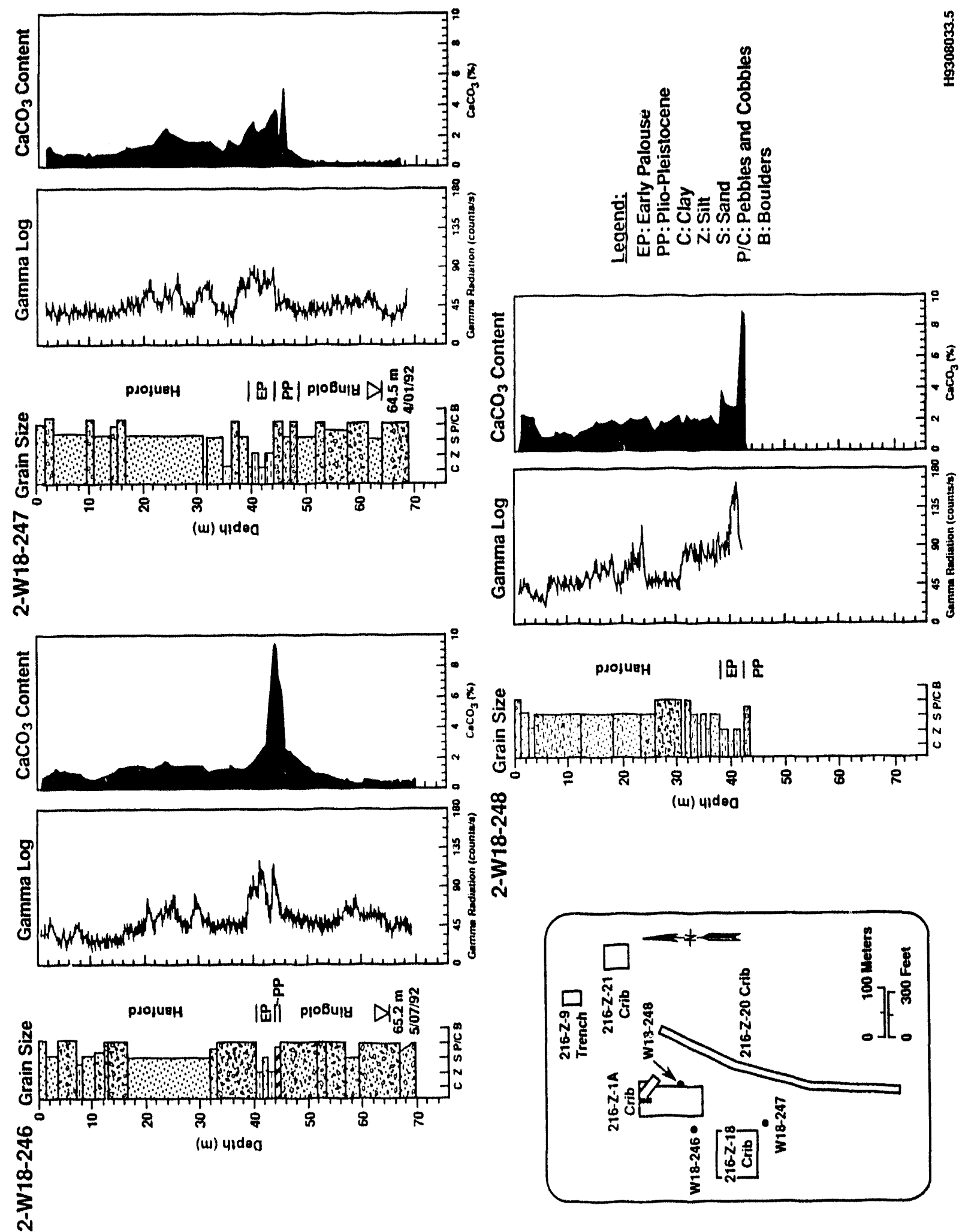
A large nitric acid spill $(3,454.5 \mathrm{~kg}[7,600 \mathrm{lb}])$ that occurred in 1984 (WHC 1990b) is equivalent to $54.8 \mathrm{kmol}$, which would consume only half as many moles of calcium carbonate or $27.4 \mathrm{kmol}$. Thus a $1-\mathrm{m}$ layer of soil contains over 10 times as much calcium carbonate as required to theoretically neutralize the largest recorded acid release to the crib. An additional safety margin is that the average calcium carbonate content of the upper soil column for the 216-Z-20 Crib (down through the Plio-Pleistocene) is 2 to $3 \%$ (see Figure 36).

Although effluent records and administrative controls suggest the $\mathrm{pH}$ of the effluent was maintained at near neutral conditions, at times the $\mathrm{pH}$ dropped to a range of 5 to 6 . Assuming the total estimated effluent discharge volume of $4 \times 10^{8} \mathrm{~L}$ had a $\mathrm{pH}$ of $5\left(10^{-5} \mathrm{~mol} / \mathrm{L}\right)$, the moles of calcium carbonate required to neutralize this hypothetical chronic acid loading of the soil column would be:

$$
1 / 2\left[4 \times 10^{9} \mathrm{~L} * 1 \times 10^{-5} \mathrm{~mol} / \mathrm{L}\right]=2 \times 10^{4} \mathrm{~mol}
$$

or $20 \mathrm{kmol}$. Thus, the first $1-\mathrm{m}$ layer of soil would easily neutralize several acid spills of the magnitude noted above, as well as an effluent stream volume of 4 billion liters with an assumed constant pH of 5 .

Based on the above considerations, it is concluded that the $\mathrm{pH}$ of the wastewater/soil/pore fluid environment beneath the crib has been maintained at a $\mathrm{pH}$ of 7 to 8. This conclusion is supported by the observed $\mathrm{pH}$ of perched water in well 2-W18-29 (7.5 to 8.3) and in water samples drawn from the risers installed in the crib (pH 7.9 to 7.95; Subrahmanyam and UIbricht 1987). Both of these observations are consistent with the predicted $\mathrm{pH}(7.3$ to 8.2$)$ of an aqueous system in equilibrium with a calcium carbonate phase and ambient or average atmospheric carbon dioxide partial pressures of $10^{-2}$ to $10^{-3.5}$ atmospheres (atm) (Drever 1982).

4.4.1.3 Retention of Transuranics By Soils vs pH. The role of pore fluid pH on TRU mobility in the soil column is discussed as follows. Laboratory soil/ water equilibration experiments with various oxidation states of plutonium as a function of $\mathrm{pH}$ (Ames et al. 1976) suggest the optimum $\mathrm{pH}$ for sorption (and retention) occurs between 7 and 8 . As illustrated in Figure 37, sorption (and/or precipitation of hydroxides or hydrous oxides) dramatically increases at neutral to slightly basic $\mathrm{pH}$. These early pH-sorption data are supported by more recent plutonium sorption experiments using Hanford Site sediment/ groundwater systems (Figure 37 ). In addition, the more recent work indicates distribution coefficients increase with contact time, suggesting that plutonium may become more tightly bound with aging. Barney (1988) further hypothesized that the higher oxidation state of piutonium $(i . e .,+6)$ may be reduced to +4 by the sediment, thus increasing the apparent $k_{d}$ values because plutonium in the +4 state is known to be more surface active than when in the +6 state.

Chemical leaching experiments also have been conducted on soils and sediments using both laboratory-labeled sediments and contaminated substrates from waste ponds and cribs (Ames et al. 1976). These studies all demonstrate 
Figure 37. Sorption of Plutonium By Soil as a Function of $\mathrm{pH}$ and Oxidation State.

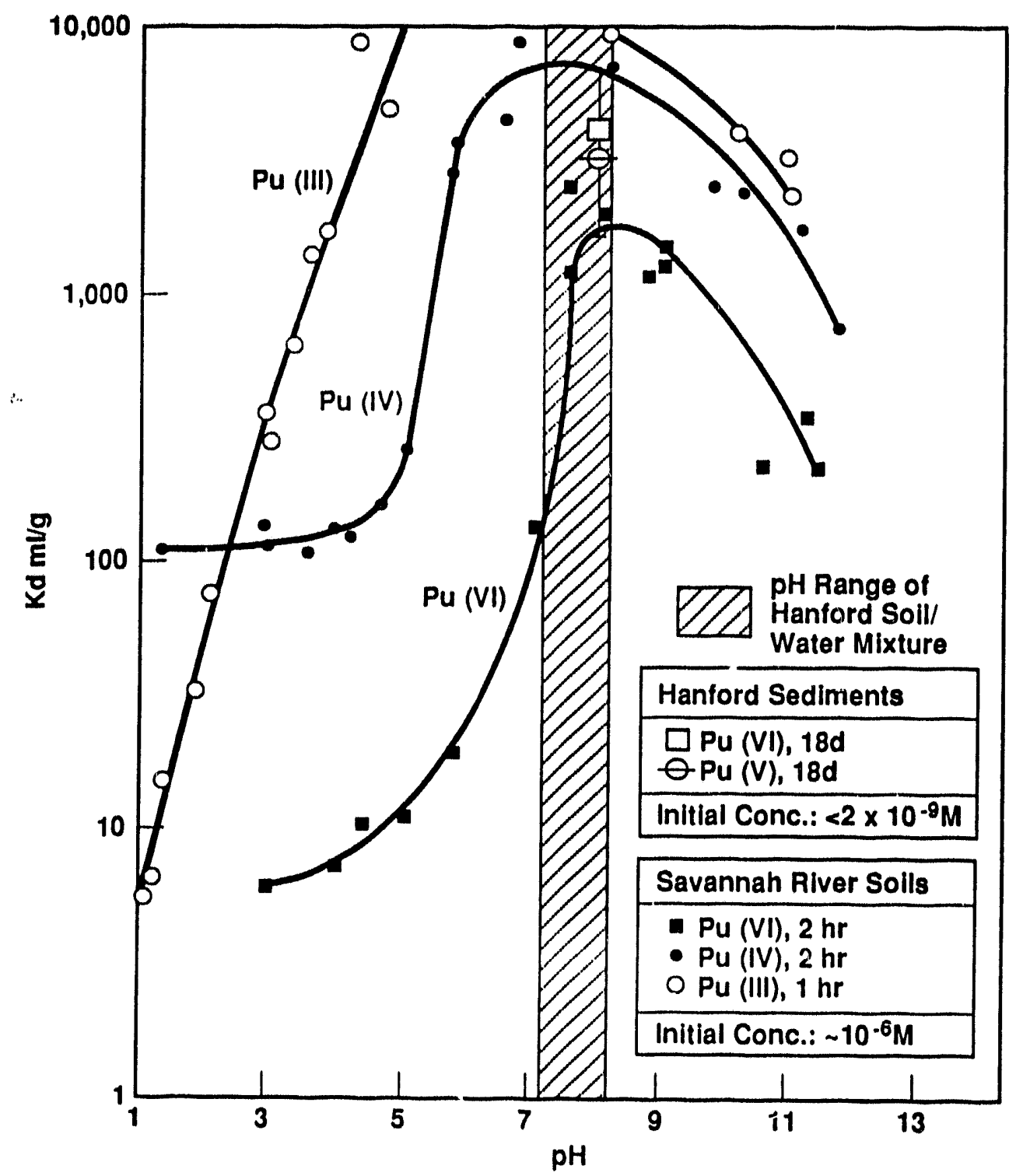

H9308033.2 
that once plutonium (and americium) are incorporated into the sediment or soil chemical complex, they are extremely difficult to remove. Various

investigators have suggested that the hydrous oxides of iron and manganese present as amorphous coatings on mineral grains account for irreversible sorption of heavy metal and TRU solutes by natural sediments and soils (Ames et a1. 1976; Jenne et a1. 1980; Johnson et a1. 1967; Johnson 1993a). Only multimolar nitric acid leachates appear to be capable of removing significant amounts of TRU radionuclides (Ames et a1. 1976). Thus, it appears that TRUs (plutonium and americium) released in slightiy acidic or neutral wastewater in the absence of complexing agents should be retained high in the soil column and once sorbed, may be considered as essentially irreversibly bound. This has important implications in developing remediation strategies, as well as for this GIA.

\subsubsection{Soil Organic Matter}

Soll organic matter content of Hanford Site soils is characteristically very 10 w $(<0.5 \%)$, especially in sands and gravels. Somewhat higher organic matter contents occur in the fine sedimentary sequences (i.e., up to $1 \%$ maximum). The organic matter portion of soil has an affinity for organic contaminants such as $\mathrm{CCl}_{4}$, in either a gaseous or liquid phase. However, based on the low organic contents in most of the sedimentary column beneath the 200 Areas, the retention and or retardation of $\mathrm{CCl}_{4}$ on soil is expected to be minor.

\subsubsection{Crib Sediment Chemical Characteristics}

A limited sediment or soil chemical characterization effort was conducted at the 216-z-20 Crib in 1986 to evaluate possible chemical factors involved in reduced infiltration rates (see Section 2.0). Shallow soil borings were made at four locations (the ends and mid-sections) along the crib. Split spoon cores were collected at depths covering a depth interval of approximately $1 \mathrm{~m}$ $(3 \mathrm{ft}$ ) below the crib floor. Sections of the cores so obtained were analyzed for TRUs and other chemical parameters.

Concentrations of TRUs were somewhat erratic but demonstrated that effluent infiltration had occurred over the full length of the crib. No vertical pattern was evident from the sediment concentrations. The average concentration was $270 \mathrm{pCi} / \mathrm{g}$ for ${ }^{241} \mathrm{Am}$ ( ${ }^{239} \mathrm{Pu}$ was estimated to be about the same concentration). Assuming a $1-m$ depth increment covered by this limited soil sampling, a crib area of $1,412 \mathrm{~m}^{2}\left(15,193 \mathrm{ft}^{2}\right)$ and a soil density of $2 \mathrm{~g} / \mathrm{cm}^{3}$, the above concentration is equivalent to approximately $0.8 \mathrm{Ci}$ each of $24 \mathrm{Am}$ and ${ }^{239} \mathrm{Pu}_{239}$ Previous effluent records suggested approximately $1 \mathrm{Ci}$ of ${ }^{249} \mathrm{Am}$ and $2 \mathrm{Ci}$ of ${ }^{239} \mathrm{Pu}$ were added to the crib before the shallow soil sampling. While the limited soil sampling results leave considerable uncertainty concerning a representative soil concentration, the estimated total present from discharge records compared with the average value based on soil data in Appendix $C$ (Attachment $(-3)$ suggests there is approximate agreement between input quantities and the calculated amount in a $1-\mathrm{m}(3-\mathrm{ft}$ ) depth increment (soil ${ }^{241} \mathrm{Am}$ content not corrected for post-depositional ingrowth from ${ }^{24} \mathrm{Pu}$, 
$T \frac{1}{2}=13.2$ years. Despite the uncertainties, the indication that at least a major part of the inventory added to the crib is accounted for in the first. $1-m$ depth increment of soil is consistent with the expected behavior of these radionuclides.

In addition to the above, physical and chemical analysis of the soil samples revealed the presence of finely divided particulates and the presence of hydrous oxides of iron, aluminum, calcium, and magnesium. The fine particulates ( $<10$ micrometers $[\mu \mathrm{m}]$ ) in the crib are attributed to the wash-in of fine sediment from roof drains (airborne deposits on rooftops) and/or chemical reaction products from release of acids and bases to the crib before 1986. Thus, a combination of fine silt buildup and formation of chemical precipitates within the crib apparently reduced infiltration. To regain infiltration capacity of the crib, 30 vertical boreholes/drains were installed.

\subsection{SUMMARY AND CONCEPTUAL MODEL}

The previous discussion and evaluation of existing data and background information are summarized for the purpose of explaining the conceptual model of hydrologic and geochemical processes occurring at the $216-2-20 \mathrm{crib}$. In addition, this information will be used in the final impact assessment (Section 5.0).

\subsubsection{CONSTITUENTS OF INTEREST}

Constituents of interest associated with past operation of the
${ }_{2-20} \mathrm{Crib}$ include acetone, aluminum, ${ }^{90} \mathrm{Sr},{ }_{137} \mathrm{Cs},{ }_{249} \mathrm{Am}, 238,239,241 \mathrm{Pu}$, and $216-2-20$ Crib include acetone, aluminum, ${ }^{90} \mathrm{Sr},{ }^{137} \mathrm{Cs},{ }^{241} \mathrm{Am},{ }^{238,239,241} \mathrm{Pu}$, and
small quantities of chlorinated hydrocarbons. Contaminants associated with current operations consist of only trace amounts of TRUs ( $<10$ picocuries per liter $[p C i / L])$ and small amounts of chloroform associated with chlorination of water used in the PFP Complex. Secondary pathway constituents of interest (constituents not in the wastewater but resulting from wastewater disposal) include $\mathrm{CCl}_{4}$ and arsenic.

\subsubsection{CONCEPTUAL MODEL}

A schematic illustration of the conceptual model described below is shown in Figure 38. The following discussion describes the hypothesized hydrologic and geochemical processes involved in wastewater disposal to the 216-2-20 Crib:

- Natural buffering maintained optimum pH conditions for retention of TRUs in the uppermost section of the soil column

- Chemical wastes released before 1986 either reacted with the soil or passed through the soil column. Formation of chemical precipitates from reaction of soil components with acids and bases released to the 216-2-20 Crib contributed to the loss in infiltration capacity that occurred in 1986. 
Figure 38. Schematic lllustration of contaminant and Wastewater Transport Beneath and Adjacent to the 216-2-20 Crib.

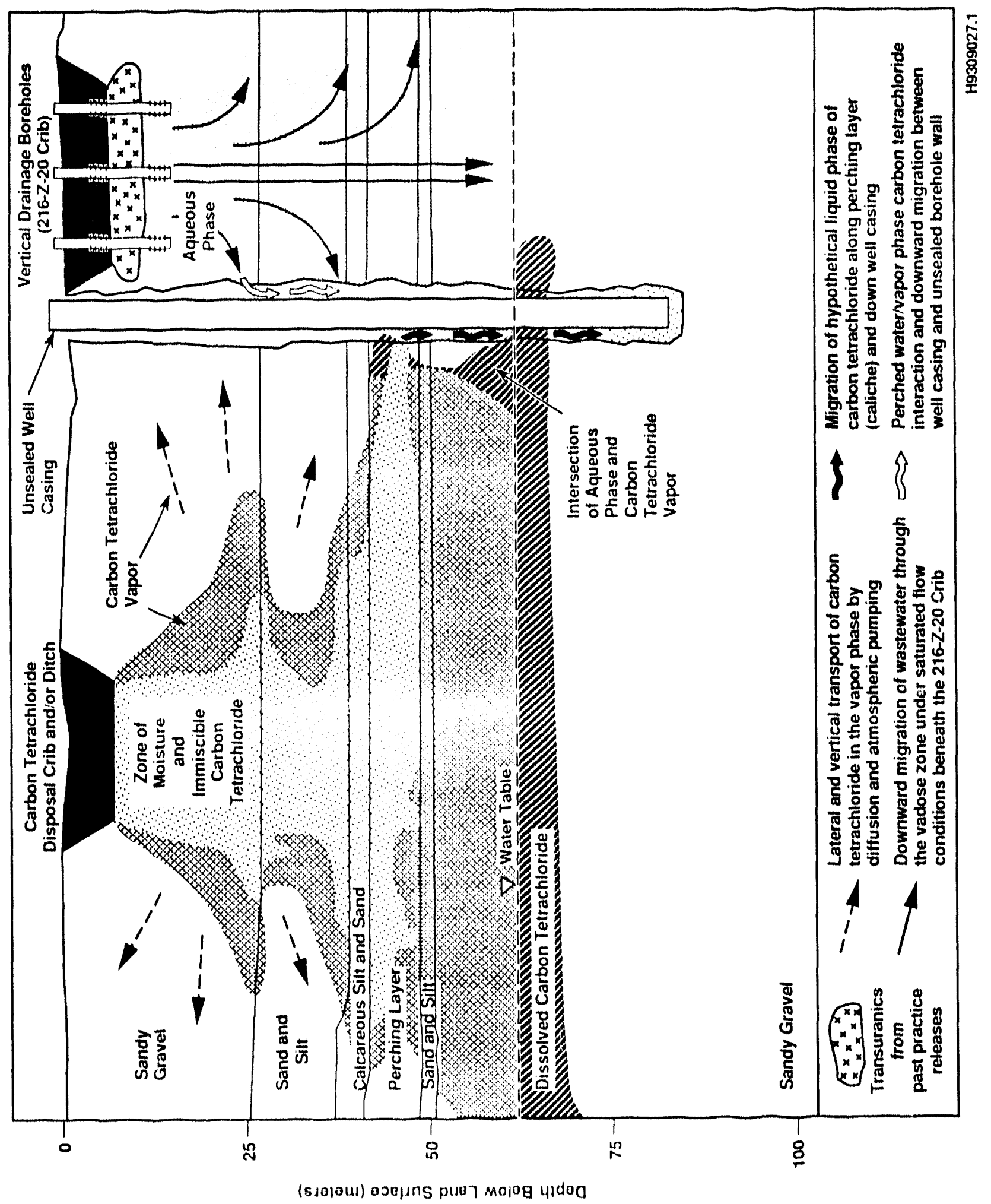


- Installation of vertical drainage boreholes to restore infiltration capacity to the 216-Z-20 Crib allowed wastewater to bypass the shallow layer of TRU-contaminated soil immediately beneath the crib, thus reducing the opportunity for contact between wastewater and a major portion of the TRU inventory of the crib.

- More mobile contaminants move downward and laterally through a multilayered sequence of sediments. For example, arsenic (as $\mathrm{HAsO}_{4}-2$ at a $\mathrm{pH}$ of 8 ), which may occur naturaliy in the soli column beneath the 216-2-20 Crib, is mobilized by infiltrating water. It is found in the perched water zones underlying the crib in concentrations above natural background (10 ppb).

- The downward migrating wastewater spreads laterally on the early Palouse and or Plio-Pleistocene sedimentary units, creating a perched water zone of unknown lateral extent. Some of the perched water may have taken a more direct path to the water table by travelling down the annular space outside the casing of inadequately sealed monitoring wells.

- $\mathrm{CCl}_{4}$ from adjacent past-practice disposal facilities is present in the soll column as a residual liquid phase (DNAPL), as a vapor phase in soll pore space, and/or dissolved in an aqueous phase.

- Wastewater from the 216-2-20 Crib may interact with the $\mathrm{CCl}_{4}$ by absorbing the vapor phase or by dissolution of the residual DNAPL in the adjacent soll column. The inadequately sealed monitoring wells also may have provided more direct pathways for movement of $\mathrm{CCl}_{4}$ to groundwater, as either a dissolved phase or as a DNAPL.

- The primary influence of previous wastewater discharges to the 216-z-20 Crib after 1986 was to "dilute" the ambient groundwater, creating a zone of low conductivity water surrounding the crib. However, as noted above, possible secondary effects of the otherwise clean wastewater, involve interaction with adjacent $\mathrm{CCl}_{4}$ sources and/or leaching of naturally occurring arsenic from the soil column.

- Significant reductions in wastewater discharge volumes after September 1993 should all but eliminate the possibility of either transport of existing contaminants or alteration of the local flow regime.

- The 200 West Area groundwater mound is declining with an apparent shift toward the largest remaining discharge sources (e.g., 284-WB Powerplant Ponds and 216-U-14 Ditch), in response to differential drainage controlled by varying hydraulic conductivity of the aquifer sedimentary units near the 216-2-20 crib.

The impact assessment presented in the following section addresses these working hypotheses using a combination of numerical modeling, perched water and groundwater sampling and analysis results, and evaluation of soil gas and related data. 


\subsection{IMPACT ASSESSMENT}

As indicated in the assessment methodology document (Tyler 1991; Section 1.0), the impact of continued wastewater discharge to the ground involves consideration of hydrologic or mass movement of water as well as contaminant transport factors. Hydrologic impacts are discussed first followed by evaluation of the contaminant transport and behavior issues summarized in Section 4.5 .

\subsection{Hydrologic Impacts}

As discussed in Section 4.2, the hydrologic impact of discharges during the last 5 years at the $216-2-20$ crib is 1 imited to the immediate area of the crib. The radial groundwater movement, because of the local groundwater mound consisting primarily of coolant water, is evident from the distribution pattern for specific conductivity for the period from 1988 to 1991 (see Figure 24). Influences on water table elevations are less definitive due to the remnant effect of the former $U$ Pond mound and active nearby wastewater disposal facilities (284-WB Powerplant Pond and the 216-U-14 Ditch). With future projected reductions to only a few gallons/min (by January 1994) to the 216-2-20 Crib, its influence on the local flow regime will be minor. The abrupt decline in PFP wastewater discharge during 1993, however, may allow the influence of discharges at the 284-WB Powerplant Pond and 216-U-14 Ditch to extend further west; $i$.e., the removal of an opposing source of water may allow greater westward migration of groundwater and associated contaminants between the 284-WB Powerplant Pond and the 216-2-20 Crib. If this occurs, the groundwater contaminant plumes from other local sources could encroach upon the area immediately beneath the 216-2-20 Crib and complicate determination of the source(s) of groundwater contaminants. This places more emphasis on the potential need for alternative monitoring strategies, which are discussed in Section 5.3 .

In summary, as discharge to the $216-2-20 \mathrm{Crib}$ is markedly reduced, local groundwater flow patterns will be dominated by other remaining artificial recharge sources.

\subsection{Contaminant Impacts on Groundwater}

Contaminant impacts from the 216-Z-20 Crib are based on (1) model predictions of contaminant transport in the vadose zone, and (2) comparison of observed contaminant concentrations in perched water and groundwater with appropriate standards. The primary purpose of the vadose zone transport modeling is to estimate the possible extent of downward migration of TRU radionuclides and the likelihood of $\mathrm{CCl}_{4}$ transport via secondary pathways. Results of soll gas sampling and transport modeling of $\mathrm{CCl}_{4}$ in the vicinity of the 216-2-20 Crib are summarized from other Comprehensive Environmental Response, Compensation, and Liability Act of 1980 (CERCLA)-related studies for evaluation of other pathways as described in the conceptual model (see Section 4.5). 
Migration potential for IRUs is assessed first in the following sections followed by consideration of $\mathrm{CC}_{2} l_{4}$ and preferential pathways potentially related to the crib.

\subsubsection{Analytical Methods (Molsture and Transurantc Migration Rates)}

Operating history and contaminant loading discussed previously demonstrate that the most significant contaminant migration issues involve the radioisotopes of plutonium and americium. Thus this is the primary focus of the vadose zone transport modeling portion of this impact assessment.

The simple one-dimensional mathematical model, described in the Liquid Effluent Study Final Project Report (WHC 1990b; WHC-EP-0367), was employed to estimate the rate of moisture and contaminant movement through the soll column beneath the 216-2-20 crib. The model considers only flow in the vertical direction and does not allow for lateral spreading, and is thus expected to provide faster migration rates than occur under actual conditions.

The model is based on steady-state flow conditions in the unsaturated zone and assumes a unit hydraulic gradient. The basic equation for any 1 ayer of sediments is

$$
t=L \times \theta / q
$$

where:

$t=$ time of travel through layer, seconds

$L=$ thickness of layer, cm

$\theta$ - moisture content of sediment, related to hydraulic conductivity

$q$ - Darcy velocity or moisture flux in layer, $\mathrm{cm} / \mathrm{s}$.

The total travel time, $T$, is determined as the summation of the travel times for each of the " $i$ " layers:

$$
T=\sum_{i=1}^{n} L_{i} \times \theta_{i} / q_{i}
$$

where $n$ is the number of sediment layers selected.

The relationship between hydraulic conductivity, $k$, and moisture content, $\theta$, is shown in Figure 39. These curves were derived empirically from laboratory tests on more than 20 different Hanford Site sediments or solls and were used to establish 5 major types, as noted in Figure 39. 
Figure 39. Hydraulic Conductivities Versus Moisture Content for Various Hanford Site Soil Types.

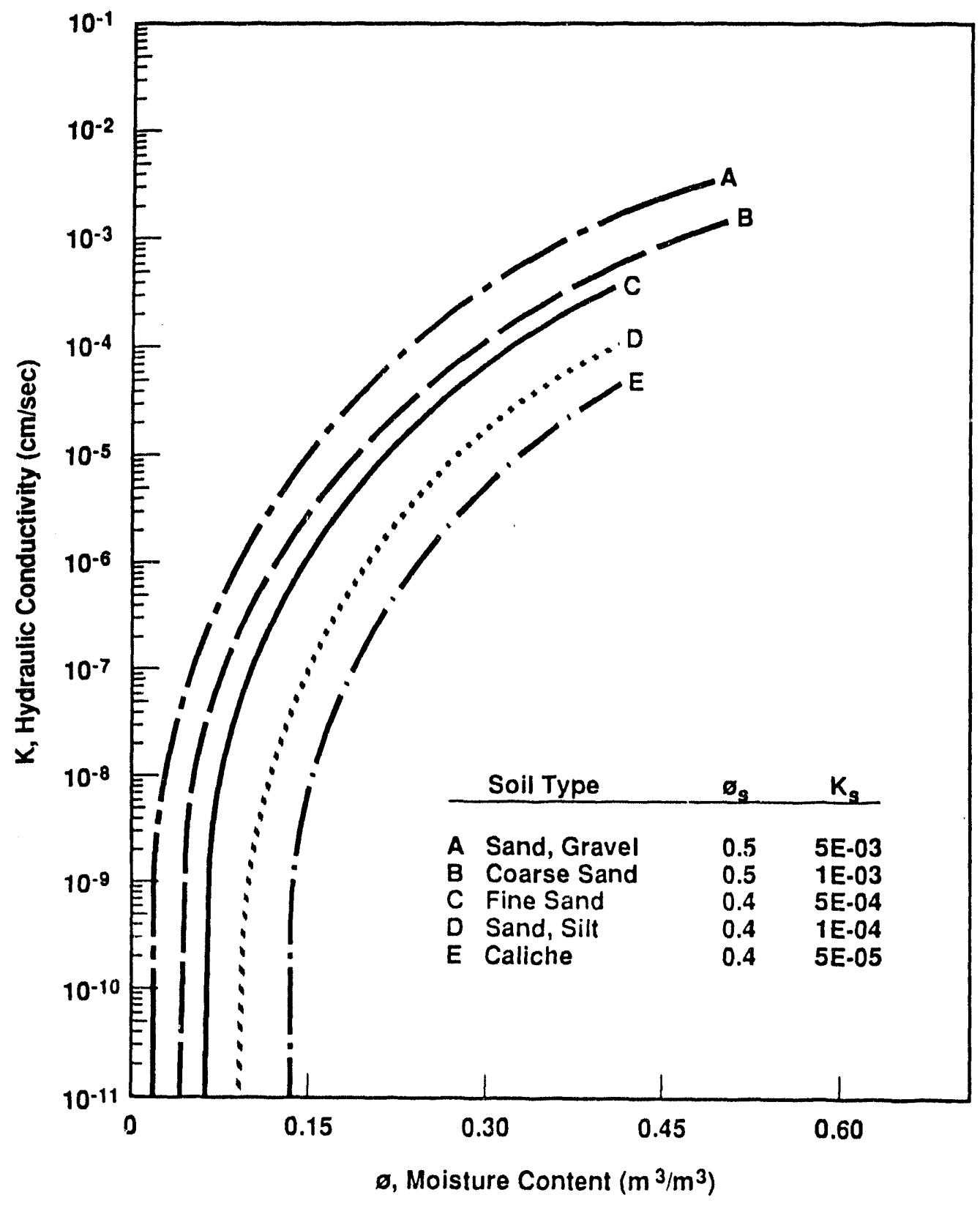

H9309026.5 
The one-dimensional flow analysis represented by Equation 2 was conducted with a Symphony spreadsheet. The total travel time, T, obtained with Equation 2 is divided into the vadose zone thickness to provide an estimate of the rate of moisture migration from the dispos 1 facility to the groundwater.

5.2.1.1 Contaminant Migration Rate Estimates. To obtain an estimate of the rate of contaminant migration, the retardation factor, $R_{f}$, for each of the contaminants identified was estimated using the approximation for Hanford Site soils (WHC 1990b):

$$
R_{f}=1+5 K_{d}
$$

The $K_{d}$ values were selected from a summary of sorption studies conducted on Hanford soils under a variety of chemical conditions (Ames and Serne 1991). The values most closely approximating current chemical conditions at the 216-2-20 Crib (i.e., low organics, low salt content, and neutral to slightly basic $\mathrm{pH}$ ) were used in selecting the applicable $K_{d}$ values from the tables in Ames and Serne (1991). The $R_{f}$ values used for each constituent of interest are based on the low end of the range of observed $K_{d}$ values indicated in Ames and Serne (1991). Dividing the moisture migration rate by the $R_{f}$ (Equation 3 ) yields an estimate of the contaminant migration rate.

The effluent discharge rate, described previously, is entered as liters per month in a computational model. Effluent volumes for the time period of interest are used to compute average infiltration rates. The total volume (liters) is divided by each operating period (months) to establish an average rate of inflow (L/month). This effluent discharge rate is divided by the crib bottom area to obtain an estimate of the average infiltration rate. Because the 216-2-20 crib was modified by installation of vertical drainage boreholes, it is difficult to estimate an appropriate or effective "area" for calculating infiltration rates. However, because of lateral spreading caused by sediment layering (anisotropy), the 30 "point sources" created by the vertical borings are assumed to be adequately approximated by an area equivalent to the bottom dimensions of the crib. Support for this assumption is provided by recent PORFLO-3 (Runchal et al. 1992) modeling for the 216-U-17 Crib (located just east of the $216-2-20 \mathrm{Crib})$, suggesting that moisture plumes from a few point sources are similar to plumes originating as line sources $50 \mathrm{~m}$ long and 1 to $3 \mathrm{~m}$ wide (Reidel et al. 1993). More details and an illustrative example for application of the overall computational approach are provided in WHC (1990b).

\subsubsection{Model Calibration Check and Related Assumptions}

Remrsbilization of TRUs has been the primary concern at this crib. Thus, this section addresses the reliability of the model used to estimate the vertical extent of TRU migration in 200 West Area soils.

${ }^{1}$ Symphony is a trademark of the Lotus Development Corporation. 
WHC-EP-0674

5.2.2.1 Crib Infiltration Area Assumption. Previous modeling for this site (WHC 1990b) assumed that wastewater was uniformly distributed over an area consisting of the physical bottom dimensions of the crib ( $3 \mathrm{~m}$ wide by $457 \mathrm{~m}$ long [10 ft wide by $1,500 \mathrm{ft}$ long]). Shallow $(1-\mathrm{m}[3-\mathrm{ft}])$ core samples from the ends and center of the crib support this assumption (see Section 4.4).

The above assumption is partly supported by the observed distribution of plutonium beneath an adjacent crib $(216-2-12)$ that received wastewater with similar chemical characteristics (Figures 40 and 41 ). In fact, the areal distribution of plutonium extends beyond the immediate bottom dimensions of the crib. The importance of anisotropy to lateral spreading in 200 We $t$ Area soils was demonstrated by Reidel et a1. (1993). The lateral spreading is due to the anisotropy resulting from "layering" of the sedimentary deposits that make up the soll column beneath the crib. Based on this observation, an infiltration area equal to the crib dimensions should be a conservative assumption (i.e., the effective area is larger than the excavated dimensions of the crib floor because of lateral spreading).

5.2.2.2 Steady-State Discharge Assumption. The discharge records for the 216-Z-20 Crib show variations that, on the average, were above $378 \mathrm{~L} / \mathrm{min}$ (100 gal/min) until very recently. After September 1993 the projected rate will drop to 23 to $45 \mathrm{~L} / \mathrm{min}$ ( 6 to $12 \mathrm{gal} / \mathrm{min}$ ). The assumption of quasi or near-saturated conditions, at least before September 1993, is partly supported by the existence of a significant thickness of perched water observed beneati this crib in June 1993. The steady-state assumption ur use of average flow rates to the crib during the primary input years (up to 1993) should be adequate for estimating the potential maximum depth of migration of plutonium and americium.

\subsubsection{Retardation Factors. The other major solute transport variable} involves the use of the retardation factor (Equation 3). It is not possible to independently evaluate retardation factors derived from published $K_{d}$ values (Ames and Serne 1991). However, the degree of conservatism in the overall migration depth estimates can be evaluated by use of an analog site. The 216-2-12 Crib site is ideal for this purpose because (1) its geology is very similar to the 216-Z-20 Crib area, and (2) it received TRUs in an aqueous waste stream with chemical properties that were similar to the average wastewater discharged to the $216-2-20 \mathrm{Crib}$ (i.e., both are neutral to slightly basic pH, low salt content and low organics). It is possible that some unplanned releases of organics to the 216-2-12 Crib may have occurred. However, this would have enhanced TRU mobility. Therefore, if anything, the 216-2-12 Crib would be a "conservative" analog site for evaluating depth of migration of TRUs beneath the 216-Z-20 Crib.

For the following calibration check, a shallow thickness of medium to fine sand is used to simulate the behavior of TRUs immediately beneath the 216-2-12 Crib based on the assigned 1ithology given by Kasper (1982) (see Figure 40). 
Figure 40. Observed Vertical Distribution of Plutonium-239 in the Vadose Zone Beneath the 216--Z-12 Crib.

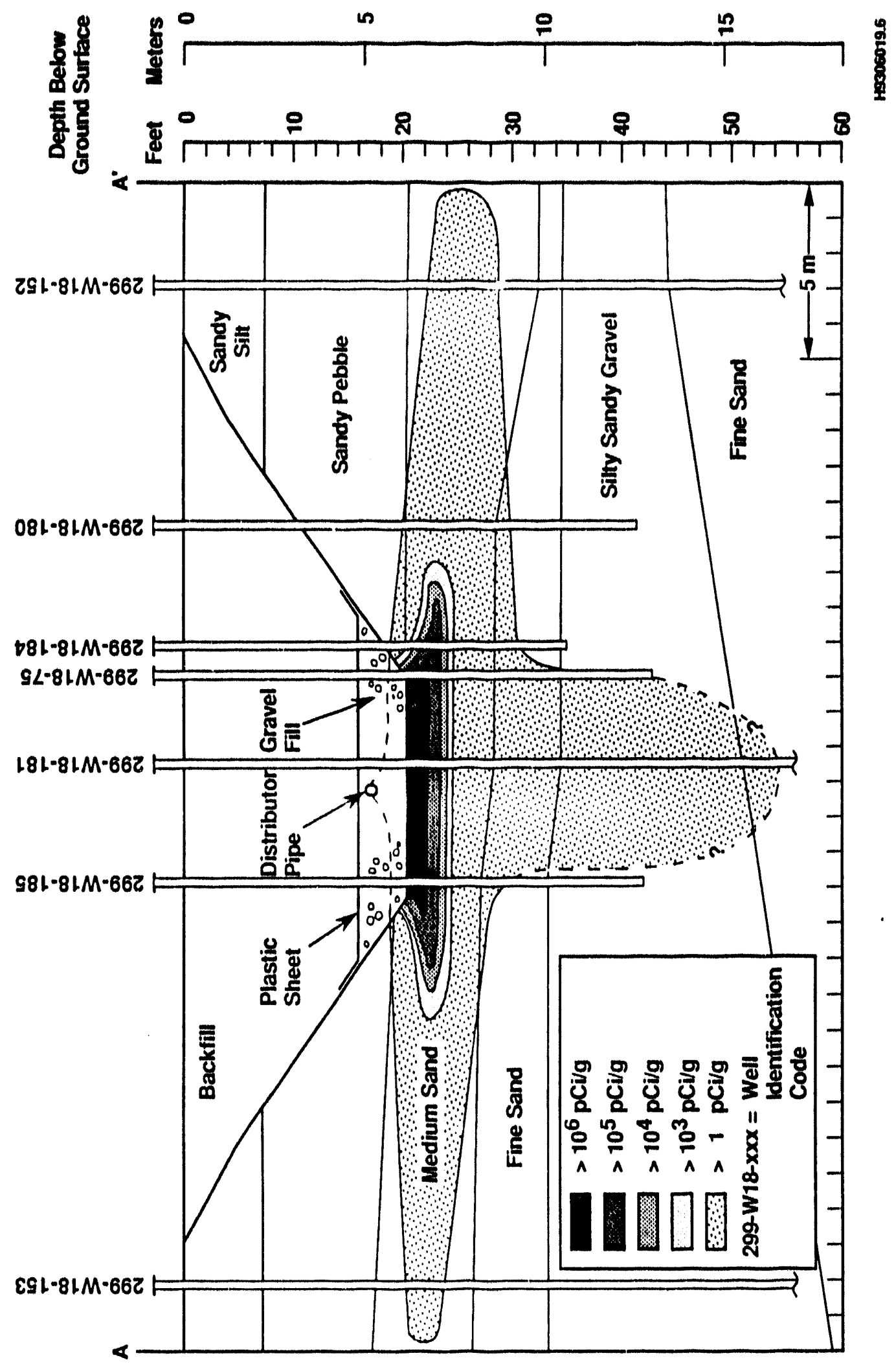


Figure 41. Plot Plan of the 216-Z-12 Crib Showing Soll Sampling Locations.

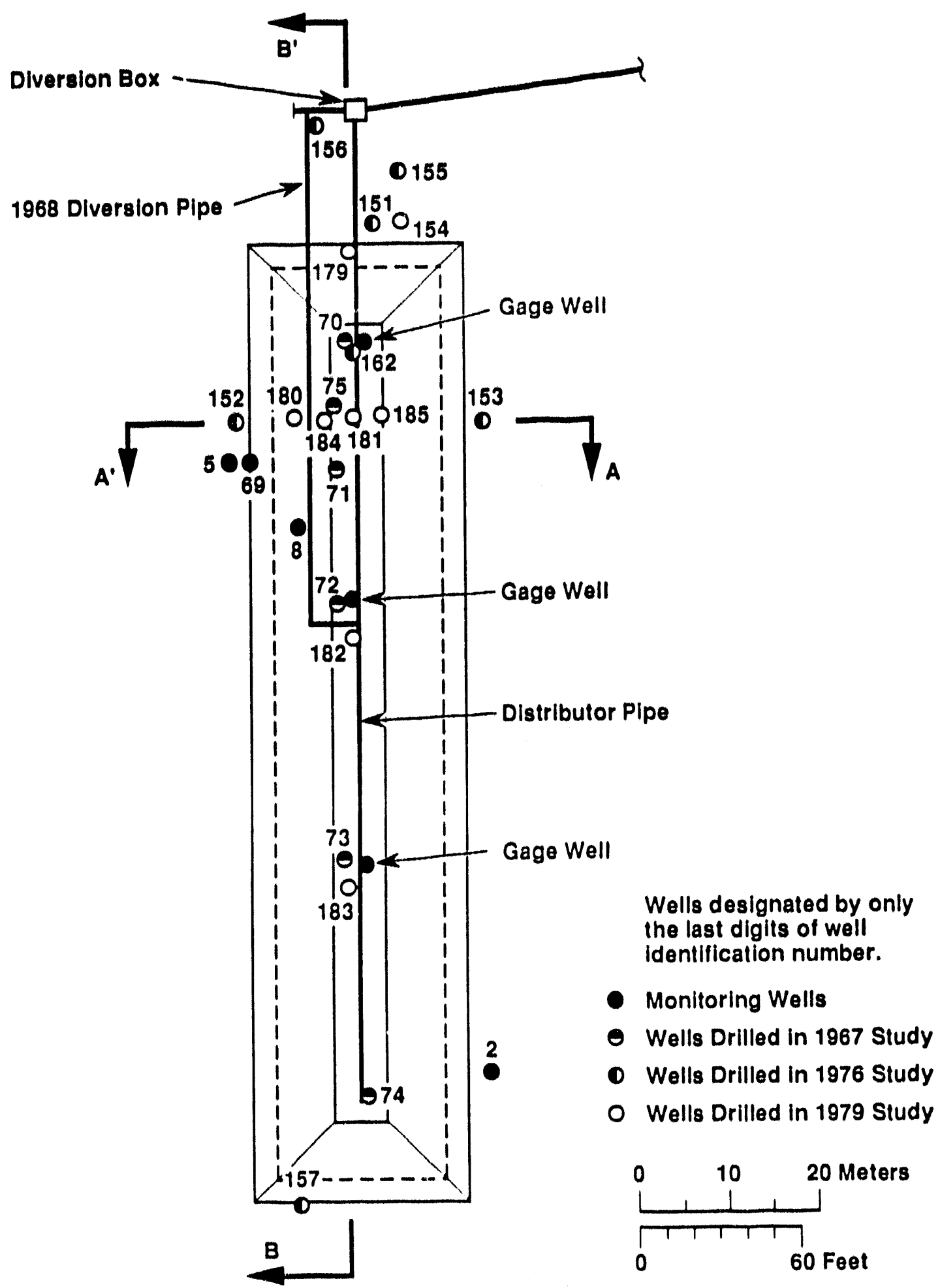




\subsubsection{Analog Site Calibration Check (216-2-12 Crib)}

The analog crib site was previously characterized by Kasper (1982). Input parameter information for the computations (e.g., flow rate, crib area, and 1 ithology beneath the crib) was taken from Kasper (1982). The soll types were chosen from the average values previousiy used in the Liquid Effluent Study (WHC 1990b) (see Figure 39) and general textural classification Indicated in Kasper (1982). Estimates are calculated based on two soll types (and corresponding hydraulic parameters from Figure 39) and three $R_{f}$ est imates representing the range of observed $K_{d} s$ and a conservative estimate for Hanford site solls as summarized in Ames and Serne (1991). The $K_{d} s$ chosen are for effluent or wastewater with low salt content, neutral to basic $\mathrm{pH}$, and low organics, as described for the 216-Z-12 Crib (Kasper 1982). Al though some contributor streams were slightly acidic due to the presence of hydrofiuoric acid, this wastewater was neutralized before discharge (1.e., adjusted to a pH of about 8 ). The $K_{d} s$ should bound the range of likely behavior for plutonium in these solls under the reported effluent chemical conditions. The soil type is assumed to be homogeneous and continuous in vertical extent. This assumption is appropriate for the expected behavior of plutonium and americium because the observed depth distribution of these TRUs beneath the subject crib occurs within the first $10 \mathrm{~m}$ beneath the crib where the soll column is a medium to fine sand. The infiltration area is based on the physical dimensions of the floor bottom of the crib. As discussed previousiy, this is considered to be a conservative assumption because the observed plutonium distribution extends (laterally) beyond the crib floor dimensions. Based on effluent discharge records (Appendix $A$ of Kasper 1982), plutonium was added continuously to the crib over its operating history (1959-1973). The average mass loading of plutonium was $1.8 \mathrm{~kg} / \mathrm{yr}(4.01 \mathrm{~b} / \mathrm{yr})$ or a total of $25 \mathrm{~kg}$ (55 1b).

The range of predicted migration depths from the one-dimensional model (Table 9) is compared with the observed depth distributions as summarized in Figure 42. The observed migration depths were tabulated in two ways:

(1) Depths below the peak concentrations in the soil profiles where concentrations were $1 / 1,000$ of the peak concentrations. (The peak concentrations occur immediately beneath the floor of the crib, within $1 \mathrm{~m}(3.3 \mathrm{ft})$ or less, and then decline exponentially with depth.)

(2) Maximum depths of penetration were estimated from the plutonium depth profiles (Kasper 1982). Concentrations for the maximum observed depths of penetration were $10^{5}$ to $10^{6}$ times lower than peak concentrations.

The statistical summary (Whisker Box plots) shown in Figure 42 indicates that over 99\% of the inventory occurs in the first few meters beneath the floor of the crib. The apparent maximum depth of penetration is, on the average, approximately $10 \mathrm{~m}(33 \mathrm{ft})$. The predicted depths of penetration indicate that an $R_{f}$ of 125 provides a conservative estimate of the maximum depth of penetration observed beneath the crib. However, Figure 42 also suggests the centroid of the soll column contaminant plume would be more accurately predicted with an $R_{f}$ of 500 to 1,000 . The greater depth of 
Table 9. Statistical Summary of Observed Plutonium Migration Depths (in Meters) Beneath the 216-z-12 Crib.

\begin{tabular}{|l|c|c|}
\hline \multicolumn{1}{|c|}{ Variable } & $\begin{array}{c}1 / 1,000 \text { th Depth } \\
(\mathrm{m})\end{array}$ & $\begin{array}{c}\text { Apparent maximum } \\
\text { depth (m) }\end{array}$ \\
\hline Sample size & 7 & 7 \\
\hline Average & 3.6 & 9.9 \\
\hline Median & 1.9 & 6.9 \\
\hline Mode & 1.7 & 6.9 \\
\hline Geometric mean & 2.7 & 8.0 \\
\hline Variance & 12.1 & 64.9 \\
\hline Standard deviation & 3.5 & 8.1 \\
\hline Standard error & 1.3 & 3.0 \\
\hline Minimum & 1.5 & 3.9 \\
\hline Maximum & 10.9 & 27 \\
\hline Range & 9.4 & 23.1 \\
\hline Lower quartile & 1.6 & 4.9 \\
\hline Upper quartile & 5.2 & 12.9 \\
\hline
\end{tabular}


Figure 42. Observed and Predicted Plutonium Migration Depths Beneath the 216-2-12 Crib.

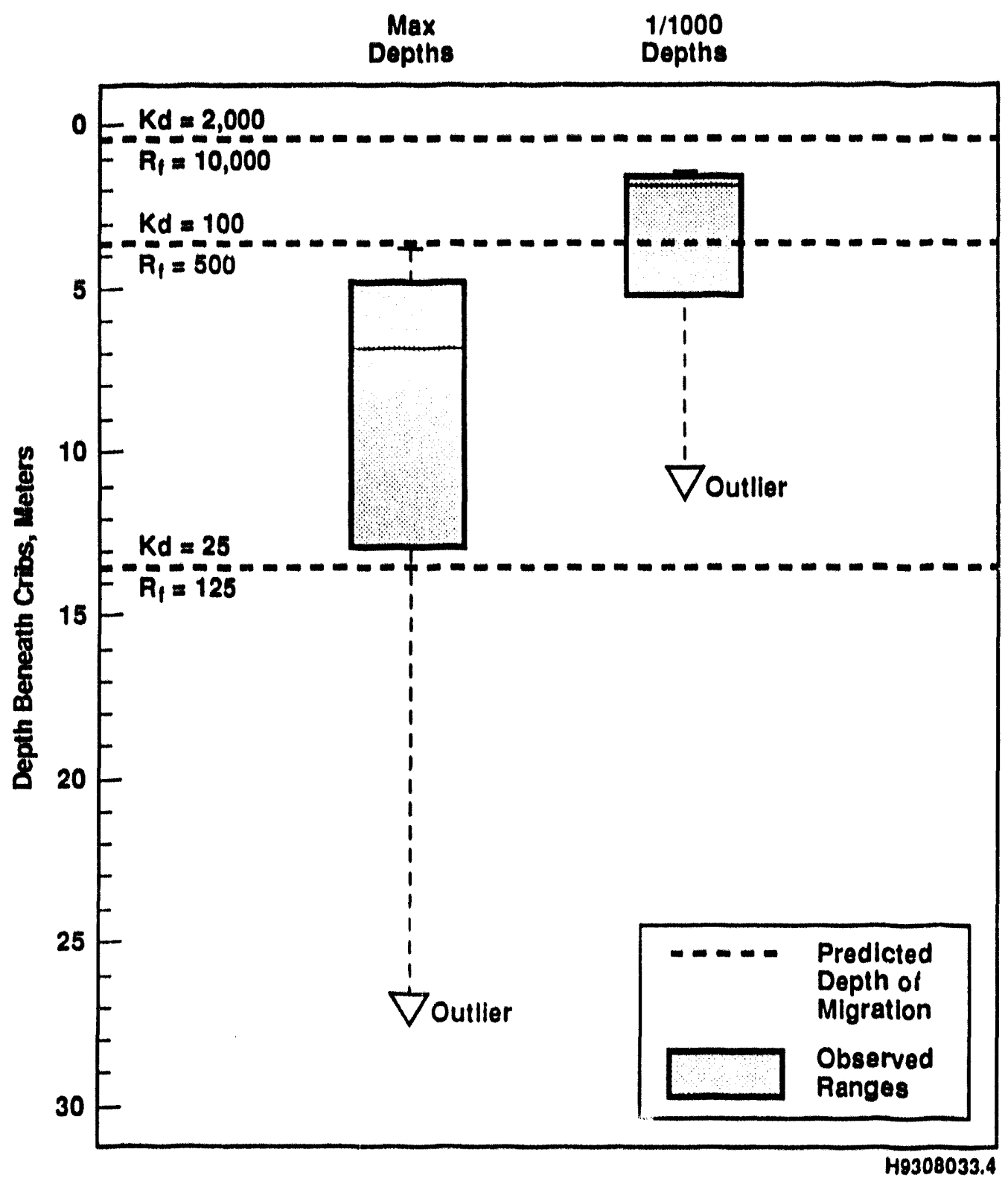


migration observed for a relatively small fraction $(<0.01 \%)$ of the total retained on the soll cclumn may be related to either preferential pathways or to other more mobile species or forms of plutonium. For example, radiocolloids or polymeric plutonium have been noted to migrate at greater rates than ionic forms.

For corrective action or remediation purposes, the more realistic prediction (centroid) would be the most appropriate. However, for impact assessments, the maximum depth of penetration (i.e., conservative $R_{f}$ or $K_{d}$ values) is considered more appropriate.

To summarize, the "calibration" check described above lends confidence to the general approach and assumptions used for the Liquid Effluent Study assessment of the $216-2-20$ Crib previously reported (WHC 1990b). The same general assumptions and approach are therefore considered adequate for use in assessing contaminant distribution in the soil column for this GIA.

\subsubsection{Provious Results (Liquid Effluent Study)}

Previous results (WHC 1990b) of the one-dimensional unit gradient calculations are summarized in Table 10. The sediment column was represented as three major layers over a total depth of $60 \mathrm{~m}(197 \mathrm{ft})$. Hydraulic parameter estimates corresponding to the three layers were derived from Figure 39. The $R_{f}$ values are based on conservative $K_{d}$ values given in Ames and Serne (1991). Constituents considered were based on the "key" constituents identified from process knowledge and effluent data (see Section 3.0). The infiltration area was assumed to consist of the physical dimensions of the crib floor $\left(1,412 \mathrm{~m}^{2}\left[15,193 \mathrm{ft}^{2}\right]\right)$. As discussed in Section 5.2.2.1, the actual or effective area may be larger due to anisotropy effects associated with the sedimentary layering in the strata beneath the crib.

A single-layer case is also provided in Table 10 for comparison with the three-layer case that includes the caliche or Plio-Pleistocene unit. As shown, the migration rates (average for 60-m [197 ft] depth interval) are increased by over four fold if the fine-textured layer (caliche) (soil type E) is removed.

The contaminant migration rate estimates for the three-layer case suggest that of the key constituents previously identified, only acetone and uranium were predicted to have broken through to groundwater. Migration rates for the most significant as well as most abundant contaminants, ${ }^{230} \mathrm{Pu}$ and ${ }^{241} \mathrm{Am}$, are 0.4 and $0.05 \mathrm{~cm} /$ day $(0.16$ and $0.02 \mathrm{in} . / \mathrm{day})$, respectively. These estimates as well as the expected chemical behavior of these constituents previously discussed suggest they should be retained in the soll column well above the caliche layer (approximately $<43 \mathrm{~m}[141 \mathrm{ft}]$ ). 


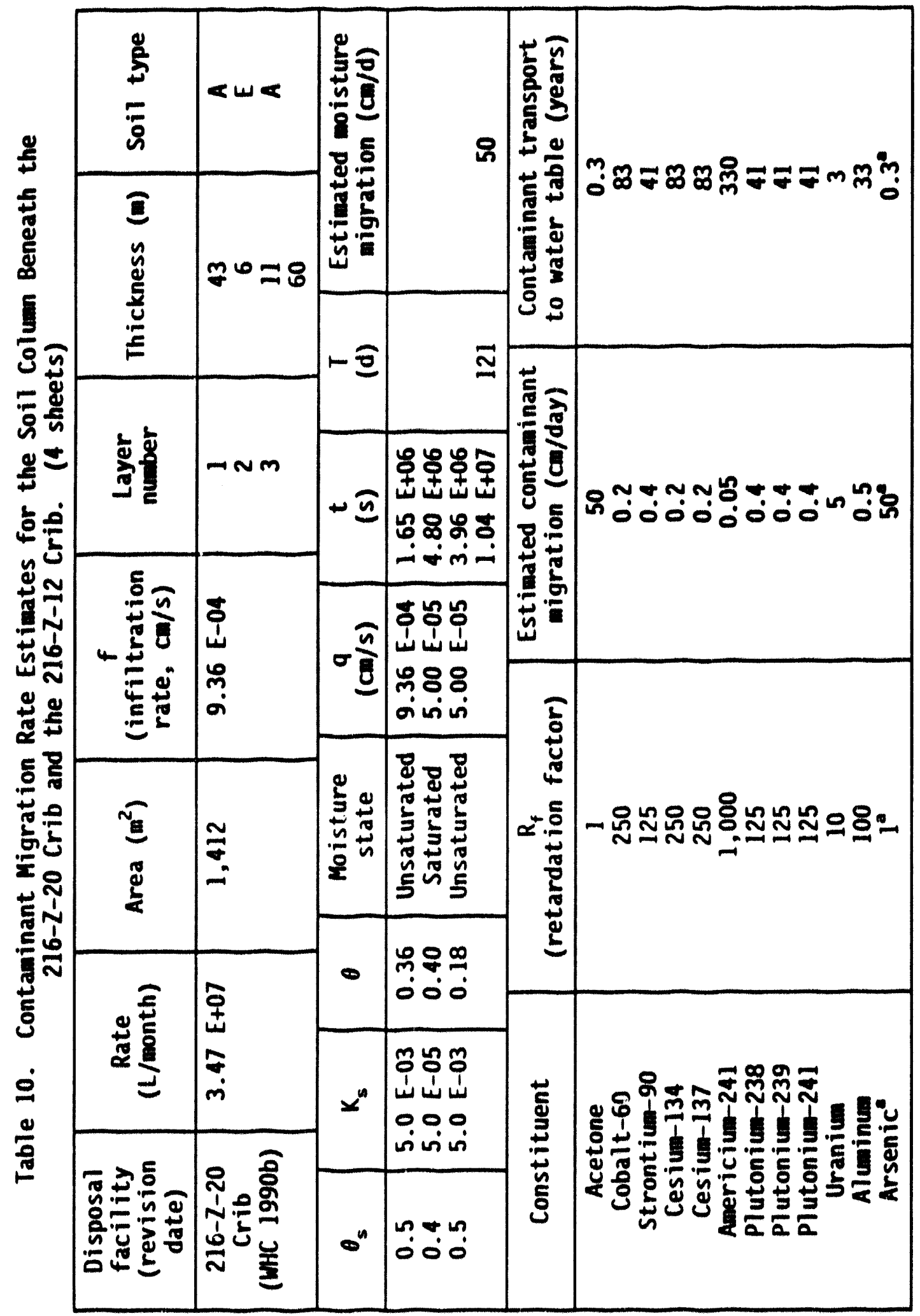




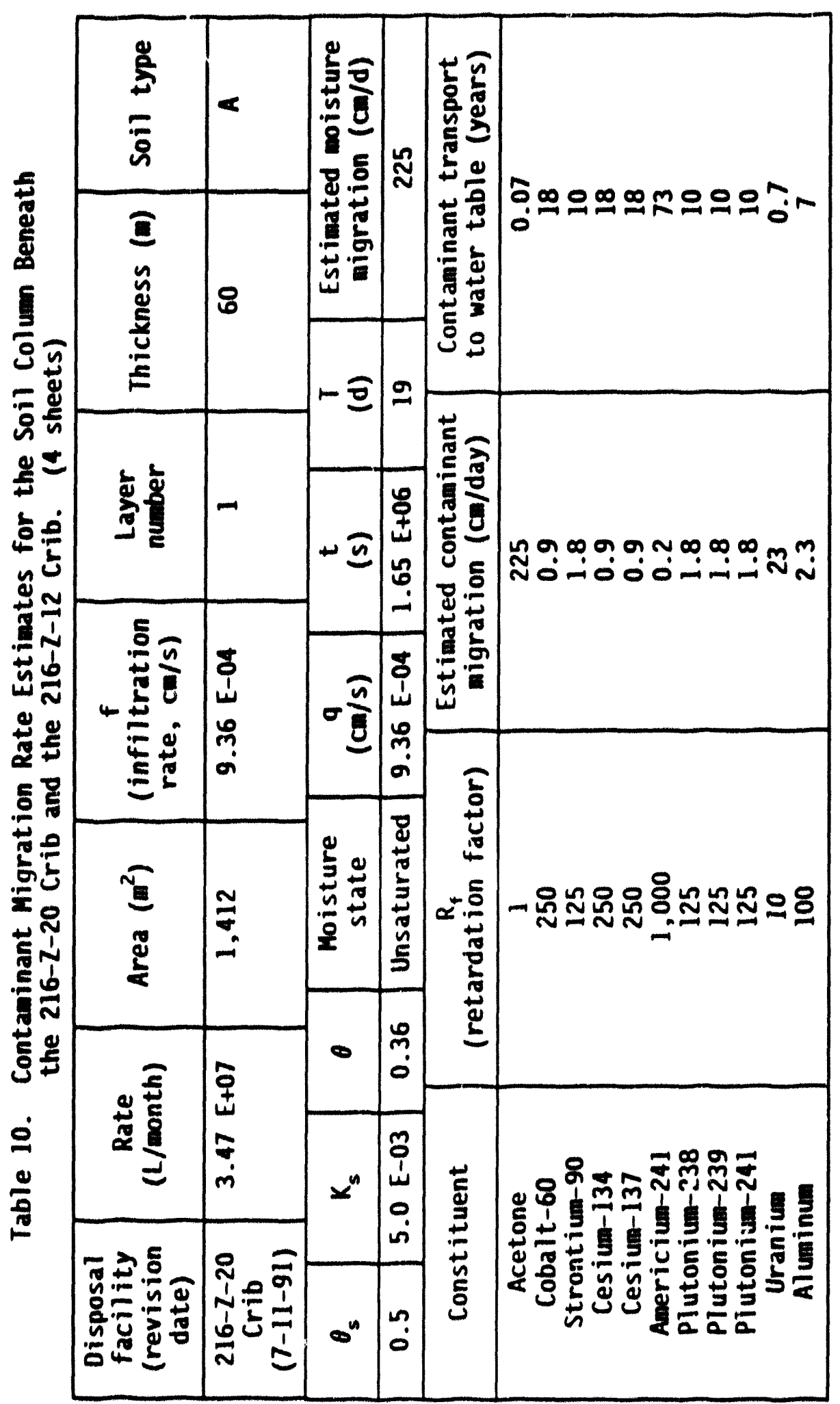




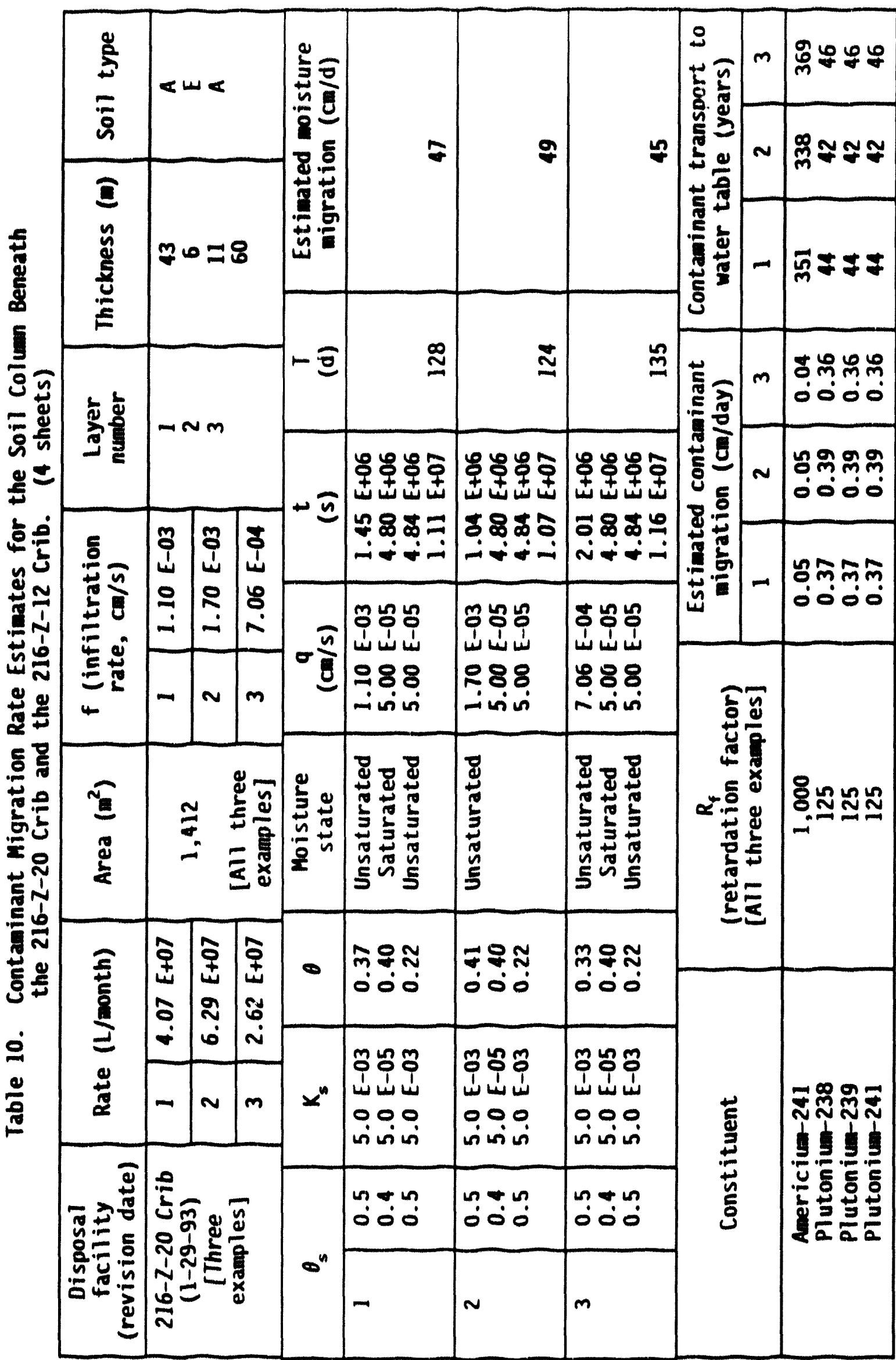




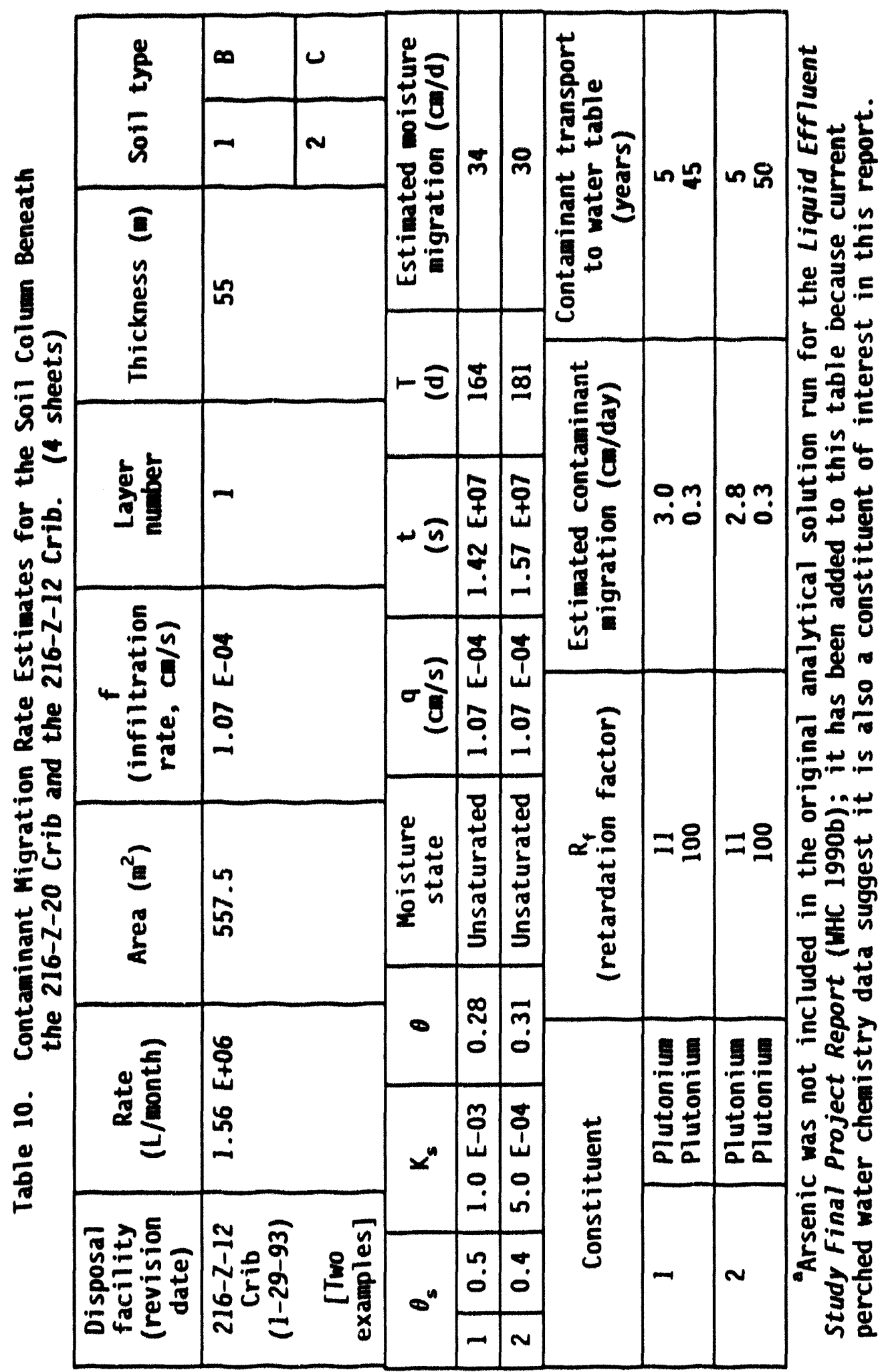




\subsubsection{Analytical Results for Revised Conceptual Model}

Revised calculations using the same unit gradient model described in Section 5.2.4 were run to address concerns not considered in the Liquid Effluent Study, including the:

- Effect of varying infiltration rates on contaminant transport rates in the soll column

- Interaction of PFP wastewater with $\mathrm{CCl}_{4}$ from adjacent faclitities.

5.2.5.1 Transuranics. The three-layer case described in Section $\mathbf{5 . 2 . 4}$ was rerun using three different flow rates representing the average discharge rates to the 216-2-20 Crib during the major operating pertods. Hydraulic parameters were also reviewed and changed slightly. Only TRUs were considered for this case because they are the most significant contaminants of concern. As indicated in Table 10, the migration rates are very simflar to the results previousiy reported for the Liquid Effluent Study (WHC 1990b). Again, the computations suggest that TRUs should be retained in the soll column well above the water table. Additionally, the analog crib site evaluation suggests the vast majority of the TRU loading should actually exist with in a few meters depth from the bottom of the crib. The absence of TRUs in perched water and sediments (see Appendix $C$ ) is consistent with this conclusion.

5.2.5.2 Carbon Tetrachloride Modeling Summary. As indicated in Sections 4.4 and $4.5, \mathrm{CCl}_{\text {as a }}$ a vapor phase or as a DNAPL from adjacent past-practice disposal facilities may interact with wastewater from the 216-2-20 Crib. To gain some insight to the relative magnitude of these interactions, a computer simulation of the transport of $\mathrm{CCl}_{4}$ from the 216-2-9 Trench, the largest adjacent source, was run using MAGNAS3 (Multiphase Analys is of Groundwater, Non-aquec'ss Phase Liquid and Soluble Component in 3 Dimensions).

Preliminary efforts completed at the time of this writing include only initial simulations of the DNAPL. Work is underway to simulate the interaction of the vapor phase and adjacent wastewater sources.

Results of the initial liquid phase, two-dimensional simulation are shown in Figure 43. Two scales are shown to illustrate near field processes (a) and the lateral extent of possible migration toward the 216-2-20 Crib (b). The lithology used was simplified from the north-south transect between the 216-2-9 Trench and the 216-2-20 Crib (see Figure 19). The bottom of the vertical dimension shown ( 0 depth on $Y$ axis) corresponds to the top of the lower mud unit of the Ringold Formation (see well 2-W15-5 in Figure 19). The elevation of this fine-grained sedimentary unit was assumed to be constant within the $700-m(2,297-f t)$ distance simulated ( $X$ axis). Soll properties (hydraulic conductivities, etc.) and other related assumptions used were as previousiy described in Piepho et a1. (1993). Input volumes of both the aqueous phase $\left(4 \times 10^{6} \mathrm{~L}\left[1.06 \times 10^{6} \mathrm{gal}\right]\right)$ and DNAPL $\left(2 \times 10^{5} \mathrm{~L}\right.$ [2.64 $\times 10^{4}$ gal]) were added to the disposal site over the operating period (1955 through 1962, or 8 years). This initial simulation, which is an extenstion of the results previously reported in Piepho et al. (1993), suggests that DNAPL settles to the bottom of the aquifer and then moves laterally to

'MAGNAS3 is a trademark of Hydrogeologic, Inc., Herndon, Virginia. 
near the north end of the 216-2-20 crib. The thin green band at the bottom of the figure represents a layer approximately $3 \mathrm{~m}(10 \mathrm{ft})$ in thickness. It should also be noted that drainage of DNAPL into the aquifer appears to continue for an extended period of time. For example, the green contour interval in the aquifer appears to be approximately continuous for at least 40 years (1955 to 1995). The DNAPL in the soii column (red contour) diminishes with time but appears to supply a much smaller but continuous amount of DNAPL to the aquifer for a long period.

The initial simulations described above suggest that a liquid phase of $\mathrm{CCl}_{4}$ may move deep in the aquifer, and spread horizontally upon encountering impermeable layers. If the Ringold lower mud unit is the only fine-grained sedimentary unit in the stratigraphic column, DNAPL migrating along the top of this unit would be too low in the aquifer to influence groundwater concentrations in the uppermost portion of the aquifer beneath the 216- $2-20 \mathrm{Crib}$. However, the process suggested by the simulation shown in Figure 43 could account for the observed $\mathrm{CCl}_{4}$ concentrations in the monitoring wells at the 216-Z-20 Crib if the $Z$ Ditches were the source (e.g., as previously discussed, the $Z$ Ditches apparently received accidental or occasional releases of $\left.\mathrm{CCl}_{4}\right)$. Downward movement of $\mathrm{CCl}_{4}$ beneath the 216-2-19 Ditch, for example, could result in a small but continuous supply to the aquifer immediately adjacent to the groundwater monitoring wells. A continuous, long-term slow drainage could account for the observation that elevated $\mathrm{CCl}_{4}$ occurs in groundwater beneath the $216-2-20 \mathrm{Crib}$ and appears to persist (see Figu': 33).

It is equally likely that residual DNAPL from the ditches may have migrated down the outside of the unsealed well casings. This preferential pathway would favor a buildup of DNAPL near the bottom of the well. Because the pump intakes were within $1.5 \mathrm{~m}(5 \mathrm{ft})$ of the static water level, a marked difference in $\mathrm{CCl}_{4}$ concentrations should be observed between the bottom and top of the perforated well casing interval, or there should at least be a sharply increasing gradient with depth within the perforated interval. The bottom and near surface of well 2-W18-20 was sampled to examine such effects. A packer was set approximately $0.3 \mathrm{~m}(1 \mathrm{ft})$ from the bottom of the $14-\mathrm{m}$ $(45-f t)$ perforated interval of this well and sampled with a Hydrostar pump just before (March 1, 1993, Appendix B) its conversion to a perched water monitoring well. The deeper sample indicated a $\mathrm{CCl}_{4}$ concentration of $100 \mathrm{ppb}$ as compared to $35 \mathrm{ppb}$ at the shallower depth sampled on April 12, 1993; thus suggesting that preferential settling or accumulation of DNAPL near the well bottom may have occurred at this location.

Additional modeling using upgraded soil properties based on aqueous/DNAPL drainage and retention curves is needed as well as additional field observations to confirm model predictions. (Ongoing CERCLA-related characterization work will provide some of this information in fiscal year 1994). The initial modeling and observations discussed above may be especially important for remediation plans that involve potential pump and treat restoration activities, i.e., the effectiveness of aquifer restoration efforts may be limited by the potential existence of long-term DNAPL draina'je sources. Additionally, this evaluation suggests some attention shoul be given to the $Z$ Ditches as possible secondary sources. 
WHC-EP-0674

This page intentionally left blank. 
Figure 43. (a) Two-dimensional Simulation of Liquid Phase Carbon Tetrachloride in the Soll Column and Unconfined Aquifer Beneath the 216-2-9 Trench, Near Fleld Cross Section.

\section{Carbon Tet Plume at 8 Years}

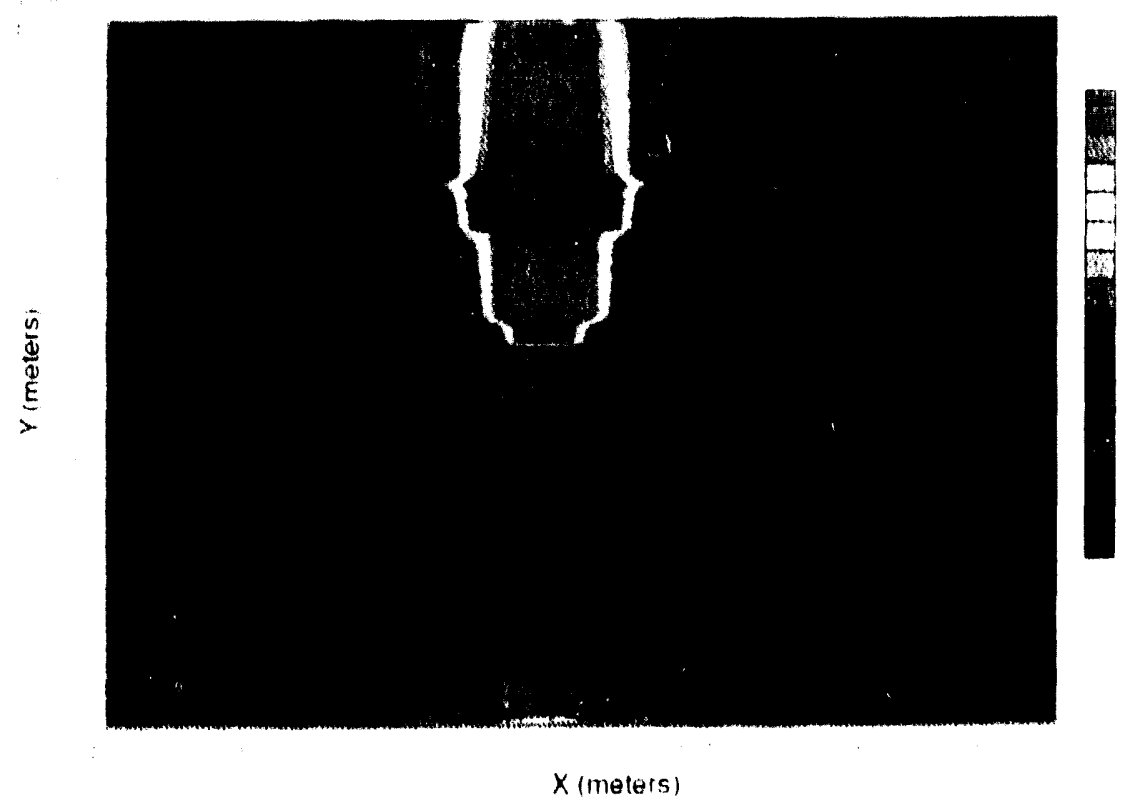

Carbon Tet Plume at 22 Years

5
$\frac{5}{0}$
$\frac{0}{0}$
$\frac{0}{2}$

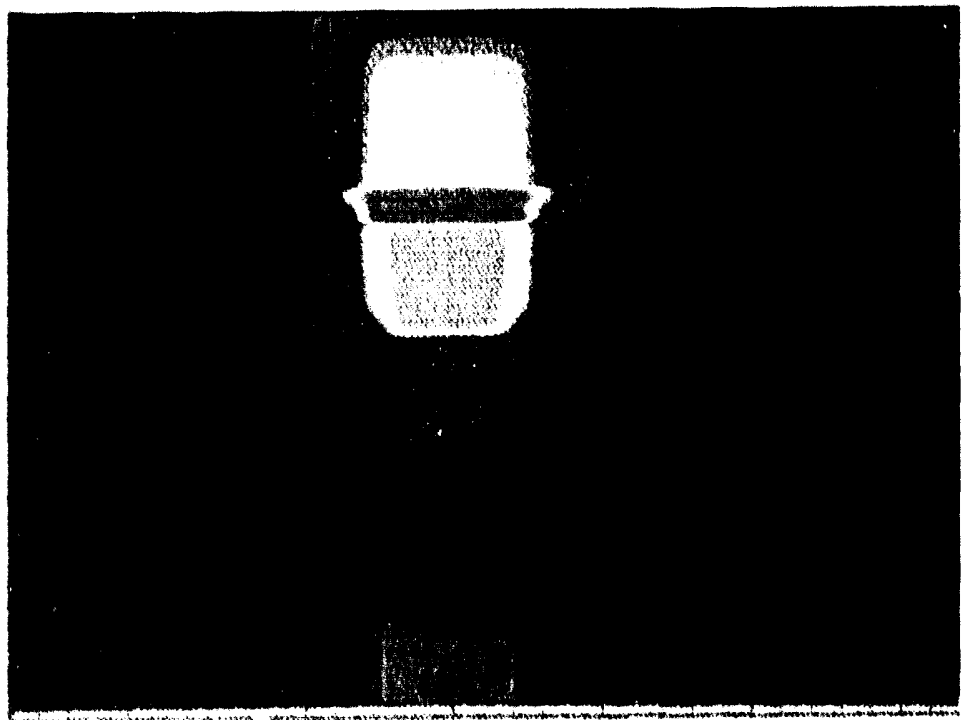

$X$ imeters! 
Figure 43. (b) Two-dimensional Simulation of Liquid Phase Carbon Tetrachloride in the Soll Column and Unconfined Aquifer Beneath the 216-2-9 Trench, Extended North-South Cross Section.

$\mathbf{z}$

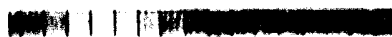
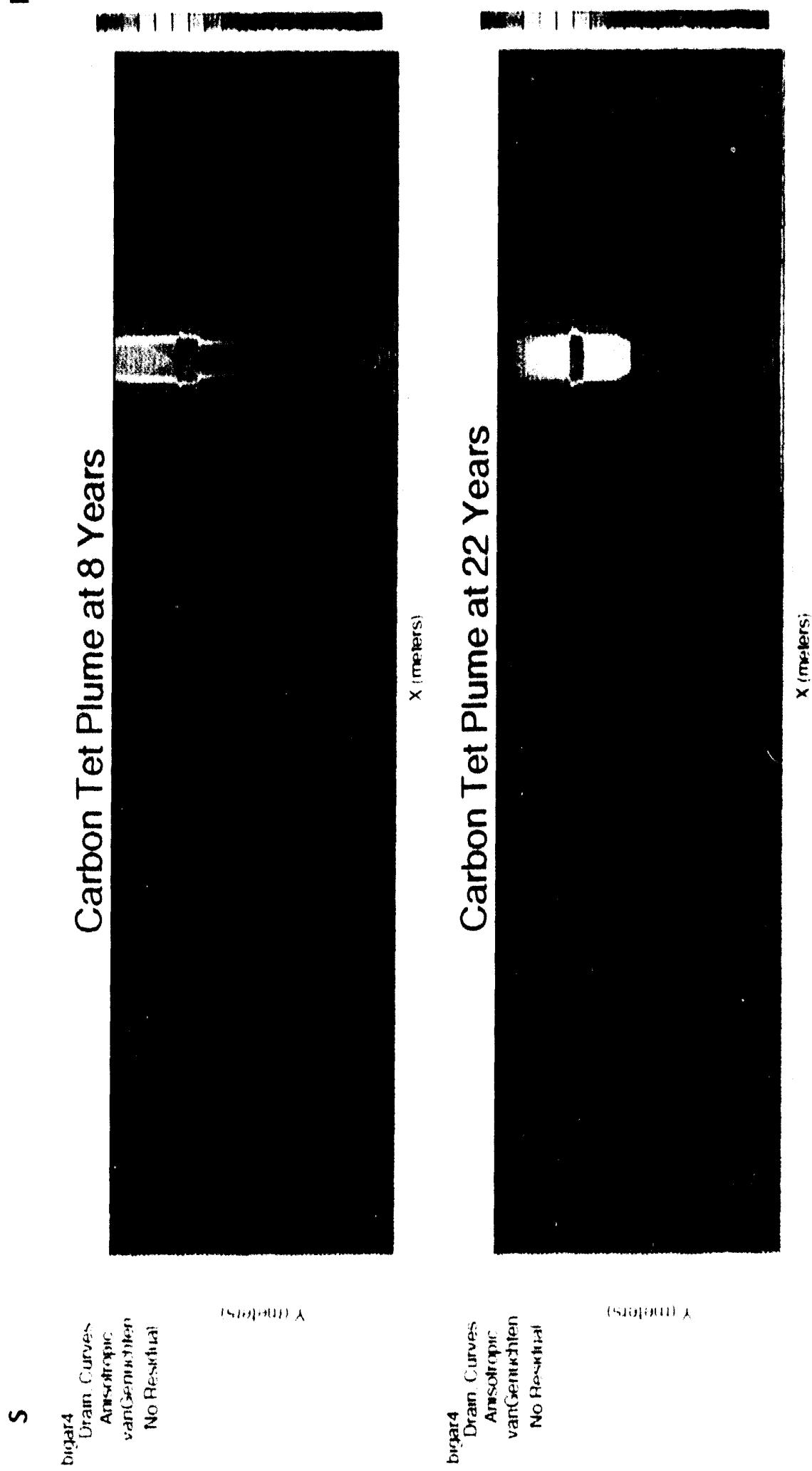

$|4| x \mid \cdot+111)$ A

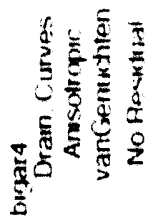

(4)istuli) A 
WHC-EP-0674

\subsubsection{Implications of Soll Gas and Perched Water Sampling Results}

Vadose zone soll gas samples were collected during conversion of the four groundwater monitoring wells to perched water wells (Appendix D). This sampling was conducted to determine if significant concentrations of vapor phase $\mathrm{CCl}_{4}$ occur in the immediate vicinity of the monitoring wells. Samples were drawn from several depths in each well and included intervals both above and below the Plio-Plelstocene unit. Samples were taken after each "lift" or interval of grout was emplaced in the borehole well casing and after the casing was perforated.

Soll gas samples for determination of $\mathrm{CCl}_{4}$ were drawn with the Seamist ${ }^{1}$ downhole sampling system that isolates the bore volume within each perforated test interval. A vacuum pump was used to draw a sample from the isolated interval through $0.63-\mathrm{cm}(0.25-\mathrm{in}$.) plastic tubing. The gas sample so obtained was analyzed in the field with both a Draeger chemical detector tube and an organic vapor meter calibrated for chlorinated hydrocarbons. Results of this sampling effort are summarized in Table 11. Excluding the maximum value of $124 \mathrm{ppmv}$ at the north end of the crib, the average of the other measurements was 11 ppmv.

The maximum value (well 2-W18-17, see Table 11) was at an elevation of approximately $3 \mathrm{~m}(10 \mathrm{ft})$ above the water table and was observed in only one sampling event. Soll vapor concentrations above the caliche layer in the same well were only $\mathrm{ca} .10 \mathrm{ppmv}$. Observed $\mathrm{CCl}_{4}$ concentrations in shallow $(<5 \mathrm{~m}$ $[<16 \mathrm{ft}])$ groundwater at this well are on the order of $1,000 \mu \mathrm{g} / \mathrm{L}$.

Additionaliy, $\mathrm{CCl}_{4}$ in initial grab samples of perched water from

wells 2-W18-19 and 2-W18-20 were $<5 \mu \mathrm{g} / \mathrm{L}$. Except for the one higher soll gas value, the perched water and soil gas $\mathrm{CCl}_{4}$ concentrations do not appear to be high enough to explain the existing groundwater concentrations of $\mathrm{CCl}_{4}$ in the vicinity of the $216-2-20 \mathrm{Crib}$. This suggests that interaction of a $\mathrm{CCl}_{4}$ vapor phase with wastewater immediately beneath the crib is not a major contributor to $\mathrm{CCl}_{4}$ in groundwater sampled from the monitoring wells at the $216-2-20 \mathrm{Crib}$. The partialiy saturated soil column beneath the crib apparently restricts the lateral migration of gaseous $\mathrm{CCl}_{4}$ through the saturated or partially saturated pore spaces. The vapor phase/perched water pathway may be more likely along the fringes of the perched water mound.

\subsubsection{Comparison of Groundwater Data with Guidelines}

This section summarizes the major findings of previous and current groundwater sampling and analys is activities associated with the operational monitoring program (Johnson 1993a) and characterization studies for CERCLArelated projects in the vicinity of the subject crib. Only the salient features of findings from these sources are discussed here. Additional detalls are contained in either the individual references cited or are provided in Appendix $B$ of this document.

\footnotetext{
'Seamist is a trademark of Eastman Cherrington Environmental.

${ }^{2}$ Draeger is a trademark of the National Draeger, Inc.
} 
Table 11. Summary of Carbon Tetrachloride Concentrations in Soll Gas from Monttoring Wells at the 216-Z-20 Crib (1993).

\begin{tabular}{|c|c|c|}
\hline $\mathrm{BOH}(\mathrm{ft})$ & & Highest reading \\
\hline \multicolumn{3}{|c|}{ We11 299-W18-17 } \\
\hline 100.8 & $\begin{array}{l}83 \text { to } 101 \mathrm{ft} \\
-13.3 \mathrm{ppm} \text { with ovM } \\
\text { - } 7 \text { ppmv with Draeger } \\
\text { chemical detector } \\
\text { tube above callche }\end{array}$ & $\begin{array}{l}\text { Below caliche: } \\
124 \text { ppmv with ovM at } \\
\text { perforated interval of } \\
170 \text { to } 191 \mathrm{ft}\end{array}$ \\
\hline \multicolumn{3}{|c|}{ Well 299-W18-18 } \\
\hline $\begin{array}{l}132.7 \text { with } \\
\text { approximately } 0.1 \mathrm{ft} \\
\text { water }\end{array}$ & $\begin{array}{l}128 \text { to } 134 \mathrm{ft} \\
\text { - } 2 \text { ppmv with ovM above } \\
\text { caliche }\end{array}$ & $\begin{array}{l}\text { Above/below caliche: } \\
12 \text { ppmv with ovM at } \\
\text { perforated interval of } \\
134 \text { to } 170 \mathrm{ft}\end{array}$ \\
\hline \multicolumn{3}{|c|}{ We11 299-W18-20 } \\
\hline$\stackrel{126.1}{\mathrm{SWL}}=111.76 \mathrm{ft}$ & 165 to $197 \mathrm{ft}$ & $\begin{array}{l}\text { Above calliche: } \\
18.9 \text { ppmv with ovM } \\
\text { Below cal iche: } \\
\text { - } 17.5 \text { ppmv at } \\
\text { perforated interval } \\
\text { of } 165 \text { to } 197 \mathrm{ft} \\
\text { - } 8.5 \text { ppmv at } \\
\text { perforated interval } \\
\text { of } 142 \text { to } 163 \mathrm{ft}\end{array}$ \\
\hline
\end{tabular}

Note: All values obtained with Seamist sampling system.

- Oraeger is a trademark of the National Draeger, Inc.

'Seamist is a trademark of Eastman Cherrington Environmental. $\mathrm{BOH}=$ Bottom of hole.

OVM = Organic vapor meter.

ppmv = Parts per million by volume.

SWL = Static water level. 
WHC-EP-0674

The potential significance of either predicted or observed contaminants in groundwater from continued disposal operations are evaluated by comparison with either:

- WAC 173-200 standards

- DOE-derlved concentration guides (4 mrem/yr equivalent) for those radionuclides not included in WAC 173-200 (Tyler 1991).

The relevant guidelines for constituents of interest for assessment of potential impacts from the 216-2-20 Crib are listed in Table 12.

5.2.7.1 Groundwater. As previously indicated, the only significant exceedances of the constituents of interest (see Table 12) in groundwater beneath the 216-2-20 Crib were for the chlorinated hydrocarbons (WHC 1989; WHC 1990b). For example, the maximum exceedances of the three chlorinated hydrocarbons identifled ware as follows: $\mathrm{CCl}_{4},>6,000$ times the Washington Water Quality Standard (WWQS) WAC 173-200; chloroform, 30 times the WWQS; and trichlorethylene, 5 times the WWQS. In addition to the $Z$ Plant-related pastpractice sources of chlorinated hydrocarbons, chloroform is also a ubiquitous contaminant that appears in virtually all treated water as a byproduct of the chlorination process. Likewise, it has been identified in PFP wastewater and may have contributed to the occurrence in groundwater beneath the crib from that source.

5.2.7.2 Perched Water. The most direct relevant information for assessing recent potentfal groundwater impacts are data obtained from the parched water monitoring well (2-W18-29) located near the south end of the crib. Results of several quarters of sample data, beginning in 1991 (Appendix B), indicate a water source that is very similar in chemical composition to cooling water (chlorinated Columbia River water). The only departure from this generalization is for arsenic, which occurs at concentrations of 20 to $25 \mu \mathrm{g} / \mathrm{L}$. The state standard for this constituent is $0.05 \mu \mathrm{g} / \mathrm{L}$; however, the average natural background concentration of arsenic upgradient of Hanford Site operational influences is $6.7 \pm 3.7$ (mean and 1 standard deviation) with a maximum observed concentration of $10 \mu \mathrm{g} / \mathrm{L}$. Where the natural background exceeds the standard, WAC 173-200 allows substitution of the natural background value for the standard. Thus, the perched water appears to have arsenic concentrations that exceed the upper range of natural background concentrations by 2 to 3 fold.

The source of the anomalous arsenic occurrence has not yet been identified. However, It seems unlikely that it is associated with past PFP wastewater discharges (see Table 7). For example, if it had been present as a co-contaminant in acids and other chemical waste previously discharged to the crib (i.e., before 1985), it should have been flushed from the soll column long before sampling at well 2-W18-29 began in 1991. This inference is based on the expected chemical state of arsenic in natural waters at slightly basic $\mathrm{pH}$ (e.g., arsenate, $\mathrm{HAsO}_{4}^{2-}$; Johnson 1993a) and the estimated travel time to the water table of less than a year (see Table 9). It has been suggested that arsenic may be leached from the soll column but data are not avallable to evaluate this possibility. Slightly elevated arsenic does occur in 
Table 12. List of Constituents of Interest and Associated Regulatory Guidelines.

\begin{tabular}{|c|c|c|}
\hline Constituent & Concentration/units & Regulatory guideline \\
\hline Acetone & NA & WAC $173-200^{\circ}$ \\
\hline Aluminum & $50 \mathrm{ppb}$ & SMCL (proposed) \\
\hline Arsenic & $0.05 \mathrm{ppb}^{\mathrm{C}}$ & WAC $173-200^{\circ}$ \\
\hline Carbon tetrachloride & $0.3 \mathrm{ppb}$ & WAC $173-200^{\circ}$ \\
\hline Chloroform & $7 \mathrm{ppb}$ & WAC $173-200^{\circ}$ \\
\hline Trichloroethylene & $3 \mathrm{ppb}$ & WAC $173-200^{\circ}$ \\
\hline Cobalt -60 & $200 \mathrm{PC} 1 / \mathrm{L}$ & $1 / 25 D C G^{d}$ \\
\hline Stront fum-90 & $8 \mathrm{pC} 1 / \mathrm{L}$ & WAC $173-200^{\circ}$ \\
\hline Cesium-134 & $80 \mathrm{pCi} / \mathrm{L}$ & $1 / 25 D^{\circ} G^{d}$ \\
\hline Cesium- 137 & $120 \mathrm{pCi} / \mathrm{L}$ & $1 / 25 D C C G^{d}$ \\
\hline Pluton Ium-238 & $1.6 \mathrm{pCi} / \mathrm{L}$ & $1 / 25 D C G^{d}$ \\
\hline Plutonfum-239 & $1.2 \mathrm{PC1} / \mathrm{L}$ & $1 / 25 D^{\circ} G^{d}$ \\
\hline Plutonium-241 & $80 \mathrm{pCt} / \mathrm{L}$ & $1 / 25 D^{\circ} G^{d}$ \\
\hline Americium-241 & $1.2 \mathrm{pC1} / \mathrm{L}$ & $1 / 25 D C^{d}$ \\
\hline Urantum & $40 \mathrm{pCi} / \mathrm{L}$ & $1 / 25 D^{\circ} G^{d}$ \\
\hline
\end{tabular}

"WAC 173-200, 1990, "Water Quality Standards for the State of Washington," Washington Administrative Code, as amended.

SMCL (proposed) - secondary maximum contaminant level; 51 FR 11396, Apri1 2, 1986; 56 FR 3526, January 30, 1991, as amended for proposed SMCL. table.

"WAC 173-200 allows natural background concentrations to be substituted for the standard in cases where natural background exceeds the standard. On the Hanford Site the provisional natural background threshold value is $10 \mathrm{ppb}$ (Johnson 1993a).

${ }_{1 / 25}$ DCG $=1 / 25$ derived concentration guide; DOE (1990). NA - Not available. 
groundwater at other locations in the 200 East and 200 west Areas in the vicinity of past and present wastewater disposal sites (Johnson 1993a; see Figure 25).

Whether arsenic is (or was) present as a co-contaminant, or was leached from the soll column is unknown. Because the concentration of this constituent is within the natural background range for the Hanford site in groundwater beneath the $c r i b$ ( $<10 \mathrm{ppb}$; see Append $1 \times \mathrm{B}$ ), the anomalous perched water occurrence is of less significance espectally when compared to existing groundwater contamination $\left(e .9 ., \mathrm{CCl}_{4}\right)$.

It should also be noted that the absence of TRU radionuclides in water samples from the perched water monitoring well $(2-W 18-29)$ is of particular significance (see Appendix $B$ for data listing). This suggests, for example, that americium and plutonium have not migrated down to this depth (ca. $40 \mathrm{~m}$ beneath the crib). In addition, the previous soll sampling from shallow borings at both ends of the crib clearly suggests that TRUs were distributed laterally over the entire length of the $457-\mathrm{m}-10 \mathrm{ng}(1,500-\mathrm{ft}-1 \mathrm{ong}) \mathrm{cr}$ ib. Thus, source of TRUs in the vicinity of the perched water monitoring well (2-Wi8-29) was avaliable for potential remobilization caused by continued addition of wastewater to the crib. The absence of TRUs in either the water or the slurried sediments collected during drflling of this well (see Appendi $x($ ), is consistent with the expected or predicted retention of these radionuclides within the upper sections of the soll column.

\subsection{MONITORING WELL ADEQUACY}

The primary monitoring well defictency identifled during this impact assessment was the existence of four unsealed groundwater monitoring wells located within the perched water zone beneath and adjacent to the 216-2-20 Crlb. Thus, remediating these wells to el iminate potential preferential pathways for groundwater contamination was a primary goal of the assessment plan for this crib (Tyler et al. 1993). In addition, it was clear that perched water monitoring wells would be the most effective "early warning" system for this crib. One such well $(2-W 18-29)$, as previously discussed, was installed near the south end of the crib as part of the RCRA monitoring network. This well provided valuable information on existing perched water contaminant levels, but was not optimally located to assess potential interaction of wastewater with the highor soll gas $\mathrm{CCl}_{4}$ concentrations near the north end of the crib (see Figure 35). Both of the above needs were solved simultaneously under the Well Remediation Program conducted by Westinghouse Hanford Company. Field activities conducted for this effort are summarized as follows.

\subsubsection{Remediation and Conversion of Existing Groundwater Monitoring Wells}

This section summarizes the field work conducted between April and August 1993 for the subject purpose (Reynolds 1993). Detalled well logs and associated fleld data are included in Appendix 0 . 
5.3.1.1 Approach. A dual-purpose approach providing both sealed wells and perched water and/or deep soll gas monitoring wells for both the operational monitoring program and the $\mathrm{CCl}_{4}$ ERA was selected. The objective was to obtain additional perched water/soll gas monitoring facllities while correcting the four inadequately installed groundwater monitoring well casings (Appendix 0 ).

Implementation of the above strategy and objectlves involved two-phased, well remediation. Phase I involved decommissioning of the lower sections of the wells coupled with temporary completion of the upper sections as multipleuse monttoring wells. Phase II involves deferred decommissioning of the upper sections of the converted wells unt 11 they are no longer needed for elther perched water or soll gas monltoring purposes, after which the remainder or upper section of the well wlll be decommisstoned.

5.3.1.2 Well Remediation Procedure. The four wells located adjacent to the 216-2-20 Crib (see Figure 4) were perforated and pressure grouted from the water table to an elovation just above the Pllo-Plelstocene layer (see Figure 20). The grouting proceeded in stages or "lifts." This involved perforating the casing section and then injecting grout through a packer assembly at a nominal hydrostatlc pressure of $5016 \mathrm{f} / \mathrm{in}^{2}$. Neutron/density logs for each well provided indications of volds and identffication of it thologic units for establishing completion depths or elevations. Volumes were calculated for each section of perforated casing between the packer and the previous grout layer. Approximately three times this volume of grout was added to ensure a continuous seal between the outer casing wall and the formation. After completion of the last lift or layer, an additional 5 to $6 \mathrm{~m}$ $(15$ to $20 \mathrm{ft}$ ) of casing was perforated to allow perched water inflow and or space for soll gas monitoring.

One of the wells $(2-W 18-19)$ required spectal perforating methods to penetrate the dual-casing. This involved use of a jet perforating tool actuated with a downhole explosive sufficient to penetrate both casing walls.

In summary, the four wells were remediated successfully using a multiple$11 \mathrm{ft}$, pressure-grouting method, the first application of such an approach at the Hanford Site. The technlques developed and experience gained at the 216-2-20 Crib can be used to improve decommissioning procedures for the multitude of older wells at the Hanford Site. Thus, significant improvements in well decommissioning procedures are expected from application of the methods devised for the 216-2-20 Crib GIA.

5.3.1.3 Perched Water Table Response. The praliminary observations on the hydrologlc response to the well remediation work. (Appendix D) suggests that perched water was previously draining down the outside of the unsealed casings, thus creating a dewatered zone around each well with in the perched water layer. When the lower sections of casing were sealed, perched water resaturated the dewatered "zone of drainage influence" around the previously unsealed casing.

The observations summarized above lllustrate the importance of sealing or decommissioning old wells, especially in the 200 West Area where perched water is encountered frequently. Post-remediation water level observations in the converted wells at the $216-2-20 \mathrm{Crib}$ should be useful in evaluating perched water dynamics in other 200 West Area active wastewater disposal sites. 


\subsubsection{Future Needs and Data Reporting}

The virtual elimination of wastewater discharges to the 216-2-20 Crib after January 1994 will 1 lkew/se reduce the need for groundwater monitoring at this site. However, cont inued soll gas monitoring will be conducted at the newly created vadose zone monitoring wells for the $\mathrm{CCl}_{4}$ ERA to assess the efficacy and areal extent of adjacent soll gas vacuum extraction operations at the 216-2-IA Crib. Perched water sampling and water levels will be followed in connection with the operational groundwater program to document the response to declining and/or terminated wastewater input. Results of this effort wlll be reported in the annual Westinghouse Hanford Company groundwater status report.

Potential future use of the new vadose monltoring wells includes postremediation monitoring or for soll venting to remove residual $\mathrm{CCl}_{4}$ potentilally present in the soll column beneath the adjacent 2 Ditches. 
WHC-EP-0674

This page intentionally left blank. 


\subsection{CONCLUSIONS}

The evaluation of existing and recent data presented in this report leads to the following conclusions about the impact of wastewater discharges to the 216-2-20 Crib:

- Estimates of TRU migration rates for the high discharge perlod (1.e., greater than $380 \mathrm{~L} / \mathrm{min}[100 \mathrm{gal} / \mathrm{min}]$ during 1982 through 1992) Indlcate these key contaminants are retained in the upper soll column (1ess than $40 \mathrm{~m}$ [130 ft]). Spectral gamma logs, sediment data, and perched water and groundwater sampiling results all support this conclusion. The significant reduction in flow rates during 1993 (to approximately $190 \mathrm{~L} / \mathrm{min}[50 \mathrm{gal} / \mathrm{min}]$ ), and the even lower projected rates for $1994(23$ to $45 \mathrm{~L} / \mathrm{min}[6$ to $12 \mathrm{gal} / \mathrm{min}$ ] of treated effluent), are expected to result in only minimal additional downward TRU movement unt 11 June 1995 when all liquid discharges to the crib will cease.

- The interaction of wastewater from the 216-2-20 $\mathrm{Cr} / \mathrm{b}$ with residual

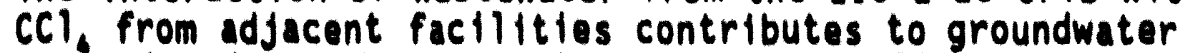
contamination. However, the amount is small compared to continual drainage of $\mathrm{CCl}_{4}$ from adjacent past-practice disposal cribs. In addition, it is concluded that elevated $\mathrm{CCl}_{4}$ concentrations (100 to $1000 \mu \mathrm{g} / \mathrm{L}$ ) in the former groundwater monitoring wells at this crib were due to elther:

- Long-term drainage of residual DNAPL from the adjacent 2 Ditches

- A result of DNAPL drainage down the outside of the formerly unsealed well casings during or shortly after installation of the monitoring wells between the 216-2-20 Crib and the 2 Ditches in 1982.

During the high discharge period (1982 to 1992) wastewater from the crib may have been a driving force for downward transport of residual DNAPL in the soll column beneath the adjacent 2 Ditches. Reduction in the discharge rate to the 216-2-20 Crib should all but - iminate additional localized groundwater contamination from this potential source.

- Unsealed well casings of four groundwater monitoring wells located in the perched water zone of the crib created potential preferential pathways that may have contributed to groundwater contamination during the earlier operational period (before 1986). However, no evidence for the presence of residual TRUs or other radiological contamination was found in recent groundwater samples from these wells. Likewise, in 1991, high resolution and standard spectral gamma surveys for radiological contamination in all four wells indicated the presence of only naturally occurring radionuclides (Appendixes $C$ and $D$ ). 
- Conversion of the four groundwater monitoring wells to perched water and/or vadose zone monitoring wells eliminated potential preferentlal pathways to groundwater and provided improved "early warning" detection monitoring at the crib (Appendix D). This resulted in an improved monitoring network. The converted wells can also act as well venting structures for enhancing removal of residual $\mathrm{CCl}_{\text {f }}$ from beneath the 2 Ditches by elther active or passive soll extraction. The well venting/extraction process will become more effective as the water drains from the soll column in response to termination of wastewater input to the crib. 
WHC-EP-0674

\subsection{REFERENCES}

Ames, L. L., D. Rai, and R. J. Serne, 1976, A Review of Actinide-Sediment Reactions with an Annotated Bibliography, BNWL-1983, Battelle Pacific Northwest Laboratories, Richland, Washington, pp. 101-130.

Ames, L. L., and R. J. Serne, 1991, Compilation of Data to Estimate Groundwater Migration Potential for Constituents in Active Liquid Discharges at the Hanford Site, PNL-7660, Pacific Northwest Laboratory, Richland, Washington.

Barney, G. S., 1988, Adsorption of Plutonium on Hanford Sediments from Shallow Groundwaters - Measurement of Distribution Coefficients, (internal memo 12714-PSL88-168 to J. L. Gieger, December 27), Westinghouse Hanford Company, Richland, Washington.

Brown, M. J., R. K. P'Pool, and S. P. Thomas, 1990, Westinghouse Hanford Company Effluent Discharges and Solid Waste Management Report for Calendar Year 1989: 200/600 Areas, WHC-EP-0141-2, Westinghouse Hanford Company, Richland, Washington.

40 CFR 264, 1992, "Standards for Owners and Operators of Hazardous Waste Treatment, Storage, and Disposal Facilities," Code of Federal Regulations, as amended.

Comprehensive Environmental Response, Compensation, and Liability Act of 1980, 42 USC 9601 , et seq.

Delaney, C. D., K. A. Lindsey, and S. P. Reidel, 1991, Geology and Hydrology of the Hanford Site: A Standardized Test for Use in Westinghouse Hanford Documents and Reports, WHC-SD-TI-003, Westinghouse Hanford Company, Richland, Washington.

DOE, 1987, Final Environmental Impact Statement, Disposal of Hanford Defense High-level, Transuranic and Tank Waste, Hanford Site, Richland, Washington, DOE/EIS-0113, U.S. Department of Energy, Richland Operations office, Richland, Washington.

DOE, 1988, Consultation Draft, Site Characterization Plan, Reference Repository Location, Hanford Site, Washington, DOE/RW-0164, Vols. 1-9, U.S. Department of Energy, Office of Civilian Radioactive Waste Management, Washington, D.C.

DOE, 1990, Radiation Protection of the Public and the Environmert, DOE Order 5400.5, U.S. Department of Energy, Washington, D.C.

DOE-RL, 1991, Expedited Response Action Proposal (EE/CA \& EA) for 200 West Area Carbon Tetrachloride Plume, DOE/RL 91-32, U.S. Department of Energy, Richland Field Office, Richland, Washington.

DOE-RL, 1992, 200 West Area Groundwater Aggregate Area Management Study Report, DOE/RL 92-16, U.S. Department of Energy, Richland Field Office, Richland, Washington. 
Drever, J. 1., 1982, The Geochemistry of Natural Waters, Prentice-Ha11, Inc., Englewood Cliffs, New Jersey.

Ecology, EPA, and DOE, 1990, Hanford Federal Facility Agreement and Consent Order, Washington State Department of Ecology, U.S. Environmental Protection Agency, and U.S. Department of Energy, 0lympia, Washington.

40 CFR 264, 1992, "Standards for Owners and Operators of Hazardous Waste Treatment, Storage, and Disposal Facilities," Code of Federal Regulations, as amended.

51 FR 11396, 1986, "National Primary and Secondary Drinking Water Regulations; Flouride," Federal Register, April 2.

56 FR 3526, 1991, "National Primary Drinking Water Regulations--Synthetic Organic Chemicals and Inorganic Chemicals; Monitoring for Unregulated Contaminants; National Primary Drinking Water Regulations Implementation; National Secondary Drinking Water Regulations, "Federal Register, January 30.

Gee, G. W., 1987, Recharge at the Hanford Site - Status Report, PNL-6403, Pacific Northwest Laboratory, Richland, Washington.

Gephart, R. E., R. C. Arnett, R. G. Baca, L. S. Leonhard, and F. A. Spane, Jr., 1979, Hydrologic Studies Within the Columbia Plateau, Washington: An Integration of Current knowledge, RHO-BWI-ST-5, Rockwell Hanford Operations, Richland, Washington.

Graham, M. J., M. D. Hal1, S. R. Strait, and W. R. Brown, 1981, Hydrology of the Separations Area, RHO-ST-42, Rockwell Hanford Operations, Richland, Washington.

Graham, M. J., G. V. Last, and K. R. Fecht, 1984, An Assessment of Aquifer Intercommunication in the $B$ Pond-Gable Mountain Pond Area of the Hanford Site, RHO-RE-ST-12-P, Rockwell Hanford Operations, Richland, Washington.

Jenne, E. A., ed., 1979, Chemical Modeling in Aqueous Systems - Speciation, Sorption, Solubility, and Kinetics, ACS Symposium Series No. 93, American Chemical Society, Washington, D.C.

Jensen, D. B., 1990, Plutonium Finishing Plant Wastewater Stream-Specific Report, WHC-EP-0342, Addendum 8, Westinghouse Hanford Company, Richland, Washington.

Johnson, V. G., N. H. Cutshall, and C. L. Osterberg, 1967, "Retention of Zinc- 65 by Columbia River Sediment," Water Resources Research, Vol. 3(1):99-102.

Johnson, V. G., 1993a, Sediment Quality and Ecorisk Assessment Factors for a Major River System, WHC-SA-1989-FP, Westinghouse Hanford Company, Richland, Washington. 
Johnson, V. G., 1993b, Westinghouse Hanford Company Operational Groundwater Status Report, WHC-EP-0595, Westinghouse Hanford Company, Richland, Washington.

Kasper, R. B., 1982, 216-Z-12 Transuranic Crib Characterization: Operational History and Distribution of Plutonium and Americium, RHO-ST-44, Rockwell Hanford Operations, Richland, Washington.

Khaleel, R., and T. LeGore, 1990, Effects of Varying Recharge on Radionuclide Flux Rates to the Water Table at a Low-Level Solid Waste Burial Site, WHC-SA-0699-FP, Westinghouse Hanford Company, Richland, Washington.

Last, G. V., M. J. Graham, and V. W. Hall, 1981, 216-U-10 Pond and 216-Z-19 Ditch Characterization Studies, RHO-ST-45, Rockwell Hanford Operations, Richland, Washington.

Last, G. V., S. P. Airhart, M. P. Bergeron, B. N. Bjornstad, M. A. Chamness, C. S. Cline, D. R. Newcomer, J. A. Schranke, D. W. Wallace, and J. S. Wilbur, 1989, Hydrogeology for the 200 Areas Low-Level Burial Grounds--An Interim Report, PNL-6820, Pacific Northwest Laboratory, Richland, Washington.

Last, G. V., and V. J. Rohay, 1993, Refined Conceptual Model for the Volatile Organic Compounds-Arid Integrated Demonstration and 200 West Area Carbon Tetrachloride Expedited Response Action, PNL-8597, Pacific Northwest Laboratory, Richland, Washington.

Ledgerwood, R. K., 1993, Summaries of Well Construction Data and Field Observations for Existing 200 West Resource Protection Wells, WHC-SD-ER-TI-005, Westinghouse Hanford Company, Richland, Washington.

Lindsey, K. A., 1991, Revised Stratigraphy for the Ringold Formation, Hanford Site, South-Central Washington, WHC-SD-EN-EE-004, Westinghouse Hanford Company, Richland, Washington.

Lindsey, K. A., B. N. Bjornstad, and M. P. Connelly, 1991, Geologic Setting of the 200 West Area: An Update, WHC-SD-EN-TI-008, Rev. 0, Westinghouse Hanford Company, Richland, Washington.

Ludowise, J. D., 1978, Report on Plutonium Mining Activities at 216-2-9 Enclosed Trench, RHO-ST-21, Rockwel1 Hanford Operations, Richland, Washington.

McCord, J. T., D. B. Stephens, and J. L. Wilson, 1991, "Hysteresis and StateDependent Anisotropy in Modelling Unsaturated Hillslope Hydrologic Processes," Water Resources Research, Vol. 27, No. 7, pp. 1501-1518.

Mualem, Y., 1976, "A New Model for Predicting the Hydraulic Conductivity of Unsaturated Porous Media," Water Resources Research, Vol. 12, No. 3, pp. 513-522.

Mualem, Y., 1984, "Anisotropy of Unsaturated Soils," Soil Sci. Soc. Am. J., Vol. 48, pp. 505-509. 
Murphy, E. M., J. E. Szecsody, and S. J. Phlllips, 1991, Moisture Content and Recharge Estimates at the Yakima Barricade Borehole, PNL-SA-20155, Pacific Northwest Laboratory, Richland, Washington.

Myers, C. W., S. M. Price, J. A. Caggiano, M. P. Cochran, W. J. Czimer, N. J. Davidson, R. C. Edwards, K. R. Fecht, G. E. Holmes, M. G. Jones, J. R. Kunk, R. D. Landon, R. K. Ledgerwood, J. T. Lillie, P. E. Long, T. H. Mitchell, E. H. Price, S. P. Reidel, and A. M. Tallman, 1979, Geologic Studies of the Columbia Plateau: A Status Report, RHO-BWI-ST-4, Rockwell Hanford Operations, Richland, Washington.

Myers, C. W., and S. M. Price, eds. 1981, Subsurface Geology of the Cold Creek Syncline: Rockwell Hanford Operations Report, Rockwell Hanford Operations, Richland, Washington.

Owens, K. W., 1981, Existing Data on the 216-Z Liquid Waste Sites, RHO-LD-114, Rockwell Hanford Operations, Richland, Washington.

Plepho, M. G., A. G. Law, M. P. Connelly, and K. A. Lindsey, 1993, Vadose Zone Modeling of Carbon Tetrachloride in 200 West Area at the Hanford Site, WHC-SD-EN-TI-112, Rev. O, Westinghouse Hanford Company, Richland, Washington.

Price, S. M., R. B. Kasper, M. K. Additon, R. M. Smith, and G. V. Last, 1979, Distribution of Plutonium and Americium Beneath the 216-Z-1A Crib: A Status Report, RHO-ST-17, Rockwell Hanford Operations, Richland, Washington.

Reidel, S. P., and K. R. Fecht, 1981, "Wanapum and Saddle Mountains Basalts of the Cold Creek Syncline Area," C. W. Myers and S. M. Price (eds.), Subsurface Geology of the Cold Creek Syncline, RHO-BWI-ST-14, Rockwell Hanford Operations, Richland, Washington.

Reidel, S. P., and P. R. Hooper, eds., 1989, Volcanism and Tectonism in the Columbia River Flood-Basalt Province: Geological Society of America Special Paper, 239, 386 pp., 1 plate.

Reidel, S. P., V. G. Johnson, and N. W. Kline, 1993, Groundwater Impact Assessment for the 216-U-17 Crib, 200 West Area, WHC-EP-0664, Westinghouse Hanford Company, Richland, Washington.

Resource Conservation and Recovery Act of 1976, 42 USC 6901, et seq.

Reynolds, K. D., 1993, Discussion of: (1) Remediation of Z-20 Wells 299-W18-17, -18, -19 , and -20 and (2) Geohydrologic Conditions at U-14 Ditch (telephone conference memorandum, with K. Kowalik, Washington State Department of Ecology, April 9), Westinghouse Hanford Company, Richland, Washington.

Rockhold, M. L., M. J. Fayer, and G. W. Gee, 1988, Characterization of Unsaturated Hydraulic Conductivity at the Hanford Site, PNL-6488, Pacific Northwest Laboratory, Richland, Washington. 


\section{WHC-EP-0674}

Rohay, V. J., and V. G. Johnson, 1991, "Site Evaluation" in Expedited Response Action Proposal for 200 West Area Carbon Tetrachloride Plume, Appendix B, DOE/RL-91-32, Draft B, U.S. Department of Energy, Richland, Washington.

Routson, R. C., and V. G. Johnson, 1990, "Recharge Estimates for the Hanford Site 200 Area Plateau," Northwest Science, Vol. 64, No. 3, Pp. 150-158.

Runchal, A. K., B. Sagar, and N. W. Kline, 1992, PORFLO-3: A Mathematical Model for Fluid Flow, Heat, and Mass Transport in Variably Saturated Geologic Media - Users Manual, Version 1.2, WHC-EP-0385, Westinghouse Hanford Company, Richland, Washington.

Sloat, R. J., 1367, Hanford Low Level Waste Management Reevaluation Study, ARH-231, Atlantic Richfield Hanford Company, Richland, Washington.

Smith, A. E., 1973, Nuclear Reactivity Evaluations of 216-Z-9 Enclosed Trench, ARH-2915, Atlantic Richfleld Hanford Company, Richland, Washington.

Stordeur, R. T., and D. L. Flyckt, 1988, 1988 Annual Status Report of the Plan and Schedule to Discontinue Disposal of Contaminated Liquids into the Soil Column and the Hanford Site, WHC-EP-0196-1, Westinghouse Hanford Company, Richland, Washington.

Subrahmanyam, V. B., and W. H. Ulbricht, 1987, Assessment and Evaluation of Decreased Drainage of the 216-2-20 Crib, SD-RE-TI-16, Rockwell

Hanford Operations, Richland, Washington.

Tallman, A. M., K. R. Fecht, M. J. Marratt, and G. V. Last, 1979, Geology of the Separations Areas, Hanford Site, South-Central Washington, RHO-ST-23, Rockwell Hanford Operations, Richland, Washington.

Tyler, D. K., 1991, A Methodology for Assessing Impacts to Groundwater from Disposal of Liquid Effluent to the Soil at the Hanford Site, SD-EN-EV-008, Westinghouse Hanford Company, Richland, Washington.

Tyler, D. K., S. P. Reidel, K. M. Singleton, V. G. Johnson, and D. J. Alexander, 1993, Groundwater Impact Assessment Plans for Z-20 Crib, U-14 Ditch, U-17 Crib, and 100-D Ponds, NSA-0037, Westinghouse Hanford Company, Richland, Washington.

van Genuchten, R., 1978, Calculating the Unsaturated Hydraulic Conductivity with a New Closed-Form Analytical Model, Report 78-WR-08, Water Resources Program, Department of Civil Engineering, Princeton University, Princeton, New Jersey.

WAC 173-200, 1990, "Water Quality Standards of the State of Washington," Washington Administrative Code, as amended.

WAC 173-303, 1990, "Dangerous Waste Regulations," Washington Administrative Code, as amended.

WHC, 1989, Waste Stream Characterization Report, WHC-EP-0287, Vol. 3, Westinghouse Hanford Company, Richland, Washington. 
WHC, 1990a, Environmental Engineering, Technology, and Permitting Function Quality Assurance Program Plan, WHC-EP-0383, Westinghouse Hanford Company, Richland, Washington.

WHC, 1990b, Liquid Effluent Study Final Project Report, WHC-EP-0367, Westinghouse Hanford Company, Richland, Washington.

WHC-CM-7-5, Environmental Compliance, Westinghouse Hanford Company, Richland, Washington.

Yeh, T., C. Jim, L. W. Gelhar, and A. L. Gutjhar, 1985a, "Stochastic Analysis of Unsaturated Flow in Heterogeneous Solls, 1. Statistically Isotropic Media," Water Resources Research, Vo1. 21, No. 4, pp. 447-456.

Yeh, T., C. Jim, L. W. Gelhar, and A. L. Gutjhar, 1985b, "Stochastic Analysis of Unsaturated Flow in Heterogeneous Sol1s, 2. Statistically Anisotropic Media With Variable $\alpha$," Water Resources Research, Vol. 21, No. 4, Pp. 457-464.

Yeh, T., C. Jim, L. W. Gelhar, and A. L. Gutjhar, 1985c, "Stochastic Analysis of Unsaturated Flow in Heterogeneous Solls, 3. Observations and Applications," Water Resources Research, Vol. 21, No. 4, pp. 465-471. 
WHC-EP-0674

\section{APPENDIX A}

\section{PLUTONIUM FINISHING PLANT}

WASTEWATER CONTRIBUTORS 
WHC-E.P-0674

This page intentionally left blank.

$A-\mid i$ 


\section{PLUTONIUM FINISHING PLANT WASTEWATER CONTRIBUTORS}

The following are terms frequently used in this document.

Enclesed drains. An enclosed drain is totally enclosed from its source to the floor coupling. The pipe is elther welded or fixed in place. This type of drain is used for heating, ventllating, and air conditioning (HVAC) drains and glovebox or equipment cooling water drains.

open drains. An open drain has an opening to the room, etther as a sink, drinking fountain, or floor drain. Open drains also include funnel drains that act as a junction for several smaller contributors and open stand pipes. It is possible for chemicals to enter the wastewater through these drains. Io prevent this from happening all open drains are posted with a sign warning against disposing of chemicals in these dralns. In addition, personnel are trained in the proper disposal of chemicals and the chemicals are typically kept in enclosed cabinets or are stored on secondary spll1 containment pallets.

HVAC drains. HVAC drains typically are found above any laboratory room that requires exact temperature control. The HVAC units use cooling water and also produce condensate from the atmosphere. No chemicals are used in these units and the wastewater contributors are essentially clean water. The cooling water is circulated through a nollcontact heat exchanger. Cooling water and condensate are discharged through separate drains.

Equioment cooling drains. Some electrical equipment requires cooling water. These cooling units al so use noncontact cooling and discharge clean wastewater. Some pumps use water to form a seal to maintain a vacuum. The wastewater is discharged after use.

Glovebex drains. Gloveboxes are used throughout the Plutonium Finishing Plant (PFP) for working on potentially contaminated materials. The glovebox will usually contain one or more processes and their support piping. Any cooling water required in a glovebox will use a noncontact heat exchanger. The cooling water does not come in contact with any contaminated material while in the glovebox.

Backflow preventers. Process water backflow preventers are a safety measure installed in the lines to prevent contaminated water from backing up into the sanitary (potable) water supply. A sudden change in water pressure will divert the water to the wastewater drain. The drain is an open standpipe located below a valve that diverts the water. This places the drain off the floor away from potential chumical spills.

NOTE: Discussion on the following pages, $A-3$ through $A-7$, is the current (October 1993) configuration of the wastewater system for the PFP Complex. 
WHC-EP-0674

This page intentionally left blank. 
MANHOLE NUMBER 1

Manhole Number I recelves wastewater from the Inactlve 232-2 Incinerator Bullding, the 2736-2B Support/Storage Complex, and from the west and of the 234-52 butlding duct level and second floor. Rout ine wastewater flow to Manhole Number 1 from 234-52 Bullding wastewater contributors is estimated to be $8 \mathrm{~L} / \mathrm{min}(2 \mathrm{gal} / \mathrm{m} / \mathrm{n})$.

\section{2-2 Bullding}

Processing activitles in this bullding were suspended in 1972. The water is turned off in 232-2 Bullding and no chemicals are stored or used in the bulliding. There are no rout ine contributions from 232-2 Bullding to Manhole Number 1. Potentially contaminated wastewater contributors are disconnected.

\section{4-52 8ullding. Duct Level.}

Wastewater contributors from the duct level consist of four equipment cooling water discharges, three process water backflow preventers, and eight safety showers. The cooling water drains are enclosed drains and the equipment is not connected to any radiologically contaminated processes. The backflow preventers have open drain pipes; however, no chemicals are stored or used nearby. The safety showers only have a potential for chemical release to the wastewater if one is used for personal safety during an emergency that involves chemical contamination.

Radiological contamination of these wastewater contributors is unilkely.

\section{4-82 Butlding. Second Level}

The second level contributors can be divided into two groups: ventilation drains and chemical preparation (CHEMPREP) drains. The ventllation section of the second floor has four cooling water drains, one drinking fountain, and four HVAC condensate drains. There are no chemicals stored near the drinking fountain. It is unlikely that a chemical discharge could occur at the HVAC drains, because these funnel drains are off the floor on standpipes and there are no chemicals stored or used in the immediate vicinity.

The 66-cm (26-in.) vacuum pumps discharge heat through two cooling towers located south of the 234-52 Bullding. The towers are part of the secondary cooling loop. Water is sprayed over the enclosed pipes carrying the coolant in the primary coolant loop. Cooling water can overflow or be discharged directly to the wastewater sewer through Manhole Number 1.

Radioactive contamination cannot enter the wastewater sewer through the second level waste stream contributors or the cooling towers. All of the floor drains located in the radiologically controlled zones of the second level have been plugged.

The two CHEMPREP rooms for the remote mechanical "C" (RMC) line are located in nonradiation zone and contain two sinks and two backflow preventers. The CHEMPREP tanks are situated over a large sump that drains to the 2735-2 chemical overflow tank. Chemical spills from the tanks will not 
enter the PFP wastewater. The sinks are labeled with a warning against disposing of chemicals in them and have been temporarlly plugged as an added measure of safety. Five floor drains are located outside of the CHEMPREP tanks sump ares, which is under the CHEMPREP tanks. The five floor drains have been permanently sealed to prevent spllls from entering the 216-2-20 crib. The santtary (potable) water backflow preventer has been routed to the sump and the hot water backflow preventer discharges to one of the sinks. Both of the CHEMPREP sinks will be disconnected from the 216-2-20 Crib.

\section{6-28 Bullding}

Room 602 houses the ventllation intake for the 2736-2 Complex. All HVAC condensate and cooling waters are discharged from this uncontaminated room. No hazardous chemicals are used or stored in this room.

\section{4-52 Bullding. Roof Drains}

The roof drains only recelve storm water. No chemicals are stored or used on the 234-52 Butlding roof. There is no radioactive contamination on the roof.

\section{GANHOLE NUMAER?}

Manhole Number 2 recelves runoff from the storm drains located on the south side of the plant. The paint shop is located near one of the storm drains so all painting supplles and solvents are kept in locked flammable proof cabinets. There are no routine wastewater contributions from Manhole Number 2.

\section{MANHOLE NUMBER 3}

Manhole Number 3 recelves wastewater from the 291-2 Exhaust Fan House: the Inactive 242-2 Waste Treatment and Americlum Facllity; the 234-52 first floor cold chemical and clean water drainage; and the east end of the 234-52 duct level, second floor, and roof drains. Routine wastewater flow to Manhole Number 3 from 234-52 wastewater contributors is estimated to be $8 \mathrm{~L} / \mathrm{min}(2 \mathrm{gal} / \mathrm{min})$. Rout ine wastewater flow to Manhole Number 3 from 291-Z wastewater contributors vartes between 76 and $151 \mathrm{~L} / \mathrm{min}(20$ and $10 \mathrm{gel} / \mathrm{min})$, depending on the time of year.

\section{1-2 Exhaust Ean House}

This butlding houses the main exhaust fans, the instrument air compressors, as well as several pumps and compressors. All of the compressor condensate and pump seal water are sent to open floor drains as clean water. The only chemicals used near the drains include nonhazardous cleaning agents and motor ofl. 
WHC-EP-0674

\section{2-2 Weste Ireatment and Americlum Eacility}

In 1976 processing activities were suspended in this bullding. The water is turned off in the 242-2 Bullding and no chemicals are stored or used in the bullding. There are no rout ine wastewater contributions from 242-z to Manhole Number 3. Contamination entering the wastewater from this buliding is

unilkaly.

\section{4-52 Bullding. Eirst Level}

Wastewater contributors from the first level consist of one drinking fountain, one sink, one eyewash station, four equipment cooling water drains, two glovebox cooling water drains, and three HVAC cooling water drains. The equipment, HVAC, and glovebox cooling water drains are enclosed. All other drains are open but are not near where chemlcals are used or stored.

Potentially radloactive contaminated contributors include the glovebox and equipment cooling water drains. These units use noncontact cooling systems.

\section{4-52 Budlding. Duat Level}

Wastewater contributors from the east end of the duct level consist of four HVAC condensate drains and two equipment cooling water drains. The HVAC condensate and equipment cooling water drains all have enclosed piping.

Chances for radioactive contamination are minimal.

\section{4-52 Bullding. Second Level}

Hastewater contributors from the east and of the second level consist of one HVAC drain and three floor drains. The HVAC condensate drain has enclosed piping. The two floor drains are in the instrument repair shop. Chemicals used in the shop are stored in a flammable-proof cabinet. All three effluent sources are located in the uncontaminated portion of the bullding.

The entrance of radioactive contamination into PFP wastewater is only possible through the floor drain in the ventilation room. All ventilation room floor drains located in a radiation zone will be plugged as part of an effort to control the wastewater quality.

\section{4-57 Bullding. Roof Drains}

The roof drains only recelve storm water. No chemicals are stored or used on the 234-52 Bullding roof. There is no radioactive contamination on the roof.

\section{MANHOLE NUMBER Q}

Manhole Number 4 receives wastewater from 234-52 process cooling water drains, 236-2 process cooling water drains, 236-2 steam condensate drains, and 
WHC-EP-0674

236- 2 waste water drains. Rout ine wastewater flow to Manhole Number 4 from 234-52 wastewater contributors is estimated to be $4 \mathrm{~L} / \mathrm{min}(1 \mathrm{gal} / \mathrm{m} / \mathrm{n})$.

\section{4-52 Bullding}

Wastewater contributors originate from either the analytical or development laboratorles, or from the RMC line or the inactive remote mechantcal "A" (RMA) line. There are four glovebox cooling water drains in the production ilines (all are inactive), one drinking fountain in the RMC ine control room, and one equipment cooling water drain on the duct level. The glovebox and equipment drains are totally enclosed and chemicals are not stored or used in the RMC line control room. The equipment with potentlally contaminated cooling water has been made inactive and is no longer used.

These contributors will be physically isolated from the PFP wastewater.

The analytical laboratory has one sink and one HVAC drain line. The HVAC drain line has two open drains and collects the cooling water and condensate from six contributors, four air conditioners, one cold water overfiow drain, and the compressed air condensate trap. A warning sign has been posted above each opening. The sink is located in the "clean" lab. This room is used only for nonradioactive laboratory work. All hazardous chemicals are stored in special cabinets located away from the sink. The sink is clearly labeled against disposing of any chemicals in it.

The cold (nonradloactive) development lab contains three lab sinks, one eyewash station, one equipment cooling water drain on the duct level, and one backflow preventer drain on the duct level. All of the drains are clearly labeled against disposing of chemicals in them. Hazardous chemicals in this room are stored in chemical storage cabinets.

\section{6-2 Building. First Leyel}

Wastewater contributors from the first level of the 236-z Building consist of elght glovebox cooling water drains. The glovebox drains are enclosed piping. The processing cooling water uses noncontact cooling to reduce the possibility of contamination. These sources will cease discharging to the 216-2-20 Crib after the closed-100p cooling system Project B-680H starts up (January 1994).

\section{6-2 Bullding. Second Level}

The second level of the 236-2 Bullding contains no wastewater contributors.

\section{6-z Bullding. Third Level}

The third level of the 236-2 Building contains 19 steam condensate drains, 5 process water backflow preventers, 1 floor drain, and 1 process water overflow drain. There are no chemicals stored on this level. The steam condensate drains are enclosed drains. All other drains are open and have been labeled against disposing of chemicals in them. The only potential sources of contamination are the $43-\mathrm{cm}(17-\mathrm{in}$.$) vacuum pump seal water$ 
discharges. The vacuum pumps and three ventilation equipment drains will cease discharging to the 216-Z-20 Crib after the closed-10op cooling system Project B-680H, is hooked up (January 1994).

236-z Building. Fourth Level

The fourth level of the 236-z Building contains one drinking fountain and one HVAC condensate drain. The glovebox drains are enclosed drains. The drinking fountain and the HVAC condensate drain are located in the Plutonium Reclamation Facility (PRF) control room and shift office. No chemicals are stored or used in these rooms. All glovebox cooling units use noncontact cooling to reduce the possibility of contamination. Glovebox components, MT-5 (dissolvers) and MT-6, are connected to the closed-loop cooling system.

236-z Building. Sixth Level

The sixth level of the 236-z Building contains one process water backflow preventer. There are no chemicals stored on this level.

\section{6- $Z$ Building Fire Protection System}

There are 10 fire protection water sources located throughout the facility that will spray water into ductwork if a fire occurs there. The water will drain to the sump built in the lowest point of the duct work. The sump can then be pumped out through the D-1 header for Manhole Number 4.

\section{MANHOLE NUMBER 7}

Manhole Number 7 receives wastewater from Manholes Number 2 and 6 and from Tank $D-9$ at the 241-ZB Building. Tank $D-9$ is set inside a sump pit. The sump pit and nearby load-in platform are configured to pump rainwater to the 216-2-20 Crib header between Manholes Number 6 and 7 . Tank D-9 holds caustic chemicals, therefore the fluids held within the sump must be analyzed for $\mathrm{pH}$ before pumping to Manhole Number 7 is allowed.

\section{MANHOLE NUMBER 9}

Manhole Number 9 receives the wastewater from the 231-Z Building. Routine wastewater flow to Manhole Number 9 from 231-Z Building contributors is estimated to be 8 to $15 \mathrm{~L} / \mathrm{min}$ ( 2 to $4 \mathrm{gal} / \mathrm{min}$ ).

\section{1-z Building. First Level}

Wastewater contributors from the first level of the 231-Z Building consist of ore air conditioner and one drain riser. The air conditioner discharges to an open drain but will be changed to an enclosed piping configuration. The drain riser has a metal cover that can be locked in place. The riser is located in the carpenter's shop and will be removed and plugged in the future. 
231-z Building, Second Level

The second level contains all of the HVAC systems for the 231- 2 Building except for the inactive supply fan on the first level. There are six drains to remove steam condensate from the ventilation, five steam traps, and three Pacific Northwest Laboratory vacuum pumps that discharge seal water. The vacuum pumps provide the only possible route for radiological contamination to enter the crib. These pumps will be replaced with a closed-loop cooling system under Project C-116 (to be completed in August 1998). 
WHC-EP-0674

APPENDIX B

GROUNDWATER DATA

$B-i$ 
WHC-EP-0674

This page intentionally left blank.

$B-i j$ 


\section{GROUNDWATER MONIT'JRING DATA}

Analytical results for the two groundwater monitoring wells (2-W18-17 and 2-W18-20) and one perched water monitoring well (2-W18-29) are 1 isted by well and sampling date on pages $B-3$ through $B-60$. The time period covered is from July 1990 through August 10, 1993, and includes all groundwater analytical results for the $216-2-20$ Crib since the last reported results that were included in the Liquid, Effluent Study Final Project Report: Groundwater Characterization Data.

\section{Qualifiers}

Qualifiers concerning the data are indicated with a letter code in the fifth column defined as follows:

B - Blank associated with analyte is elevated

D - Sample was diluted before analysis

E - Concentration is out of instrument calibration range

$J$ - Concentration is estimated

$U$ - Analyte concentration is below contract required quantification limit

$H$ - Laboratory holding time exceeded

$R$ - Suspect data; currently under review

Q - Result associated with suspect quality control data

P - Potential problem.

It should also be noted that not all of the data in the listing were reviewed at the time this report was prepared. Thus some unflagged "suspect" data may exist in the listing.

\section{Significant Figures}

No more than three significant figures are justified; any additional places are format related.

'WHC, 1990, Liquid Effluent Study Final Project Report: Groundwater Characterization Data, WHC-EP-0366, Westinghouse Hanford Company, Richland, Washington. 


\section{Sampling Depths}

Results for well 2-W18-20 include three different sampling depths described as follows: (1) data listed for 1991 are for samples collected at an intermediate depth $(6 \mathrm{~m}[20 \mathrm{ft}]$ below static water leve1), (2) results for March 3, 1993 are for samples drawn approximately $0.3 \mathrm{~m}(1 \mathrm{ft})$ from the bottom of the well using a single packer assembly, and (3) data listed for the April 12, 1993 sampling date represent a collection depth of approximately 0 to $3 \mathrm{~m}(0$ to $10 \mathrm{ft})$ below static water level. All other data 1 isted are based on a sampling depth interval of 0 to $3 \mathrm{~m}(0$ to $10 \mathrm{ft})$.

\section{Natural Background Reference Levels}

A summary of provisional background concentrations for naturally occurring constituents is provided on pages B-61 through B-63. Naturally occurring constituent (monitoring) results listed on pages B-3 through B-60 can be compared with either the average natural background concentrations or with the provisional threshold values (column 5, pages B-61 through B-63). The latter represent the upper range of naturaliy occurring concentrations that are considered likely to occur at the Hanford Site based on currently avallable data. A major sampling effort is underway to better define both soll and groundwater natural background for the Hanford Site. 


\section{WHC-EP-0674}

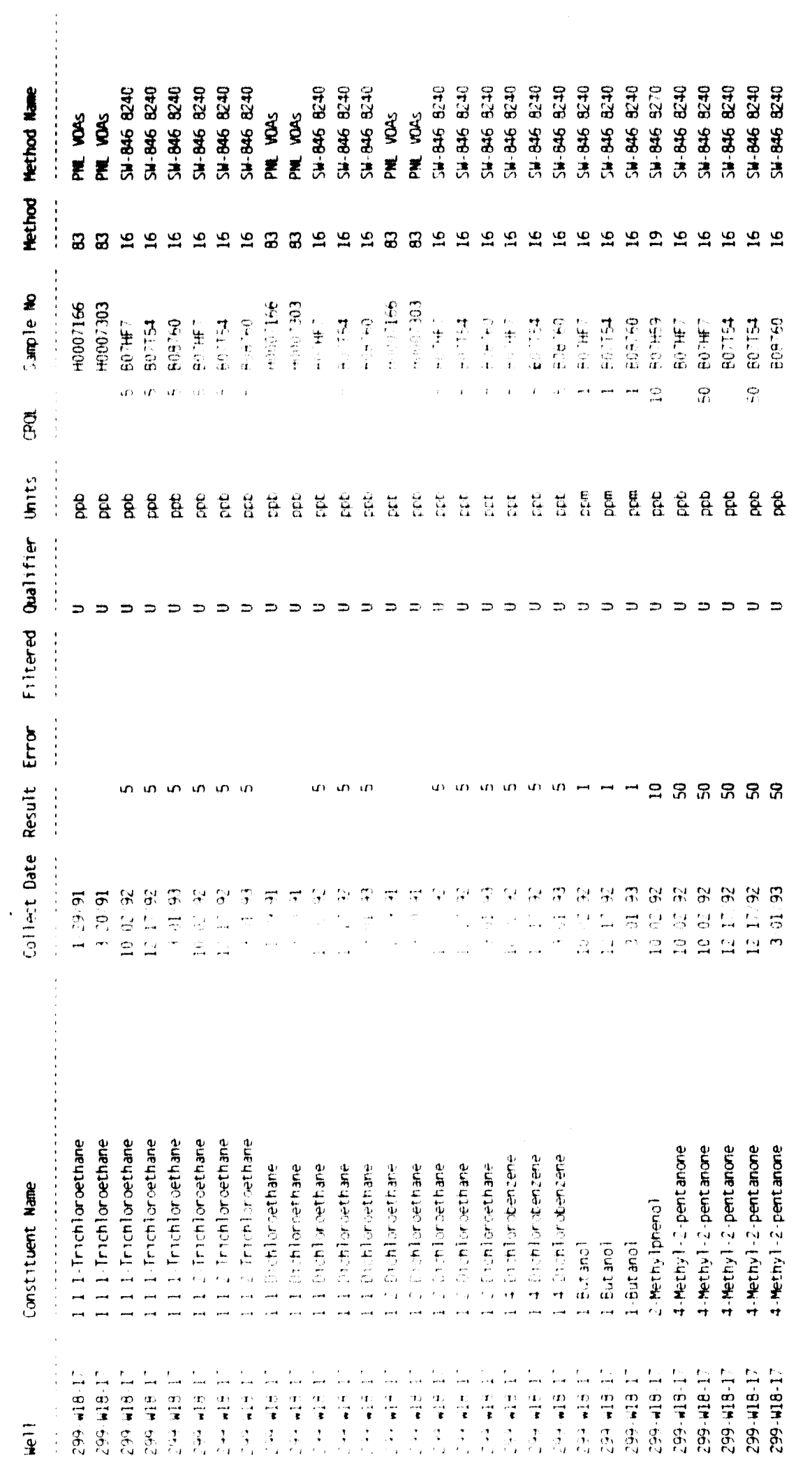




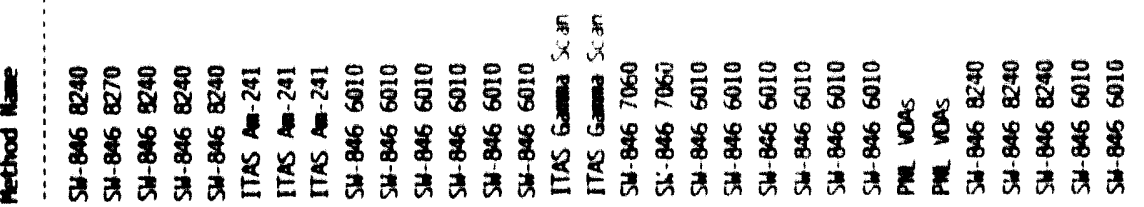
焉

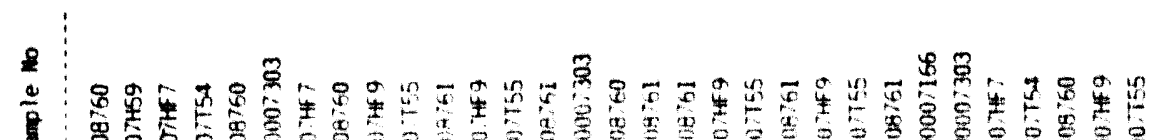

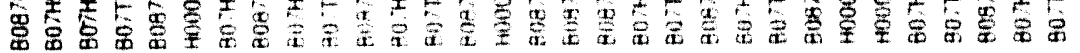

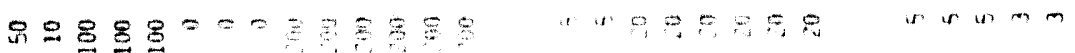
항

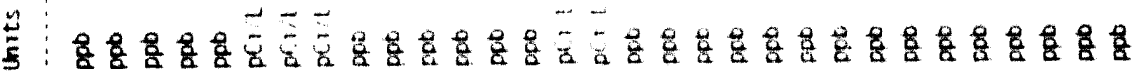
\begin{tabular}{l}
5 \\
$\frac{5}{3}$ \\
8 \\
5 \\
\hline 5
\end{tabular}

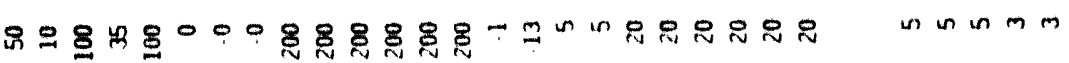
范

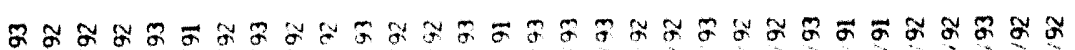

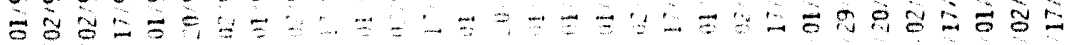
mo의.

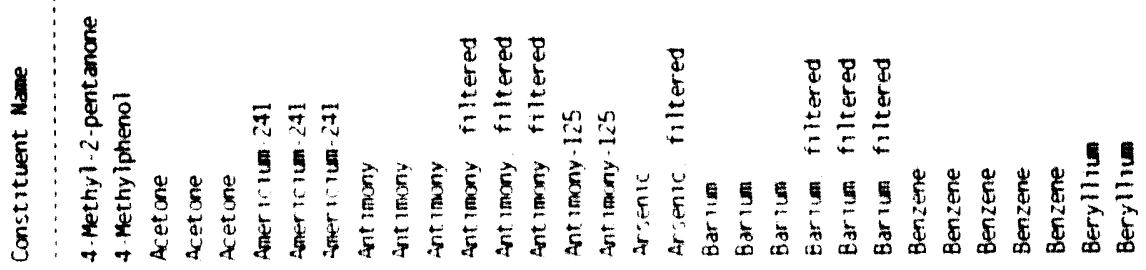

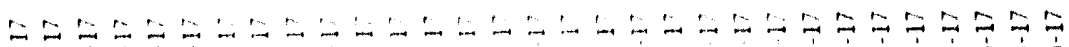

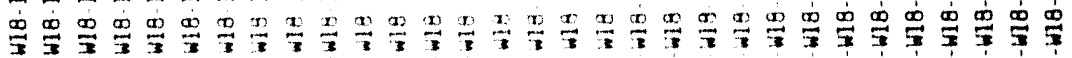

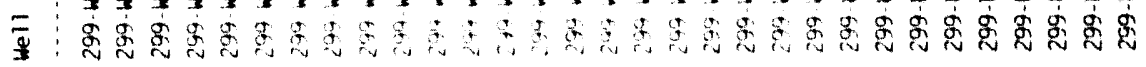




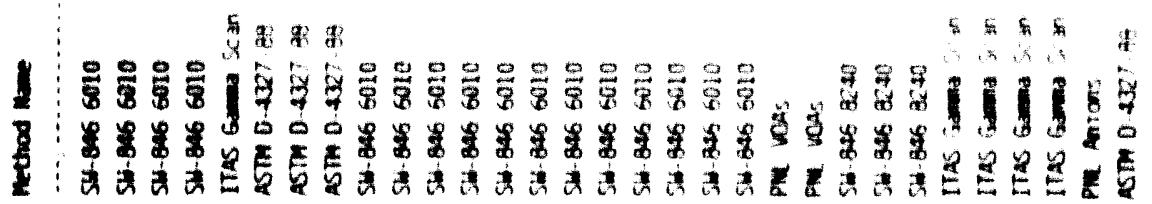

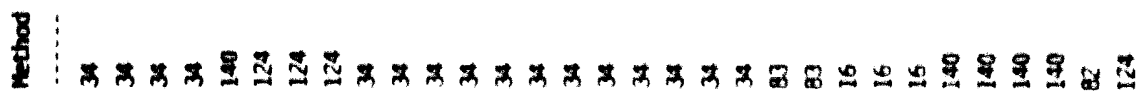

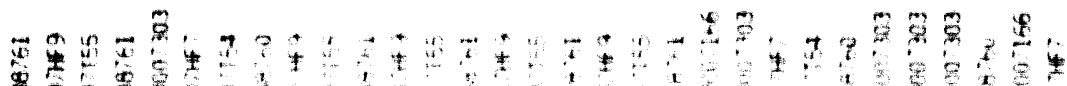

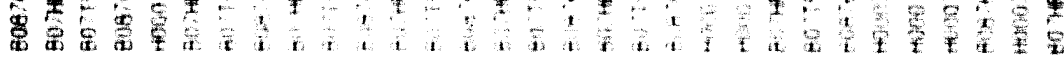

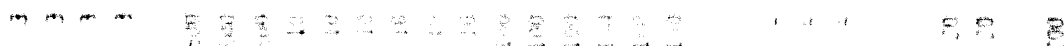
$\tilde{E}$

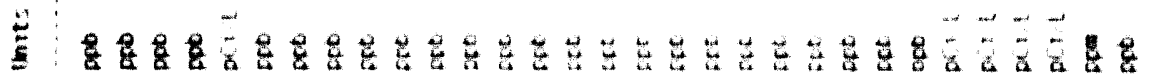

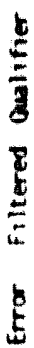

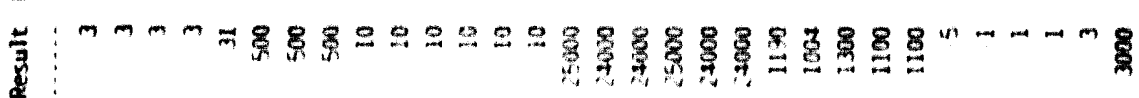

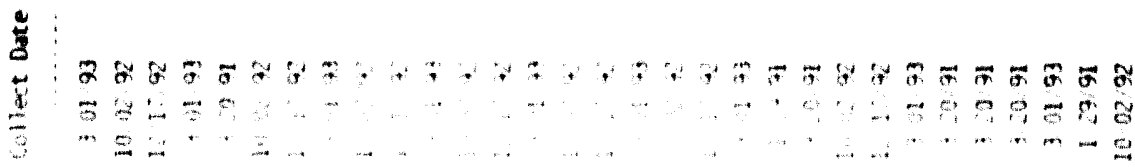

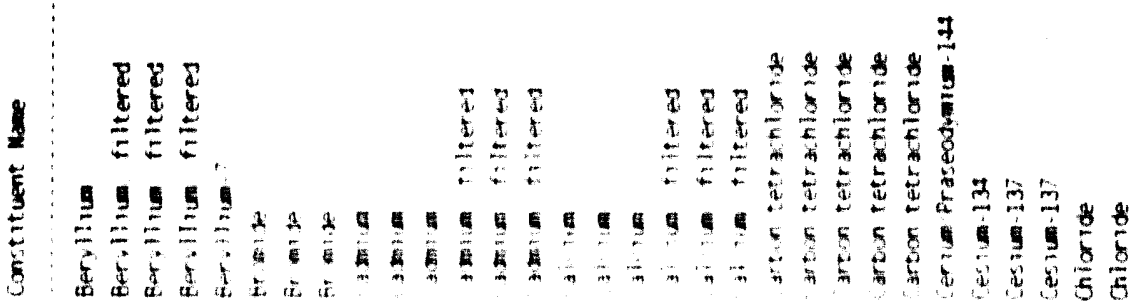

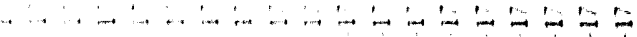

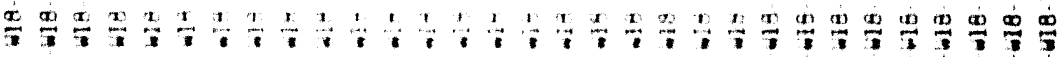

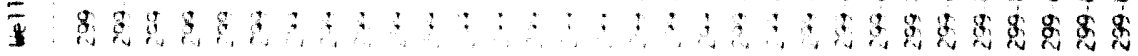




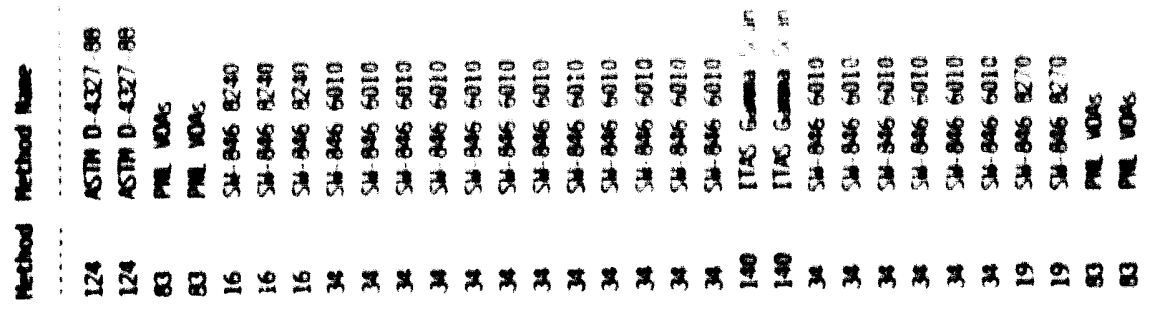

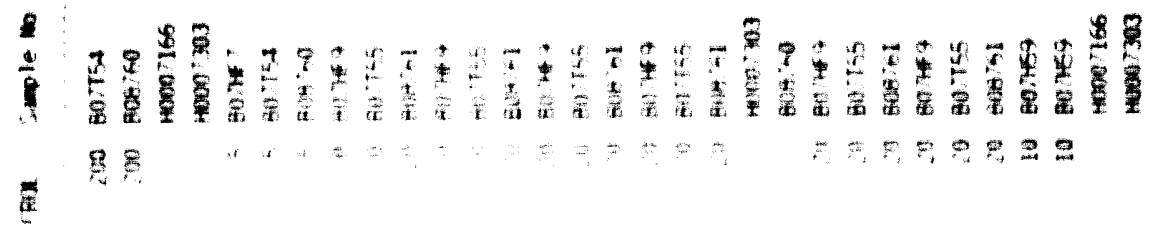

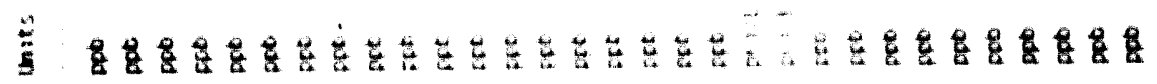
$\stackrel{5}{\mathbf{z}}$

点

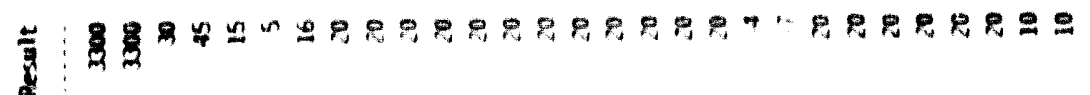
$\mathbf{g}$

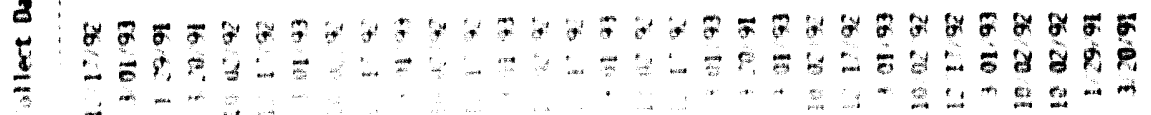

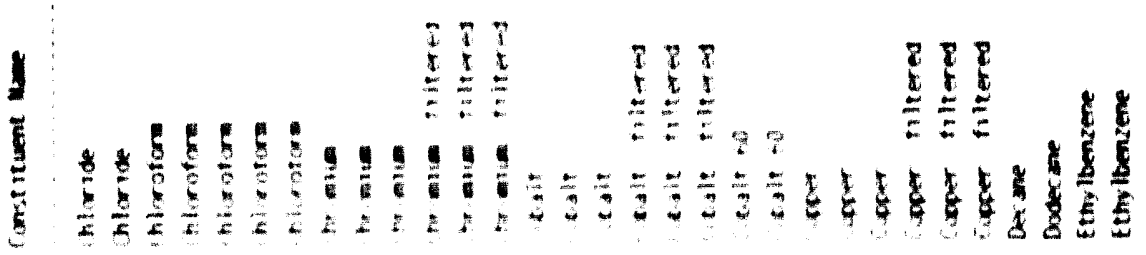

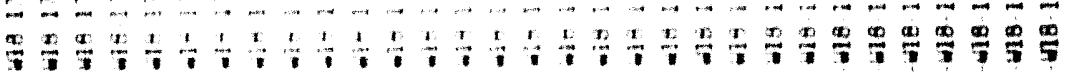

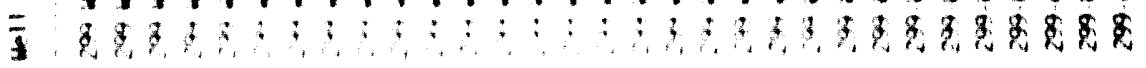




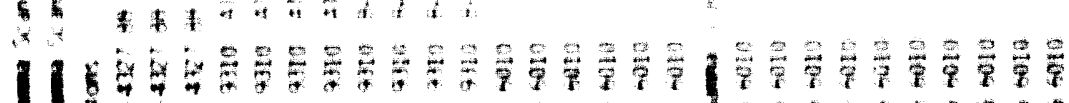

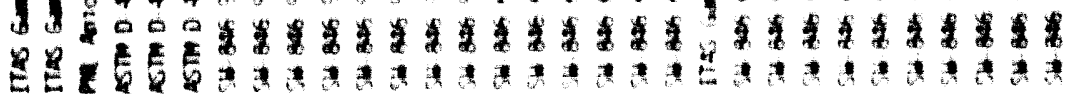

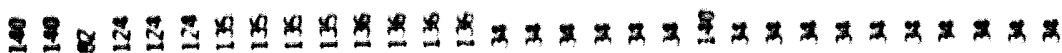

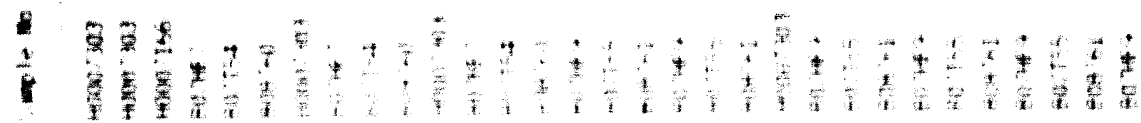
*

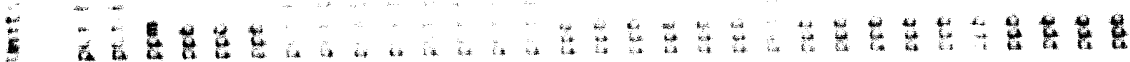

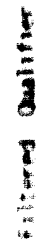

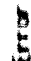

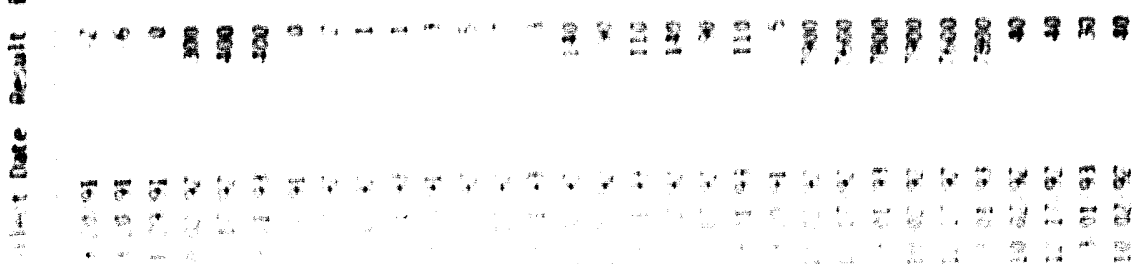

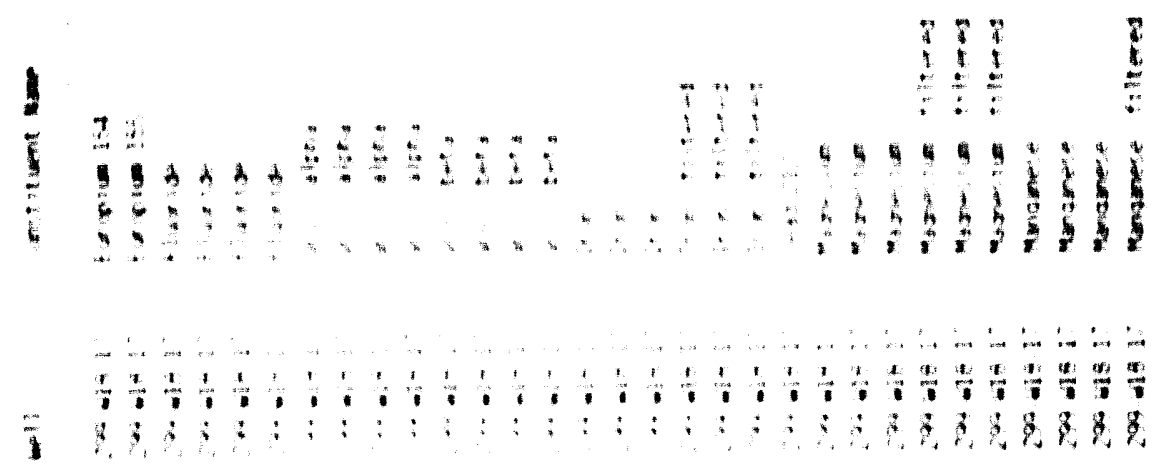




\section{$+1+1+1$}

表草 1

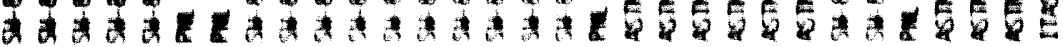

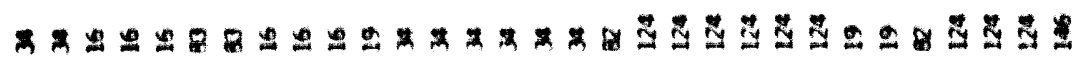

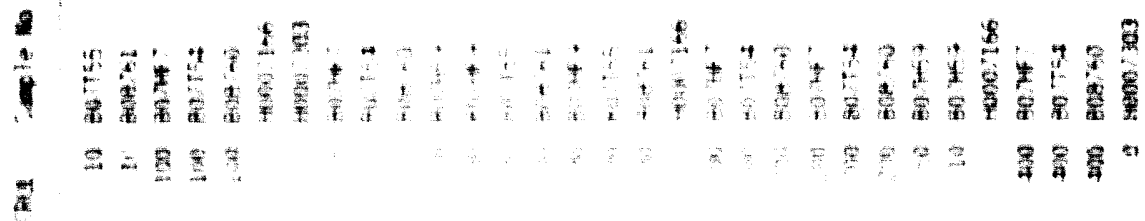

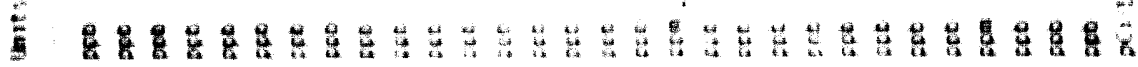

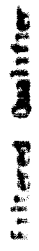
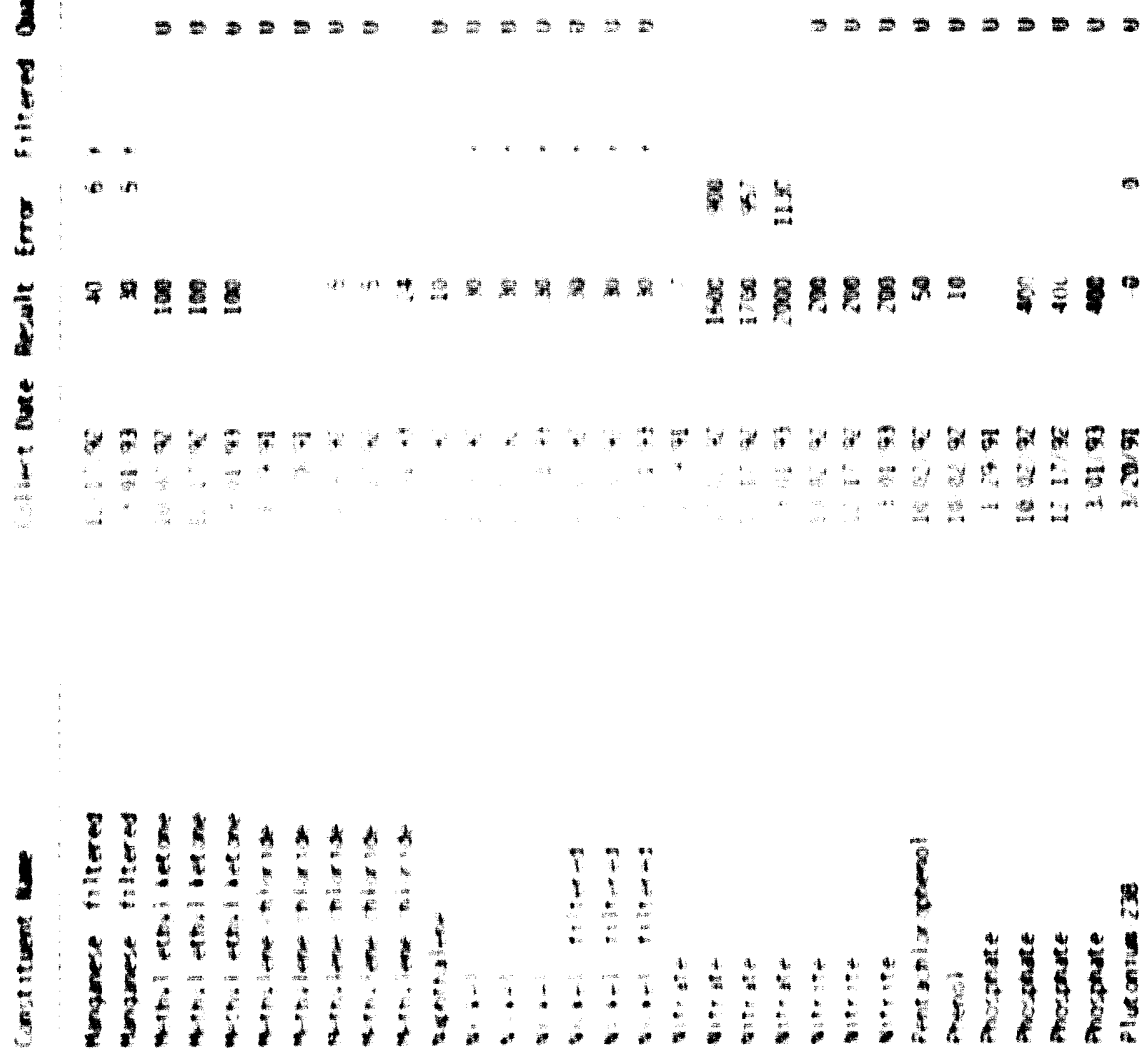

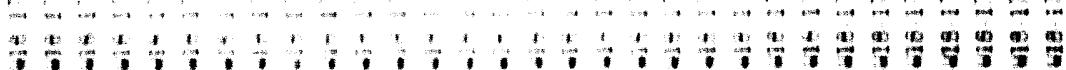

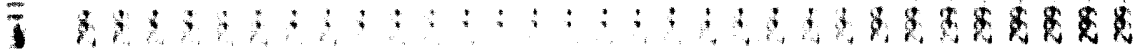




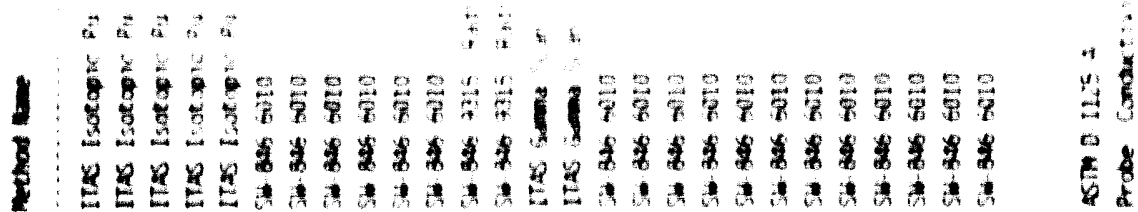

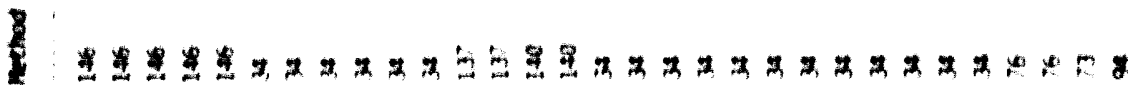

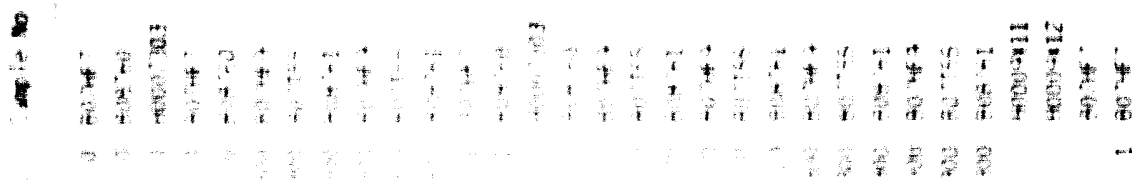
7

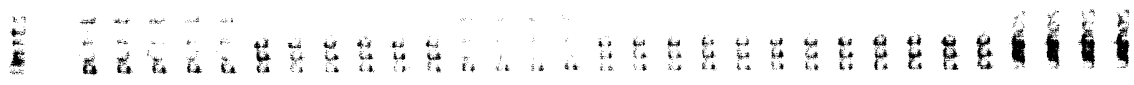

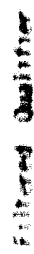

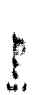

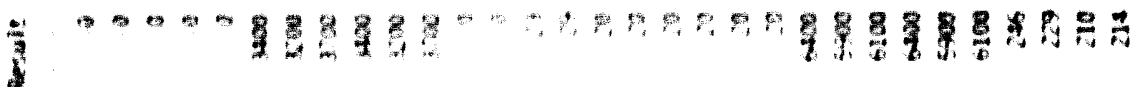

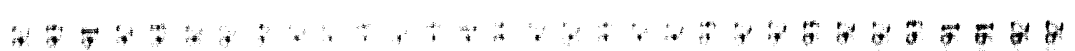

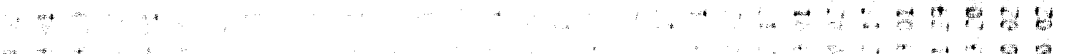

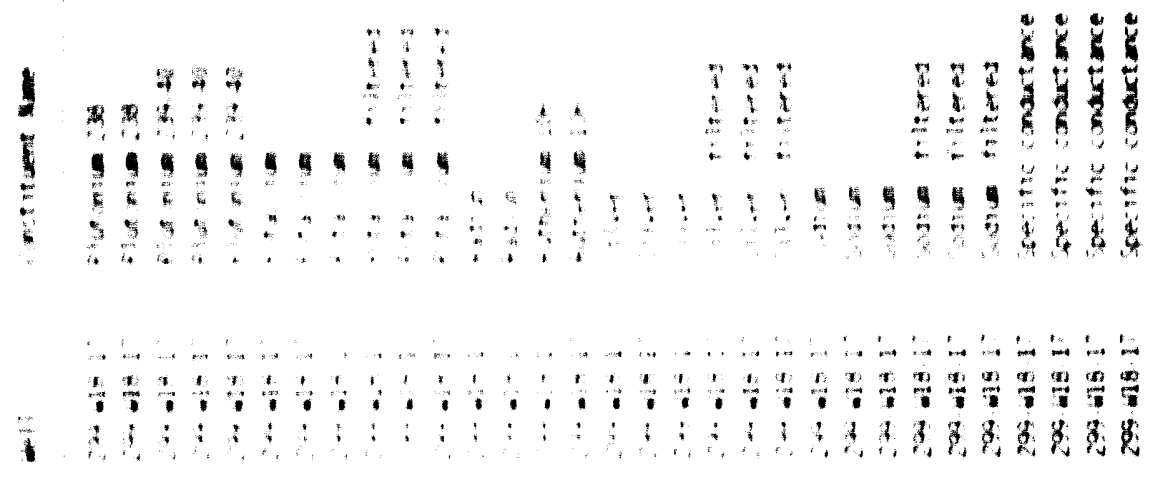



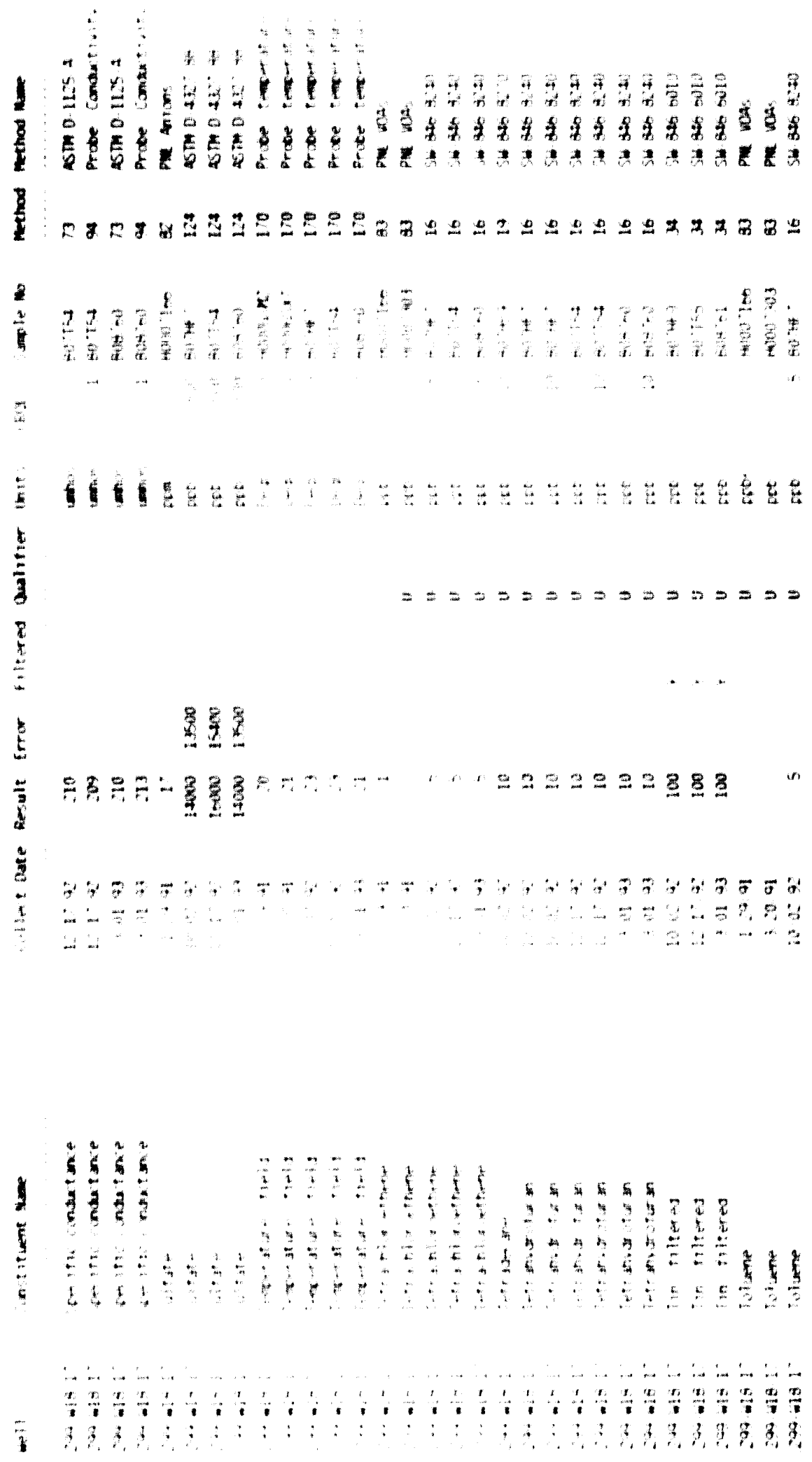


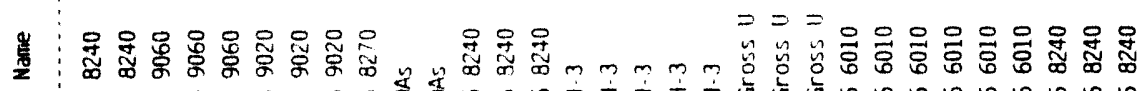

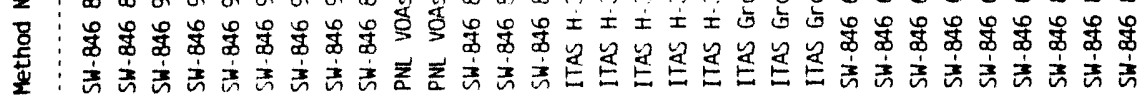

童

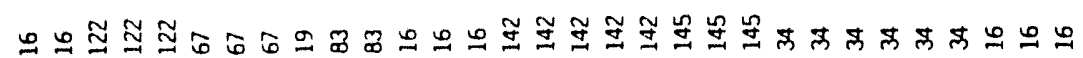

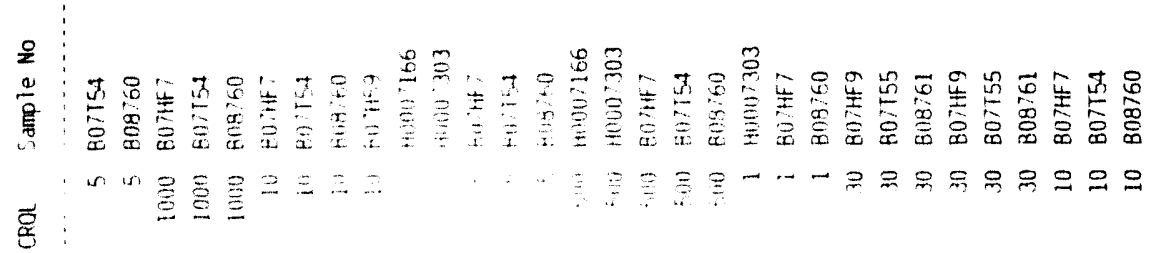

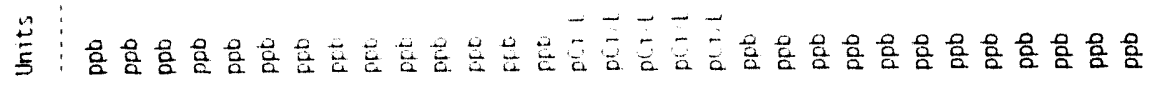

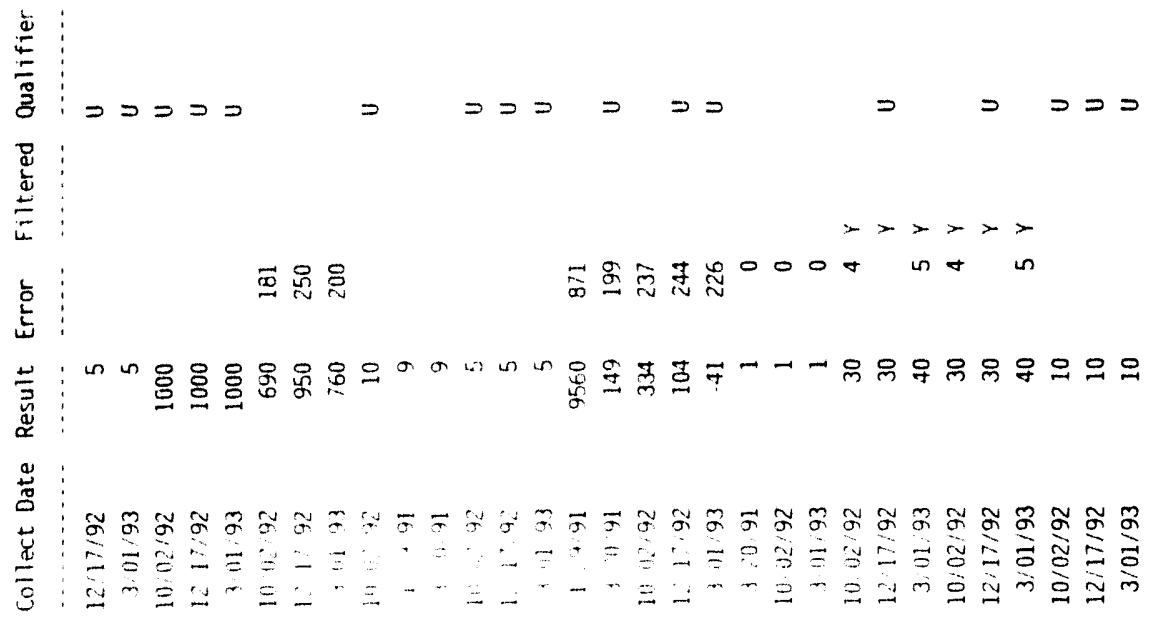

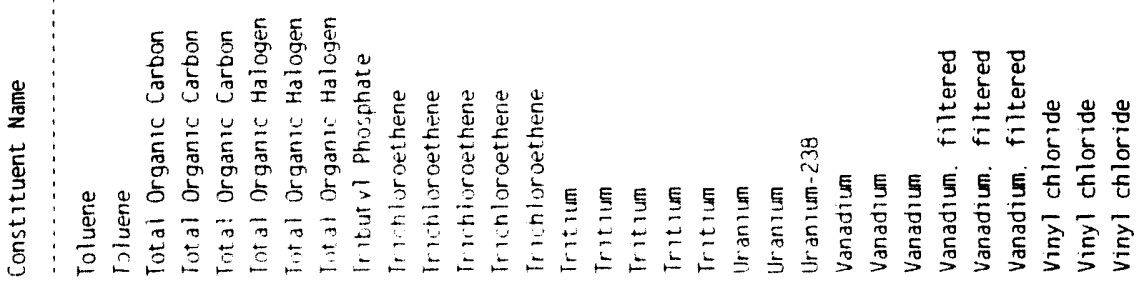

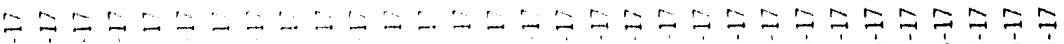

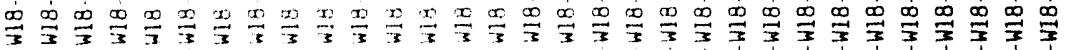

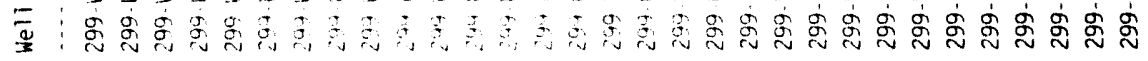




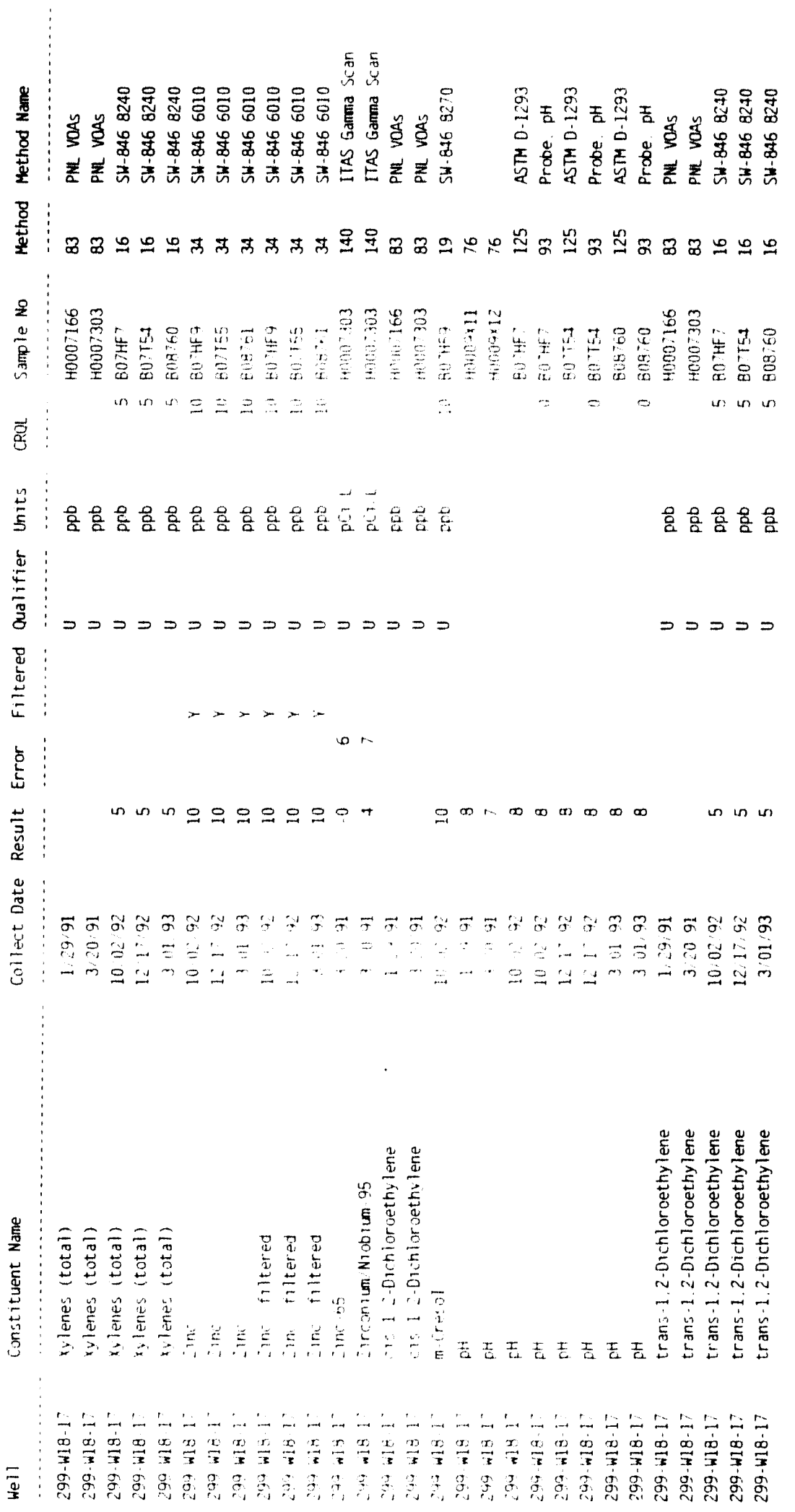




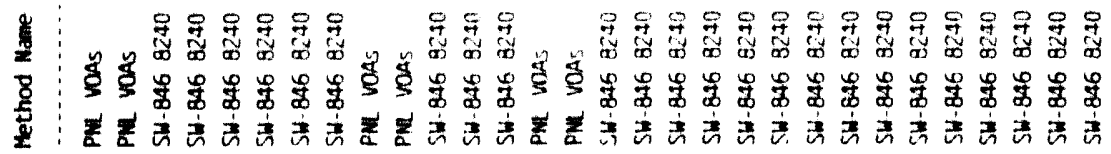

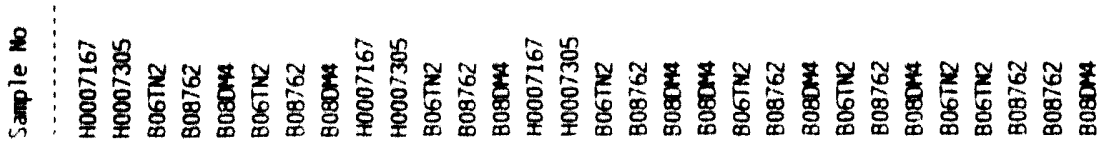

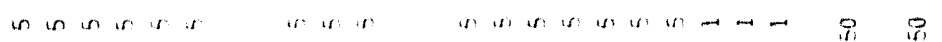

$\overrightarrow{3}$

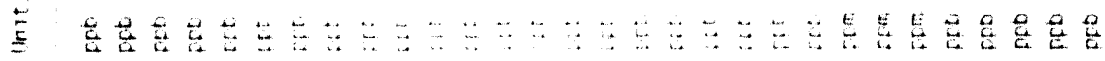

$\frac{\mathfrak{d}}{3}$

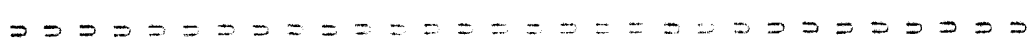

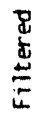

点

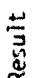

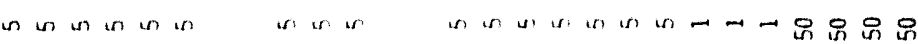

总

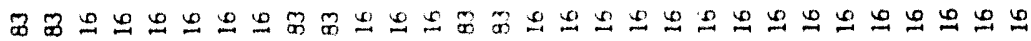

$\stackrel{4}{0}$

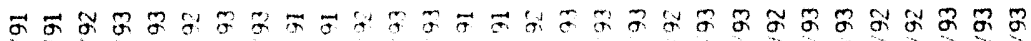

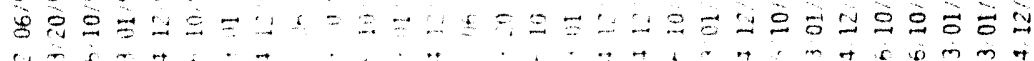

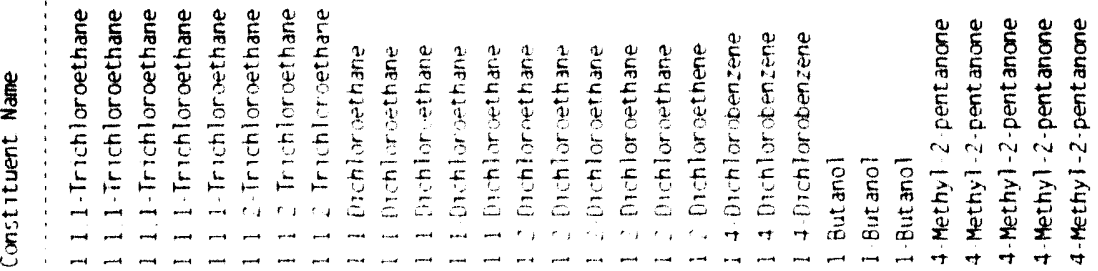

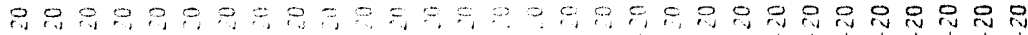

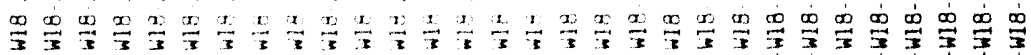

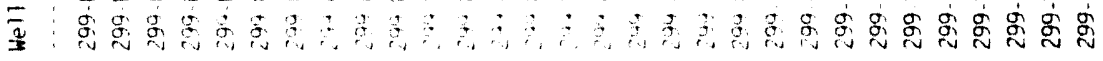




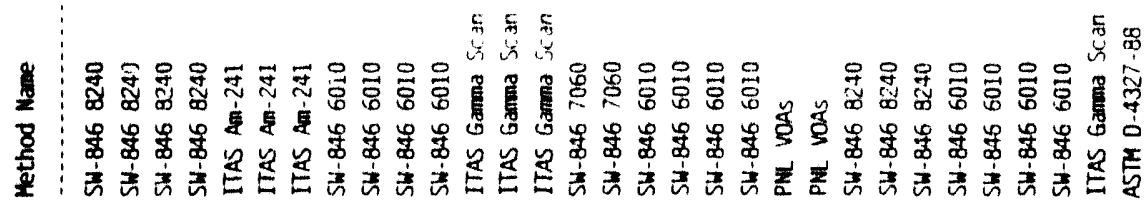

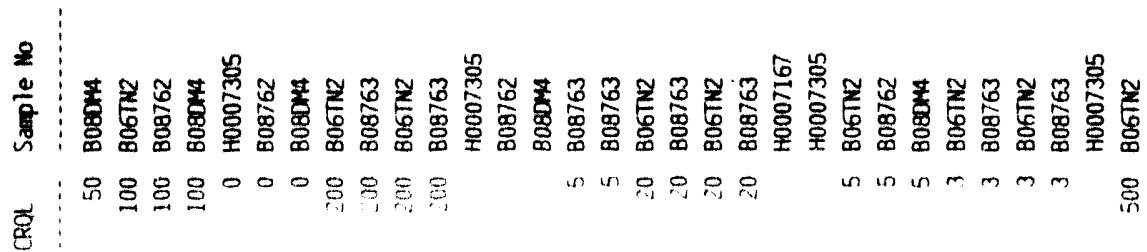

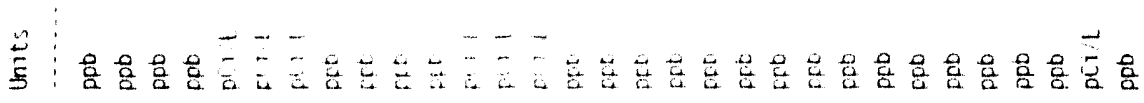

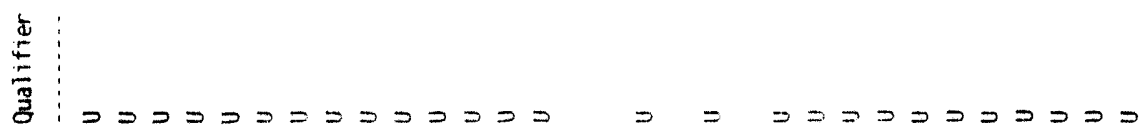

畩

妾

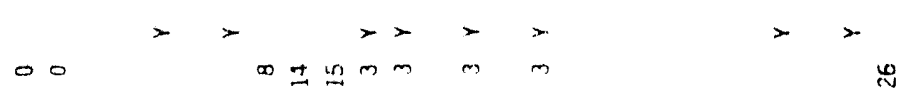

节

总

萮

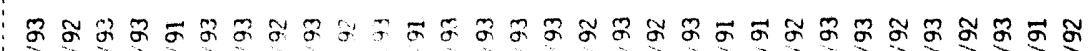

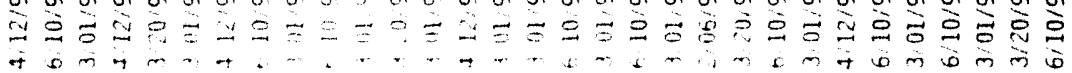

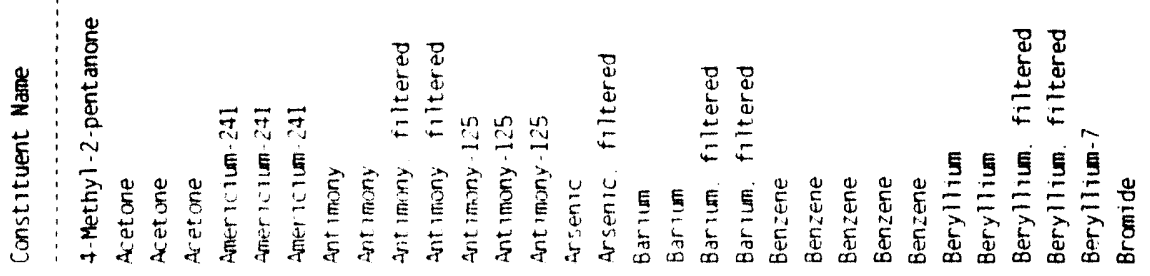

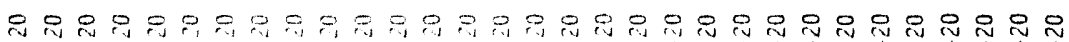

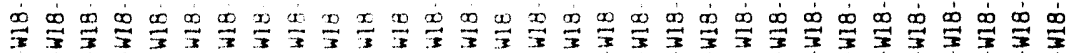

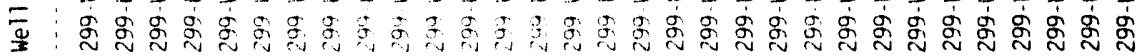




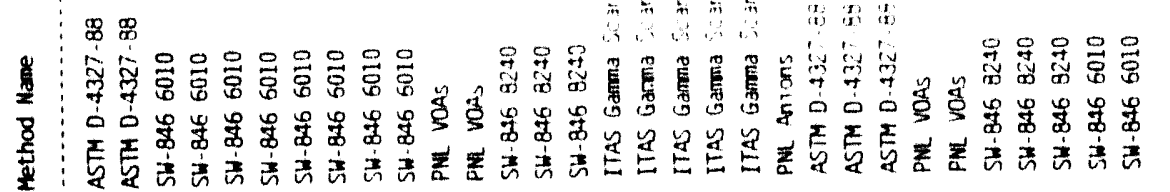

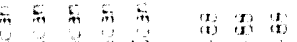

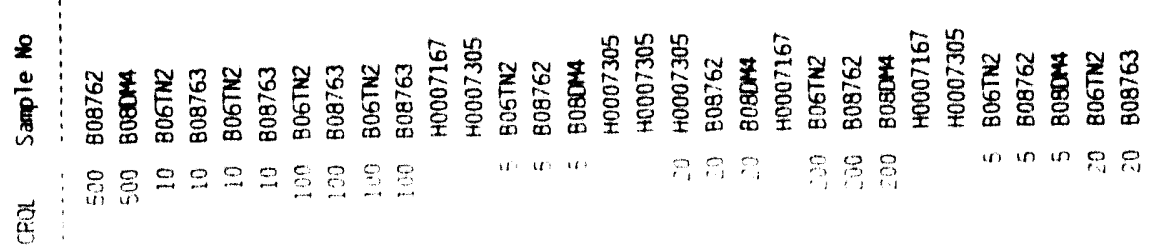

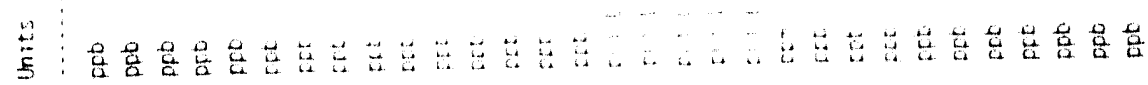

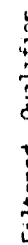

总

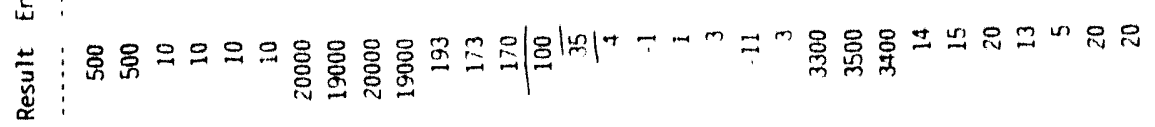
故

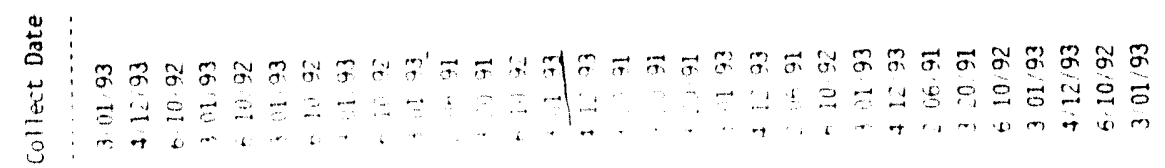

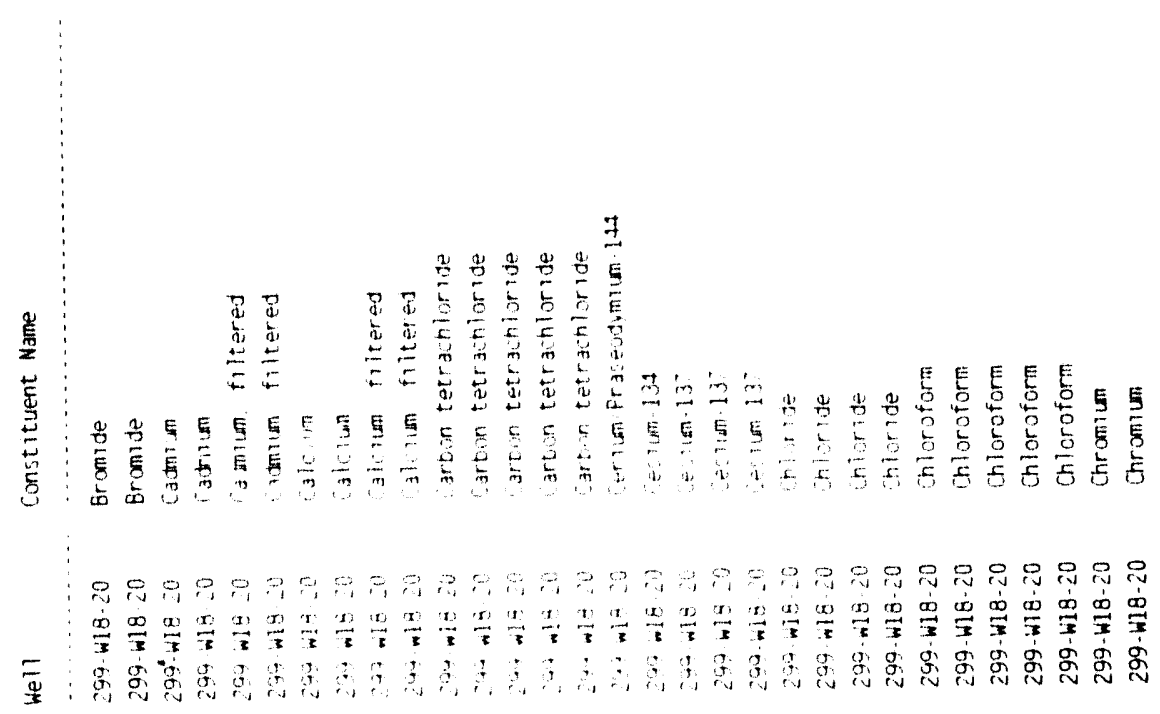


点焉

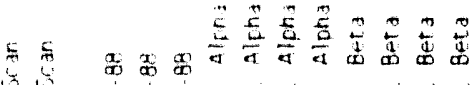
\begin{tabular}{lll}
1 & 0 \\
\hline 0 & 0 & 0 \\
\hline
\end{tabular}

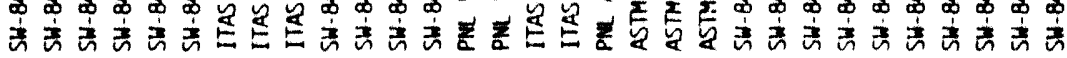

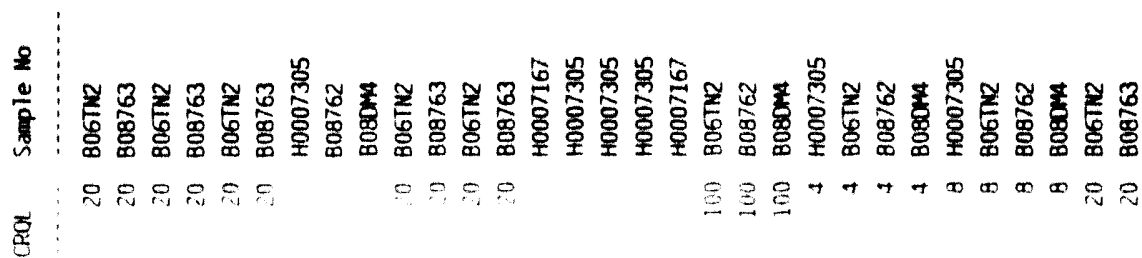

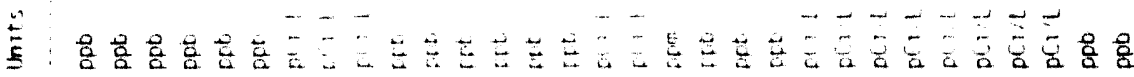

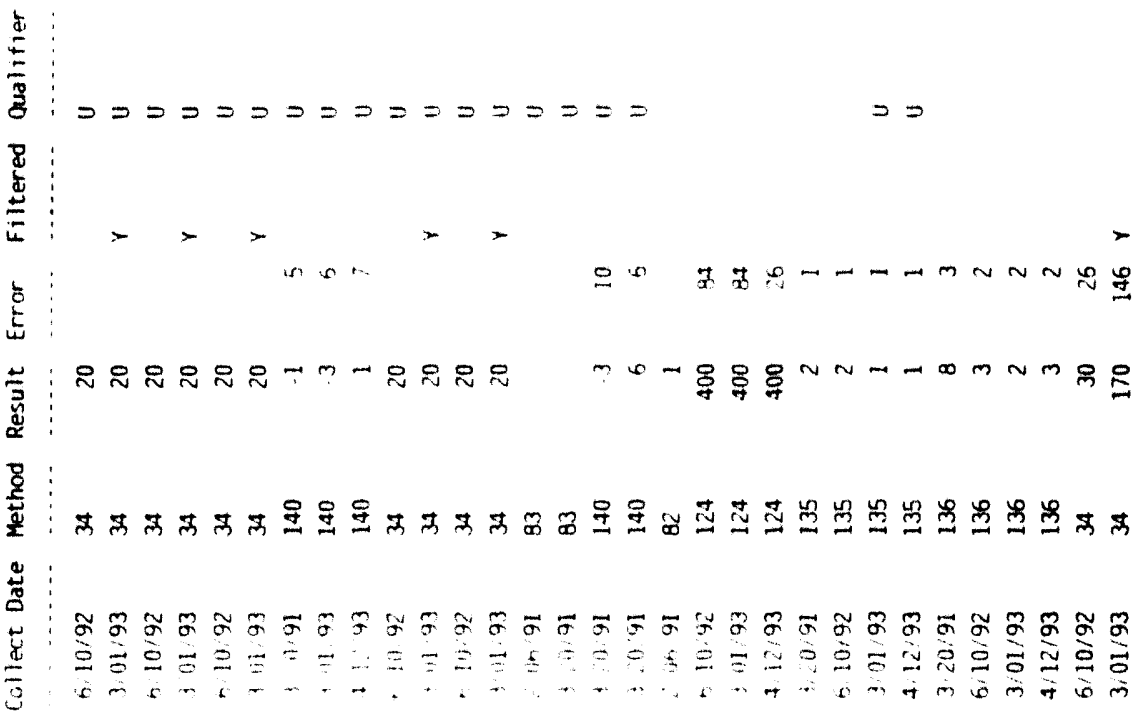

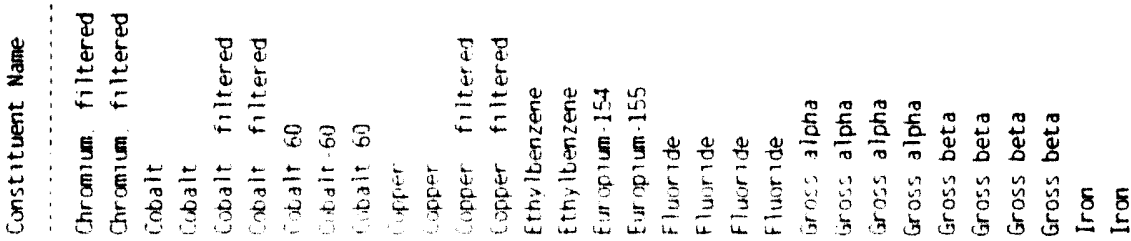

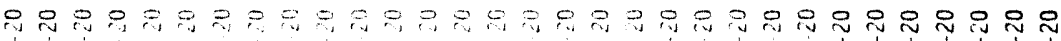

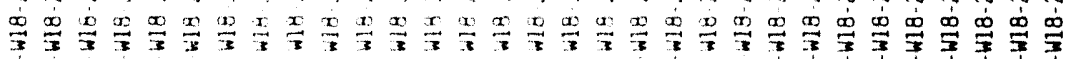

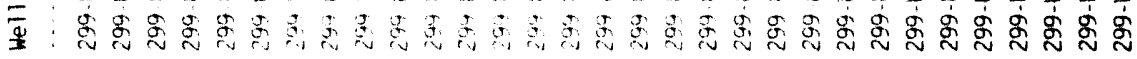




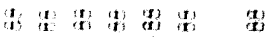

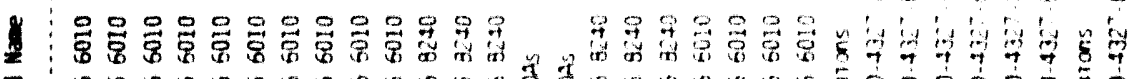

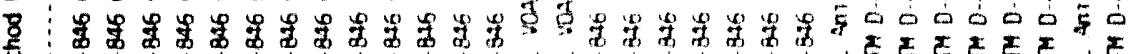

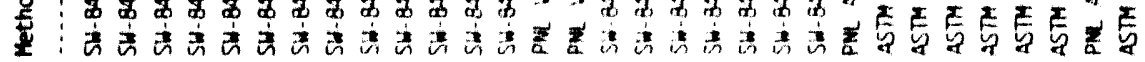

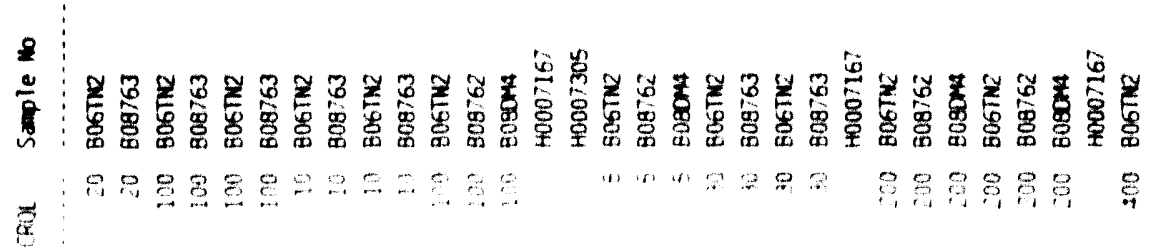

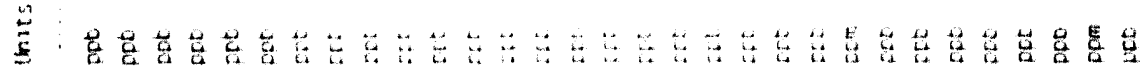

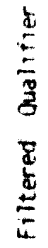

है

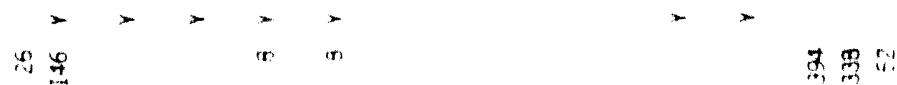

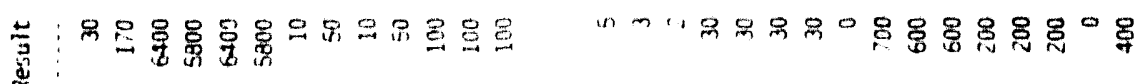

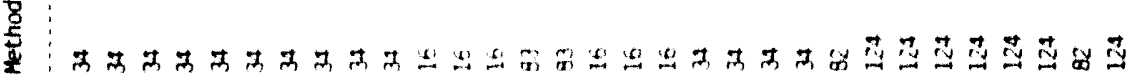

$\stackrel{8}{0}$

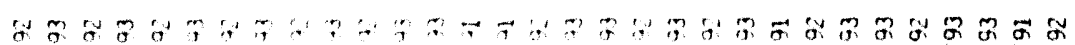

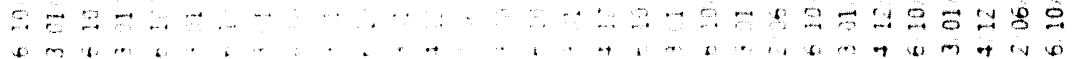

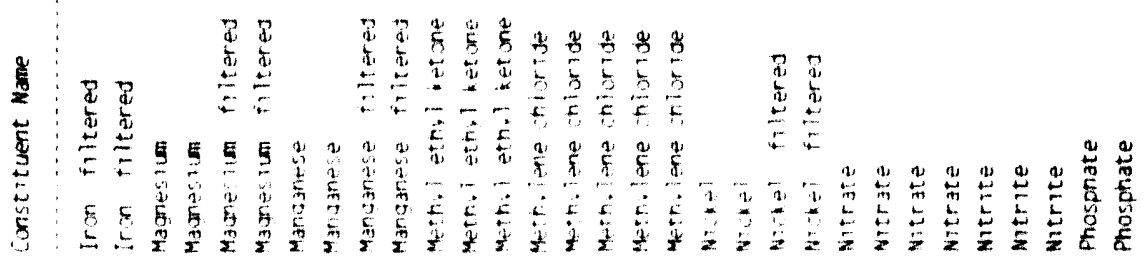

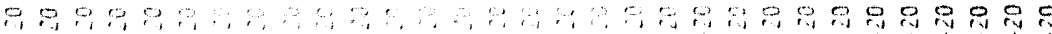

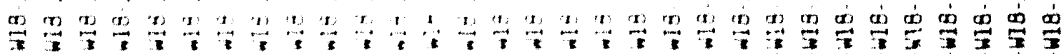

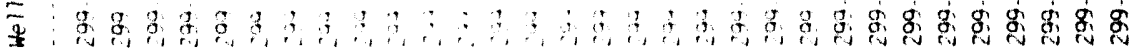




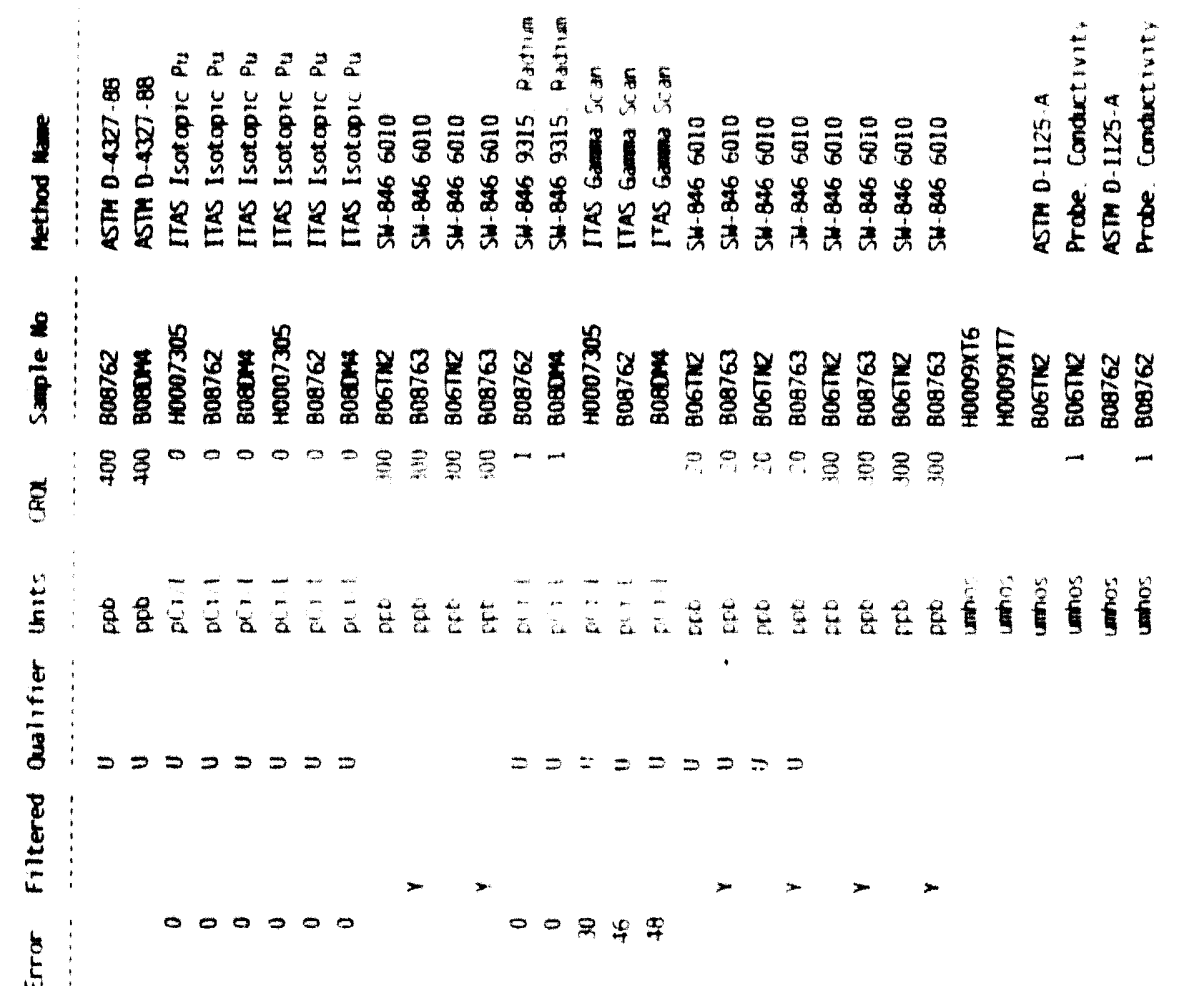

泀

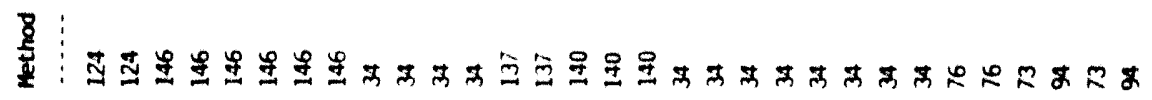

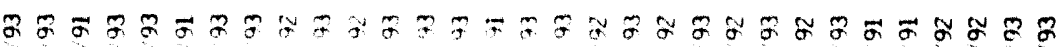

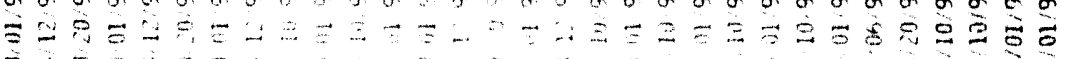

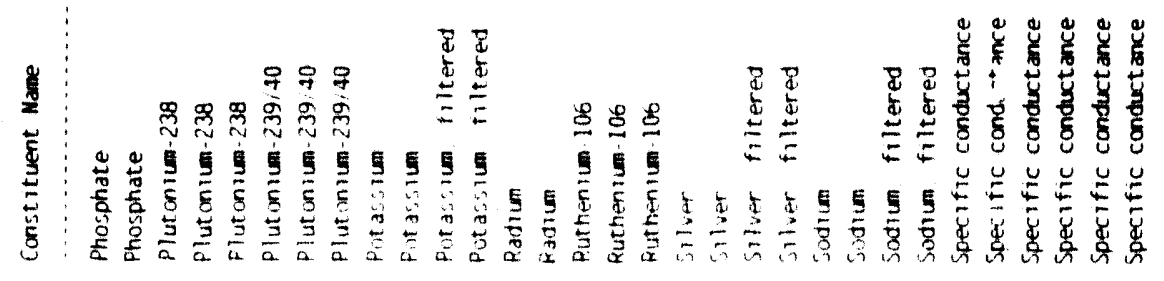

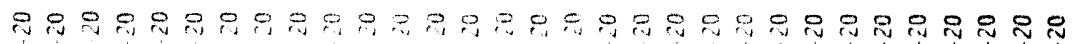

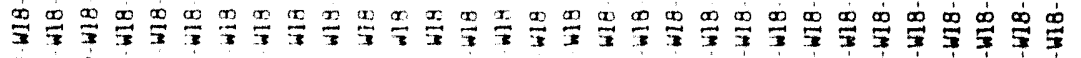

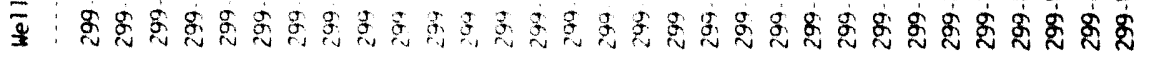




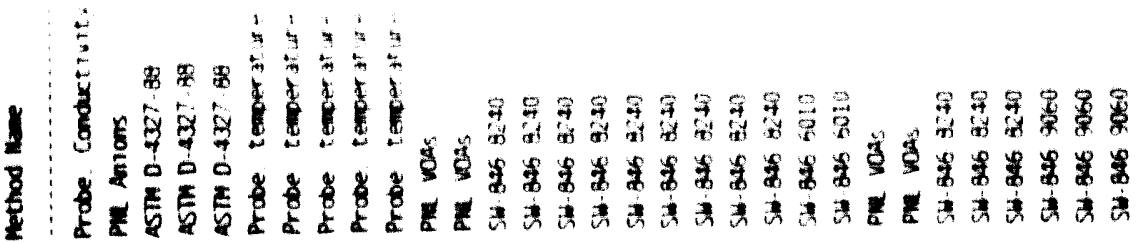

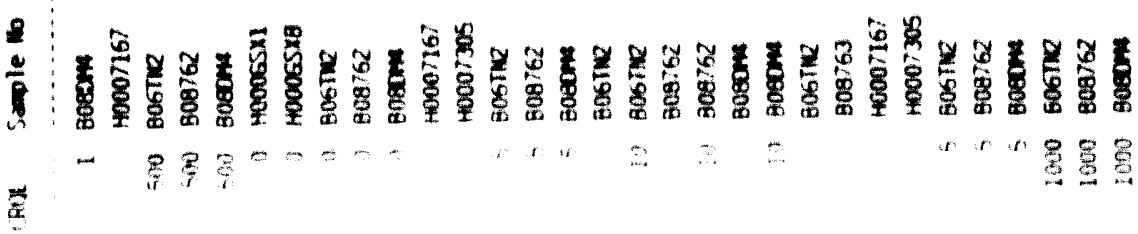

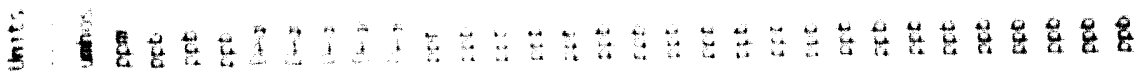

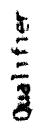

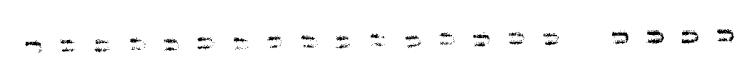

:

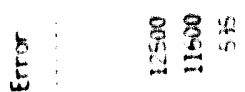

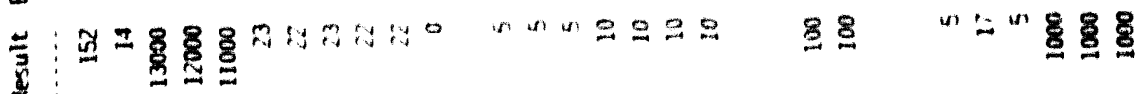

马

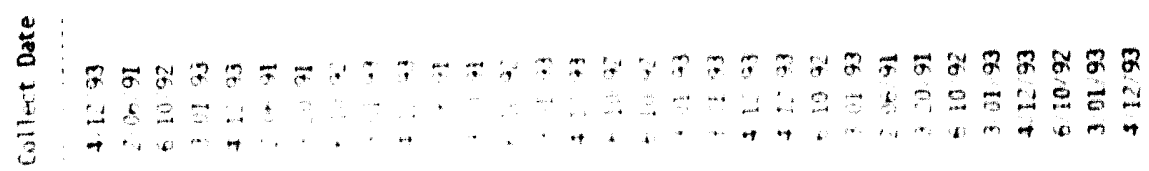

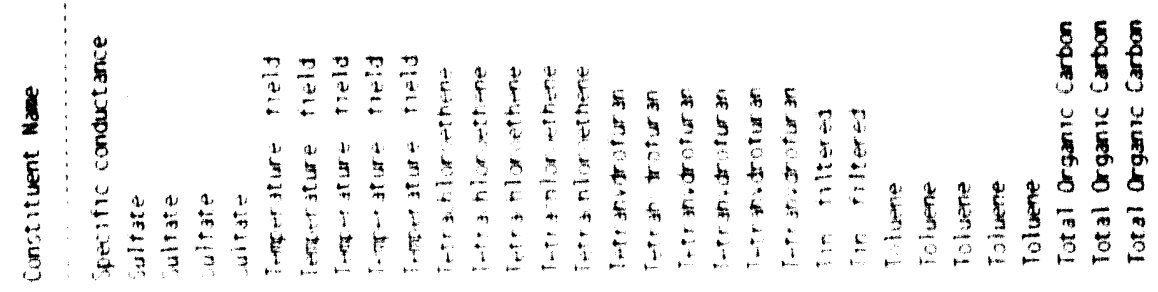

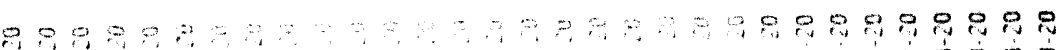

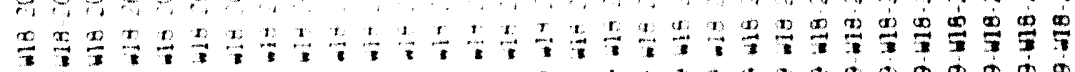

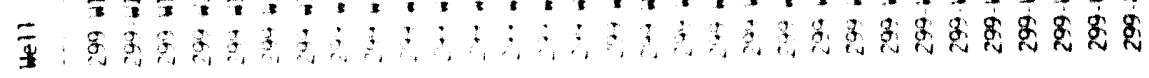



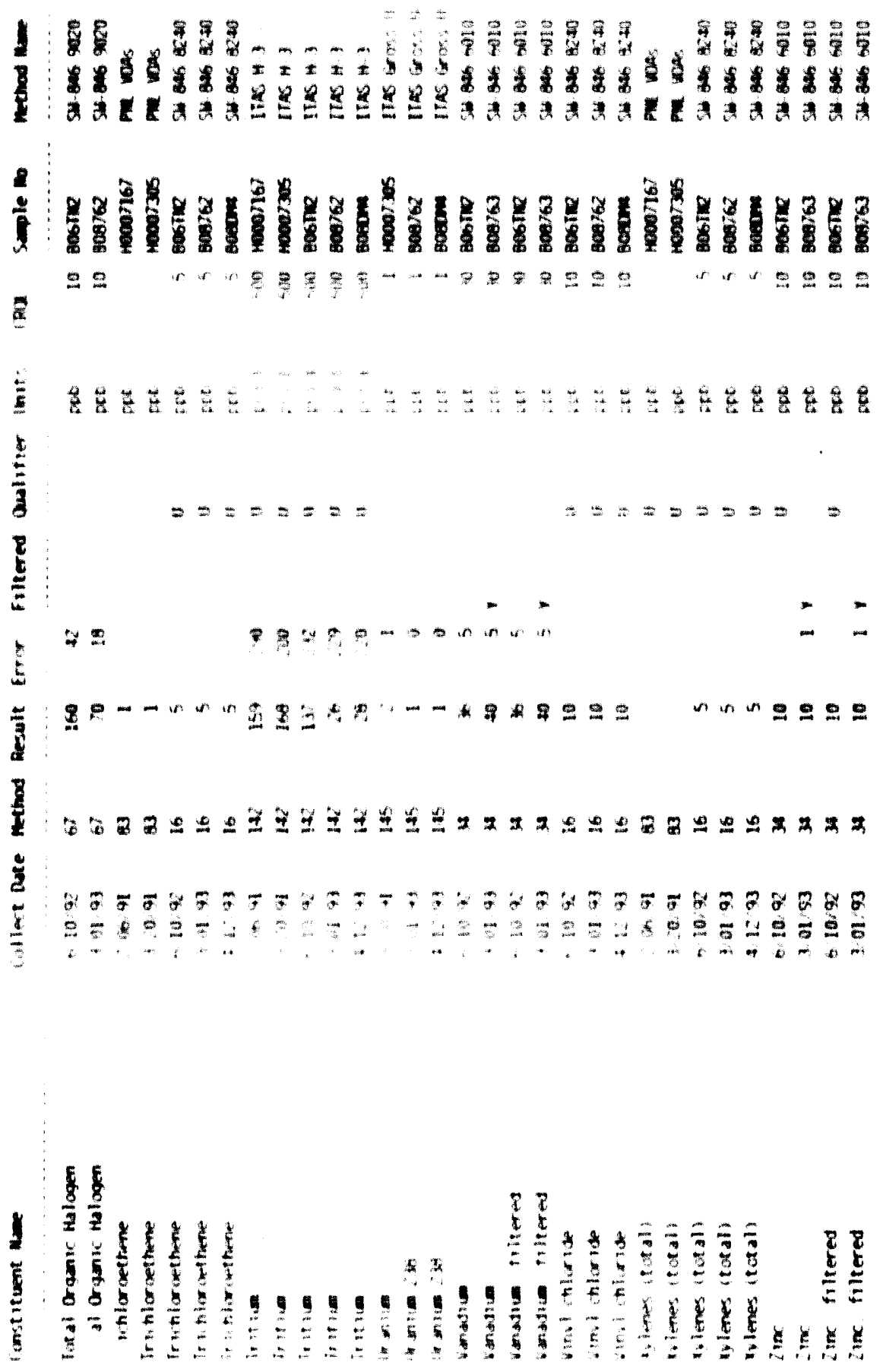

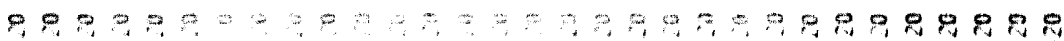

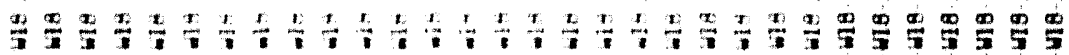

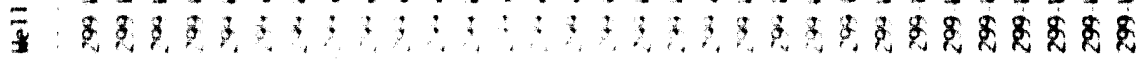



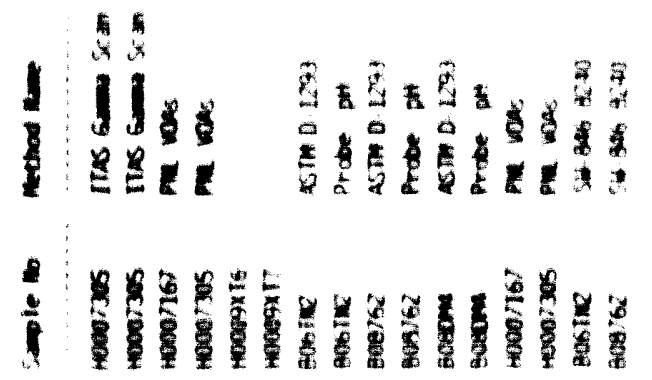

3
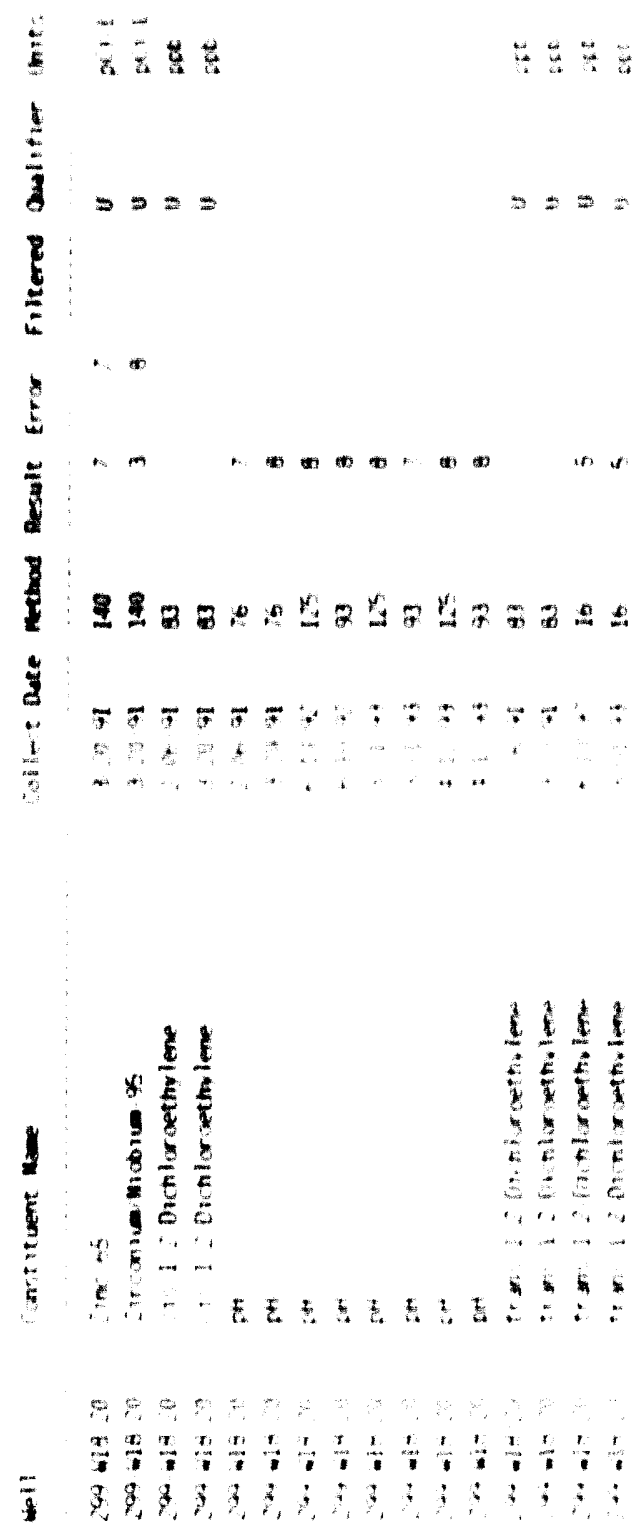

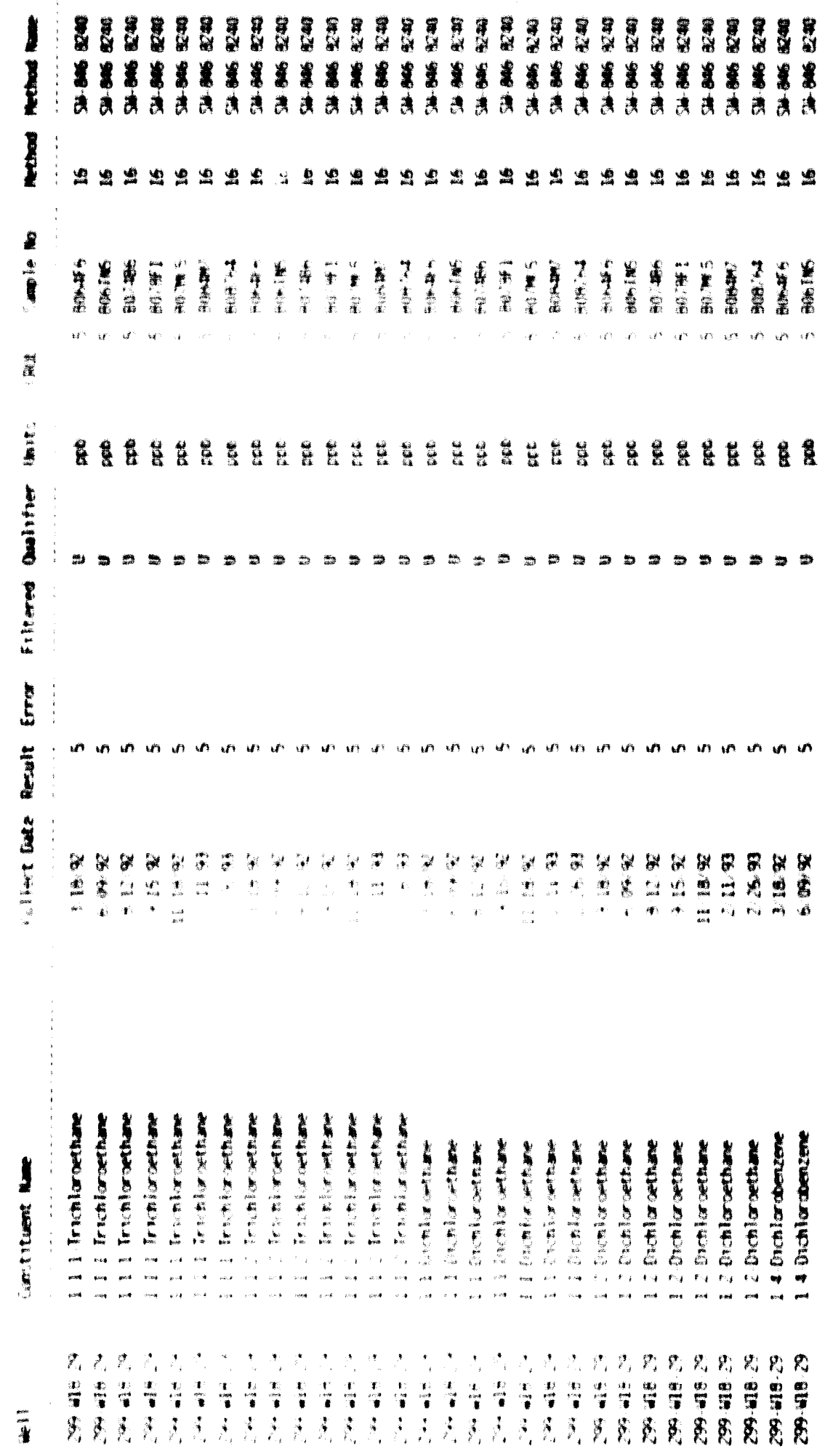


\section{WHC-EP-0674}
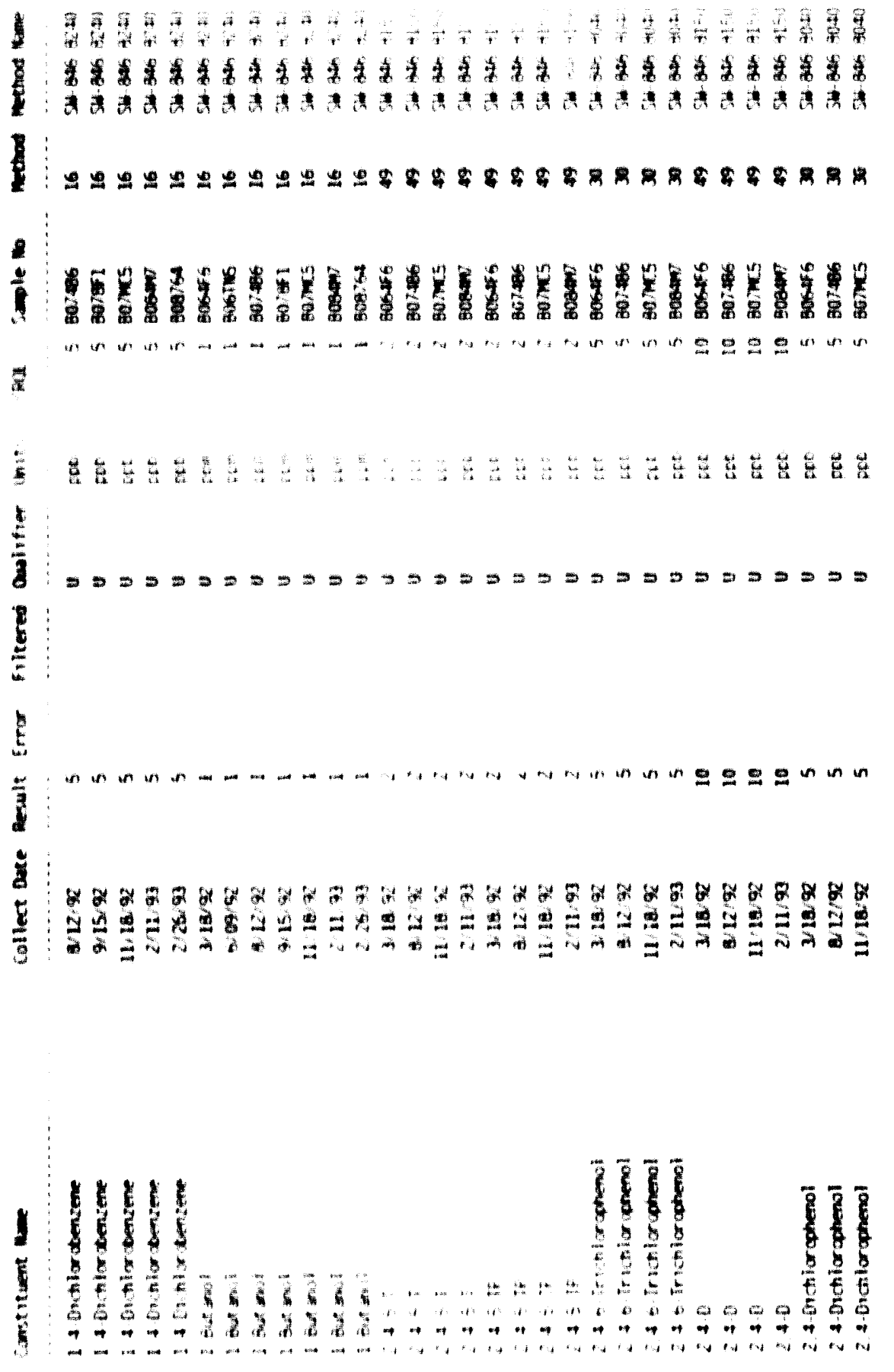

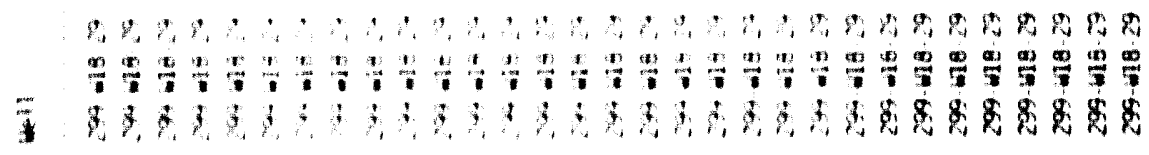



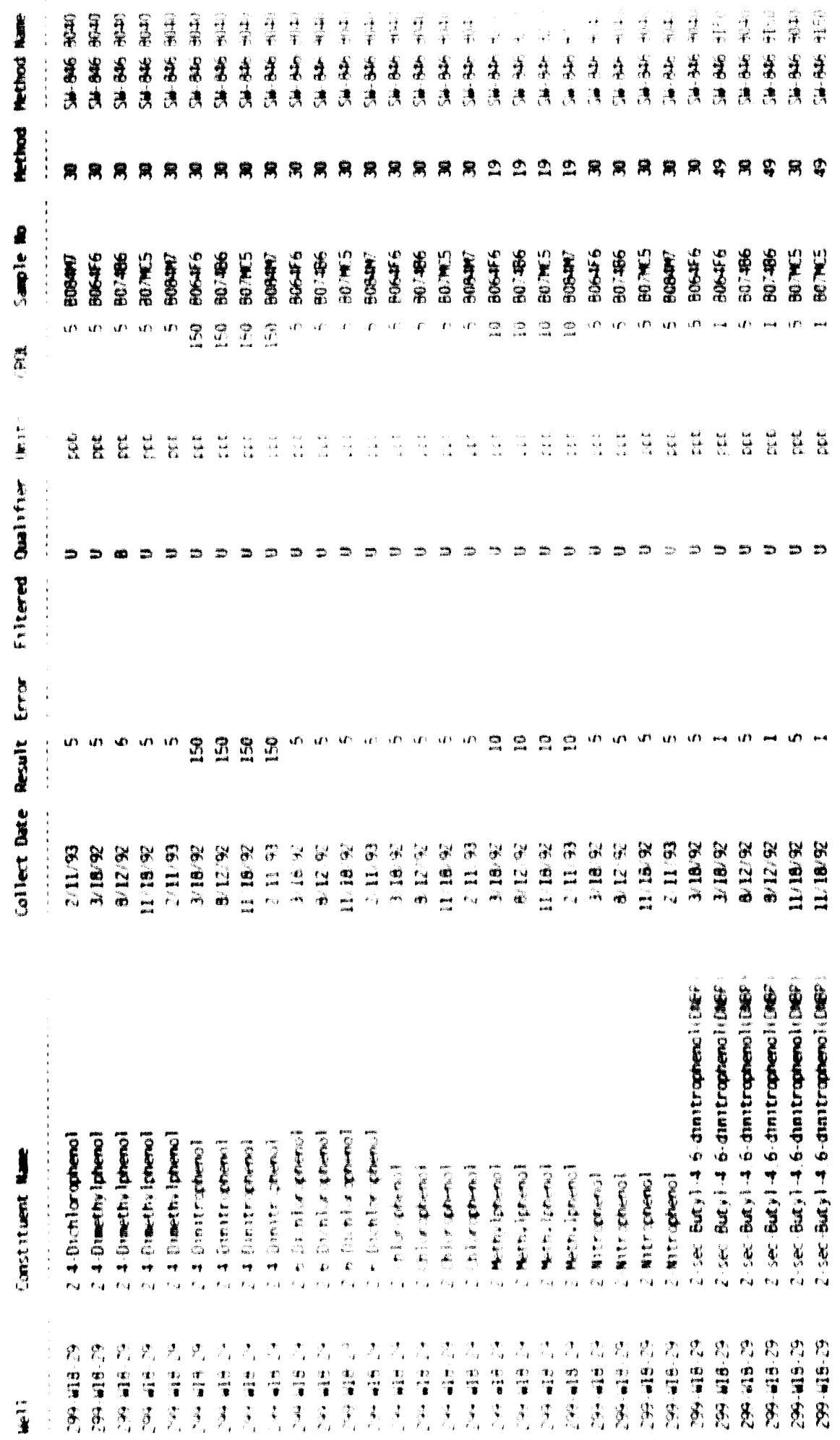


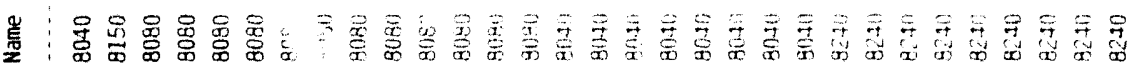

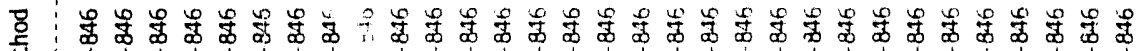

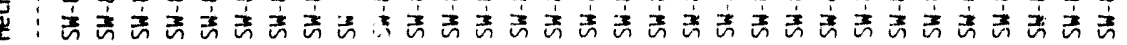

釆

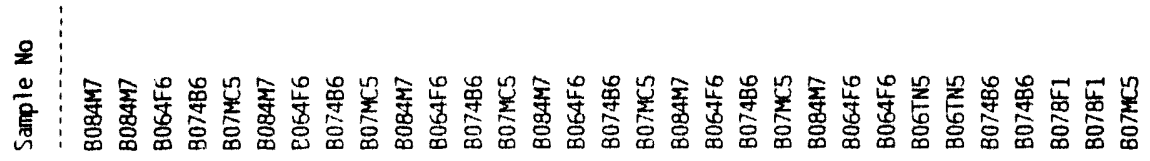
㞓

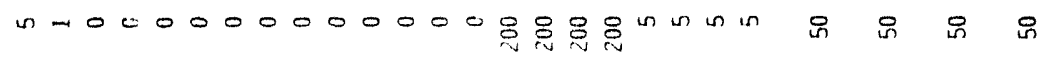

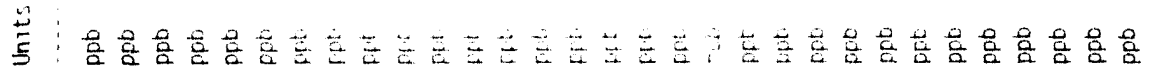

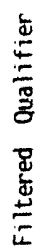

旁:

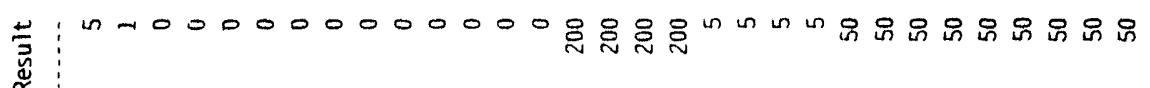

$\stackrel{4}{\text { 苛 }}$

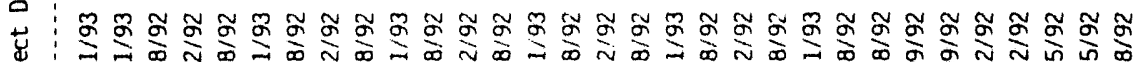
尊

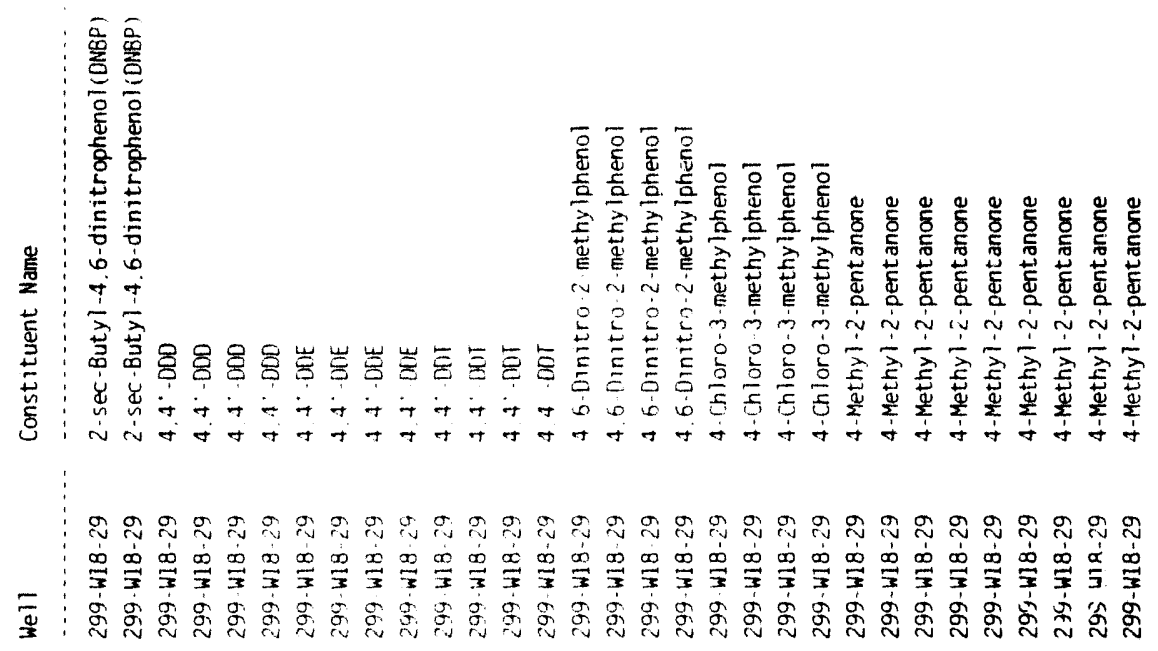




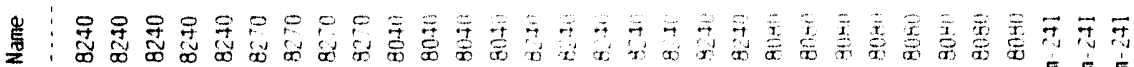

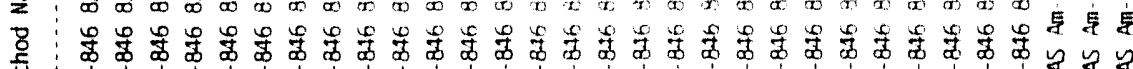

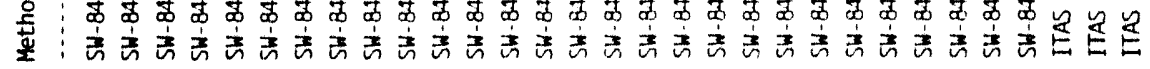
案:

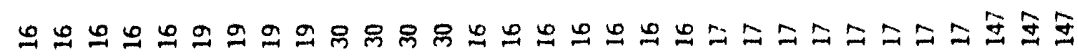

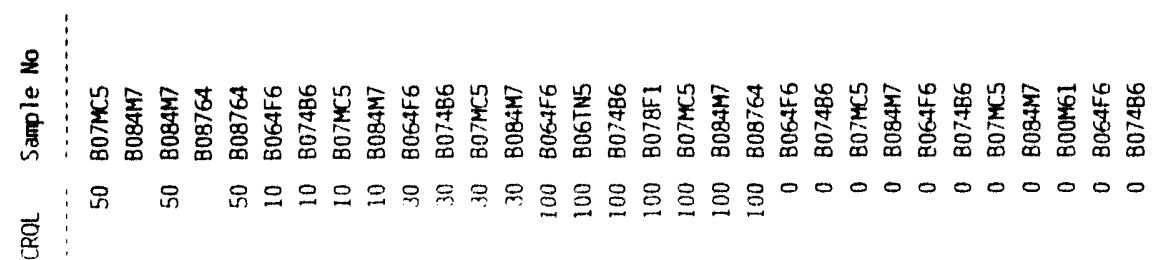

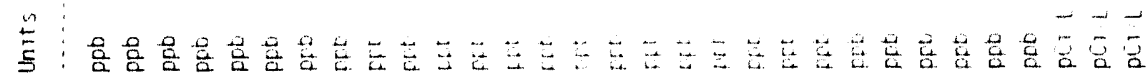
: :

站 늘 苛

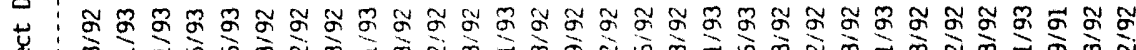

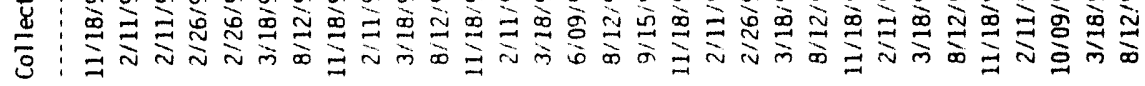

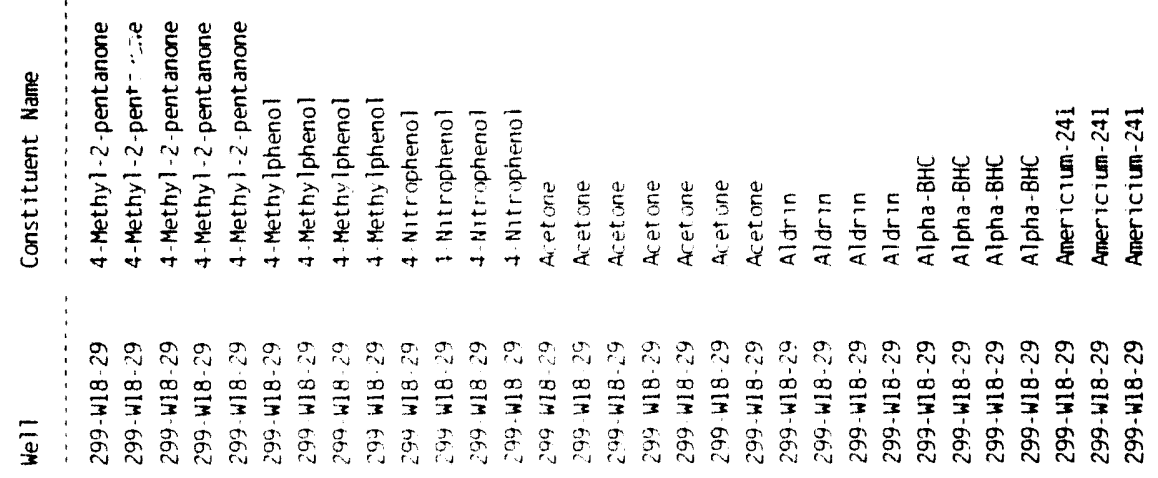




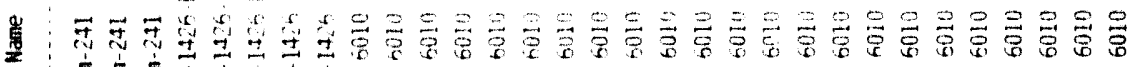

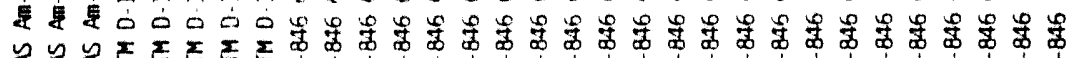

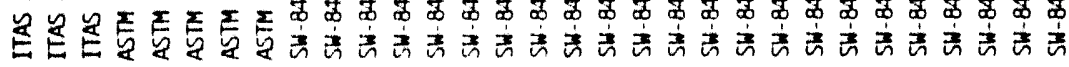

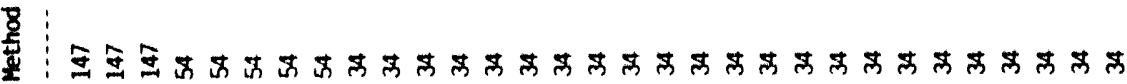
운

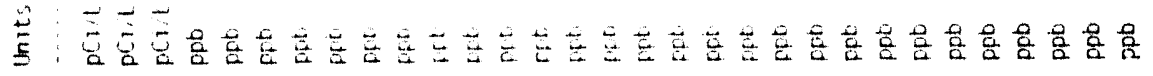

富

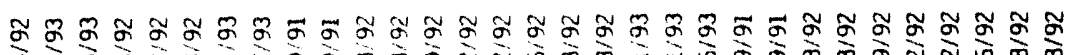

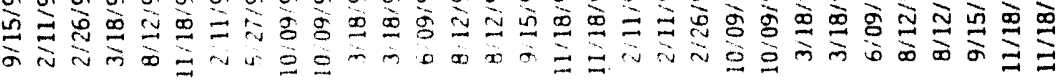




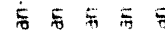

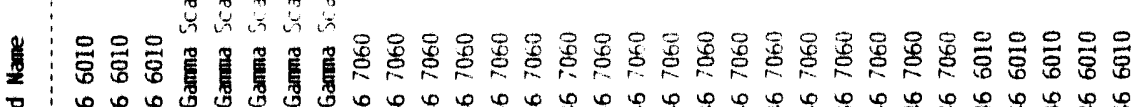

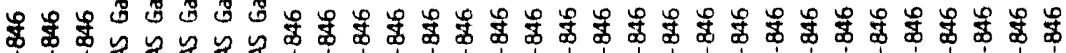

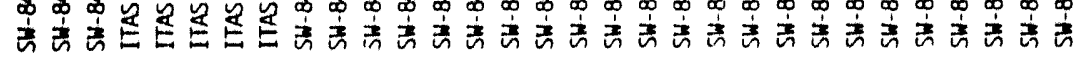

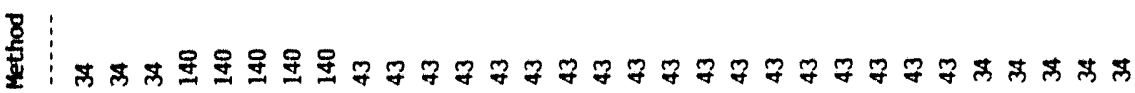

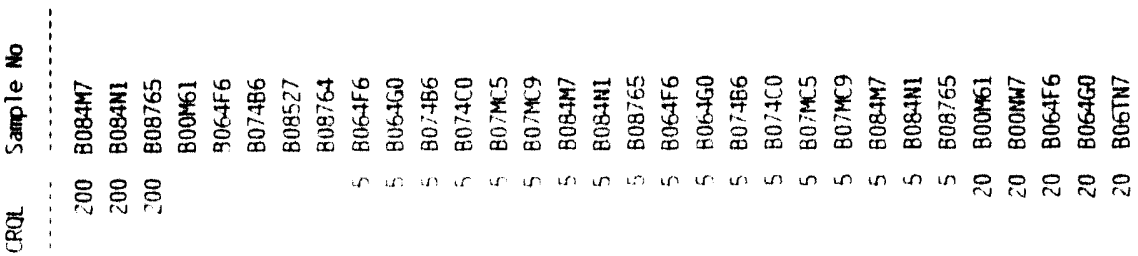

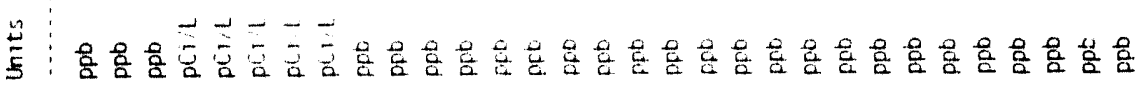
:

若

$\frac{b}{2}$

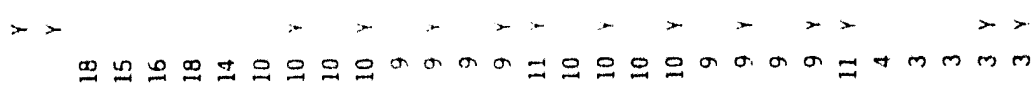

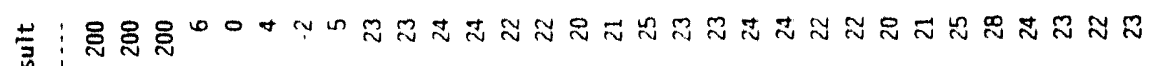
范

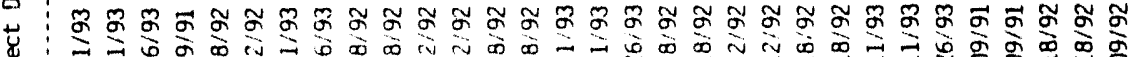
喜

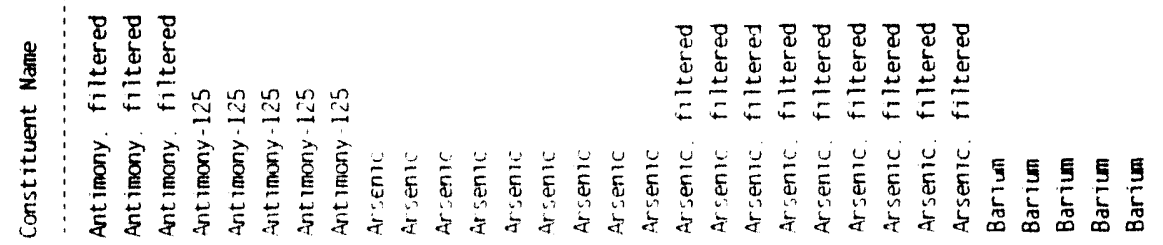

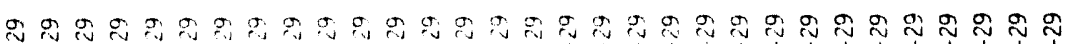

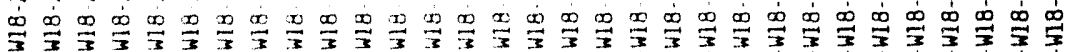

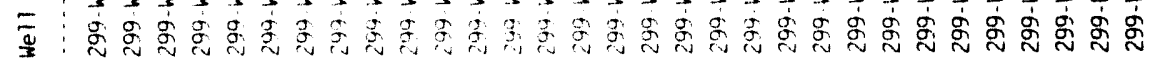


基

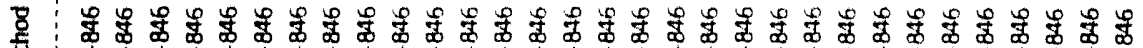

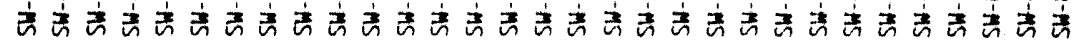

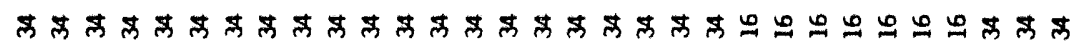

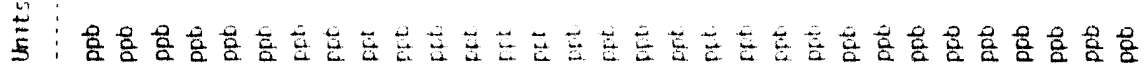

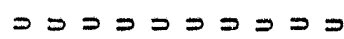

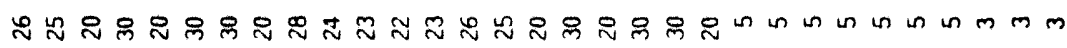
范

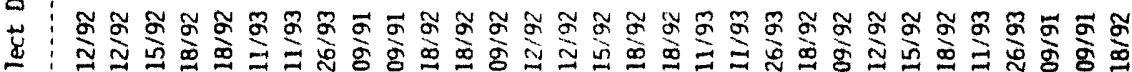

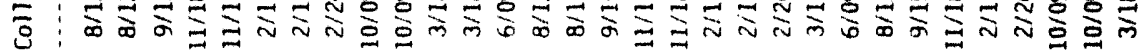




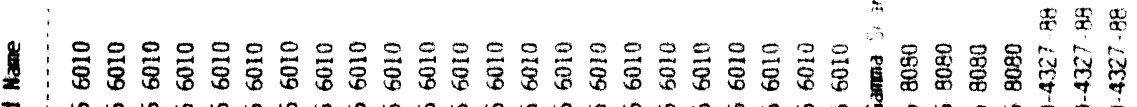

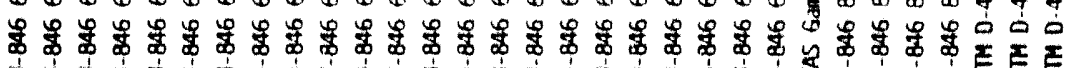

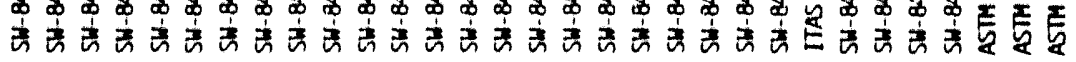

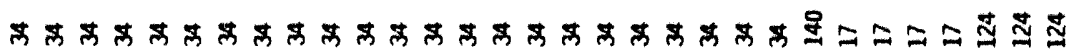

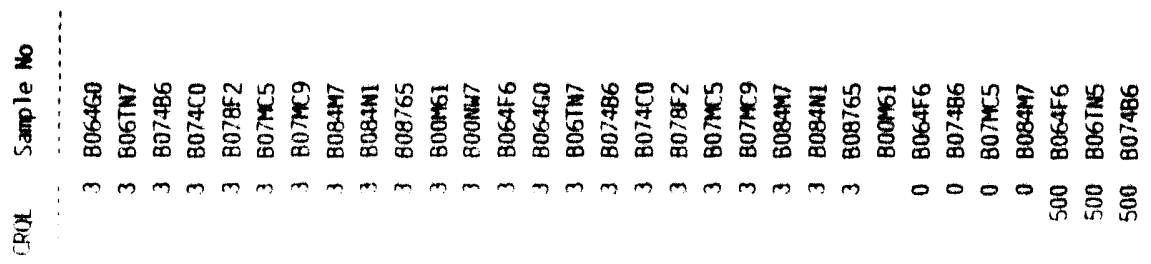

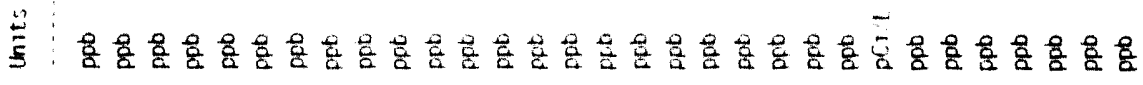
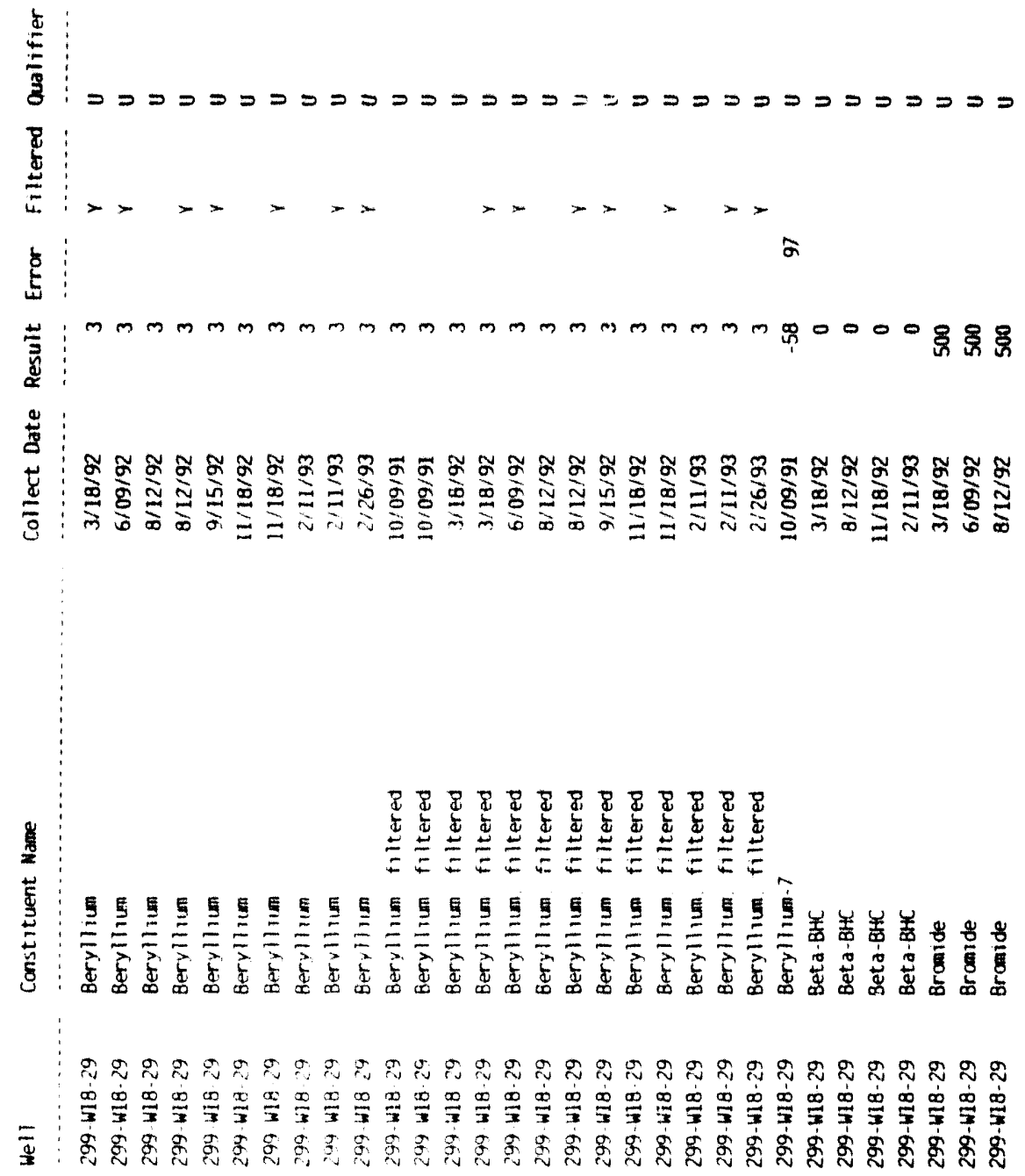


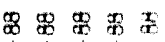

4

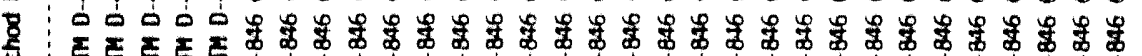

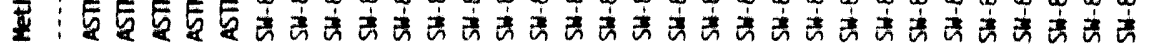
8

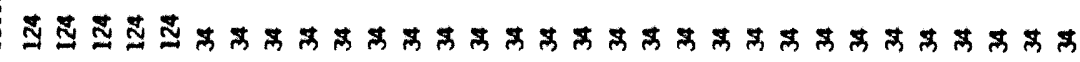

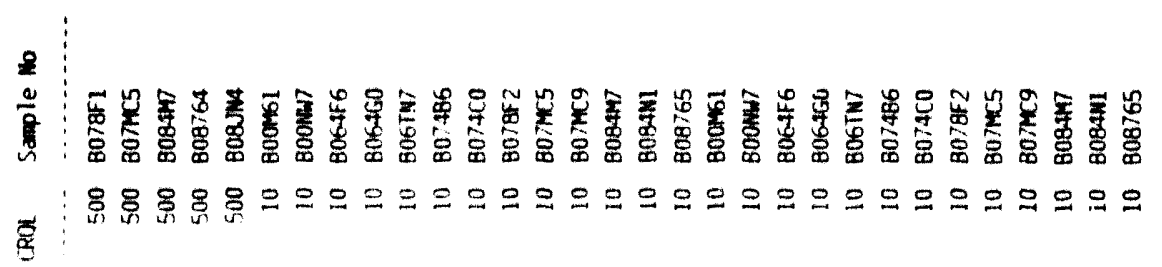

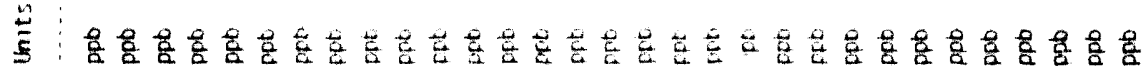

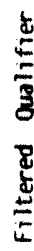

t

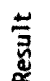

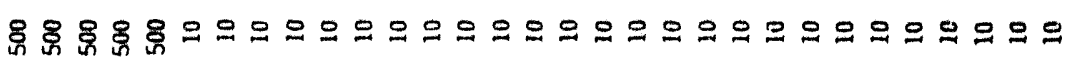

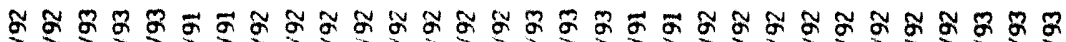
造

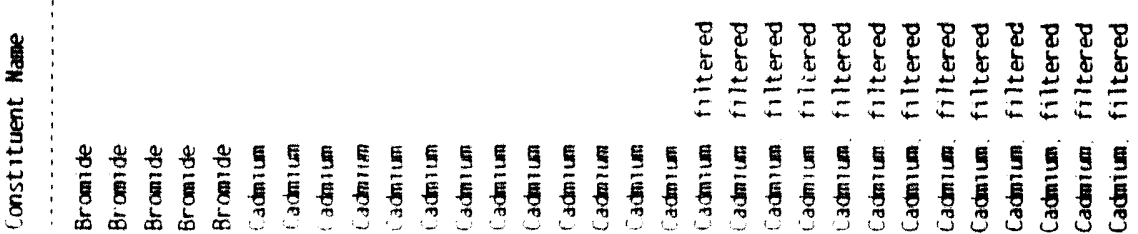

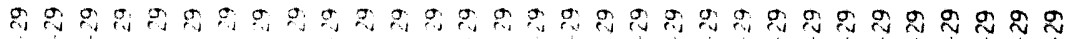

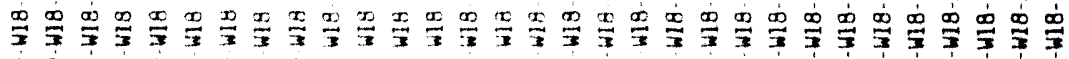

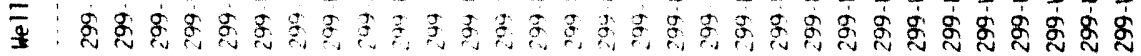




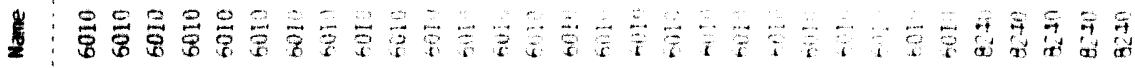

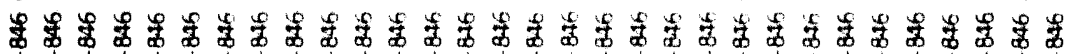

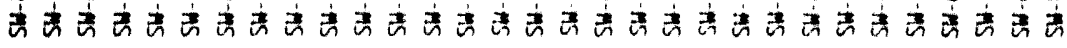

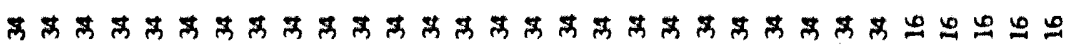

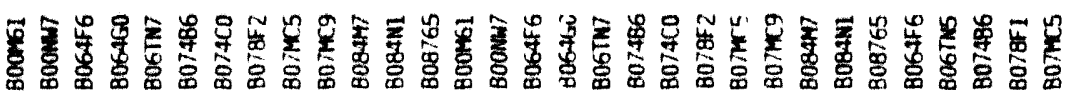

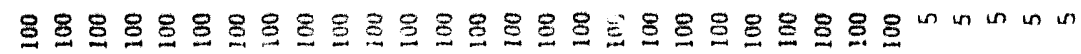

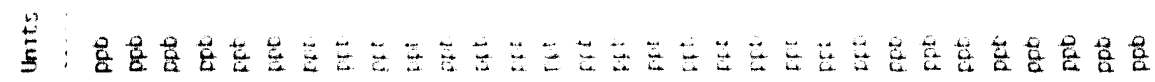

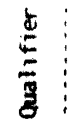

$\stackrel{8}{2}$

点

蒙

:

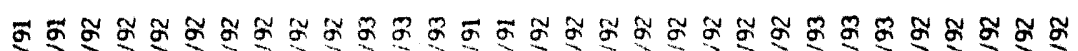

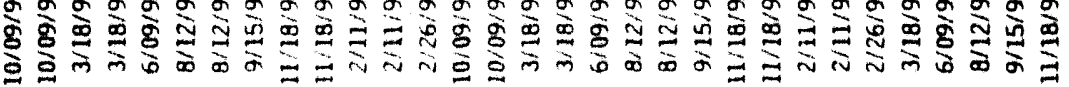

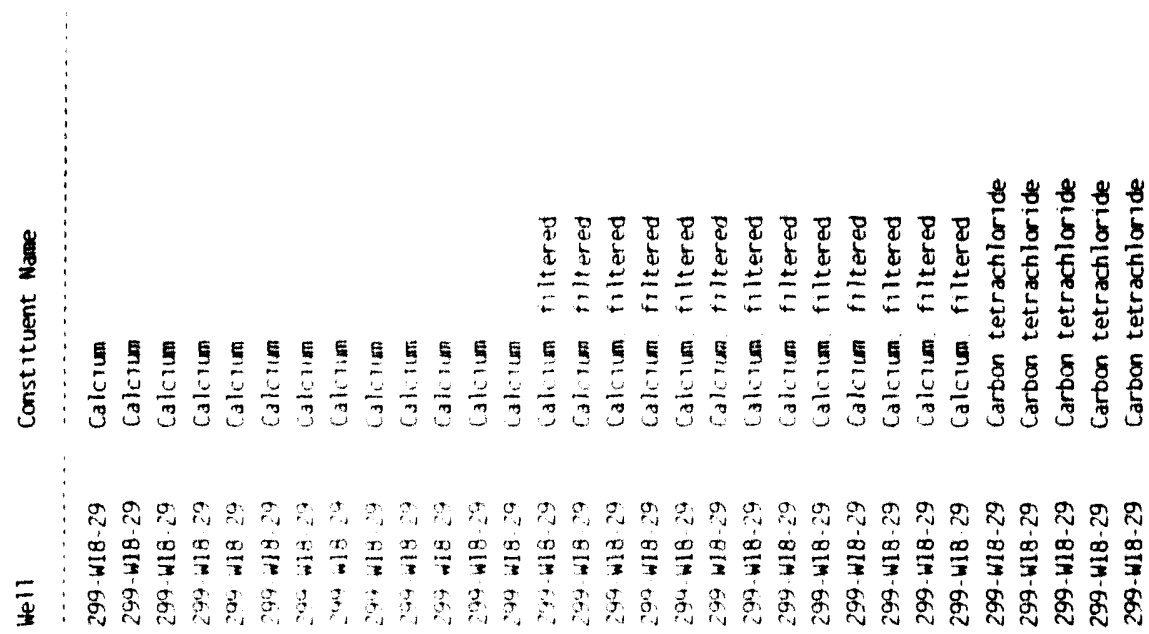



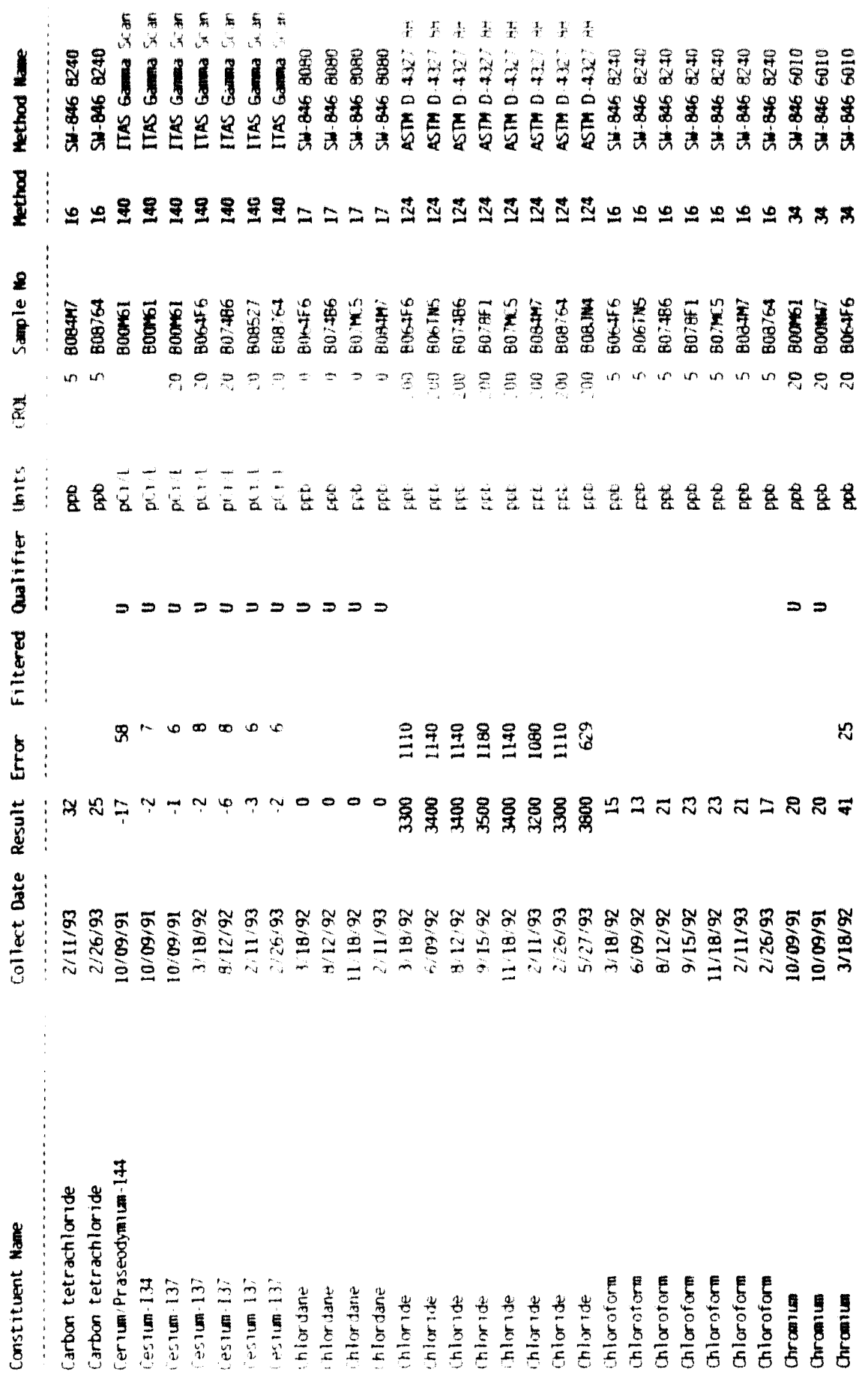

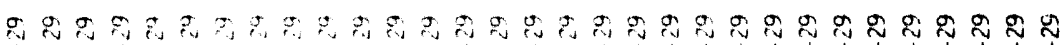

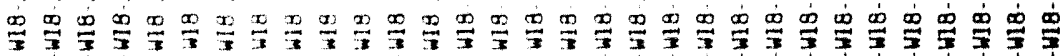

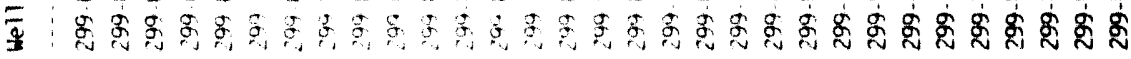




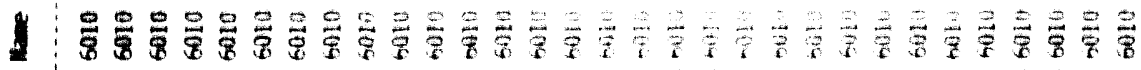

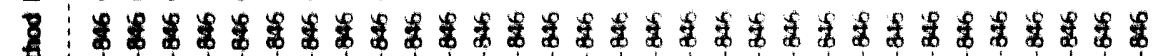

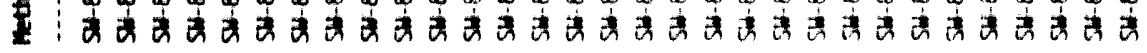
+

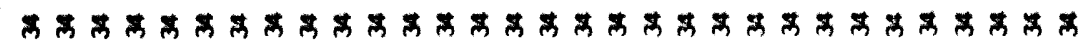

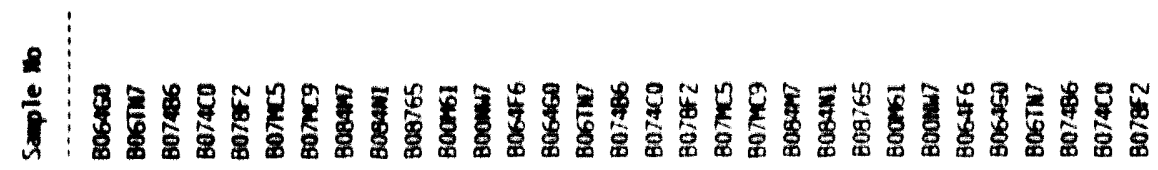
8

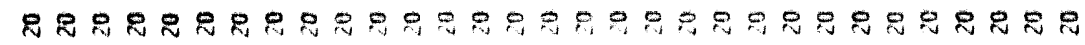

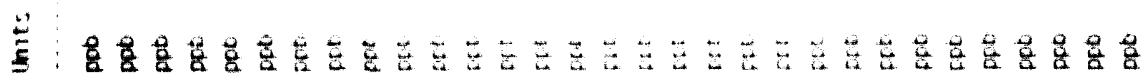
$\stackrel{\text { }}{2}$ 3 $\frac{E}{E}$

t.

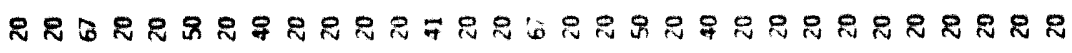

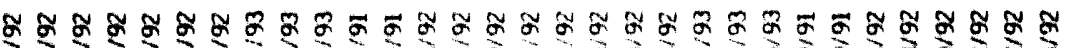

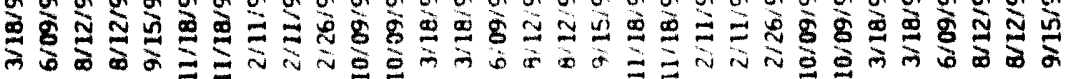

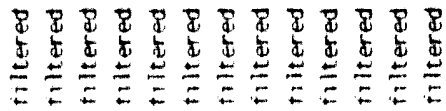

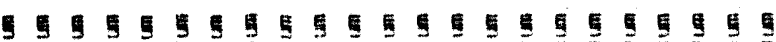

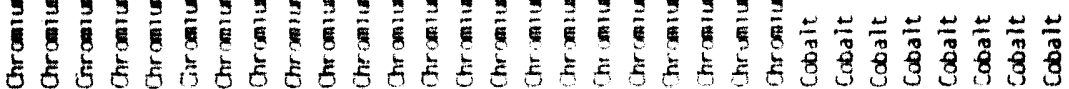

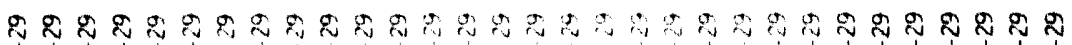

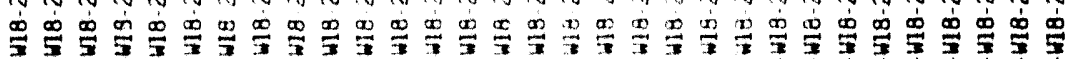

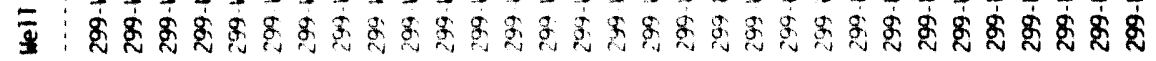




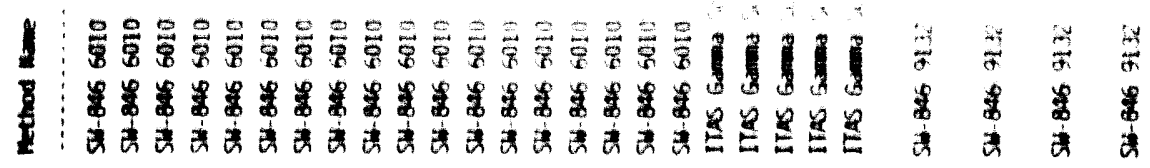

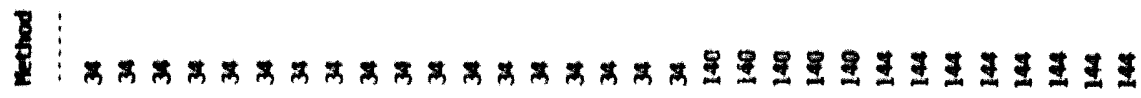

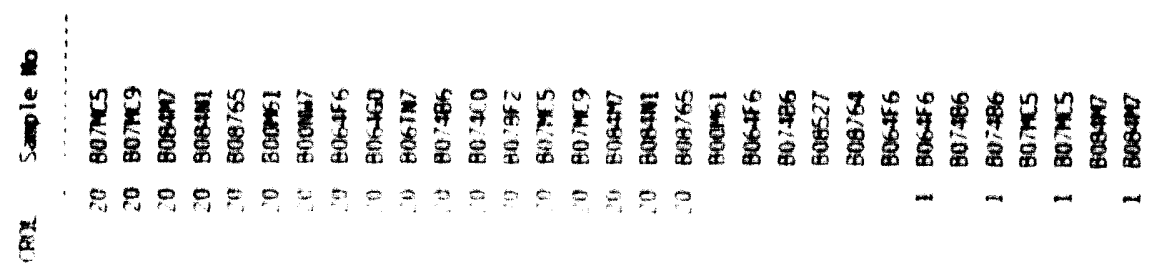

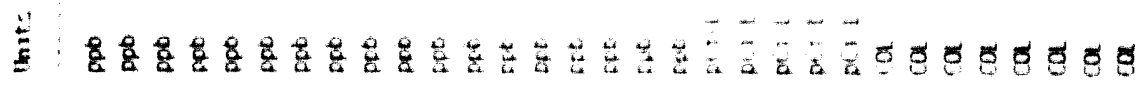
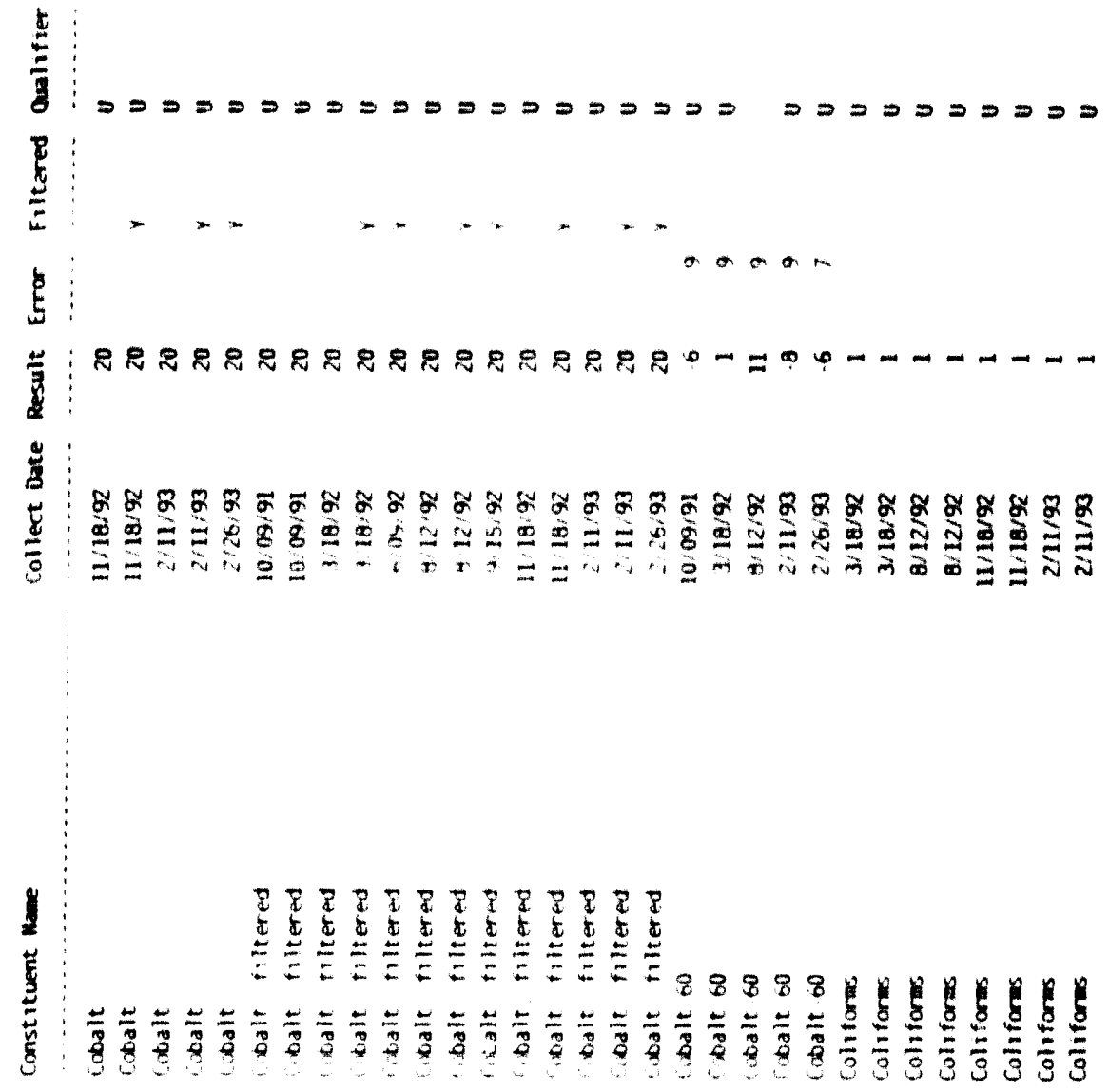

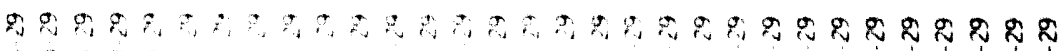

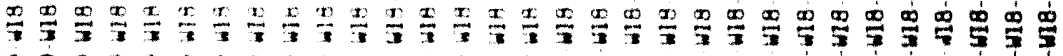

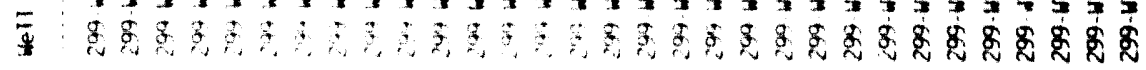




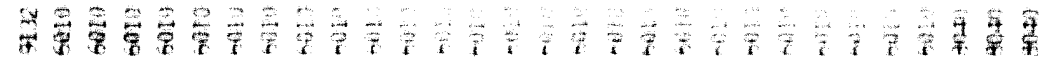

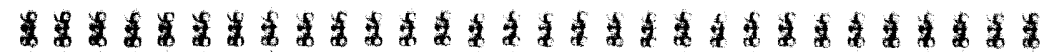

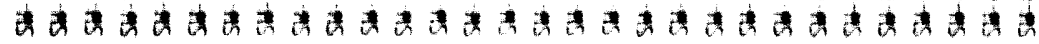

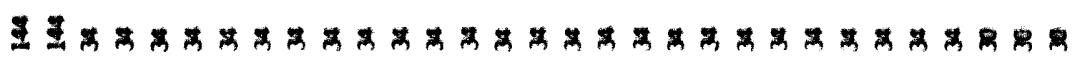

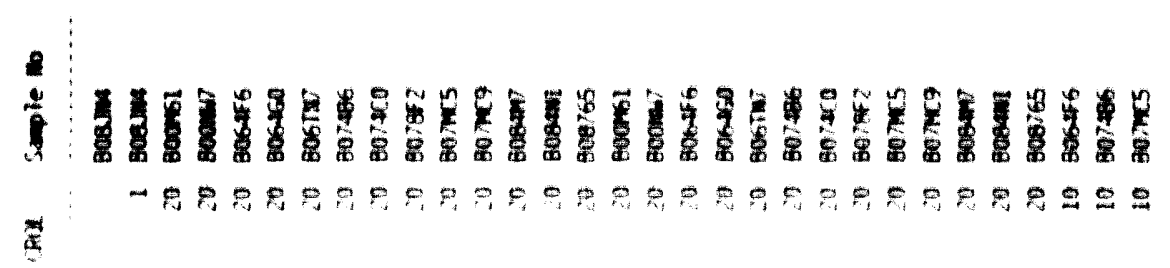

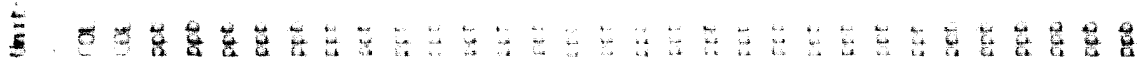

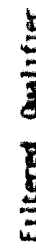

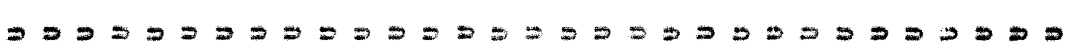

\begin{tabular}{l}
8 \\
$E$ \\
\hline
\end{tabular}

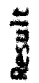

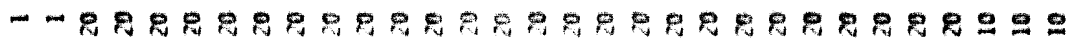

范

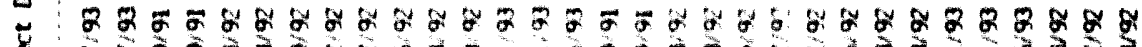

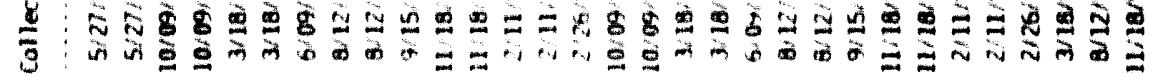

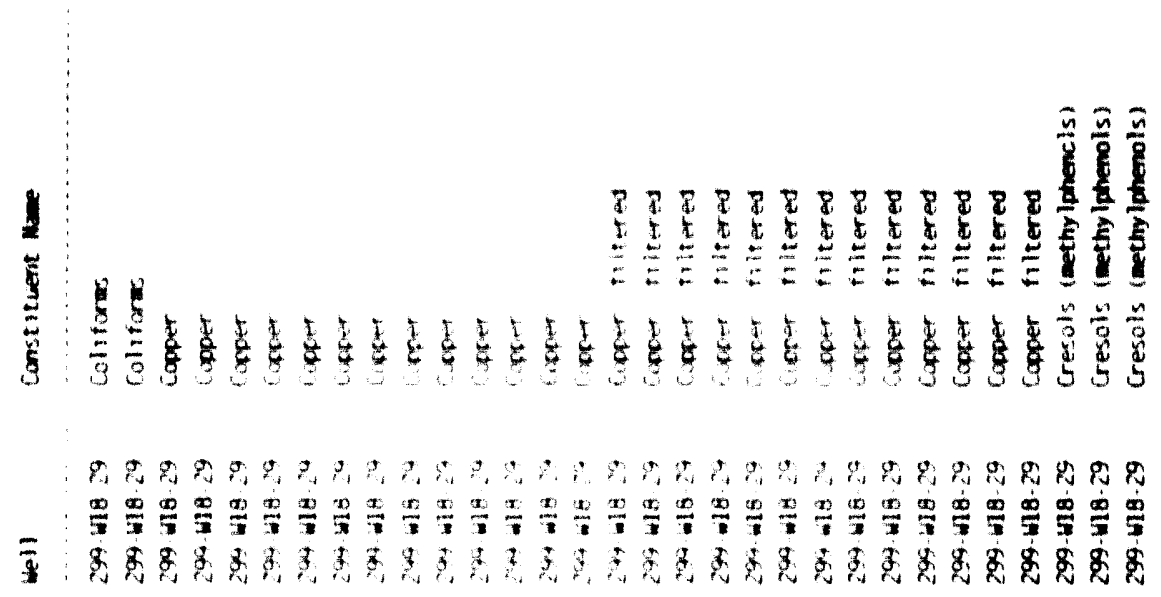



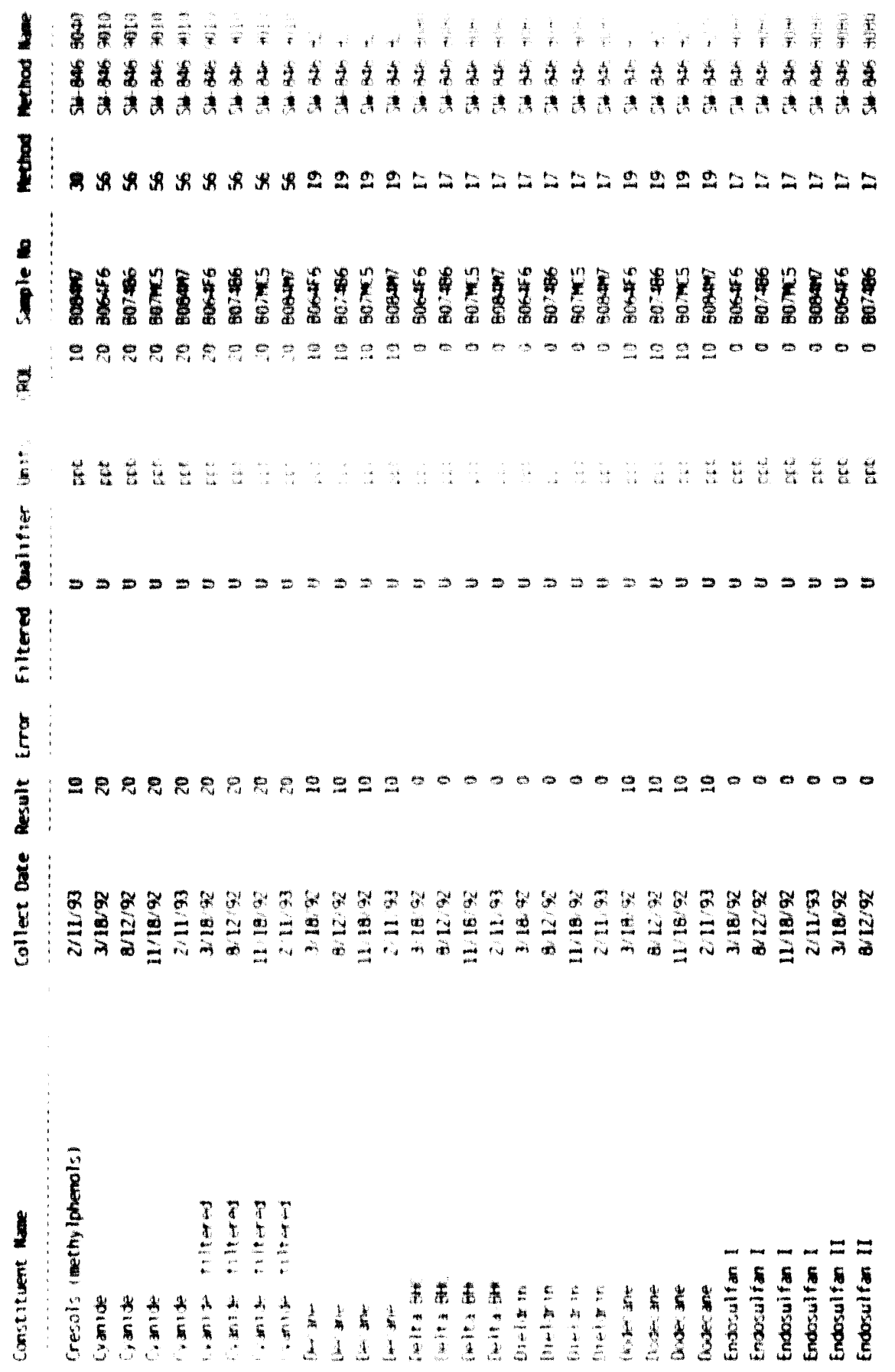

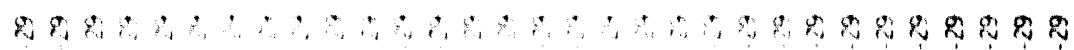

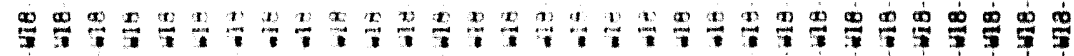

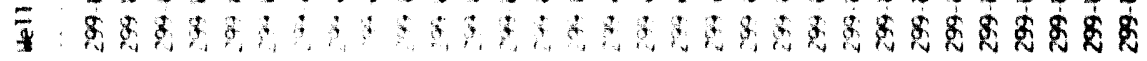




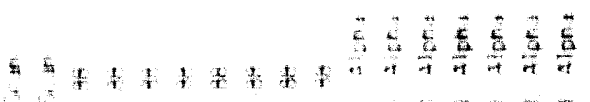

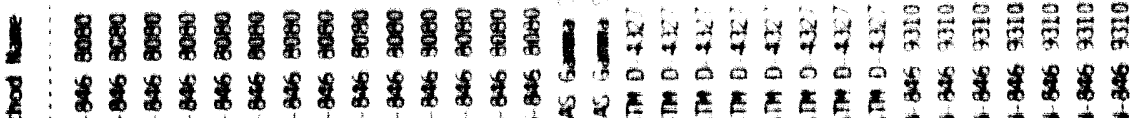

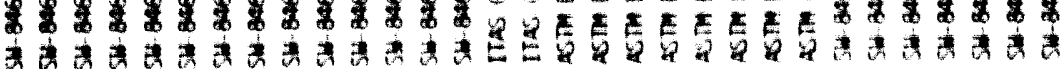

量

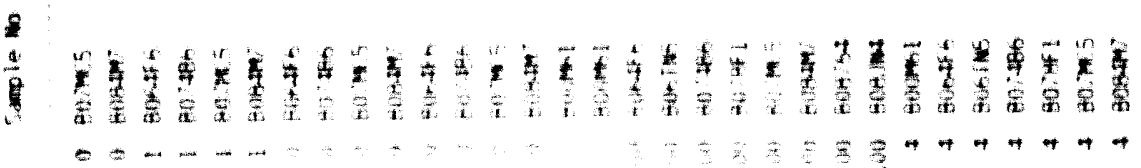
产

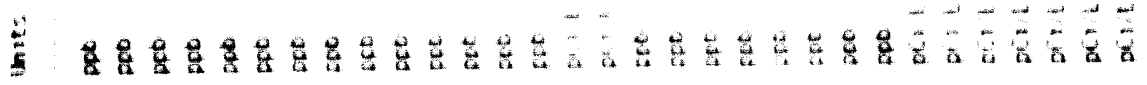

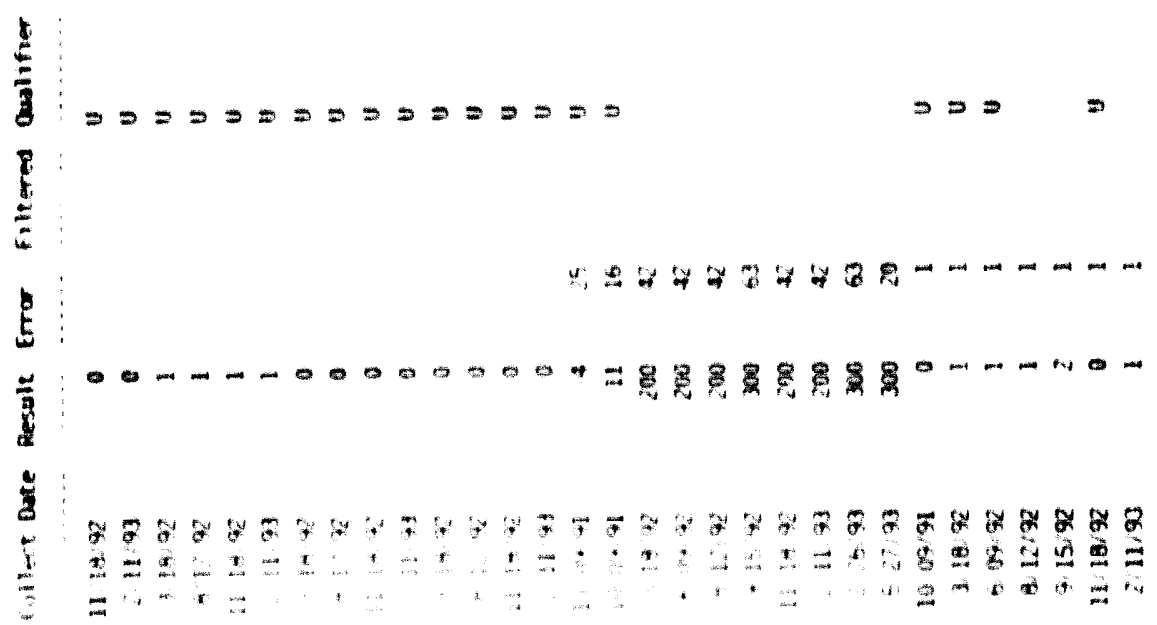

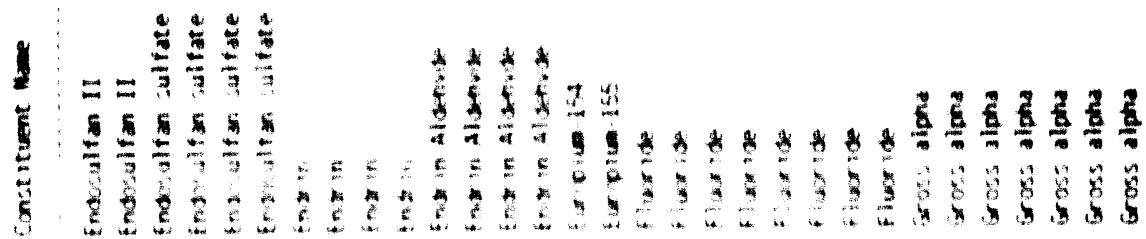

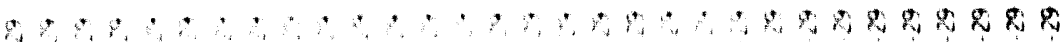

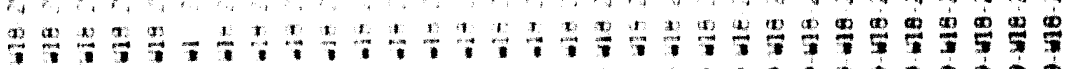

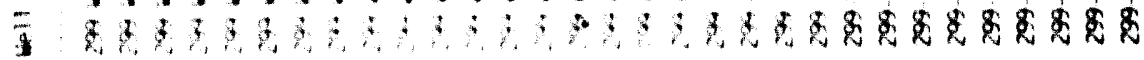




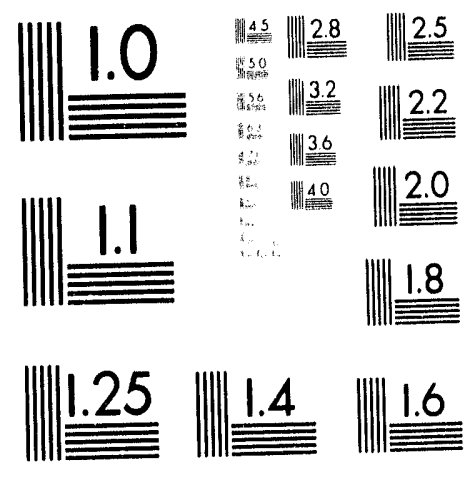



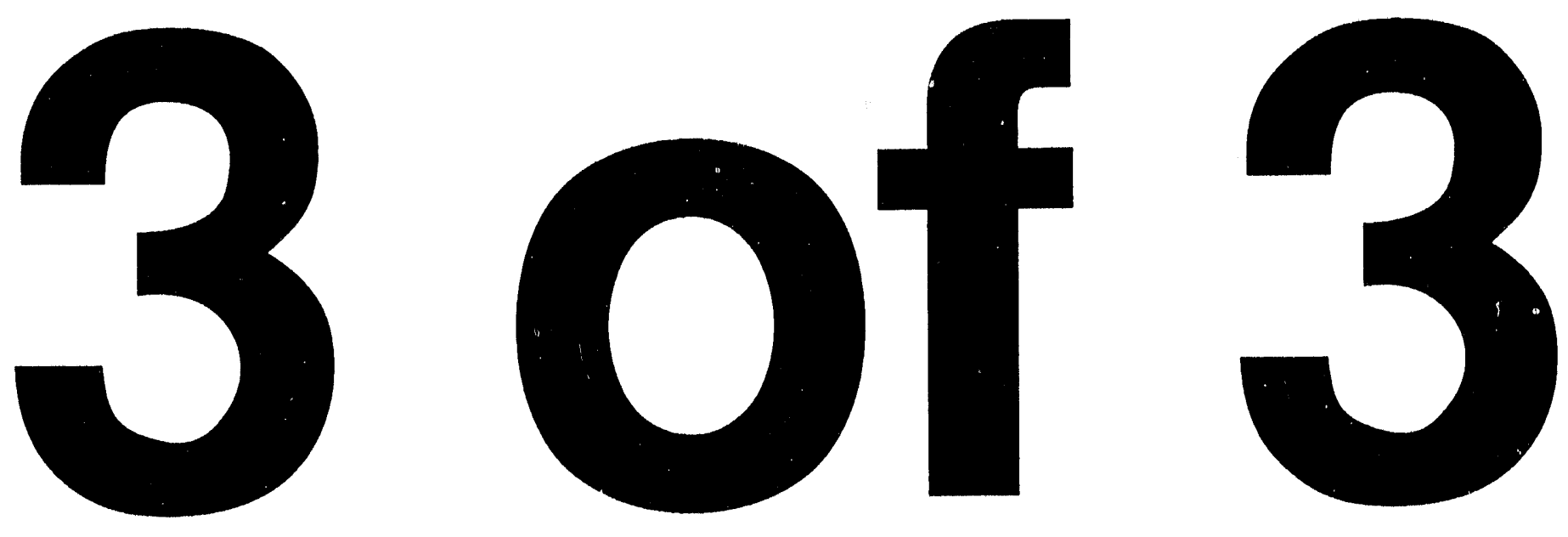


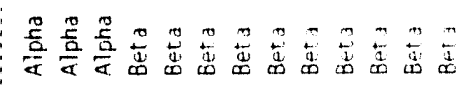

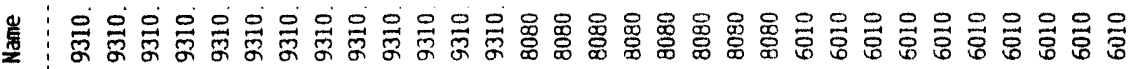

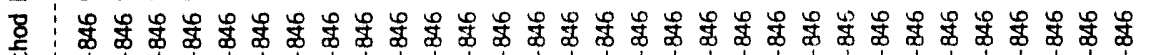

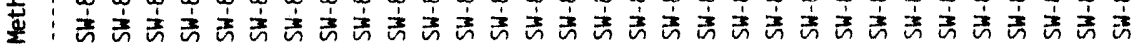

密

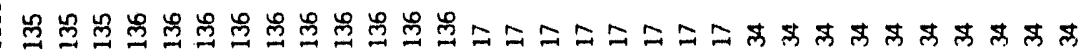

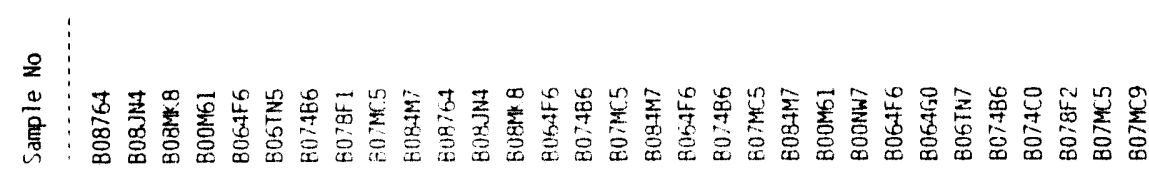

石

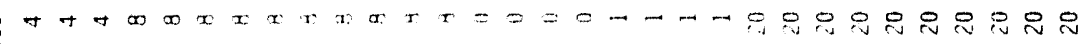

点

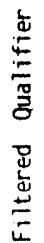

站

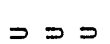

$P D D D D=D$ DD D D

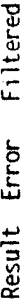

$-\rightarrow-n N N N N N$ N N

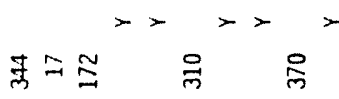

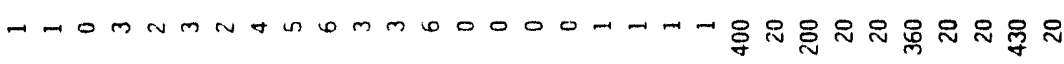

$\stackrel{\$}{\mathrm{D}}$

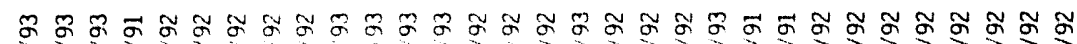

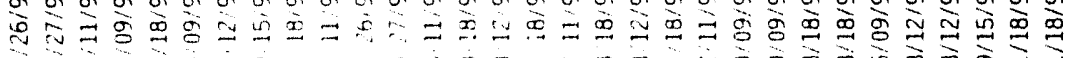

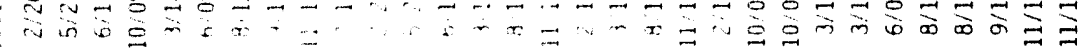

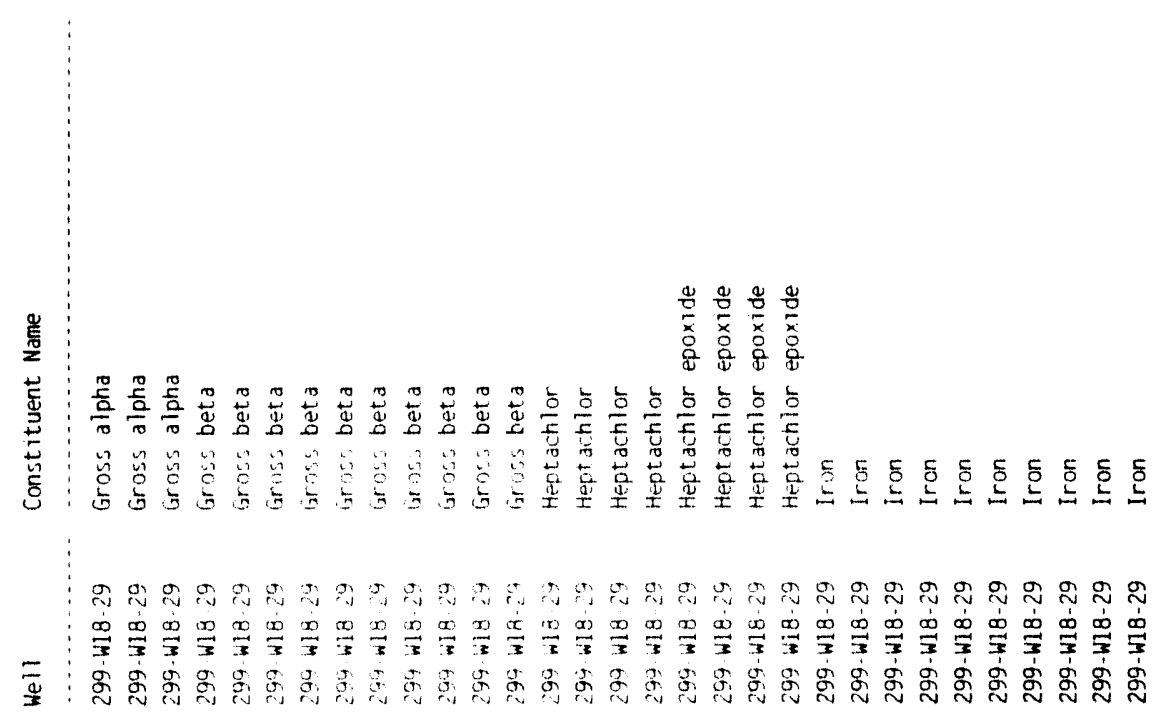




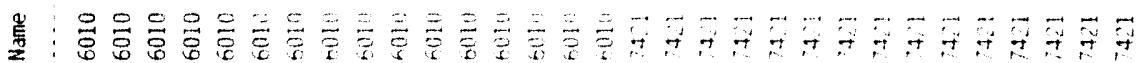

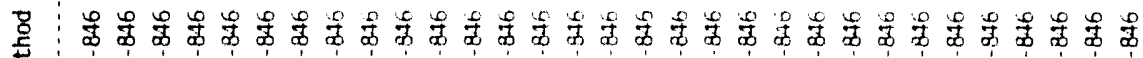

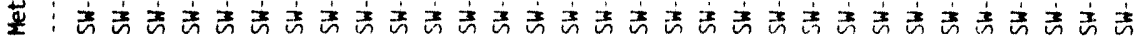

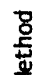

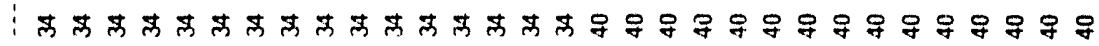

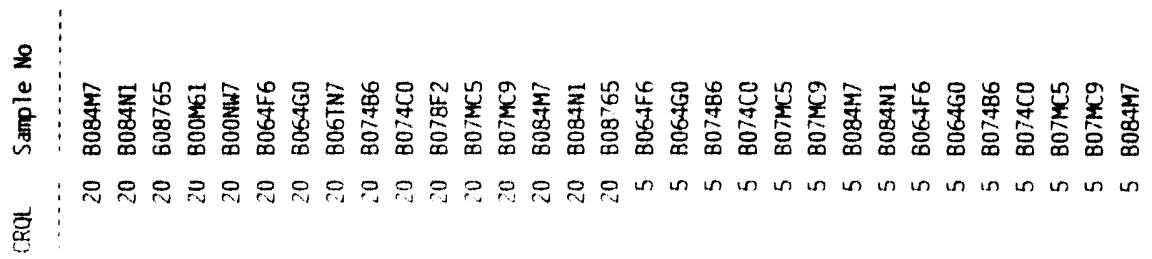

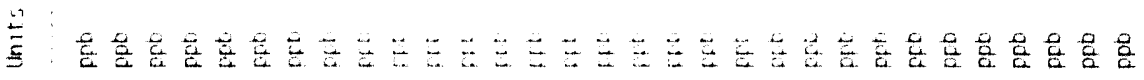

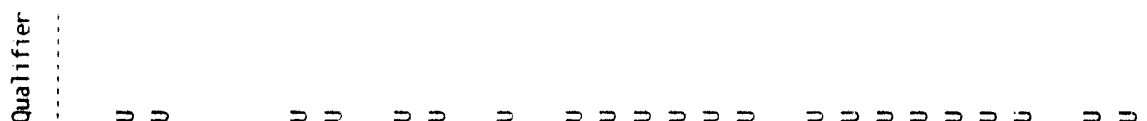

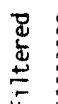

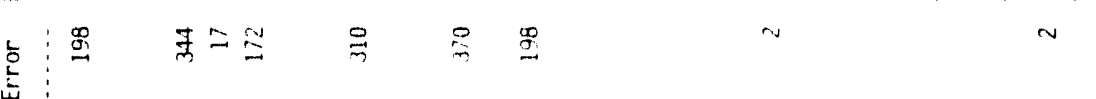

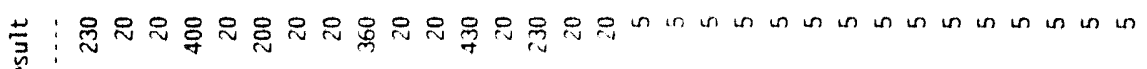
$\stackrel{2}{\alpha}$

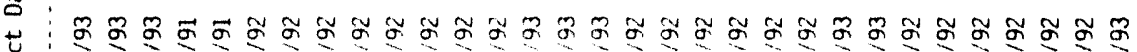
更

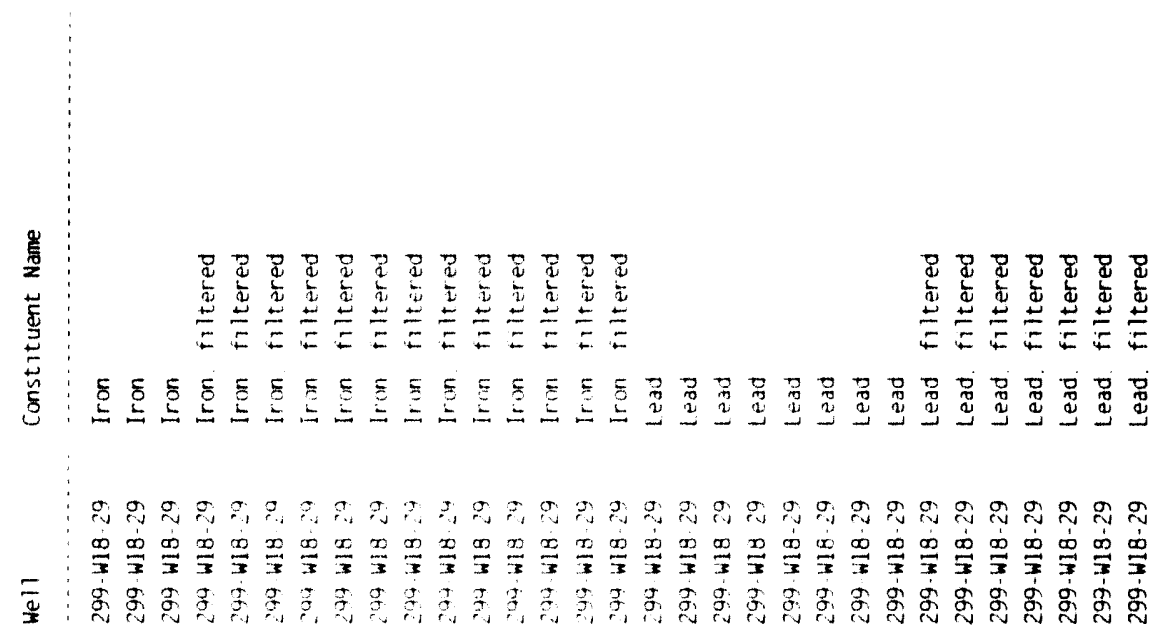




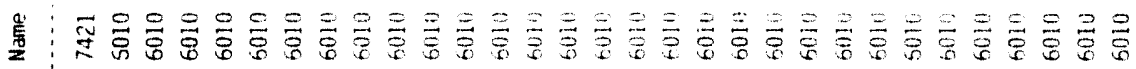

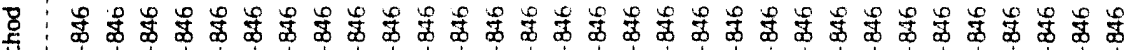

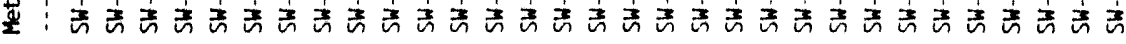

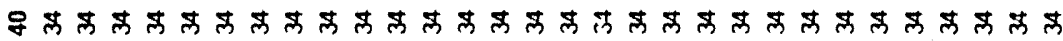

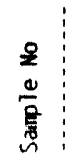

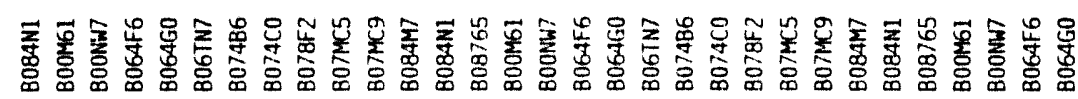

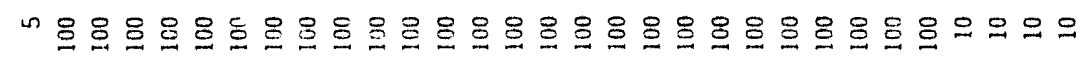

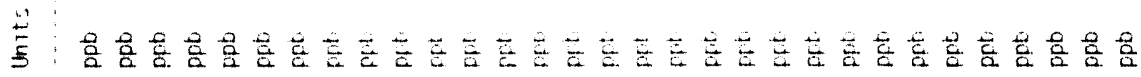

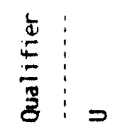

$$
=0
$$

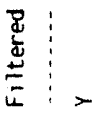

¿:

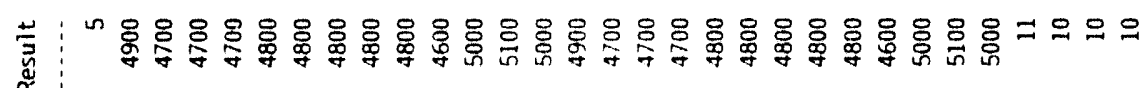

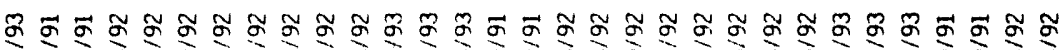

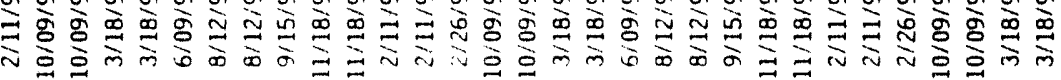

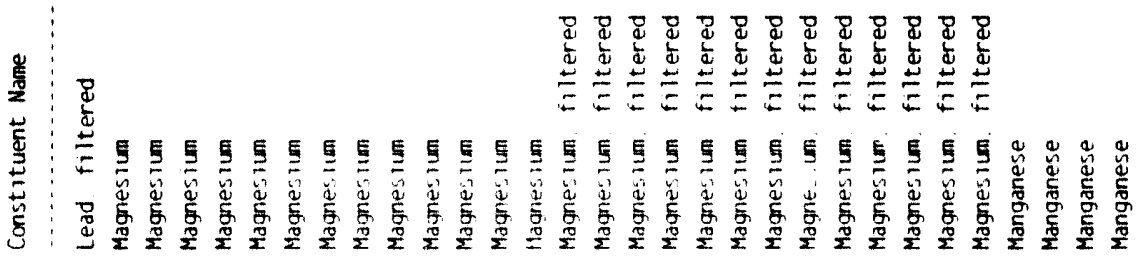

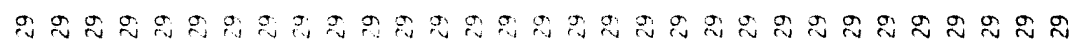

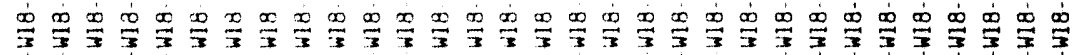

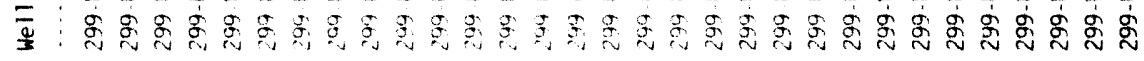




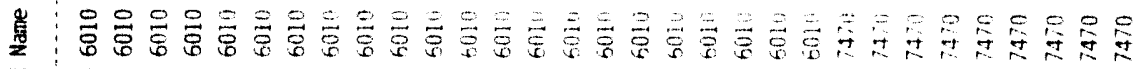

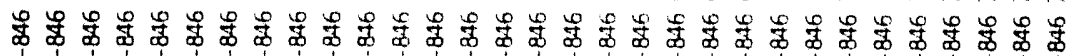

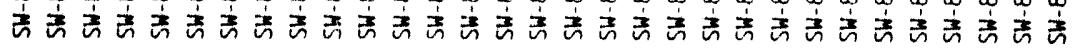
密

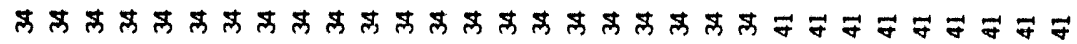
일 \&্ট

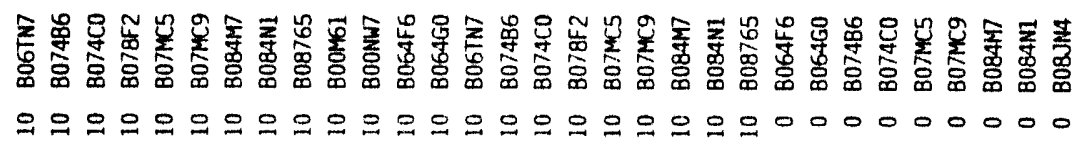
宸

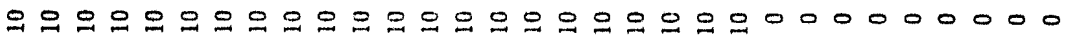

点

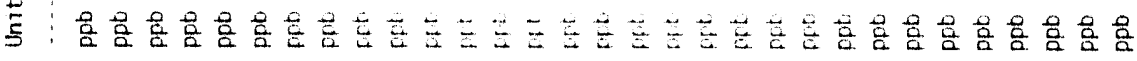
咅

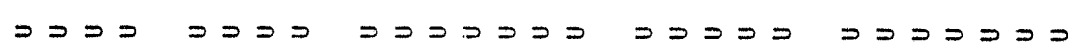
焉 总

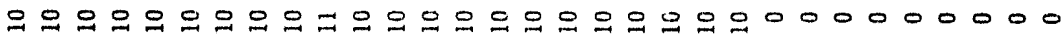

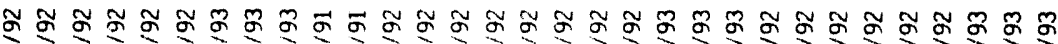

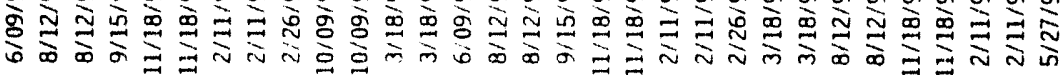

\section{8 Mํ.}

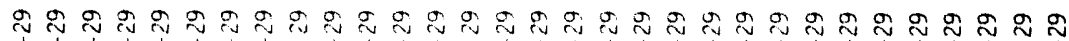

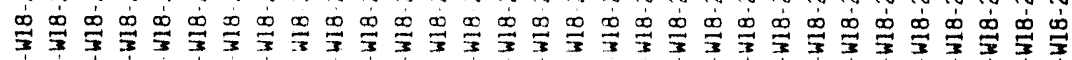

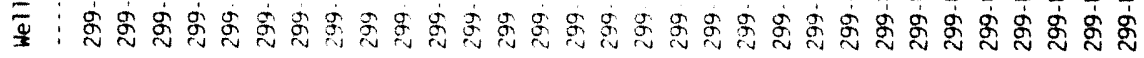




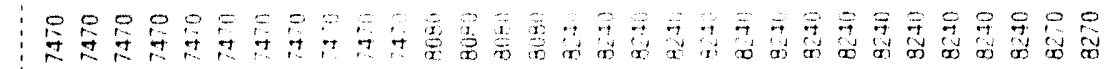

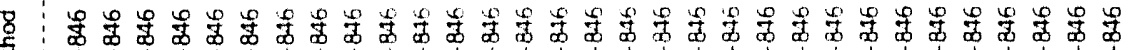

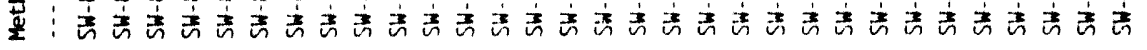

㙂:

美

$\vec{s}$

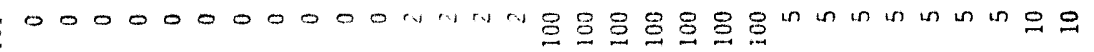

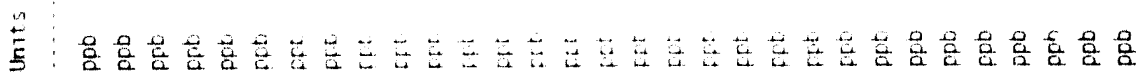
:

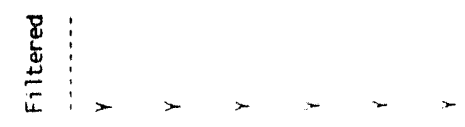

占

苛:

落

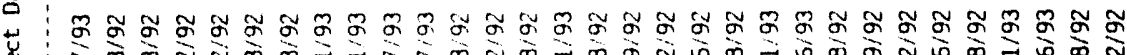
尊

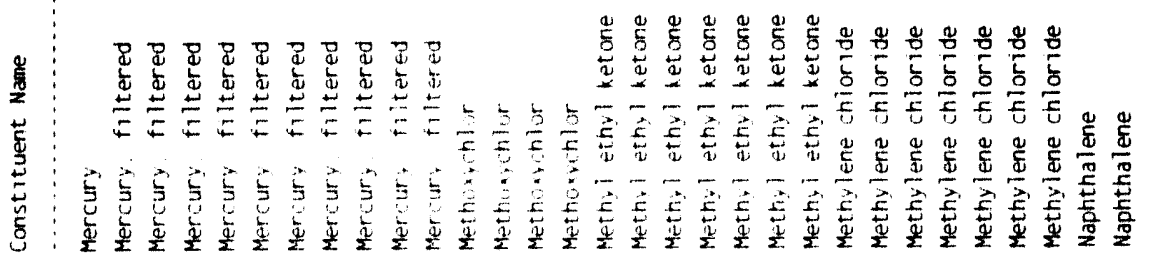

o.

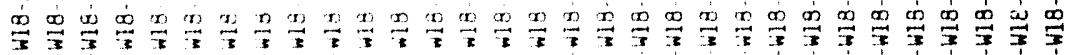

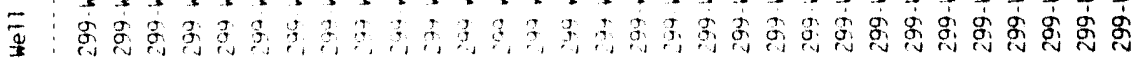




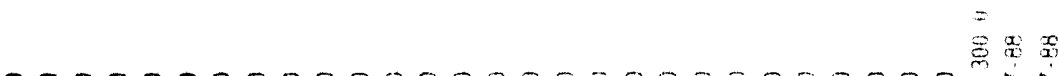

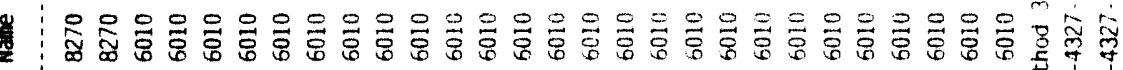

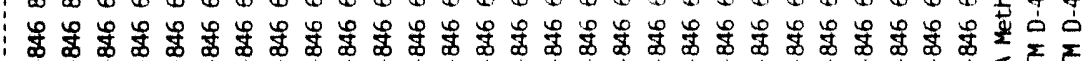

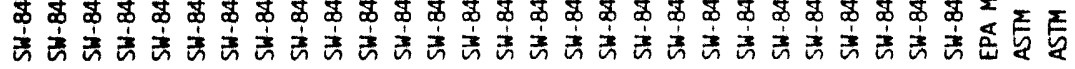
童

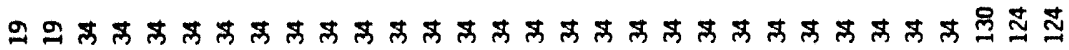

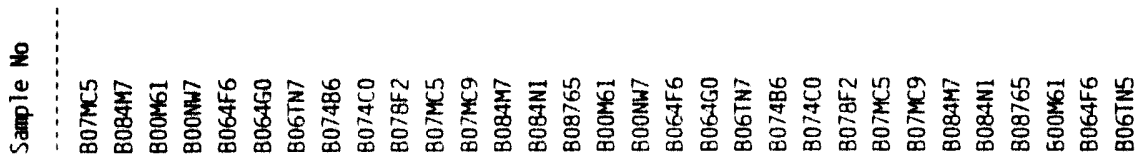
कृष्ठ

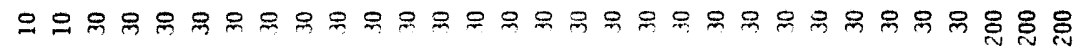

莺
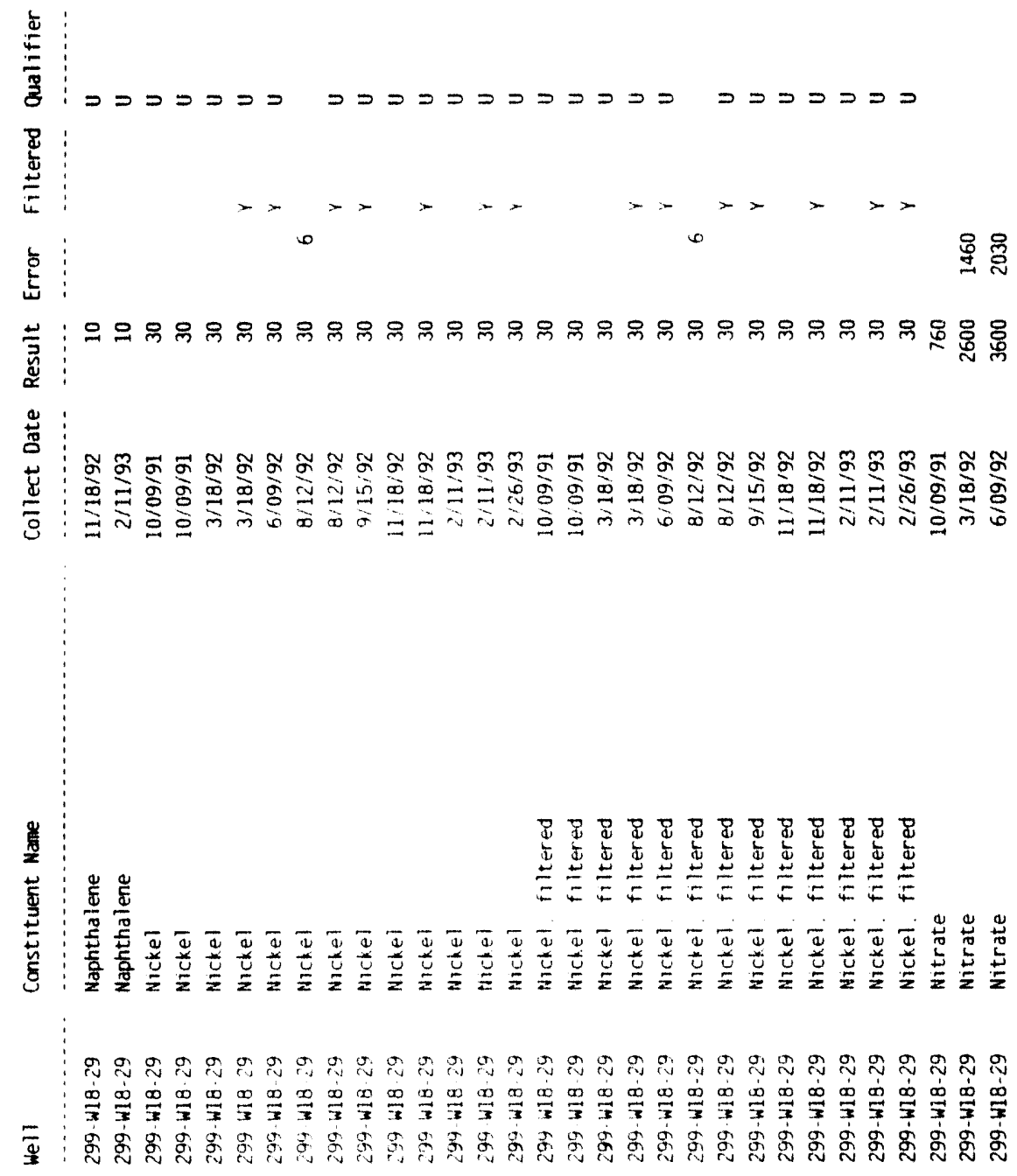


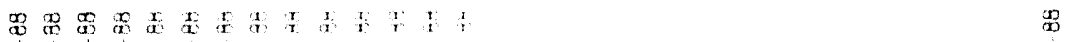

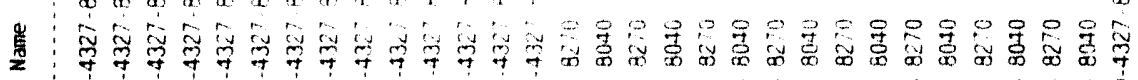

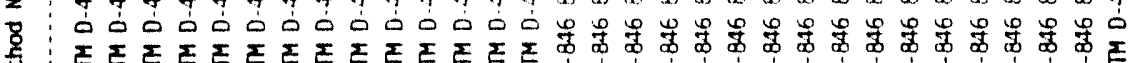

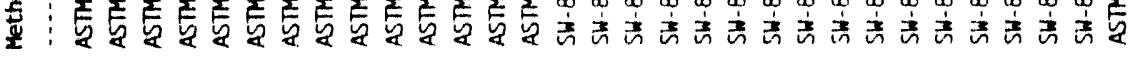
昰

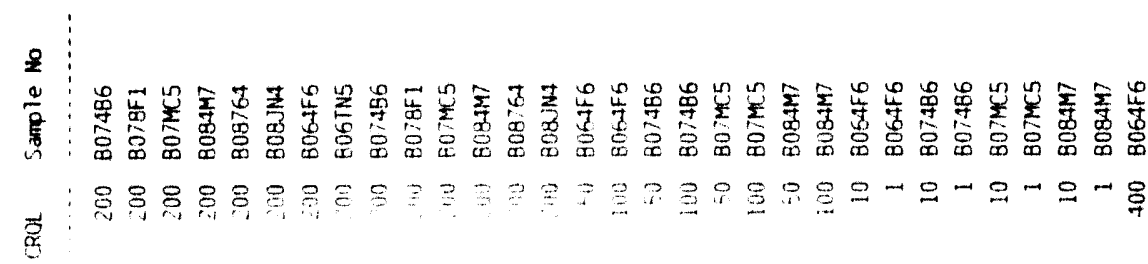

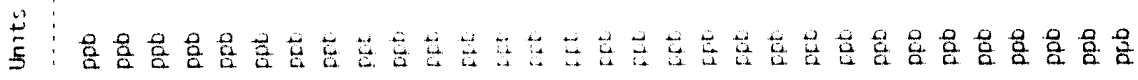

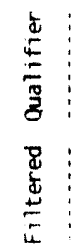

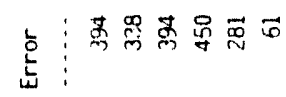

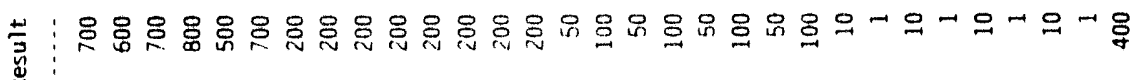

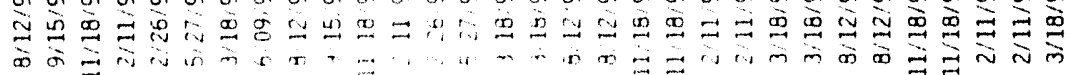

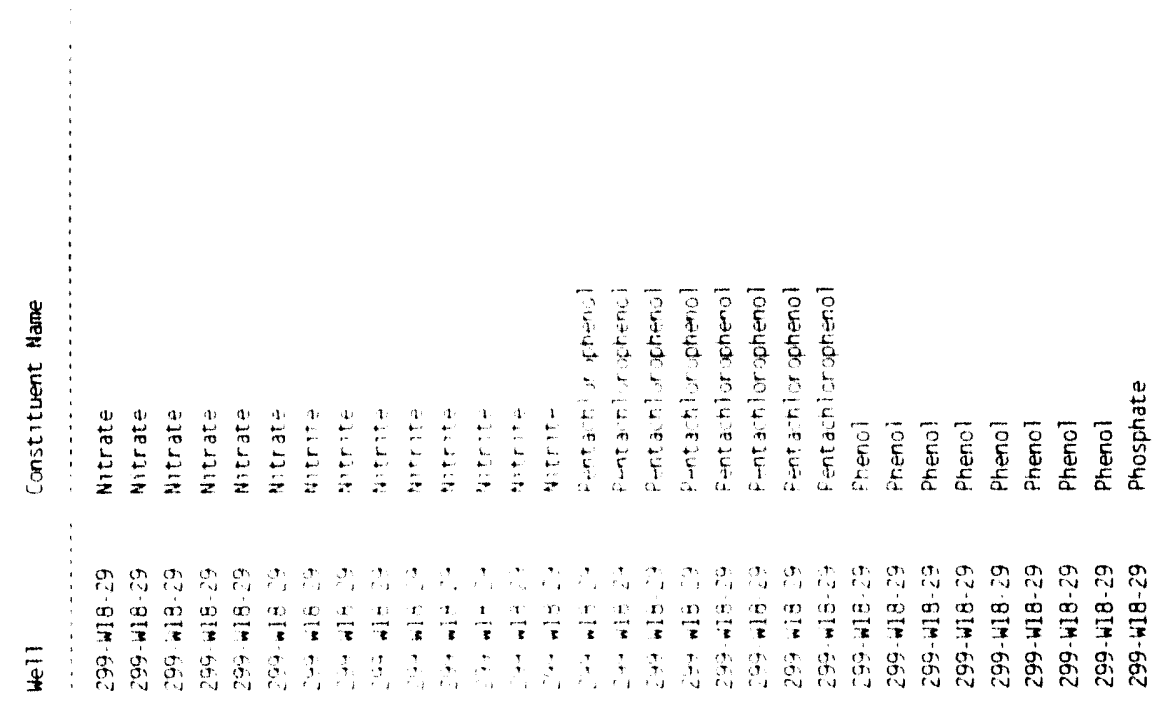




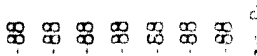

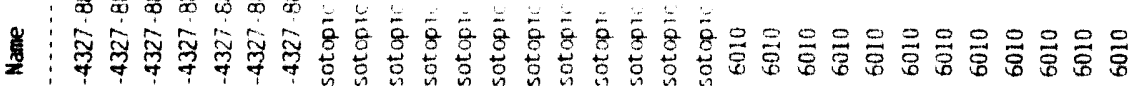

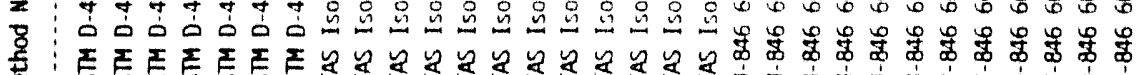

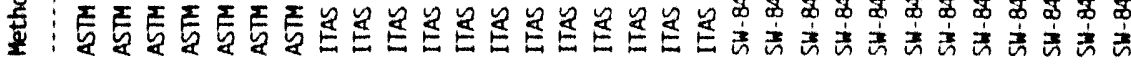
焉

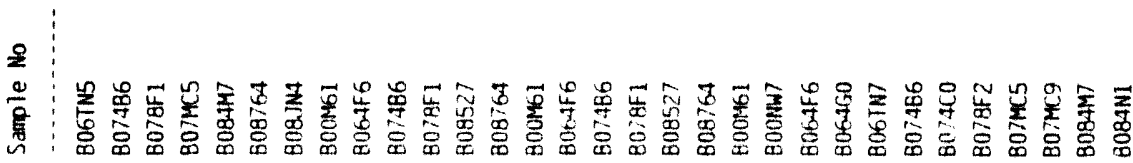
旁

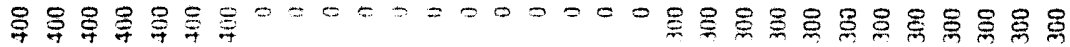

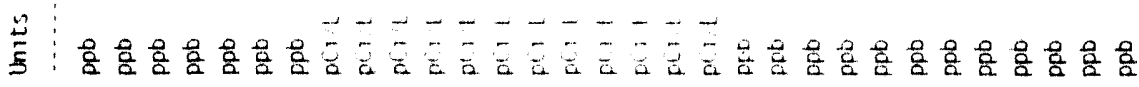

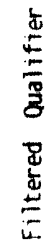

:

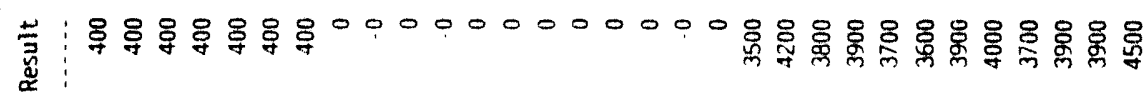

苋

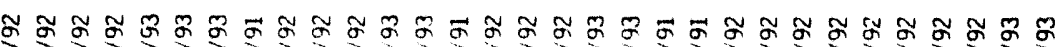

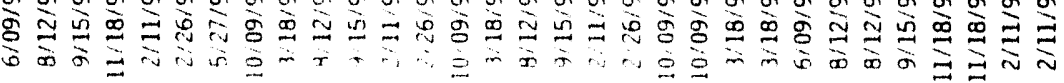

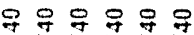

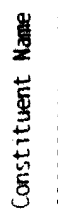

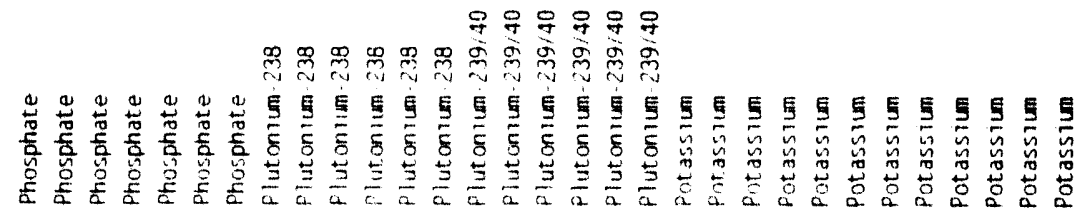

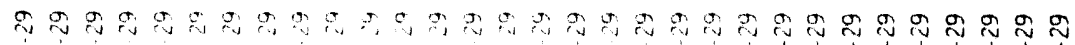

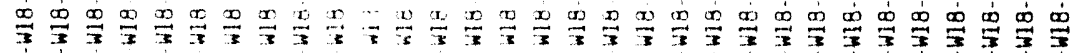

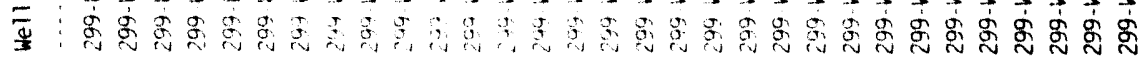




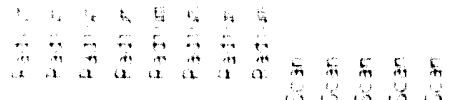

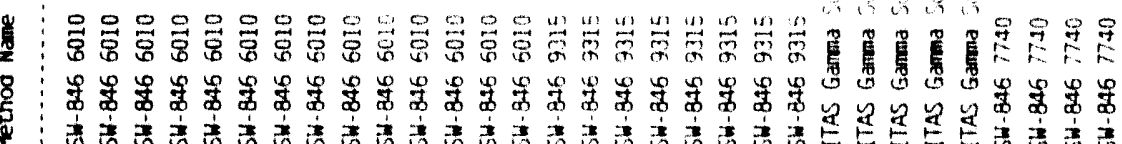

8

焉

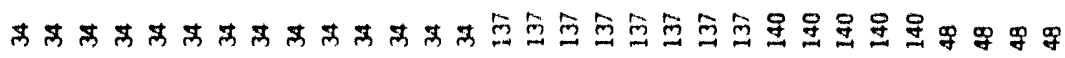

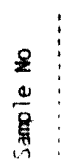
हี.

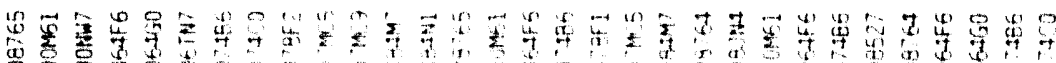

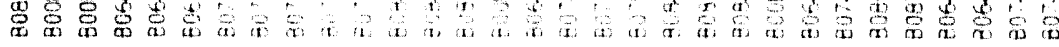

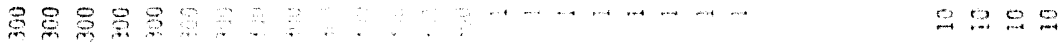

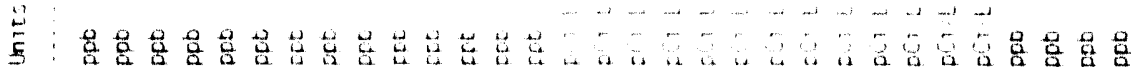
$\frac{\Phi}{3}$

恋 to

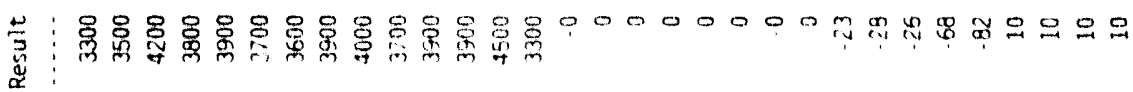
范

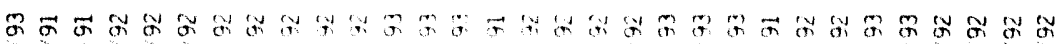

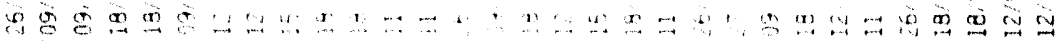

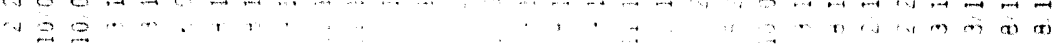

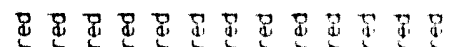

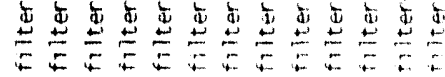

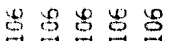

5 5555555555

55

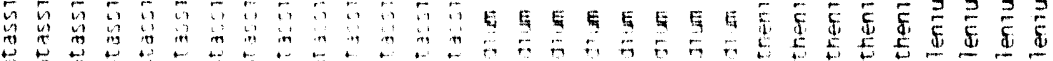

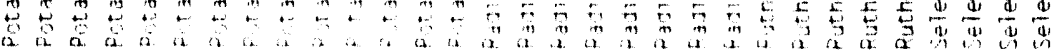

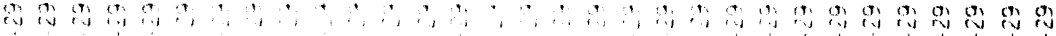

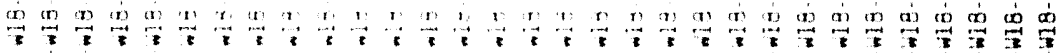

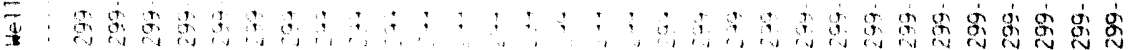




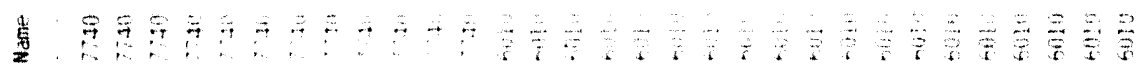

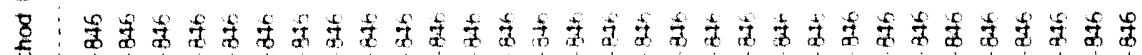

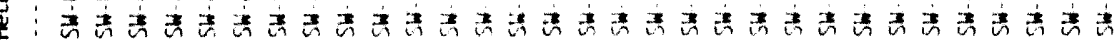

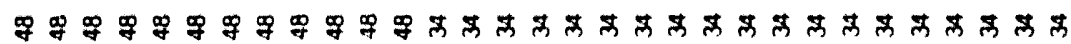

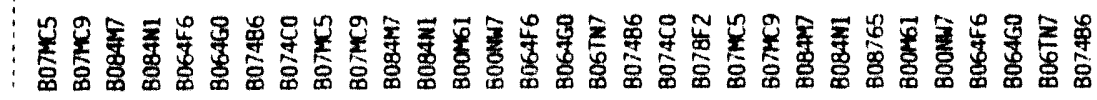
宫

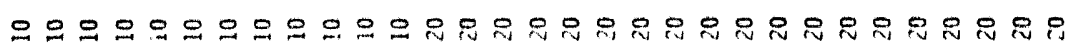

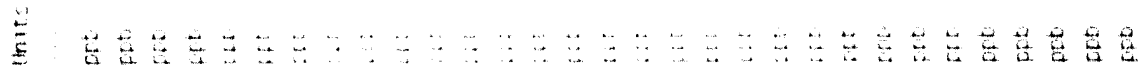
:

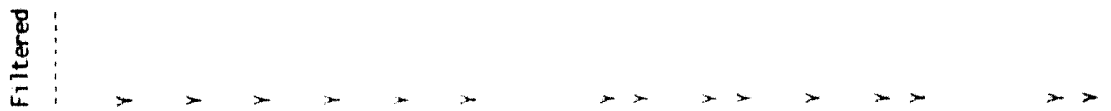

L

$\stackrel{4}{\underset{3}{3}}$

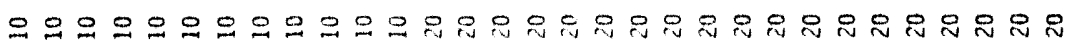

范

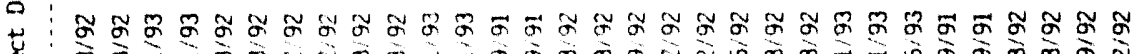

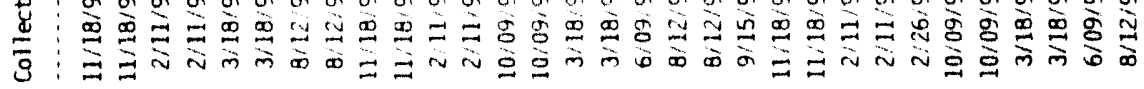

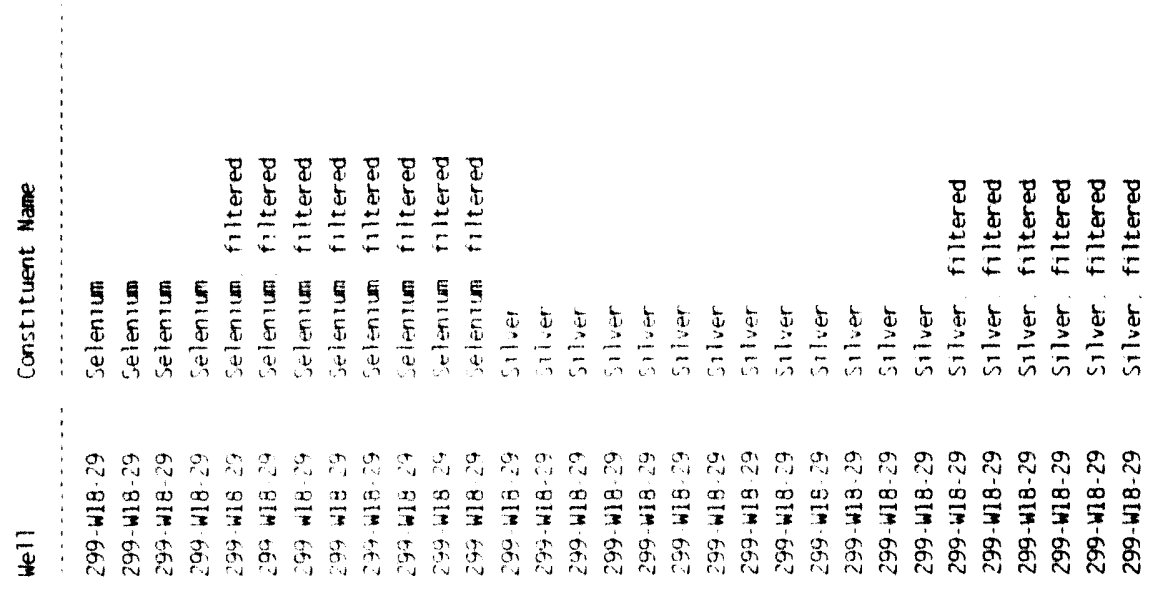




\section{WHC-EP-0674}
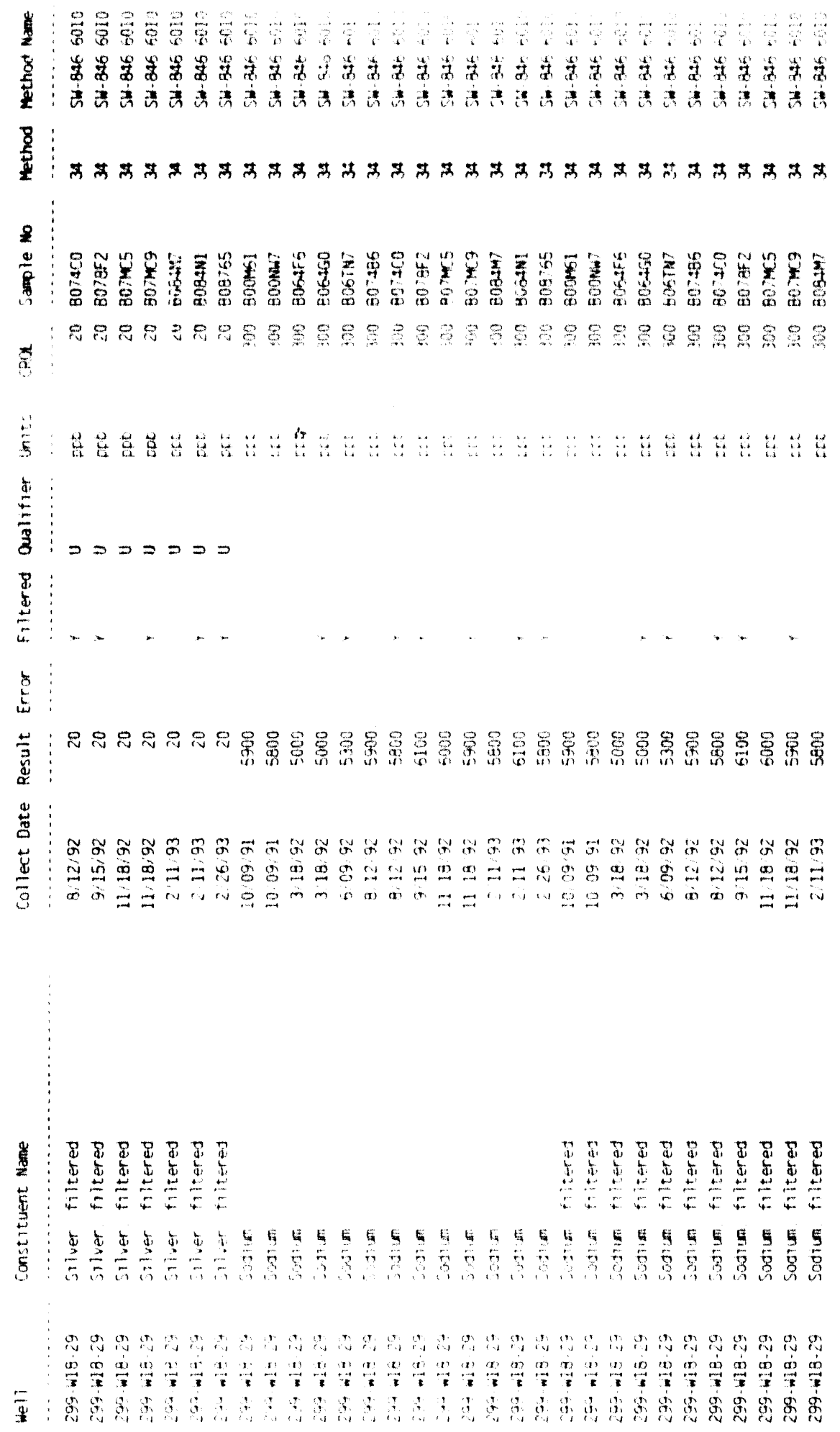


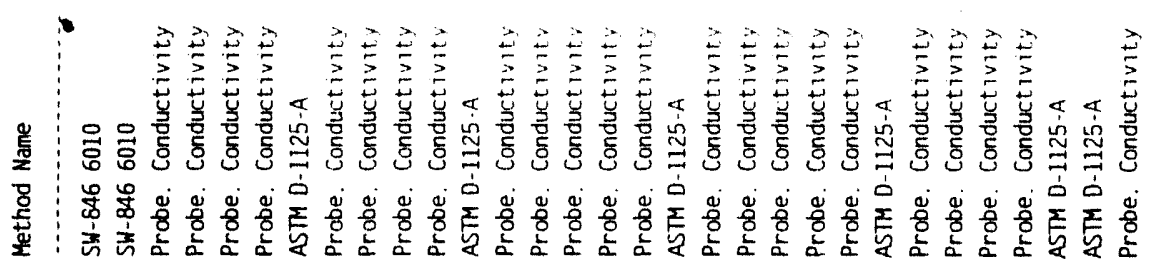

$\sqrt{1}$

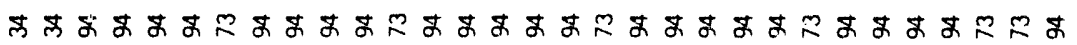

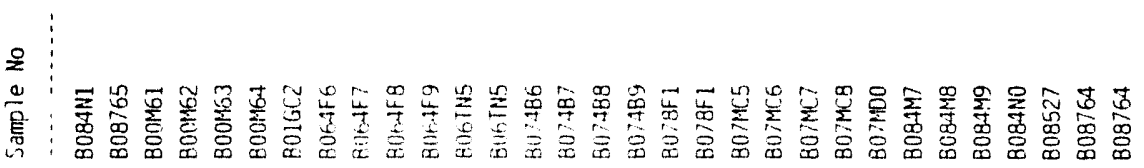

总:

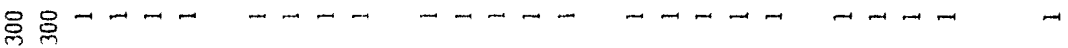

莺

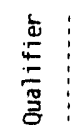

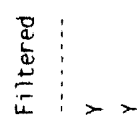

空

苛

范

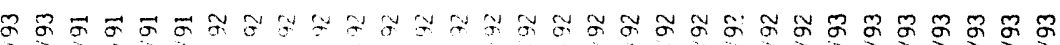

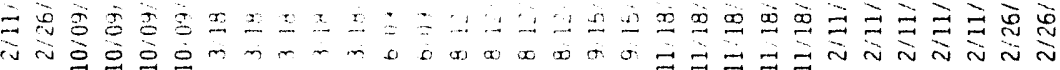

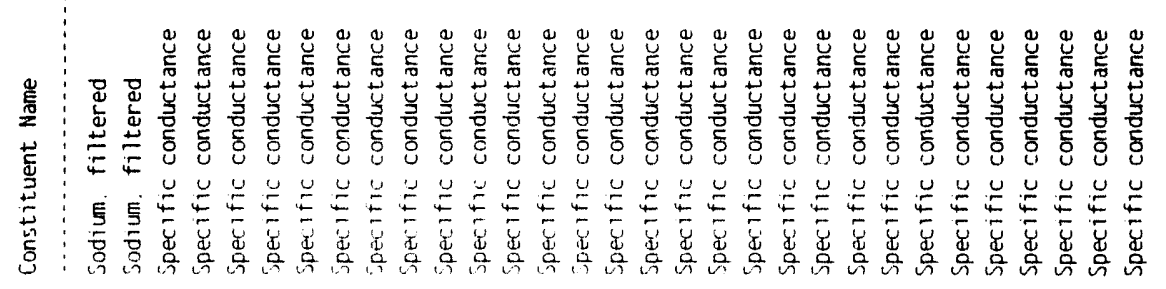

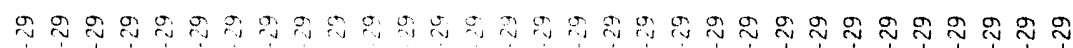

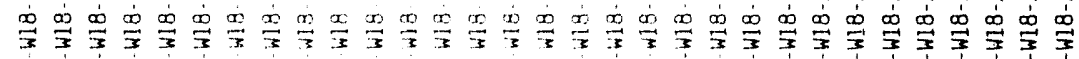

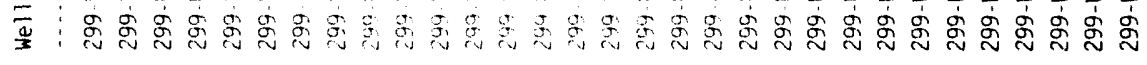




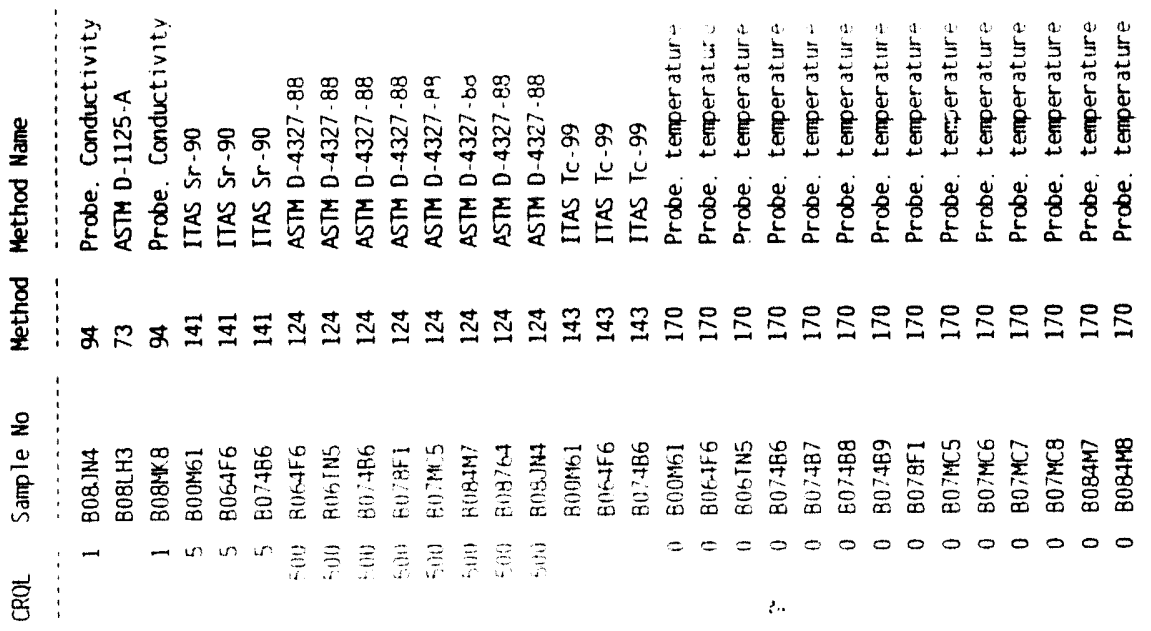

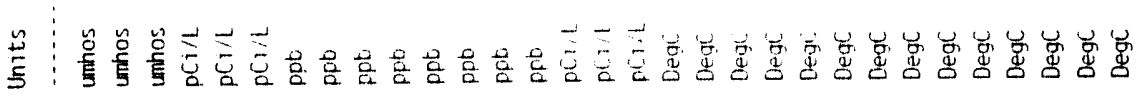

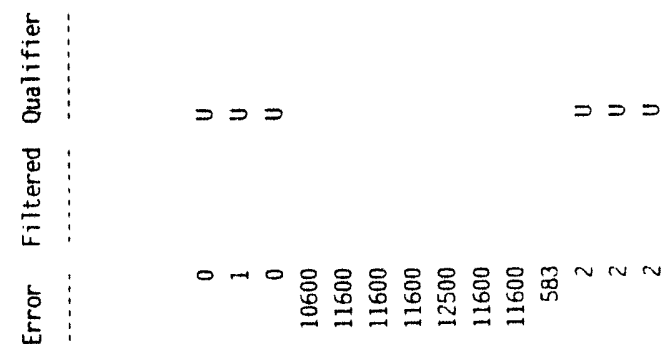

芸

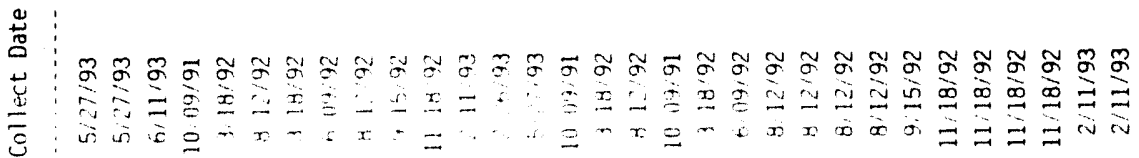

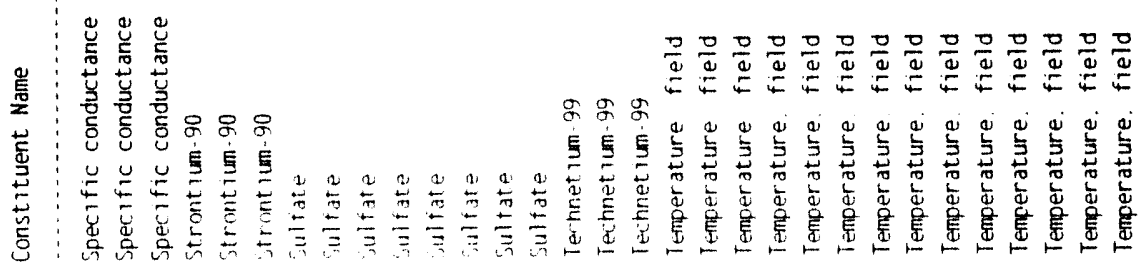

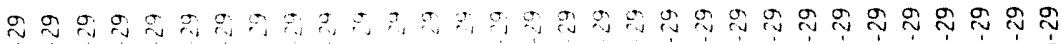

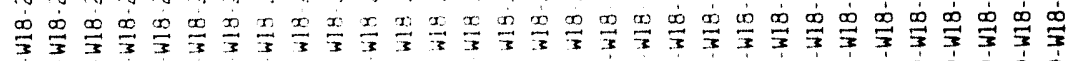
̄ 


\section{WHC-EP-0674}

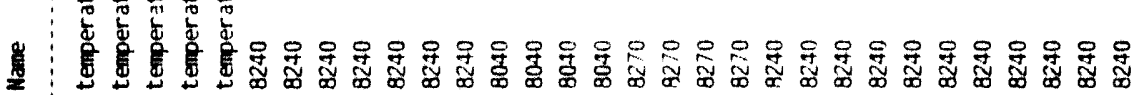
1ำ M. I!

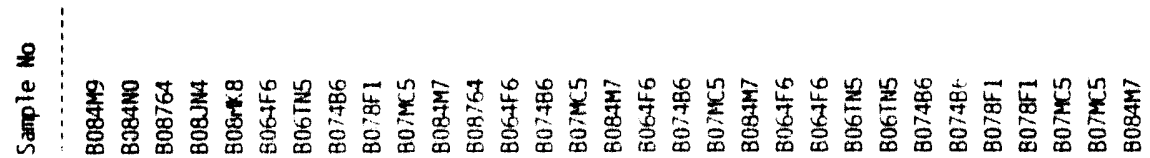
宕 oo 000 in $n$ n

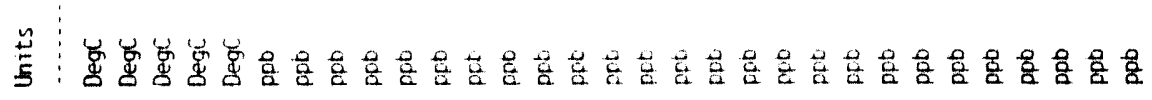

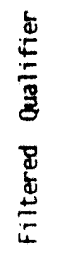

点

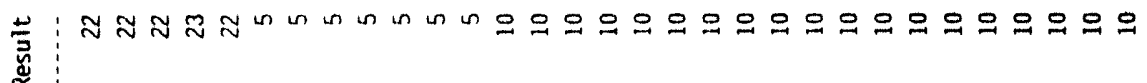
落

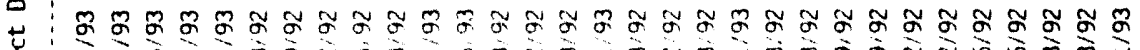

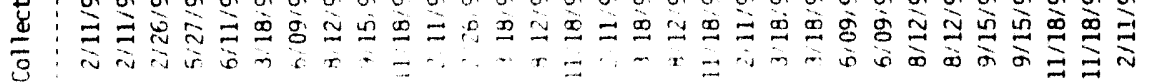

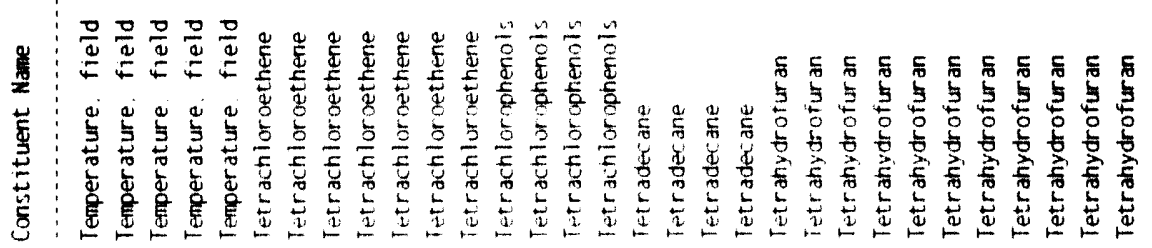

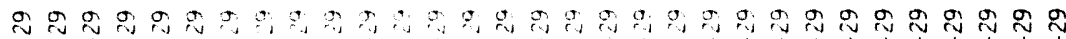

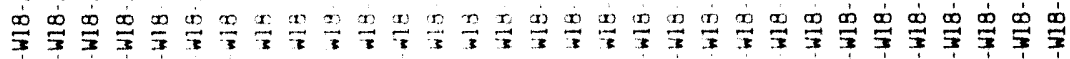

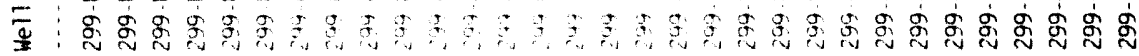




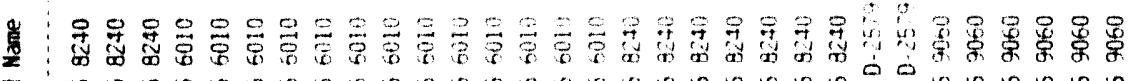

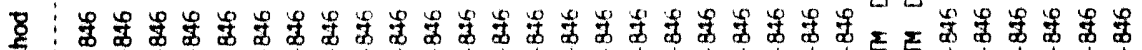

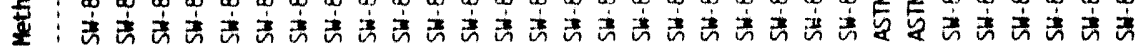
案

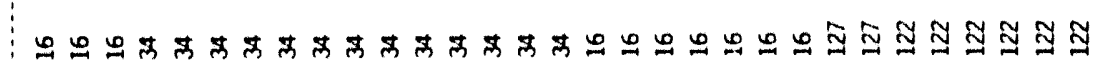

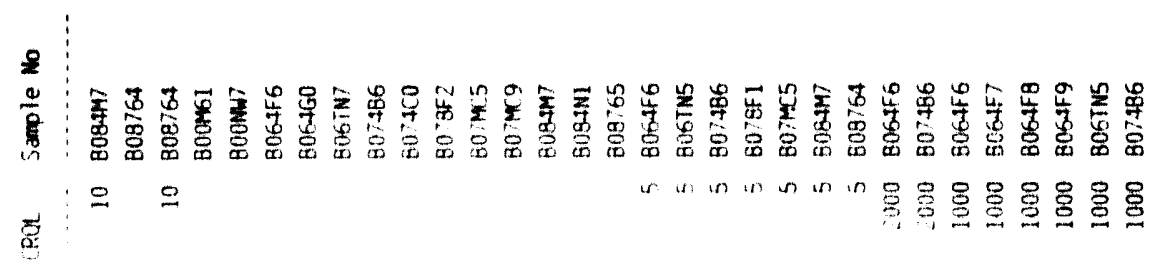

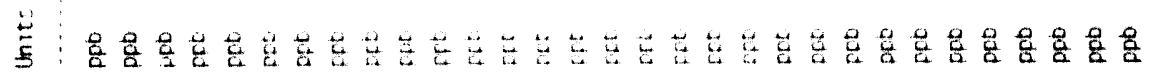
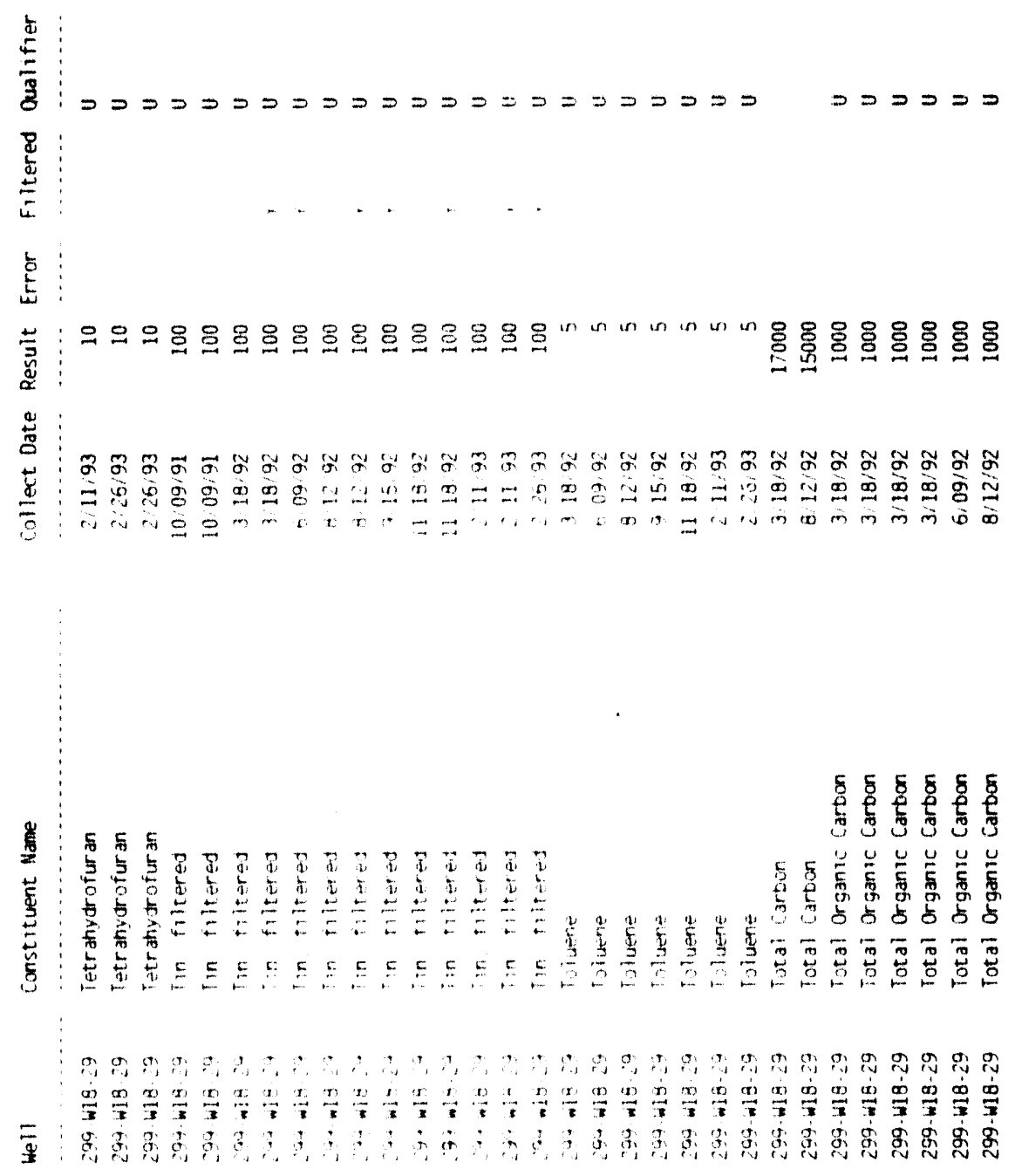


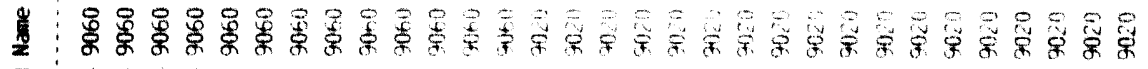

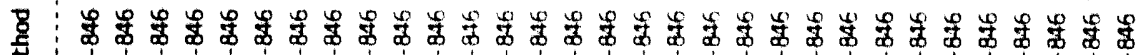

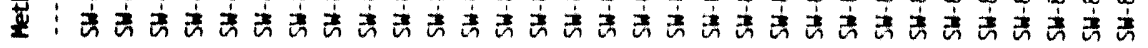

(8)

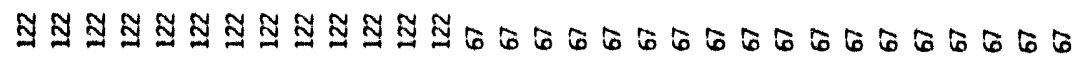
要

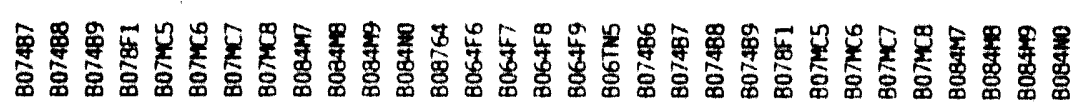

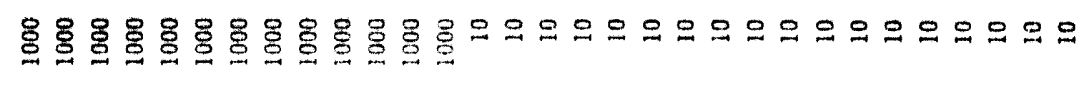

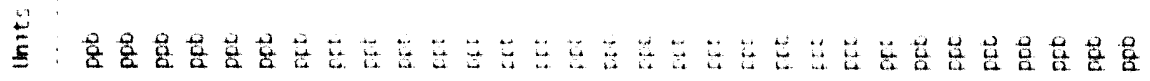
焉

to

洷 帘

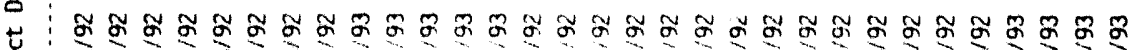
范

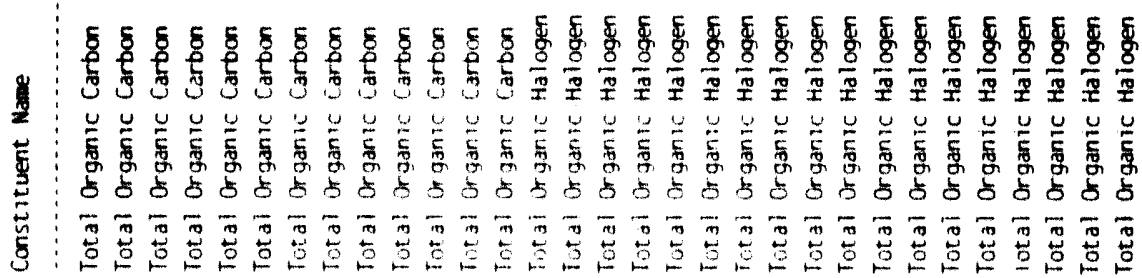

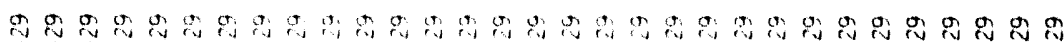

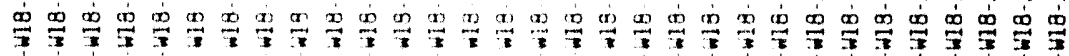

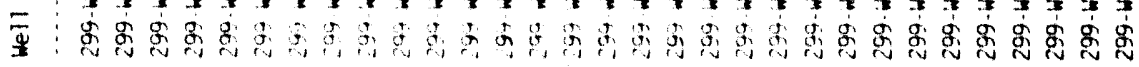




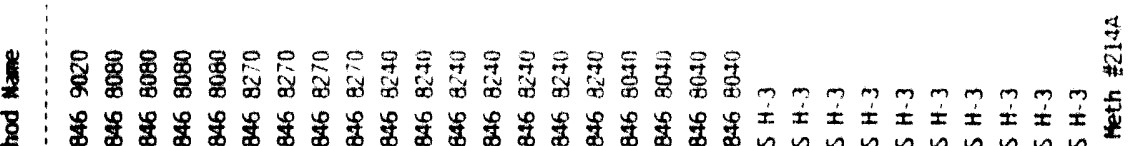

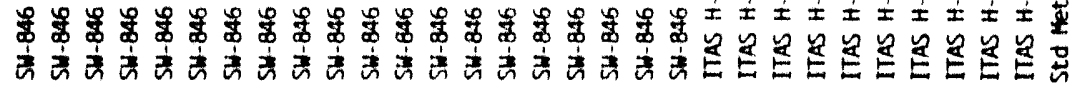

เレニニニ

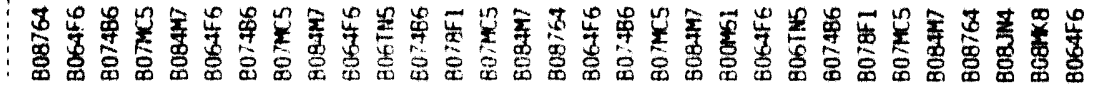

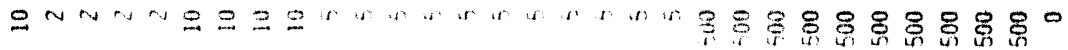
8

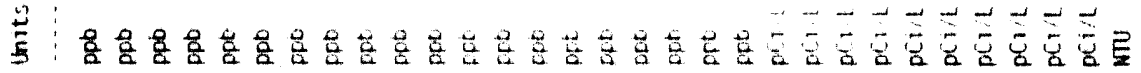
\begin{tabular}{l}
5 \\
5 \\
5 \\
\hline
\end{tabular}

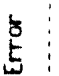

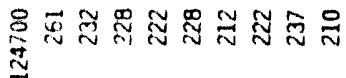
菜:

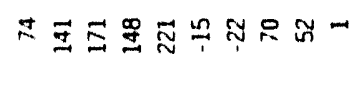
离

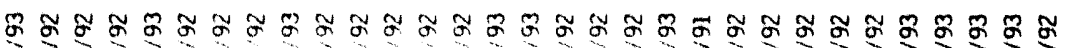

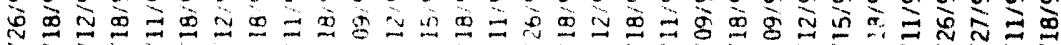

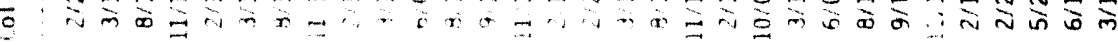

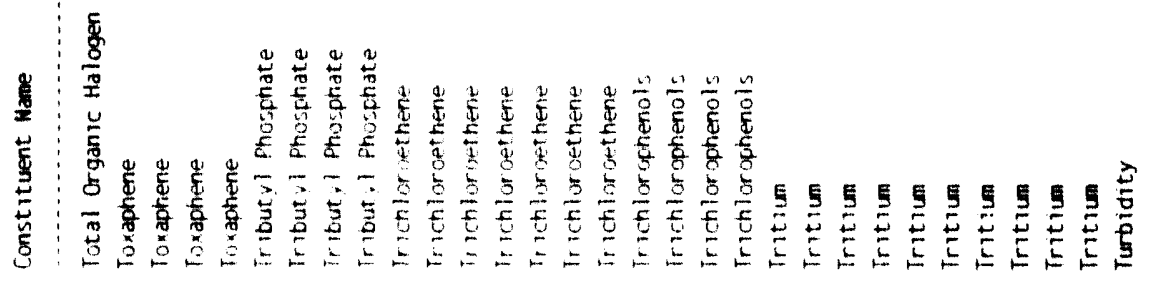

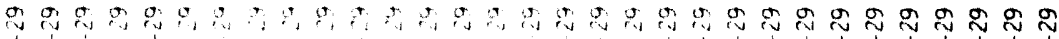

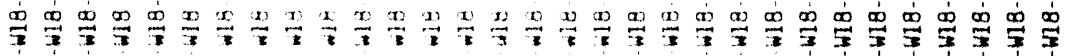

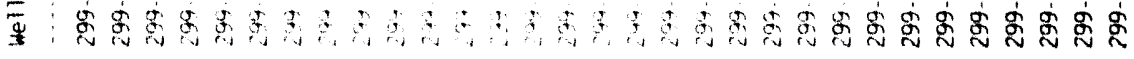




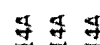

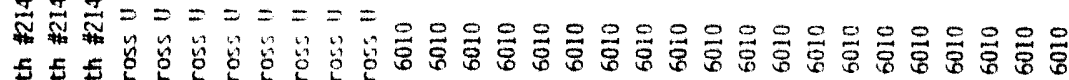

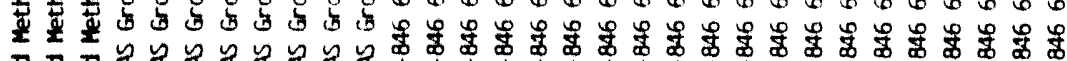

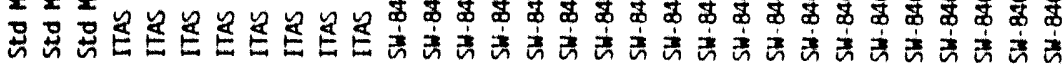

8

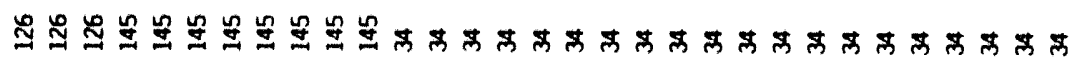

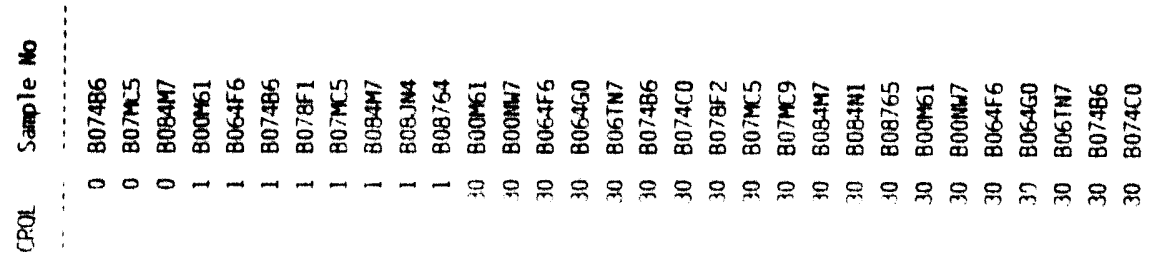

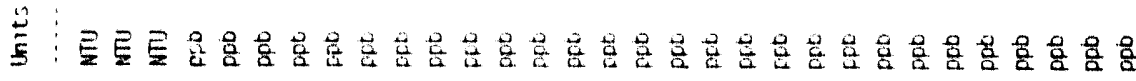

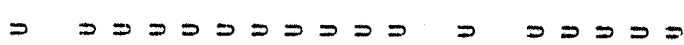

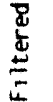

है:

$\frac{ \pm}{3}$

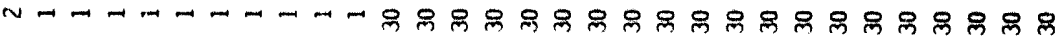

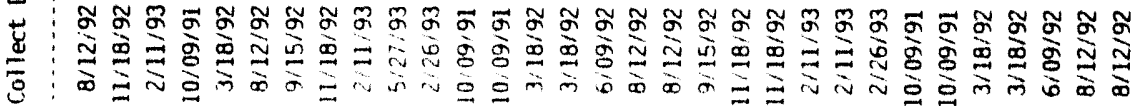

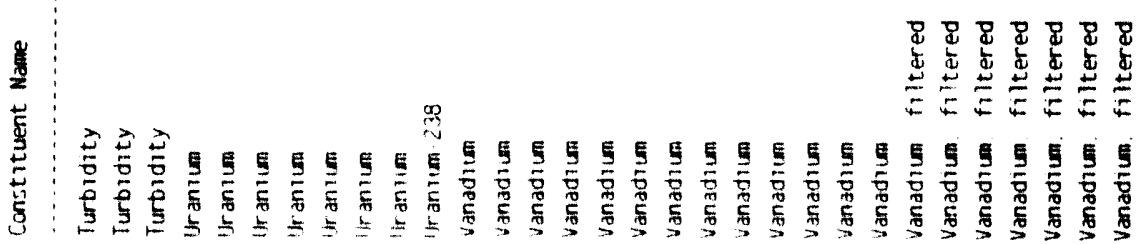

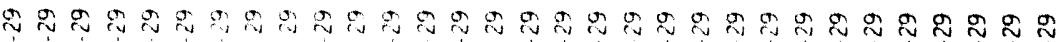

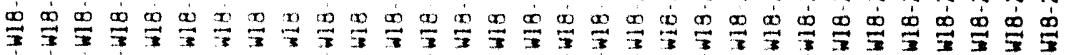

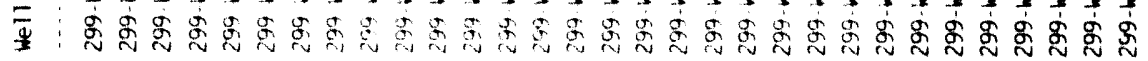




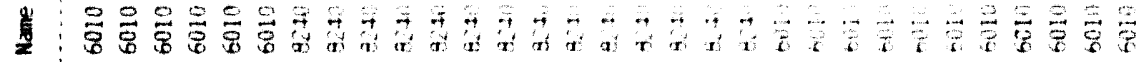

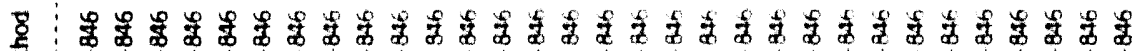

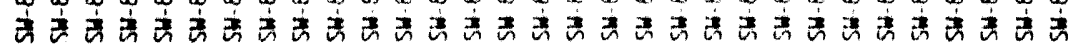

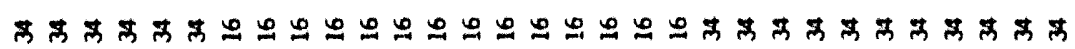

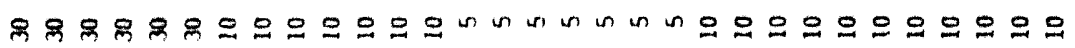

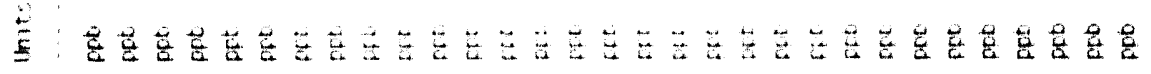

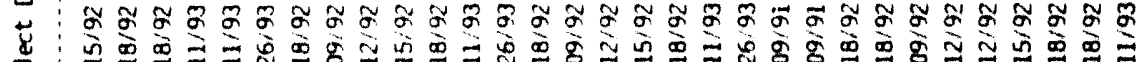

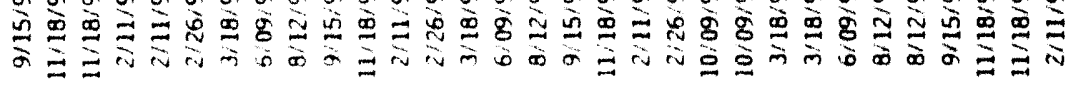

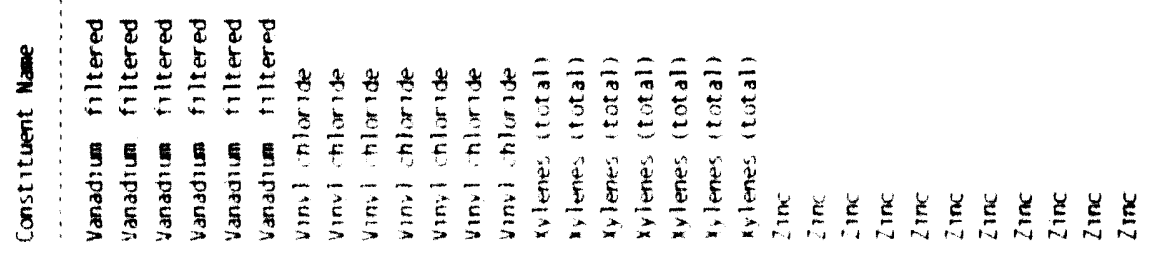

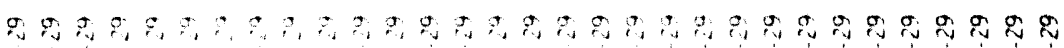

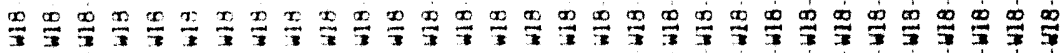

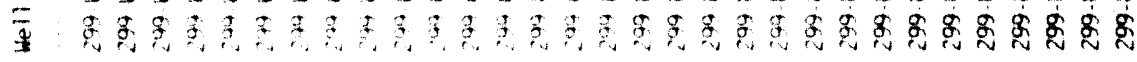




\section{5}

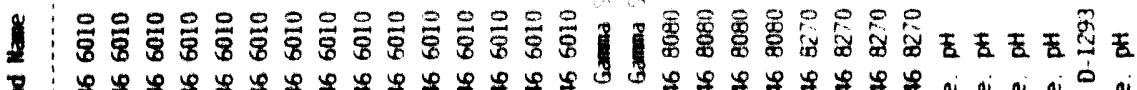

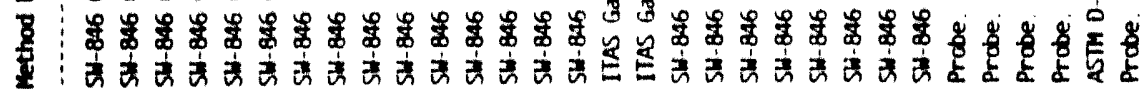

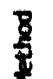

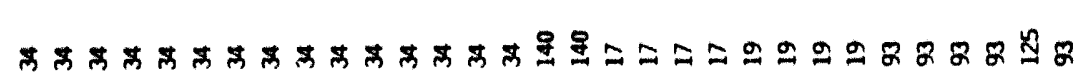

2

要

㻤

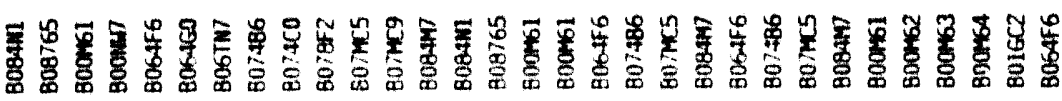

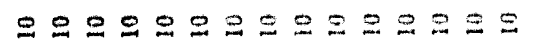

O0009900000

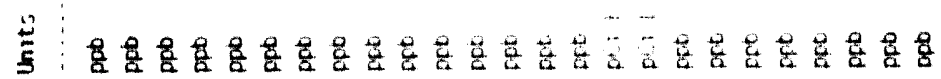

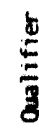

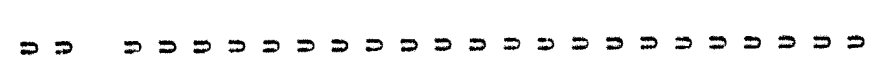

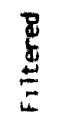

点

요 오

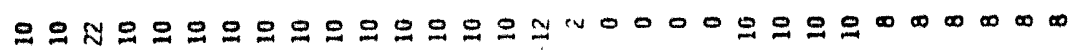

范

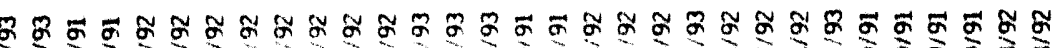

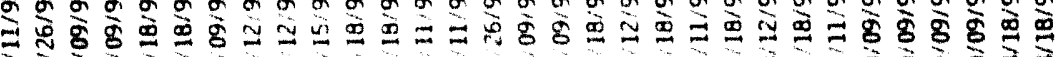

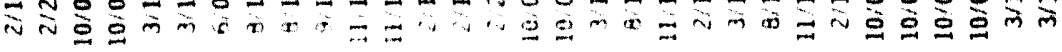

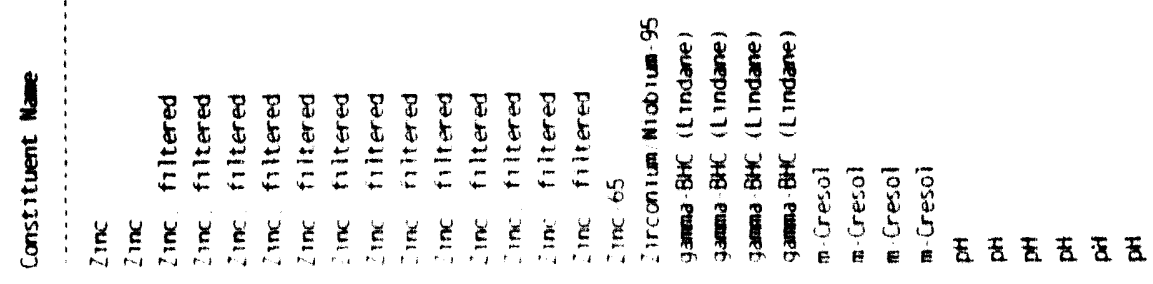

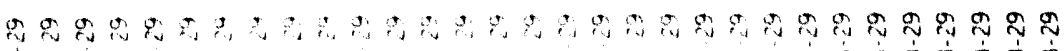

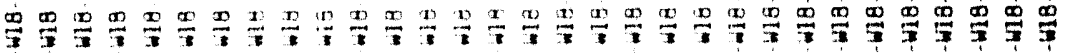

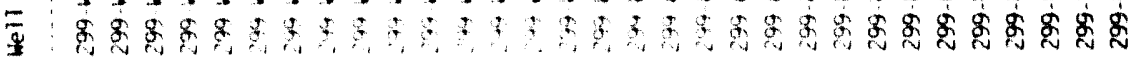




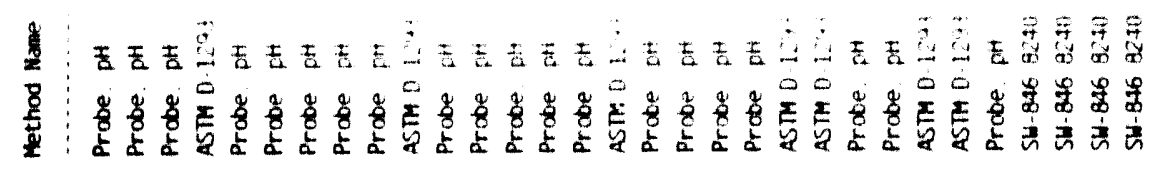

昰

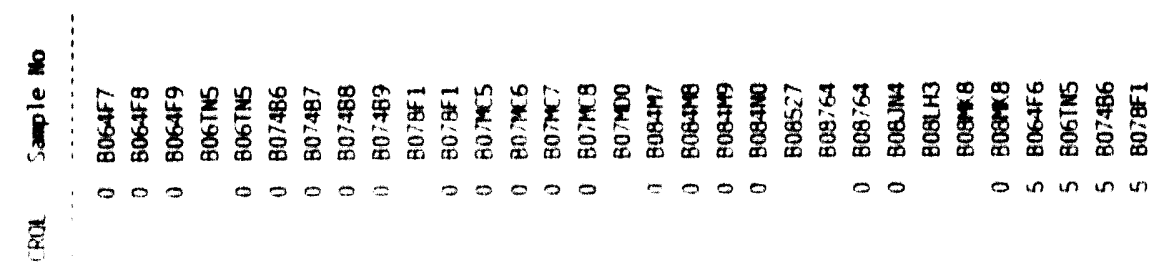

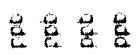

$\frac{5}{2}$
$\frac{9}{3}$
$\frac{8}{4}$
$\frac{8}{4}$

$p=0$

$\frac{5}{5}$

$\stackrel{4}{\mathscr{3}}$

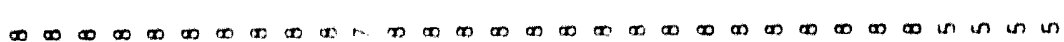

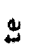

कू

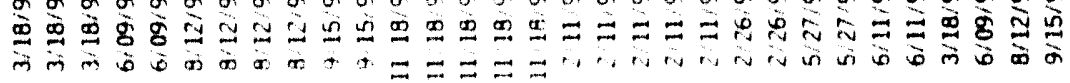

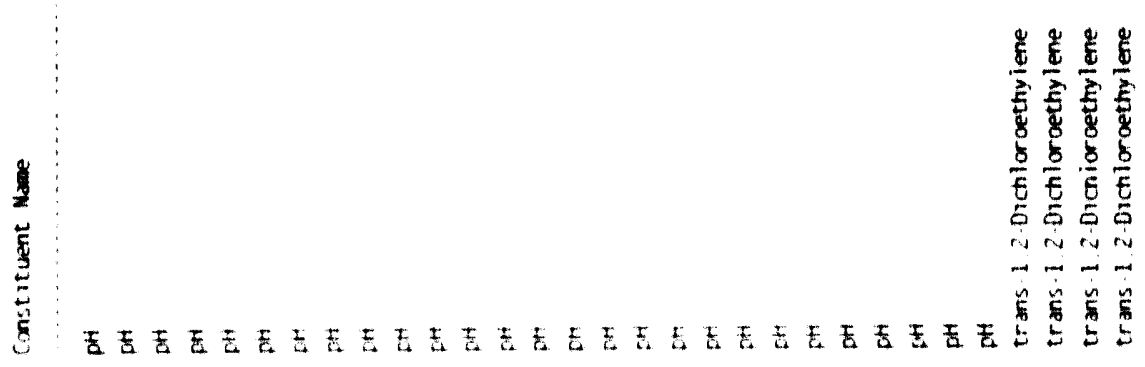

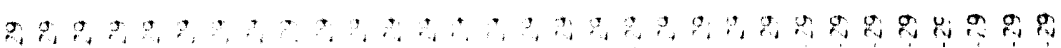

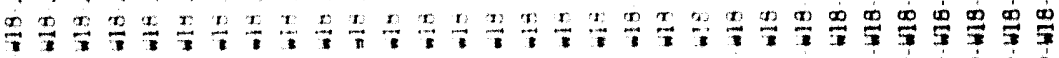
五 

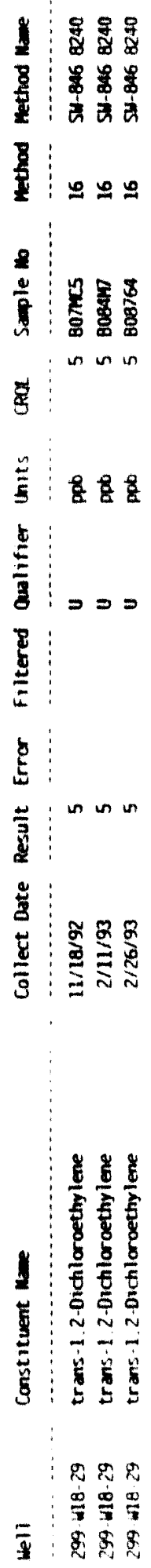
Summary of Provisional Hanford Site Groundwater Background Values" (Johnson 1993). (3 sheets)

\begin{tabular}{|c|c|c|c|c|}
\hline $\begin{array}{c}\text { Consel tuent } \\
\text { (concentration) }\end{array}$ & PNL resultes" & $\begin{array}{l}\text { UsCs results" } \\
\text { (sample } 120)\end{array}$ & $\begin{array}{l}\text { WHC unconfined } \\
\text { (somple } 120)\end{array}$ & $\begin{array}{l}\text { WHC provislonal } \\
\text { threshold } \\
\text { values }\end{array}$ \\
\hline Aluiman & 42 & $110 \underset{(12)}{ \pm} 139$ & $\begin{array}{l}<200 \\
(50)\end{array}$ & $<200$ \\
\hline$\underset{(p m b)}{A}$ & 450 & NA & $\begin{array}{l}<50 \\
(18)\end{array}$ & 120 \\
\hline $\begin{array}{c}\text { Arsenle } \\
(p p b)\end{array}$ & $3.9 \pm 2.4$ & $6.7{\underset{(7)}{ }}^{3.7}$ & $\begin{array}{c}45 \\
(14)\end{array}$ & 10 \\
\hline $\begin{array}{l}\text { Berlum } \\
\text { (ppb) }\end{array}$ & $42 \pm 20$ & ${ }_{(111)^{14}}$ & $41 \pm 2 \pm 20$ & 68.5 \\
\hline $\begin{array}{l}\text { Berylllium } \\
\text { (ppb) }\end{array}$ & $<0.3$ & NA & $\begin{array}{l}25 \\
(16)\end{array}$ & 45 \\
\hline $\begin{array}{l}\text { Bismuth } \\
\text { (ppb) }\end{array}$ & $<0.02$ & NA & (4) & 45 \\
\hline $\begin{array}{l}\text { Boron } \\
\text { (ppb) }\end{array}$ & $<50$ & $\begin{array}{l}550 \\
(14)\end{array}$ & $\begin{array}{l}\$ 100 \\
(35)\end{array}$ & $<100$ \\
\hline $\begin{array}{l}\text { Coctmilum } \\
\text { (ppb) }\end{array}$ & $<0.2$ & $\begin{array}{l}10 \\
\text { (1) }\end{array}$ & $\begin{array}{l}(10 \\
(16)\end{array}$ & $\$ 10$ \\
\hline $\begin{array}{c}\text { Colclum } \\
(p p b)\end{array}$ & $40,400 \pm 10,300$ & $40,857 \underset{(14)}{ \pm} 8,282$ & $\begin{array}{c}38,542 \pm 11,02 \\
\frac{3}{(53)}\end{array}$ & 63,600 \\
\hline $\begin{array}{c}\text { Chlorlda-lon } \\
\text { (ppob) }\end{array}$ & NA & $5,825 \underset{(8)}{ \pm} 1,355$ & $5,032 \underset{(53)}{ \pm 1,774}$ & 8,690 \\
\hline $\begin{array}{l}\text { Chlorlda-high } \\
\text { (ppb) }\end{array}$ & NA & $20,667 \underset{(6)}{ \pm 2,503}$ & $23,296 \underset{(14)}{ \pm 2,463}$ & 28,500 \\
\hline $\begin{array}{c}\text { Chlorlda-all } \\
\text { (ppb) }\end{array}$ & $10,300 \pm 6,500$ & $\begin{array}{c}12,186 \pm \underset{(14)}{ \pm} 7,842 \\
\end{array}$ & $\left.{ }_{(67)}^{8,848 \pm}\right)^{7,723}$ & NC \\
\hline $\begin{array}{c}\text { Chromium } \\
(p p b)\end{array}$ & $4 \pm 2$ & $\begin{array}{l}550 \\
\text { (111) }\end{array}$ & $\begin{array}{l}<30 \\
(8)\end{array}$ & $<30$ \\
\hline $\begin{array}{l}\text { Copper } \\
\text { (ppb) }\end{array}$ & 21 & $\begin{array}{l}110 \\
(10)\end{array}$ & $\begin{array}{l}<30 \\
(50)\end{array}$ & $<30$ \\
\hline $\begin{array}{c}\text { Fluoride } \\
(p p b)\end{array}$ & $370 \pm 100$ & $550 \underset{(16)}{ } 330$ & $437 \pm \pm_{(47)^{131^{c}}}$ & $\begin{array}{l}1,340 \\
775^{\circ}\end{array}$ \\
\hline $\begin{array}{l}\text { Iron- } 10 \mathrm{~m} \\
(p p b)\end{array}$ & NA & $22 \pm 16^{6}$ & $\begin{array}{l}550 \\
(34)\end{array}$ & 86 \\
\hline $\begin{array}{l}\text { Iron-mid } \\
(p p b)\end{array}$ & NA & $\mathrm{NA}$ & ${ }_{(7)}^{115} 52$ & 291 \\
\hline $\begin{array}{c}\text { Iron-hlgh } \\
(p p b)\end{array}$ & NA & NA & ${ }^{494} \frac{ \pm}{(12)}^{118}$ & 818 \\
\hline $\begin{array}{l}\text { Iron-all } \\
\text { (ppb) }\end{array}$ & NA & NA & $149 \underset{(53)}{ \pm} 199$ & NC \\
\hline $\begin{array}{l}\text { Lead } \\
\text { (ppb) }\end{array}$ & $<0.5$ & $\begin{array}{l}230^{*} \\
(6)\end{array}$ & $\begin{array}{c}25 \\
(15)\end{array}$ & 45 \\
\hline $\begin{array}{l}\text { Magnasiun } \\
\text { (ppob) }\end{array}$ & $11,800 \pm 3,400$ & $10,814 \underset{(16)}{ \pm 1,813}$ & $11,190 \underset{(14)}{ \pm} 2,578$ & 16,480 \\
\hline $\begin{array}{c}\text { Manganase- low } \\
\text { (ppb) }\end{array}$ & NA & $26 \underset{(8)}{ \pm 27}$ & $\begin{array}{l}<20 \\
(33)\end{array}$ & 24.5 \\
\hline $\begin{array}{c}\text { Manganwee-high } \\
(p p b)\end{array}$ & NA & $150 \pm 87$ & $\underset{(20)}{118 \pm 17}$ & 163.5 \\
\hline
\end{tabular}


Summary of Provisional Hanford Site Groundwater Background Values" (Johnson 1993). (3 sheets)

\begin{tabular}{|c|c|c|c|c|}
\hline $\begin{array}{c}\text { Constl tuent } \\
\text { (concentration) }\end{array}$ & PNL result te" & $\begin{array}{l}\text { uscs resul t:" } \\
\text { (semple size) }\end{array}$ & $\begin{array}{l}\text { WHC unconf ined" } \\
\text { (semple s/ze) }\end{array}$ & $\begin{array}{c}\text { WHC provisional } \\
\text { threshold } \\
\text { valuas }\end{array}$ \\
\hline$\underset{(p p b)}{\operatorname{Mangennse-all}}$ & $\cdots$ & ${ }_{(11)^{73}}{ }^{70}$ & $50 \underset{(53)}{ \pm} 35$ & NC \\
\hline $\begin{array}{l}\text { Mercury } \\
\text { (ppb) }\end{array}$ & $\because$ & NA & $\begin{array}{l}80.1 \\
(14)\end{array}$ & $<0.1$ \\
\hline $\begin{array}{l}\text { Nlckel } \\
\text { (ppob) }\end{array}$ & 24 & $\begin{array}{l}450 \\
(14)\end{array}$ & $\begin{array}{l}30 \\
(23)\end{array}$ & 430 \\
\hline $\begin{array}{l}\text { Nitrate } \\
\text { (ppb) }\end{array}$ & MA & $3,224{ }_{(13)} 3,380$ & $5,170 \underset{(78)}{ \pm} 3,576$ & 12,400 \\
\hline $\begin{array}{l}\text { Phosphete } \\
\text { (ppb) }\end{array}$ & $<1,000$ & ${ }_{(3)}^{140 \pm 62}$ & $<1,000$ & $<1,000$ \\
\hline $\begin{array}{l}\text { Potasefium } \\
\text { (ppos) }\end{array}$ & $4,950 \pm 1,240$ & $5,900 \underset{(14)}{ \pm 1,253}$ & $4,993 \pm(53) 1,453$ & 7.975 \\
\hline $\begin{array}{l}\text { Selenium } \\
\text { (ppos) }\end{array}$ & $<2$ & NA & $\begin{array}{c}45 \\
(14)\end{array}$ & 45 \\
\hline $\begin{array}{l}\text { sllver } \\
\text { (Dpob) }\end{array}$ & $<10$ & NA & $<10$ & $<10$ \\
\hline $\begin{array}{l}111 \text { con } \\
(p p b)\end{array}$ & MA & $16,786 \underset{(14)}{ \pm 3,683}$ & $18,152 \underset{(35)}{ \pm} 4,974$ & 26,500 \\
\hline $\begin{array}{l}\text { Sodium } \\
\text { (ppos) }\end{array}$ & $18,260 \pm 10.150$ & $20,286 \underset{(14)}{ \pm} 7,907$ & $15,774 \underset{(53)}{ \pm} 6,784$ & 33,500 \\
\hline $\begin{array}{l}\text { strontium } \\
\text { (ppb) }\end{array}$ & $236 \pm 102$ & $\begin{array}{c}159 \pm 78 \\
(14)\end{array}$ & ${ }^{164} \frac{ \pm}{(43)} 47$ & 264.1 \\
\hline $\begin{array}{l}\text { sulfote } \\
(p p b)\end{array}$ & $34,300 \pm 16,900$ & $41,286 \underset{(14)}{ \pm} 27,880$ & $\begin{array}{c}30,605 \pm 22,61 \\
1 \\
(67)\end{array}$ & 90,500 \\
\hline $\begin{array}{l}\text { Uranlum } \\
(p c i / L)\end{array}$ & $1.7 \pm 0.8$ & NA & $1.7 \pm 1.2$ & 3.43 \\
\hline $\begin{array}{c}\text { Venadium } \\
\text { (ppob) }\end{array}$ & $17 \pm 9$ & NA & $\begin{array}{c}9 \pm 4 \\
(18)^{4}\end{array}$ & 15 \\
\hline $\begin{array}{c}2 \text { inc-low } \\
(p p b)\end{array}$ & NA & ${ }_{(11)^{20}}$ & $\begin{array}{l}<50 \\
(36)\end{array}$ & 450 \\
\hline $\begin{array}{c}2 \text { Ine-hlgh } \\
(p p b)\end{array}$ & MA & $373 \pm 284$ & $247 \underset{(17)^{ \pm 165}}{ }$ & 673 \\
\hline $\begin{array}{c}2 \text { inc-all } \\
(p p b)\end{array}$ & $6 \pm 2$ & $91 \pm \frac{ \pm 190}{(14)^{-190}}$ & $95 \underset{(53)^{ \pm}}{ \pm 140}$ & NC \\
\hline Fiald $\underset{(p p b)}{\text { olkolinity }}$ & NA & $134,100 \underset{(10)}{ \pm} 20,469$ & $\begin{array}{c}137,758 \pm 33,6 \\
56 \\
(31)\end{array}$ & 215,000 \\
\hline Lab $\underset{(p a p b)}{(k a l \text { ininlty }}$ & $123,000 \pm 21,000$ & $130,000 \pm 8,165$ & $\begin{array}{c}133,717 \pm 29,3 \\
99 \\
(52)\end{array}$ & 210,000 \\
\hline Field pH & NA & NA & $\begin{array}{c}7.57 \pm 0.29 \\
(57)^{0.29}\end{array}$ & {$[6.90,8.24]$} \\
\hline Lab pH & $7.64 \pm 0.16$ & NA & ${ }_{(52)}^{7.75 \pm 0.21}$ & $(7.25,8.25)$ \\
\hline $\begin{array}{c}\text { TOC } \\
\text { (ppob) }\end{array}$ & $586 \pm 347$ & NA & $519 \underset{(62)}{ \pm} 367$ & $\begin{array}{l}2,610 \\
1,610^{\circ}\end{array}$ \\
\hline
\end{tabular}


Summary of Provisional Hanford Site Groundwater Background Values* (Johnson 1993). (3 sheets)

\begin{tabular}{|c|c|c|c|c|}
\hline $\begin{array}{l}\text { Const ituent } \\
\text { (concentration) }\end{array}$ & PNL resulte" & $\begin{array}{l}\text { USCS resultso } \\
\text { (sample s/ze) }\end{array}$ & $\begin{array}{l}\text { WHC unconflined" } \\
\text { (sample size) }\end{array}$ & $\begin{array}{l}\text { WHC provistonal } \\
\text { threshold } \\
\text { values }\end{array}$ \\
\hline $\begin{array}{l}\text { Pleld cond. } \\
\text { ( } \mu \text { mhos } / \mathrm{cm})\end{array}$ & MA & NA & ${ }_{(22)}^{344}{ }^{ \pm 3}$ & 339 \\
\hline $\begin{array}{l}\text { Lab cond. } \\
\text { ( } \mu_{\text {mhos } / \mathrm{cm})}\end{array}$ & $380 \pm 82$ & NA & $\underset{(36)}{332 \pm 93}$ & 530 \\
\hline $\begin{array}{l}\text { TOX, LDL } \\
\text { (ppb) }\end{array}$ & NA & NA & $\begin{array}{l}220^{c} \\
(14)\end{array}$ & $\begin{array}{r}60.8 \\
37.6^{\circ} \\
\end{array}$ \\
\hline $\begin{array}{c}\text { POC } \\
\text { (ppb) }\end{array}$ & NA & NA & $\begin{array}{c}31,772 \pm 7.022 \\
(48)\end{array}$ & 50,100 \\
\hline $\begin{array}{l}\text { Gross olphe } \\
(p C \mid / L)\end{array}$ & $2.5 \pm 1.4$ & NA & $\frac{2.5 \pm 1.5}{(36)^{1.5}}$ & $\begin{array}{c}63 \\
5.79^{\circ}\end{array}$ \\
\hline $\begin{array}{l}\text { Grose bota } \\
(p C \mid / L)\end{array}$ & $19 \pm 12$ & NA & $7.1 \pm 2.6_{(46)}^{2}$ & $\begin{array}{c}35.5 \\
12.62^{\prime}\end{array}$ \\
\hline $\begin{array}{l}\text { Radlum } \\
(\mathrm{pCl} / \mathrm{L})\end{array}$ & $<0.2$ & NA & $\begin{array}{l}\text { ND } \\
(10)\end{array}$ & 0.23 \\
\hline
\end{tabular}

Notes Johnson, v. O., 1993, Mert Inghouse Henford Comoany Operectlongl Groundweter

Stetur Regers, WHC-EP-0595, Wost Inghouse Hanford Company, Richland, Washington.

sourcel From Tables 5.9 and 5.11 of DOE-RL (1992b).

Resulte shoun are meen \pm one standard deviation.

"Potentlal outller observation(s) were removed.

LOL = lower detection limit.

WA " not evallable.

NC - not calculated.

ND = not detected.

PNL = Pacifle Northwest Laboratory.

ppb = parte per billion.

TOC * total organic carbon.

rox - total organic halogen.

USCS - United states Geological survey.

WHC * Westinghouse Henford Company. 
WHC-EP-0674

This page intentionally left blank. 
WHC-EP-0674

APPENDIX C

SOIL COLUMN RADIONUCLIDE AND CHEMICAL DATA 
WHC-EP-0674

This page intentionally left blank. 
SOIL COLUMN RADIONUCLIDE AND CHEMICAL DATA

This appendix consists of internal letter reports that document soll column sampling and analysis and spectral gamma logging results for field work conducted in 1991 to evaluate the transuranic status of the 216-2-20 crib. Contents aro organized in the following three attachments:

C-1, Calculated and Observed Soll Column Transuranic Concentrations

C-2, Borehole Logging Activity Report

C-3, Shallow Soll Column Chemical and Radioanalytical Results (1987). 
WHC-EP-0674

This page intentionally left blank. 
WHC-EP-0674

Attachment $\mathrm{C}-1$

(28) Wostinghous:

\section{From: Geosctences Group}

Phone: 6-0916 H4-56

Date: July 10, 1991, July 18, 1991

SUbject: CALCULATED AND OBSERVED SOIL COLUMN TRU CONCENTRATIONS BENEATH THE 216-2-20 CRIB

To:

$$
\text { J. L. Brand T5.54 }
$$

cc: L. A. Garner $\begin{array}{rr}T 5-54 \\ \text { A. Jnepp } & H 4-56 \\ & \end{array}$

The purpose of this meno is to document recent subject-related measurements and calculations performed to assess the TRU status of contaminated soll beneath the 216-z-20 Crib. Results of spectral gamma logging to determine the presence and or actual depth distribution of americium and plutonium at the subject site are reported in a separate Geosciences Group mamo (Price, 1991). Findings of the spectral gamma logging effort will be referenced in this memo as appropriate.

\section{Defintitions}

A TRU-contaminated soil site is one at which 1) the average concentration of TRU in the potentially contaminated soll volume is estimated to be greater than $100 \mathrm{nC} / \mathrm{g}$ (at a soll density of $1.8 \mathrm{~g} / \mathrm{cm} 3$ ) or 2) has received more than 80 grams of plutonium per $100 \mathrm{m2}$ (DOE, 1987). The latter definition is based on characterization data showing TRU concentrations decrease rapidly with depth in Hanford solls (DOE, 1987; 0.3.9).

\section{Estimated Depth Distribution}

In order to calculate the average concentration for definition l) above, an appropriate site-specific depth increment over which to average the TRU inventory is needed. Ames and Serne (1991) have reviewed the expected behavior of americium and plutonium isotopes in Hanford solls under average effluent chemical conditions. The ir summary included wastewater discharged to the 216-2-20 Crib. They characterized this wastewater (PFP) as having low dissolved salt and low organic contents with a pH greater than 6 (or neutral to slightly basic) for which conservative distribution coefficient (Kd) values of 25 and 200 for plutonium and americium, respectively, were assigned (Ames and Serne, 1991; pp. 4.6, 4.19, 4.20). This information suggests plutonium would migrate at a faster rate than americium. Thus the soll column concentrations of these two transuranic radionuclides would be expected to exhibit a differential distribution with depth. 
Using the above information, an average erlb bottom area of $1412 \mathrm{m2}$, an average discharge rate to the $\mathrm{er} 1 \mathrm{~b}$ of $3.47 \mathrm{E}+71$ 1ters/month, and average soll properties, migration rates of 0.4 and $0.05 \mathrm{~cm} /$ day were estimated for plutonfum and amertctum (WHC, 1990; D. B-35). For 10 years (3650 days) of operation (1981 to 1991) this implies a maximum migration depth of 15 and 1.8 meters respectively. As Ames and Serne (1991) and Moody (1991) point out, these estimates are based on very conservative $\mathrm{Kd}$ values that may under estimate the actual retention of these radionuclides by Hanford solls. Additionally, it should be noted that either increasing the discharge rate to the crib or decreasing the effective crib area used to calculate inflitration would result in proportionally greater radionuclide migration rates.

\section{Soil Core Messurements}

Limited soll sampling results provide some clues concerning the representativeness of the above estimates. For example, four core samples were obtained along the centerline of the crib in December 1986 (Subrahmanyam and Uibricht, 1987). The cores were posittoned near the inlet end of the crib, midway and near the downslope end. The core samples were collectud by first augering down to the bottom elevation of the crib ( approx. I meters below grade). A $7.5 \mathrm{~cm}$ diameter by 1 -meter long split spoon core barrel was then driven into the soll and the resulting core subsampled from the top, mid and bottom over the nominal 1-meter length. Americium was analyzed by low energy gamma-ray spectrometry. A total of ten soll sections were analyzed for which a mean of $0.27+-0.54$ ( one sigma) and a maximum of $1.5 \mathrm{nCl} / \mathrm{g}$ was obtained. No particular pattern with depth was evident. The highest concentration was from the inlet end of the $\mathrm{crib}(1.5 \mathrm{nCl} / \mathrm{g})$ followed by the downslope end $(0.34 \mathrm{nCl} / \mathrm{g})$. It should also be noted that an Am-24l/Pu-239 ratio of 1-2 was reported for one core sample which was subjected to detalled $x$-ray spectral analysis. The input Am-24l/Pu-239 ratio to the crib was approximately 0.5 , supdorting the inferences concerning differential migration rates noted previousiy (1.e., the Am-241/Pu-239 ratio would increase with time as plutonium in the upper soil layer decreases due to its more rapid migration rate).

The above data suggest that a depth increment of at least one reter should be used for averaging and that active infiltration of wastewater has occurred over the entire length of the crib 


\section{Burched Bntere and sodimant Analvals}

The maximum migration depth is unknown, however, some inferences can be made that may set limits on the extent of downward migration. For exumle, as Moody (1991) pointed out, there is no evidence that plutonfum has aigrated all the way to the water table (approximately 67 meters below grade). In addition, perched water and sediment samples were collected and analyzed from a new well (299-W18-29) adjacent to the downslope end of the crib during Spring 1991. (Perched water refers to the occurrence of saturatad conditions above the general water table due to a layer of impermeable or semi-permeable strata that retards the downward movement of water). Split spoon core samples were taken in the vicinity of the perched water zone (produced by wastewater discharge to the 216-z-20 (rib). Perched water was encountered at 39 meters below grade. These samples were analyzed for both Am-241 and Pu-239 In the 222-S Radiochemistry Lab. A sample of the perched water was also collected and analyzed as the water plus suspended material. Analytical results for these samples are sumarized in Table l. All measurements were less than the indicated detection limits. These data suggest americium and plutonium have not migrated to a depth represented by the perched water zone. This observation is also consistent with the spectral gamma logging results for other monitoring wells located along the length of the crib (Price, 1991).

The installation of several drainage boreholes to a depth of 8 meters below grade and an acid spill in 1984 may have resulted in some remobilization and or greater depth of migration of some of the TRU already present in the crib or subsequently added. The acid splll probably had very little net effect on TRU migration since the carbonate in less than meter of soll beneath the crib was calculated to be more than sufficlent to neutralize the reported quantity of nitric acid involved (WHC, 1990). The effect of more direct pathways induced by the drainage boreholes is difficult to assess. However, as noted above, the negative spectral gamma logging results and the perched water sample and sediment analyses together suggest that americlum and plutonium have not reached the perched water level depth at approximately 39 meters below grade. 


\section{Gonaluations}

Based on the above arguments and data, the maxtmum depth incrament for averaging soll concentrations is taken as is moturs with a minimum of 1 mater. The impact of reducing the effective crib area is well is the effoct of averaging over various depth inerements is shown in figure 1 . This plot is besed on calculated soll concentrations resulting from a TRU inventory of 3.05 curies, consisting of the sum of Am-241, Pu-239 and Pu-238 roported in liquid discharges to the crib (Moody 1991).

The most conservative condition (highest concentrations) would be if all the inventory were assumed to be contained in a I-meter layer beneath the bottom of the crib. However, even under this unilikely condition, and oven if the effective crib area were reduced by 10 fold, the calculated sediment concentration would still be an order of magnitude lower than the $100 \mathrm{nCl} / \mathrm{g}$ needed to meet definition 1) for a TRU site. The actual expected concentrations, oven allowing for 1 sox reduction in the effective erib area, are less than $3 \mathrm{nCl} / \mathrm{g}$ (shown as the dashed box in figure 1).

The mass of Pu-239 added to the crib is calculated to be 33 grams. Assuming this is uniformly distributed over $1412 \mathrm{m2}$ on areal loading of 2 grams $/ 100 \mathrm{~m} 2$ is obtalnod, or grans $/ 100 \mathrm{~m} 2$ if only $50 x$ of the bottom area of the $\mathrm{cr} / \mathrm{b}$ is used. This is 20-40 times lower than the areal loading quantity of 80 grams/100 m2 for a TRU-contaminated soll site (definition 2 above).

On the basis of the above analysis of avallable data it is concluded that the 216-2-20 Crib does not meet oither definition of a TRU-contaminated soll site (DOE, 1987; p. 3.9).

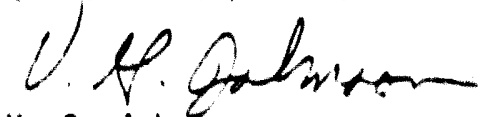

V. G. Johnson

Principal Scientist

Geosciencens Group

dy 1 ,

Attachment

CHECKED BY:

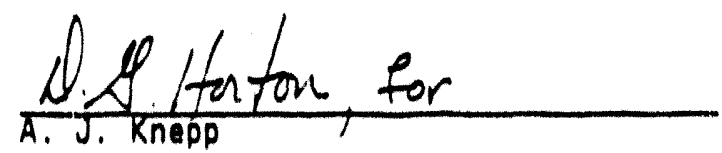

Date: $7 / 22 / 91$ 


\section{REFERENCES}

Ames, L. L. and R. J. Serne. 1991. Compllation of Date to Fstimnte Groundwater Miarstion Potentidel for Constituents in Active Liould Dischreans it the Hinford Site, PNL-7660, Pacific Northwest Laboratories, Richland, Washington.

DOE, 1987. Disposal of Hanford Defense Hiah-Level. Iransuranic and Tank Wastes, Final Environmental Impact Statement, DOE/EIS-0113, Vol. I, U.S. Department of Energy, Richland, Washington.

Moody, T. E. 1991. Westinghouse Hanford Internal Memo to

J. L. Brand, Letter No. 81223-91-013, June 27, 1991.

WHC, 1990. Llauld Effluent Study Final Project Reoert,

WHC-EP-0367, Westinghouse Hanford Operations, Richland, Washington.

Subrahmanyam, V. B. and W. H. Uibricht. 1987. Assessment and Evaluntion of Decreased Drainae of 216-2-20 Crib, SD-RE-TI-168, Rockwoll Hanford Operations, Richland, Washington.

Price, R. K. Westinghouse Hanford Internal Memo to J. L. Brand, Letter No. 81232-91-028, July 22, 1991 . 
TABLE 1. Radioanytical Results for Sediment Samples from Well 299-W18-29

\begin{tabular}{|c|c|c|c|c|}
\hline Sample iD & Depth (ft) & Sample Type & $\begin{array}{c}P C 1 / 9 \text { dry wt } \\
\text { Am-24l } \\
\text { Pu-239 }\end{array}$ & pec1/g \\
\hline 034913 & 27 & grab & $<.24$ & $\leq 50$ \\
\hline 014513 & 80 & grab & & \\
\hline 014916 & 100 & grab & $<.24$ & $<50$ \\
\hline 0141019 & 120 & grab & & \\
\hline 01411113 & 128 & baller/water & $* 10^{-4} u C 1 / 9<10^{-4} u C 1 / 9$ & $<50$ \\
\hline 01411116 & $129-131$ & Split spoon & $<.26$ & $<50$ \\
\hline 01412119 & $131-133$ & Split spoon & $<.26$ & $<50$ \\
\hline 01412122 & $133-135$ & Split spoon & $<.23$ & $<50$ \\
\hline 014235125 & $150-152$ & Solit spoon & $<.24$ & $<50$ \\
\hline
\end{tabular}

Raw data avtlable.

- As fllterable solids

NOTE: Less than values are reported as less than the detection limit appropriate for each determination. (Variable detection limits arise because of variation in sample size and/or counting time used.) 
Figure 1

\section{Calculated TRU Concentrations vs. Sediment Depth and Crib Area}

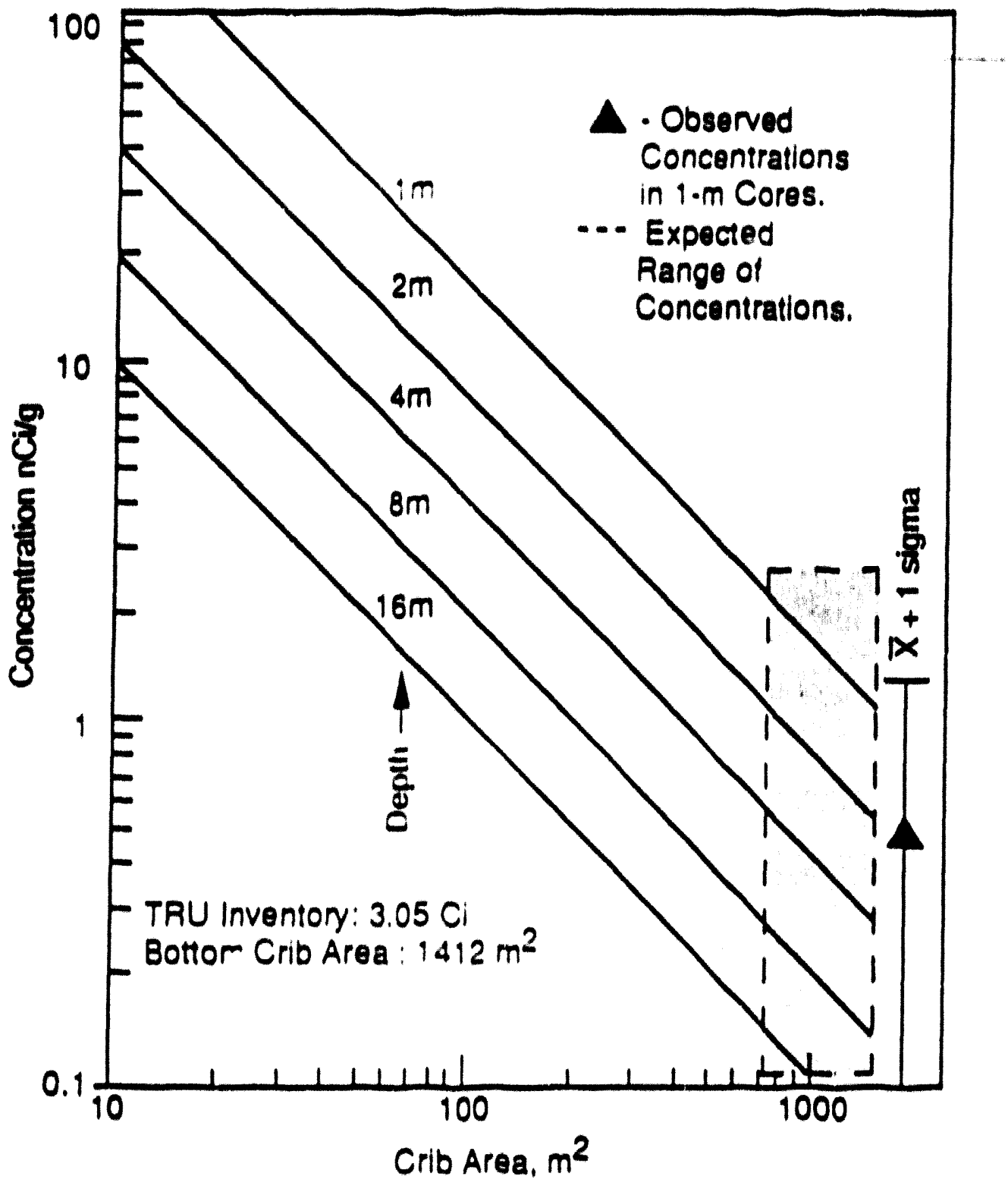


WHC-EP-0674

This page intentionally left blank. 
WHC-EP-0674

Attachment $\mathrm{C}-2$

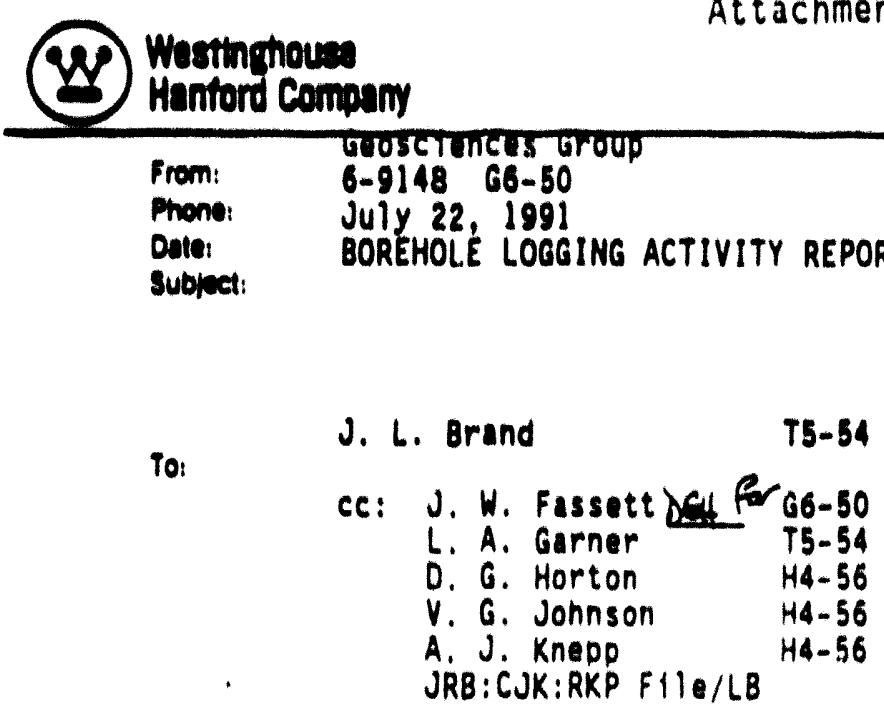

\section{EXECUTIVE SUMMARY}

Borahole logging of four existing groundwater monitoring wells and a newly constructed RCRA monltoring well near crib 216-2-20 was completed June 19, 1991 with the high purity germanium system in the Radionuclide Logging System (RLS). The objective was to identify depth intervals containing americium and plutonium. Gross count gamma-ray profiles along each well bore length were recorded then used to identify numerous depth positions along each well to be selectively scanned for extended counting times with the germanium detector. No depth intervals were identified which had gamma-ray activity greater than the normal background. No gamma-ray signals indicating the existence of americlum or plutonium were found. The identification numbers of the five wells along the $2-20$ crib that were logged for this project are:

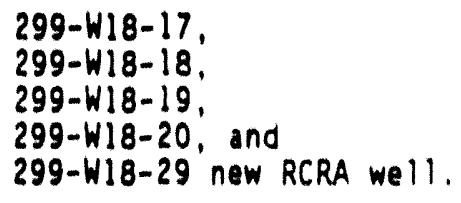

HISTORICAL DATA

Since no sources of borehole-spectfic historical data for the $2-20 \mathrm{cr}$ tb were found prior to initiation of logging activities, transuranic

concentration information from an adjacent transuranic site was utilized.

This information was taken from the report RHO-ST-17, "Distribution of Plutonium and Americium beneath the 216-2-1A Crib, Status Report," (Rockwell Hanford, February 1979).

RHO-ST-17 presents results of laboratory analysis from drill cutting samples of several newly constructed boreholes. Two boreholes near the 
J. L. Brand

Page 2

July 22, 1991

216-Z-1A crib were logged by the RLS to demonstrate that americium and plutonium gamma-ray signals are identifiable. The borehole numbers are:

$299-W 18-159$

$299-W 18-171$

\section{TRANSURANIC GAMMA-RAY IDENTIFICATION}

Borehole 299-W18-159 was selected based on the laboratory analysis of several closely spaced drill cutting samples that appeared to be the most uniform through a depth range of at least three meters. The americium concentrations between 3 and 6.5 meters $(10-21 \mathrm{ft})$ cluster about the 100 $\mathrm{nCi} / \mathrm{g}$ level. The plutonium concentrations through this depth interval exhibit the most uniformity but are more variable than the americium. A graphical summary of the laboratory analysis data is duplicated in Figure I.

Borehole 299-W18-159 was logged on March 19, 1991. The depth interval was 0.0 to 60.0 feet. The logging speed was 20 feet/hour. A representative gamma-ray spectrum is shown in Figure 2. Spectrum A0291027. CHN represents the gamma-ray activity observed at 13.5 to 14.0 feet (4.2 meters) below the ground leve1. Ground level within crib 2:16-Z-1A is the zero reference of the logging data. The spectrum in Figure 1 was selected to represent the gamma-ray activity that is characteristic of americium and plutonium concentrations near 100 nanocuries per gram. The counting time for this depth interval was only 56 seconds. A logarithmic scale for the vertical axis effectively reflects the number of gamma-ray peaks present. All gamma-ray peaks in this display, except the 609- and 583-keV peaks from naturally occurring uranium and thorium, are identified as signals from americium-241, plutonium-239 and plutonium-240. The source for identification is "The Gamma Rays of the Radionuclides" by Gerhald Erdtmann and Werner Soyka (1979).

Spectra A0291027. CHN is displayed in figure 3 with the vertical scale changed from logarithmic to linear. The change permits more effective comparisons with the remaining figures. Note that the maximum range for the vertical scale is 3000 counts. The remaining displays have a maximum vertical scale range of only 300 counts.

Borehole 299-W18-171 was selected on the bases of low concentrations of americium and plutonium. This borehole is located about 10 feet outside the perimeter fence of the 216-2-1A crib. The laboratory analyses of drill cutting samples reported concentrations of americium and plutonium that did not exceed approximately $0.1 \mathrm{nCi} / \mathrm{g}(100 \mathrm{pCi} / \mathrm{g})$. The graphical presentation of the laboratory analysis data from the report is duplicated in Figure 4. 
J. L. Brand

Page 3

July 22, 1991

Borehole 299-W18-171 was logged with the RLS on February 13, 1991. The depth interval was 0.0 to 99.0 and 115.5 to 124.0 feet. The logging mode was move-stop-acquire with a counting time of 180 seconds at each half foot sample station. Spectrum A0231079.CHN, shown in figure 5, is from the depth location at 84.0 feet were the gamma-ray activity from man-made radionuclides is most intense. The counting time was over three times longer than the spectra from the center of the 216-2-1A crib. All gamma-ray peaks in this display, except three peaks, are identified as americium-241. The three exceptions are the 352- and 609-keV ganma-ray peaks from naturally occurring uranium and the 583-keV gamma-ray peak from naturally occurring thorium.

\section{GEOPHYSICAL BOREHOLE LOGGING OF CRIB 216-Z-1A}

Borehole data acquisition of high resolution germanium gamma-ray spectroscopy by the RLS required several days of field activity. The measurements were completed on June 19, 1991. The details of the in situ borehole measurements are given in Appendix A: "Record of Borehole Geophysical Data Acquisition." The counting time for detailed radionuclide identification were at least 150 seconds. The detailed spectra from the remaining three boreholes were recorded over 500-second acquisition times after concerns were voiced about the lower detection limit for transuranics.

The logging speed for the newly constructed RCRA groundwater monitoring well was the normal 20 feet per hour. The limited financial budget for RCRA activities was the cause of reduced time on the well.

The field activities were performed in accordance to WHC procedures. The current equipment configuration and data acquisition standards are given in Appendix $B$. The spectral borehole logging equipment is undergoing development that will continue for several more months. The measurements have been stored on permanent non-erasable media, so the data can be retrieved at a later date and concentrations of the gamma emitting radionuclides present in the formation can be calculated.

The objective of the borehole logging was satisfied: gamma-ray spectra from boreholes around the 216-2-1A crib prove that americium and plutonium can be detected, and gamma-ray spectra from the $216-2-20 \mathrm{crib}$ boreholes do not show peaks characteristic of americium and plutonium. The ability to precisely quantify the minimum detectable concentration limits for americium and plutonium has not been established at the time of this 
ง. L. Brand

Page 4

July 22, 1991

report. Analytical algorithms are in progress and additional capabilities

will be forthcoming. However, if the laboratory work reported in RHO-ST-17 is credible, then the spectra from the 216-2-20 crib boreholes indicate that the americium and plutonium concentrations, if different from zero, are significantly below 100 nanocuries per gram.

Analysis of all spectra from the five boreholes associated with crib 216-2-20 indicate that all of the identifiable gamma-ray are associated with the naturally occurring sources, namely potassium, uranium, and thorium. Figure, a typical spectrum, was recorded in borehole 299-W18-19 at the depth of 57.5 feet. The counting time of 500 seconds is about ten times longer than the spectra in figure 3. Five gamma-ray peaks were identified. The gamma-rays are:

$\begin{array}{ccc}\text { Gamma-ray } & \text { Daughter } & \text { Original } \\ \mathrm{keV} & \text { Radionuclide } & \text { Radionuclide } \\ 295 & \text { Pb-214 } & U-238 \\ 352 & \mathrm{~Pb}-214 & U-238 \\ 510 & T 1-208 & T h-232 \\ 583 & T 1-208 & T h-232 \\ 609 & 81-214 & U-238\end{array}$

The gamma-ray from naturally occurring potassium-40, at $1460.7 \mathrm{keV}$, is beyond the energy ranges displayed in these figures. All spectra acquired by the RLS include the maximum energy of $2800 \mathrm{keV}$. The figures in this report did not include the spectral information above $800 \mathrm{keV}$ because the naturally occurring gamma-rays dominate the spectra at the higher energies. other man-made radionucl ides have gamma-ray photo peaks above $800 \mathrm{keV}$, cobalt-60 is one prominent example.

\section{CONCLUSIONS}

High resolution spectral gamma-ray borehole logging of five wells adjacent to the 216-2-20 crib was completed June 27, 1991. The in situ geophysical measurements along the entire length of each borehole indicated that only the natural radionuclides of potassium, uranium, and thorium were present. No man-made radionuclides were identified in the five wells adjacent to the $z-20 \mathrm{crib}$.

The justification of the statement is based on measurements by the same borehole gamma spectroscopy tool in two boreholes associated with a known transuranic site, 216-Z-1A. The man-made radionuclides, americium and 
J. L. Brand

Page 5

July 22, 1991

plutonium, were Identified from spectra from a borehole adjacent to and a borehole through the 216-2-1A crib. Spectra from a borehole that contained significant concentrations of americium and plutonium were to demonstrate identification capabilities. Spectra from borehole 299-W18-171 which, according to laboratory analyses, did not contain americium or plutonium at significant concentration levels, were used to demonstrate instrumentation sensitivity to low concentrations of americium and plutonium.

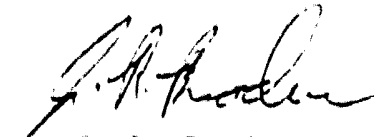

J. R. Brodeur Engineer

Attachments
RKP Priew to

c. J. Koizumi

Scientist
PKOW

R. K. Price

Scientist 
WELL 299-W18-159

Transuranic site: Crib 216-2-1A

ELEVATION (METERS ABOVE MSL), 204.5

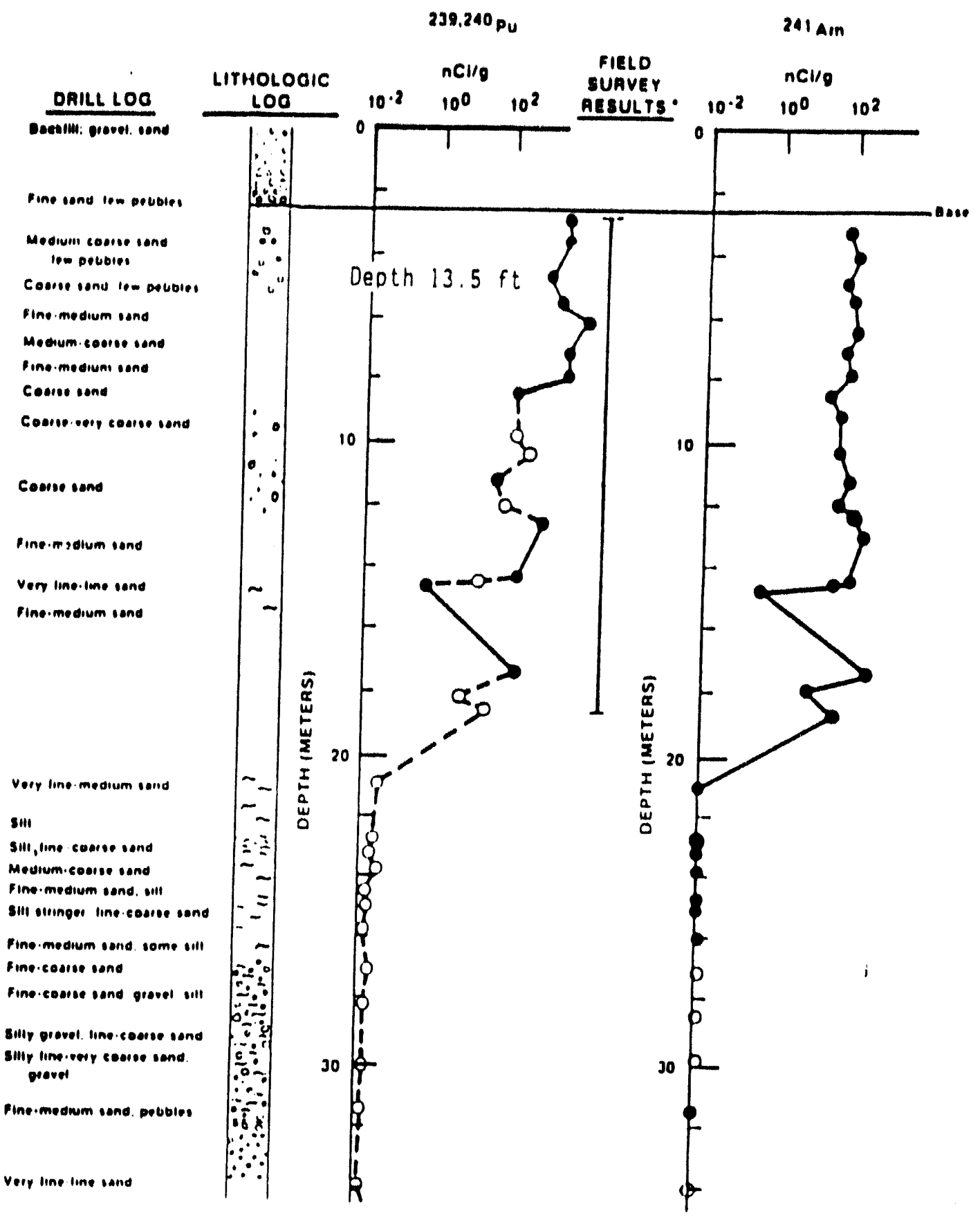

Figure 1 Distribution of Plutonium and Americium in borehole 299-W18-159 from Laboratory analys is of drill cutting samples

See report: RHO-ST-17 February 1979 


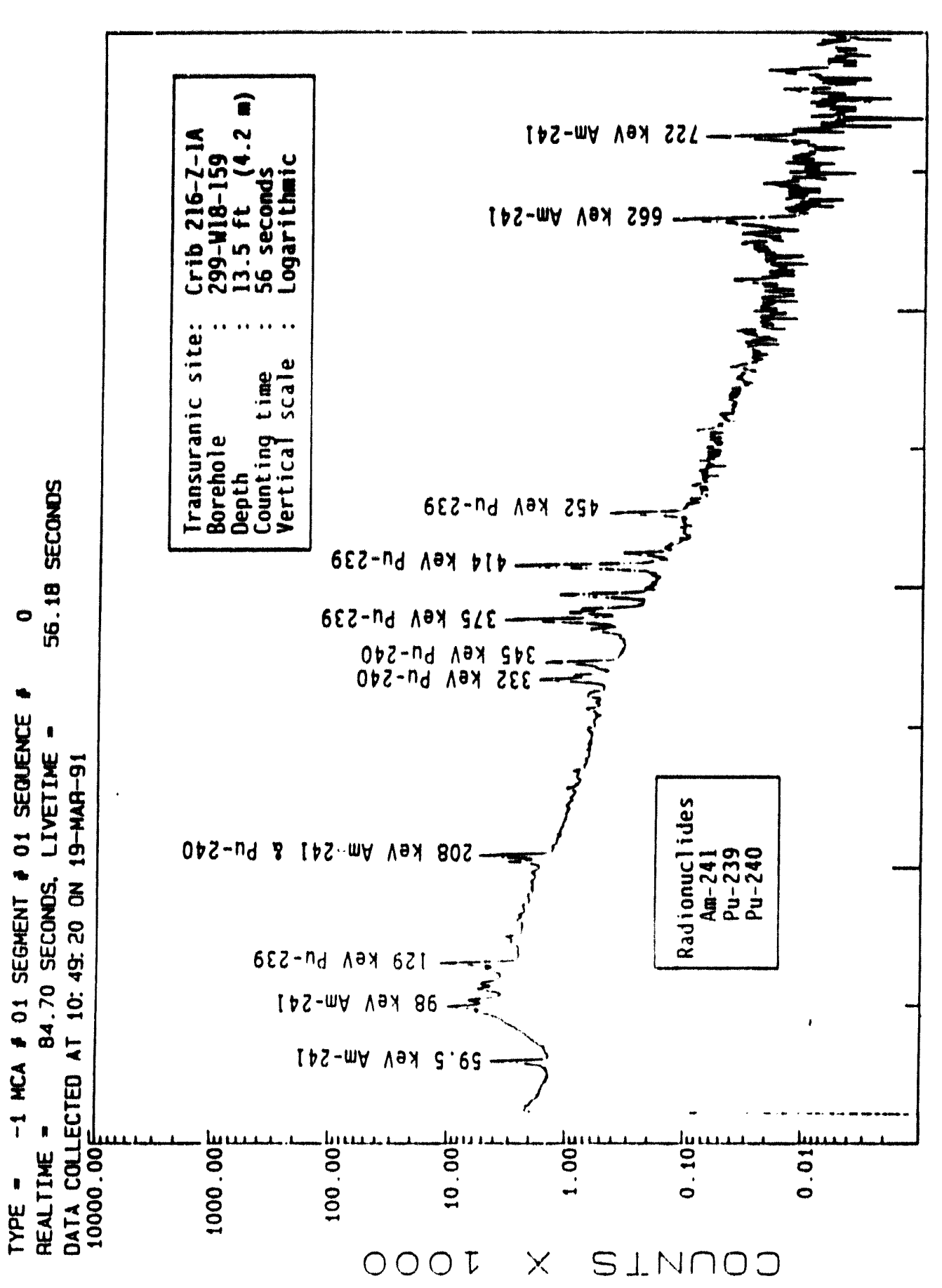

名

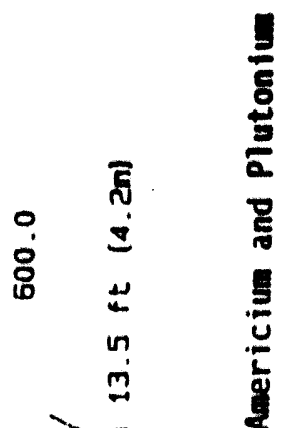

i)

Y

유 율

$\succ$ 尔里

可要

زلسن

.

山己

宊

疋

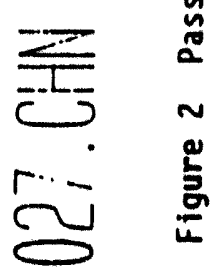




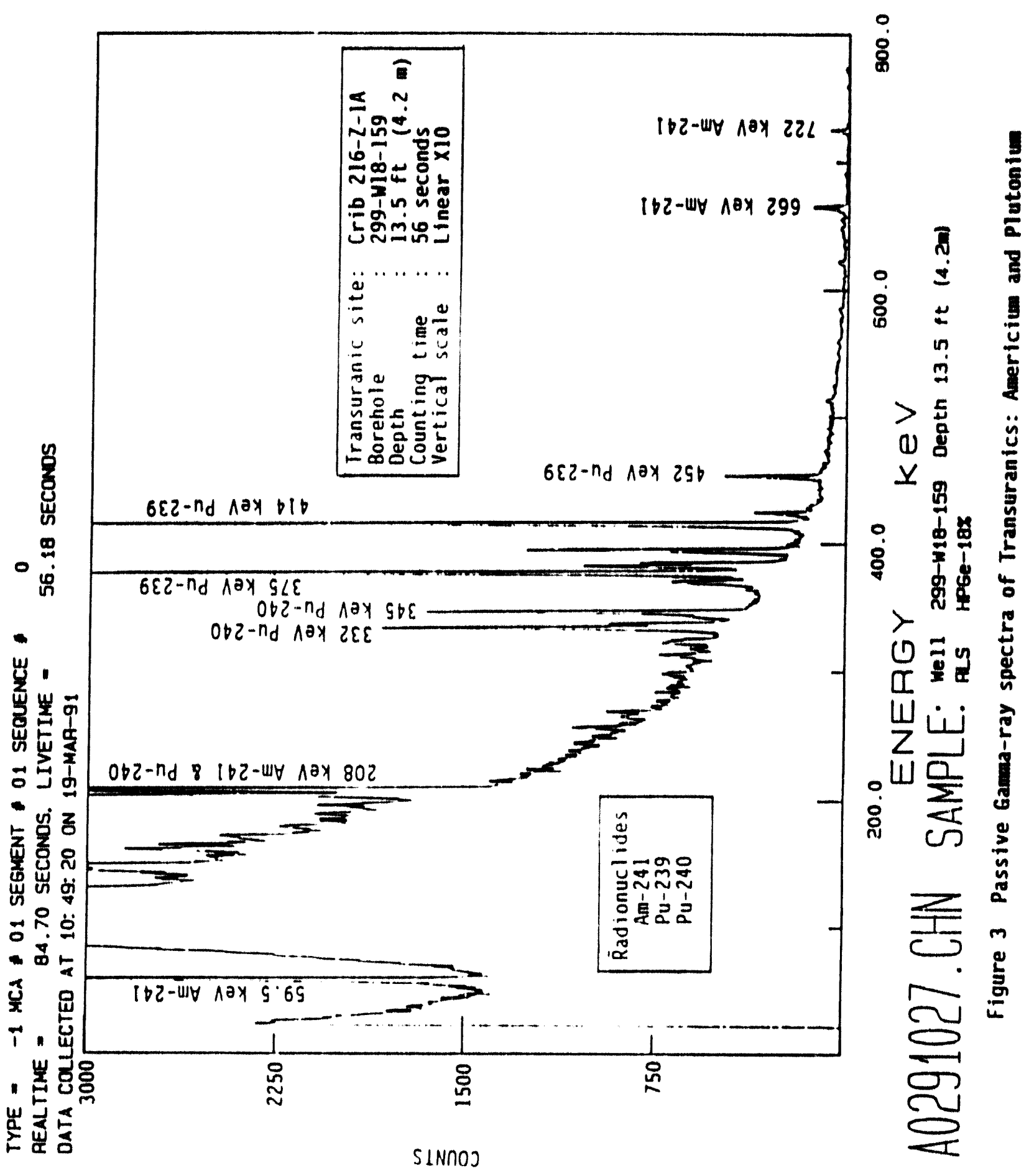


WELL 299-W18-171

ILEVATION (METENS ABOVE MSL): 2003

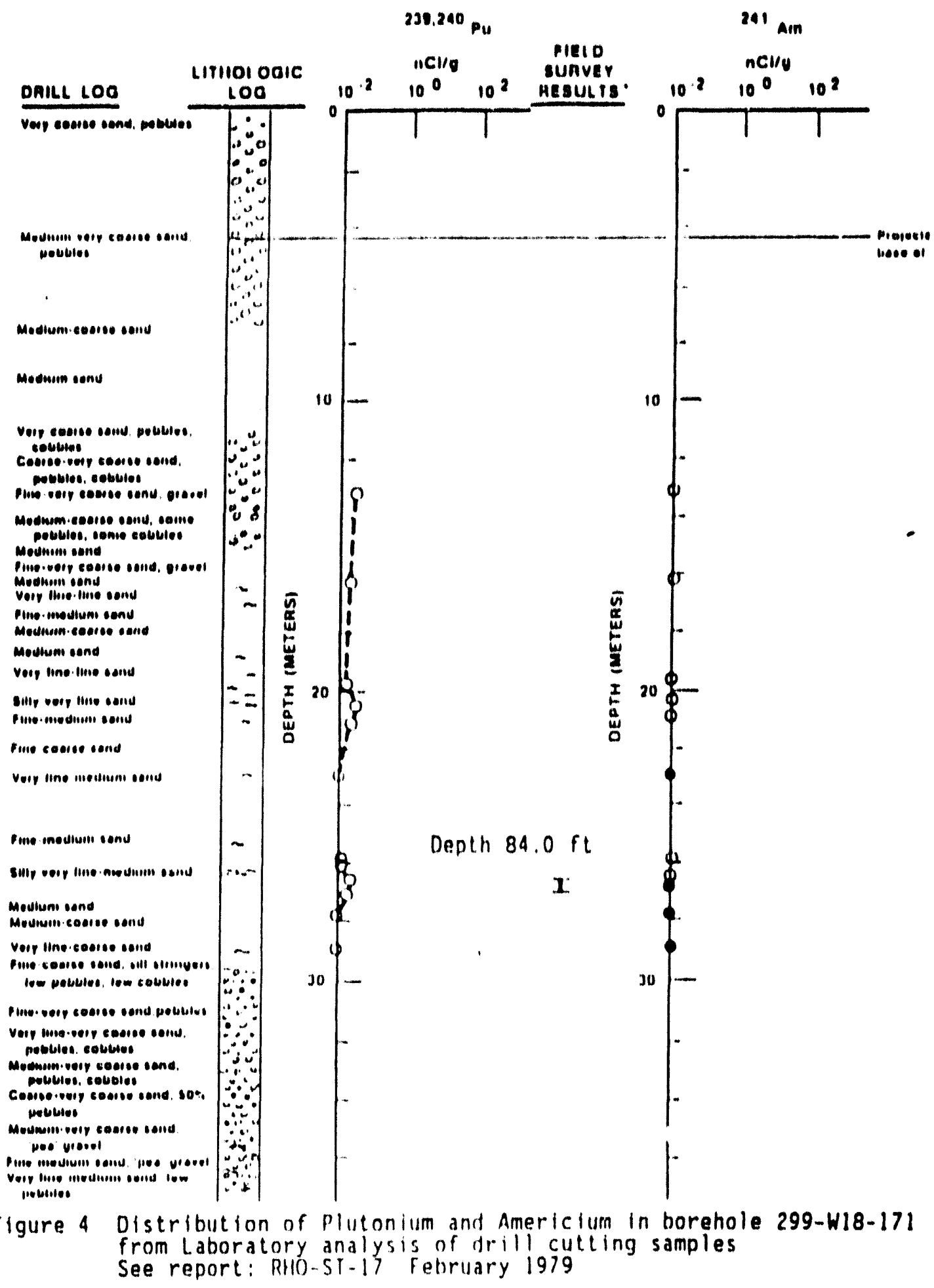




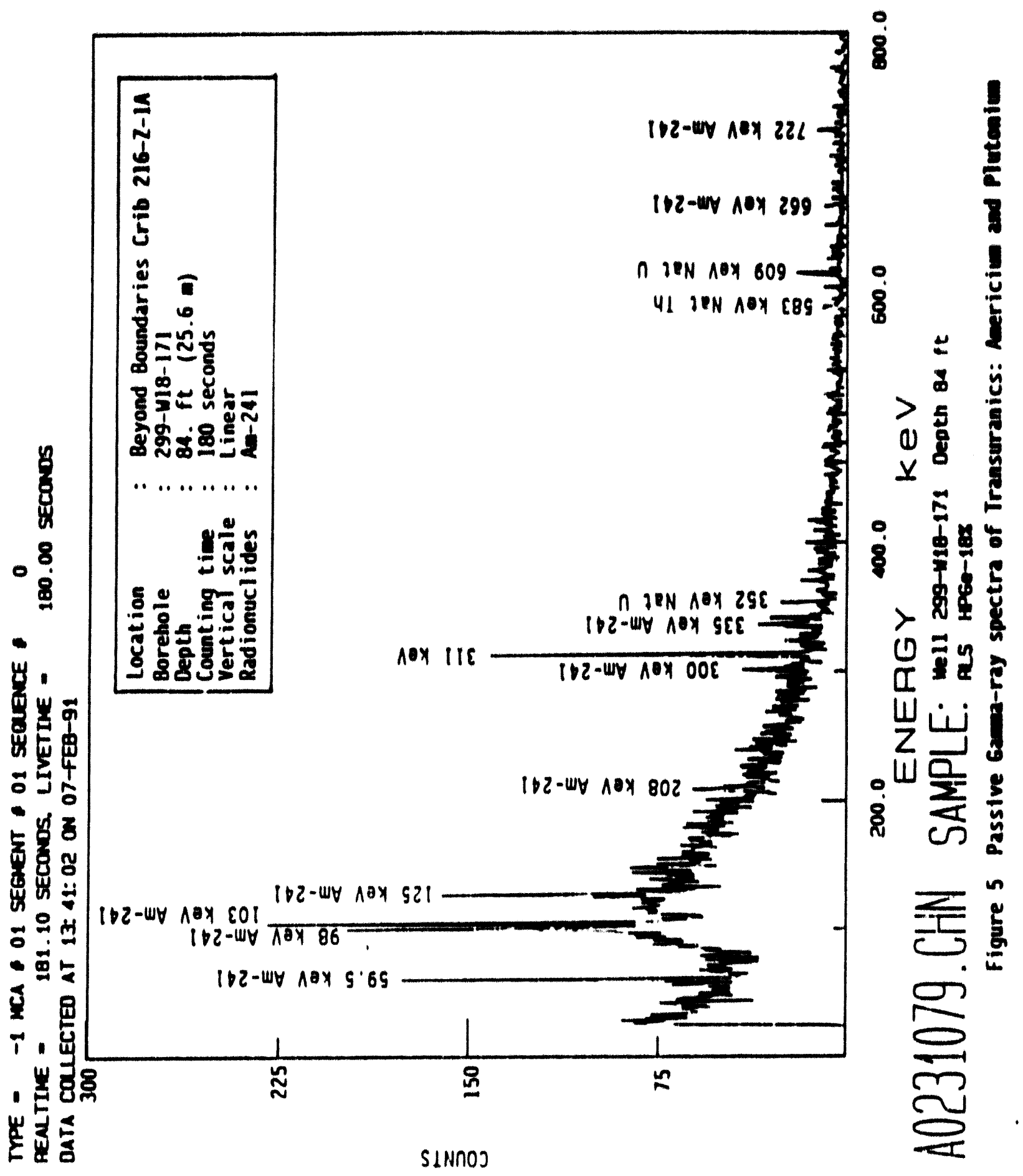


WHC-EP-0674

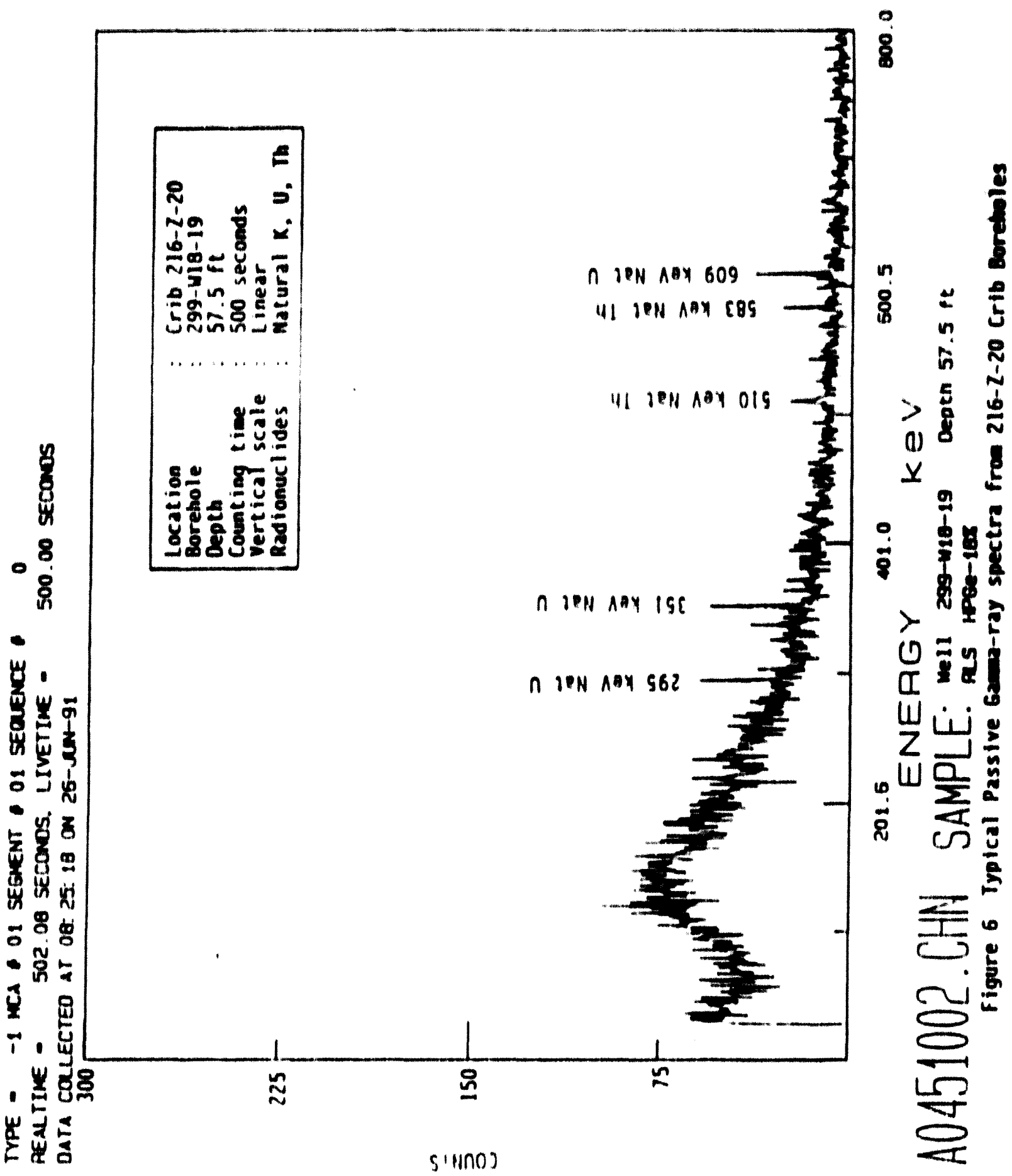


APPENDIX A: RECORO OF BOREHOLE GEOPHYSICS DATA ACQUISITION

Deta acquisition required several days of logging. Many dally log spectfications were common to the entire logging perlod whlle others ware untque for each day. The ipecification common to ell ecquistition sesstons are given below.

\section{Dotector}

EGLC Ortec HPGe POP-TOP, 18x

increment between depth measuraments

$$
0.5 \text { foet }
$$

Depth reference

Flle control ground level -0.0 feet

spectra for each depth incrament recorded under computer control, spectra flles transferred to non-erasable optical disk (WORM) upon completion of dally logging activities

Flle format. EGAG Ortec PHA, integer data flles (.CHN) recorded in IBM-PC DOS compatible format, fliename prefixes limited to 8 characters with last 3 positions reserved for sequence number

Spectra format

gamme-ray energy spectra subdivided into 4000 channels, gamme-ray spectra recorded for energy range of about 50 to 2850 keV

Logging activitles unlque to each day of fleld acquistition are given below. Possibly some entries may not be immediately obvious; their explanations follow:

- The fllename prefix is the first four characters for all saved spectra flles. The fifth character indicates which detector, ofther number I for HPGe or number 2 for $\mathrm{Nal}$ was uesd.

- The flle sequence number and data acquisition point represent aneto-one correlation. Only the start and stop depth and flle sequence number are presented below.

- The difference between encoder depth and tool position is masured whon the tool is returned to the zero depth, generally at the and of the dally logging activities.

\begin{tabular}{|c|c|c|c|c|c|}
\hline Date & Depth & Feet & $\begin{array}{l}\text { Flle } \\
\text { seq. no. }\end{array}$ & & \\
\hline 4Aprg! & Start & $\begin{array}{l}\cdots \\
0.0\end{array}$ & $\cdots$ & $\begin{array}{l}\text { Flle name prefix } \\
\text { Logging mode } \\
\text { Count time }\end{array}$ & $\begin{array}{l}\text { - A032 } \\
\text { - move-stop-acquire } \\
\text { - I50 sec (real time) }\end{array}$ \\
\hline
\end{tabular}


WHC-EP-0674

Stop $\quad 71.0 \quad 142$

- - - .

Start $71.0 \quad 143$

Stop $0.0 \quad 283$

- . . - Depth error, tool return 7. Inch Low

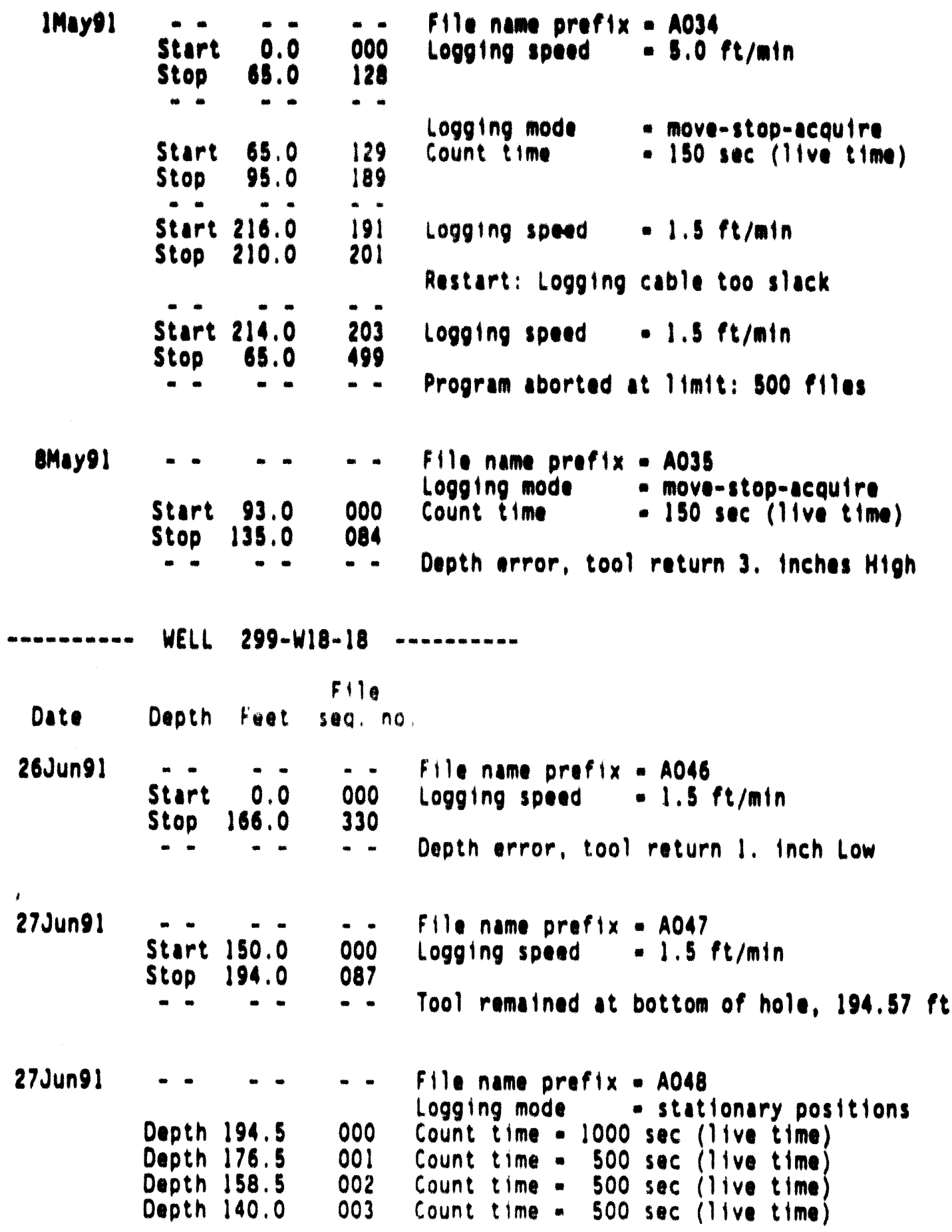




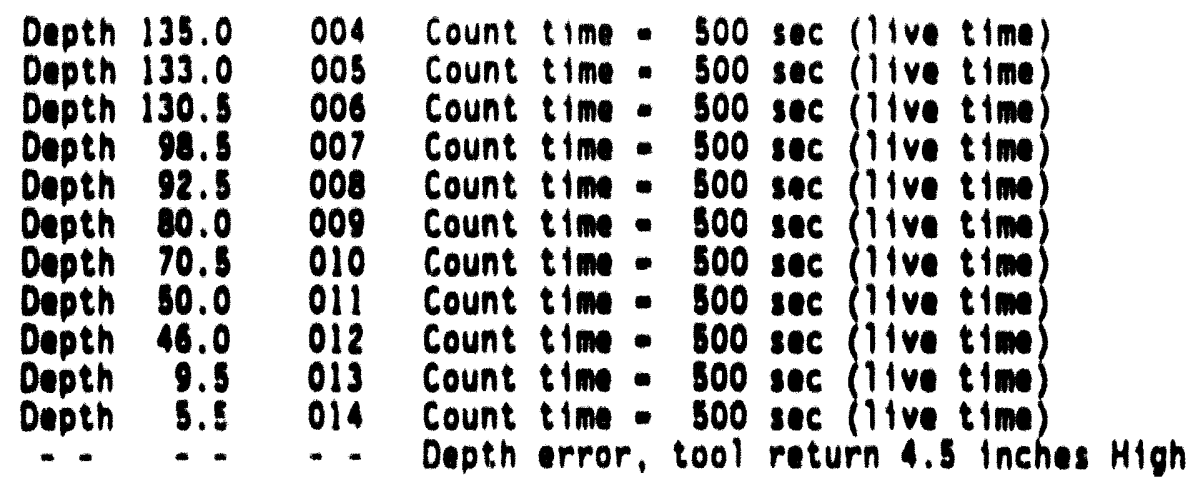

WELL 299-W18-19

flle

Date Depth Feet seq. no.

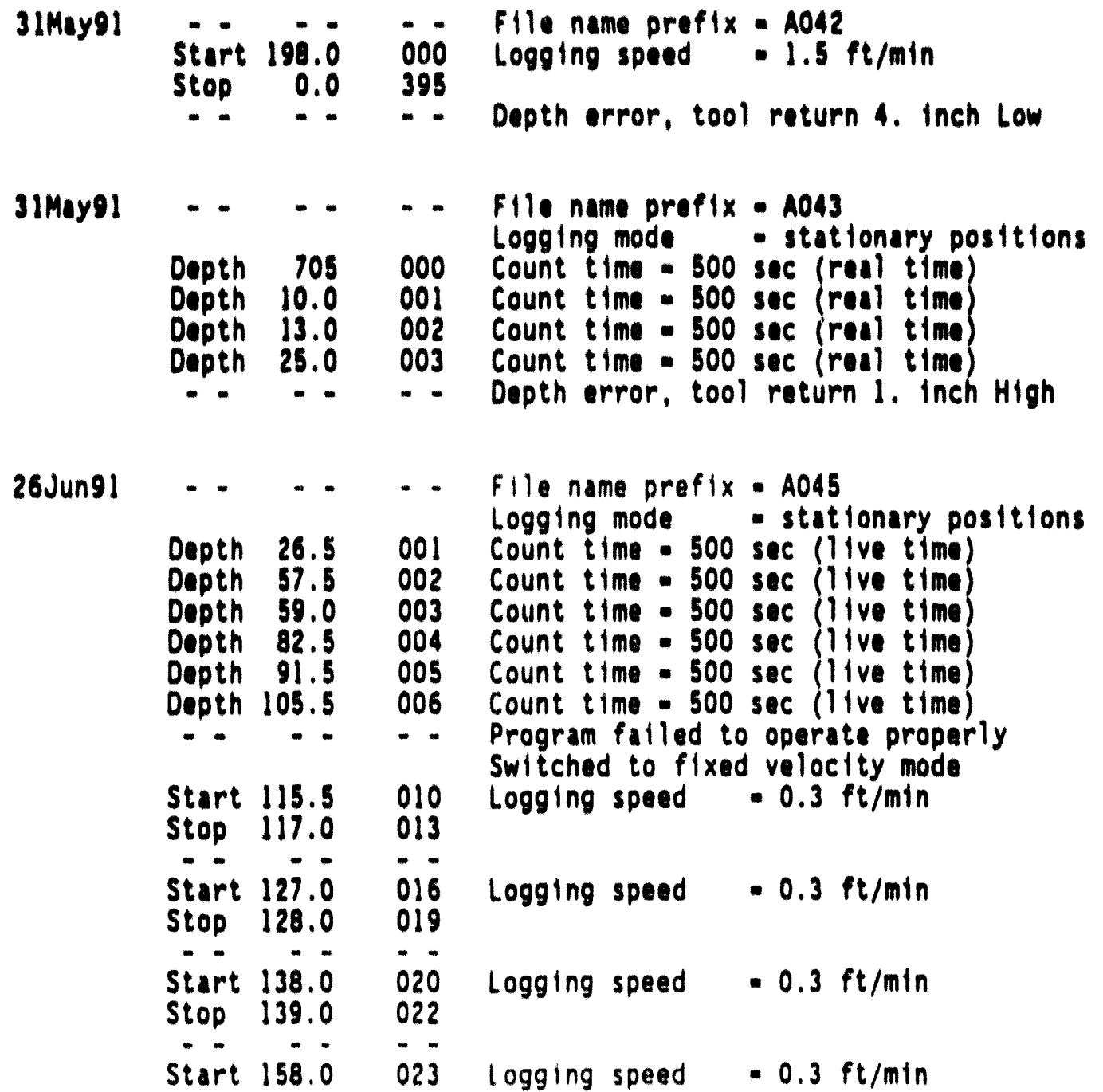


WHC-EP-0674

Stop $159.0 \quad 025$

- - - - -

Start $175.0 \quad 026$

Stop 177.5030

- - $1977^{-}-$

Start 197.0 031

Stop $195.0 \quad 035$

Logging speed $\quad-0.3 \mathrm{ft} / \mathrm{min}$

Logging speed $\quad-0.3 \mathrm{ft} / \mathrm{min}$

Depth error, tool return 4.0 inches High

WELL 299-W18-20

File

Date Depth Feet sea. no.

29May91

Start $\quad \overline{0.0} \quad \overline{000}$

File name prefix $-A 037$

Stop $233.5 \quad 465$

logging speed $=1.5 \mathrm{ft} / \mathrm{m} / \mathrm{n}$

-. -

- Tool remained at bottom of hole, $233.5 \mathrm{ft}$

29May91

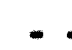

Depth 214.0

Depth 197.5

Depth 189.2

Depth 169.5

Depth 154.4

Depth 137.0

Dopth 136.5

Depth 134.0

Depth 118.0

Depth 111.0

Depth 105.5

Depth 96.5

- - - $\cdots$

000

001

002

003

004

005

006

007

008

009

010

011

$-\cdot$
File name prefix - $A 038$

logging mode - stationary positions

Count time - 1000 sec (live time)

Count time - 1000 sec (real time)

Count time - $500 \mathrm{sec}$ (real time)

Count time. $500 \mathrm{sec}$ (real time)

Count time - $500 \mathrm{sec}$ (real time)

Count time - 500 sec (real time)

Count time. $500 \mathrm{sec}$ (real time)

Count time. $500 \mathrm{sec}$ (real time)

Count time - $500 \mathrm{sec}$ (real time)

Count time - $500 \mathrm{sec}$ (real time)

Count time. $500 \mathrm{sec}$ (live time)

Count time. 500 sec (live time)

Depth error, tool return 1. inch High

31 May9l

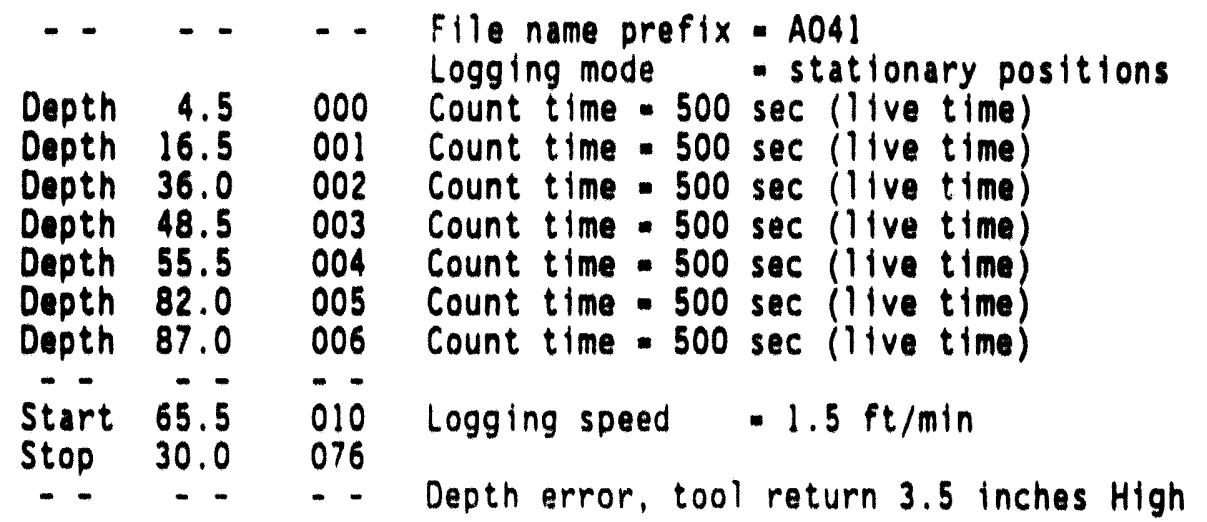




\section{WHC-EP-0674}

WELL 299-W18-29

Date Depth Feet sile no.

16Apr91 - - - - - File name prefix $=\mathrm{A033}$

Start 94.0 000 Logging speed $=0.4 \mathrm{ft} / \mathrm{min}$

Stop $135.5 \quad 080$

- - - - -

$\begin{array}{llll}\text { Start } 136.7 & 082 & \begin{array}{l}\text { Logging mode } \\ \text { Count time }\end{array} & =200 \mathrm{sec} \text { (1ive time) }\end{array}$

Stop $135.0 \quad 086$

$\begin{array}{lll}- & - & - \\ \text { start } & 0.0 & -\end{array}$

Start $0.0 \quad 088$ Logging speed $=0.4 \mathrm{ft} / \mathrm{min}$

Stop $20.0 \quad 127$

- - - _ - Depth error, tool return 2.0 inches Low 
WHC-EP-0674

APPENDIX B: RLS INSTRUMENTATION CONFIGURATION

\section{CONFIGURATION OF LOGGING INSTRUMENTATION}

The RLS is a computer controlled borehole data acquisttion system. The computer controls the functions are:

o tool depth measurements,

0 winch control for tool positioning, and

- borehole detector measurement control.

The borehole detector measurement control is responsible for the following subfunctions:

- clear/initialize multichannel counter,

- activate multichannel counting gate,

- terminate counting,

0 attach identification information, and

$0 \quad$ store data on mass storage device.

The spectral borehole logging equipment is undergoing development that will continue for several more months. This report is an interim action to document field data acquisition activities and summarize findings. Final quantification of radionuclide concentrations can be reported at a later date after more studies of the equipment and analysis techniques are complete.

The RLS high purity germanium logging system was first calibrated in November 1990 at the DOE calibration center in Grand Junction, Colorado. The equipment appeared stable prior to the calibration trip. However, its operation during the calibration studies was compromised by elevated noise from electrical ground loops between three system components. The ground loops appeared after repeated vibrations due to highway travel. The equipment was repaired upon return from the calibration trip. Measurement during repairs indicated that the calibration, although compromised, could still be considered valid. Since December 20, 1990 the equipment has been very stable. The equipment performance and stability will be reported in an internal memorandum when scheduling permits.

Configuration of the equipment hardware, computer software, and interpretation technique is subject to change as additional calibrations, geophysical studies, and other types of borehole measurements are completed and implemented. The current equipment 
configuration, al though not mature, is adequate to satisfy the stated objective of this logging activity. The equipment configuration at the time of this logging activity is identified as VERSION A.O. The equipment configuration used for this borehole logging activity is identical to the configuration used for the November 1990 calibration trip to DOE Grand Junction, Colorado. The equipment configuration will be reported in an internal memorandum, when scheduling permits.

\section{ACQUISITION STANDARDS}

In-situ borehole measurements were acquired in accordance with procedure WHC-CM-7-7 Environmental Investigation and Site Characterization Manual, Section EII 11.1 Geophysical Logging, Appendix B: Spectral Gamma-ray Logging, Rev I March 5, 1991. Relevant supportive details about the field activities are included in this report for historical purposes and to confirm the quality of recorded data.

A portable field reference source serves to check equipment efficiency, repeatability, resolution, and voltage gain of signal pulses. The logging procedure indicates that a field reference source must be used and how the mearsurement must be taken. The source is not specifically identified in the procedure, but is described as follows.

Field reference source identification: 79840

Radionuclides in source: $\mathrm{Ba}-133, \mathrm{Cs}-137, \mathrm{Co}-60, \mathrm{Ra}-226$, Th-232

Photo-peaks used for two-point energy calibration in Maestro II $609.3 \mathrm{keV}$ of $\mathrm{Ra}-226$ and $1332.5 \mathrm{keV}$ of $\mathrm{CO}-60$

The field reference source spectrum is recorded with the tool suspended above the ground with the truck stationary. Immediately following this measurement a second measurement must also be recorded with the source removed, this permits the ambient, or background, gamma-ray signature present from local sources to be quantified. The background response is subtracted from the previous measurement of combined field reference source and background. The difference yields the net contribution from the reference source. The tool responses to the field reference before and after the borehole logging are compared to the tool responses that were observed when the equipment was calibrated.

The field reference source becomes the connecting link which permits the' $j$ calibration coeffients to be applied for computing the radionuclide concentrations. Nuclide concentrations in the subsurface can be computed for gamma energies within tha November 1990 DOE Grand Junction, Colorado calibration study limits of 350 to $2800 \mathrm{KeV}$. The energy range for which the calibration measurements and calibrated detector efficiency are valid cannot be extended below $350 \mathrm{KeV}$ until additional studies are completed. The lower gamma-ray energy limit of $350 \mathrm{KeV}$ is imposed by at least three nonlinear and nontrivial phenomena.

1. The calibration for man-made gamma-ray emitters depends on the determination of an efficiency function which relates a measured count rate in a gamma-ray peak to the corresponding gamma-ray intensity in 
the surrounding medium. Using calibration data for three gama rays from the uranium decay chain, three gamma rays from the thorium decay chain, and the potassium-40 gamma ray, seven values for the efficiency function have been determined over a gamma-ray energy range from 351 $\mathrm{keV}$ to $2615 \mathrm{keV}$. For gamma-ray energies of about $350 \mathrm{keV}$ and higher, increases in gamma-ray energy are accompanied by a log-linear decrease in the effictency function because the detector efficiency is dominated by Compton scattering. Because the efficiency function is well behaved above $350 \mathrm{keV}$, calibration factors for man-made radionuclides can be found by interpolation. However, as the gammaray energy decreases below about $350 \mathrm{Kev}$, the role of photoelectric absorption in the detector efficiency becomes more and more pronounced. The November 1990 calibration measurements were not designated to map the complex changes in detector efficiency that occur below $350 \mathrm{keV}$.

2. Gamma ray attenuation from borehole materials, such as casing, changes rapidiy with gamma-ray energy at energies below $350 \mathrm{KeV}$.

3. The presence of high-atomic-number atoms, such as americium-241 ( $Z$ = $95)$, in the formation selectively reduces the low-energy gamma-ray fluxes. If the high-z elements exist in low concentrations, the nonlinear flux reduction is confined to energies below about $300 \mathrm{keV}$, but the nonlinear region approaches $1000 \mathrm{keV}$ as the concentrations of high-Z elements increase toward levels that, although high, can still occur naturally, Some features of this so-called " $Z$-effect" were characterized by work for the DOE's National Uranium Resource Evaluation project.

Computer interface with a depth encoder is required to control the detector position within the borehole. A problem has been identified in the depth measuring system and a solution is being investigated. The problem is that the logging cable diameter is non constant and infrequently exceeds the groove diameter machined into the depth encoding sheave wheel. This causes the cable to ride above the engineered position on the sheave wheel and permits the radius to the wheel center to increase.

During the logging runs, the encoder conversion factor was 793.0 pulses per foot. 
WHC-EP-0674

This page intentionally left blank. 
SOMFi:-

Attachment $\mathrm{C}-3$

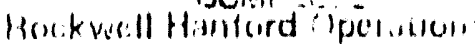

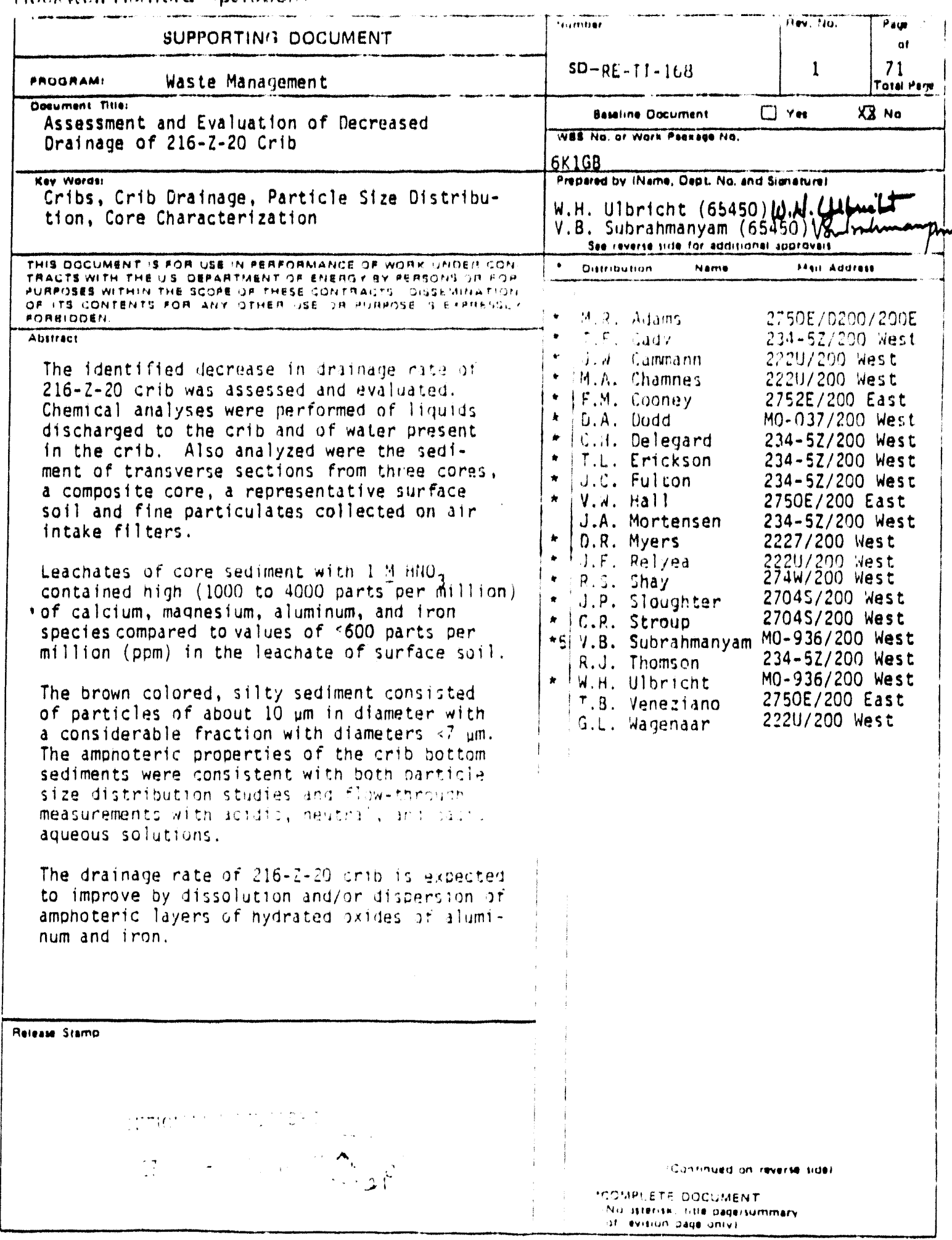


TABLE I

ANALYSES OF EFFLUENTS TO 216-2-20 CRIB

\begin{tabular}{|c|c|c|c|c|c|c|c|}
\hline $\begin{array}{l}\text { Sampling } \\
\text { Date }\end{array}$ & $\begin{array}{l}\text { Plant } \\
\text { Condition }\end{array}$ & $\begin{array}{l}\mathrm{pH} \\
(-100[\mathrm{H}+1])\end{array}$ & $T \propto C$ & $\mathrm{Ca}$ & $\begin{array}{ll}\mathrm{Mg} \\
\mathrm{O} / \mathrm{L}\end{array}$ & Al & Fo \\
\hline $4 / 24 / 86$ & $\begin{array}{l}\text { Plant } \\
\text { Idle }\end{array}$ & 7.80 & 1.3 & 17.6 & 4.3 & 0.21 & 0.04 \\
\hline $6 / 16 / 86$ & $\begin{array}{l}\text { FMC } \\
\text { Running }\end{array}$ & 7.13 & 3.1 & 18.0 & 3.8 & 0.37 & 0.03 \\
\hline $7 / 25 / 86$ & $\begin{array}{l}\text { PRF } \\
\text { Running }\end{array}$ & 5.30 & 2.5 & $18 . ?$ & 4.3 & 0.25 & 0.03 \\
\hline $9 / 4 / 86$ & $\begin{array}{l}\text { PMC } \\
\text { Running }\end{array}$ & 6.72 & 1.5 & 18.5 & 4.2 & 0.28 & 0.05 \\
\hline $10 / 20 / 86$ & $\begin{array}{l}\text { Plant } \\
\text { Idle }\end{array}$ & 7.30 & 0.83 & 16.7 & 3.6 & 0.15 & 0.04 \\
\hline $9 / 12 / 86$ & $\begin{array}{l}\text { Raw } \\
\text { Process } \\
\text { Water }\end{array}$ & 7.72 & 1.5 & 16.5 & 4.1 & 0.02 & 0.04 \\
\hline
\end{tabular}


WHC-EP-0674

TABLE 【I

ANALYSES OF WATER* STAGNANT IN 216-2-20 CRIB

\begin{tabular}{|c|c|c|c|c|c|c|c|}
\hline $\begin{array}{l}\text { Posittion } \\
\text { (ID) }\end{array}$ & $\begin{array}{l}\mathrm{PH} \\
\left(-\log \left(\mathrm{H}^{+}\right)\right.\end{array}$ & $\begin{array}{l}\text { Carbonate } \\
\text { (mu) }\end{array}$ & $T \propto C^{*}$ & $\mathrm{Ca}$ & $\begin{array}{l}\mathrm{Mg} \\
\mathrm{mol}\end{array}$ & $A I$ & $F_{\theta}$ \\
\hline $\begin{array}{l}\text { Riser } n \\
(1-2)\end{array}$ & $\begin{array}{l}\text { No stagnant } \\
\text { water }\end{array}$ & & & & & & \\
\hline $\begin{array}{l}\text { Riser } 12 \\
(2-2)\end{array}$ & 7.95 & 1.06 & 74 & 105 & 58 & 71 & $<217$ \\
\hline $\begin{array}{l}R / \text { ser } \quad 13 \\
(3-2)\end{array}$ & 7.30 & 32 & 4 & $\therefore 2$ & 50 & 83 & -217 \\
\hline $\begin{array}{l}\text { Riser } \\
(4-2)\end{array}$ & 7.95 & 1.56 & 58 & $: 35$ & 63 & $<114$ & 4217 \\
\hline
\end{tabular}


WHC-EP-0674

TABLE III

LEACHATE ANALYSES OF SEDIMENT FROM 216-2-20 CRIB BOTTOM

\begin{tabular}{|c|c|c|c|c|c|}
\hline $\begin{array}{l}\text { Core } \\
\text { Location }\end{array}$ & Depth & Ca & Mg & Al & Fo \\
\hline Riser 11 & $\begin{array}{l}10^{\prime}-12^{\prime} \\
\text { Composite }\end{array}$ & 300 & 287 & 1.500 & 855 \\
\hline Risor 2 & 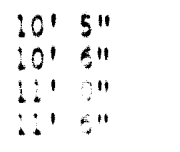 & $\begin{array}{r}60 \\
3,60^{2} \\
\therefore \\
\vdots \\
\vdots\end{array}$ & $\begin{array}{r}391 \\
\therefore \quad 45 \\
25 \\
3\end{array}$ & 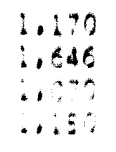 & $\begin{array}{r}815 \\
4.244 \\
2.526 \\
\hdashline .145\end{array}$ \\
\hline Riser $B$ & $\begin{array}{l}101 \\
121 \\
121 \\
211\end{array}$ & $\begin{array}{r}7.290 \\
7.130 \\
400\end{array}$ & $\begin{array}{l}3.9 \\
369 \\
172\end{array}$ & $\begin{array}{l}740 \\
750 \\
700\end{array}$ & $\begin{array}{l}375 \\
541 \\
223\end{array}$ \\
\hline Core $M$ & $\begin{array}{l}101 \\
101 \\
121\end{array}$ & $\begin{array}{l}N / A \\
N / A \\
800\end{array}$ & $\begin{array}{l}328 \\
294 \\
277\end{array}$ & $\begin{array}{l}590 \\
590 \\
720\end{array}$ & $\begin{array}{l}277 \\
286 \\
447\end{array}$ \\
\hline $2-20-5011$ & O' 6" & $N / A$ & 311 & 570 & 102 \\
\hline Fll tor Cako & & 22,004 & $\therefore \therefore 42$ & 1.376 & 1,340 \\
\hline
\end{tabular}


TABLE IV

ROTONUCLIDE ANALYSES OF 216-2-20 SEOIMENTS

\begin{tabular}{|c|c|c|c|c|c|c|}
\hline sumale & Denth & $\begin{array}{l}\text { Mass } \\
\text { Lol }\end{array}$ & $241_{A m}$ & ${ }^{137} \mathrm{Cs}$ & $\begin{array}{l}154_{E U} \\
C .1 / Q\end{array}$ & 1OK \\
\hline Core 1 & $\begin{array}{l}10^{\prime}-12^{\prime} \\
\text { Composite }\end{array}$ & 72.44 & 1502 & 3.5 & 34.1 & 32.5 \\
\hline Core 12 & 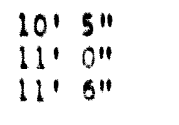 & $\begin{array}{l}69.13 \\
80.28 \\
4.39\end{array}$ & $\begin{array}{r}63 \\
5 \\
--0\end{array}$ & $\begin{array}{l}3.6 \\
3.1 \\
3.1\end{array}$ & $\begin{array}{l}1.6 \\
1.4 \\
1.3\end{array}$ & $\begin{array}{l}31.2 \\
28.5 \\
29.5\end{array}$ \\
\hline cor 13 & $\begin{array}{l}: 1 \\
121 \\
121\end{array}$ & $\begin{array}{c}35.5 \\
160.74\end{array}$ & $\begin{array}{r}83 \\
53\end{array}$ & $\begin{array}{l}\vdots . \\
3.0 \\
2.3\end{array}$ & $\frac{1.1}{1.2}$ & $\begin{array}{l}26.8 \\
31.4 \\
21.9\end{array}$ \\
\hline Core 14 & $\begin{array}{l}101 \\
101311 \\
121\end{array}$ & $\begin{array}{l}51.67 \\
50.67 \\
59.41\end{array}$ & $\begin{array}{r}180 \\
44 \\
307\end{array}$ & $\begin{array}{l}3.6 \\
3.8 \\
3.7\end{array}$ & $-\ldots$ & $\begin{array}{l}33.7 \\
31.3 \\
34.6\end{array}$ \\
\hline Fan Dust & $\cdots$ & 59.41 & $=-$ & 8.7 & 2.1 & 36.2 \\
\hline $2-20$ sol1 & 611 & 77.04 & -... & 3.0 & 0.9 & 34.9 \\
\hline
\end{tabular}


WHC-EP-0674

Th1s page intentionally left blank. 
WHC-EP-0674

\section{APPENOIX 0}

MELL REMEDIATION AT THE 216-2-20 CRIB 
WHC. -EP-0674

This page intentionally left blank.

$0-11$ 
DON'T SAY IT ... Write It!
TO: V. a. JOHNSON
H8.06
D. K. TYLER
H6.06

DATE: $8 / 18 / 93$

FROM: K. D. REYNOLDS

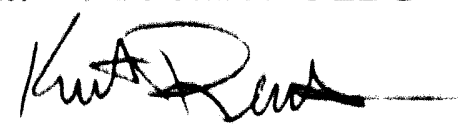

Attached is the final report documenting the completion of remediation activities undertaken for the 216.Z-20 Crib. The report outlines the sequence of events, procedures used and a brief evaluation of the success of the remediations for wells 299-W18-17, W18-18, W18-19, and W1820. This work was undertaken in response to the DSI dated February 23, 1993 from D. K. Tyler. 
WHC-EP-0674

This page intentionally left blank. 


\section{DI.0 INTRODUCTION}

This appendix documents the well remediation conducted for the four groundwater monitoring wells located within the perched water zone at the 216-z-20 Crib. The objectives of the remediation were to:

- Seal any openings between the casing and the borehole wall and to eliminate potential pathways for contaminant movement

- Re-complete the wells to control temporary perched water and/or provide for soil gas monitoring above the deepest perching lithologic unit.

\section{D1.1 GENERAL DESCRIPTION OF APPROACH}

The four wells (299-W18-17, 299-W18-18, 299-W18-19, and 299-W18-20) located adjacent to the $216-2-20 \mathrm{Crib}$ were perforated and pressure grouted from the water table to an elevation at or above the Plio-Pleistocene layer. The grouting proceeded in stages or "lifts." This involved perforating the casing section and then injecting, grout through a packer assembly at a

hydrostatic pressure of $3.45 \times 10^{5}$ Newtons $/ \mathrm{m}^{2}$ (50 psi). Neutron/density $\operatorname{logs}$ for each well provided indications of voids and aided in identification of lithologic units for establishing completion depths or elevations. Grout volumes were calculated for each section of perforated casing between the packer and the previous grout layer. Based on interpretations of geologic, geophysical, and construction information, varying volumes of grout were added to ensure a continuous seal between the outer casing wall and the formation. After completion of the last lift or layer, an additional 4 to $6 \mathrm{~m}$ (15 to $20 \mathrm{ft}$ of casing was perforated to allow perched water inflow and soil gas monitoring. Additional details are described in the following sections.

\section{D1.2 SELECTION OF COMPLETION DEPTHS}

Completion depths were selected based on the assumption that the Plio-Pleistocene layer was the deepest stratigraphic unit that could cause perched water to accumulate. Lithologic logs from drilling records and geophysical logs as well as lithologic logs from adjacent boreholes were used to interpret local geology and to define the target elevation for emplacement the final grout layer. Geophysical logs with stratigraphic and generalized well construction information for the four wells are shown in Figures D-1 through D-4.

Stratigraphic sections were prepared and compared with the natural gamma and neutron logs to determine which lithologic facies of the Hanford formation or Ringold Formation were present. Known relationships and properties of the individual facies, such as porosity, permeability, cementation, and grain size, were used to aid in the interpretation of the logs and correction of the cross section. Based on the above information discrete "lifts" or zones corresponding to well-specific lithologic properties were selected for perforation and grouting. 


\section{D1.3 PERFORATING AND GROUTING PROCEDURE}

As noted in Section D1.1, the casings were perforated and grouted in upward progressing stages or lifts. Each lift or vertical section involved first perforating the casing with a PERF-HAWK mechanical perforator and then insertion of a inflatable mechanical packer assembly immediately above the last perforation. Grout was then pumped into the interval below the packer through the tubing used to place and control the packer. Because the vadose sediments were predominately uncemented, minimal grout injection distances and therefore placement pressures were required. The well remediation design specified a displacement pressure of $3.45 \times 10^{5}$ Newtons $/ \mathrm{m}^{2}$ (50 psi) on each ilft to ensure adequate injection of the grout into the annular space and the adjacent disturbed portion of the formation.

Specifications for each 1 ift included the volume of grout, length, and elevation of the intervals to be perforated. These specifications were determined by:

- Drilled and cased size of ihe borehole

- Lithology (physical characteristics indicative of possible grout loss volume to the formation)

- Expected effects of drilling method on lithologic unit (e.g., washouts or over-drilled portions of the borehole that would require increased volume to adequately fill)

- Interpretation of the neutron logs for identification of potential void spaces behind the casing and indications of saturated zones.

The design considerations noted above are 111 ustrated in Figures $D-2$ and $D-3$ at the 53- to 55-m $(175-$ to $180-\mathrm{ft})$ depth levels. For this interval, the neutron $\mathrm{log}$ deflects sharply to the left (a deflection to the left indicates the presence of either water or a void space behind the casing). Because the static water level in these wells is at approximately 60 to $61 \mathrm{~m}$ (197 to $200 \mathrm{ft}$ ) below ground surface, the large deflection is interpreted as a major void space. The tendency of uncemented cobble gravel overlain by a highly cemented zone to cave, or "ravel" when drilled al so supports this interpretation. Specifications for such intervals called for injection of grout volumes that are two to three times greater than calculated based on borehole dimensions (minimum hole volumes) to properly fill the volds. Daily activity sheets for these jobs indicate that the specified volumes could be injected without the need of excess pumping pressures. The lack of resistance to pumping and the ready acceptance of volumes in excess of the minimum hole volumes support the interpretation that large voids existed where significant leftward deflections occurred in the neutron logs (i.e., at depths above static water level in the well).

The original well construction as-builts, proposed remediation design, and remediated well as-builts and other details of the construction and remediation are shown in Figures $D-5$ through $D-16$.

${ }^{1}$ PERF-HAWK is a trademark of Hawk Industries. 


\section{D1.3.1 Jet-Shot Perforating}

Well 299-W18-19 was constructed with an inner lining of casing that could not be penetrated with the standard perforating tool (see Figure D-11). To solve this problem, a tool commonly used in the oil industry, the jet shot perforator, was used. This was the first use of this type of device on the Hanford Site since the large bore diameter drilling was performed for the Basalt Waste Isolation Project (before 1987), and required U.S. Department of Energy and Washington State Department of Ecology approval. The perforation process involves detonation of small metal-lined explosive "shaped charges" within the wellbore, at preselected intervals. The force of detonation is so great that the metal liner is atomized, and a shock wave weighted with metal particles is generated. The inertial force of this shock wave is sufficient to drive a hole through casing, cement, and into the formation. As much as $3.45 \times 10^{10}$ Newtons $/ \mathrm{m}^{2}$ ( $5 \mathrm{milli}$ ion $1 \mathrm{bf} / \mathrm{in}^{2}$ ) of force is exerted against the casing and adjacent formation. The depth of penetration is controlled by the length of the jet stream or shock wave, which in turn is controlled by the size of the shaped charge. For this application a configuration of charges that perforated four holes $(0.63$ to $1.3 \mathrm{~cm}[0.25$ to $0.50 \mathrm{in.}])$ per linear foot of casing was used. The upper zones of the well $(26$ to $43 \mathrm{~m}$ [85 to $140 \mathrm{ft}$ ] below ground surface) were perforated at least twice, resulting in a minimum of eight perforations per foot.

After the perforations and cementing were completed, the wells were scrubbed and cleaned before sampling to remove debris that resulted from the charges.

\section{D1.3.2 Indicators of Successful Completions}

The major criteria used in design of the well remediation completions were Washington Administrative Code (WAC) 173-160. Each well had a "Hold Point" where prior actions were evaluated to determine their compliance with WAC 173-160 and with commonly accepted industry criteria. The factors used to evaluate remediation success were:

(1) Was the specified cement grout volume successfully placed in the formation? If not, how much was placed verses the calculated nominal borehole volume?

(2) When the wells were perforated above the perching zones in saturated intervals, did the well accumulate water?

The well diagrams (Figures $0-7,-10,-13$, and -15) summarize the types of information used to judge the success and acceptability of the remediation activities.

\section{D1.3.3 Suggested Improvements (Lessons Learned)}

Two operational problems were observed during the completion of this remediation work. The first was the debris left from the jet shot, and the second was an equipment problem. 
D1.3.3.1 Use Debris Catchers. The debris left in the wellbore described in Section D1.3.1 caused delays in sampling efforts while the well was brushed down and the debris in the well removed. Debris from the explosion along with casing fragments and formation materials are common byproducts of this type of perforating. The use of a junk basket suspended below the detonation point would greatly reduce the amount of material left in the well and reduce cleanup requirements.

D1.3.3.2 Larger Work Over Rig Needed. During the pressure grouting phase of the work, some difficulty in holding the inflatable packers at the correct pressures and depths was encountered. The pump setting rig used on the job was not capable of exerting enough down pressure to keep the packers from rising when the required $3.45 \times 10^{5}$ Newtons $/ \mathrm{m}^{2}$ (50-psi) pressures were reached. The system also suffered a gradual loss of pressure during the cement setup time. The design called for maintaining pressure on the pumped grout during the setup time in an effort to hold the cement in place. A dedicated rotary-type workover rig would solve this problem.

\section{D1.4 REFERENCES}

WAC 173-160, 1990, "Minimum Standards for Construction and Maintenance of Wells," Washington Administrative Code, as amended. 
Figure $0-1$. Well Construction and Geophysical Logs for Wel1 299-W18-17. (2 sheets)

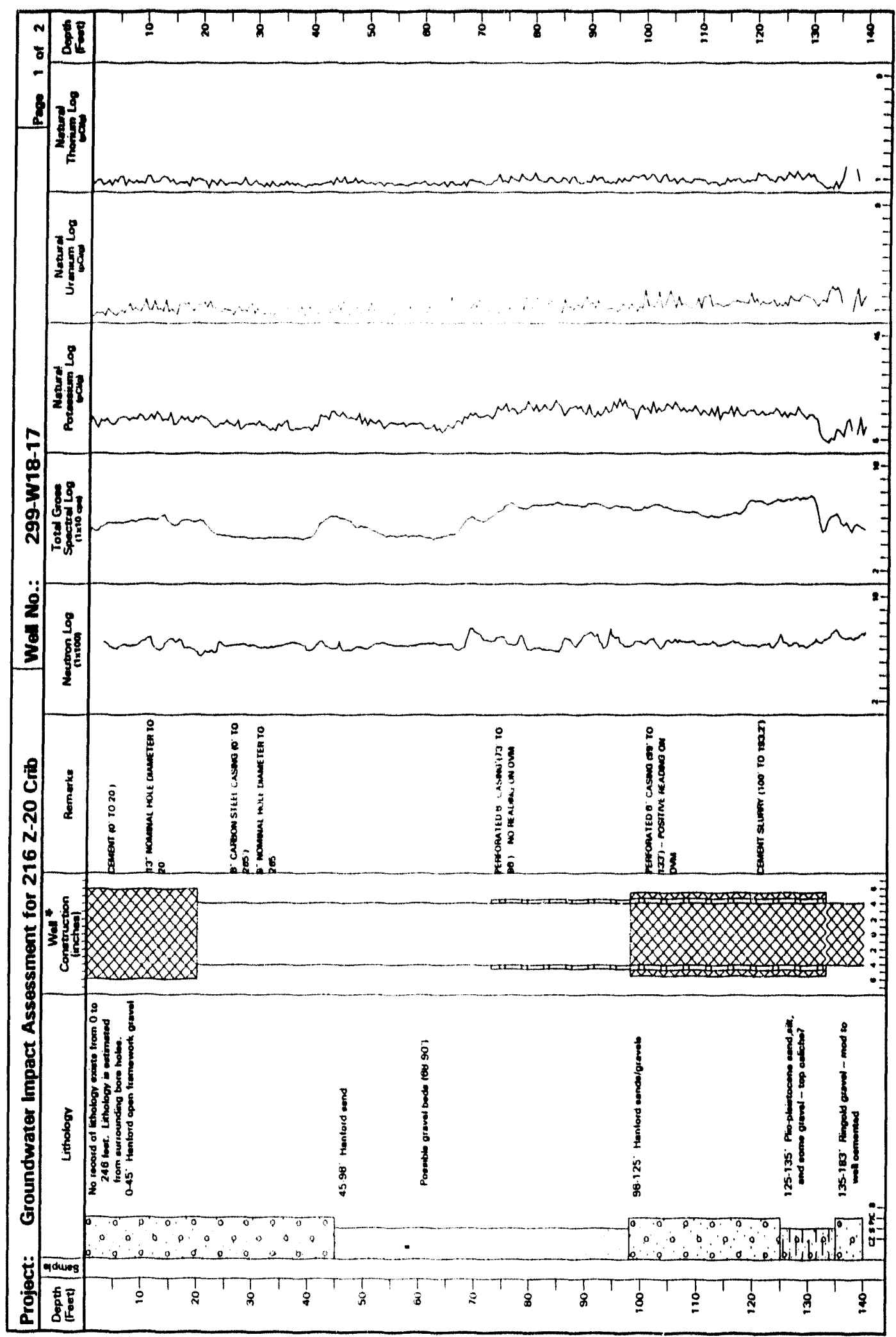


Figure D-1. Well Construction and Geophysical Logs for Well 299-W18-17. (2 sheets)

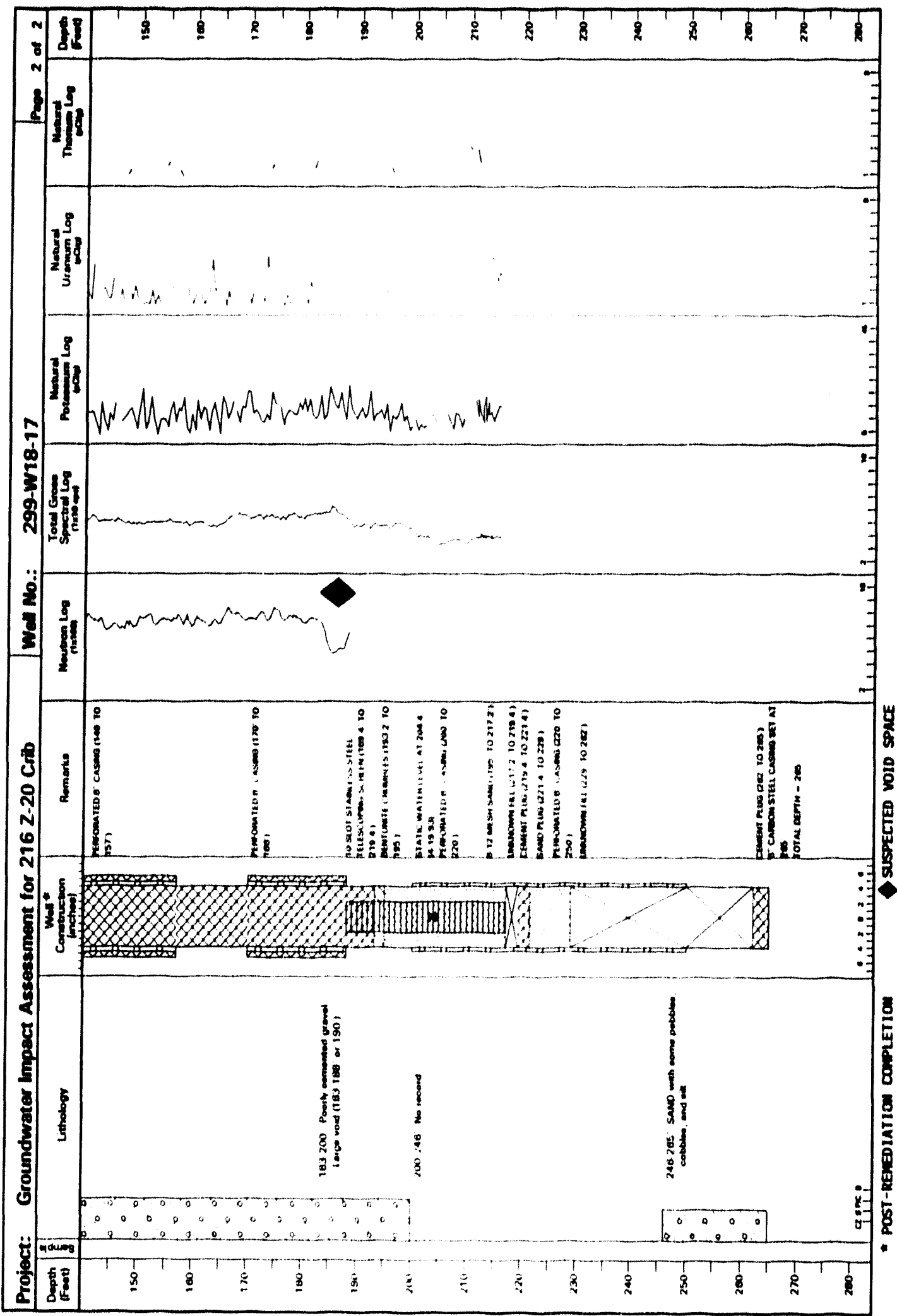


Figure D-2. Well Construction and Geophysical Logs for Well 299-W18-18. (2 sheets)

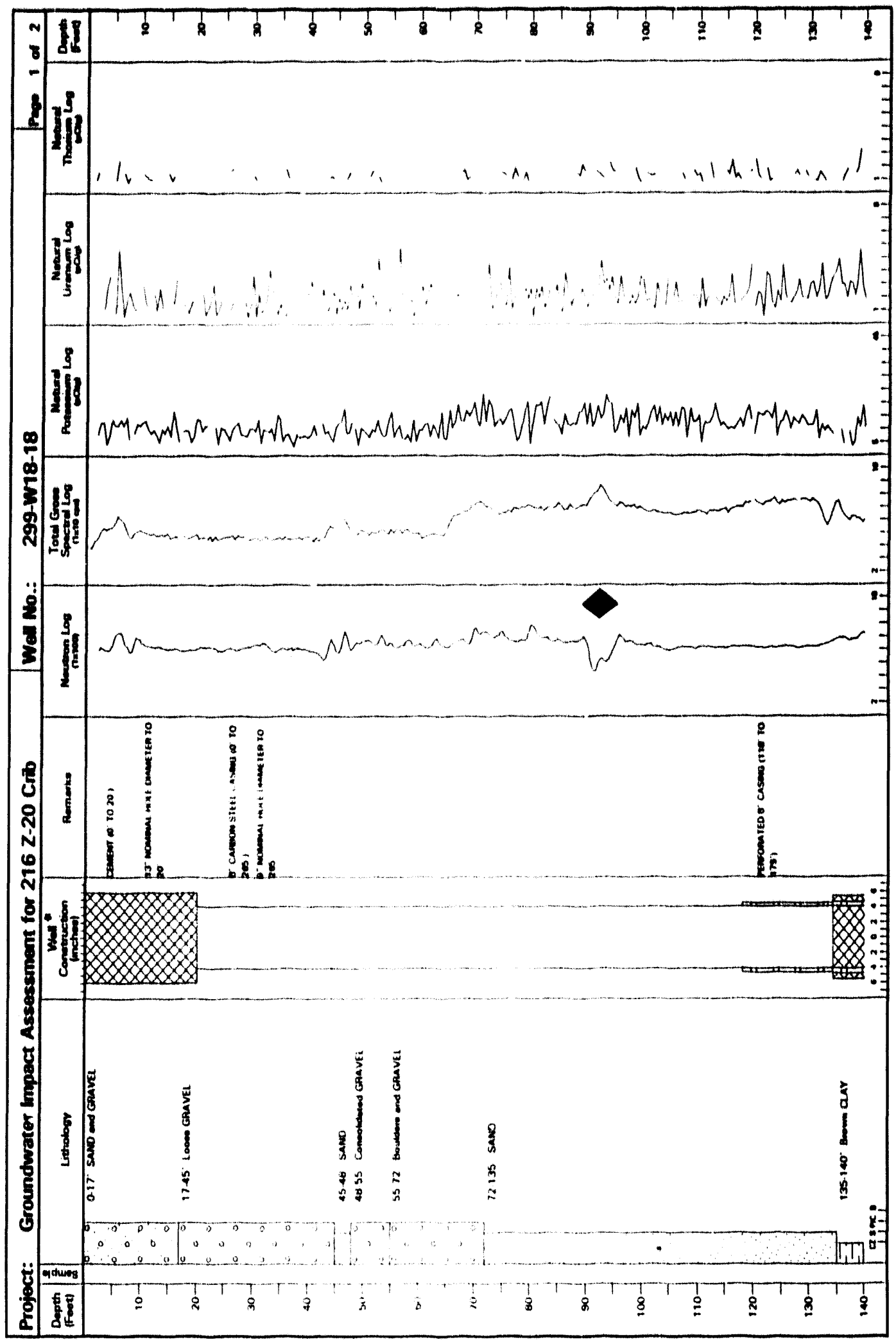


Figure D-2. Well Construction and Geophysical Logs for Well 299-W18-18. (2 sheets)

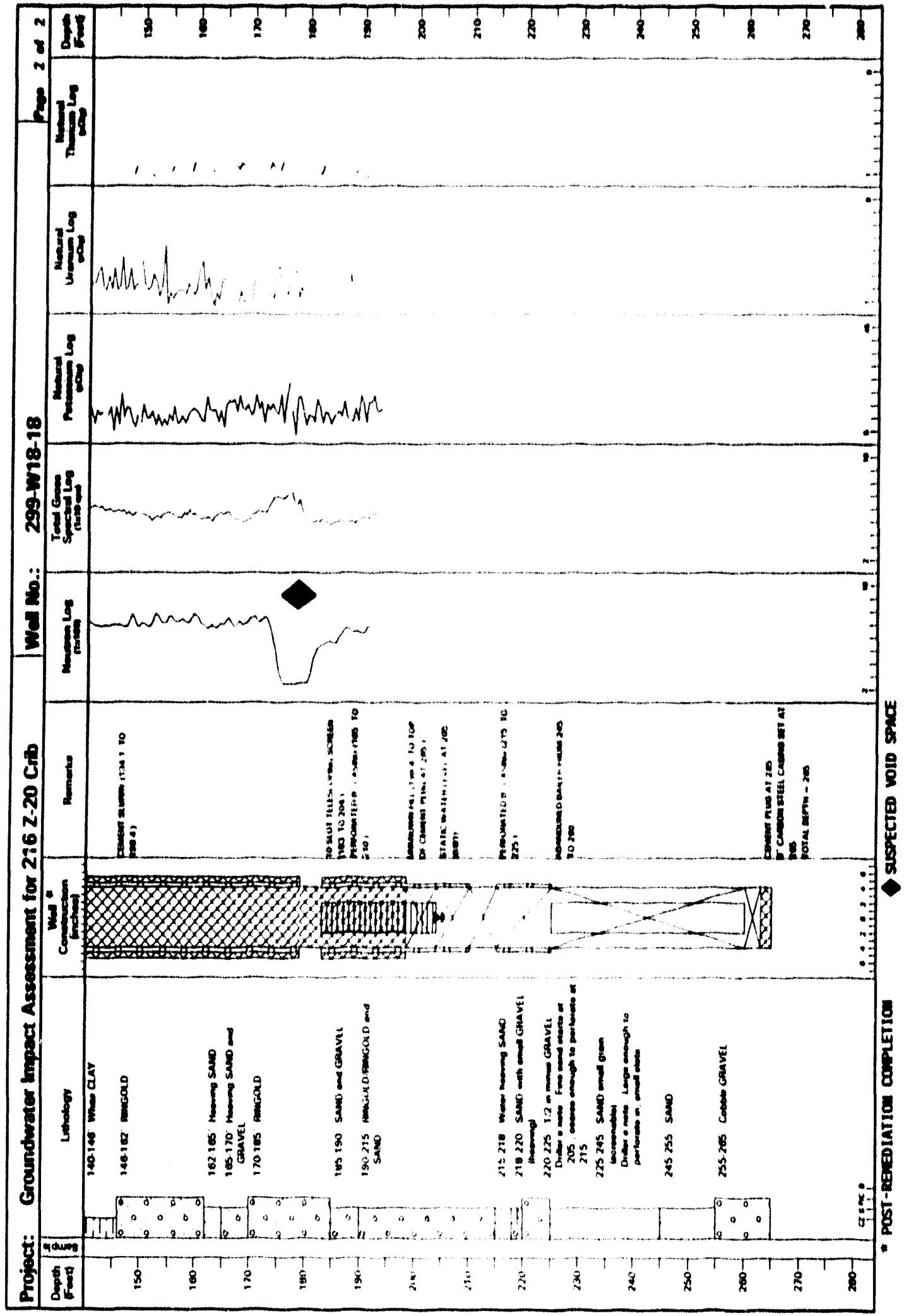


WHC-EP-0674

Figure 0-3. Well Construction and Geophysical Logs for Well 299-W18-19. (2 sheets)

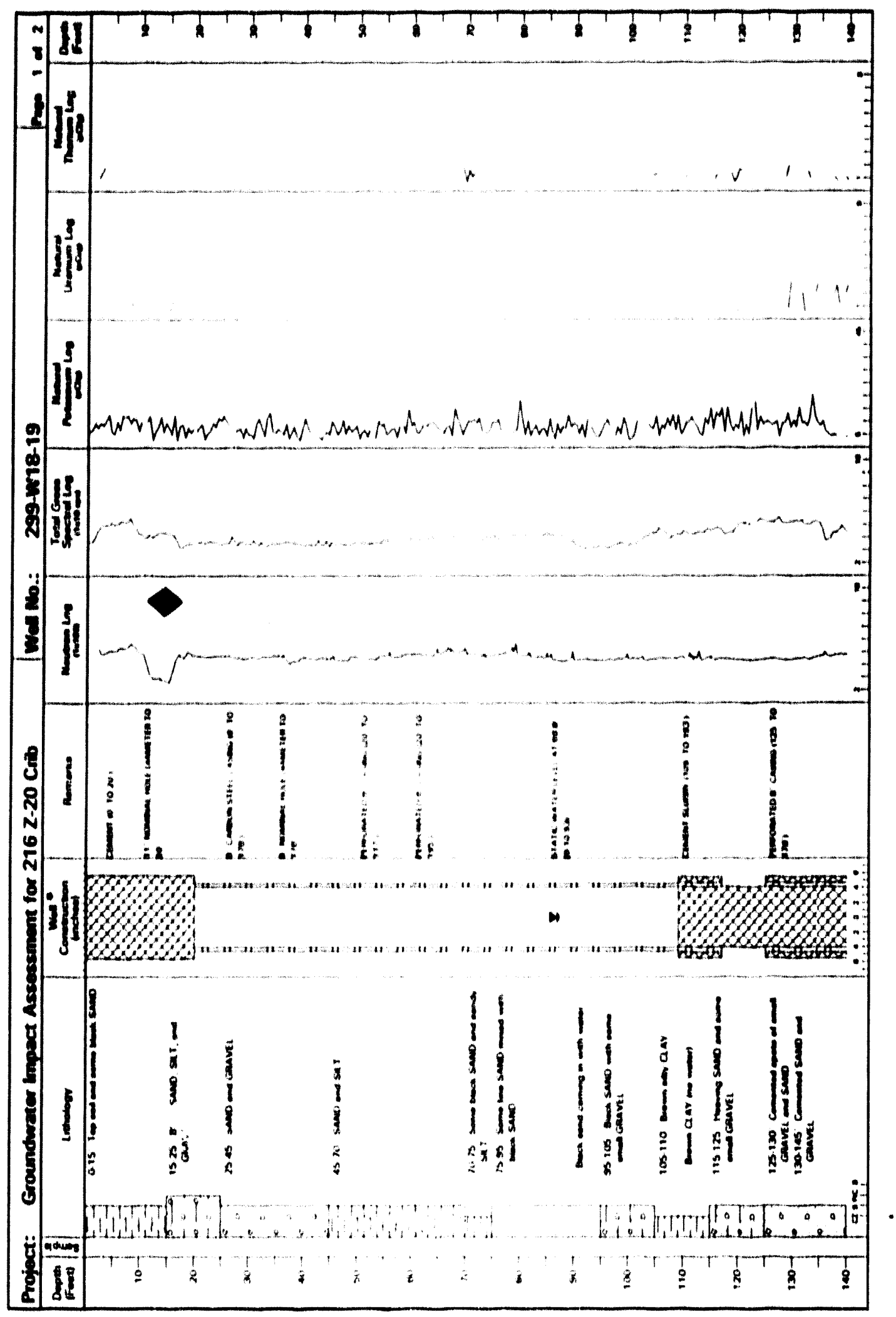

$0-11$ 
Figure D-3. Well Construction and Geophysical Logs for Well 299-W18-19. (2 sheets)

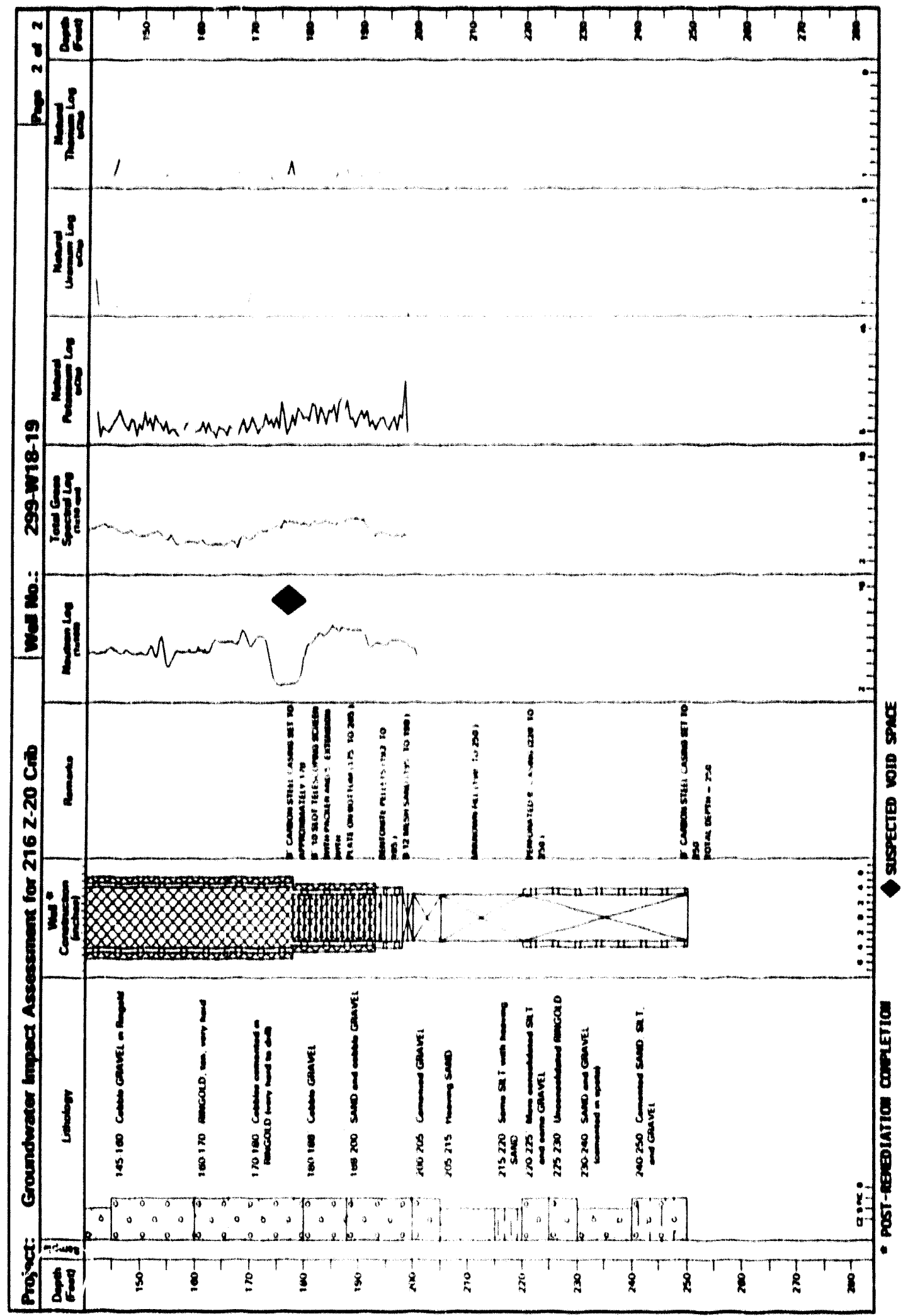


Figure D-4. Well Construction and Geophystcal logs for Well 299-W18-20. (2 sheets)

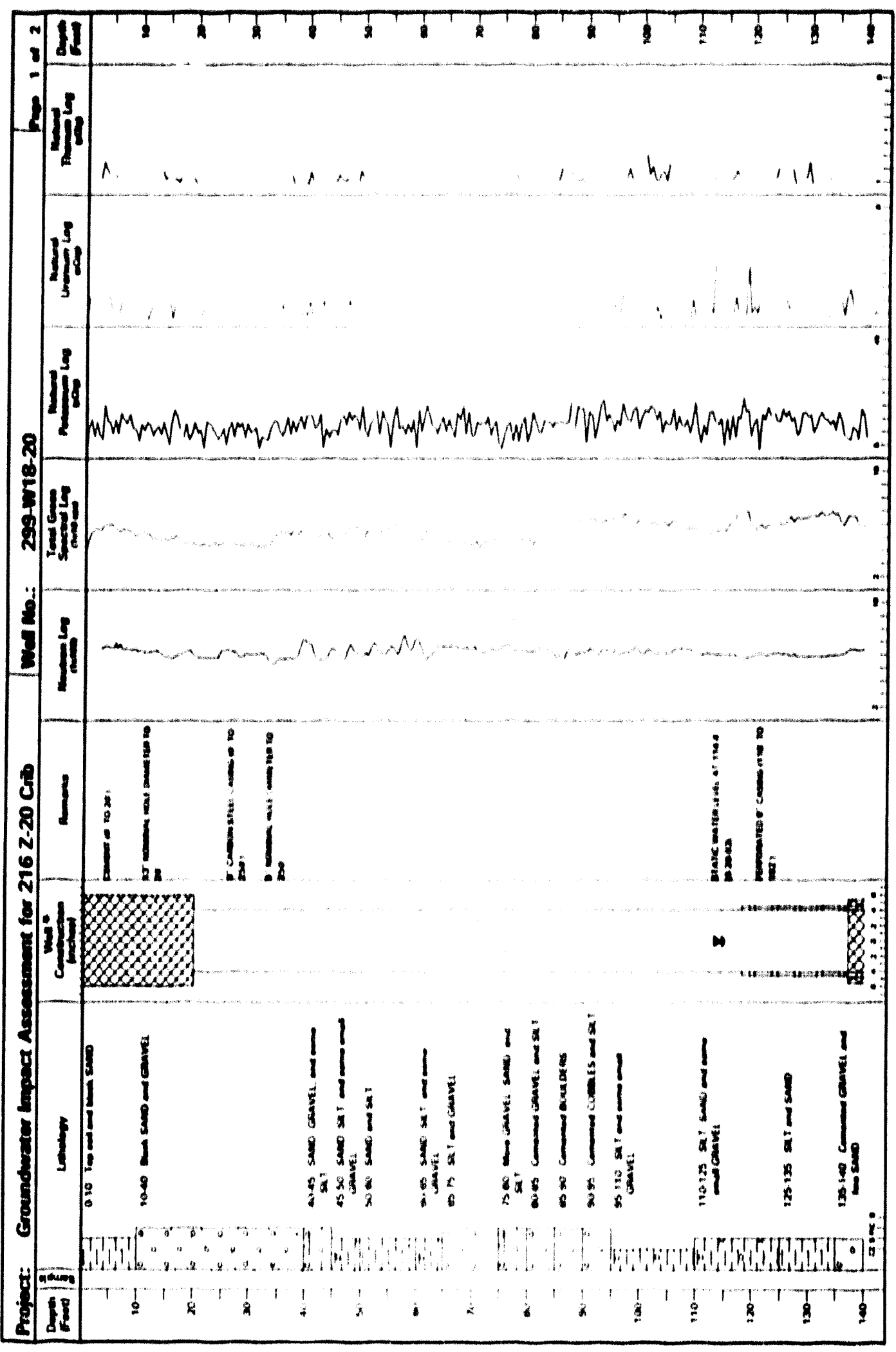


Figure 0.4. Well Cunstruction and Geophysical Logs for Well 299-W18-20. (2 sheets)

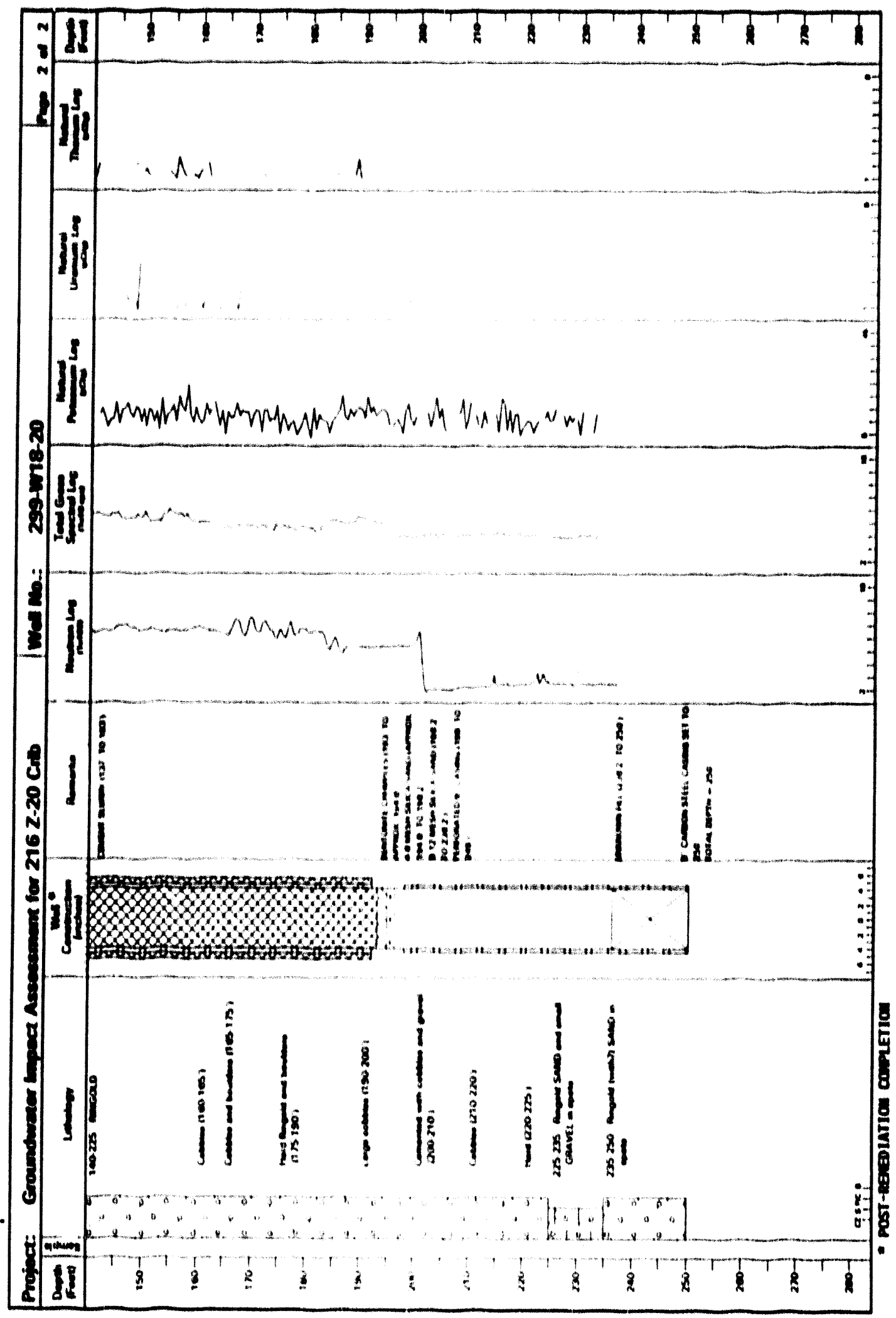


Figure D-5. Pre-Remediation As Bullt for well 299-w18-17.

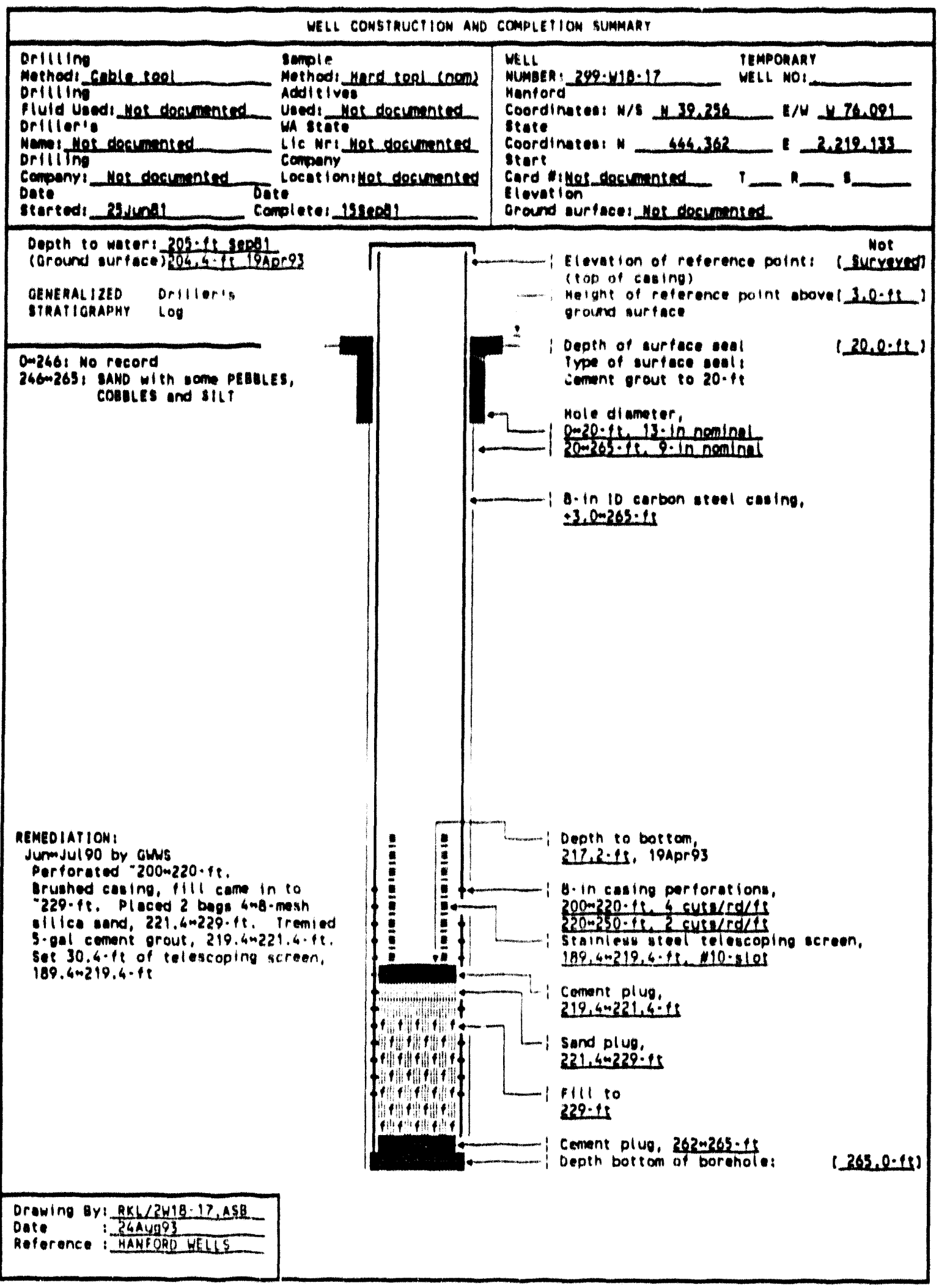


Figure D-6. Remediation/Decommissioning Plan for Well 299-W18-17.

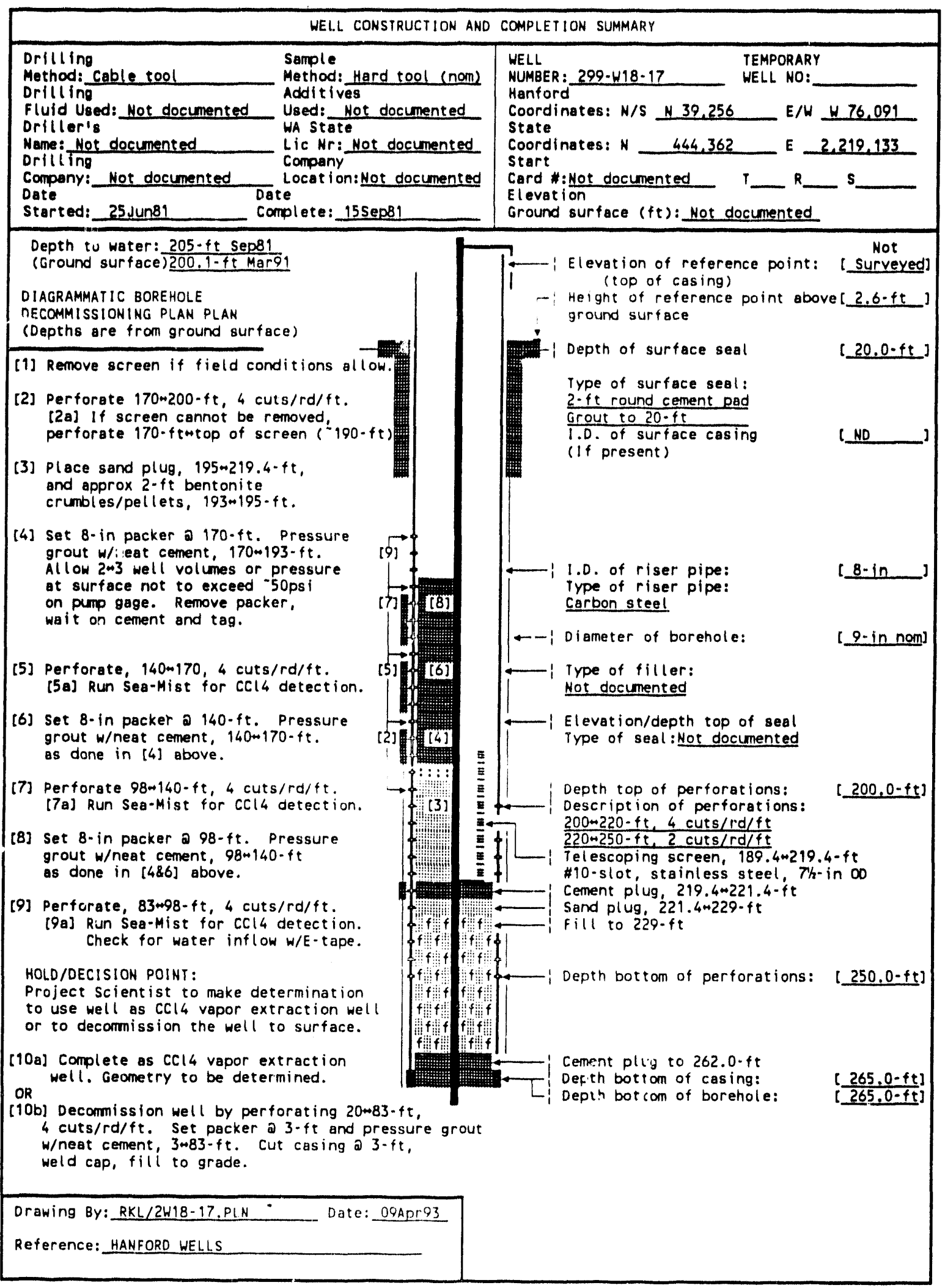


Figure D-7. Post-Remediation Completion Survey for We11 299-W18-17.

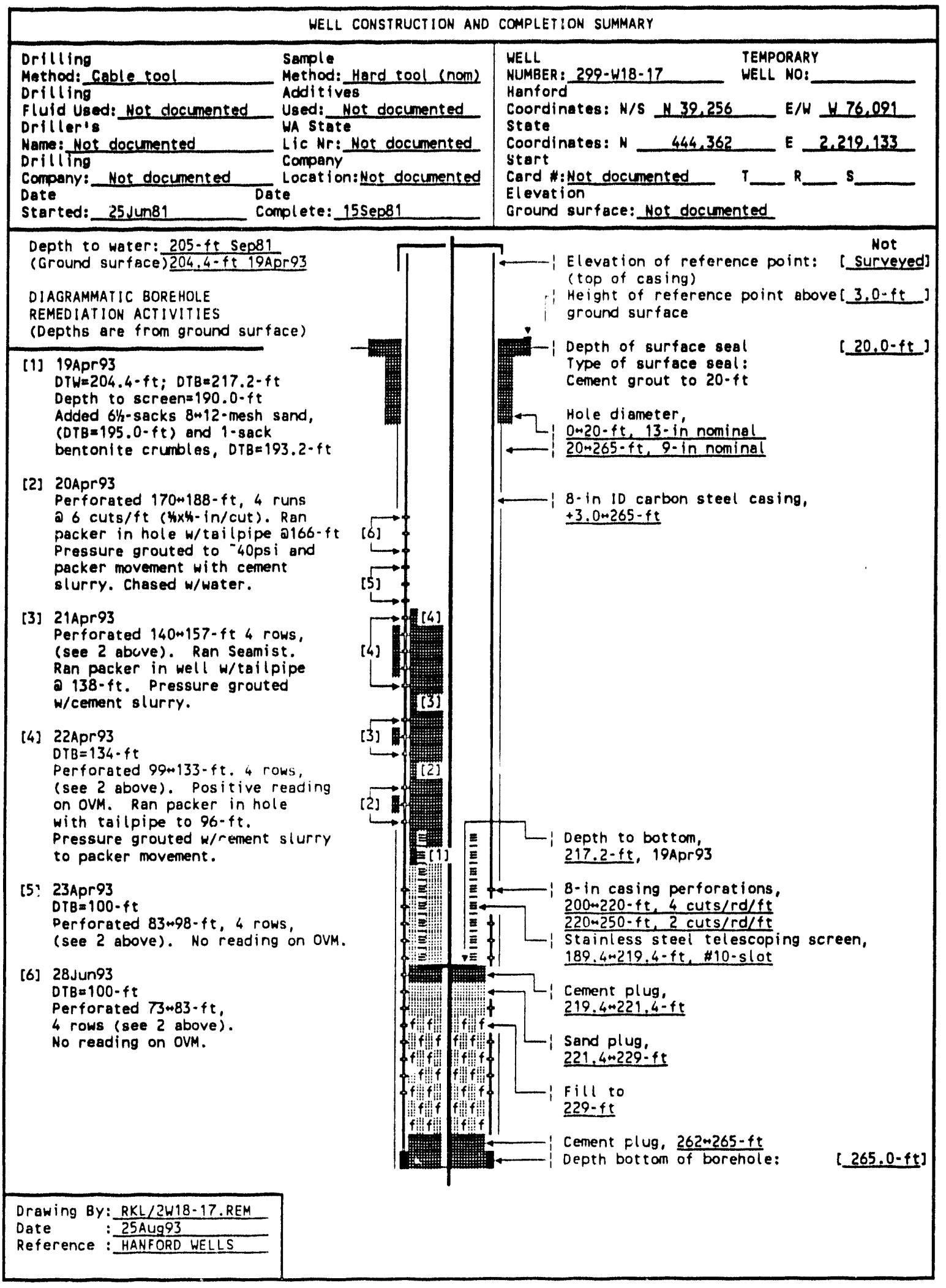


Figure D-8. Pre-Remediation As-Built for Well 299-W18-18.

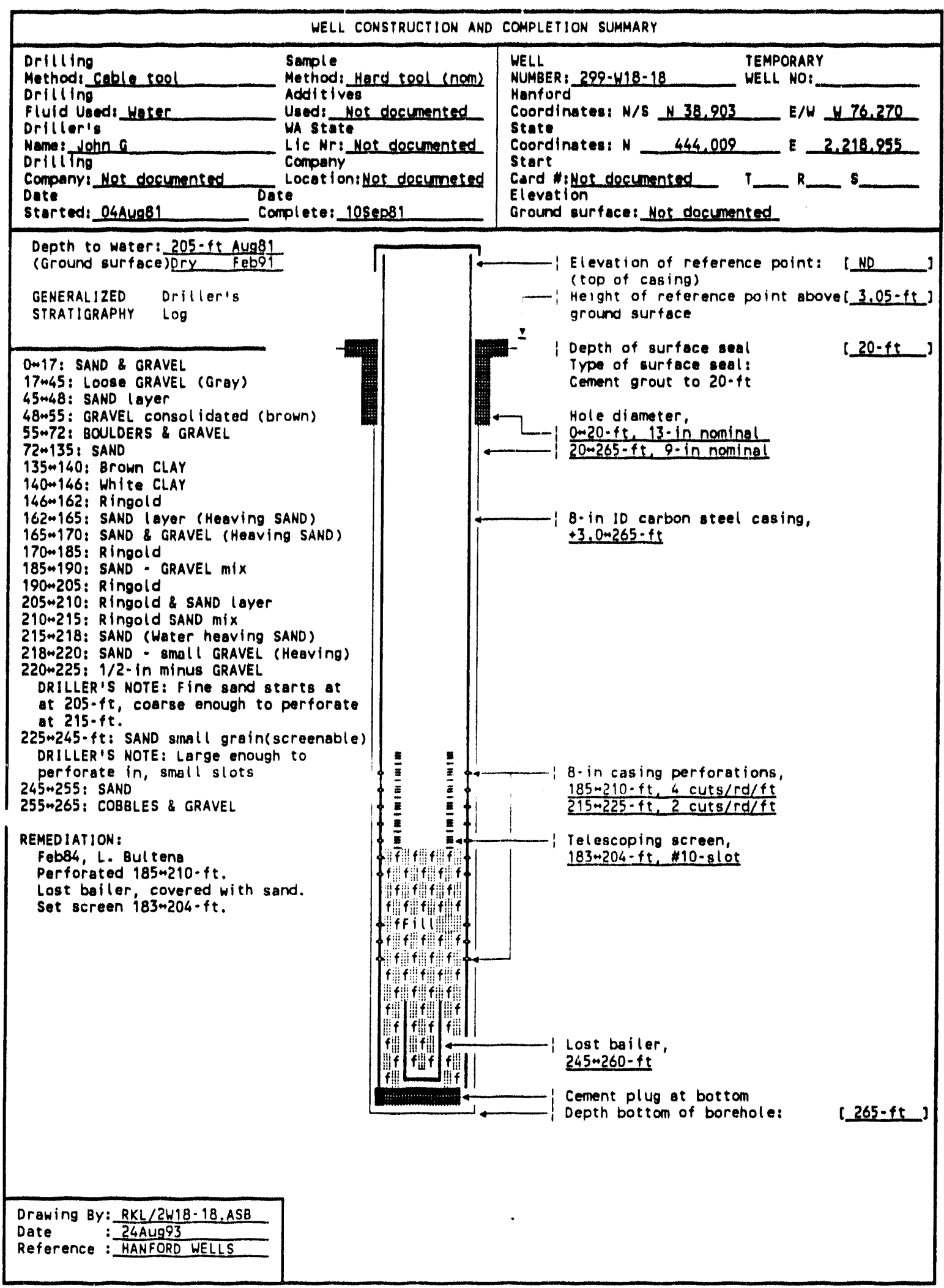


Figure D-9. Remediation/Decommissioning Plan for Well 299-W18-18.

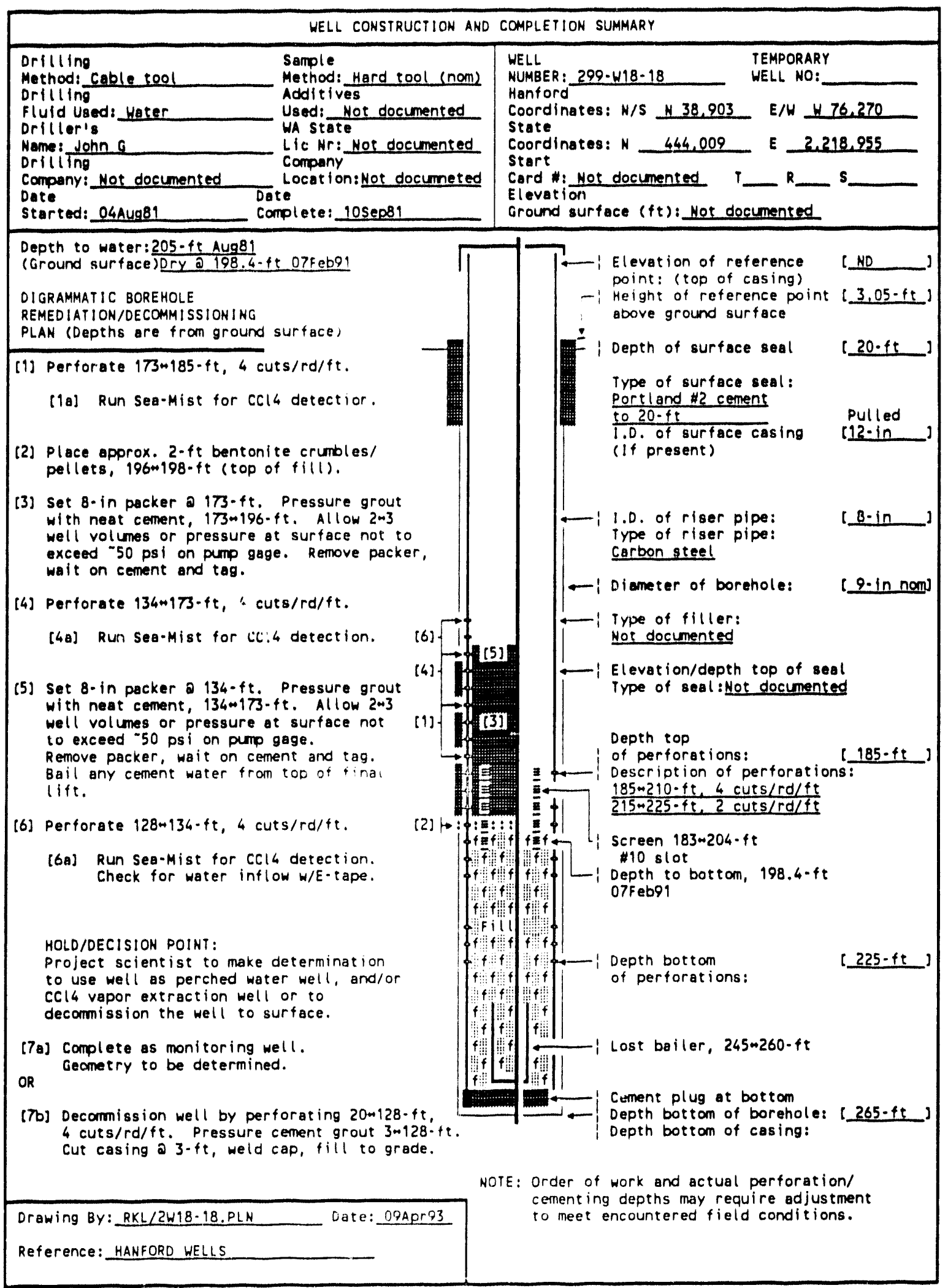


Figure D-10. Post-Remediation Completion Survey for Well 299-W18-18.

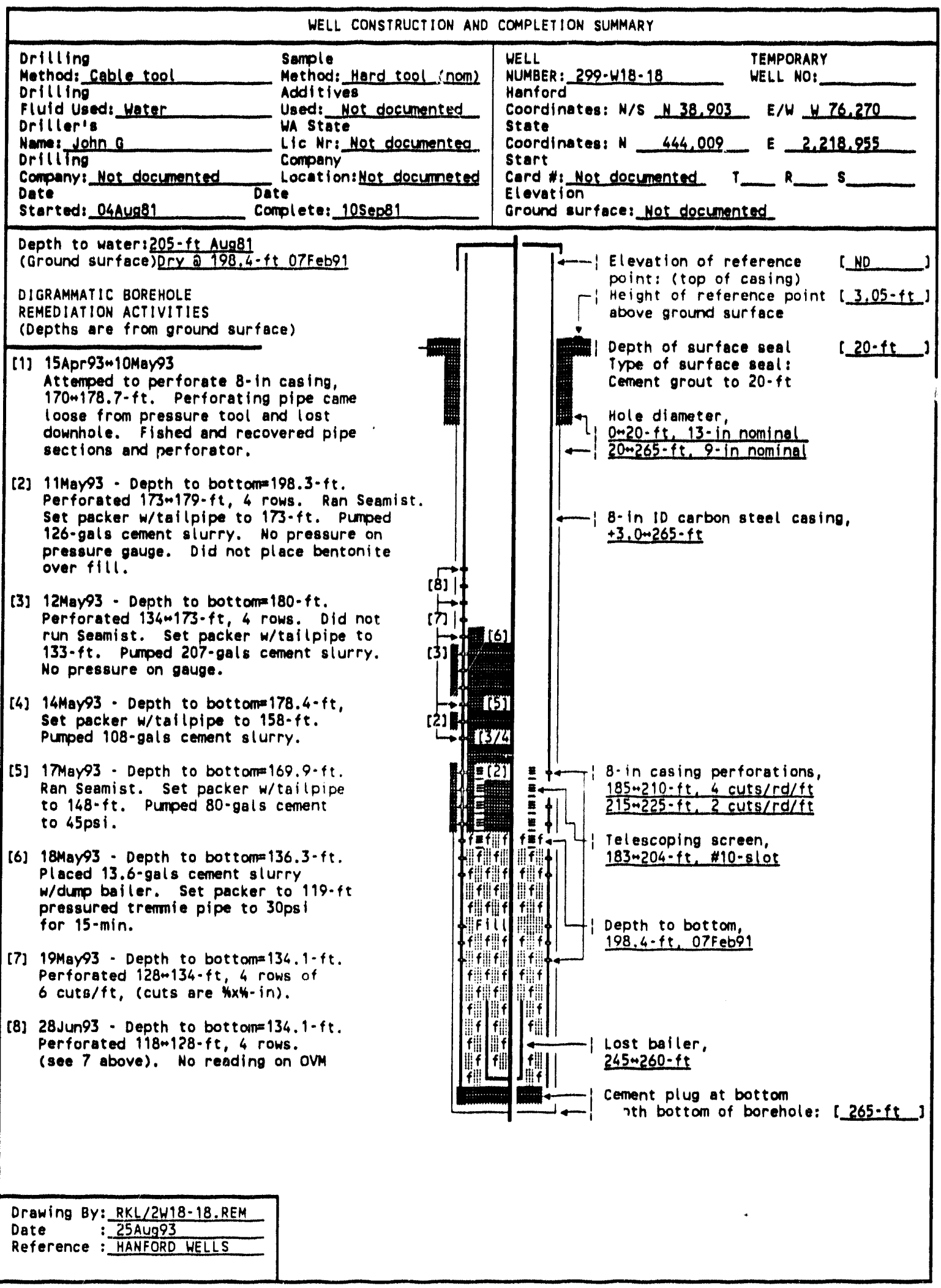


Figure D-11. Pre-Remediation As-Built for Well 299-W18-19.

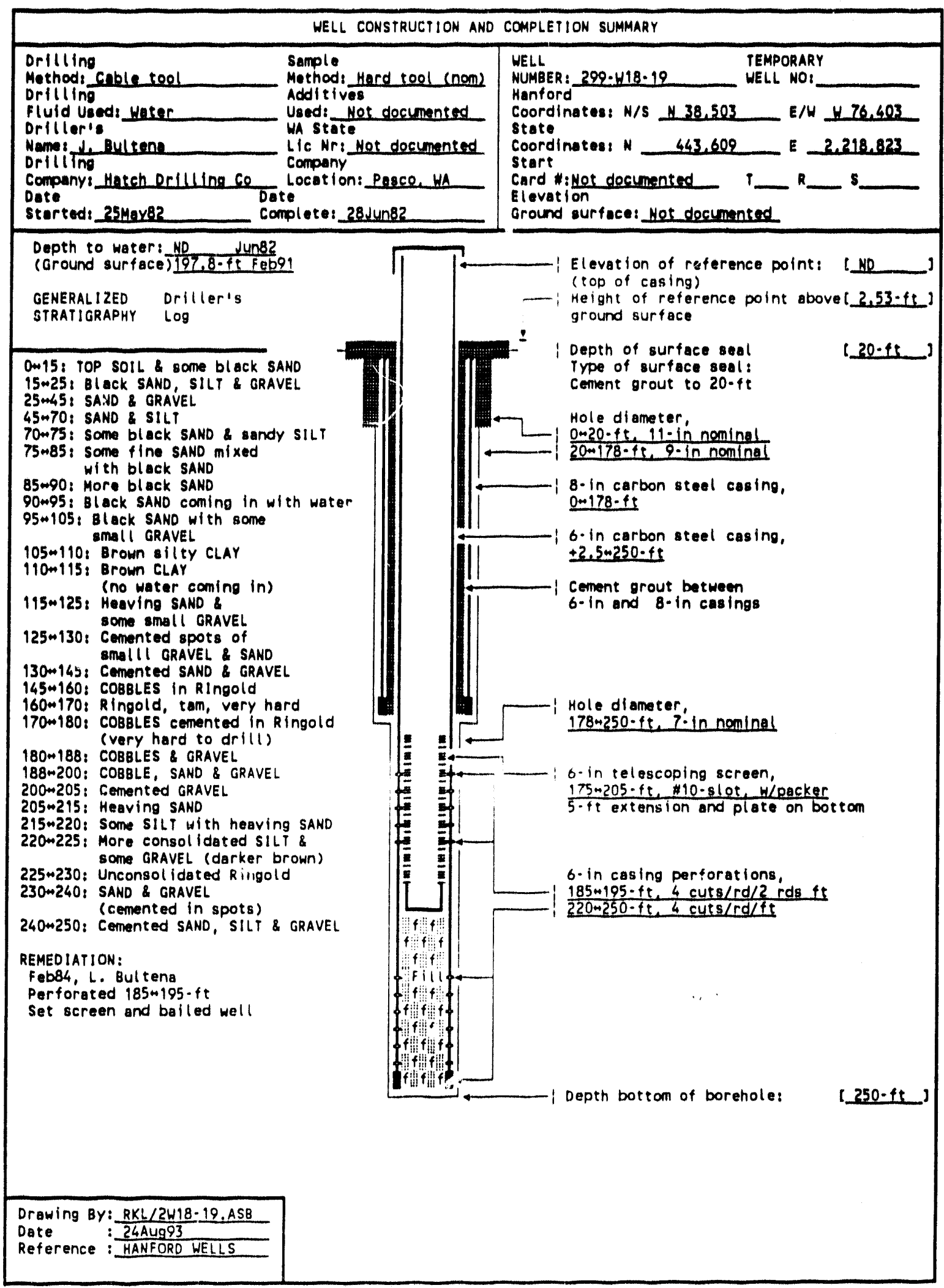


Figure D-12. Remediation/Decommissioning Plan for We11 299-W18-19.

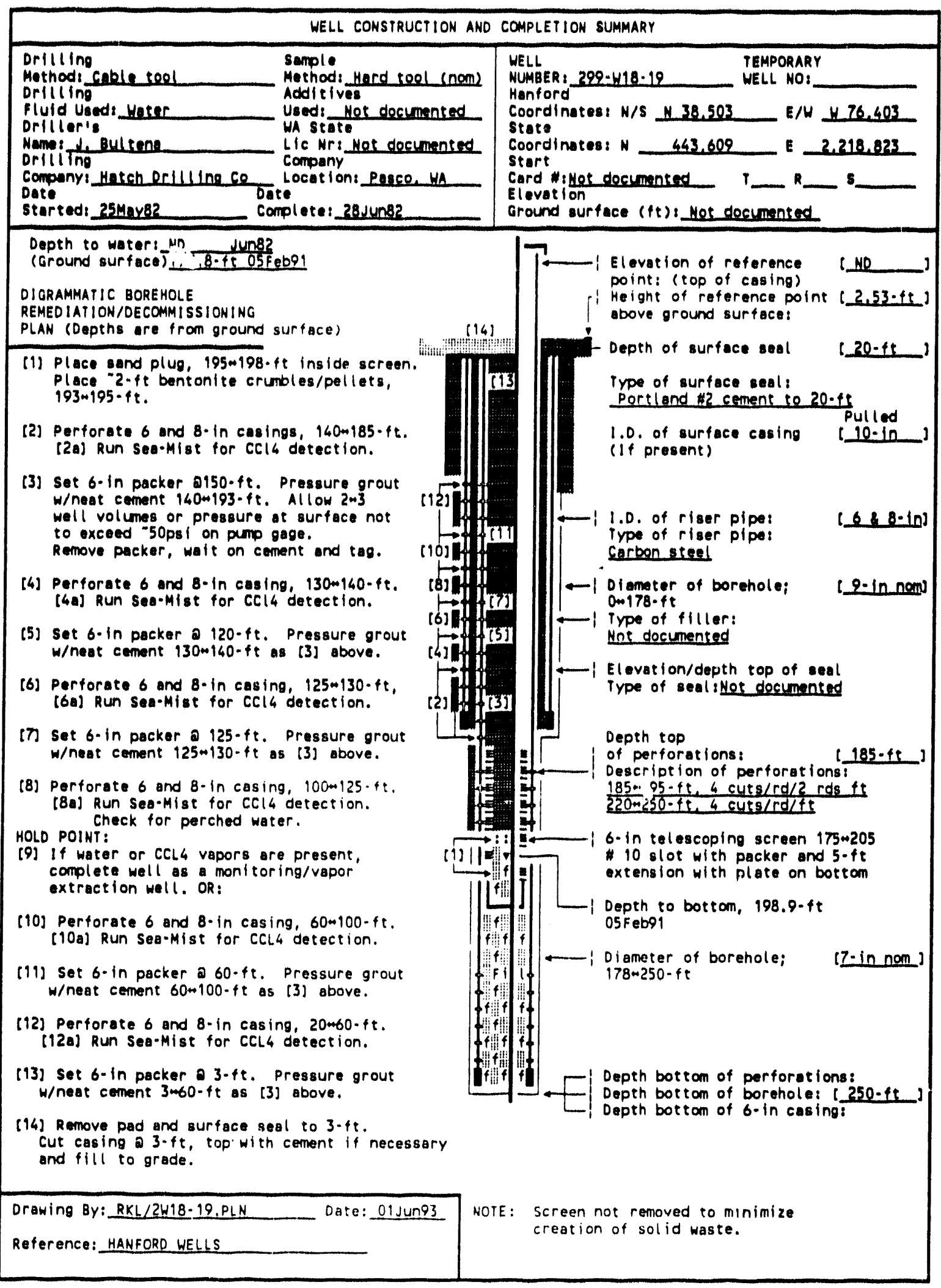


WHC-EP-0674

Figure D-13. Post-Remediation Completion Survey for Well 299-W18-19.

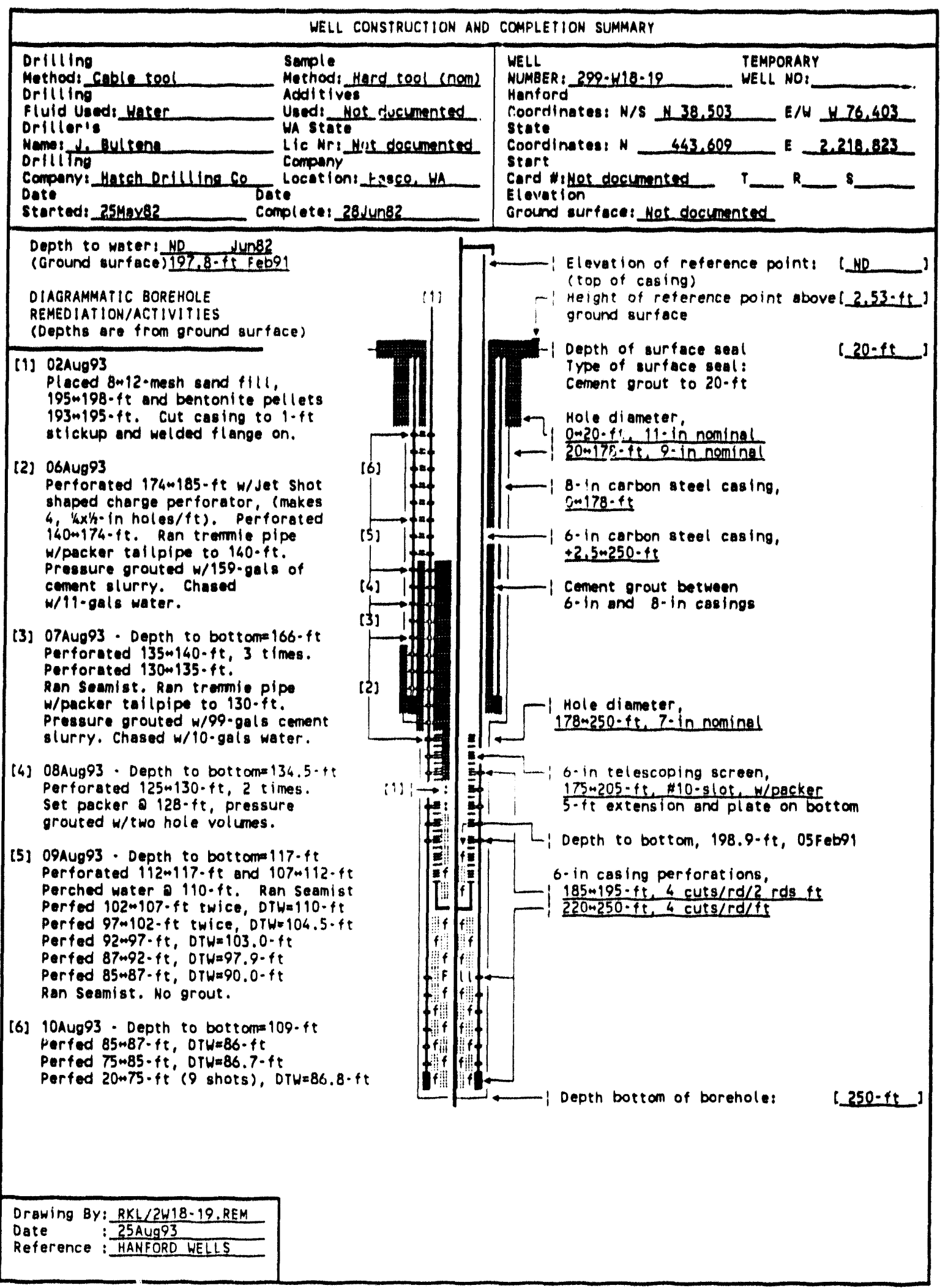


Fiqure D-14. Pre-Remediation As-Built for Well 299-W18-20.

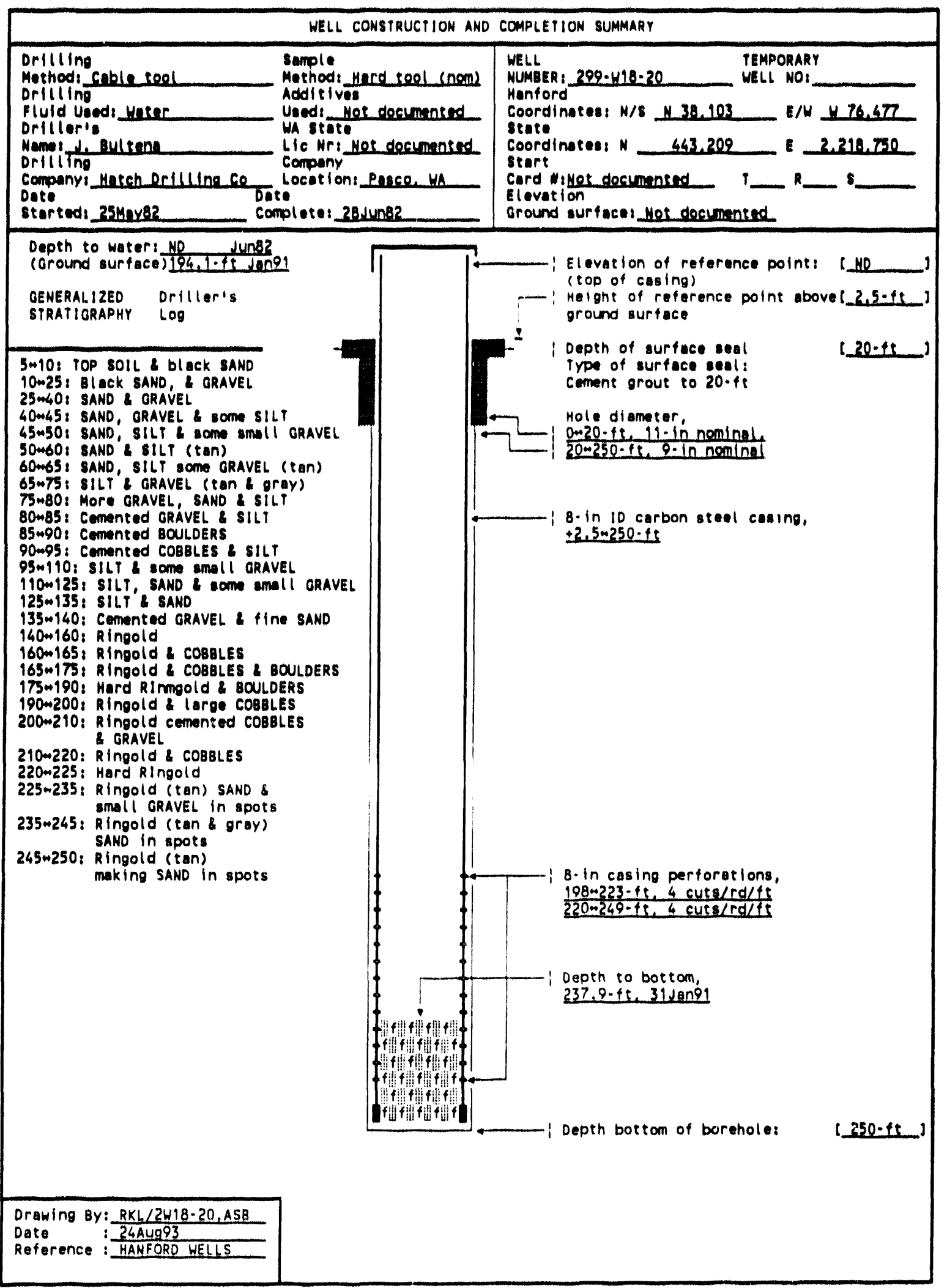


Figure D-15. Remediation/Decommissioning Plan for well 299-W18-20.

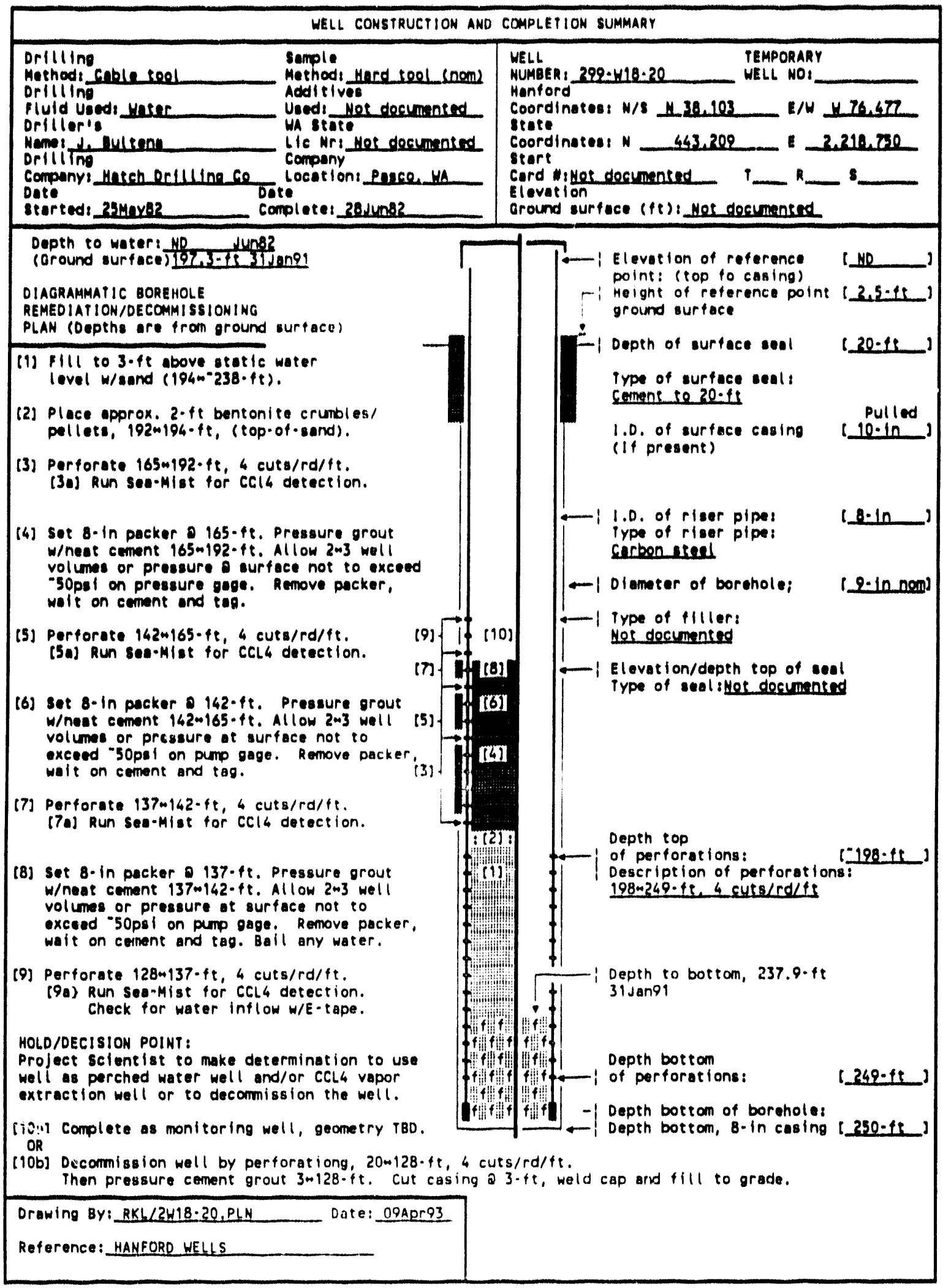


Figure D-16. Post-Remediation Completion Survey for Well 299-W18-20.

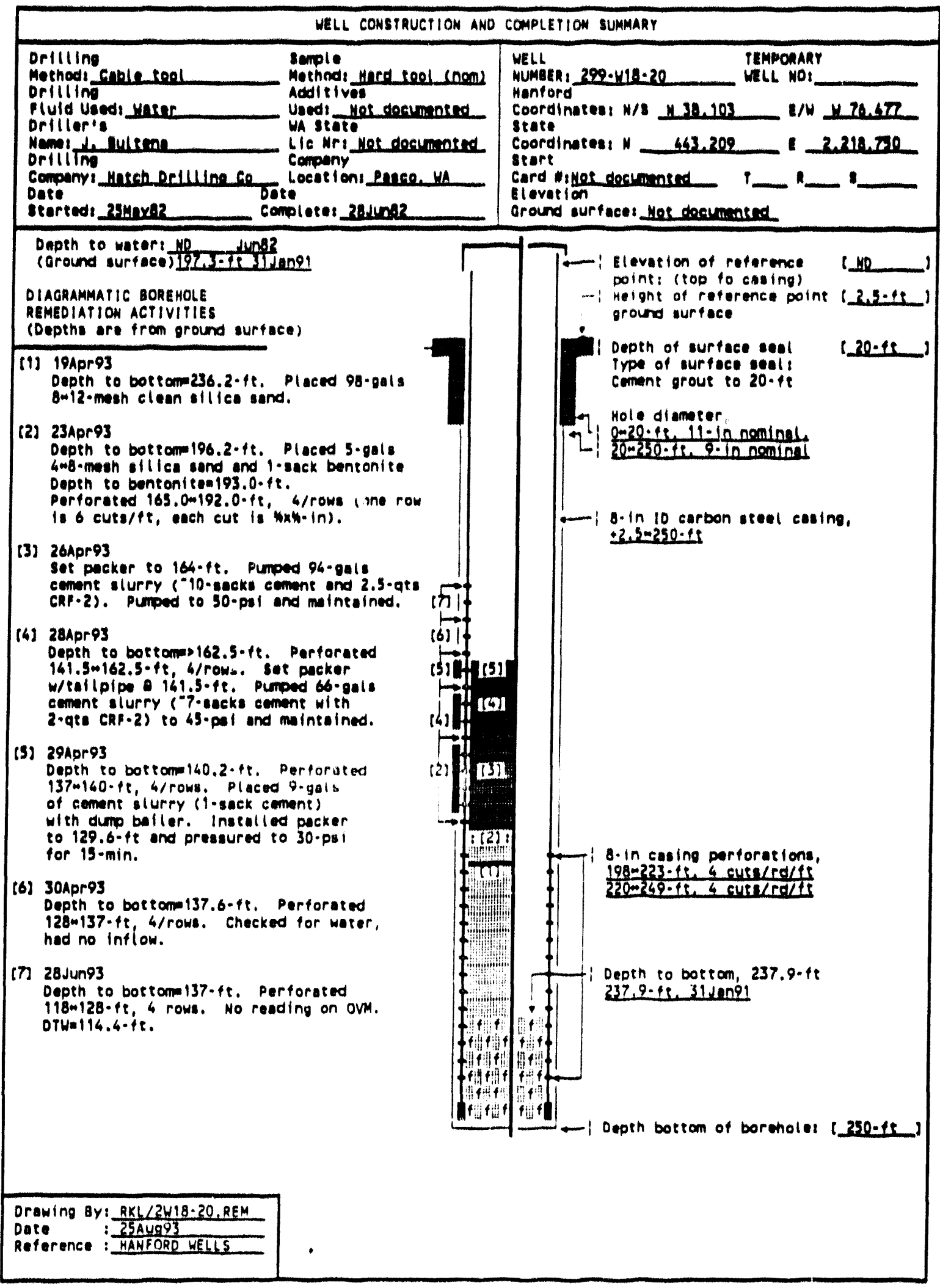




\section{DISTRIBUTION}

\section{Numbar of cootes}

\section{OEESITE}

2

Confederated Irtbes of the Umatilla Reservation

P.0. Box 638

Pendleton, Oregon 97801

J. R. W11kinson

2

Nez Perce Iribal office

P. 0. Box 305

Lapwat, Idaho 83540

\section{Powaukee}

1

\section{Southwest Research institute} 6220 Culebra Road

San Antonio, Texas 78284

\section{B. Sagar}

2

Yakima Indiar Nation
2552 Haines
Richland, WA 99352

R. F. Cook

\section{ONSIIE}

U.S. Department of Eneray. B/chland Opera tons off Ice

S. S. Clark

K. V. Clarke

R3-81

B. A. Davis

$A 5-15$

M. J. Furman

J. M. Hennig

M. P. Johansen

J. E. Rasmussen

R. K. Stewart

S. H. Wisness

RL Public Reading Room

R3-82

R3-81

R3-80

A5-19

A5- 15

A5-19

A5- 15

Al -65

Pacific Northwest Laboratory

PNL Technical files

$k 1-11$ 
WHC-EP-0674

DISTRIBUTION (cont)

\section{Number of coples}

ONSITE

39

Westinghouse Hanford Company

D. J. Alexander

E. G. Backlund

L. E. Borneman

J. L. Brand

S. D. Evelo

K. R. Fecht

B. H. Ford

M. J. Galgoul

L. A. Garner

D. G. Horton

V. G. Johnson (5)

D. E. Kelley

A. J. Knepp

S. E. Knaus

A. G. Law

D. L. Parker

M. G. Plepho

S. P. Reidel

K. R. Simpson

K. M. Singleton

D. R. Speer

D. K. Tyler (3)

E. C. Vogt

B. D. Willitamson

Central Files

Document Processing and Distribution (2)

Environmental Restoration

Program Information Center (5) H6-08

Information Release Administration

H6-06

T5-54

B2-35

T5-54

H6-06

H6-06

H6- 06

H6- 03

H6-22

H6-06

H6-06

R3-46

H6-06

H6-26

H6-06

H6-03

HO-36

H6-06

H6-06

H6-06

RI-48

H6-06

T5-50

B3- 15

L8-04

L8-15

H4-17 

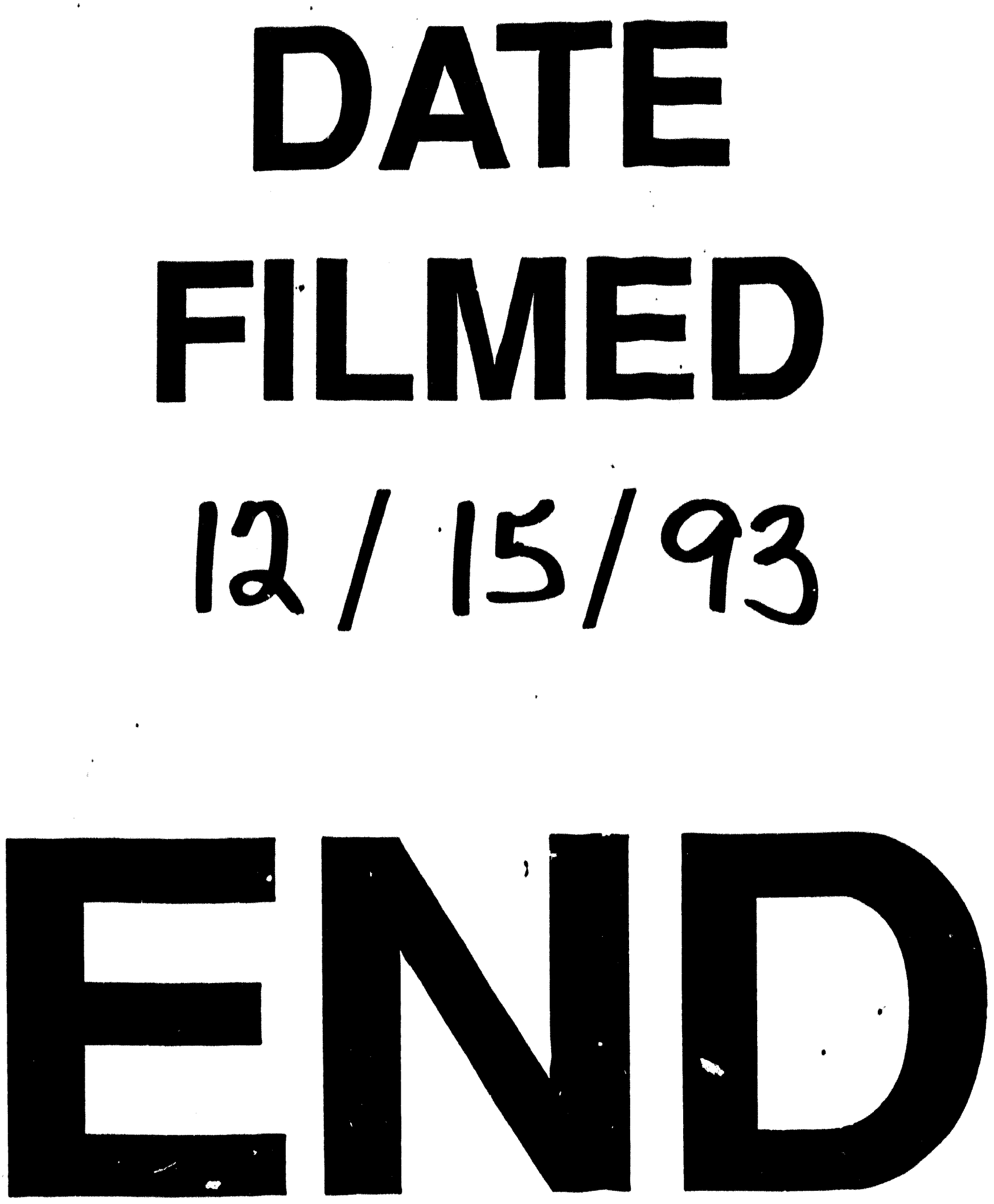